\title{
ZONEAMENTO GEOAMBIENTAL COM AUXÍLIO DE LÓGICA FUZZY E PROPOSTA DE UM GEOINDICADOR PARA CARACTERIZAÇÃO DO MEIO FÍSICO DA BACIA DO RIO DO PEIXE
}

\author{
VOLUME I
}

Sandra Fernandes da Silva

Tese apresentada à Escola de Engenharia de São Carlos, da Universidade de São Paulo, como parte dos requisitos para obtenção do título de Doutor em Geotecnia

ORIENTADOR: Prof. Dr. Osni José Pejon

São Carlos

2005 
Aos meus dois grandes amores, José Otacílio e Ireci. Meus pais e exemplos de vida. 
"A pior coisa que pode acontecer na vida de uma pessoa não é quando seu projeto não dá certo, seu plano de ação não funciona, ou quando sua viagem termina no lugar errado. O pior é não começar. Esse é o maior naufrágio."

Amyr Klink - Mar sem fim 


\section{AGRADECIMENTOS}

Ao Prof. Dr. Osni José Pejon, não apenas pela orientação técnica dispensada a realização deste trabalho, mas também, pela amizade e valiosa contribuição a minha formação e amadurecimento profissional.

À FAPESP, por disponibilizar os recursos financeiros utilizados na realização desta pesquisa.

Aos Professores, Dr. Oswaldo Augusto Filho e Dr. Marcos Ferreira, pelas sugestões, críticas e avaliações tecidas.

Ao Prof. Dr. Lázaro Valentim Zuquette, pela amizade, pelos momentos de descontração e inúmeras dicas e observações tecidas ao longo de todo o trabalho, e por estar sempre disposto a colaborar.

A professora e amiga Dra Gene Stancatti, por me acolher, apoiar e incentivar a seguir sempre em frente.

Ao Professor Dr. Edmundo Esquivel e ao Dr Carlos Vaz, pela paciência e auxílio nas fases de calibração e ensaio com a sonda-TDR.

Aos técnicos e funcionários do Departamento Benedito, Zé Luiz, Álvaro, Antônio, Décio e Maristela por tanta presteza e atenção dispensada em todos este anos.

Ao técnico de informática Herivelto, pelas preciosas assessorias e presteza em todos os momentos.

Aos muitos amigos que fiz durante esta longa jornada aqui no Departamento de Geotecnia, Domingos Borges, Célio Piedade Jr, Jeselay Reis, Kleber Dourado, Rogério Pinto, Leonardo Silveira, Miguel Alfáro, Marcos Musso, Vinícius Santos, Maurício Giambastiani, Luiz Baras, Mauro Menegotto, Edmundo Talamini, Ricardo Gomes, Wilson Cartaxo, Guilherme Daives Daniele Aparecida, Eliana Martisn, Marta Souza, Ana Carina Collares, Luciene Moraes, Wanessa Cartaxo, Adriana Arhendet, Gilvana Marques e Juliana Silveira não apenas pela troca de informações e conhecimentos, mas pela valiosa convivência.

Ao amigo de tantos anos, Paulo Lopes, pelo companheirismo, pela troca de conhecimentos e ajuda em diversas etapas deste e de tantos outro projetos que trilhei.

As minhas amigas e companheiras da sala de mapeamento Silvana Fontes e Gracinete Bastos pela troca de conhecimentos, incentivos e muitos momentos de alegrias, que tornaram esta jornada, por muitas vezes, mais leve.

As minhas amigas de São Carlos, Adriana Goulart, Ana Furlan, Soraia, Simoni Gheno, Maria Cecília Almeida, Josilene Costa e Karine Itmam pela amizade, companheirismo e incentivo constante. 
Ao meu querido amigo Oscar dos Santos Neto, por sua amizade incondicional ao longo de todos estes anos, e por me ensinar e incentivar a ter força e serenidade para lidar com tantas adversidades pessoais e profissionais.

A Neiva Rosális por estar sempre presente e disposta a ajudar com uma palavra de carinho e amizade, e pelo acolhimento junto a sua família.

A Nívea Pons não apenas pela troca de conhecimentos profissionais e incentivos, mas pela sua preciosa amizade, compreensão e inestimável ajuda nas etapas finais de elaboração deste trabalho.

A Ana Paula Vianna, mais que minha amiga, mais que uma companheira de trabalho, minha irmã de coração, minha família e apoio durante todos os anos que morei em São Carlos.

Aos meus pais, José Otacílio e Ireci, irmãs Lizi e Nan, e a minha tia e segunda mãe Iêda, pelo apoio constante e irrestrito. 


\section{SUMÁRIO}

\section{VOLUME I}

LISTA DE FIGURAS

LISTA DE TABELAS ix

LISTA DE QUADROS xiv

LISTA DE SÍMBOLOS $\quad$ xv

RESUMO xvi

ABSTRACT. xvii

1 - INTRODUÇÃO 1

1.1 - Objetivos 3

1.1.1 - Objetivo geral.

1.1.2 - Objetivos específicos. 3

2. - REVISÃO BIBLÍOGRÁFICA 4

2.1 - O Meio Ambiente e o Processo de Avaliação Ambiental 4

2.2. - Leis Ambientais $\quad 7$

2.3. - Zoneamento Geoambiental 12

2.3.1. Metodologias de Zoneamento Geoambiental 14

2.4. Bacias Hidrográficas como Unidades de Planejamento 19

2.4.1. Condicionantes de Alterações Ambientais em Bacias Hidrográficas 22

2.4.1.1. Condicionantes de Ordem Natural 22

2.4.1.2. Condicionantes de Natureza Antrópica 23

2.5. Indicadores Geoambientais 25

2.6. Geoprocessamento e Estudos Ambientais 27

2.6.1 Estrutura de um Sistema de Informações Geográficas 29

2.6.2. Operações Matemáticas nos Sistemas de Informações Geográficas 31

2.7 - Lógica Fuz:y

2.7.1 Teoria Fuгæy - Princípios Básicos 34

2.7.2 Teoria dos Conjuntos Difusos - Conceituação Matemática 34

2.7.3 - Aplicações da Lógica Fu₹æyy 38

2.7.3.1. -. Exemplos de Aplicação da Lógica Fuそæ̃y 40 
3.1. Localização e Acesso 42

3.2. Aspectos Fisiográficos 45

3.2.1 Clima 45

3.2.2. Cobertura Vegetal $\quad 45$

3.2.3. Pedologia 46

3.2.4. Geomorfologia $\quad 48$

3.3. Aspectos Sócio-Econômicos 48

3.3.1 Demografia $\quad 48$

3.3.2. Quadro Econômico $\quad 50$

3.3.2.1 Turismo 51

3.3.2.2. Atividade Agrícola

4. MATERIAIS E MÉTODOS 56

4.1. Avaliação Ambiental do Meio Físico 56

4.1. 1 Levantamento e Produção de Informações Básicas Relativas ao Meio 57

- Base de Dados Fundamentais

4.1.2 Processamento Computacional com Aplicação de Fundamentos de 58

Lógica Fuz:y - Base de Dados Fuzzy e Elaboração de Cartas Interpretativas

4.2. Avaliação de Alterações do Meio Físico por Atividades Modificadoras 58

4.3. Zoneamento Geoambiental 59

5. BASE DE DADOS - MAPAS BÁSICOS FUNDAMENTAIS 61

5.1. Mapa de Documentação (ANEXO I) 61

5.2. Mapa de Substrato Rochoso (ANEXO II) 61

5.2.1 Procedimentos Empregados 62

5.2.2. Unidades do Substrato Rochoso 62

5.2.2.1 Rochas Ígneas

5.2.2 2 Rochas Metamórficas 68

5.3. Mapa de Landforms (ANEXO III)

5.3.1 Procedimentos Empregados 77

5.3.2 Sistemas e Unidades de Landforms

5.3.2.1 Sistemas de Terreno A 80

5. 3.2.2. Sistemas de Terreno B 85

5.3.2.3 Sistemas de Terreno C 90

5.3.2.4 Sistemas de Terreno D 95 
5.3.2.5 Sistema de Terreno E 102

5.4 Mapa de Unidades de Materiais Inconsolidados (ANEXO IV) 108

5.4.1 Procedimentos Empregados 108

5.4.2 Ensaios de Laboratório Realizados 109

5.4.3 Unidades de Materiais Inconsolidados 115

5.4.3.1 Unidade de Materiais Aluvionares - (Al) 116

5.4.3.2. Unidades de Materiais Retrabalhados - (Rt) 116

5.4.3.3 Unidades de Materiais Residuais $\quad 119$

5.5. Mapa de Uso e Ocupação do Terreno (ANEXO V) 138

5.5.1 - Procedimentos Empregados 138

5.5.1.1 Atividades de Pré-processamento 138

5.5.1.2 Atividades de Processamento 144

5.5.1.3 Atividades de Pós-processamento 144

5.5.2 - Classes de Uso e Ocupação do Terreno 145

6. DOCUMENTOS CARTOGRÁFICOS FUZZY - CARTAS DERIVADAS 147

6.1 Suporte Computacional - Sistema d Informação Geográfica Spring 148

6.1.1 Linguagem de Programação LEGAL 150

6.1.2. Estruturação de um Programa em LEGAL 151

6.2 Base de Dados Básicos Fundamentais Furay 154

6.2.1 Declividade 155

6.2.1.1 Procedimentos Empregados 155

6.2.1.1.1Carta de Declividade - Documento Temático 157

6.2.1.1.2 Dados Declividade Fuzzy 161

6.2.2 Carta de Extensão do menor Percurso de Água Superficial (CEMPAS) 163

6.2.1.1 Procedimentos Empregados 164

6.2.3 Substrato Rochoso e Materiais Inconsolidados 167

6.2.3.1 Procedimentos Empregados 167

6.2.3.1.1- Caracterização das relações de contato 171

6.2.3.1.2- Elaboração e execução de Programas em LEGAL 174

6.4 Cartas Derivadas Interpretativas Furąy

6.4. 1 Procedimentos de elaboração das cartas derivadas 182

6.4.1.1 Comparação pareada entre informações - Técnica AHP 182

6.4.1.2 Disposição dos atributos em classes 184 
6.4.1.3 Análise das Cartas interpretativas fuzzy

6.4. 2 Carta de Potencial ao Escoamento SuperficiaL (ANEXO VII) 190

6.4.3. Carta de Susceptibilidade a Erosão (ANEXO VIII) 194

6.4.4. Carta de Potencial Agrícola (ANEXO IX) 198

7. - CARACTERIZAÇÃO DE ALTERAÇÕES DO MEIO - PROPOSTAS 203 DE UM NOVO GEOINDICADOR

$\begin{array}{ll}7.1 \text { - Resistência a Penetração } & 203\end{array}$

7.1.1. Teoria da Técnica de Reflectrometria no Domínio do Tempo (TDR) 205

7.2 Equipamento - Penetrômetro/Sonda-Tdr 205

$\begin{array}{ll}\text { 7.2.1 WinTDR } 6.0 & 207\end{array}$

$\begin{array}{ll}\text { 7.3. Medidas de Resistência A Penetração } & 208\end{array}$

$\begin{array}{ll}\text { 7.4 Procedimentos Empregados } & 209\end{array}$

7.4.1 Experimentos em laboratório 209

7.4.2 Experimentos em Campo 211

7.4.3 - Uso e ocupação do terreno e solos ensaiados 215

7.5 Caracterização do Comportamento de Resistência A Penetração 217

8. - ZONEAMENTO GEOAMBIENTAL DA BACIA DO RIO DO 231 PEIXE

8.1 - Unidades Geoambientais 232

9. - CONCLUSÕES 326

9.1 - Quanto a utilização da Lógica Fuzzy no Processo de Avaliação Ambiental 326

9.2 - Quanto a Ferramenta Computacional Utilizada para Aplicação Da Lógica 328

Fuzzy No Processo De Avaliação Ambiental

9.3 - Quanto ao Indicador Ambiental Proposto para caracterização de 329 Alterações Ambientais introduzidas no Meio.

9.4 - Quanto ao Zoenamento Geoambiental Elaborado 330

10 - REFERÊNCIAS BIBLIOGRÁFICAS 333

11 - APENDICE A - Rotinas de programação em linguagem LEGAL 345 
VOLUME II

ANEXO I - Mapa de Documentação

ANEXO II - Mapa de Substrato Rochoso

ANEXO III - Mapa de Lanforms

ANEXO IV - Mapa de Materiais Inconsolidados

ANEXO V - Mapa de Uso e Ocupação

ANOXO VI - Carta de Declividade

ANEXO VII - Carta de potencial ao Escoamento Superficial

ANEXO VIII - Carta de Susceptibilidade a Erosão

ANEXO IX - Carta de Potencial Agrícola

ANEXO X - Carta de Zoneamento Geoambiental 


\section{LISTA DE FIGURAS}

Figura 2.1 - Abordagens distintas dos estudos de natureza geoambiental (Sobreira, 1995). 13

Figura 2.2 - Fluxograma da metodologia de Cendrero et al.(1983). 16

Figura 2.3 - Representações gráficas dos conjuntos clássicos e difusos para definição da $\mathbf{3 8}$ temperatura do ambiente (Galvão, 1999).

Figura 3.1 - Localização da área de estudo

Figura 3.2 - Localização da Bacia do Rio do Peixe com relação aos Estados de São Paulo e 44 Minas Gerais.

Figura 3.3 - Municípios da Bacia do Rio do Peixe.

Figura 3.4 - Distribuição demográfica na Bacia do Rio do Peixe.

Figura 3.5 - Distribuição da população urbana e rural na Bacia do Rio do Peixe (IBGE, 51 2002).

Figura 3.6 - Percentual em área ocupado pela produção agrícola na Bacia do Rio do Peixe $\mathbf{5 2}$ (IBGE, 2002).

Figura 3.7 - Distribuição em área plantada dos produtos de lavoura permanente. $\quad \mathbf{5 4}$

Figura 3.8 - Distribuição em área plantada dos produtos de lavoura temporária. $\quad \mathbf{5 5}$

Figura 4.1 - Fluxograma das etapas desenvolvidas para obtenção do zoneamento $\mathbf{6 0}$ geoambiental da bacia

Figura 5.1 - Fluxograma das etapas desenvolvidas na obtenção do Mapa de Substrato 63 Rochoso.

Figura 5.2 - Detalhe de afloramento de granitos cataclasados. Notar orientação 65 apresentada pelos cristais de k--feldspato.

Figura 5.3 - Detalhe dos pórfiros de k-feldspato dos granitos porfiróides. Notar 66 orientação dos cristais de k-feldspato.

Figura 5.4 a e b - Afloramentos típico de granitos porfiróides.

Figura 5.5 -Bandamento típico exibido pelos Granito-Gnaisses.

Figura 5.6 -A)Afloramento de Gnaisse intercaldos com quartzitos e xistos, (B) detalhe da $\mathbf{6 9}$ lente de xisto

Figura 5.7 - Afloramentos de gnaisses intercalados com rochas básicas, com aspecto $\mathbf{7 0}$ cataclasado, apresentando heterogeneidade litológica.

Figura 5.8 - Afloramentos de veios pegmatíticos comum nos gnaisses intercalados com 71 rochas básicas nas proximidades do município de Serra Negra.

Figura 5.9 - Afloramentos de quartzitos com intercalações de lentes de xisto gnaisse. $\quad 71$

Figura 5.10 - Afloramento de quartzito sem ocorrência de níveis intercalados. $\quad \mathbf{7 2}$

Figura 5.11 A e B)Afloramentos de Migmatitos com leucossomas e paleossomas exibindo $\mathbf{7 3}$ aspecto dobrado.

Figura 5.12 - Afloramentos de Ultramilonitos de gnaisse cataclasados.

Figura 5.13 Plano de falha comum nos Ultramilonitos presentes junto as zonas de falhas. $\quad \mathbf{7 5}$

Figura 5.14 - Etapas desenvolvidas na obtenção do Mapa de Landforms da bacia. $\quad 78$

Figura 5.15 - Dados de Hipsométria da bacia. $\quad \mathbf{7 8}$

Figura 5.16. - Detalhe em Modelo Digital do Terreno da Unidade A2. Notar destaque aos $\mathbf{8 2}$ morros de topos angulosos, definindo cristas com disposição em arco.

Figura 5.17. Detalhe perfil de encosta da Unidade A2. $\quad \mathbf{8 2}$

Figura 5.18 Unidade de landform A3. Colinas associadas a vales abertos. $\quad \mathbf{8 3}$

Figura 5.19. Unidade de landform A4. Morros de topos aplinados associadas a vales abertos. $\mathbf{8 3}$

Figura 5.20 - Detalhe Unidade de landform A5. Morro de topos arredondados e vertentes $\mathbf{8 4}$ convexas.

Figura 5.21 - Detalhe Unidade de landform A6. Morro de topos angulosos alongados na 84 direção NE/SW.

Figura 5.22 - Unidade de landform A7. Morros de topos arredondados a levemente 85 angulosos.

Figura 5.23 - Unidade de landform A8. Colinas de topos arredondados suaves. 
Figura 5.24. Unidade de landform B1. Morros de topos angulosos restritos e encosta 86 retilíneo-convexos.

$\begin{array}{ll}\text { Figura 5.25. Unidade de Landform B2. Morros de topos arredondados e restritos. } & \mathbf{8 7}\end{array}$

Figura 5.26. Unidade de Landform B3. Serras de topos angulosos extensos.

Figura 5.27. Unidade de Landfrom B4. a) Morros com topos angulosos restritos. b) Morros $\mathbf{8 8}$ com topos arredondados.

Figura 5.28. Unidade de landform B5. Detalhe encostas convexas e extensas voltadas para $\mathbf{8 9}$ oeste

Figura 5.28. Unidade de landform B5. Detalhe encostas convexas e extensas voltadas para 89 oeste

Figura 5.30. Unidade de landform B7. Morros de topos angulosos estreitos, encostas 90 convexo-retilíneas associadas a vales abertos

Figura 5.31 Unidade de lanform C1. Serras de topos angulosos, vertentes convexo- 91 retilíneas.

Figura 5.32 Unidade de landform C2. Morros de encostas convexas e topos anguloso, 92 associado a vales abertos.

Figura 5.33. Unidade de landform C3. Serras de topos angulosos a arredondados. Detalhe $\mathbf{9 2}$ dos perfis de encosta voltados para leste.

Figura 5.34. Unidade de landform C3. Detalhe forma dos topos angulosos e encosta 93 retililíneo-convexas.

Figura 5.35 Unidade de lanform C5. Serras de topos estreitos.Detalhe encostas retilíneas 93 voltadas para leste.

Figura 5.36. Unidade de landform C6. Serras de topos angulosos estreitos, encostas 94 convexo-retilíneas.

Figura 5.37 - Unidade de landform C7. Serras de topos angulosos restritos, vertentes 95 retilíneo-convexas.

Figura 5.38. Detalhe da Unidade de landfom D1. Serras de encostas retilíneo-convexas com 96 presença de ravinas.

Figura 5.39. Unidade de landfom D2. Colinas de encostas suavizadas associadas a vales $\mathbf{9 6}$ abertos.

Figura 5.40. Unidade de lanform D3. Morros de encostas convexas com inclinação média, 97 associados a vales abertos.

Figura 5.41. Unidade de lanform D4. Colinas de topos arredondados e encostas convexas. $\quad \mathbf{9 8}$

Figura 5.42. Unidade de landform D5. Morros de topos angulosos restritos e encostas $\mathbf{9 8}$ convexas.

Figura 5.43. Unidade de landform D6. a) Morros de topos arredondados e b) Morros de 99 topos angulosos.

Figura 5.44. Unidade de landform D7, conjunto de serras associadas a vales abertos. a) 100 Representação em Modelo Digital do Terreno, b) Detalhe encostas retilíneas.

Figura 5.45. Detalhe da unidade de landfom D8. Serras de topo anguloso e encostas 101 retilíneas.

Figura 5.46. Unidade de landfom D9. Serras de topo anguloso de encostas desiguais. a) 101 Encostas retilíneas e b) Encostas convexas.

Figura 5.47. Unidade de landfom D10. Morros de topo anguloso de encostas retilíneas. 102

Figura 5.48.Unidade de landfom D11. Vale abertos com desenvolvimento de planície 102 aluvionar.

Figura 5.49. Unidade de landform E1. Morros de topos angulosos.

Figura 5.50. Unidade de landform E2. Serras de topos arredanodados associadas a vales 104 abertos.

Figura 5.51. Unidade de landform E3. Morors de topos arredanodados e encostas convexo- 104 retilíneas.

Figura 5.52. Unidade de landform E4. a) Serras com perfil de encostas retilíneo voltado para $\mathbf{1 0 5}$ o norte e oeste e b) Perfil convexo-retilíneo voltados para o sul e leste. 
Figura 5. 53. Unidade de landform E5. Morros e vales abertos.

Figura 5. 54. Unidade de landform E6. Morros de topos angulosos e encostas retilíneo- 106 convexas.

Figura 5.55. Unidade de landform E7. Morros de topos arredondados extensos com perfis 107 de encostas são convexo-retilíneos suaves.

Figura 5.56 -Unidade de lanform E8. Colinas de topos arredondados extenssos e encostas 107 convexas suaves.

Figura 5.57. Fluxograma com as etapas desenvolvidas para elaboração do Mapa de 109 Unidades de Materiais Inconsolidados.

Figura 5.58. Fluxograma do ensaio de adsorção de azul de metileno pelo Método do Papel 112 de Filtro (Pejon, 1992).

Figura 5.59. Coleta de amostra indeformada para execução dos ensaios de absorção de $\mathbf{1 1 4}$ águas e perda por imersão.

Figura 5.60. Esquema ilustrativo do equipamento utilizado na execução do ensaio de $\mathbf{1 1 4}$ absorção de água (Pejon, 1992).

Figura 5.61. Ilustração do conjunto anel/solo imerso em recipiente com água para $\mathbf{1 1 5}$ execução do ensaio de perda de massa por imersão.

Figura 5.62.A) Ocorrência de materiais retrabalhados presente sobre residuais sem linha de $\mathbf{1 1 8}$ seixo.B) Linha de seixos separando materiais retrabalhados e residuais.

Figura 5.63. Detalhe de afloramento de materiais residuais de Granitos cataclsaos. $\quad 119$

Figura 5.64. Perfil de solo e rocha alterada de ReGrp. Variações de cor caracterizando 121 composição da rocha original.

Figura 5.65. A)Perfil de solo e rocha alterada de ReGr-Gn. B) Detalhe rocha alterada 122 diferenças de coloração porção gnaissificada.

Figura 5.66. A) Perfil de solo ReQtz. Gradação entre rocha alterada e solos bem $\mathbf{1 2 4}$ desenvolvido. B) Detalhe rocha alterada de quartzitos impuros.

Figura 5.67. Movimento de massa gravitacional tipo creeping comum em solos da undade $\mathbf{1 2 4}$ ReQtz1.

Figura 5.68. A) Exposição de rocha quatzítica e solos residuais de gnaisse intercalados com 126 quartzitos, B) diferença de cores caracterizando porções quartziticas e gnáissicas.

Figura 5.69. Exposição de pacote de solos residuais de gnáissicas intercalados com 127 quatzto.

Figura 5.70 Detalhe ocorrência de rocha sã a alterada de gnaisses intercaladas com 127 quartzito, sem presença de solos desenvolvidos.

Figura 5. 71. Afloramento de solos residuais de Gnaisses intercaldos com rochas básica

Figura 5. 72. Afloramento rocha alterada de gnaisses intercalados com rochas básicas em $\mathbf{1 3 0}$ envolta em massa de solo.

Figura 5. 73 A e B. Exemplos da ocorrência de variações de cores em gnaisses intercalados $\mathbf{1 3 0}$ com rochas básicas alterados, delimitando alternância de bandas mais ricas em quartzo e feldspato, e ricas em biotitas.

Figura 5.74 Veio de quartzo disposto em meio a massa de solo de gnaisses intercalados 131 com rochas básicas.

Figura 5. 75 A) Afloramento de solos de migmatitos bem desenvolvidos. B). Detalhe da 133 predominância de tons laranjas.

Figura 5. 76 Diferença de coloração observada em afloramentos de solos de migmatito 133 resultante das difrenças de concentração mineralógica da rocha.

Figura 5. 77 Movimentos de massa gravitacional tipo creeping, comum em solos de 134 migmatito que apresentam foliação verticalizada e vegetação original removida.

Figura 5. 78 A) Afloramento de solos de ultramilonitos caracterizado pela ocorrência de $\mathbf{1 3 5}$ intercalações de pacotes de solo e rochas pouco a muito alteradas $\mathrm{B}$ e C) Detalhe de porções pouco alteradas envoltas na massa de solo. 
Figura 5.79 A) Afloramento de solos de Blastomilonitos B).Detalhe da ocorrência de 137 rocha alterada ladeada por solo residual.

Figura 5.80 - Etapas executadas na obtenção do Mapa de Uso e Ocupação. 139

Figura 5.81 - Exemplo de ocorrência em campo da classe temática área urbana. $\quad 141$

Figura 5.82 - Exemplo de ocorrência em campo da classe temática cana-de-açúcar estágio 141 de crescimento.

Figura 5.83 - Exemplo de ocorrência em campo da classe temática café.

Figura 5.84 - Exemplo de ocorrência em campo da classe temática outras culturas 142 (exemplo milho).

Figura 5.85 -Exemplo de ocorrência em campo da classe temática mata. A) Mata nativa 142 fechada e B)Mata nativa esparsa

Figura 5.86- Exemplo de ocorrência em campo da classe temática mata ciliar.

Figura 5.87 - Exemplo de ocorrência em campo da classe temática pastagem.

Figura 5.88 - Exemplo de ocorrência em campo da classe temática solo exposto.

Figura 5.89 - Exemplo de ocorrência em campo da classe temática reflorestamento.

Figura 5.90 - Exemplos de amostras de treinamento identificadas na composição de $\mathbf{1 4 5}$ bandas 4-5-3 (observar áreas demarcadas com o quadrado vermelho).

Figura 6.1 A) Projeto criado para informações do meio físico da bacia. B) Banco de Dados 149 associado ao Projeto.

Figura 6.2 Exemplo de criação de modelo temático associado a informações do meio 150 físico da bacia. B) Atribuição de escala e resolução as informações contidas no PI da categoria criada.

Figura 6.3 A) Mensagem de erro informativa de incoerência no programa a ser executado. 151 B) Informação da linha do programa em que se encontra a incoerência.

Figura 6.4 - Etapas executadas para obtenção da Carta de Declividade da bacia.

Figura 6.5 - Módulo de execução e obtenção de dados de declividade no SPRING.

Figura 6.6 - Etapas do procedimento de fatiamento para obtenção de documento 159 temático a partir de superfície numérica.

Figura 6.7 - Exemplo do resultado de uma operação de fatiamento de uma grade 159 numérica (manual SPRING).

Figura 6.8 - Representação numérica fuž̃y da Declividade da Bacia.

Figura 6.9 - Detalhe da representação numérica fu₹:y dos valores de declividade da bacia. 163

Figura 6.10 - Etapas de importação de dados como Amostras MNT. 164

Figura 6.11 - Operação de elaboração de mapa de distancia. $\quad 165$

Figura 6.12 - Detalhe da grade de distância construída a partir dos dados representativos 166 da rede de drenagem da bacia.

Figura 6.13 - Representação temática das faixas de distância regularmente distribuídas ao longo da rede de drenagem da bacia.

Figura 6.14 - Representação numérica fur:y das faixas de distância regularmente 169 distribuídas ao longo da rede de drenagem da bacia.

Figura 6.15 - Detalhe da representação numérica furayy dos valores das classes de $\mathbf{1 7 0}$ densidade de drenagem da bacia.

Figura 6.16 -Relações de contato verificadas entre unidades do substrato rochoso da $\mathbf{1 7 2}$ bacia. A) Contato abrupto, B) Contato homogêneo, C) Contato heterogêneo e D) Região de contato complexo - destacada em vermelho.

Figura 6.17 - Etapas de edição vetorial de polígonos representativos de unidades temáticas 175

Figura 6.18 - Etapas transformação de dados temáticos vetorias para representação 176 matricial.

Figura 6.19 - Exemplo de unidade com relações gradativas diferentes ao longo da $\mathbf{1 7 6}$ extensão de sua linha de contato.

Figura 6.20 Representação numérica fuz:y de relações de contato heterogêneo gradativo. 180 Faixa interna 250 metros e externa 200 metros.

Figura 6.21 -Representação numérica de relação de contato homogêneo abrupto. 
Figura 6.22 -Representação numérica de relação de contato gradativo homogêneo 181 abrupto. Faixas contatos homogêneos interno/externo de 200 metros e 100 metros.

Figura 6.23 - Exemplo de operação de análise AHP no sistema SPRING.

Figura 6.24 - Exemplo de disposição dos atributos constituintes da informação substrato rochoso em classes crescentes de importância quanto ao aumento do escoamento superficial.

Figura 6.25 - A) Exemplo de agrupamento de unidades representativas de classe de 186 importância alta. B) Detalhe zona de gradação da classe apresentada.

Figura 6.26 - Representação numérica fuz:y das classes de influencia dos atributos 187 gênese/textura dos materiais inconsolidados frentes ao aspecto de susceptibilidade a erosão.

Figura 6.27 - A) Exemplo da ocorrência de regiões anômalas de distribuição contínua de valores entre classes de influência. B) Detalhe de região anômala caracterizada por valores de influência muito alta entre as classes adjacentes, baixa e média.

Figura 6.28 - Exemplo de operação de estatística de imagem por polígono.

Figura 6.29 - Exemplo operação de medida de classe em imagem temática matricial 189

Figura 6.30 - Representação numérica fuz:yy do potencial ao escoamento da Bacia do Rio 193 do Peixe.

Figura 6.31 - Representação numérica fu₹:yy susceptibilidade a erosão da Bacia do Rio do Peixe.

Figura 6.32 - Representação numérica fuž̃y do potencial agrícola da Bacia do Rio do 202 Peixe.

Figura 7.1 - A)Penetrômetro de impacto com sonda espiral de TDR. B) Esquema da haste 206 do penetrômetro de impacto com sonda espiral TDR (Vaz \& Hopmans, 2001).

Figura 7.2 - Detalhe da sonda espiral de TDR. Fios metálicos envoltos em um material 206 plástico duro (Kevlar-Nylon).

Figura 7.3 - Equipamentos utilizados para aquisição de medidas de $\varepsilon_{\mathrm{b}}$ e $\theta$ em campo.

Figura 7.4 - Exemplo de formas de ondas geradas pelo TDR e analisada pelo software 208 WinTDR 6.0 (Or et al, 2001).

Figura 7.5 - Alocação dos pontos de ensaio de resistência a penetração nos solos 212 presentes na Bacia do Rio do Peixe.

Figura 7.6 - Exemplo de medida de penetração lida na haste do penetrômetro. a) posição 213 inicial; b)posição final da primeira leitura, correspondente a penetração de 0-6 cm; c) posição final da segunda leitura, correspondente a penetração de 6-11,5 cm (Stolf et all, 1983).

Figura 7.7 - Ensaio de medida de resistência a penetração realizada em campo. 214

Figura 7.8 - Detalhe cravação do penetrômetro em ensaios de campo. 214

Figura 7.9 - Valores de NTG e umidade média X tipos de ocupação dos materiais 218 residuais de granitos porfiríticos (ReGrP).

Figura 7.10 - Valores de NTG e umidade média X tipos de ocupação dos materiais 218 residuais de gnaisses intercalados com rochas básicas (ReGnB)..

Figura 7.11 - Valores de NTG e umidade média X tipos de ocupação dos materiais 219 residuais intercalados com quartzitos (ReGnQ).

Figura 7.12 - Valores de NTG e umidade média X tipos de ocupação dos materiais 219 residuais de migmatitos (ReMig).

Figura 7.13 - Valores de NTG e umidade média X tipos de ocupação dos materiais 220 residuais de ultramilonitos (ReUtm)..

Figura 7.14 - Valores de NTG e umidade média X tipos de ocupação dos materiais 220 residuais de blastomilonitos (ReBtm).

Figura 7.15 - Correlação NGT X Umidade média para os materiais inconsolidados 221 residuais de granitos porfiríticos (ReGrP). 
Figura 7.16 - Correlação NGT X Umidade média para os materiais inconsolidados 222 residuais de gnaisses intercalados com rochas básicas (ReGnB).

Figura 7.17 - Correlação NGT X Umidade média para os materiais inconsolidados 222 residuais de gnaisses intercalados com quartzitos (ReGnQ).

Figura 7.18 - Correlação NGT X Umidade média para os materiais inconsolidados 223 residuais de migmatitos (ReMig).

Figura 7.19 - Correlação NGT X Umidade média para os materiais incosolidados residuais 223 de ultramilonitos (ReUtm).

Figura 7.20 - Correlação NGT X Umidade média para os materiais incosolidados residuais 224 de blastomilonitos (ReBtm).

Figura 7.21 - Comportamento da resistência a penetração frente as práticas de pastagem, 226 café e outras culturas nos materiais residuais de gnaisses intercalados com rochas básicas $(\mathrm{ReGnB})$.

Figura 7.22 - Comportamento da resistência a penetração frente as práticas de pastagem, 228 café e outras culturas nos materiais residuais de granitos porfiríticos (ReGrP).

Figura 7.23 - Comportamento da resistência a penetração frente as práticas de pastagem, 228 café e outras culturas nos materiais residuais de migmatitos (ReMig).

Figura 7.24 - Comportamento da resistência a penetração frente as práticas de pastagem, 229 café e outras culturas nos materiais residuais de ultramilonitos (ReUtm).

Figura 7.25 - Comportamento da resistência a penetração frente as práticas de pastagem, 229 café e outras culturas nos materiais residuais de blastomilonitos (ReBtm).

Figura 8.1 - Percentual de ocorrência das classes de uso e ocupação na Unidade 234 Geoambiental I.

Figura 8.2 - Percentual de ocorrência das classes de uso e ocupação na Unidade 236 Geoambiental II.

Figura 8.3 - Percentual de ocorrência das classes de uso e ocupação na Unidade 238 Geoambiental III.

Figura 8.4 - Percentual de ocorrência das classes de uso e ocupação na Unidade 240 Geoambiental IV.

Figura 8.5 - Percentual de ocorrência das classes de uso e ocupação na Unidade 243 Geoambiental V.

Figura 8.6 - Percentual de ocorrência das classes de uso e ocupação na Unidade 245 Geoambiental VI.

Figura 8.7 - Percentual de ocorrência das classes de uso e ocupação na Unidade 247 Geoambiental VII.

Figura 8.8 - Percentual de ocorrência das classes de uso e ocupação na Unidade 250 Geoambiental VIII.

Figura 8.9 - Percentual de ocorrência das classes de uso e ocupação na Unidade 252 Geoambiental IX.

Figura 8.10 - Percentual de ocorrência das classes de uso e ocupação na Unidade 254 Geoambiental X.

Figura 8.11 - Percentual de ocorrência das classes de uso e ocupação na Unidade 256 Geoambiental XI.

Figura 8.12 - Percentual de ocorrência das classes de uso e ocupação na Unidade 259 Geoambiental XII.

Figura 8.12 - Percentual de ocorrência das classes de uso e ocupação na Unidade 261 Geoambiental XII.

Figura 8.14 - Percentual de ocorrência das classes de uso e ocupação na Unidade 263 Geoambiental XIV.

Figura 8.15 - Percentual de ocorrência das classes de uso e ocupação na Unidade 265 Geoambiental XV.

Figura 8.16 - Percentual de ocorrência das classes de uso e ocupação na Unidade 267 Geoambiental XVI. 
Figura 8.17 - Percentual de ocorrência das classes de uso e ocupação na Unidade 269 Geoambiental XVII.

Figura 8.18 - Percentual de ocorrência das classes de uso e ocupação na Unidade 272 Geoambiental XVIII.

Figura 8.19 - Percentual de ocorrência das classes de uso e ocupação na Unidade 274 Geoambiental XIX.

Figura 8.20 - Percentual de ocorrência das classes de uso e ocupação na Unidade 276 Geoambiental XX.

Figura 8.21 - Percentual de ocorrência das classes de uso e ocupação na Unidade 278 Geoambiental XXI.

Figura 8.22 - Percentual de ocorrência das classes de uso e ocupação na Unidade 281 Geoambiental XXII.

Figura 8.23 - Percentual de ocorrência das classes de uso e ocupação na Unidade 283 Geoambiental XXIII.

Figura 8.24 - Percentual de ocorrência das classes de uso e ocupação na Unidade 285 Geoambiental XXIV.

Figura 8.25 - Percentual de ocorrência das classes de uso e ocupação na Unidade 287 Geoambiental XXV.

Figura 8.26 - Percentual de ocorrência das classes de uso e ocupação na Unidade 290 Geoambiental XXVI.

Figura 8.27 - Percentual de ocorrência das classes de uso e ocupação na Unidade 292 Geoambiental XXVII.

Figura 8.28 - Percentual de ocorrência das classes de uso e ocupação na Unidade 294 Geoambiental XXVIII.

Figura 8.29 - Percentual de ocorrência das classes de uso e ocupação na Unidade 296 Geoambiental XXIX.

Figura 8.30 - Percentual de ocorrência das classes de uso e ocupação na Unidade 299 Geoambiental XXX.

Figura 8.31 - Percentual de ocorrência das classes de uso e ocupação na Unidade 301 Geoambiental XXXI.

Figura 8.32 - Percentual de ocorrência das classes de uso e ocupação na Unidade 303 Geoambiental XXXII.

Figura 8.33 - Percentual de ocorrência das classes de uso e ocupação na Unidade 305 Geoambiental XXXIII.

Figura 8.34 - Percentual de ocorrência das classes de uso e ocupação na Unidade 307 Geoambiental XXXIV.

Figura 8.35 - Percentual de ocorrência das classes de uso e ocupação na Unidade 309 Geoambiental XXXV.

Figura 8.36 - Percentual de ocorrência das classes de uso e ocupação na Unidade 312 Geoambiental XXXVI.

Figura 8.37 - Percentual de ocorrência das classes de uso e ocupação na Unidade 314 Geoambiental XXXVII.

Figura 8.38 - Percentual de ocorrência das classes de uso e ocupação na Unidade 316 Geoambiental XXXVIII.

Figura 8.39 - Percentual de ocorrência das classes de uso e ocupação na Unidade 318 Geoambiental XXXIX.

Figura 8.40 - Percentual de ocorrência das classes de uso e ocupação na Unidade 320 Geoambiental XL.

Figura 8.40 - Percentual de ocorrência das classes de uso e ocupação na Unidade 323 Geoambiental XL.

Figura 8.42 - Percentual de ocorrência das classes de uso e ocupação na Unidade 325 Geoambiental XLII. 


\section{LISTA DE TABELAS}

Tabela 2.1 - A) Processos do Meio Físico. B) Atividades modificadoras do meio 5 relacionadas aos processos tecnológicos (modificado de Collares, 1996).

Tabela 2.2 - Alguns dos atributos fundamentais ao Zoneamento Geoambiental, e a $\mathbf{1 8}$ formas de obtenção dos mesmos. (modificado de Zuquette et al., 1997).

Tabela 2.3 - Parâmetros que condicionam o input de energia, as características 20 intrínsecas a bacia e as prováveis respostas às mudanças no sistema (Rawat, 1987 apud Collares, 1996).

Tabela 2.4 - Geoindicadores: influência natural X influência humana (ITC, 1996). 26

Tabela 3.1 - Levantamento de vegetação nativa na área da bacia do Rio do Peixe 46 (modificado de Mion \& Cavaleire, 1999).

Tabela 3.2 - Dados Populacionais da Bacia do Rio do Peixe. Número de Habitantes, 49 Percentual de Habitantes e Taxa Geométrica de Crescimento Anual (IBGE, 2002).

Tabela 3.3 - Dados de População Urbana e Rural nos Municípios da Bacia no ano de $\mathbf{5 0}$ 2000 (IBGE, 2002).

Tabela 3.4 - Distribuição em Área das Lavouras Temporária e Permanente nos 53 Municípios da Bacia(IBGE, 2002).

Tabela 3.5- Distribuição em Área e Produção de Café e Laranja na Bacia (IBGE, 54 2002).

Tabela 3.6 - Distribuição em Área e Produção de Cana-de-Açúcar, Milho e Batata- 55 Inglesa na Bacia (IBGE, 2002).

Tabela 5.1 - Atributos para classificação dos tipos de terreno (IPT, 1981).

Tabela 5.2 - Atributos utilizados na caracterização das formas de relevo da bacia $\mathbf{7 9}$ (adaptado de Saraiva, 1995).

Tabela 5.3 - Caracterização geral das unidades de materiais inconsolidados da Bacia 117 Hidrográfica do Rio do Peixe.

Tabela 5.4. Dados dos ensaios de caracterização realizados em amostra de Materiais 118 Retrabalhados.

Tabela 5.5. Dados dos ensaios de caracterização realizados em amostra de Materiais 119 Residuais de Granitos Cataclasados.

Tabela 5.6. Correlação entre subunidade de materiais inconsolidados residuais de $\mathbf{1 2 0}$ granitos porfiríticos e unidades de lanforms.

Tabela 5.7. Dados dos ensaios de caracterização realizados em amostra de Materiais $\mathbf{1 2 0}$ Residuais de Granitos Porfiríticos.

Tabela 5.8. Correlação entre unidade de materiais inconsolidados residuais de $\mathbf{1 2 1}$ granitos-gnaisses e unidade lanforms.

Tabela 5.9 Dados dos ensaios de caracterização realizados em amostra de Materiais $\mathbf{1 2 2}$ Residuais de Granitos-Gnaisses.

Tabela 5.10. Correlação entre unidade de materiais inconsolidados residuais de $\mathbf{1 2 2}$ quartzitos impuros e unidade lanforms.

Tabela 5.11 - Dados dos ensaios de caracterização realizados em amostra de Materiais $\mathbf{1 2 3}$ Residuais de Quartzitos Impuros.

Tabela 5.12. Correlação entre unidade de materiais inconsolidados residuais de $\mathbf{1 2 5}$ gnaisses intercalados com quartzitos e unidade lanforms.

Tabela 5.13. Dados dos ensaios de caracterização realizados em amostras de Materiais $\mathbf{1 2 5}$ Residuais deGnaisses intercalados com Quartzitos. 
Tabela 5.14. Correlação entre unidade de materiais inconsolidados residusi de $\mathbf{1 2 8}$ Gnaisses intercalados a rochas básicas e unidade lanforms.

Tabela 5.15 Dados dos ensaios de caracterização realizados em amostra de Materiais 128 Residuais de Gnaisses intercalados Rochas Básicas.

Tabela 5.16 Correlação entre unidade residuais de materiais inconsolidados de $\mathbf{1 3 1}$ migmatitos e unidade lanforms.

Tabela 5.17 Dados dos ensaios de caracterização realizados em amostra de Materiais 132 Residuais de Migmatitos.

Tabela 5.18 Correlação entre unidade de materiais inconsolidados residuais de $\mathbf{1 3 4}$ ultramilonitos e unidade lanforms.

Tabela 5.19 Dados dos ensaios de caracterização realizados em amostra de Materiais $\mathbf{1 3 5}$ Residuais de Ultramilonitos.

Tabela 5.20 Correlação entre unidade de materiais inconsolidados residuais de $\mathbf{1 3 6}$ Blastomilonitos e unidade lanforms.

Tabela 5.21 Dados dos ensaios de caracterização realizados em amostra de Materiais 137 Residuais de Blastomilonitos.

Tabela 5.22 Tipos de uso e ocupação levantados na Bacia do Rio do Peixe para serem 140 utilizados como amostras de treinamento na classificação supervisionada.

Tabela 5.23 - Dados referentes à extensão das classes de uso e ocupação na Bacia do 146 Rio do Peixe.

Tabela 6.1 - Valores de Declividade (\%) que delimitam a ocupação do meio físico 160 (adaptado de Zuquette, 1987).

Tabela 6.2 - Classes de Declividade e valores de ocorrência em área.

Tabela 6.3 - Relações de transição estabelecidas a partir de critérios de formas de $\mathbf{1 7 4}$ terreno

Tabela 6.4 - Escala AHP de comparação par a par (SAAty, 1978)

Tabela 6.5 - Ordenação das informações do meio físico e distribuição dos atributos 190 em classes crescentes de influência.

Tabela 6.6 - Matriz de comparação pareada e pesos de ponderação de cada 190 informação.

Tabela 6.7 - Valores medida de classe temática e estatística de imagem por polígono. 194

Tabela 6.8 - Ordenação das informações do meio físico e distribuição dos atributos 194 em classes crescentes de influência.

Tabela 6.9 - Matriz de comparação pareada e pesos de ponderação de cada 195 informação.

Tabela 6.10 - Valores medida de classe temática e estatística de imagem por polígono. 196

Tabela 6.11 - Ordenação das informações do meio físico e distribuição dos atributos $\mathbf{1 9 8}$ em classes crescentes de influência.

Tabela 6.12 - Matriz de comparação pareada e pesos de ponderação de cada 198 informação.

Tabela 6.13 - Valores medida de classe temática e estatística de imagem por polígono. 201

Tabela 7.1. Coeficientes de determinação $\left(\mathrm{r}^{2}\right)$ e coeficiente de ajuste polinomial de $3^{\circ} \mathbf{2 1 0}$ grau $\left(\boldsymbol{\theta}=\mathrm{a}+\mathrm{b} \boldsymbol{\varepsilon}+\mathrm{c} \varepsilon^{2}+\mathrm{d} \boldsymbol{\varepsilon}^{3}\right)$ para solos arenosos e argilosos.

Tabela 7.2 - Relação dos pontos ensaiados por tipo de solo e uso de terreno vigente. $\quad 213$

Tabela 7.3 - Caracterização geral dos solos com registro de ensaio de resistência a 216 penetração.

Tabela 7. 4 - Relação de Valores NTG x Umidade volumétrica média, para os 217 diferentes tipos de solos, e atividades de ocupação do terreno.

Tabela 7.5 - Valores de correlação NTG x Umidade por tipo de ocupação do terreno. 
Tabela 7.6 - Valores de correlação NTG x Umidade por tipo de solo e atividade de 226 ocupação do terreno.

Tabela 8.1 - Características de potencialidade e susceptibilidade do meio para unidade 232 $\mathrm{I}$

Tabela 8.2- Atributos do meio físico da unidade I

Tabela 8.3 - Características de potencialidade e susceptibilidade do meio para unidade 235 II.

Tabela 8.4- Atributos do meio físico da unidade II.

Tabela 8.5 - Características de potencialidade e susceptibilidade do meio para unidade 237 III.

Tabela 8.6- Atributos do meio físico da unidade III

Tabela 8.7 - Características de potencialidade e susceptibilidade do meio para unidade IV.

Tabela 8.8- Atributos do meio físico da unidade IV.

Tabela 8.9 - Características de potencialidade e susceptibilidade do meio para unidade 241 V.

Tabela 8.10- Atributos do meio físico da unidade V.

Tabela 8.11 - Características de potencialidade e susceptibilidade do meio para 244 unidade VI.

Tabela 8.12- Atributos do meio físico da unidade VI.

Tabela 8.13 - Características de potencialidade e susceptibilidade do meio para 246 unidade VII.

Tabela 8.14- Atributos do meio físico da unidade VII.

Tabela 8.15 - Características de potencialidade e susceptibilidade do meio para 248 unidade VIII.

Tabela 8.16- Atributos do meio físico da unidade VIII.

Tabela 8.17 - Características de potencialidade e susceptibilidade do meio para 250 unidade IX.

Tabela 8.18- Atributos do meio físico da unidade IX.

Tabela 8.19 - Características de potencialidade e susceptibilidade do meio para 253 unidade X.

Tabela 8.20- Atributos do meio físico da unidade X.

Tabela 8.21 - Características de potencialidade e susceptibilidade do meio para 254 unidade XI.

Tabela 8.22 - Atributos do meio físico da unidade XI.

Tabela 8.23 - Características de potencialidade e susceptibilidade do meio para 257 unidade XII.

Tabela 8.24- Atributos do meio físico da unidade XII.

Tabela 8.25 - Características de potencialidade e susceptibilidade do meio para 260 unidade XIII.

Tabela 8.26- Atributos do meio físico da unidade XIII.

Tabela 8.27 - Características de potencialidade e susceptibilidade do meio para 262 unidade XIV.

Tabela 8.28- Atributos do meio físico da unidade XIV.

Tabela 8.29 - Características de potencialidade e susceptibilidade do meio para 264 unidade XV.

Tabela 8.30- Atributos do meio físico da unidade XV.

Tabela 8.31 - Características de potencialidade e susceptibilidade do meio para 266 unidade XVI. 
Tabela 8.32- Atributos do meio físico da unidade XVI.

Tabela 8.33 - Características de potencialidade e susceptibilidade do meio para 268 unidade XVII.

Tabela 8.34- Atributos do meio físico da unidade XVII.

Tabela 8.35 - Características de potencialidade e susceptibilidade do meio para 270 unidade XVIII.

Tabela 8.36- Atributos do meio físico da unidade XVIII.

Tabela 8.37 - Características de potencialidade e susceptibilidade do meio para 273 unidade XIX.

Tabela 8.38- Atributos do meio físico da unidade XIX.

Tabela 8.39 - Características de potencialidade e susceptibilidade do meio para 274 unidade XX.

Tabela 8.40- Atributos do meio físico da unidade XX.

Tabela 8.41 - Características de potencialidade e susceptibilidade do meio para 277 unidade XXI.

Tabela 8.42- Atributos do meio físico da unidade XXI.

Tabela 8.43 - Características de potencialidade e susceptibilidade do meio para 279 unidade XXII.

Tabela 8.44- Atributos do meio físico da unidade XXII.

Tabela 8.45 - Características de potencialidade e susceptibilidade do meio para 282 unidade XXIII.

Tabela 8.46- Atributos do meio físico da unidade XXIII.

Tabela 8.47 - Características de potencialidade e susceptibilidade do meio para 284 unidade XXIV.

Tabela 8.48- Atributos do meio físico da unidade XXIV.

Tabela 8.49 - Características de potencialidade e susceptibilidade do meio para 286 unidade XXV.

Tabela 8.50- Atributos do meio físico da unidade XXV.

Tabela 8. 51 - Características de potencialidade e susceptibilidade do meio para unidade XXVI.

Tabela 8.52- Atributos do meio físico da unidade XXVI.

Tabela 8.53 - Características de potencialidade e susceptibilidade do meio para 291 unidade XXVII.

Tabela 8.54- Atributos do meio físico da unidade XXVII.

Tabela 8.55 - Características de potencialidade e susceptibilidade do meio para 293 unidade XXVIII.

Tabela 8.56- Atributos do meio físico da unidade XXVIII.

Tabela 8.57 - Características de potencialidade e susceptibilidade do meio para 295 unidade XXIX.

Tabela 8.58- Atributos do meio físico da unidade XXIX.

Tabela 8.59 - Características de potencialidade e susceptibilidade do meio para 297 unidade XXX.

Tabela 8.60- Atributos do meio físico da unidade XXX.

Tabela 8.61 - Características de potencialidade e susceptibilidade do meio para $\mathbf{3 0 0}$ unidade XXXI.

Tabela 8.62- Atributos do meio físico da unidade XXXI.

Tabela 8.63 - Características de potencialidade e susceptibilidade do meio para $\mathbf{3 0 2}$ unidade XXXII.

Tabela 8.64- Atributos do meio físico da unidade XXXII. 
Tabela 8.65 - Características de potencialidade e susceptibilidade do meio para 304 unidade XXXIII.

Tabela 8.66- Atributos do meio físico da unidade XXXIII.

Tabela 8.67 - Características de potencialidade e susceptibilidade do meio para 306 unidade XXXIV.

Tabela 8.68- Atributos do meio físico da unidade XXXIV.

Tabela 8.69 - Características de potencialidade e susceptibilidade do meio para $\mathbf{3 0 8}$ unidade XXXV.

Tabela 8.70- Atributos do meio físico da unidade XXXV.

Tabela 8.71 - Características de potencialidade e susceptibilidade do meio para $\mathbf{3 1 0}$ unidade XXXVI.

Tabela 8.72- Atributos do meio físico da unidade XXXVI.

Tabela 8.73 - Características de potencialidade e susceptibilidade do meio para $\mathbf{3 1 2}$ unidade XXXVII.

Tabela 8.74- Atributos do meio físico da unidade XXXVII.

Tabela 8.75 - Características de potencialidade e susceptibilidade do meio para 315 unidade XXXVIII.

Tabela 8.76- Atributos do meio físico da unidade XXXVIII.

Tabela 8.77 - Características de potencialidade e susceptibilidade do meio para 316 unidade XXXIX.

Tabela 8.78- Atributos do meio físico da unidade XXXIX.

Tabela 8.79 - Características de potencialidade e susceptibilidade do meio para 319 unidade XL.

Tabela 8.80- Atributos do meio físico da unidade XL.

Tabela 8.81 - Características de potencialidade e susceptibilidade do meio para 321 unidade XLI.

Tabela 8.82- Atributos do meio físico da unidade XLI.

Tabela 8.83 - Características de potencialidade e susceptibilidade do meio para $\mathbf{3 2 3}$ unidade XLII.

Tabela 8.84- Atributos do meio físico da unidade XLII. 


\section{LISTA DE QUADROS}

Quadro 5.1 - Unidades Litológicas que compõem o Substrato Rochoso da Bacia do 64 Rio do Peixe.

Quadro 5.2 - Sistemas e Unidades de Landoforms da Bacia do Rio do Peixe

Quadro 6.1 - Exemplo de programa em LEGAL

Quadro 6.2 - Resumo dos Limites críticos de ocupação do meio frente os valores de ocupação (adaptado de Zuquette, 1987).

Quadro 6.3 - Exemplo de programa LEGAL para espacialização contínua de relações de contatos gradativos.

Quadro 6.4 - Exemplo de programa LEGAL para espacialização contínua de relações 178 de contato abrupto. 


\section{LISTA DE SÍMBOLOS}

$\begin{array}{ll}\rho s & \text { Massa específica dos sólidos } \\ \rho d & \text { Massa específica seca de campo } \\ \underline{e}_{o} & \text { Índices de vazios natural } \\ \underline{n}_{0} & \text { Porosidade natural } \\ \text { CTC } & \text { Capacidade de troca catiônica dos materiais inconsolidados. } \\ \text { SE } & \text { Superfície específica } \\ \mathrm{E}_{40} & \text { Erodibilidade dos materiais inconsolidados } \\ \text { NTG } & \text { Número total de golpes executados } \\ \theta \text { méd } & \text { Umidade volumétrica média } \\ \mathrm{R}^{2} & \text { Coeficientes de correlação } \\ \text { SIG } & \text { Sistema de Iinformação geográfica } \\ \text { SPRING } & \text { Sistema de Processamento de Informações Geográficas } \\ \text { ABNT } & \text { Associação Brasileira de Normas Técnicas } \\ \text { IBGE } & \text { Instituto Brasileiro de Geografia e Estatísitica } \\ \text { LEGAL } & \text { Linguagem Espacial de Geoprocessamento Algébrico } \\ \text { INPE } & \text { Instituto Nacional de Pesquisas Espaciais }\end{array}$




\section{RESUMO}

SILVA, Sandra Fernandes da. Zoneamento Geoambiental com auxílio de Lógica Fuzzy e proposta de um geoindicador para caracterização do meio físico da Bacia do Rio do Peixe. 2005. Tese Doutorado- Escola de Engenharia de São Carlos, Universidade de São Paulo, São Carlos

O trabalho apresenta uma proposta metodológica para caracterização de aptidões e restrições do meio físico, considerando a variação contínua dos atributos e também a existência de gradação nos contatos entre as unidades. Os mapas do Substrato Rochoso e dos Materiais Inconsolidados foram obtidos utilizando-se de procedimentos da lógica fuzzy para representação da gradação nos contatos. As cartas de Declividade, de Menor Extensão do Percurso da Água Superficial, de Potencial de Escoamento Superficial, de Susceptibilidade à Erosão e de Potencial Agrícola foram obtidas utilizando-se mapas numéricos e a variação contínua dos atributos. Para realização das operações de geoprocessamento foram utilizados o sistema de informação geográfica SPRING e a linguagem de programação LEGAL, que permitiram, tanto a representação dos contatos gradacionais (fuzzy) quanto a classificação contínua e o cruzamento das informações. Para avaliação de alterações introduzidas no meio, foi proposta a aplicação do atributo resistência à penetração do solo como geoindicador ambiental. As medidas de resistência à penetração foram feitas utilizando-se um novo equipamento, que consiste de um penetrômetro de solo acoplado a uma sonda TDR. Este procedimento permitiu a caracterização de modificações das condições naturais de compactação dos solos da bacia, frente às atividades de uso do terreno vigentes, bem como forneceu um parâmetro para comparação frente a modificações de uso futuras. $\mathrm{O}$ zoneamento da área foi obtido a partir da adoção das unidades de lanforms como unidades de compartimentação, o que possibilitou a caracterização das aptidões, restrições e conflitos de uso.

Palavras chave: geoprocessamento, classificação contínua, compactação do solo, sonda TDR, aptidões e restrições do meio. 


\begin{abstract}
SILVA, Sandra Fernandes da. Geoenvironmental Zoning using Fuzzy logic and proposal of a geoindicador to characterize Rio do Peixe Basin Environment. 2005. Tese Doutorado- Escola de Engenharia de São Carlos, Universidade de São Paulo, São Carlos

This study presents a methodological technique to characterize environmental restrictions and aptitudes considering continuous variation in the attributes and gradation in contact between units. Fuzzy logic procedures were used to generate representation of contact gradation for Rocky Substratum and Unconsolidated Materials maps. Continuous attribute variation and numerical maps were used to produce Slope, Least Water Runoff Distance, Runoff Potential, Erosion Susceptibility and Agricultural Potential Charts. Geoprocessing operations using the SPRING Geographical Information System and its LEGAL programming language permitted the representation of gradation in contact (fuzzy), continuous classification and information crossing. Soil penetration resistance was proposed as the environmental geoindicator to evaluate environmental changes. Measurement of soil penetration resistance by a soil penetrometer connected to a TDR probe permitted the characterization and specification of natural basin soil compaction conditions and the comparison of different occupation activities on the soil. A parameter for future changes due to soil occupation was therefore identified by this procedure. Area Zoning was attained by the adoption of landform units as segmentation units. The characterization of aptitudes, restrictions and conflicts in occupation were achieved by this procedure.
\end{abstract}

Key words: Geoprocessing, Continuous Classification, Soil Compaction, TDR Probe, Environmental Aptitudes and Restrictions 
CAPÍTULO 1

\section{1. - INTRODUÇÃO}

Realizar um zoneamento geoambiental consiste em caracterizar uma área com relação às suas aptidões e restrições à atividades em desenvolvimento e/ou prováveis de serem implantadas na mesma. Permite também indicar porções do terreno com uma maior qualidade ambiental que possam ser preservadas (Grecchi, 1998). Esta caracterização é executada por meio da obtenção organizada de informações relativas ao meio físico, e constitui um instrumento que auxilia o planejamento e o ordenamento territorial. Processo que visa a adequação do uso, controle e proteção do ambiente às aspirações sociais e/ou governamentais, expressa em uma política ambiental.

O processo de zoneamento tem por resultado uma ordenação territorial em unidades ambientais com características homogêneas de uso intensivo, extensivo, de preservação e de uso múltiplo, que permitem orientar a ocupação do espaço e uso dos recursos.

Uma forma de elaborar um zoneamento geoambiental é com a aplicação de duas ferramentas de levantamento e caracterização de informações: a avaliação ambiental relativa aos atributos do meio físico e a avaliação de alterações introduzidas por atividade modificadoras.

O processo de avaliação ambiental de uma região permite identificar as potencialidades do meio quanto ao uso e ocupação, suas vulnerabilidades e seu desempenho futuro, além de orientar quanto às decisões relacionadas a sua preservação, conservação e desenvolvimento (Macedo, 1995). 
As informações obtidas no processo de avaliação ambiental são, tradicionalmente, representadas sob a forma de documentos cartográficos, os quais são elaborados com fundamentação em técnicas de lógica binária. Neste processo os contatos que delimitam a ocorrência espacial dos atributos do meio físico (solo, vegetação, litologia, etc) são definidos por linhas que representam limites bem definidos, precisos (Moreira et al, 2001). Esta representação precisa, rígida, passa ao usuário a idéia de que os limites entre os atributos do meio físico são sempre bem delimitados, e que as características das unidades retratadas são invariáveis espacialmente. Porém, sabe-se que em muitas situações os atributos do meio apresentam variações em sua ocorrência espacial, caracterizadas por transições gradacionais.

Entende-se que a representação de dados do meio físico por documentos elaborados com base na inferência da lógica binária não retrata as reais condições encontradas, e a análise dos mesmos para obtenção de uma avaliação ambiental, pode vir a acarretar a perda de informações importantes.

Uma forma de melhor retratar as reais condições de comportamento de ocorrência espacial de atributos do meio físico é com a aplicação de fundamentos de inferência de Lógica Fuž̨y na elaboração de documentos cartográficos. Esta técnica apresenta como vantagem a possibilidade de incorporar na representação dos contatos entre unidade de atributos do meio, informações sobre a natureza destes, assim como a incerteza associada à classificação e ao posicionamento dos mesmos (Burrough \& MacDonell 1998).

A caracterização de possíveis modificações das condições naturais do meio físico devido ao desenvolvimento de atividades antrópicas é possível mediante a utilização de geoindicadores, que segundo a Comission on Geological Science of Enviroment Planning (COGEOENVIROMENT 1992), consistem de atributos e/ou processos do meio capazes de servir como forma de identificação e quantificação de alterações no meio.

Um aspecto importante a ser considerado no uso desses, é que nem todos os geoindicadores eleitos pela COGEOENVIRONMENT (1992) têm ampla aplicabilidade, pois dependem de esferas de abordagem, como escala local e política. Isto faz com que em alguns casos, em função de condições peculiares do meio, torna-se necessário o estabelecimento ou proposição de novos atributos para serem utilizados como indicadores de modificações ambientais. 


\section{1 - OBJETIVOS}

\subsection{1 - Objetivo geral}

Em consideração aos aspectos anteriormente expostos, aqui é proposta uma metodologia a qual tem por objetivo principal a elaboração de um zoneamento geoambiental em uma bacia hidrográfica, em escala regional, a partir da consideração de aspetos relativos ao meio físico e de alterações introduzidas por atividades modificadoras de uso e ocupação do terreno, de forma disponibilizar um instrumento de auxílio na avaliação geoambiental, o qual informa sobre aptidões, restrições e conflitos de uso.

\subsection{2 - Objetivos específicos}

- Avaliar o uso de técnicas e aplicativos de geoprocessamento fundamentados na inferência de lógica furæ̧y para representação adequada das relações de transição entre unidades, assim como dos aspectos de variação espacial contínua de atributos para obtenção das características de potencialidades e suscetibilidades naturais do meio físico;

- Avaliar o sistema de informações geográficas SPRING como ferramenta computacional para aplicação da inferência de lógica furzy no modelamento das informações relativas os meio físico;

- Avaliar o uso do atributo resistência a penetração dos solos como geoindicador ambiental de alterações, para aferir e comparar os impactos decorrentes das atividades transformadoras presentes, em um mesmo intervalo de tempo.

- Avaliar a utilização do equipamento penetrômetro/sonda-TDR como meio de medida da resistência a penetração. 
CAPÍTULO 2

\section{2. - REVISÃO BIBLIOGRÁFICA}

\section{1 - O MEIO AMBIENTE E O PROCESSO DE AVALIAÇÃO AMBIENTAL}

Em estudos de natureza ambiental é importante compreender o termo "meio ambiente", seus componentes e suas inter-relações.

"O meio ambiente consiste na interação de componentes abióticos (rochas, ar e água), bióticos (vegetal e animal) e sociais e econômicos (humanos), considerados, respectivamente, em meio físico, biótico e sócioeconômico ou antrópico (Fornasari Filho \& Bitar, 1995)".

"O Meio ambiente consiste em um determinado espaço, onde ocorre a interação entre os componentes bióticos (fauna e flora), abióticos (águas, rocha e ar) e bióticosabióticos (solo) (ABNT, 1989)".

De acordo com Fornasari Filho \& Bitar (1995), os processos do ambiente podem ser divididos em:

- Processos do meio físico - decorrem de interações com predominância de componentes abióticos e referem-se ao desenvolvimento de sucessões de fenômenos potencializados pela interação de componentes materiais e tipos de energia, podendo ser deflagrado, acelerado ou retardado por agentes físicos, químicos e biológicos (fauna e flora).

- Processos tecnológicos - relacionam-se às interferências do homem no meio ambiente, sendo responsáveis pelas atividades modificadoras do mesmo.

As mudanças impostas ao meio ambiente, decorrentes da ação dos processos do meio físico ou dos processos tecnológicos caracterizam alterações ambientais. Tais 
alterações podem ser qualificadas e quantificadas, sendo ou não favoráveis ao ecossistema e à sociedade humana (Tommasi, 1994).

As Tabelas 2.1A e B apresentam os processos considerados do meio físico e atividades modificadoras do meio, relacionadas aos processos tecnológicos.

Para que uma área não venha a sofrer alterações em seus componentes, de forma significativa, torna-se necessário que a mesma seja submetida a um processo de avaliação ambiental

Tabela 2.1 - A) Processos do Meio Físico. B) Atividades modificadoras do meio relacionadas aos processos tecnológicos (modificado de Collares, 1996).

A) PROCESSOS DO MEIO FÍSICO

\begin{tabular}{l|l}
\hline Circulação de água no mar & Interações físico-químicas na água, solo e rocha \\
\hline Corrida de massa & Movimentação das águas de sub-superfície \\
\hline Deposição de sedimentos ou partículas & Movimento de bloco \\
\hline Erosão eólica & Potencialização e desencadeamento de sismos \\
\hline Erosão pela água & Processos pedogenéticos \\
\hline Escoamento das águas em superfície & Queda de detritos \\
\hline Escorregamento & Rastejo de solo \\
\hline \multicolumn{1}{c}{ B) ATIVIDADES MODIFICADORAS DO MEIO AMBIENTE } \\
\hline Aeroporto & Irrigação \\
\hline Agroindústria & Linha de transmissão \\
\hline Aterro sanitário & Mineração \\
\hline Barragens & Porto \\
\hline Canal e retificação de cursos d'água & Projeto urbanístico \\
\hline Dutovia & Unidade industrial \\
\hline Estrada de rodagem & Usina termoelétrica \\
\hline Ferrovia & \\
\hline
\end{tabular}

De acordo com Macedo (1995), o processo de avaliação ambiental de uma região permite identificar as potencialidades do meio quanto ao uso e ocupação, suas vulnerabilidades e seu desempenho futuro, além de orientar quanto às decisões relacionadas a sua preservação, conservação e desenvolvimento. Para o autor, a avaliação ambiental deve servir como ferramenta para avaliação das transformações ambientais de qualquer natureza, devendo conter três dimensões distintas e complementares, a saber:

- Avaliações relativas ao meio ambiente;

- Avaliações relativas às atividades transformadoras; e

- Avaliações relativas a ambos. 
Nos modelos de avaliação relativos ao ambiente são considerados não só a qualidade ambiental de um ecossistema, a qualidade de vida (específica do homem), os indicadores ambientais e o meio ambiente, como também suas compartimentações, sua representação e suas relações ambientais (troca de energia entre os fatores ambientais que constituem um ecossistema).

Nos modelos relativos às atividades transformadoras, consideram-se quaisquer processos, oriundos ou não da ação humana, capazes de alterar um ecossistema, em qualquer um de seus níveis.

Tais processos são denominados, de acordo com Macedo (1995) de:

- Fator de ameaça (quando causam adversidades ambientais, geram impactos negativos) e;

- Fator de oportunidade (quando causam benefício, geram impactos positivos).

Nos modelos de avaliação relativos a ambos, considera-se a implementação e a operação de uma atividade transformadora e as modificações na ordem e na complexidade dos ecossistemas susceptíveis à sua presença direta ou indireta. Dessa relação decorrem dois processos:

1) a intervenção ambiental - qualquer tipo de atividade que se instale numa determinada região e;

2) a alteração ambiental - nova configuração ambiental decorrente de pelo mesmo uma intervenção ambiental.

Macedo (1995) considera que o modelo de avaliação ambiental pode ser abordado de duas maneiras:

- Avaliação estrutural: a qual busca aferir e comparar os impactos ambientais decorrentes das atividades transformadoras distintas e suas relações ambientais em um mesmo intervalo de tempo, numa dada região;

- Avaliação temporal: a qual afere e compara os impactos ambientais referentes a dois cenários, atual e tendencial, com a mesma estrutura ambiental, em instantes distintos.

Estas formas de avaliação permitem que uma área seja avaliada com relação ao montante de alterações decorrentes das atividades transformadoras existentes e, em 
relação as alterações que uma dada região está submetida caso sejam implementadas novas atividades modificadoras no meio físico.

Um princípio importante que deve ser considerado no processo de avaliação ambiental de uma região é o planejamento ambiental, o qual consiste de um processo de obtenção organizada de informações, reflexão sobre problemas e potencialidades de uma região, definição de metas, objetivos e estratégias de ação, projetos e atividades, bem como a definição do sistema de monitoramento e avaliação a serem utilizados (Lanna, 1995). Este processo visa a adequação do uso, controle e proteção do ambiente às aspirações sociais e/ou governamentais, expressa em uma política ambiental.

Dentro deste processo merecem destaque o zoneamento ambiental e o zoneamento ecológico - econômico e a avaliação de impactos ambientais, os quais são tidos como instrumentos do planejamento ambiental e têm suas aplicações determinadas por lei.

\section{2. - LEIS AMBIEMTAIS}

As leis e políticas ambientais visam assegurar o desenvolvimento econômicosocial compatível com a conservação do meio ambiente, com a utilização dos recursos naturais, de maneira mais equilibrada e adequada. Dentre as diversas leis que objetivam manter a qualidade do meio e fazem referência à utilização adequada (preservação) dos recursos destacam-se:

- lei $\mathrm{N}^{\circ} 6.938$ (31 de agosto de 1981) - estabelece a política nacional do meio ambiente, seus fins e mecanismos de formulação e aplicação; e

- $\quad$ lei $\mathrm{N}^{\circ} 9.433$ (8 de janeiro de 1997) - estabelece a política nacional de recursos hídricos.

- $\quad$ Lei $n^{\circ} 4.771\left(15\right.$ de setembro de 1965)/Alterada pela Lei $n^{\circ} 7.803 / 89$ - estabelece o código florestal

\section{Politica Nacional do Meio Ambiente}

A política nacional do meio ambiente constitui o sistema nacional do meio ambiente. Tem por objetivos gerais a preservação, a melhoria e a recuperação da qualidade ambiental propícia à vida, com objetivo de assegurar no país, condições ao 
desenvolvimento socioeconômico, aos interesses da segurança nacional e a proteção da dignidade da vida humana.

Como objetivos mais específicos são apresentados:

1. Compatibilização do desenvolvimento econômico social com a preservação da qualidade do meio ambiente e do equilíbrio ecológico;

2. Definição de áreas prioritárias de organização governamental relativa à qualidade e ao equilíbrio ecológico, atendendo aos interesses da União, dos Estados, do Distrito Federal, do território e dos Municípios;

3. Estabelecimento de critérios e padrões da qualidade ambiental e das normas relativas ao uso e manejo de recursos ambientais;

4. Desenvolvimento de pesquisas e tecnologias nacionais orientadas para o uso racional de recursos ambientais; à difusão de tecnologias do meio ambiente, à divulgação de dados e informações ambientais e a formação de uma consciência pública sobre a necessidade de preservação da qualidade ambiental e do equilíbrio ecológico;

5. Preservação e restauração dos recursos ambientais com vistas à sua utilização racional e disponibilidade permanente, concorrendo para manutenção do equilíbrio ecológico propício à vida; e,

6. Imposição ao poluidor, da obrigação de recuperar e/ou indenizar os danos causados, e ao usuário, de contribuição pela utilização de recursos ambientais com fins econômicos..

Para a operacionalização e implementação da política nacional do meio ambiente foram instituídos instrumentos que são definidos pelo artigo $9^{\circ}$ da mesma, e são relacionados pelo decreto no 99224 de 06/06/90. Os doze instrumentos definidos são:

1. O estabelecimento de padrões de qualidade ambiental;

2. O zoneamento ambiental;

3. A avaliação de impactos ambientais;

4. O licenciamento e a revisão de atividades efetivas ou potencialmente poluidoras; 
5. Os incentivos à produção e instalação de equipamentos e a criação ou absorção de tecnologia voltada para a melhoria da qualidade ambiental;

6. A criação de espaços territoriais especialmente protegidos pelo poder público Federal, Estadual e Municipal, tais como áreas de proteção ambiental, de relevante interesse ecológico e reservas extrativistas;

7. O sistema nacional de informações sobre o meio ambiente;

8. O cadastro técnico federal das atividades e instrumentos de defesa ambiental;

9. As penalidades disciplinares ou compensatórias ao não cumprimento das medidas necessárias à preservação ou correção da degradação ambiental;

10. A instituição do relatório de qualidade do meio ambiente, a ser divulgado, anualmente, pelo Instituto Brasileiro do Meio Ambiente e Recursos Naturais Renováveis - IBAMA;

11. A garantia da prestação de informações relativas ao meio ambiente, obrigandose o Poder Público a produzi-las, quando inexistentes;

12. O cadastro técnico federal de atividades potencialmente poluidoras e/ou utilizadoras dos recursos ambientais.

Uma observação sobre a Política Nacional do Meio Ambiente que merece destaque é a determinação do zoneamento ambiental como instrumento da política nacional do meio ambiente.

\section{Política Nacional de Recursos Hídricos}

A Política Nacional de Recursos Hídricos criou o Sistema Nacional de Gerenciamento de Recursos Hídricos, estabelecendo os seguintes princípios gerais básicos para a gestão dos recursos hídricos:

1. A gestão por bacia hidrográfica;

2. A observância aos usos múltiplos;

3. O reconhecimento da água como valor econômico; 
4. A gestão descentralizada e participativa; e

5. O reconhecimento da água como bem finito e vulnerável.

Como fundamentos foram estabelecidos:

1. A água é um bem de domínio público,

2. Tratando-se de um recurso natural limitado, dotado de valor econômico; em situações de escassez, o uso prioritário dos recursos hídricos é o consumo humano e a dessedentação de animais; a gestão dos recursos hídricos deve sempre proporcionar o uso múltiplo das águas;

3. A bacia hidrográfica é a unidade territorial para implementação da Política Nacional de Recursos Hídricos e atuação do Sistema Nacional de Gerenciamento de Recursos Hídricos;

4. A gestão dos recursos hídricos deve ser descentralizada e contar com a participação do Poder Público, dos usuários e das comunidades.

A Política Nacional de Recursos Hídricos tem por objetivos: assegurar à atual e às futuras gerações a necessária disponibilidade de água, em padrões de qualidade adequados aos respectivos usos; garantir a utilização racional e integrada dos recursos hídricos, incluindo o transporte aquaviário, com vistas ao desenvolvimento sustentável; e, a prevenção e a defesa contra eventos hidrológicos críticos de origens naturais ou decorrentes do uso inadequado dos recursos naturais.

Para assegurar a implementação da política com o cumprimento de seus objetivos são tomados como diretrizes a gestão sistemática dos recursos hídricos, sem a dissociação dos aspectos de quantidade e qualidade; a adequação da gestão de recursos hídricos às diversidades físicas, bióticas, demográficas, econômicas, sociais e culturais das diversas regiões do País; a integração da gestão de recursos hídricos com a gestão ambiental; a articulação do planejamento de recursos hídricos com o dos setores usuário e com os planejamentos regionais, estaduais e nacionais; a articulação da gestão de recursos com o uso do solo; e, a integração da gestão das bacias hidrográficas com a dos sistemas estuarinos e zonas costeiras.

Como instrumentos da Política Nacional de Recursos Hídricos, a Lei 9433/97 estabeleceu: a) os planos de recursos hídricos b) a outorga de direito de uso dos recursos hídricos; c) a cobrança pelo uso dos recursos hídricos; d) o enquadramento dos corpos 
de água em classes de uso; e, e) o sistema nacional de informações sobre recursos hídricos.

Uma observação da Política nacional de Recursos hídricos que merece destaque é a determinação da bacia hidrográfica como unidade de gestão.

\section{Código Florestal}

O código florestal tem por objetivo geral reconhecer que as florestas são bens de interesse comum a todos os habitantes do País, instituindo como áreas de preservação permanente as florestas e demais formas de vegetação natural situadas nas seguintes regiões:

a) ao longo dos rios ou de qualquer curso d'água desde o seu nível mais alto em faixa marginal cuja largura mínima seja:

1 - de $30 \mathrm{~m}$ (trinta metros) para os cursos d'água de menos de $10 \mathrm{~m}$ (dez metros) de largura;

2 - de $50 \mathrm{~m}$ (cinqüenta metros) para os cursos d'água que tenham de 10 (dez) a $50 \mathrm{~m}$ (cinqüenta metros) de largura;

3 - de $100 \mathrm{~m}$ (cem metros) para os cursos d'água que tenham de 50 (cinqüenta) a $200 \mathrm{~m}$ (duzentos metros) de largura;

4 - de $200 \mathrm{~m}$ (duzentos metros) para os cursos d'água que tenham de 200 (duzentos) a $600 \mathrm{~m}$ (seiscentos metros) de largura;

5 - de $500 \mathrm{~m}$ (quinhentos metros) para os cursos d'água que tenham largura superior a $600 \mathrm{~m}$ (seiscentos metros). (Redação determinada pela Lei $\mathrm{n}^{\circ}$ $7.803 / 892$

b) Ao redor das lagoas, lagos ou reservatórios d'água naturais ou artificiais;

c) Nas nascentes, ainda que intermitentes e nos chamados "olhos d'água", qualquer que seja a sua situação topográfica, num raio mínimo de $50 \mathrm{~m}$ (cinqüenta metros) de largura (Redação determinada pela Lei n $\left.{ }^{\circ} 7.803 / 89\right)$;

d) No topo de morros, montes, montanhas e serras;

e) Nas encostas ou partes destas, com declividade superior a $45^{\circ}$, equivalente a $100 \%$ na linha de maior declive;

f) Nas restingas, como fixadoras de dunas ou estabilizadoras de mangues; 
g) Nas bordas dos tabuleiros ou chapadas

h) Em altitude superior a $1.800 \mathrm{~m}$ (mil e oitocentos metros), qualquer que seja a vegetação.Redação determinada pela Lei n ${ }^{\circ} 7.803 / 89$

\section{3. - ZONEAMENTO GEOAMBIENTAL}

Cendrero (1975) ressalta a importância dos estudos geoambientais, salientando que o planejamento, de acordo com a capacidade das unidades ambientais, permite o máximo uso dos recursos naturais de uma área com um mínimo de dano ambiental.

O zoneamento geoambiental pode ser caracterizado como um instrumento de auxílio no planejamento e no ordenamento territorial, seja em escala regional ou local, pois estudos desta natureza possibilitam a caracterização de áreas quanto às suas aptidões e restrições às atividades já em desenvolvimento e/ou prováveis de serem implantadas, além de indicar porções do terreno com uma maior qualidade ambiental que possam ser preservadas (Grecchi, 1998).

A autora (op cit) ressalta que de um modo geral, o zoneamento geoambiental pode ser entendido como uma aplicação da geologia ambiental, resultante da interação de caracterizações geológicas, geomorfológicas, hidrológicas, acrescida de informações sobre recursos naturais, científicos e culturais.

Para Montaño (2002) nos últimos anos o zoneamento ambiental tem se destacado como instrumento estratégico do planejamento regional. $\mathrm{O}$ autor ressalta que este é fortemente vinculado ao parcelamento do solo e definição de usos específicos.

Diegues (1998) destaca que "a base do gerenciamento geoambiental, entendida do prisma de ordenação territorial, é constituída pelas técnicas de zoneamento, resultando num plano de ocupação do espaço e uso dos recursos. Esse plano definirá as unidades ambientais em termos de área para uso intensivo, extensivo, de preservação e de uso múltiplo. O tipo de uso recomendável dependerá das vocações naturais, das restrições encontradas e das demandas por bens e serviços".

De acordo com Sobreira (1995), os estudos de natureza geoambiental apresentam três formas de abordagem distintas: planejamento e ordenamento territorial, análise dos perigos e riscos naturais e estudos de impactos ambientais (Figura 2.1). O autor ressalta ainda que as abordagens, apesar de distintas, apresentam-se interligadas, pois têm como problemática central à intervenção do homem na natureza. 
Para Jacinto (2003), o ordenamento territorial é um importante instrumento de gestão ambiental que deve ser aplicado dentro dos princípios do desenvolvimento sustentável.

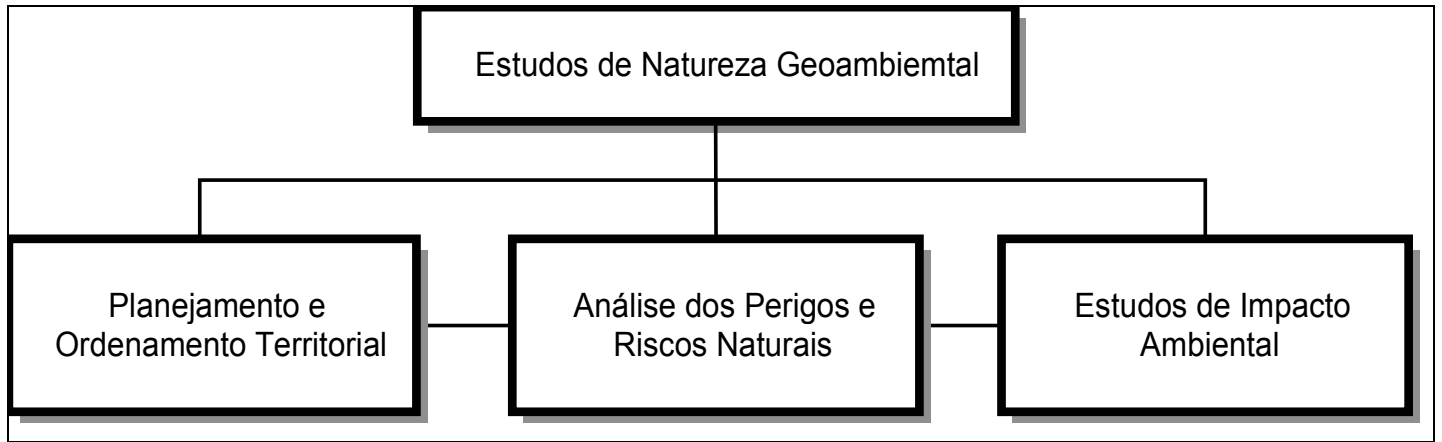

Figura 2.1 - Abordagens distintas dos estudos de natureza geoambiental (Sobreira, 1995).

Sobreira (1995), cita três etapas que devem ser atendidas em estudos de natureza geoambiental: 1) planificação - análise, diagnóstico e recomendação; 2) ordenamento normas estabelecidas com base na etapa anterior; e 3) manejo e gestão - implantação, acompanhamento e controle das atividades do uso do território.

Espinosa (1993) salienta que os estudos geoambientais são úteis ao planejamento territorial e surgem como necessidade frente a um crescimento intensivo e conseqüente comprometimento das águas, do ar e do solo como receptores de dejetos.

A importância de se considerar os elementos e processos naturais no planejamento ambiental está não só no auxílio à distribuição das atividades humanas, mas também nos possíveis impactos negativos que possam ocorrer (Francés, 1990 apud Sobreira, 1995). Outros objetivos mais específicos a serem considerados são a definição cartográfica de porções do terreno com maior qualidade ambiental que devam ser preservadas:

- A proposição de medidas de atuação direcionadas a melhorar, a recuperar ou a reabilitar os elementos e ou processos do meio natural que se encontrem degradados por atividades incompatíveis com sua vocação de uso (entendidas essas como atividades que causam menor rendimento do meio, causando deterioração desnecessária de seus parâmetros ambientais);

- A delimitação de áreas com elevada produtividade primária, cuja vocação de uso aconselhe sua exclusão do perímetro urbano, evitando sua consolidação ou deterioração por obras de infra-estrutura, polígonos industriais, etc; e 
- O estabelecimento de linhas de atuação para valorização dos recursos naturais insuficientemente aproveitados.

A cartografia geoambiental, como enfatizada por Grecchi (1998), é um importante instrumento de planejamento, seja de enfoque local ou regional, e pode suprir as solicitações ambientais dentro dos processos de planejamento e ordenamento territorial.

\subsubsection{Metodologias de Zoneamento Geoambiental}

Há uma grande diversidade de metodologias empregadas em trabalhos que visam o zoneamento geoambiental. Segundo Cendrero (1990), estas se diferenciam em função das características geológicas e climáticas, do nível de ocupação humana e das atividades predominantes em cada região onde são aplicadas.

Faria (1989, apud Sobreira, 1995) ressalta que, de uma maneira geral, as metodologias de ordenamento territorial podem ser divididas em dois grupos principais:

- Metodologias que apresentam as características geológicas como base para caracterização de domínios e obtenção de aptidões do terreno.

- Metodologias que consideram os aspectos geológicos de maneira não aprofundada.

Sobreira (1995) salienta que as metodologias, do primeiro e segundo grupos, apresentam como fator comum à representação dos territórios por meio de mapas de vários tipos, os quais servem de base para a orientação de decisões futuras dos organismos de planejamento.

Dentre as metodologias que utilizam as características geológicas como base para obtenção de aptidões do terreno merecem destaque as propostas de Cendrero (1975), Cendrero et al. (1983), Francés et all. (1992), Zuquette et al. (1997), Lopes (2000), Amorim (2003) e Fontes (2004).

Metodologia de Cendrero (1975)

Em seu trabalho, Cendrero (1975) faz comparações de feições geológicas ambientais com a capacidade de reuso e uso atual da terra e da água, obtendo desta 
forma um mapa de geologia ambiental. A capacidade das unidades é definida em termos de atividades humanas ou pelo uso das mesmas.

Nessa metodologia, os parâmetros considerados na obtenção e classificação das unidades ambientais incluem processos ativos, landforms, propriedades físicas do substrato rochoso e depósitos superficiais, assembléias biológicas e feições antrópicas. Podem ainda ser utilizados dados de solos, de produtividade agrícola e outros parâmetros que permitam um entendimento completo do meio natural e antrópico. Estas informações, adicionadas aos dados socioeconômicos, permitirão um melhor e mais eficiente planejamento do meio.

\section{Metodología de Cendrero et al. (1983)}

Baseia-se na utilização do mapeamento geocientífico como ferramenta na avaliação e planejamento do meio ambiente. Esta ferramenta objetiva a preparação de mapas temáticos descritivos, mapas derivados ou de qualidades significantes e mapas de conflito de uso recomendado do solo.

A metodologia proposta por esses autores $(o p$ cit) consiste de uma fase preliminar (de investigação) e três estágios: 1) coleta de dados; 2) avaliação dos hazard; e 3) avaliação dos riscos (Figura 2.2). Os mapas produzidos são aplicados diretamente a problemas de riscos naturais.

\section{Metodología de Francés et all. (1990)}

Apresenta aplicação da cartografia geoambiental como ferramenta no diagnóstico de unidades territoriais, na fase de planejamento e gestão do uso da terra.

Francés et all. (1990) ressaltam que as escalas dos mapas elaborados devem ser observadas. Para estudos de caráter regional, a escala mais adequada é de 1:50.000 ou menores, enquanto que em nível de gestão dos espaços naturais e ocupação urbana, ou atividade mais específicas, as escalas devem ser de detalhe, maiores que 1:50.000.

Nesta metodologia, os estudos ambientais são classificados em três tipos: 1) Diretrizes de Ordenamento Territorial - DTO (escala regional); 2) Plano de gestão e Uso dos Espaços Naturais (implantação de parques naturais); e 3)plano de ordenamento Urbano do Município (escala de detalhe). 


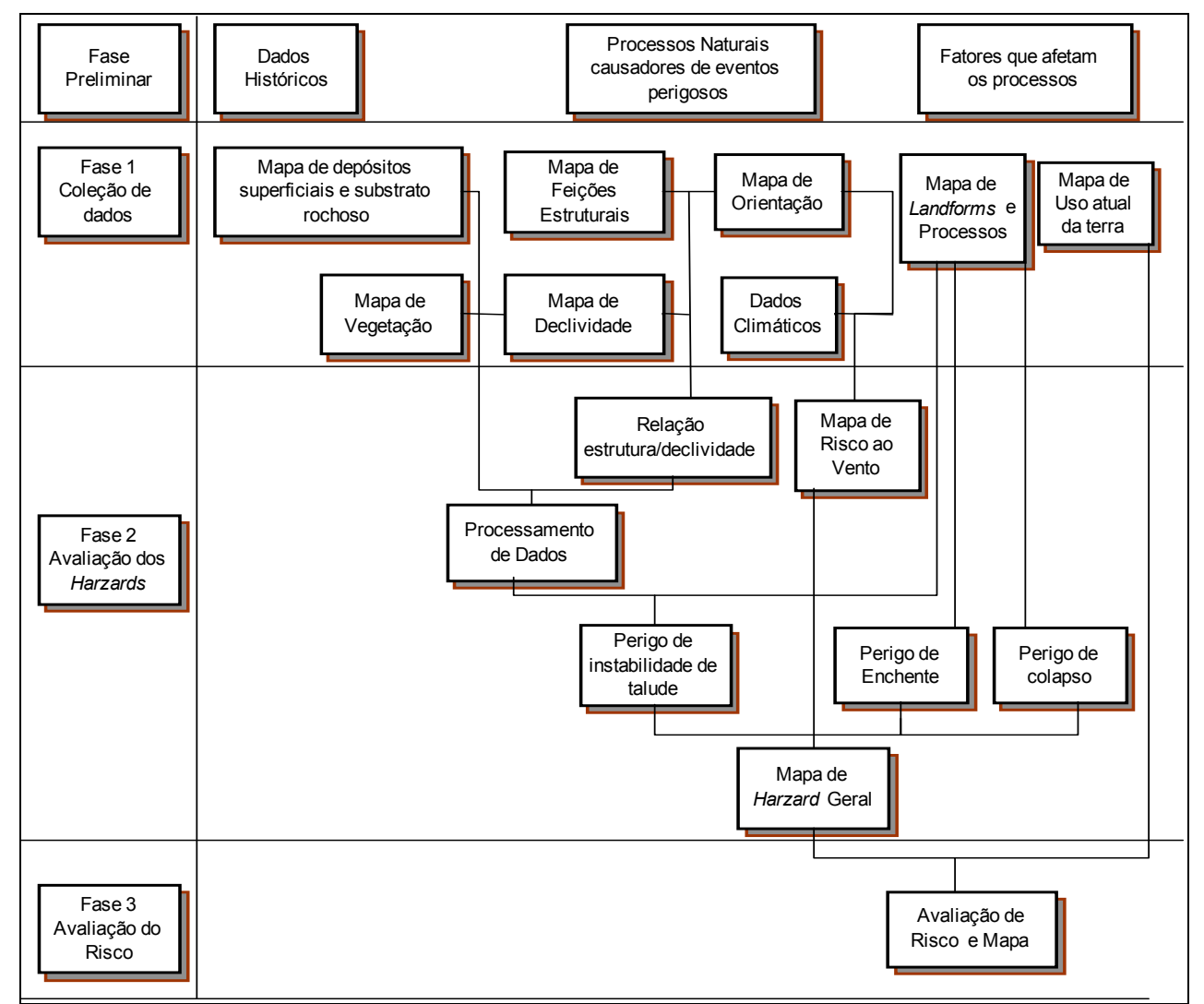

Figura 2.2 - Fluxograma da metodologia de Cendrero et al.(1983).

Metodologia de Zuquette et al. (1997)

Nesta metodologia, a carta de zoneamento geoambiental, corresponde a uma cartografia geotécnica, no que se refere à avaliação do contexto global das potencialidades do meio físico.

Segundo Zuquette et al. (1997), para obtenção da carta de zoneamento geoambiental é necessária a análise de documentos cartográficos preliminares, os quais são divididos em quatro grupos:

- Documentos Fundamentais Básicos - mapa de substrato rochoso, mapa de qualidade das águas, mapa de landforms, mapa de bacias hidrográficas, mapa de documentação, etc;

- Cartas Fundamentais de Síntese - mapa de condições geológico-geotécnicas, etc;

- Cartas Derivadas ou Interpretativas - carta de potencial ao escoamento superficial, carta de potencial ao movimento de massa, carta de zona de recarga de aqüífero, carta para disposição de rejeitos e resíduos, etc; 
- Cartas Analíticas Básicas - carta de probabilidade de ocorrência de eventos naturais, carta de possibilidade de ocorrer eventos perigosos, etc.

Uma ressalva importante feita por Zuquette (1993), é que se deve admitir um critério rigoroso na seleção dos atributos a serem considerados e suas respectivas classificações, as quais devem atender diretamente às solicitações do trabalho. Isto é possível por meio da hierarquização de cada componente, para o detalhamento da região. A priorização adequada dos atributos pode proporcionar uma maior confiabilidade na caracterização dos problemas de determinada área, possibilitando a exclusão de alguns atributos do meio físico, seja em função de sua pouca expressão ou pela impossibilidade de obtenção dos dados ou ainda pela sua confiabilidade.

A Tabela 2.2 apresenta alguns dos atributos considerados essenciais e necessários à elaboração e análise dos documentos cartográficos propostos anteriormente por Zuquette (1993).

\section{Metodologia de Lopes (2000)}

Propõem a elaboração de zoneamento para bacias hidrográficas como unidades de planejamento. $\mathrm{O}$ zoneamento realizado prevê determinação das restrições e potencialidades do meio físico a partir da avaliação de uma série de tributos do meio como geologia, pedologia, materiais inconsolidados, menor extensão do percurso de águas superficiais, entre outros. Lopes (2000), adota com unidades de análise os landforms, e determina as características de potencial a infiltração, potencial agrícola e susceptibilidade a erosão do meio.

\section{Metodologia de Amorim (2003)}

Propõem o desenvolvimento de um zoneamento geoambiental com fins ao planejamento territorial, baseado nas condições brasileiras e nos procedimentos e produtos da cartografia geotécnica. São considerados parâmetros geomorfológicos, geológicos, o comportamento geotécnico dos solos e a aptidão agrícola da região em enfoque. A carta de zoneamento foi produzia a partir de procedimentos de geoprocessamento, envolvendo de análises por agrupamentos (cluster). Esta análise 
estatística permitiu verificar a adequação do uso dos landforms como unidade de compartimentação para análise dos atributos e definição do zoneamento geoambiental.

Tabela 2.2 - Alguns dos atributos fundamentais ao Zoneamento Geoambiental, e a formas de obtenção dos mesmos. (modificado de Zuquette et al., 1997).

\begin{tabular}{|c|c|c|c|}
\hline Componente & Tipo & Atributo & Forma de Obtenção \\
\hline \multirow{10}{*}{ Águas } & \multirow{4}{*}{ Superficiais } & Escoamento superficial & M. Cook / Es \\
\hline & & $\begin{array}{l}\text { Áreas de acúmulo d'água } \\
\text { (temporário / permanente) }\end{array}$ & FI \\
\hline & & $\begin{array}{c}\text { Bacias hidrográficas desde primeira } \\
\text { ordem }\end{array}$ & FI \\
\hline & & Canais com fluxo permanente & Tc; FAb; Im \\
\hline & \multirow{6}{*}{ Subterrânea } & Presença de lentes salgadas & Tc \\
\hline & & Aqüíferos(livres/confinados) & FI; TC \\
\hline & & Áreas de recarga & FI \\
\hline & & Fontes naturais & Tc (GPS) \\
\hline & & Escoamento básico & AR \\
\hline & & Áreas de descarga & TC; FI \\
\hline \multirow[b]{2}{*}{ Geomorfologia } & Morfometria & Declividade & TC; TE; FI \\
\hline & Morfologia & Landforms & FI \\
\hline \multirow{14}{*}{ Geologia } & \multirow{2}{*}{$\begin{array}{l}\text { Substrato } \\
\text { Rochoso }\end{array}$} & Litologia & $\mathrm{TC}$ \\
\hline & & Distribuição (área/profundidade) & FI; TC \\
\hline & \multirow{5}{*}{$\begin{array}{l}\text { Evidência de } \\
\text { Processos }\end{array}$} & $\begin{array}{l}\text { Deposição (indício de } \\
\text { assoreamento) }\end{array}$ & $\mathrm{TC}$ \\
\hline & & Sismicidade & $\operatorname{Re}$ \\
\hline & & $\begin{array}{c}\text { Subsidência (áreas calcárias } \\
\text { abandonadas) }\end{array}$ & TC; FI \\
\hline & & erosivos (concentrados/laminares) & TC; FI \\
\hline & & $\begin{array}{c}\text { Alterações naturais de canais de } \\
\text { drenagem }\end{array}$ & FI; TC \\
\hline & \multirow{7}{*}{$\begin{array}{c}\text { Materiais } \\
\text { Inconsolidados }\end{array}$} & Movimento de massa & FI; TC \\
\hline & & $\begin{array}{c}\text { Gerais } \\
\text { Origem (residual/retrabalhado) }\end{array}$ & FI; TC; L \\
\hline & & Textura & $\mathrm{TC} ; \mathrm{L}$ \\
\hline & & $\begin{array}{l}\text { Variação em profundidade } \\
\text { (perfil de alteração) }\end{array}$ & TC \\
\hline & & Distribuição (em área) & FI; TC \\
\hline & & Potencial à salinidade & $\mathrm{L}$ \\
\hline & & $\begin{array}{c}\text { Específicos } \\
\text { Potencial quanto a fertilidade }\end{array}$ & L; Es \\
\hline \multirow{6}{*}{ Feições do Tecnógeno } & & Áreas de aterro e entulho & TC;FI \\
\hline & & $\begin{array}{l}\text { Áreas de explotação de material } \\
\text { para construção civil }\end{array}$ & TC; FI \\
\hline & & $\begin{array}{c}\text { Depósitos relacionados à } \\
\text { exploração mineral }\end{array}$ & TC; FI \\
\hline & & Explorações minerais & TC; FI \\
\hline & & $\begin{array}{l}\text { Antigos depósitos de rejeitos e } \\
\text { resíduos }\end{array}$ & TC; FI \\
\hline & & $\begin{array}{c}\text { Depósitos devido a alterações } \\
\text { antrópicas junto a canais de } \\
\text { drenagem }\end{array}$ & TC; FI \\
\hline \multicolumn{4}{|c|}{ FORMA DE OBTENÇÃO DOS ATRIBUTOS } \\
\hline \multicolumn{2}{|c|}{ TC - trabalho de campo } & \multicolumn{2}{|c|}{ FAb - fotos aéreas baixas } \\
\hline \multicolumn{2}{|c|}{ FI - fotointerpretação } & \multicolumn{2}{|c|}{ GPS } \\
\hline \multicolumn{2}{|c|}{$\mathrm{L}$ - ensaios laboratório } & \multicolumn{2}{|c|}{ TE - trabalho de escritório } \\
\hline \multicolumn{2}{|c|}{ E S - estimativas } & \multicolumn{2}{|c|}{ Re - registros } \\
\hline \multicolumn{2}{|c|}{ Im - imagens de satélite } & \multicolumn{2}{|c|}{$\mathrm{Li}$ - literatura } \\
\hline
\end{tabular}


Os procedimentos adotados por Amorim (2003) viabilizaram cruzamento de informações do meio e determinação das aptidões e restrições da área. Este autor mostrou também a necessidade e a importância da implementação de banco de dados digitais e do uso do SIG no zoneamento geoambiental.

\section{Metodologia de Fontes (2004)}

Nesta metodologia a autora propõem adoção de unidades de Ottobacias como regiões base para compartimentação e análise do meio físico, segundo um nível de homogeneidade. As informações dos atributos, substrato rochoso, materiais inconsolidados, declividade, drenagem e landforms, foram obtidas por técnicas de cartografia geotécnica, e são analisadas em cada uma das unidades. A compartimentação elaborada conduziu a obtenção de 90 unidades, pertencentes a 15 subgrupos com aptidões e restrições geoambientais diferenciadas para a bacia do Rio Pardo, constituindo uma base para um estudo geoambiental mais detalhado.

\subsection{BACIAS HIDROGRÁFICAS COMO UNIDADES DE PLANEJAMENTO}

Para Silveira (1993), uma bacia hidrográfica constitui uma área de captação natural de água precipitada, onde os escoamentos convergem para um único ponto: Apresenta como constituintes básicos o conjunto de vertentes e as redes de drenagem, formadas pela confluência dos cursos d'água.

Para Chorley et al. (1984), uma bacia hidrográfica é considerada um sistema ou unidade geomorfológica, constituída de divisores de água, encostas, redes de drenagem e um canal principal de maior extensão.

Guerra \& Cunha (1996) ressaltam que um fator importante a ser destacado é que, internamente, a bacia está em constante ajuste de seus elementos e formas, em função das mudanças de entrada e saída de energia, que podem ser catalisadas pelo uso inadequado dos componentes do meio pelo homem. Rawat (1987 apud Collares, 1996) apresenta algumas prováveis modificações em função de input de energia e características intrínsecas de uma bacia(Tabela 2.3). 
A bacia hidrográfica pode ser definida como uma área topográfica, drenada por um curso de água ou sistema conectado de cursos de água de forma que toda vazão afluente seja descarregada através de uma simples saída. (Polette et al, 2000).

Tabela 2.3 - Parâmetros de input de energia, características intrínsecas a bacia e prováveis respostas às mudanças no sistema (Rawat, 1987 apud Collares, 1996).

\begin{tabular}{lll}
\hline & \multicolumn{2}{c}{ Bacias Hidrográficas } \\
\hline Input de energia & Características da Bacia & Respostas do sistema (perda de energia) \\
\hline A) Processos exógenos: & A) Características físicas: & A) Processos hidrológicos: \\
Precipitação & Morfometria & Transpiração, Evaporação, \\
Temperatua & Geologia, Rocha, resistência da & Infiltração, Percolação, Fluxo do canal \\
Umidade & rocha, densidade de juntas, fraturas & Fluxo de superfície \\
& Regime climático, Vegetação, Vida & \\
& biológica & \\
\hline B) Processos Endógenos & B) Características culturais: & B) Processos geomorfológicos: \\
Historia tectônica & Distribuição da população & Erosão \\
Morfotectônica & Padrão de uso do solo & Boçorocas, ravinas e sulcos \\
Neotectônica & Mineradoras & Erosão do canal \\
& Tipo de obra implantada & Maior ou menor carga de fundo, material em \\
& Indústrias & suspensão e dissolvido \\
& & Movimentos de massa \\
\hline
\end{tabular}

Barrow (1998), conceitua amplamente as bacias hidrográficas como unidades biogeográficas com alto grau de integridade funcional, representando sistemas relativamente homogêneos. Para o autor cada bacia é única, com características geológicas, hidrológicas e ecológicas que a caracterizam como uma unidade de paisagem operacional amplamente usada para o planejamento e o manejo integrado, buscando manter a qualidade ambiental e o desenvolvimento sustentável.

Nos tempos atuais, a gestão ambiental caminha progressivamente para adotar as bacias hidrográficas como unidades de planejamento e, apesar da clara ênfase na questão dos recursos hídricos, é necessário que seja feito um planejamento global que contemple todos os componentes dos recursos naturais e componentes sócio-econômicos (Souza et al., 1997; Ross \& Del Pettre., 1998)

Para Montaño (2002), a bacia hidrográfica é considerada a unidade territorial mais adequada por alguns especialistas para uma gestão ambiental integrada que busque adotar práticas sustentáveis, considerando os aspectos físicos e econômicos.

Prochnow (1990) destaca que a adoção da bacia hidrográfica como unidade de planejamento justifica-se não apenas porque a bacia constitui uma unidade física bem caracterizada, tanto do ponto de vista da integração como da finalidade de seus elementos, mas também porque não há qualquer área de terra, por menor que seja, que não se integre a uma bacia hidrográfica. 
Bourlon \& Berthon (1993) destacam que a adoção da bacia hidrográfica como unidade de planejamento não é uma unanimidade internacional. Os autores citam vários países da Europa, como por exemplo, Alemanha, Áustria, Bélgica e Dinamarca que adotam unidades de planejamento com limites administrativos.

Lanna (1995) descreve a bacia como uma das alternativas para o planejamento e gerenciamento ambiental, destacando algumas vantagens e desvantagem. Dentre as vantagens, o autor (op cit) destaca que a rede de drenagem de uma bacia consiste em um dos caminhos preferências das relações de causa-efeito, particularmente aquelas que envolvem o meio hídrico. Dentre as desvantagens argumenta que nem sempre os limites municipais e estaduais respeitam os divisores da bacia.

Roos \& Del Pettre (1998) ressaltam que a gestão ambiental caminha progressivamente para tomar as bacias hidrográficas como unidade de planejamento regional, mas com uma clara ênfase nos recursos hídricos. Advertem, entretanto, sobre a necessidade de uma política que contemple os outros componentes dos recursos naturais (solos, relevo, atmosfera, substrato rochoso, fauna e flora) e os componentes sociais e econômicos, não em termos de bacias hidrográficas, mas também considerando sua interação regional e sua articulação com os problemas nacionais.

Leite (2000) define o gerenciamento de bacia hidrográfica como um instrumento que orienta o poder público e a sociedade, em longo prazo, na utilização e monitoramento dos recursos ambientais - naturais, econômicos e sócio-culturais, na área de abrangência de uma bacia hidrográfica, de forma a promover o desenvolvimento sustentável. Constituindo, portanto, parte integrante da gestão de recursos hídricos.

Para Lazlo (1986, apud Salati, 1996), planejar uma bacia hidrográfica significa estruturar um conjunto de procedimentos, os quais devem ser capazes de assegurar um uso ambiental correto de todos os recursos naturais do meio, objetivando:

- Promover o desenvolvimento sustentado da bacia;

- Melhorar a qualidade de vida das populações, e;

- Garantir a construção e a preservação ambiental.

Dentro do processo de planejamento de bacias hidrográficas, Vlaschos (1982 apud Salati, 1996) salienta a importância da avaliação de impactos ambientais, como uma das mais importantes etapas de planejamento. Para Vlaschos (op. cit.), tais avaliações 
constituem um processo de previsão, destinado tanto à avaliação de um futuro melhor como também à garantia da sobrevivência do homem sobre a Terra.

Para Salati (1996), o planejamento regional de bacias hidrográficas, também almeja alcançar um desenvolvimento espacialmente equilibrado, de maneira a criar ligações efetivas entre áreas urbanas e rurais.

\subsubsection{Condicionantes de Alterações Ambientais em Bacias Hidrográficas}

As principais alterações registradas no meio ambiente são, de uma maneira geral, originadas ou potencializadas por atividades humanas, independente de limites administrativos, topográficos, geomorfológicos ou ecológicos. Estas atividades alteram propriedades ou características do meio físico e podem interferir em usos preexistentes de um determinado ambiente (Fornassari Filho, 1992).

Prochnow (1990) cita que os fatores de degradação ambiental de uma bacia são reflexo das condições ambientais predisponentes da área e das opções políticas e econômicas da sociedade nela inserida. Estes fatores podem ser subdividos em dois grupos:

- Fatores de ordem natural - relacionados à pré-disposição do meio físico a degradação ambiental;

- Fatores de natureza antrópica - resultantes das atividades humanas na organização do espaço (aspectos, econômicos, sociais, tecnológicos, políticos e institucionais).

\subsubsection{Condicionantes de Ordem Natural}

De acordo com Prochnow (1990), os principais condicionantes naturais capazes de induzir alterações nos recursos renováveis de uma bacia hidrográficas são as características geológicas, geomorfológicas, climáticas, hidrológicas, pedológicas, etc. Estes apresentam-se interelacionados e atuam em conjunto no condicionamento do meio físico frente aos processos de degradação natural.

As características geológicas de uma determinada bacia influenciam diretamente a resistência e a permeabilidade do material rochoso, bem como o tipo de solo residual a 
ser formado. Os solos, por sua vez, são submetidos a processos intempéricos resultantes das condições climáticas atuantes na área da bacia.

Para Prochnow (1990), a configuração geomorfológica e seus mecanismos de evolução definem o modelado da paisagem, conferindo maior ou menor capacidade ao desenvolvimento dos processos de erosão, ravinamento e boçorocamento.

A infiltração da água está relacionada com as condições litológicas, topográficas, pedológicas e fitogeográficas locais, que irão responder pelas diferenças entre os totais de chuva e evapotranspiração, constituindo-se em importantes elementos no balanço hídrico, cujas conseqüências são refletidas, principalmente, no comportamento e estruturação da drenagem.

\subsubsection{Condicionantes de Natureza Antrópica}

Prochnow (1990) destaca diferentes atividades como principais responsáveis pelas modificações das condições naturais do meio físico, no âmbito de uma bacia hidrográfica. Dentre estas são ressaltadas aqui: 1) As atividades agro-pecuárias e agroindustriais; 2) O desmatamento; 3) A erosão e o assoreamento; e 4) A ocupação humana.

\section{Atividades Agro-pecuárias e Agro-industriais}

Essas atividades acarretam, principalmente, a erosão das terras cultivadas e a poluição de aquíferos, pelo uso de fertilizantes, pesticidas e herbicidas, e o lançamento de efluentes de animais (Doyle, 1991; Seager et al., 1992). Além destas, existem também as consequências secundárias, como o desmatamento e perda de florestas, gerados pelo processo de abertura de clareiras e criação de animais; a perda e desperdício de água utilizada para irrigação de terras, e a diminuição de nutrientes do solo, pelo uso excessivo deste recurso (Corson, 1993).

\section{Desmatamento}

A retirada da vegetação provoca o descobrimento do solo, o aumento da erosão e a perda da fertilidade. O solo descoberto é carreado para os mananciais, provocando 
assoreamento, e as seguintes conseqüências negativas:a) redução da capacidade de armazenamento, redução da infiltração de água e de recarga de aqüíferos subterrâneos; b) aumento do escoamento das águas superficiais, provocando cheias e enchentes; c) aumento da turbidez da água e redução da incidência de luz solar; d) comprometimento da vida aquática; e, e) aumento do risco de poluição dos mananciais.

Prochnow (1990) ressalta que a vegetação tem um papel importante em uma bacia hidrográfica, pois garante a biodiversidade local, protege o solo contra a erosão provocada pelo vento e pela chuva, e contribui para fertilização com o fornecimento da matéria orgânica.

\section{Erosão e Assoreamento}

Os processos erosivos são deflagrados pela ocupação do solo e passam a ser controlados por fatores naturais relacionados à chuva, o relevo, o solo e a cobertura vegetal (Salomão \& Iwasa, 1995). Parte dos sedimentos provenientes da erosão são depositados em determinadas posições das vertentes, podendo comprometer a fertilidade dos solos, além de poder atingir o fundo dos vales gerando o assoreamento dos cursos d'água e reservatórios.

Segundo os autores (op cit), o assoreamento desequilibra as condições hidráulicas, promove enchentes e perda de capacidade de armazenamento d'água, gerando prejuízos para o abastecimento e a produção de energia.

\section{Ocupacão Humana}

A ocupação humana constitui um fator decisivo de incremento de processos geradores de impactos como erosão, assoreamento e escorregamento. A ocorrência destes processos é induzida por meio de atividades como o desmatamento, cultivo de terra, construção de obras e criação ou expansão de cidades (Salomão \& Iwasa, 1995).

Conforme Collares (1996), uma das principais consequências da erosão, além da perda de terrenos, é o assoreamento que ocorre nos cursos d'água e reservatórios. $\mathrm{O}$ principal impacto provocado pelo assoreamento é o desequilíbrio das condições hidráulicas, gerando enchentes, perda de capacidade de armazenamento d'água, incremento de poluente e o prejuízo no abastecimento e produção de energia. 
Uma forma de quantificar as modificações introduzidas no meio ambiente, sejam de ordem natural, sejam de natureza antrópica, é por meio da utilização de indicadores ambientais.

\subsection{INDICADORES GEOAMBIENTAIS}

De acordo com ITC (1996), baseado em tendências internacionais, tem-se utilizado os "Geoindicadores Ambientais" em estudos que objetivam relatar o estado do meio ambiente e possibilitar avaliações de sustentabilidade ambiental.

Conforme definido em 1992 pela International Union of Geological Science - (IUGS) pelo do grupo de trabalho sobre geoindicadores, COGEOENVIRONMENT Comission on Geological Science of Environmental Planning, os geoindicadores podem ser definidos como "medidas de taxa, magnitude, freqüência e tendência de processos e fenômenos geológicos que vêm ocorrendo na superfície da terra, ou próximo desta, dentro de um período de 100 anos ou menos, sujeitos às variações significativas para a compreensão das mudanças ambientais rápidas".

Simões (1997) define os geoindicadores como atributos do meio que descrevem processos e parâmetros ambientais que são capazes de mudanças com ou sem interferência da atividade humana.

Para Berger (1997), os geoindicadores são capazes de descrever tanto eventos catastróficos como eventos mais graduais, porém com evidente influência na vida humana. O Autor (op cit) destaca que a utilização dos geoindicadores ajuda a responder quatro questões básicas em estudos de natureza ambiental:

1. O que está acontecendo com o meio ambiente? (condições e tendências);

2. Porque acontece? (causas, associações entre influências humanas e processos naturais);

3. Porque é significante? (efeitos econômicos, ecológicos e à saúde);

4. O que se pode fazer acerca disso? (implicações para o desenvolvimento de uma política de aplicações).

A COGEOENVIRONMENT (1992) identificou e definiu vinte e sete indicadores para monitorar e avaliar as mudanças que ocorrem no meio físico, tanto de origem 
natural quanto induzida pelas atividades antrópicas. Na Tabela 2.4 são apresentados exemplos destes indicadores.

Berger (1997) ressalta, que os indicadores ambientais devem permitir o monitoramento das condições do meio, de forma a representar o estado em que este se encontra em relação às rápidas mudanças ou a sua estabilidade no tempo.

Tabela 2.4 - Geoindicadores: influência natural X influência humana (ITC, 1996).

\begin{tabular}{|c|c|c|}
\hline Geoindicadores & $\begin{array}{c}\text { Influência } \\
\text { Natural }\end{array}$ & $\begin{array}{c}\text { Influência } \\
\text { Humana }\end{array}$ \\
\hline $\begin{array}{l}\text { Magnitude, duração e freqüência de tempestade de } \\
\text { poeira }\end{array}$ & $\bullet$ & $\bullet$ \\
\hline Flutuações de geleiras & $\bullet$ & $\Delta$ \\
\hline Qualidade da água subterrânea & 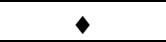 & $\bullet$ \\
\hline Química da água subterrânea em zona insaturada & 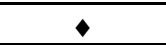 & 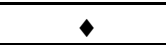 \\
\hline Nível da água subterrânea & $\bullet$ & $\bullet$ \\
\hline Nível de lagos e salinidade & $\bullet$ & $\bullet$ \\
\hline Nível relativo do mar & $\bullet$ & $\bullet$ \\
\hline Posição da linha de costa & $\bullet$ & 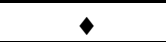 \\
\hline Erosão de solos e sedimentos & $\bullet$ & $\bullet$ \\
\hline Qualidade do solo & $\bullet$ & $\bullet$ \\
\hline Escoamento/fluxo d'água & $\bullet$ & $\bullet$ \\
\hline Morfologia dos canais & $\bullet$ & $\bullet$ \\
\hline Transporte e deposição de sedimentos & $\bullet$ & $\bullet$ \\
\hline 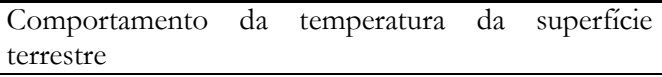 & $\bullet$ & $\bullet$ \\
\hline Qualidade da água superficial & $\bullet$ & $\bullet$ \\
\hline Extensão, estrutura e hidrologia de terras alagadas & $\bullet$ & $\bullet$ \\
\hline Erosão eólica & 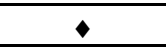 & $\bullet$ \\
\hline \multicolumn{3}{|l|}{$\begin{array}{l}\text { - Fortemente influenciado por } \\
\text { - - Pode ser influenciado por } \\
\Delta \text { - Não exerce influencia substancial sobre }\end{array}$} \\
\hline
\end{tabular}

Os geoindicadores representam uma ferramenta importante para compreender os impactos ambientais e os riscos associados aos processos atuantes, sendo muito aplicados no monitoramento ambiental integrado (Berger, 1997).

Simões (1997) destaca, em uma análise de sistemas e geoindicadores, o quão fundamentais são os geoindicadores para subsidiar programas de monitoramento e avaliação de impactos ambientais, com ressalva à necessidade de se utilizar a avaliação de mais de um índice em algumas situações, devido a dinâmica de cada geossistema, que envolve processos multivariados.

Para Santos (2004) as medidas fornecidas pelos indicadores ambientais permitem comparar territórios de diferentes dimensões e complexidades diversas. Podendo ser usados para avaliar e projetar tendências ao longo do tempo, além de serem úteis para prognosticar cenários futuros e nortear ações preventivas. 
De acordo com Neimains \& Kerr (1996), os geoindicadores devem seguir os critérios de análise descritos a seguir:

- Validade científica - o geoindicador deve ser relevante no entendimento científico do sistema ou do elemento a ser descrito, além de que o geoindicador deve sofrer modificações quando houver mudanças no ambiente e, os dados avaliados por este devem corresponder a diferentes períodos de tempo.

- Representatividade - a informação fornecida pelo geoindicador deve ser representativa do fenômeno como um todo, devendo ser simples e clara, para facilitar o entendimento de pessoas não especialistas.

- Relevância - os dados a serem adquiridos devem ser de fácil obtenção e fundamentais ao usuário potencial.

- Limite - devem ser estabelecidos limites para avaliação dos valores obtidos e o indicador deve ter aplicação regional.

ITC (1996) salienta que alguns geoindicadores já possuem parâmetros padronizados, como é o caso da qualidade das águas superficiais, enquanto que outros deveriam ganhar mais espaço na avaliação ambiental.

De uma forma geral, nem todos os geoindicadores eleitos pela COGEOENVIRONMENT (1992) tem ampla aplicabilidade, pois dependem de esferas de abordagem (escala, local e política). Com isso entende-se que em alguns casos, em função de condições peculiares do meio, torna-se necessário o estabelecimento ou proposição de novos atributos para serem utilizados como indicadores de modificações ambientais.

A United Nations Comission on Sustainnable Development - UNCSD - em 1996 propôs a categoria de indicadores ambientais de desenvolvimento sustentável, os quais são atributos do meio físico, utilizados para medir a qualidade ambiental de uma região, de forma a tentar conduzir ao desenvolvimento sustentável. São esses: ar, água, solo, fauna e clima.

\subsection{GEOPROCESSAMENTO E ESTUDOS AMBIENTAIS}

$\mathrm{Na}$ perspectiva moderna de gestão do território, toda ação de planejamento, ordenação ou monitoramento do espaço deve incluir a análise dos diferentes 
componentes do meio ambiente, incluindo o meio físico-biótico, a ocupação humana e o interelacionamento destes. Neste contexto, vem se destacando o uso do geoprocessamento e suas ferramentas (Câmara \& Medeiros, 1998).

O termo geoprocessamento pode ser entendido como a tecnologia que utiliza técnicas computacionais para tratamento de informações geográficas. Esta tecnologia utiliza ferramentas computacionais chamadas de sistemas de informações geográficas (SIG), as quais permitem realizar análises espaciais complexas, ao integrar dados de diversas fontes e ou criar bancos de dados georreferenciados (Câmara \& Medeiros, 1998).

O geoprocessamento vem influenciando de maneira crescente nas áreas de cartografia, análise de recursos naturais, transportes, comunicação, energia e planejamento urbano e regional. Com relação aos estudos ambientais os SIG vêm sendo muito empregados na realização de mapeamento temático, diagnóstico ambiental, avaliação e impacto ambiental e ordenamento territorial.

Os SIG apresentam duas características principais, que são: 1) inserir e integrar, em uma base de dados única, informações espaciais obtidas de dados cartográficos, censitários e cadastro urbano e rural, imagens de satélite, redes e modelos numéricos de terreno e, 2) oferecer mecanismos para combinar os vários níveis de informação, por meio de operações de manipulação e análise, por algoritmos, bem como consultar, recuperar visualizar e plotar o conteúdo da base de dados georreferenciados.

Atualmente, de forma sumarizada, os SIG, podem ser conceituados como sistemas de processamento de dados, que se apoiam em processos gráficos e capturam dados espacialmente referenciados, administrando e processando estes dados para aplicações no campo das geodisciplinas (Lopes, 2000).

Muitos autores (GTZ, 1994; Assad \& Sano, 1993; Bähr \& Vöght, 1991 e Dale \& Mclaughen, 1990), afirmam que o ambiente computacional permite analisar dados de forma integrada, revolucionando o modo como as informações geográficas (fotografias aéreas e imagens de satélite), são manipuladas, as quais são freqüentemente usadas em pesquisas e nos processos de planejamento (Dale \& Mclaughen, 1990).

A grande adaptabilidade destes sistemas faz com que os SIG tenham grande aplicação, podendo ser utilizados em processos de análise ambiental, de planejamento de uso da terra, de planejamento de uso de recursos hídricos, de economia, entre outras finalidades (Intera Tydac, 1992). 


\subsubsection{Estrutura de um Sistema de Informações Geográficas}

De acordo com Câmara \& Medeiros (1998), os sistemas de informações geográficas apresentam cinco componentes básicos:1) interface com o usuário; 2) entrada e integração de dados; 3) funções de processamento gráfico e de imagens; 4) visualização e plotagem e, 5) armazenamento e recuperação de dados (na forma de um banco de dados georreferenciados).

De uma maneira geral os componentes dos sistemas de informações geográficas podem ser organizados em quatro categorias: 1) Entrada de dados, 2) Gerenciamento e recuperação de informações, 3) Manipulação e análise e 4) Exibição e produção de saída.

\section{Entrada de Dados}

De forma contrária aos sistemas de bancos de dados convencionais, os SIG são capazes de armazenar informações variadas, de natureza gráfica, como vetores e imagens. Para isto, é necessário que o SIG conte com módulos ou interfaces que permitam que o usuário possa incorporar dados e visualizá-los graficamente. Uma das formas, mais usuais, que vêm sendo utilizadas para a entrada de dados em SIG é o processo de digitalização semi-automática e automática, que transforma dados gráficos em formato vetorial.

\section{Gerenciamento e Recuperacão de Informacõos}

Uma vez formada a base de dados geográficos, o SIG precisa ser capaz de gerenciá-la. Isto é, o SIG precisa garantir ao usuário o acesso rápido e eficiente às informações por ele gerenciada, devendo:

- Manter a consistência da base de dados por meio das operações realizadas pelos usuários;

- Controlar o acesso simultâneo aos dados;

- Garantir a integridade da relação gráfico-alfa;

- Executar operações de salvamento (back up) e recuperação de informações;

- Garantir a recuperação total ou parcial do banco de dados em caso de falhas; e 
- Garantir a segurança no acesso às informações contidas no banco de dados, impedindo acesso não autorizados e limitando o acesso a dados sensíveis.

\section{Manipulacão e Análise}

As funções de manipulação e análise de dados geográficos são agrupadas de acordo com o tipo de dado tratado (correspondente a uma geometria distinta):

- Análise Geográfica - permite a combinação de informações temáticas. Pode ser realizada no domínio vetorial ou matricial (“raster”).

- Processamento Digital de Imagens - permite o tratamento de imagens de satélite e de "scaners" para obtenção referentes ao meio físico e cadastrais.

- Modelagem Numérica do Terreno - permite a execução de cálculos como declividade, volume, cortes transversais e linha de visada, por meio da construção de modelos (grade regular ou triangular) a partir de pontos amostrais esparsos ou linhas.

- Modelagem de Redes - consiste tipicamente de cálculo de caminho ótimo e crítico. No sistema de modelagem de redes a determinação do caminho ótimo depende da necessidade do usuário.

\section{Exibição e Producãa de Saída}

As saídas dos dados são enfocadas na forma de duas categorias: 1) Produção na qual são priorizados a produção otimizada de mapas em papel, tabelas e relatórios e

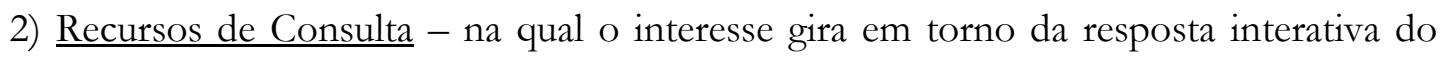
sistema às demandas do usuário.

A apresentação espacial dos dados (mapas) pode ser feita por meio de duas grandes classes:

1. Representação Matricial - na qual o espaço é representado como uma matriz P $(\mathrm{m}, \mathrm{n})$ composta de $\underline{\mathrm{m}}$ colunas e $\underline{\mathrm{n}}$ linhas, onde cada célula possui um número de linha, um número de coluna e um valor correspondente ao atributo estudado e, 
cada célula é individualmente acessada pelas suas coordenadas (Câmara \& Medeiros, 1998).

2. Representação Vetorial - na qual são considerados três elementos gráficos: 1) Ponto - Também chamados de elementos pontuais, abrangem todas as entidades geográficas que podem ser perfeitamente posicionadas por um único par de coordenadas X e Y. Além das coordenadas, outros dados não-espacias (atributos) podem ser arquivados para indicar de que tipo de ponto está se tratando; 2) Linhas, arcos ou elementos lineares - conjunto de pontos conectados. Além das coordenadas dos pontos que compõem a linha, deve-se armazenar informações que indiquem de que tipo de linha se está tratando, ou seja, a que atributo ela está associada;e 3) Área ou polígono - são representados pela lista de linhas que a compõem.

Teixeira et. al. (1992) descreve a representação matricial como "a partição do espaço em uma malha com linhas verticais e horizontais espaçadas de forma regular, formando células chamadas de pixel, ou quadrícula". Geralmente, os pixels possuem dimensões verticais e horizontais iguais, que define a resolução da malha.

De acordo com Eastman (1998), a forma vetorial é definida por uma série de pontos, linhas e polígonos, os quais formam a representação gráfica das feições. Cada ponto está georreferenciado a um sistema de coordenadas, como latitude/longitude ou a grade de coordenadas UTM (Universal Transverse Mecator).

\subsubsection{Operações Matemáticas nos Sistemas de Informações Geográficas}

Os SIG apresentam operações matemáticas (funções) que permitem a realização de operações diversas. Isto é o que distingue esses sistemas de outros tipos de sistemas de informações. Essas funções realizam análises espaciais, utilizando atributos espaciais ou não das informações armazenadas na base de dados, na tentativa de serem realizados modelamento (simulações) sobre os fenômenos reais, seus aspectos ou parâmetros (Câmara \& Medeiros, 1998).

Nos estudos de natureza ambiental, um fator muito importante é o tipo de operação empregada, pelos sistemas de informações geográficas, no tratamento dos atributos que serão analisados. 
As principais operações existentes em um sistema de informação geográfica são: 1) Operações Pontuais, 2) Operações Booleanas, 3) Operações matemáticas, 4) Operações de Vizinhança 5) Operações Zonais, e 6) Operações de classificação contínua (operações com fundamentos de lógica fuг:ay) .

Estas operações permitem que sejam realizadas simulações diversas sobre os dados armazenado nos SIG. As operações booleanas são as tradicionalmente aplicadas na análise espacial de atributos do meio físico. As operações de classificação contínua utilizam técnicas fundamentadas em noções de conjuntos nebulosos (fuz:y) para efetuar análises sobre os dados espaciais considerandos suas variações transicionais, e elaborar documentos cartográficos com dados representados em formato numérico Isto é, as variáveis espaciais como solo, geomorfologia, vegetação, entre outras. não são manipuladas em formato temático, mas sim numérico. De acordo com Câmara \& Medeiros (1998) as operações de classificação contínua substituem os processos tradicionais de elaboração de mapas.

\section{7 - LOGICA FUZZY}

A Lógica Fuży pode ser vista como uma generalização da lógica booleana convencional. A grande diferença entre as duas está no fato de a lógica fuz̧̧y permitir um certo grau de incerteza, isto é, ela aceita a noção de parcialmente verdadeiro ou parcialmente falso (Zimmermann, 1987).

A lógica tradicional trabalha com os dois extremos 1 e 0 , ou o elemento está no conjunto ou não está. A lógica furzy viola estas suposições. De acordo com Zimmermann (1987), um sim ou um não como resposta a determinadas questões é, na maioria das vezes, incompleta. Na verdade, entre a certeza de ser e a certeza de não ser, existem infinitos graus de incerteza (os elementos podem assumir qualquer valor dentro do intervalo [0,1], valor esse conhecido como grau de pertinência). Esta imperfeição intrínseca à informação representada numa linguagem natural foi tratada matematicamente no passado com o uso da teoria das probabilidades. Contudo, a lógica furzy, com base na teoria dos conjuntos furzy, tem se mostrado mais adequada para tratar imperfeições da informação do que a teoria das probabilidades (Olivera et al., 1999). 
De forma mais objetiva e preliminar, a lógica fuz:y pode ser definida como sendo uma ferramenta capaz de capturar informações vagas, em geral descritas em linguagem natural e convertê-las para um formato numérico, de fácil manipulação pelos computadores de hoje em dia (Zadeh \& Jamshidi, 1997).

A lógica furzy também pode ser definida como a lógica que suporta os modos de raciocínio que são aproximados, ao invés de exatos, como estamos naturalmente acostumados a trabalhar. Esta lógica baseia-se na teoria dos conjuntos nebulosos e difere dos sistemas lógicos tradicionais em suas características e detalhes. Nessa, o raciocínio exato corresponde a um caso limite do raciocínio aproximado, sendo interpretado como um caso de composição nebulosa (Galvão, 1999).

De acordo com Saraiva (2000) a lógica furzy é uma teoria matemática a qual utiliza critérios da teoria furay que fazem uso da nebulosidade. Os critérios gerais da teoria são: 1) Teoria dos conjuntos fuzzy; 2) Lógica fuz:y;; e 3) Teoria de medidas fuzzy.

A teoria dos conjuntos furay é basicamente uma teoria de conceitos graduados, na qual tudo é objeto de gradação ou, de modo figurativo, tudo tem elasticidade. Expressa nebulosidade stricto sensu por meio de conceito da teoria dos conjuntos.

O que é chamado de nebulosidade leva em consideração um aspecto de incerteza. Nebulosidade (furziness) é a ambiguidade que pode se encontrada na definição de um conceito ou no sentido de uma palavra. Por exemplo, expressões como uma velha pessoa, alta temperatura ou pequeno número são nebulosas, pois apresentam ambigüidade em seus sentidos e incerteza (Saraiva, 2000).

Saraiva (2000) chama atenção para o fato de que nebulosidade não significa o mesmo que probabilidade. Anteriormente, a probabilidade era a única incerteza com que os matemáticos trabalhavam. A incerteza da probabilidade refere-se à incerteza de fenômenos, como simbolizados pelo conceito de aleatoriedade. Aleatoriedade (coisa que ocorre sem um plano definido) e nebulosidade diferem em sua natureza, são aspectos diferentes da incerteza.

Saraiva (2000) exemplifica casos de incerteza de probabilidade, como as expressões: choverá amanhã e jogue os dados e retire um três. Estas expressões contêm incertezas de ocorrências fenomenológicas. A incerteza de choverá amanhã ocorre causada por uma previsão metereológica feita antes que amanhã se torne realidade (no tempo). A incerteza desta expressão é esclarecida com a passagem do tempo e a chegada do amanhã. A incerteza de jogar os dados e retirar um três é também o resultado de tentar 
antes de rolar os dados e, se os dados são rolados e este resultado ocorre, a proposição torna-se certa. Porém a incerteza de pessoas velhas ou altas temperaturas não é esclarecida com a passagem do tempo ou com a ocorrência de um resultado.

\subsubsection{Teoria Fuzzy-Princípios Básicos}

A teoria furzy baseia-se no princípio de que o pensamento humano é estruturado em classes de objetos, não em números, cuja transição entre pertencer ou não a um conjunto é gradual e não abrupta. Assim, enquanto as fronteiras dos conjuntos clássicos são bem definidas, as dos conjuntos furzy apresentam uma nebulosidade, a qual se tenta aproximar das imperfeições do modo de raciocínio humano (Olivera et al., 1999).

A teoria furąy se propõe a uma boa aproximação de modelagem do significado das palavras empregadas na linguagem natural.

As três principais características da teoria furayy são:

- Uso de variáveis lingüísticas no lugar ou em adição as variáveis numéricas;

- Caracterização das relações simples entre variáveis por expressões condicionadas;

- Caracterização das relações complexas por algorítimos fu₹æyy.

\subsubsection{Teoria dos Conjuntos Difusos - Conceituação Matemática}

De acordo com Zimmermann (1987), Galvão (1999) e Olivera et al. (1999), na teoria clássica de conjuntos existem três conceitos primitivos básicos, a saber:

\section{Conjunto}

$\mathrm{Na}$ linguagem furảy, conjunto tem definição similar à noção clássica. É uma coleção, agrupamento, classe ou sistema. Sua notação clássica e furayy são: X (notação clássica) e $\tilde{\mathbf{A}}$ (notação fur:ðy).

$\mathrm{Na}$ teoria clássica, os conjuntos são ditos “crisp". Isto é, nestes conjuntos, o limite de transição dos membros para não-membros é abrupto e repentino. O grau de associação do conjunto é especificado, freqüentemente, por um número "1" para 
membros e "0" para não-membros. Na teoria dos conjuntos furày, diferentemente, as transições entre membros e não-membros estão em uma faixa gradual, sendo associado um grau ao elemento entre " 0 " (totalmente não-membro) e " 1 " (totalmente membro). Este grau é chamado relação ou função de pertinência.

Outra boa definição de conjunto fuz̧y é dada por Fang (1997), que define como um conjunto de pares de valores, onde o primeiro valor (lingüístico) é o membro do conjunto; e o segundo valor (numérico) é o grau de relação do membro para com o conjunto.

Para Burrough e McDonnell (1998), o conjunto fuzzy é uma forma de caracterização de classes que, por várias razões, não têm ou não podem definir limites rígidos (contatos) entre classes. Essas classes, definidas de maneira inexata, são chamadas de conjunto furæy. A utilização de um conjunto fuz:yy é indicada sempre que se tiver que lidar com ambigüidade, abstração e ambivalência em modelos matemáticos ou conceituais de fenômenos empíricos.

\section{Elemento}

É cada membro que forma o conjunto e, sua notação clássica são as letras latinas minúsculas (Ex.: x). A notação furæyy é o par ordenado $\{\mathbf{x}, \boldsymbol{\mu} \mathbf{A}(\mathbf{x})\}$, ou elemento $\mathbf{x}$ com grau de pertinência $\boldsymbol{\mu} \tilde{\mathbf{A}}(\mathbf{x})$.

\section{Relacões de Pertinência}

A noção clássica de pertinência pode ser definida pela função característica onde 1 indica $\mathbf{x} \in \mathbf{X}$ ( o elemento $\mathrm{x}$ pertence ao conjunto $\mathrm{X}$ ) e 0 indica $\mathbf{x} \notin \mathbf{X}$ (não pertence ao conjunto X). Pela teoria dos conjuntos furzy a função característica pode assumir outros valores reais não negativos além de 0 e 1, tal que o supremo seja infinito. Em outras palavras, a função de pertinência mapeia os elementos contidos em um conjunto $\mathbf{X}$, definidos em um universo $\mathbf{U}$, para o intervalo $[0,1]$. Desta forma a função de pertinência associa para cada elemento $\mathbf{x}$ pertencente a $\mathbf{U}$ um número real $\boldsymbol{\mu} \mathbf{A}(\mathbf{x})$ no intervalo $[0,1]$, que representa o grau de possibilidade de que o elemento $\mathbf{x}$ venha a 
pertencer ao conjunto $\mathbf{X}$, isto é, quanto é possível para o elemento $\mathbf{x}$ pertencer ao conjunto $\mathbf{X}$.

Os conjuntos podem ser representados e descritos de três formas:

1. Pela designação de seus elementos entre chaves

Ex.: $\{a, e, i, o, u\}-$ indica o conjunto das vogais

2. Pelas propriedades de seus elementos. Conhecida uma propriedade característica P dos elementos de um conjunto, fica ele determinado. Deste modo, o conjunto dos elementos x que têm a propriedade $\mathrm{P}$ é indicado por $\{\mathrm{x} / \mathrm{x}$ tem a propriedade $\mathrm{P}\}$

Ex.: $\{x / x$ é um real e $x>2\}$

3. Pela definição dos membros utilizando a função características, em que 1 indica pertinência e 0 , não pertinência. Para um conjunto fu₹:yy, a função característica permite vários graus de pertinência para os elementos do conjunto dado.

Galvão (1999) destaca que na abordagem clássica, cada elemento tem uma pertinência $\mu$, a qual vale 1 (indica pertinência) ou 0 (indicando não pertinência). Nos conjuntos difusos são permitidos, no intervalo $\mu=[1,0]$, vários graus de pertinência, podendo ser representados por meio de uma função de pertinência $\mu$.

Saraiva (2000) cita que a teoria dos conjuntos fuzæyy é um modo matemático de tratar conjuntos que são definidos por elementos difíceis de serem delimitados em um conjunto crisp. Galvão (1999) explica bem isto, apresentando um exemplo onde são considerados três conjuntos de temperatura do ambiente: "frio", "quente" e "confortável". O autor (op cit) ressalta que na abordagem clássica de conjuntos, os limites de temperatura que os delimitam devem ser rigorosamente definidos podendo assumir os seguintes valores:

$\underline{\text { Fria }}-\mathrm{T} \leq 20^{\circ} \mathrm{C}$ tem pertinência $\mu=1$ (pertencem ao conjunto), $\mathrm{T}>20^{\circ} \mathrm{C}$ tem pertinências $\mu=0$ (não pertencem ao conjunto). 
Confortável $-20^{\circ} \mathrm{C}<\mathrm{T}<24^{\circ} \mathrm{C}$ têm pertinência $\mu=1$ (pertencem ao conjunto); valores de temperaturas diferentes deste intervalo têm pertinência $\mu=0$ (não pertencem ao conjunto).

Quente $-\mathrm{T} \geq 24^{\circ} \mathrm{C}$ têm pertinência $\mu=1$ (pertencem ao conjunto), $\mathrm{T}<24^{\circ} \mathrm{C}$ têm $\mu=$ 0 (não pertencem ao conjunto).

$\mathrm{Na}$ abordagem difusa, os limites de temperatura são delimitados da seguinte forma:

$\underline{\text { Fria }}-\mathrm{T} \leq 19^{\circ} \mathrm{C}$ têm pertinência $\mu=1$ (certamente frio, pertencem completamente ao conjunto).

$\mathrm{T} \geq 21^{\circ} \mathrm{C}$ têm pertinência $\mu=0$ (certamente não frio, não pertencem ao conjunto)

$19^{\circ} \mathrm{C}<\mathrm{T}<21^{\circ} \mathrm{C}$ têm pertinência $\mu$ variando entre 1 e 0 (de certo modo frio, pertencem parcialmente ao conjunto)

Confortável $-21^{\circ} \mathrm{C}<\mathrm{T}<23^{\circ} \mathrm{C}$ têm pertinência $\mu=1$ (certamente confortável, pertencem completamente ao conjunto).

$\mathrm{T} \leq 19^{\circ} \mathrm{C}$ ou $\mathrm{T} \geq 25^{\circ} \mathrm{C}$ têm pertinência $\mu=0$ (certamente não confortável, não pertencem ao conjunto)

$19^{\circ} \mathrm{C}<\mathrm{T}<21^{\circ} \mathrm{C}$ ou $23^{\circ} \mathrm{C}<\mathrm{T}<25^{\circ} \mathrm{C}$ têm pertinência $\mu$ variando entre 1 e 0 (de certo modo confortável, pertencem parcialmente ao conjunto)

Quente $-\mathrm{T} \geq 25^{\circ} \mathrm{C}$ têm pertinência $\mu=1$ (certamente quente, pertencem completamente ao conjunto)

$\mathrm{T} \leq 23^{\circ} \mathrm{C}$ têm pertinência $\mu=0$ (certamente não quente, não pertencem ao conjunto)

$23^{\circ} \mathrm{C}<\mathrm{T}<25^{\circ} \mathrm{C}$ têm pertinência $\mu$ variando entre 1 e 0 (de certo modo quente, pertencem parcialmente ao conjunto).

A Figura 2.3apresenta as representações gráficas dos conjuntos de temperatura segundo a abordagem clássica e difusa. 


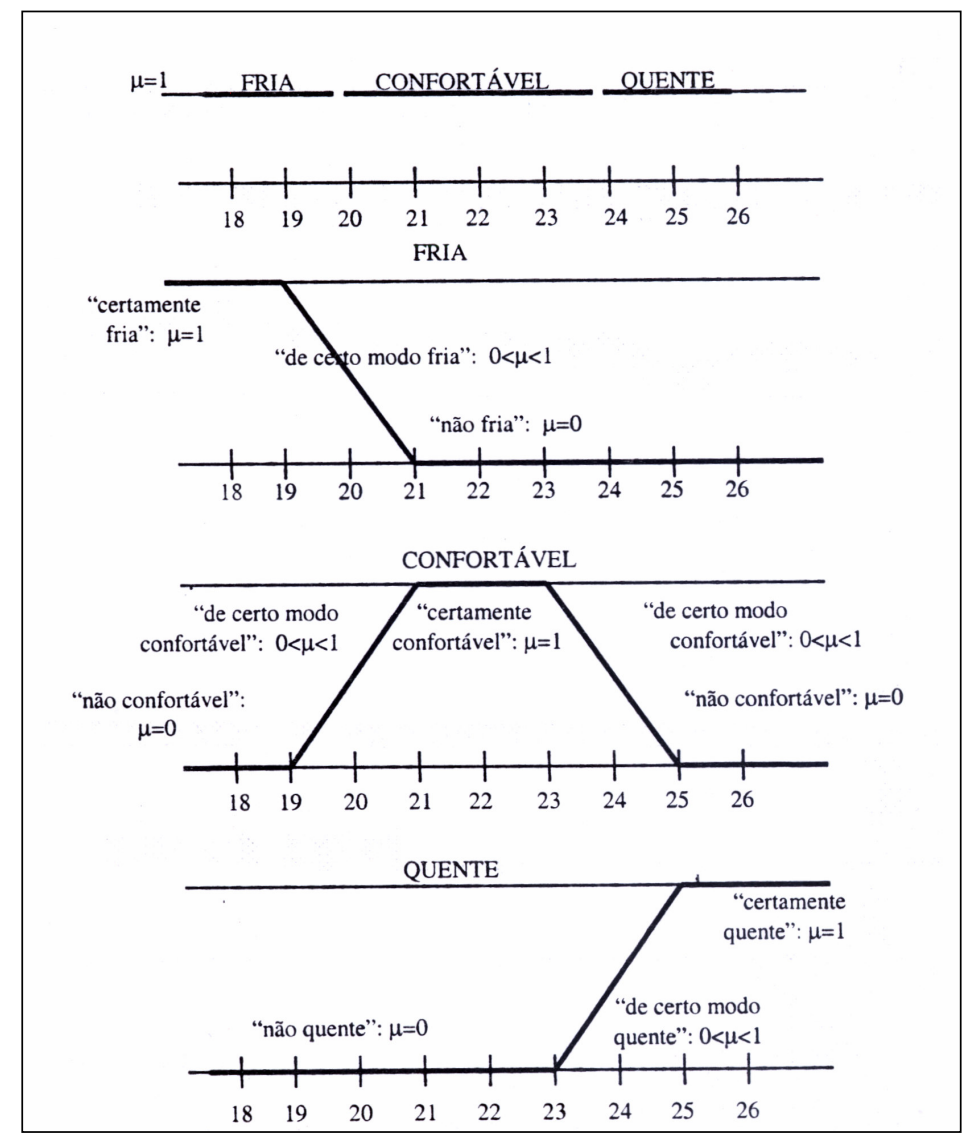

Figura 2.3 - Representações gráficas dos conjuntos clássicos e difusos para definição da temperatura do ambiente (Galvão, 1999).

\subsection{3 - Aplicações da Lógica Fuzzy}

Diversas áreas estão sendo beneficiadas pela tecnologia decorrente da Lógica Fuz:y, como a área de desenvolvimento industrial e a área de ciências ambientais, onde são abordados, principalmente, temas voltados aos recursos hídricos e ao uso do solo (Gomide \& Rocha, 1992 a e b).

$\mathrm{Na}$ área de mapeamento, a representação dos atributos do meio físico em documentos cartográficos é fundamentada em técnicas de lógica booleana,. Neste tipo de técnica os atributos retratados apresentam as mesmas características em toda sua extensão espacial. Têm o mesmo comportamento e as mesmas propriedades, não sendo representadas ou consideradas possíveis variações.

Burrough et al. (2000) ressalta que nos métodos tradicionais de mapeamento, os limites entre unidades são tomados como linhas discretas. De forma que retratam a inexistência de gradação entre características das diferentes unidades. O estabelecimento 
de um limite determina o término e/ou começo abrupto de uma unidade. A execução de mapeamento desta forma implica em uma representação errada do meio, com perda de informações importantes, além de a ocorrência de erro na elaboração de um mapa, pela adoção arbitrária de limite de atributos.

Esta perda é devida ao fato do meio físico se caracterizar como um sistema complexo, e segundo Zadeh (1972), para sistemas complexos os modelos tradicionais fornecem informações de qualidade diminuta, pois não são possíveis de lidar com os conceitos inexatos, ambíguos e/ou vagos, tão comuns em sistemas geológicos.

De acordo com Câmara \& Medeiros (1998), uma alternativa o problema acima descrito seria sempre trabalhar com dados em representação contínua, o que na prática, equivale a trabalhar com modelos numéricos de terreno, para representar variáveis espaciais como solo, geomorfologia e vegetação.

Sui (1992) ressalta que a utilização da lógica fuz:y permite acrescentar detalhes de transição gradual, reduzindo assim a perda de informações relacionadas com as atividades de cada parcela analisada, possibilitando uma identificação mais analítica destas unidades.

Neste contexto, trabalhos como os de Burrough (1989), Burrough \& Heuvelink (1992); Banai (1993); Altman (1994) e Moreira et al (2001), vem sendo desenvolvidos com aplicação de técnicas de lógica furæyy para confecção de documentos cartográficos.

De acordo com Moreira et all. (2001), as vantagens do modelamento fuz:yy são inúmeras quando comparadas aos modelamentos convencionais, os quais forçam os especialistas a definir regras dicotômicas rígidas com contatos normalmente artificiais, que diminuem a habilidade de articular eficientemente soluções para problemas complexos, tão comuns em processos naturais.

Para Davidson et al. (1993), a utilização da lógica fuz:yy, na avaliação do uso do solo entre outras aplicações, fornece uma metodologia mais satisfatória do que as metodologias que se utilizam de outras operações, como a booleana. Burrough (1996) apresenta este fato como evidente, pois o uso pontual da álgebra boolerana, como uma lógica simples de verdadeiro ou falso, de combinação de modelos exatos e rígidos é freqüentemente inapropriado para análise, modelamento e representação de aspectos de naturezas contínuas, como solos, topografias, vegetação e litologias.

Hall et al. (1992) cita que a classificação usando a "lógica furæyy" na avaliação do uso da terra/solo é menos sensível a perturbações nos dados, ocorrência de ruídos, do 
que com as aproximações feitas por meio das operações booleanas. Segundo Burrough \& Heuvelink (1992), muito menos informações são rejeitadas em todos os estágios de análise, sendo muito melhor para a classificação de variações contínuas. Para os autores (op cit), o modelo gerado com a aplicação de inferência de lógica fuzzy ilustra uma representação mais próxima da realidade.

Silvert (2000) acrescenta que a utilização da lógica fu₹zy em estudos de natureza ambiental possibilita a execução de estudos capazes de descrever modificações naturais e antropogênicas, ocorrentes no meio. $\mathrm{O}$ autor (op cit) enfatiza que o emprego da lógica possibilita a integração de diferentes tipos de dados, permitindo realizar um balanço entre observações favoráveis e desfavoráveis e, entre efeitos incomensuráveis como impactos sociais, econômicos e biológicos. Ainda possibilita a classificação e quantificação ambiental de atributos de natureza subjetiva.

\subsubsection{1. -. Exemplos de Aplicação da Lógica Fuzzy}

MacMillan et al. (2000) utiliza a lógica furzy para delimitar uma área em elementos de landforms que apresentem diferenças significantes com respeito a propriedades do solo. A delimitação da área é feita por meio de um modelo digital de elevação (DEM), elaborado a partir de coordenadas x, y e z fornecidas por um sistema diferencial de posicionamento global (DGPS) e interpoladas no programa GRASS. Para segmentação da área foram considerados atributos do terreno (gradiente de declividade, perfil e curvatura plana e iluminação relativa) que foram calculados após conversão para atributos de landforms fuz:yy, os quais foram expressos em termos de associação de valores com variação contínua entre 0-100.

Burrough et al., (2000) utilizam um método de classificação contínua para determinação de landforms semelhante ao apresentado por MacMillan et al. (2000), denominado de método furąy K-means, juntamente com o auxílio de modelos digitais de elevação do terreno. Este método busca suprir os problemas que comumente são encontrados no mapeamento de unidades do terreno, tanto pelo método tradicional de mapeamento como pela utilização dos SIG, que em sua maioria têm suas funções baseadas em operações booleanas.

Burrough et al.(2000) emprega o método de classificação contínua para a segmentação de uma are com 68ha, a qual teve seus dados representados no formato 
raster, por uma malha com 153 linhas por 178 colunas, com células de 5 X 5 metros. Para segmentação do terreno foram feitas 100.000 observações dos dados x, y e z, os quais foram interpolados pelo programa GRASS, para gerar um modelo de elevação digital (DEM). A partir do DEM foram obtidas informações referentes à declividade, o perfil de curvatura, o plano de curvatura, o índice total anual de incidência de radiação solar, o índice de umidade e a distância entre topos.Todos estes atributos foram computados juntamente com a elevação, fornecendo de forma independente informações sobre o terreno.

Moreira et al. (2001) apresentam um exemplo de aplicação da técnica de lógica furzy, entre outras, juntamente com a tomada de suporte a decisão para fins de elaboração de documentos cartográficos, voltados para delimitação de cenários potenciais a ocorrência de minerais radioativos. Como ferramentas, os autores (op cit), utilizam o SIG SPRING (Sistema para Processamento de Informações Georeferenciadas) e a linguagem de programação LEGAL (Linguagem Espacial de Geoprocessamento Algébrico), para tratar as informações do meio em formato contínuo e delimitar os cenários pretendidos. 


\section{CAPÍTULO 3}

\section{CARACTERIZAÇÃO DA ÁREA}

\subsection{LOCALIZAÇÃO E ACESSO}

A área de estudo corresponde a Bacia Hidrográfica do Rio do Peixe situada na porção centro-leste do Estado de São Paulo e Sudoeste de Minas Gerais. Está compreendida entre os meridianos $46^{\circ} 7^{\prime} 50^{\prime \prime}$ e $47^{\circ} 00^{\prime}$ e os paralelos $22^{\circ} 15^{\prime}$ e $22^{\circ} 45^{\prime}$, englobando parte das folhas topográficas Mogi-Guaçu (SF-23-Y-A-III-3), Águas de Lindóia (SF-23-Y-A-III-4), Ouro Fino (SF-23-Y-B-III-1), Amparo (SF-23-Y-A-VI-1), Socorro (SF-23-Y-A-IV-2), Munhoz (SF-23-Y-B-IV-1) e Cambuí (SF-23-Y-B-IV-2) . Totaliza uma área de aproximadamente $1670 \mathrm{Km}^{2}$, (Figura 3.1).

A bacia tem $36 \%$ de sua área total $\left(618 \mathrm{Km}^{2}\right)$ correspondendo a terrenos mineiros e $64 \%$ a terrenos paulistas $\left(1056 \mathrm{Km}^{2}\right.$ ) (Figura 3.2). Nos terrenos mineiros localiza-se a porção da alta bacia, a qual corresponde a área de cabeceira da bacia. Nos terrenos paulistas localizam-se as porções média e baixa da bacia, as quais correspondem, respectivamente, a parte central e de foz.

A Bacia engloba áreas pertencentes a sete municípios, dos quais cinco localizamse no Estado de São Paulo: Águas de Lindóia, Itapira, Lindóia, Serra Negra e Socorro; e dois no Estado de Minas Gerais, Bueno Brandão e Munhoz(Figura 3.3). Os sete municípios somam uma população de 150.904 habitantes (IBGE, 2002). 


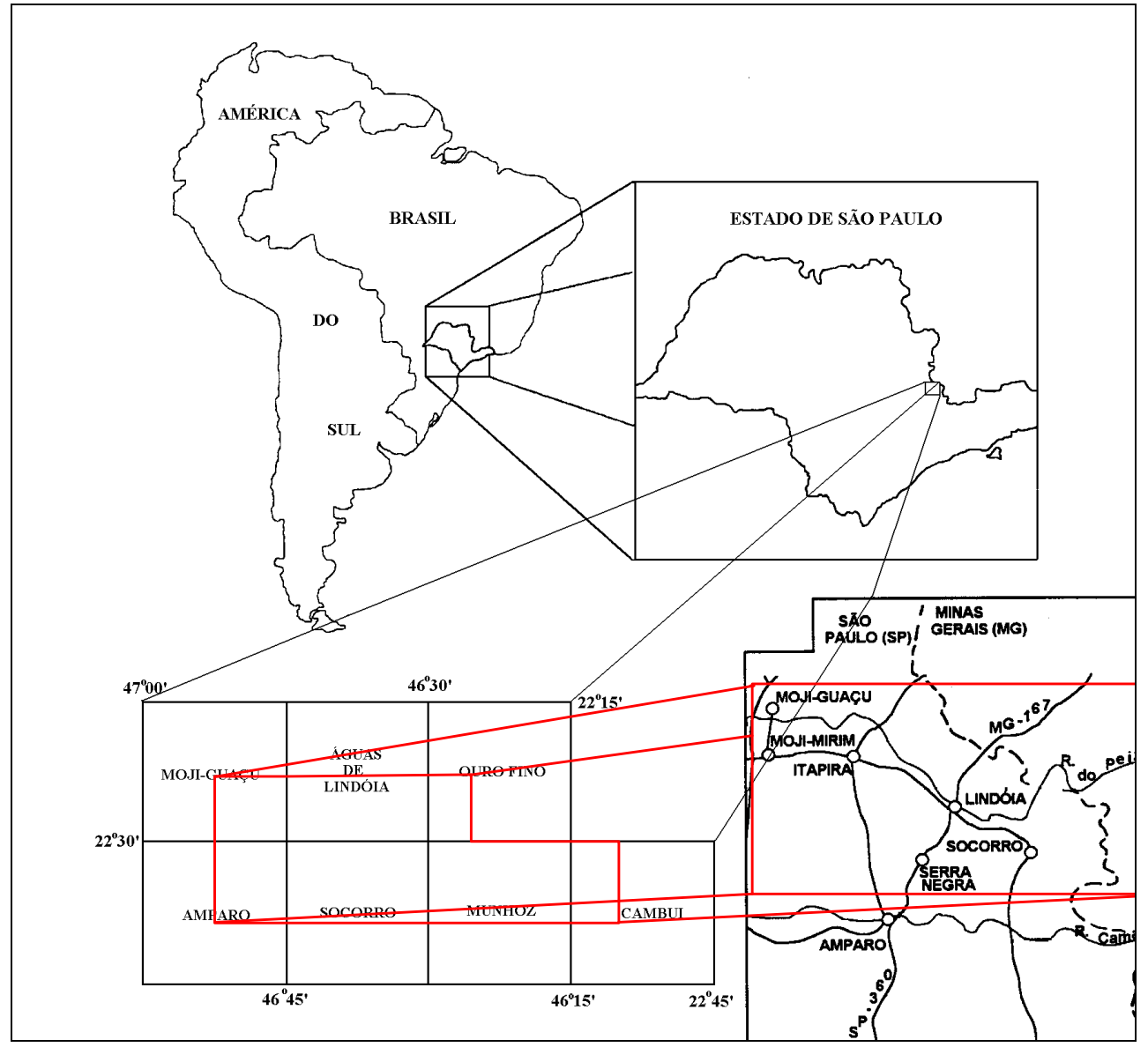

Figura 3.1 - Localização da área de estudo

O Rio do Peixe nasce no Estado de Minas Gerais, no município de Munhoz e se desenvolve no sentido sudeste-noroeste, indo desaguar em terrenos paulistas, no Rio Mogi-Guaçu, as proximidades do município de mesmo nome. De acordo com Mion \& Cavaleire (1999), o Rio do Peixe constitui um compartimento (sub-bacia hidrográfica) da Unidade Gerenciamento de Recursos Hídricos do Mogi-Guaçu.

As principais vias de acesso presentes na área são SP-340, SP-147, SP-191 e SP352. 


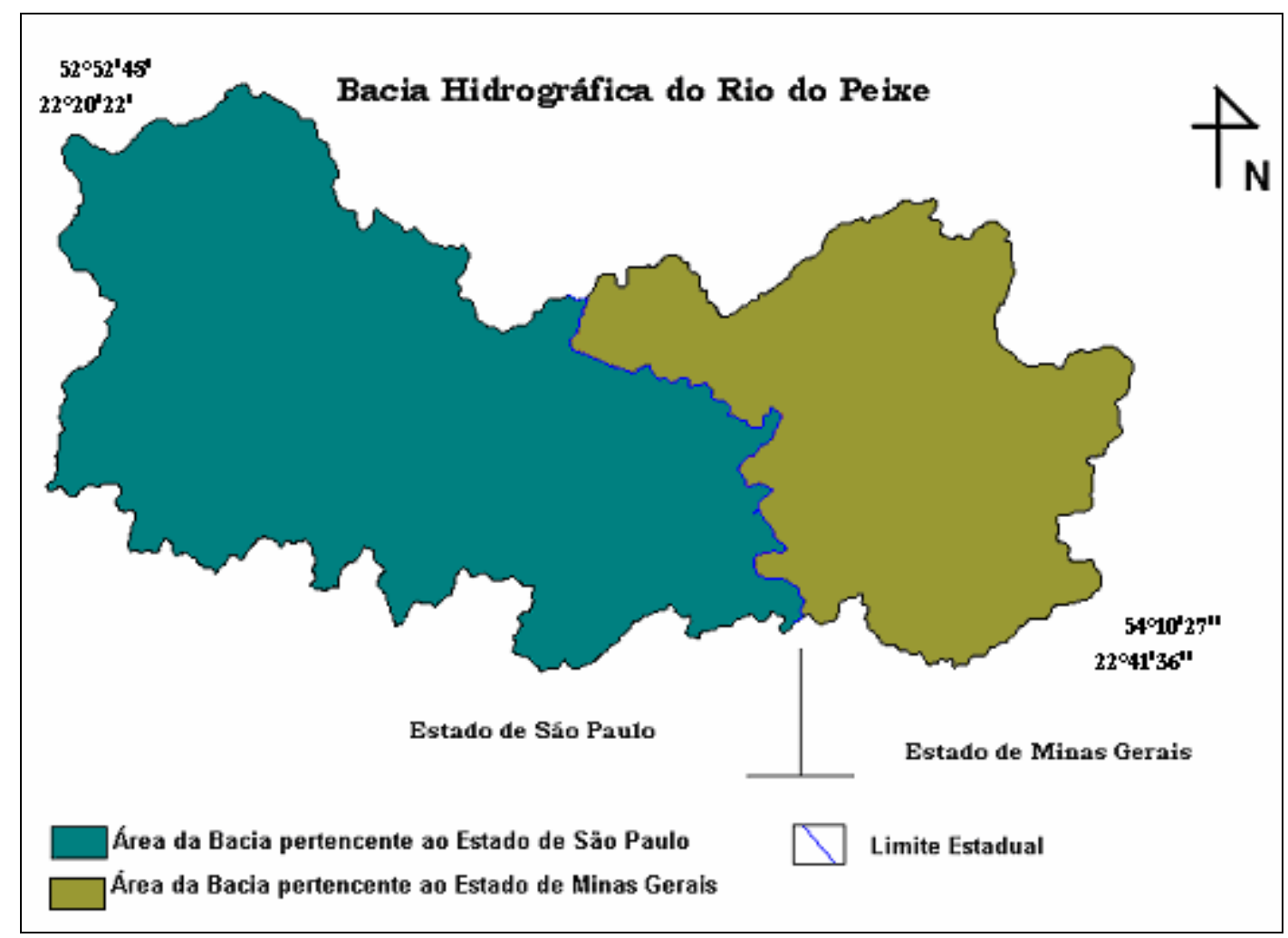

Figura 3.2 - Localização da Bacia do Rio do Peixe com relação aos Estados de São Paulo e Minas Gerais.

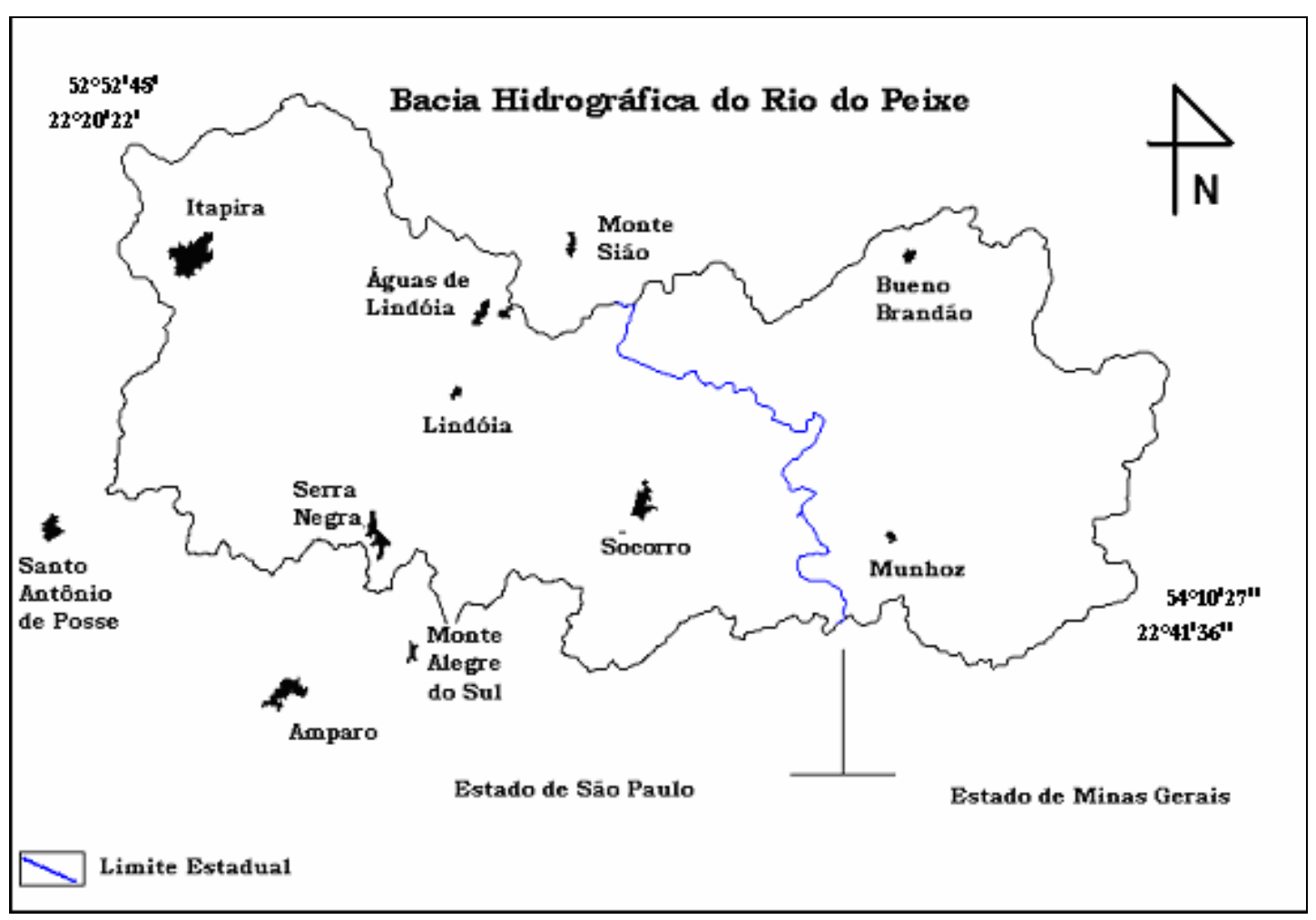

Figura 3.3 - Municípios da Bacia do Rio do Peixe. 


\subsection{ASPECTOS FISIOGRÁFICOS}

\subsubsection{Clima}

O Clima da Bacia pode ser caracterizado, de uma forma geral, como clima mesotérmico de inverno seco, com a estação seca ocorrendo entre os meses de abril a julho, sendo os meses mais chuvosos janeiro e fevereiro (Mion \& Cavaleire, 1999).

De acordo com o sistema de classificação climático de Köppen, é possível identificar três divisões climáticas presentes na bacia Hidrográfica do Rio do Peixe: Cwa, Cwb e Cfa (Mion \& Cavaleire, 1999). A descrição de cada divisão climática identificada na área da bacia é apresentada a seguir:

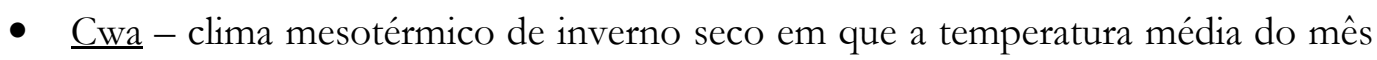
mais frio é inferior a $18^{\circ} \mathrm{C}$ e a do mês mais quente oscila entre 22 e $24^{\circ} \mathrm{C}$. O total de chuvas do mês mais seco não é superior a $30 \mathrm{~mm}$. O índice pluviométrico varia entre 1100 e $1700 \mathrm{~mm}$, com diminuição da precipitação de leste para oeste. A estação seca ocorre nos meses de abril a setembro, sendo julho o mês mais seco. Os meses mais chuvosos são janeiro e fevereiro.

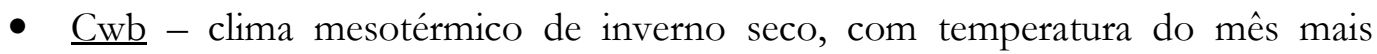
quente inferior a $22^{\circ} \mathrm{C}$. O índice pluviométrico varia entre1300 e $1700 \mathrm{~mm}$. O mês mais seco e mais frio é julho, com temperaturas médias em torno de $16,5^{\circ} \mathrm{C}$. A estação seca vai de maio a setembro e, o mês mais chuvoso é janeiro, chegando a atingir um total de chuvas 10 vezes superior ao valor do mês de julho.

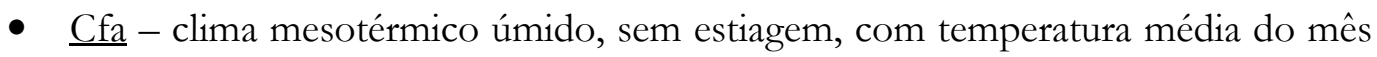
mais quente superior a $22^{\circ} \mathrm{C}$. O mês mais seco é julho, com um índice pluviométrico superior a $30 \mathrm{~mm}$. O mês mais chuvoso é janeiro com índice pluviométrico variando entre 1100 e $1700 \mathrm{~mm}$.

\subsubsection{Cobertura Vegetal}

De acordo com Mion \& Cavaleire (1999) nos terrenos paulistas da bacia é identificado um único tipo de vegetação nativa. 
A Tabela 3.1 apresenta dados da ocorrência de vegetação nativa na porção da bacia relativas a terras do Estado de São Paulo.

Tabela 3.1 - Levantamento de vegetação nativa na área da bacia do Rio do Peixe (modificado de Mion \& Cavaleire, 1999).

Tipo de Vegetação Nativa

\begin{tabular}{l|c|c|c|c|c}
\cline { 2 - 7 } & \multicolumn{3}{c}{ Mata } & \multicolumn{2}{c}{ Total } \\
\hline Municípios & Área (ha) & (ha) & $\%$ & $($ ha $)$ & $\%$ \\
\hline Águas de Lindóia & 128.200 & 5.490 & 26 & 5.490 & 26 \\
\hline Itapira & 4.300 & 372 & $8 ., 65$ & 372 & 8,65 \\
\hline Lindóia & 6.000 & 305 & 5,08 & 305 & 5,08 \\
\hline Serra Negra & 18.600 & 800 & 4.3 & 800 & 4,3 \\
\hline Socorro & 44.600 & 1.446 & 3.24 & 1.446 & 3,24 \\
\hline
\end{tabular}

Na porção da cabeceira da bacia, correspondente a terras do Estado de Minas Gerais, foram identificadas mediante realização de campanhas de campo a existência de vegetação do tipo mata, cerrado, e mata ciliar.

\subsubsection{Pedologia}

De acordo com o Levantamento de Reconhecimento do Solo do Estado de São Paulo, realizado pelo Centro Nacional de Ensino e Pesquisas Agronômicas (1960), os solos presentes na Bacia Hidrográfica do Rio do Peixe são dos tipos: Podzólico Vermelho Amarelo, Latossolo Roxo, Laossolo Vermelho, Litossolo, Regossolo e Hidromórficos.

\section{$\underline{\text { Solos Podzólicos Vermelho Amarelo }}$}

Os solos podzólicos vermelho amarelos são solos bem drenados, com seqüência de horizontes A-E-B-C, com nítida diferenciação entre os horizontes, com teor de argila do horizonte B bem mais elevado que os horizontes superficiais, são ácidos e com saturação de bases baixas.

$\mathrm{Na}$ bacia do Rio do Peixe é encontrada a unidade de solo Podizólico Vermelho Amarelo variação Piracicaba (PVp), localizada na região da depressão Periférica, com relevo fortemente ondulado a ondulado, vegetação original de floresta e materiais argilosos folhelhos. 
Latossolo Roxo

São solos bem drenados, com seqüência de horizonte A-B-C e pequena diferenciação de horizontes. Apresentam coloração vermelho-arroxeada, argilosos, bastante porosos e profundos, com pequena variação de cor entre os horizontes. Tem saturação de base muito variável.

O material de origem desses solos são rochas eruptivas básicas, o relevo varia de ondulado a suave e a vegetação original é de floreta, ocorrendo áreas com cerrado.

\section{$\underline{\text { Latossolo Vermelho Amarelos }}$}

São solos bem drenados, com seqüência de horizontes A-B-C, com pequena diferenciação entre horizontes, de coloração variando de amarela até vermelha. São ácidos, com relação textural (\% de argila do horizonte $\mathrm{B} / \%$ de argila do horizonte $\mathrm{A}$ ) em torno de 1,3 e a saturação em bases é baixa.

$\mathrm{Na}$ bacia é encontrada a unidade Latossolo Vermelho Amarelo orto (LV), localizada no Planalto Atlântico, em relevo montanhoso, com material de origem granítica e gnáissica. A vegetação original é de floresta.

\section{$\underline{\text { Solos Hidromórficos }}$}

São solos intrazonais, nos quais não há desenvolvimento das características dos solos zonais, o que se deve a grande influência de água no perfil. Essa influência está condicionada principalmente as caracterísitcas do relevo.

O encharcamento desses solos pode ocasionar um acúmulo de matéria orgânica ou fenômeno gleização, provocado pela redução e solubilização de compostos de ferro. Isto é evidenciado pela ocorrência de coloração cinzenta e mosqueamentos.

\section{$\underline{\text { Litossolos }}$}

São solos muito rasos, pouco desenvolvidos, constituídos pelo horizonte superficial. Apresentam pequena espessura, formados por acumulo de matéria orgânica, seguido de rocha pouco alterada, consolidada ou semi-branda. Os litossolos são 
separados de acordo com a natureza do substrato, sendo encontrada na bacia a unidade Litossolo fase substrato granito-gnaisse.

\subsubsection{Geomorfologia}

De acordo com IPT (1981), a bacia hidrográfica do Rio do Peixe apresenta a ocorrência de duas grandes provícias geomorfológicas: Planalto Atlântico e Depressão Periférica. Com destaque a ocorrência da Serrania de Lindóia (Planalto Atlântico) e da Zona do Mogi-Guaçu (Depressão Periférica), as quais fazem limite ao norte da bacia.

O Planalto Atlântico localiza-se a montante, desde a nascente do Rio do Peixe, no Estado de Minas Gerais, ocupando aproximadamente $80-90 \%$ da área. A topografia apresenta grande diversidade de declividade, com altitudes médias de até $1600 \mathrm{~m}$.

A província geomorfológica Depressão Periférica ocorre junto a foz do Rio do Peixe, ocupando aproximadamente $20-10 \%$ da área. Apresenta relevo uniforme, com vales amplos e profundos, planícies fluviais restritas e alguns terraços. O contato entre as rochas sedimentares da Depressão Periférica com as rochas cristalinas do Planalto Atlântico oferece áreas de diferentes resistências à erosão fluvial, proporcionando o aparecimento de cachoeiras e corredeiras.

\subsection{ASPECTOS SÓCIO-ECONÔMICOS}

\subsubsection{Demografia}

A Bacia do Rio do Peixe apresenta uma população total de 150.9041 habitantes distribuídos em sete municípios, Itapira, Águas de Lindóia, Lindóia, Serra Negra, Socorro, Bueno Brandão e Munhoz (IBGE, 2002). Destes, Itapira caracteriza-se como o município com a maior população, 63.377 habitantes que correspondem à aproximadamente $40 \%$ da população total da bacia. Socorro e Serra Negra apresentamse como os outros dois municípios mais populosos, com 20,5\% e 15\% da população total da bacia, respectivamente. Lindóia constitui o município de menor população, 5.331 habitantes, que corresponde a 3,35\% da população total da bacia (Figura 3.4). 
A Tabela 3.2 apresenta os dados populacionais dos municípios da Bacia, número; percentuais de habitantes e taxa geométrica de crescimento anual, para os anos de 1991, 1996 e 2000 (IBGE, 2002).

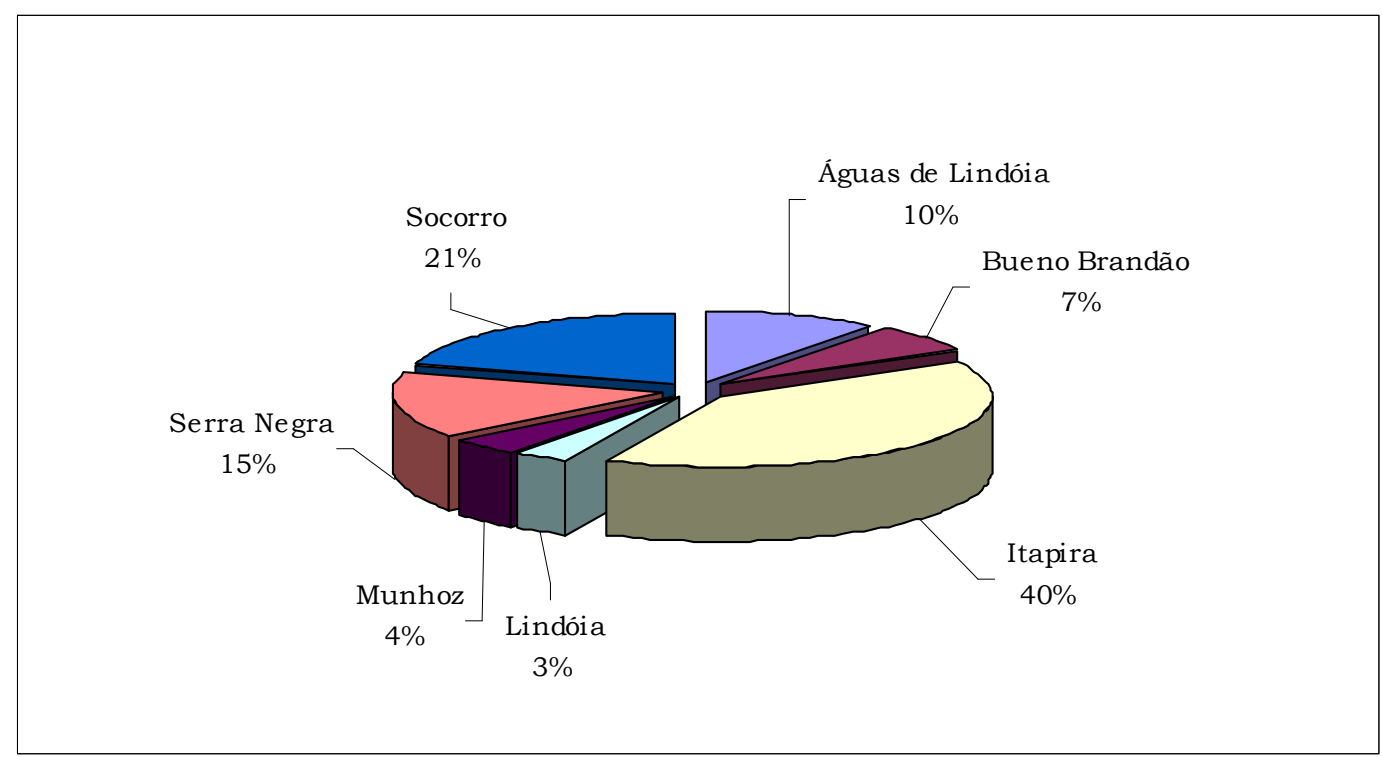

Figura 3.4 - Distribuição demográfica na Bacia do Rio do Peixe.

Tabela 3.2 - Dados Populacionais da Bacia do Rio do Peixe. Número de Habitantes, Percentual de Habitantes e Taxa Geométrica de Crescimento Anual (IBGE, 2002).

\begin{tabular}{l|c|c|c|c|c|c|c|c|c}
\hline Municípios & $\begin{array}{c}\text { Num } \\
\mathbf{H a b} \\
\mathbf{( 1 9 9 1 )}\end{array}$ & $\begin{array}{c}\mathbf{* * 0} \mathbf{H a b} \\
\mathbf{( 1 9 9 1 )}\end{array}$ & $\begin{array}{c}\mathbf{N u m} \\
\mathbf{H a b} \\
\mathbf{( 1 9 9 6 )}\end{array}$ & $\begin{array}{c}\mathbf{9} \\
\mathbf{H a b} \\
\mathbf{( 1 9 9 6 )}\end{array}$ & $\begin{array}{c}\text { Num } \\
\mathbf{H a b} \\
\mathbf{( 2 0 0 0 )}\end{array}$ & $\begin{array}{c}\mathbf{\%} \\
\mathbf{H a b} \\
\mathbf{( 2 0 0 0 )}\end{array}$ & $\begin{array}{l}\text { TCMA* } \\
\mathbf{( 9 1 / 9 6 )}\end{array}$ & $\begin{array}{l}\text { TCMA* } \\
\mathbf{( 9 6 / 0 0 )}\end{array}$ & $\begin{array}{l}\text { TCMA* } \\
\mathbf{( 9 1 / 0 0 )}\end{array}$ \\
\hline $\begin{array}{l}\text { Águas } \\
\text { Lindóia }\end{array}$ & 11.966 & 8,45 & 13.542 & 9,07 & 16.190 & 10,18 & 2,50 & 4,56 & 3,42 \\
\hline $\begin{array}{l}\text { Bueno } \\
\text { Brandão }\end{array}$ & 10.787 & 7,62 & 10.578 & 7,09 & 10.932 & 6,87 & $-0,39$ & 0,83 & 0,15 \\
\hline Itapira & 56.586 & 39,96 & 60.791 & 40,75 & 63.377 & 39,85 & 1,44 & 1,05 & 1,27 \\
\hline Lindóia & 4.118 & 2,90 & 4.916 & 3,29 & 5.331 & 3,35 & 3,60 & 2,05 & 2,91 \\
\hline Munhoz & 5.652 & 3,99 & 6.206 & 4,16 & 6.656 & 4,18 & 1.88 & 1,76 & 1,83 \\
\hline $\begin{array}{l}\text { Serra } \\
\text { Negra }\end{array}$ & 21.704 & 15,33 & 22.295 & 14,94 & 23.851 & 14,99 & 0,54 & 1,70 & 1,05 \\
\hline Socorro & 30.763 & 21,73 & 30.847 & 20,68 & 32.704 & 20,56 & 0,05 & 1,47 & 0,68 \\
\hline
\end{tabular}

*Taxa Geométrica de Crescimento Anual

** Percentual de habitantes por municipio em relação a população total da bacia

A população da bacia pode ser subdividida em duas categorias, população urbana e população rural. $\mathrm{Na}$ bacia como um todo predomina a população urbana, aproximadamente $80 \%$ da população total (Tabela 3.3). Os municípios com maior índice de população urbana relativo a população urbana total da bacia são: Itapira (45,5\%), Socorro (16,31\%) e Serra Negra (16,03\%). Munhoz e Lindóia destacam-se 
como os municípios de menor índice de população urbana, respectivamente, 2,74\% e 3,66\% (Figura 3.5).

No que se refere à população rural, o município de Socorro apresenta o maior percentual de habitantes rurais com relação a população total da bacia, 38,48\%, seguido pelos municípios de Bueno Brandão (18,68\%) e Itapira (17,5\%). Os municípios com menores percentuais de habitantes rurais são Lindóia (2,01\%) e Águas de Lindóia (2,4\%) (Figura 3.5).

Tabela 3.3 - Dados de População Urbana e Rural nos Municípios da Bacia no ano de 2000 (IBGE, 2002).

\begin{tabular}{lcccccc}
\hline Municípios & \multicolumn{2}{c}{ População Total } & \multicolumn{2}{c}{ População Urbana } & \multicolumn{2}{c}{ População Rural } \\
\cline { 2 - 7 } & $\begin{array}{l}\text { Num. } \\
\text { Hab }\end{array}$ & \% Hab* & $\begin{array}{c}\text { Num. } \\
\text { Hab }\end{array}$ & \% Hab** & $\begin{array}{c}\text { Num. } \\
\text { Hab }\end{array}$ & \% Hab** \\
\hline Águas de Lindóia & 16190 & 10,18 & 15463 & 12,02 & 727 & 2,38 \\
\hline Bueno Brandão & 10932 & 6,9 & 5241 & 4,08 & 5691 & 18,68 \\
\hline Itapira & 63377 & 39,85 & 58042 & 45,14 & 5335 & 17,51 \\
\hline Lindóia & 5331 & 3,35 & 4716 & 3,66 & 615 & 2,02 \\
\hline Munhoz & 6656 & 4,18 & 3524 & 2,74 & 3132 & 10,28 \\
\hline Serra Negra & 23851 & 14,99 & 20612 & 16,03 & 3239 & 10,63 \\
\hline Socorro & 32704 & 20,56 & 20980 & 16,31 & 11724 & 38,48 \\
\hline Total & 159041 & 100 & 128578 & 100 & 30463 & 100 \\
\hline * Percentual de habitantes nos municípios em relação à população total da bacia & & \\
** Percentual de habitantes nos municípios com relação à população urbana total da bacia. \\
*** Percentual de habitantes nos municípios com relação à população rural total da bacia.
\end{tabular}

\subsubsection{Quadro Econômico}

A economia dos municípios da Bacia do Rio do Peixe baseia-se em duas atividades principais, o turismo e a agricultura. $\mathrm{O}$ turismo é marcado pela presença do circuito das águas paulistas, o qual compreende na área as estâncias de águas de Lindóia, Lindóia, Serra Negra e Socorro. As estâncias funcionam como centros de lazer e oferecem contato com a natureza (vales, montanhas, cachoeiras, etc), fontes da água potável e águas termais, muito utilizadas para fins medicinais. A atividade agrícola destaca-se principalmente, nas cidades de Itapira, Serra Negra, Socorro e Bueno Brandão, com o cultivo de produtos de lavoura temporária e de lavoura permanente.

Além das atividades acima citadas são desenvolvidas também outras atividades como produção pecuária, com a criação de rebanhos e aves e a produção de ovos e leite; e atividades extrativistas, com a extração de madeira; e os setores comerciais e industriais, ligados a agricultura e ao turismo. 


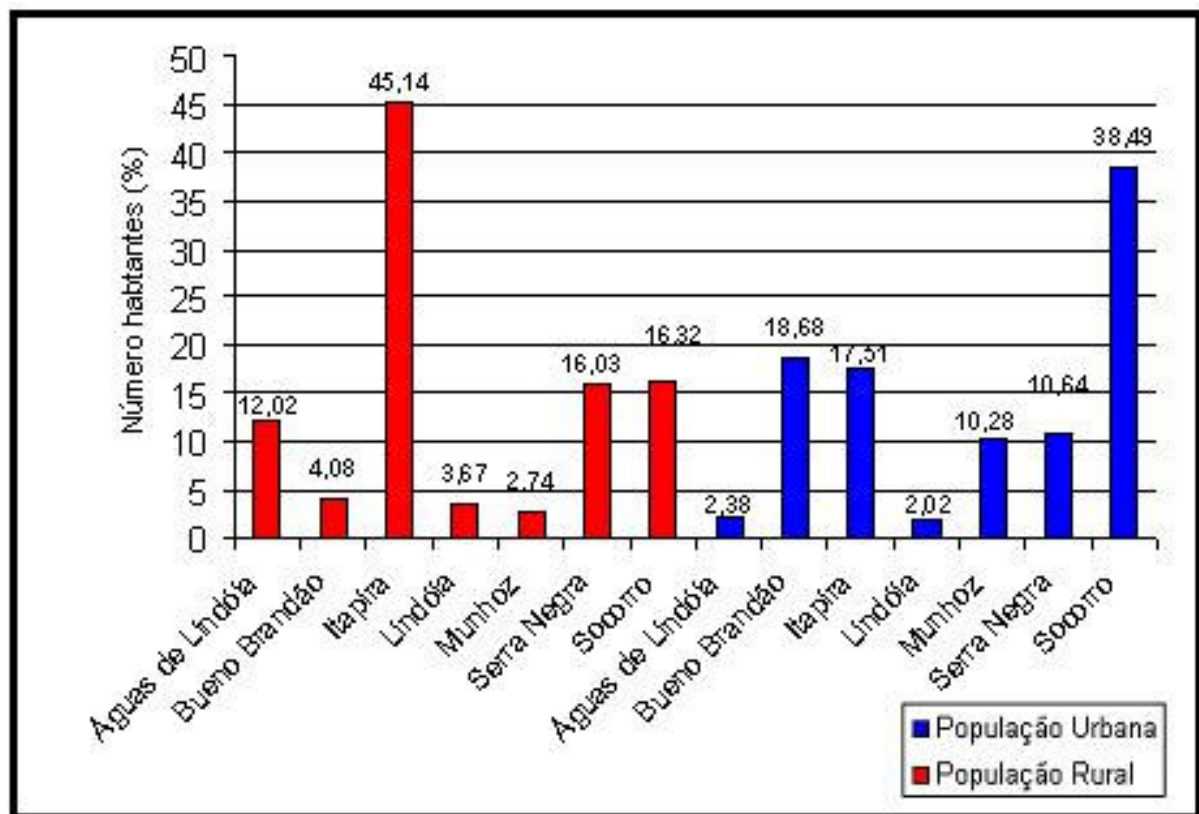

Figura 3.5 - Distribuição da população urbana e rural na Bacia do Rio do Peixe (IBGE, 2002).

\subsubsection{Turismo}

O turismo é a atividade econômica de maior destaque na bacia em terrenos paulistas. Seu desenvolvimento concentra-se nos municípios integrantes do circuito das águas paulistas, Águas de Lindóia, Lindóia, Serra Negra e Socorro, denominados estâncias termais.

As estâncias apresentam uma avançada infra-estrutura hoteleira e têm como principal ponto atrativo à qualidade de suas águas, conhecidas em âmbito nacional e internacional por aplicações medicinais. Outro ponto atrativo é a localização do circuito, na Serra da Mantiqueira, oferecendo aos turistas uma bela paisagem com vales cobertos de muito verde, cachoeiras, fontes de água potável e um clima entre os melhores do mundo.

As atividades de turismo na área se dividem em quatro categorias:

- Turismo Tradicional - voltado para realização de passeios;

- Turismo de Compras - voltado para o comércio de artigos produzidos nas Estâncias, como artigos de couro, de lã, de linha, da madeira, de bambu, de vime e laticínios;

- Turismo de Negócios - voltado para realização de congressos, feiras e convenções nos hotéis e centros especializados; e 
- Turismo Rural - voltado para realização de passeios em propriedades abertas a visitação e pesqueiros.

De uma maneira geral, as quatro atividades são bem desenvolvidas nas estâncias da Bacia, não havendo maior destaque a uma em especial.

\subsubsection{Atividade Agrícola}

A atividade agrícola na bacia é desenvolvida segundo duas categorias, 1) Produção agrícola permanente e 2) Produção agrícola temporária.

A bacia tem $13,21 \%$ de sua área destinada ao cultivo de lavoura temporária, a qual é 2,67 vezes superior ao cultivo de lavoura permanente. Esta última ocupa 6,89\% da área total da Bacia (Figura 3.6, Tabela 3.4).

No que se refere ao número de produtos cultivados, as duas atividades merecem o mesmo destaque. A produção agrícola temporária tem seu cultivo baseado em dez produtos e a produção agrícola permanente em oito produtos.

Quando analisado o número de produtos plantados por municípios, merece destaque, no que se refere à lavoura temporária, Socorro e Serra Negra que cultivam, respectivamente, oito e sete produtos. Com relação à lavoura permanente, Socorro e Bueno Brandão destacam-se com o plantio, respectivo, de nove e oito dos dez produtos cultivados na Bacia.

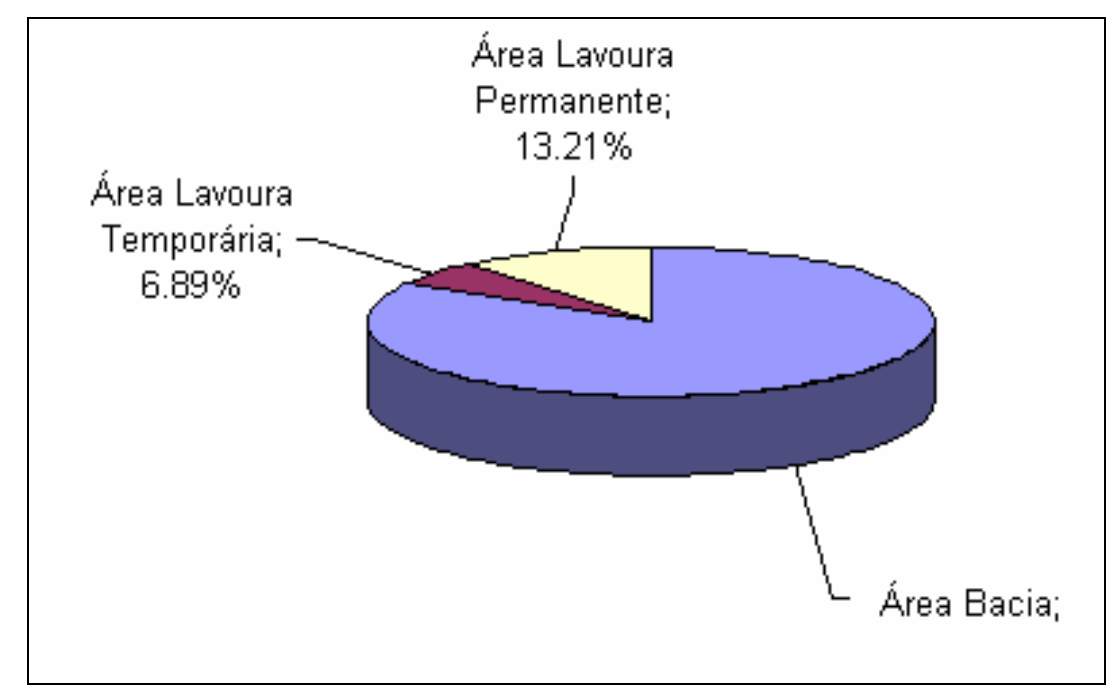

Figura 3.6 - Percentual em área ocupado pela produção agrícola na Bacia do Rio do Peixe (IBGE, 2002). 
Tabela 3.4 - Distribuição em Área das Lavouras Temporária e Permanente nos Municípios da Bacia(IBGE, 2002).

\begin{tabular}{|c|c|c|c|c|c|c|c|c|c|}
\hline \multirow{2}{*}{\multicolumn{2}{|c|}{$\begin{array}{c}\text { Produtos } \\
\text { Cultivados }\end{array}$}} & \multicolumn{8}{|c|}{ Área Plantada nos Municípios da Bacia $\left(\mathrm{Km}^{2}\right)$} \\
\hline & & $\begin{array}{c}\text { Águas } \\
\text { Lindóia }\end{array}$ & $\begin{array}{c}\text { Bueno } \\
\text { Brandão }\end{array}$ & Itapira & Lindóia & Munhoz & $\begin{array}{c}\text { Serra } \\
\text { Negra }\end{array}$ & Socorro & $\begin{array}{l}\text { Total } \\
\text { Bacia } \\
\end{array}$ \\
\hline \multirow{8}{*}{$\begin{array}{l}\mathrm{P} \\
\mathrm{E} \\
\mathrm{R} \\
\mathrm{M} \\
\mathrm{N} \\
\mathrm{E} \\
\mathrm{N} \\
\mathrm{T} \\
\mathrm{E}\end{array}$} & Abacate & -- & -- & -- & -- & -- & 0,2 & 1,3 & 1,5 \\
\hline & Banana & -- & 0.2 & -- & -- & -- & 0,13 & 0,09 & 0,22 \\
\hline & Café & 8,51 & 18 & 27,69 & 1,38 & 0,01 & 17,69 & 12,31 & 85,59 \\
\hline & Laranja & 0,13 & 0,15 & 22,31 & 0,19 & 0,01 & 0,19 & 3,08 & 26,06 \\
\hline & Limão & 0,02 & -- & -- & 0,04 & -- & 0,04 & 0,04 & 0,14 \\
\hline & Manga & -- & -- & -- & -- & -- & 0,8 & 0,17 & 0,97 \\
\hline & Tangerina & 0,1 & -- & -- & 0,04 & -- & 0,08 & 0,45 & 0,67 \\
\hline & Uva & -- & 0,01 & -- & -- & -- & -- & 0,06 & 0,07 \\
\hline \multirow{10}{*}{$\begin{array}{l}\mathrm{T} \\
\mathrm{E} \\
\mathrm{M} \\
\mathrm{P} \\
\mathrm{O} \\
\mathrm{R} \\
\hat{A} \\
\mathrm{R} \\
\mathrm{I} \\
\mathrm{A}\end{array}$} & Algodão & -- & -- & $2,5--$ & -- & -- & -- & -- & 2,5 \\
\hline & Alho & -- & 0,08 & -- & -- & 0,01 & -- & 0,05 & 0,14 \\
\hline & Arroz & 0,03 & 1,4 & 15 & 0,03 & -- & 0,15 & 0,4 & 17,01 \\
\hline & $\begin{array}{l}\text { Batata- } \\
\text { Inglesa }\end{array}$ & -- & 2,5 & -- & -- & 11,5 & 0,08 & 9,5 & 23,58 \\
\hline & $\begin{array}{l}\text { Cana-de- } \\
\text { açúcar }\end{array}$ & -- & 0,24 & 150 & 0,2 & 0,04 & 7,5 & 0,3 & 158,28 \\
\hline & Feijão & 0,15 & 5,6 & 1,3 & 0,18 & 0,6 & -- & 8 & 15,83 \\
\hline & Fumo & -- & -- & -- & -- & -- & -- & 0,2 & 0,2 \\
\hline & Mandioca & -- & 0,2 & $\begin{array}{ll}- \\
--\end{array}$ & -- & 0,11 & -- & 0,5 & 0,81 \\
\hline & Milho & 1,1 & 0,02 & -- & 0,08 & -- & 0,6 & 0,15 & 1,95 \\
\hline & Tomate & 0,01 & 0,02 & -- & 0,08 & -- & 0,6 & 0,15 & 0,86 \\
\hline
\end{tabular}

\section{Produção Agrícola Permanente}

A produção agrícola permanente da Bacia é responsável pelo cultivo de oito produtos: Abacate, Banana, Café, Laranja, Limão, Manga e Tangerina. Desses produtos os que apresentam maior percentual da área plantada são o café e a laranja (Figura 3.7).

O café é o produto com maior destaque na bacia. Apresenta-se com suas maiores plantações nos municípios de Itapira, Serra Negra e Socorro. Juntos esses municípios são responsáveis pela produção de 9.190 toneladas de café, $73 \%$ da produção total da Bacia.

A laranja destaca-se como o produto com segunda maior área destinada ao cultivo de lavoura permanente. A maior plantação de laranja na área da bacia ocorre no município de Itapira, o qual é responsável por uma produção de 176.000 toneladas. A exceção de Itapira e de Bueno Brandão, a produção de laranja nos demais municípios da Bacia é calculada em números de frutos colhidos (Tabela 3.5). 


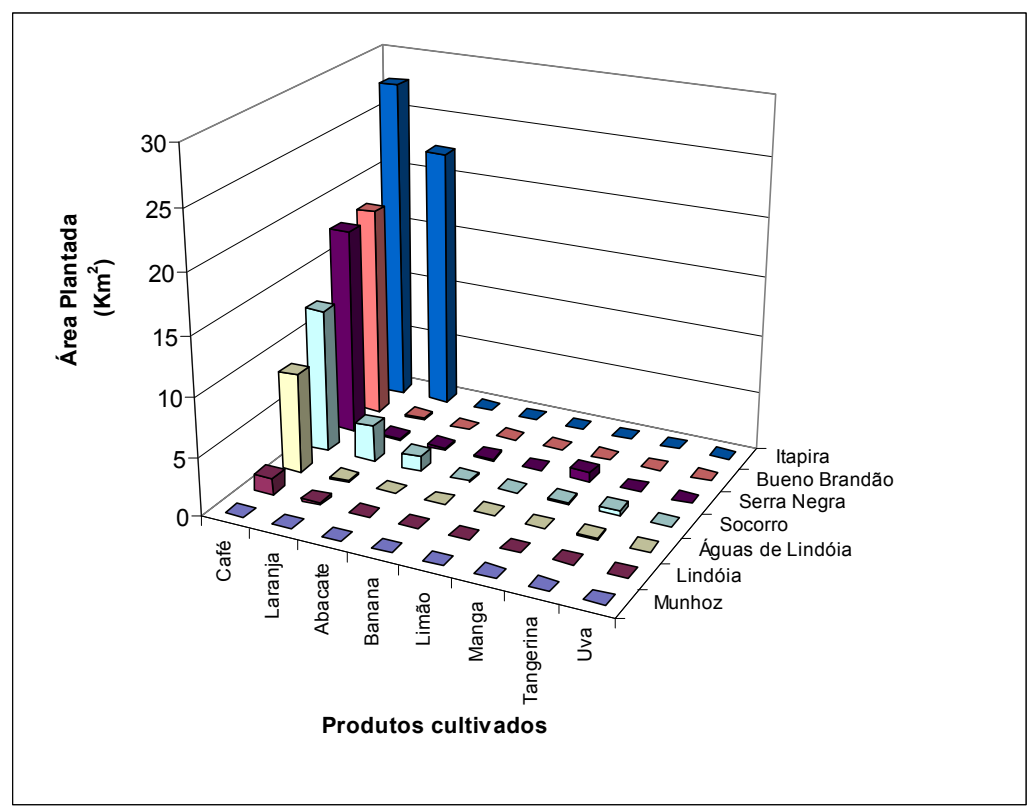

Figura 3.7 - Distribuição em área plantada dos produtos de lavoura permanente.

Tabela 3.5- Distribuição em Área e Produção de Café e Laranja nos municípios da Bacia (IBGE, 2002).

\begin{tabular}{l|c|c|c|c}
\hline \multirow{2}{*}{ Municípios } & \multicolumn{2}{|c|}{ Café } & \multicolumn{2}{c}{ Laranja } \\
\cline { 2 - 5 } & $\begin{array}{c}\text { Área Plantada } \\
\left(\mathbf{K m}^{\mathbf{2}}\right)\end{array}$ & Produção (Ton) & $\begin{array}{c}\text { Área Plantada } \\
\left(\mathbf{K m}^{\mathbf{2}}\right)\end{array}$ & $\begin{array}{c}\text { Produção } \\
\text { (Frutos) }\end{array}$ \\
\hline Águas Lindóia & 8,51 & 755 & 0,13 & 1.750 \\
\hline Bueno Brandão & 18,0 & 2.340 & 0,15 & $750^{*}$ \\
\hline Lindóia & 27,69 & 4.890 & 22,31 & $176.000^{*}$ \\
\hline Itapira & 1,38 & 180 & 0,19 & 3.125 \\
\hline Munhoz & 0,01 & 1 & 0,01 & 120 \\
\hline Serra Negra & 1,69 & 2300 & 0,19 & 2.500 \\
\hline Socorro & 12,31 & 2.000 & 3,08 & 32.500 \\
\hline Total & $\mathbf{6 9 , 5 9}$ & $\mathbf{1 2 4 . 6 6}$ & $\mathbf{2 6 , 0 6}$ & $\mathbf{3 9 . 9 9 5}$ \\
\hline
\end{tabular}

*Produção em Toneladas

\section{Produção Agrícola Temporária}

A produção agrícola temporária da Bacia é baseada no cultivo de dez produtos, Alho, Algodão Herbáceo, Arroz (casca), Batata-Ingleza, Cana-de-açúcar (não forragem), Feijão (grão), Fumo (folha),Mandioca, Milho (grão) e Tomate. Destes os produtos com maior percentual de área plantada são a cana de açúcar, o milho, o arroz, o feijão e a batata-inglesa (Figura 3.8).

A cana-de-açúcar é o produto da lavoura temporária de maior destaque, apresentando uma área destinada ao plantio em torno de $158 \mathrm{Km}^{2}$. Itapira destaca-se como o município com a maior área destinada ao cultivo de cana-de-açúcar, e a maior produção da mesma na bacia, 1.125.000 toneladas (Tabela 3.6). O milho apresenta uma 
área de cultivo de aproximadamente $65 \mathrm{Km}^{2}$. Itapira e Socorro são os municípios com as maiores áreas de cultivo de milho, 23 e $20 \mathrm{Km}^{2}$, respectivamente, e as maiores produções também, 6.600 e 4.800 toneladas.

A batata-inglesa é cultivada em apenas quatro dos sete municípios da Bacia. A área destinada ao cultivo deste produto é de 43,58 $\mathrm{Km}^{2}$. Destacam-se com as maiores plantações e produções de batata-inglesa os municípios de Bueno Brandão, com 22,5 $\mathrm{Km}^{2}$ de área plantada e 40.500 toneladas produzidas; e Munhoz com $11.5 \mathrm{Km}^{2}$ de área plantada e uma produção de 23.856 toneladas.

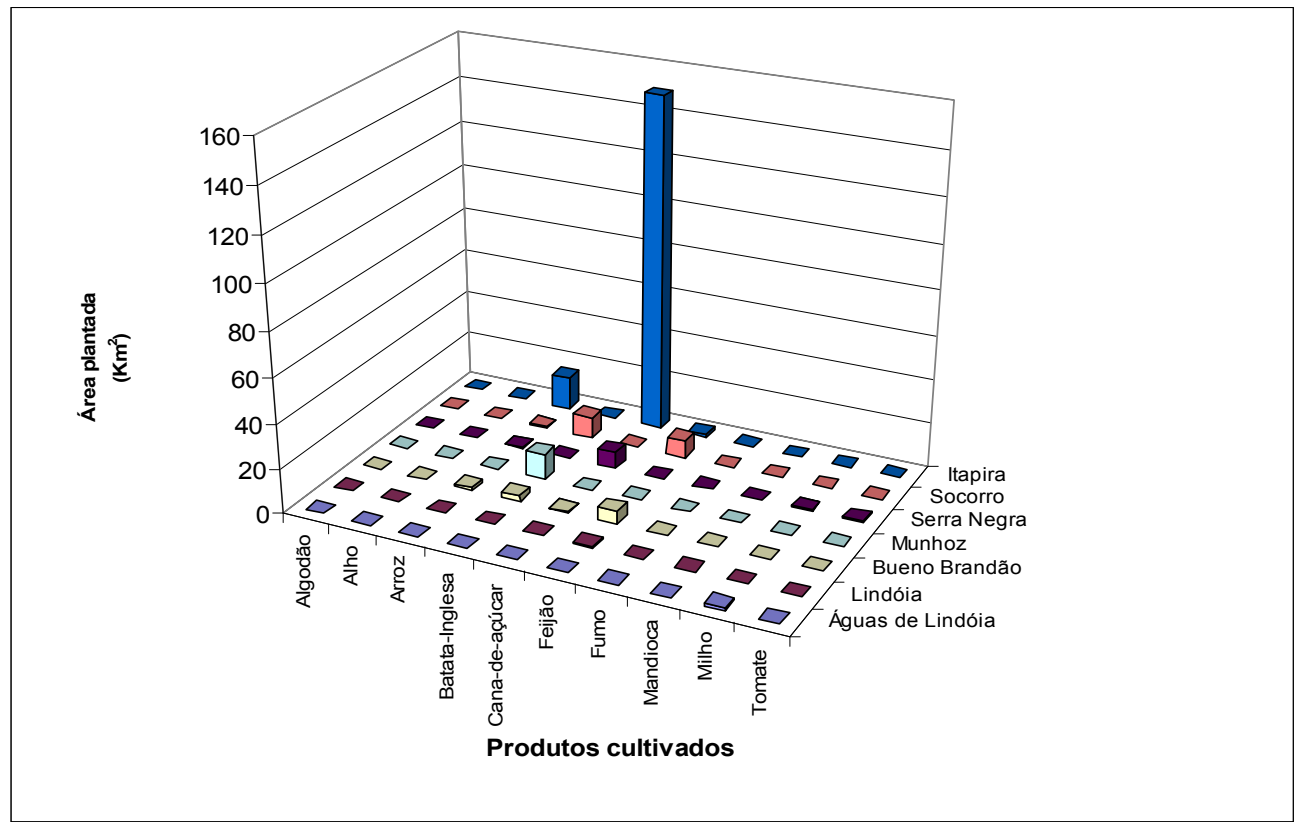

Figura 3.8 - Distribuição em área plantada dos produtos de lavoura temporária.

Tabela 3.6 - Distribuição em Área e Produção de Cana-de-Açúcar, Milho e BatataInglesa na Bacia (IBGE, 2002).

\begin{tabular}{l|c|c|c|c|c|c}
\hline \multirow{2}{*}{ Municípios } & \multicolumn{2}{|c|}{ Cana-de-Açúcar } & \multicolumn{2}{c|}{ Milho } & \multicolumn{2}{c}{ Bata-Inglesa } \\
\cline { 2 - 7 } & $\begin{array}{c}\text { Área } \\
\text { Plantada } \\
\left(\mathbf{K m}^{2}\right)\end{array}$ & $\begin{array}{c}\text { Produção } \\
\text { (Ton) }\end{array}$ & $\begin{array}{c}\text { Área } \\
\text { Plantada } \\
\left(\mathbf{K m}^{2}\right)\end{array}$ & $\begin{array}{c}\text { Produção } \\
\mathbf{( T o n )}\end{array}$ & $\begin{array}{c}\text { Área } \\
\text { Plantada } \\
\left(\mathbf{K m}^{2} \mathbf{)}\right.\end{array}$ & $\begin{array}{c}\text { Produção } \\
\text { (Ton) }\end{array}$ \\
\hline $\begin{array}{l}\text { Águas } \\
\text { Lindóia }\end{array}$ & -- & -- & 1,1 & 330 & -- & -- \\
\hline $\begin{array}{l}\text { Bueno } \\
\text { Brandão }\end{array}$ & 0,24 & 1440 & 13 & 4550 & 22,5 & 40,500 \\
\hline Itapira & 150 & 1.125 .000 & 23 & 4.080 & -- & -- \\
\hline Lindóia & 0,2 & 100 & 0,5 & 150 & -- & -- \\
\hline Munhoz & 0,04 & 120 & 5,15 & 1030 & 11,5 & 23.856 \\
\hline $\begin{array}{l}\text { Serra } \\
\text { Negra }\end{array}$ & 7,5 & 60.000 & 7 & 2520 & 0,08 & 144 \\
\hline Socorro & 0,3 & 1960 & 20 & 6.600 & 9,5 & 92 \\
\hline Total & $\mathbf{1 5 8 , 2 8}$ & $\mathbf{1 . 1 8 9 . 5 2 0}$ & $\mathbf{6 9 , 7 5}$ & $\mathbf{1 5 . 5 8 8}$ & $\mathbf{4 3 , 5 8}$ & $\mathbf{6 4 . 5 9 2}$ \\
\hline
\end{tabular}




\section{CAPÍTULO 4}

\section{MATERIAIS E MÉTODOS}

O Zoneamento Geoambiental da bacia foi elaborado a partir da aplicação de dois instrumentos do processo de planejamento ambiental, a avaliação ambiental relativa ao meio físico e a avaliação de alterações por atividades modificadoras; e da análise conjunta dos resultados produzidos, a qual consistiu da avaliação compartimentada das informações por unidades de terreno. Este processo resultou em uma base orientativa que informa sobre potencialidades, restrições e alterações vigentes no meio, caracterizadas em diferentes unidades geoambientais.

\subsection{AVALIAÇÃO AMBIENTAL DO MEIO FÍSICO}

A avaliação ambiental relativa ao meio físico consistiu da caracterização de potencialidades e restrições naturais da área, determinadas a partir da elaboração e análise de documentos cartográficos em formato fuzzy. Estes correspondem a documentos em formato numérico, nos quais os atributos, fenômenos ou processo retratados apresentam distribuição contínua, o que permite caracterizar situações de gradação entre esses.

Para determinação das potencialidades e restrições do meio foram realizadas duas etapas distintas, na primeira foram realizados o levantamento e produção de informações básica relativas aos compartimentos do meio físico e na segunda o tratamento e análise destas informações por meio de processamento computacional com a aplicação de fundamentos de lógica funsy. A primeira etapa correspondeu a elaboração da base de dados fundamentais do meio, com a caracterização de 
informações importantes a determinação dos aspectos de potencialidade e restrições da área, e a segunda da criação da base de dados em formato fuz̧yy, para obtenção das cartas derivadas e interpretavas em formato contínuo.

O processo de análise e tratamento computacional das informações, tanto básicas com derivadas e interpretativas, caracterizou-se pela elaboração e execução rotinas de processamento baseadas nos princípios de lógica furày.

\subsection{Levantamento e Produção de Informações Básicas Relativas ao Meio Físico- Base de Dados Fundamentais}

Consistiu na execução de diferentes atividades com levantamento de informações preexistentes, realização de processo de fotointerpretação, criação de base cartográfica e trabalhos de campo.

O levantamento de informações previamente produzidas sobre a área permitiu a caracterização inicial dos atributos do meio físico e a elaboração de mapas preliminares. Estas correspondem principalmente a trabalhos de zoneamento e caracterização geotécnica e geológica, Alberchet,(1992), Mio (1992), Barison (1995), Saraiva (1995) e Projeto Geológico Metalogenético (1999).

A elaboração da base cartográfica e a realização das interpretações de fotografias aéreas conjuntamente com trabalhos de campo permitiram caracterização dos diferentes atributos do meio e apresentaram como produto os mapas fundamentais básico: Mapa de Substrato Rochoso, Mapa de Materiais Inconsolidados, Mapa de Lanforms e Mapa de Uso e Ocupação do Terreno.

Como base cartográfica para a elaboração dos mapas fundamentais foram utilizadas folhas topográficas do Instituto Brasileiro de Geografia e Estatística (IBGE 1972), em escala 1:50.000 - Mogi-Guaçu (SF-23-Y-A-III-3), Águas de Lindóia (SF-23-YA-III-4), Ouro Fino (SF-23-Y-B-III-1), Amparo (SF-23-Y-A-VI-1), Socorro (SF-23-YA-IV-2), Munhoz (SF-23-Y-B-IV-1) e Cambuí (SF-23-Y-B-IV-2). Estas folhas foram digitalizadas e georreferenciadas utilizando-se o programa Autocad.

As fotografias aéreas utilizadas no processo de fotointerpretação, têm escala 1:60.000 e foram obtidas pela Base - Aérea Fotogrametria e Projetos S / A e pelo Ministério do Exército( $5^{\frac{a}{2}}$ Divisão de Levantamento). 
Nos trabalhos de campo foram realizadas observações e descrições de diferentes atributos do meio fisco, com a caracterização das unidades de substrato rochoso e suas relações de contato, além da coleta de amostras de materiais inconsolidados deformada e indeformadas para análise em laboratório.

\subsubsection{Processamento Computacional com Aplicação de Fundamentos de Lógica Fuzzy - Base de Dados Fuzzye Elaboração de Cartas Interpretativas}

Compreendeu a realização de diferentes etapas de processamento em ambiente computacional, as quais consistiram, principalmente, na transformação de informações básicas para o formato furzy e elaboração de documentos representativos dos aspectos de restrições e potencialidade do meio físico, Mapa de Potencial ao Escoamento, Mapa de Susceptibilidade a Erosão e Mapa de Potencial Agrícola.

Para transformação das informações básicas e análise das mesmas, foram elaboradas rotinas de processamento em linguagem de programação LEGAL, no sistema de informações geográficas SPRING. Estas permitiram caracterização da distribuição espacial de atributos e aspectos do meio, retratados como informações contínuas.

As informações relativas aos aspectos de potencialidades e restrições do meio físico foram obtidas a partir do cruzamento de informação fundamentais, após análise comparativa e ponderação de atributos segundo importância e influência no condicionamento de menor ou maior favorabilidade a um dos aspectos acima enfocados.

\subsection{AVALIAÇÃO DE ALTERAÇÕES DO MEIO FÍSICO POR ATIVIDADES MODIFICADORAS}

Constitui a identificação e determinação de alterações ambientais introduzidas no meio físico pelo desenvolvimento de atividade de uso e ocupação da região. Para caracterização destas alterações foi proposta a adoção de um atributo do meio com indicador ambiental. 
O atributo proposto corresponde à medida de resistência a penetração do solo. Para realização da quantificação desse atributo foi desenvolvida uma metodologia com base nas técnicas de penetrometria e de reflexão no domínio do tempo (TDR).

Para emprego do atributo proposto como meio de medida e caracterização de modificações foram investigados e caracterizados comportamentos de resistência a penetração em diferentes tipos de materiais inconsolidados existentes na área, com relação a diferentes atividades de ocupação do meio.

Nos capítulos 5, 6 e 7 são apresentadas descrições mais detalhadas das etapas e procedimentos desenvolvida nos dois processo de avaliação. A Figura 4.1 ilustra as principais etapas executadas na elaboração do zoneamento geoambiental da bacia

\subsection{ZONEAMENTO GEOAMBIENTAL}

As informações básicas e derivadas interpretativas produzidas foram analisadas de forma setorizada, por unidade de terreno, e confrontadas com os aspectos de alterações registrados, e informações legais de preservação do meio. O resultado deste processo constitui um documento cartográfico, o qual retrata diferentes aspectos relativos ao meio e serve de base orientativa para processos futuros de planejamento e zoneamento da área. 


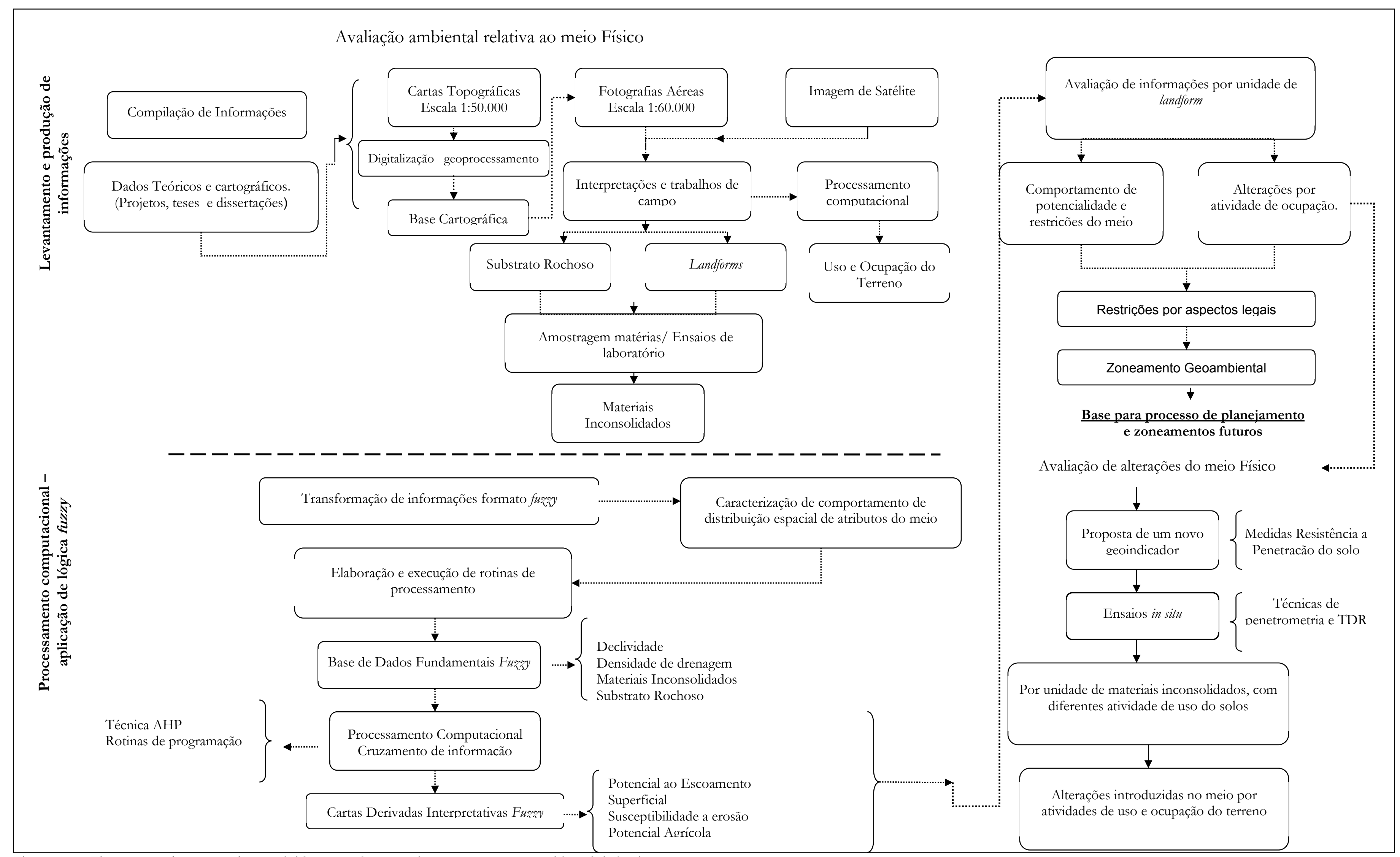

Figura 4.1 - Fluxograma das etapas desenvolvidas para obtenção do zoneamento geoambiental da bacia 
CAPÍTULO 5

\section{BASE DE DADOS - MAPAS BÁSICOS FUNDAMENTAIS E CARTA DERIVADA}

\subsection{MAPA DE DOCUMENTAÇÃO (ANEXO I)}

Este documento consiste da representação cartográfica de todos os pontos descritos e realizados em campo. Consta neste documento a localização dos pontos de observação e descrição de compartimentos do meio físico, coleta de materiais para execução de ensaios em laboratório e pontos de realização de ensaios in situ. Além da localização dos municípios da bacia, assim como vias de acesso, rede de drenagem e informações referentes à topografia da área. Este documento constitui a carta base primária utilizada na caracterização da área em estudo.

\subsection{MAPA DE SUBSTRATO ROCHOSO (ANEXO II)}

A Bacia do Rio do Peixe caracteriza-se por apresentar um quadro litológico complexo gerado por forte estruturação tectônica, que resultou na superposição de efeitos de diferentes fases de metamorfismo, e deformação das litologias presentes na área (Mio, 1992; Barison, 1995; Saraiva, 1995). Isto gera grande dificuldade no ordenamento cronológico-estratigráfico da geologia da área.

Em consideração ao acima exposto, aqui foi adotada uma organização litológica que não obedece a uma cronologia estratigráfica, e sim a um agrupamento das rochas mediante seu provável comportamento geotécnico. Para tal foram levados em consideração aspectos como gênese, constituição mineralógica, textura, estrutura e arranjo espacial. 
De uma maneira geral, as litologias presentes na área da bacia podem ser enquadradas em dois grupos: 1) Rochas Ígneas, as quais não foram muito afetadas pela ação da deformação e 2) Rochas Metamórficas, as quais foram afetadas pela deformação.

As rochas encontradas na área constituem, principalmente, gnaisses, migmatitos, granitóides, quartzitos e rochas cataclásticas. São encontrados também xistos, pegmatitos e anfibolitos.

Na bacia, a ação das deformações nas litologias é denotada principalmente por meio da ocorrência de estruturas como a foliação, definida pela orientação planar de minerais. Esta é bem caracterizada nos gnaisses, quartzitos e migmatitos, sendo nestes últimos paralela ao bandamento das rochas.

Além das foliações, merecem destaque outras duas estruturas, os falhamentos (Zonas de Falhas de Monte Sião e Ibitinga que caracterizam zonas de metamorfismo dinâmico ou cataclástico) e as dobras, descritas por Grossi Sad et al. (1992) e Saraiva (1995).

A descrição das unidades e dos procedimentos empregados na obtenção do Mapa de Substrato Rochoso é apresentada a seguir.

\subsubsection{Procedimentos Empregados}

O Mapa do Substrato Rochoso da Bacia do Rio do Peixe foi obtido mediante realização de duas fases gerais de trabalho: 1) Levantamento de dados pré-existentes, que objetivou fornecer um conhecimento prévio do substrato da região e 2) Trabalhos de campo, que tiveram por objetivo a elaboração do mapa final com as unidades litológicas da área. A Figura 5.1 apresenta um fluxograma com as etapas desenvolvidas.

As informações prévias levantadas sobre a geologia da área correspondem, principalmente, aos trabalhos realizados por Mio (1992), Albrecht (1992), Barison (1995), Saraiva (1995) e Projeto G eológico Metalogenético (1999),

\subsubsection{Unidades do Substrato Rochoso}

As unidades do substrato rochoso enquadram-se em dois grupos: 1) Rochas Ígneas e 2) Rochas Metamórficas (Quadro 5.1). 


\subsubsection{Rochas Ígneas}

As rochas ígneas presentes na bacia caracterizam uma associação litológica subdividida em três unidades: 1) ganitos porfiróides, 2) ganitos cataclasados e 3) granitos-gnaisse. As duas primeiras foram assim denominadas por Mio (1992).

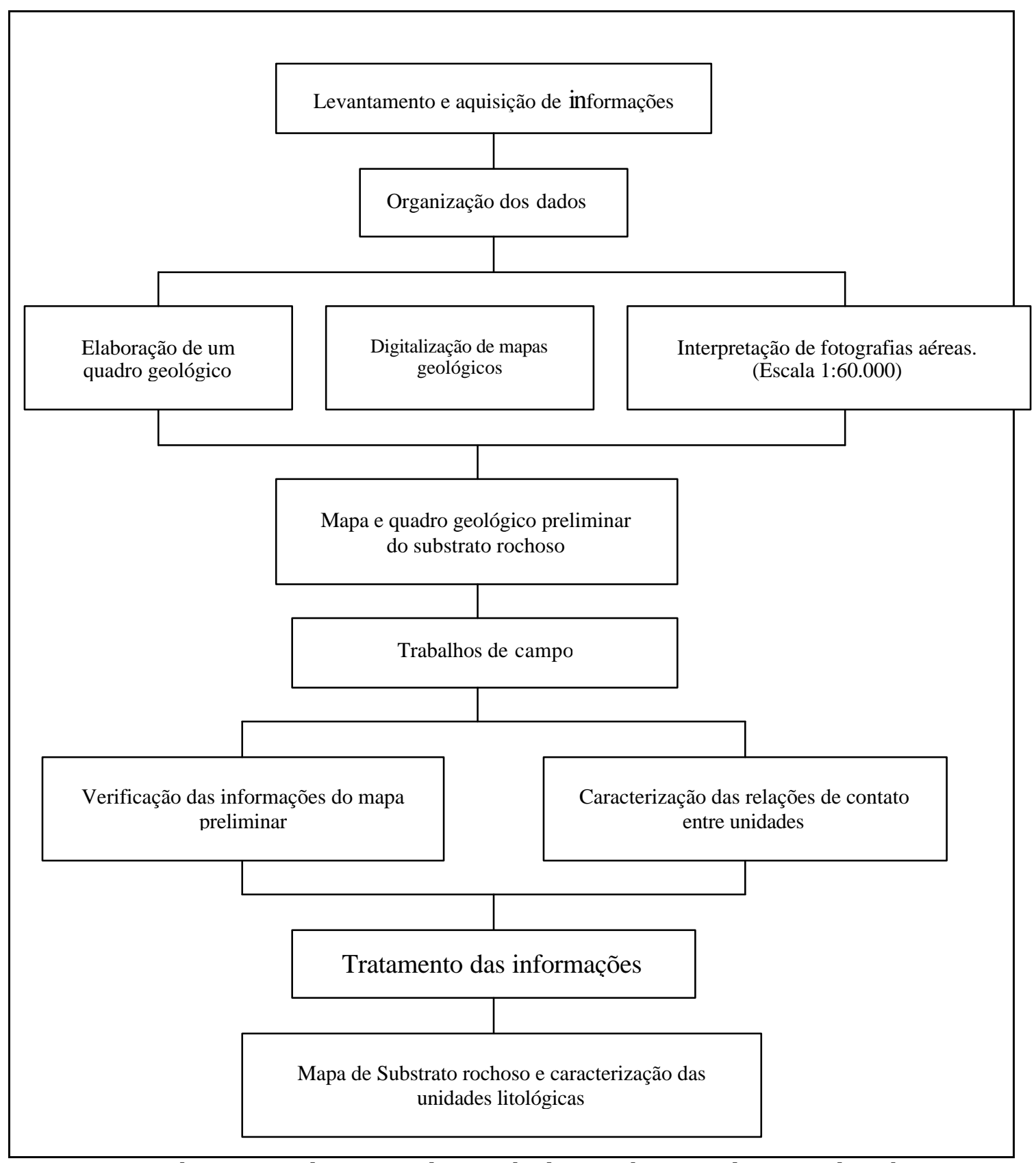

Figura 5.1 - Fluxograma das etapas desenvolvidas na obtenção do Mapa de Substrato Rochoso. 
Quadro 5.1 - Unidades Litológicas que compõem o Substrato Rochoso da Bacia do Rio do Peixe.

\begin{tabular}{|c|c|c|c|}
\hline \multicolumn{3}{|c|}{ Rochas } & Descrição \\
\hline \multirow{3}{*}{$\stackrel{8}{g}$} & & $\begin{array}{l}\text { Granitos Cataclasados } \\
\text { (Grc) }\end{array}$ & $\begin{array}{l}\text { Rocha de constituição quartzo-feldspatica, granulação média a grossa, de cor rosa a cinza. Exibe graus variáveis de catáclase, denotados pela } \\
\text { orientação de cristais de feldspatos muito fraturados. }\end{array}$ \\
\hline & & $\begin{array}{l}\text { Granitos Porfiróides } \\
\qquad(\mathrm{Grp})\end{array}$ & $\begin{array}{l}\text { Rocha com pórfiros de k-feldspato envoltos em uma matriz granodiorítica, fina a média, cor cinza claro a escuro. Exibe concentrações variáveis de } \\
\text { quartzo, e orientação dos cristais de feldspato. }\end{array}$ \\
\hline & & $\begin{array}{l}\text { Granitos G naisses } \\
\quad(\mathrm{Gr}-\mathrm{Gn})\end{array}$ & $\begin{array}{l}\text { Rocha de composição granodionítica, com foliações e bandamentos discretos irregulares, denotado pela alternância de lentes escuras caracterizada } \\
\text { pela concentração de biotita e hornblenda, e claras caracterizada pela concentração quartzo e feldspato. O corrência de intercalações com anfibolitos e } \\
\text { biotita gnaisses, e eventualmente com xistos. }\end{array}$ \\
\hline \multirow{6}{*}{ 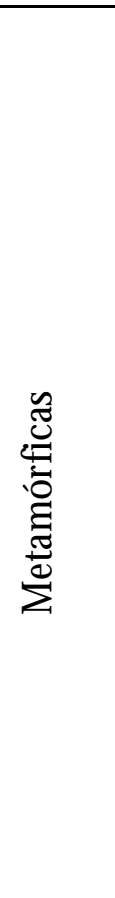 } & & $\begin{array}{l}\text { Gnaisses Intercalados } \\
\text { com Q uartzitos (Gnq) }\end{array}$ & Associação litológica constituída de Horniblenda e Biotita G naisses intercalados com quartzitos, presentes como níveis ou lentes. \\
\hline & Gnaisses & $\begin{array}{l}\text { G naisses Intercalados } \\
\text { com Rochas Básicas } \\
\text { (Gnb) }\end{array}$ & $\begin{array}{l}\text { Associação litológica constituída de Biotita e Horniblenda Gnaisse, presentes na forma de lentes e camadas de espessuras variáveis, intercaladas a } \\
\text { anfibolitos e, eventualmente, gonditos. }\end{array}$ \\
\hline & \multicolumn{2}{|c|}{ Q uartzitos Impuros } & $\begin{array}{l}\text { Quartzitos impuros intercalados com Xistos G naisses (Sericita e Biotita). Constituídos de quartzo, feldespatos, mica e anfibolito em proporções } \\
\text { variadas. }\end{array}$ \\
\hline & & $\begin{array}{l}\text { Rocha de bandamento bem marcado, leucossomas constituídos de feldspato e quartzo. Espessura média } 2-3 \mathrm{~cm} \text {. Paleossomas ricos em biotita. } \\
\text { Espessura média de } 1 \mathrm{~cm} \text {. A presenta ocorrência de lentes de xisto, quartzito e anfibolito. }\end{array}$ \\
\hline & \multirow{2}{*}{$\begin{array}{c}\text { Rochas } \\
\text { Cataclasadas }\end{array}$} & $\begin{array}{l}\text { Ultramilonitos } \\
\text { (Utm) }\end{array}$ & $\begin{array}{l}\text { Ultramilonitos e blastomilonitos de gnaisse acinzentado e migmatitos caracterizados por forte cominuição de grãos. Exibe intercalações com xistos e } \\
\text { quartzitos. }\end{array}$ \\
\hline & & $\begin{array}{l}\text { Blastomilonitos } \\
\text { (Btm) }\end{array}$ & $\begin{array}{l}\text { Blastomilonitos e ultramilonitos (em menor proporção que os primeiros), derivados de granitos e migmatitos. Comumente são observados } \\
\text { intercalações com milonito gnaisse rosa a cinzento claro, de estruturas lenticulares dominantes. }\end{array}$ \\
\hline
\end{tabular}


$\underline{\text { G ranitos Catadasados (G rc) }}$

São rochas de composição granítica porfiróide, de constituição quartzo feldspática, de granulação média a grossa, com cores rosadas a cinzentas. Caracterizamse por apresentar graus variáveis de catáclase e foliação marcante, denotada pela orientação dos cristais de feldspatos muito fraturados (Figura 5.2).

Estas rochas ocorrem em uma porção localizada da bacia, extremo noroeste, junto à foz do Rio do Peixe, na confluência com o Rio Mogi-Guaçu. De acordo com Mio (1992), o aspecto cataclasado destas rochas é conferido pela ação da Zona de Cisalhamento de Jacutinga localizada mais a norte da área. Tal litologia condiciona um relevo pouco ondulado, de baixas altitudes e canais de drenagem pouco extensos.

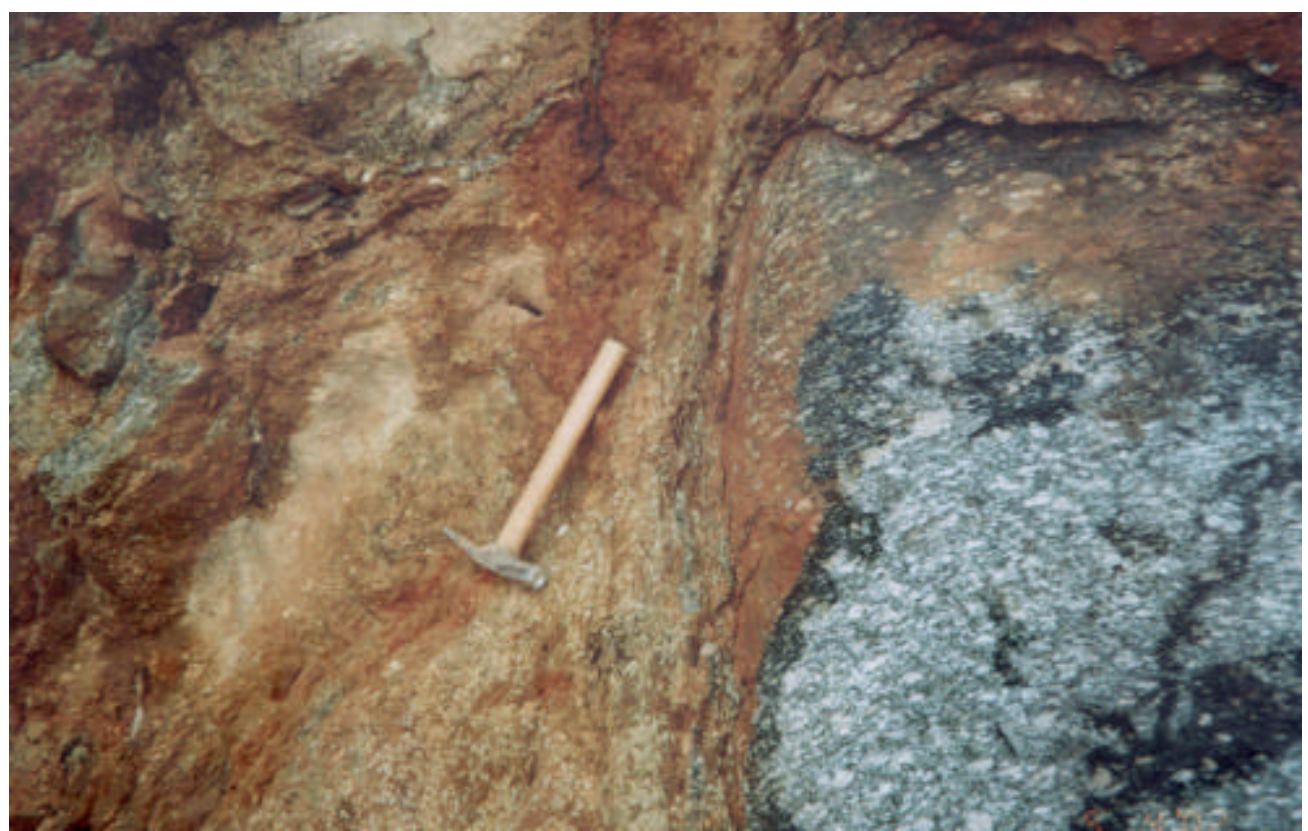

Figura 5.2 - Detalhe de afloramento de granitos cataclasados. Notar orientação apresentada pelos cristais de k--feldspato.

$\underline{G \text { ranitos Porfiróides (G rp) }}$

Esta unidade é composta por granitos com cristais centimétricos de k-feldspato róseo (pórfiros), normalmente idiomórficos, envoltos por uma matriz granodionítica fina a média, de cores cinza claro a escuro. A concentração mineralógica de quartzo nestas rochas é muito variável, ora muito expressiva; ora pouco. A dimensão dos cristais de kfeldspato varia de 1 a $5 \mathrm{~cm}$. Junto a Zona de Falha de Ibitinga estes apresentam orientação bem pronunciada (Figura 5.3), e são comuns as intercalação com cataclasitos 
e a ocorrência de porções gnaissificadas. De forma secundária são encontradas inercalações com corpos de anfibolitos.

Os granitos porfiróides comumente afloram na forma de matacões com diâmetros médios de 1 a 3m, ocorrendo dispersos em toda unidade(Figura 5.4 A e B). Esta unidade caracteriza um relevo de serras, de altitude elevada e rede de drenagem com forte condicionamento estrutural.

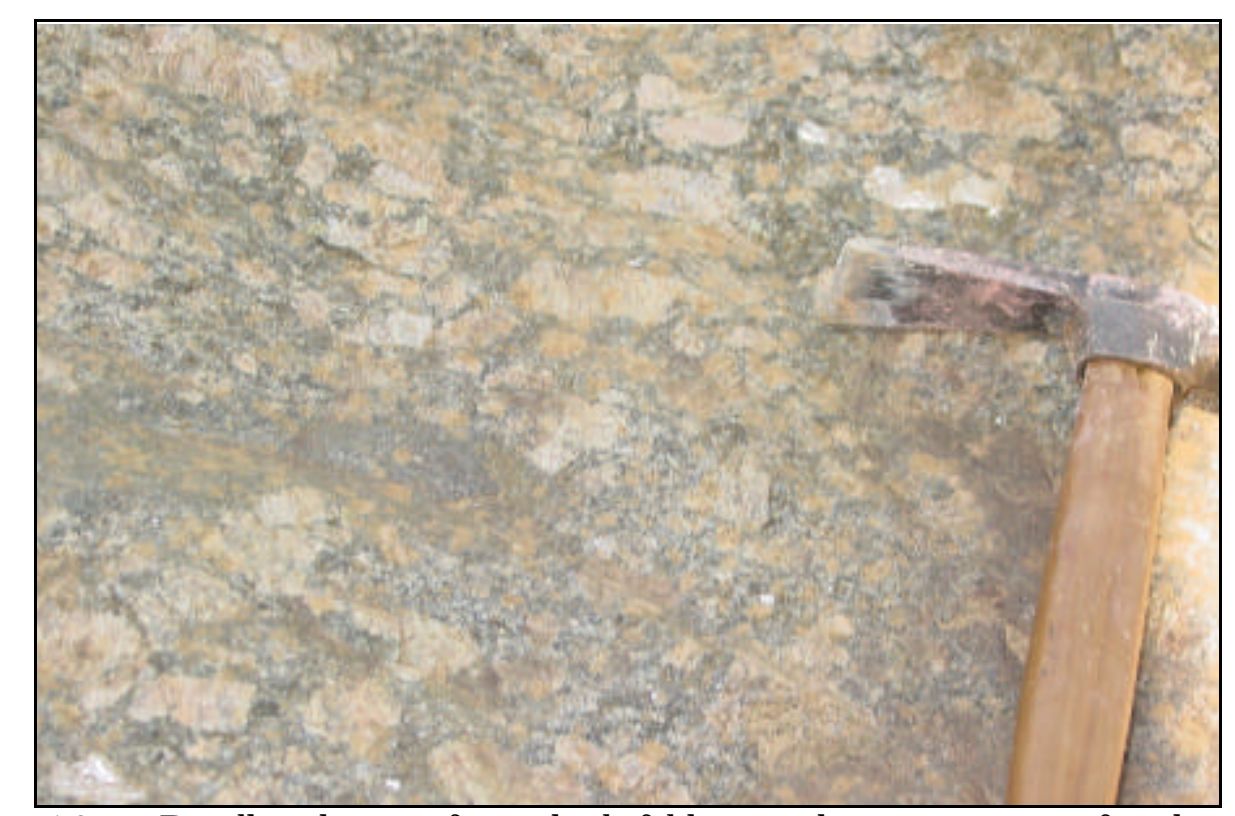

Figura 5.3 - Detalhe dos pórfiros de k-feldspato dos granitos porfiróides. Notar orientação dos cristais de k-feldspato.

\section{Granitios $\mathrm{G}$ naisses (G r-G n)}

Unidade constituída por rochas do tipo gnaisse granito cinzentos de composição granodiorítica composta de quartzo, plagioclásio, k-feldspato, biotita e anfibólio. Apresenta foliações e bandamento discreto, denotado pela alternância de lentes escuras caracterizada pela concentração de biotita e hornblenda, e claras caracterizada pela concentração de quartzo e feldspato (Figura 5.5). Intercalam-se com anfibolito e biotita gnaisse. Eventualmente são encontrados intercalações com corpos de xistos.

As foliações a bandamentos desta rocha apresentam distribuição irregular, ora são bem caracterizadas e ora não. Tem ocorrência restrita, porção da cabeceira da bacia. Ocorrem como ilhas alongadas que afloram envoltas por migmatitos e granitos porfiríticos condicionam relevo de serras com topos extensos e encostas convexas. 

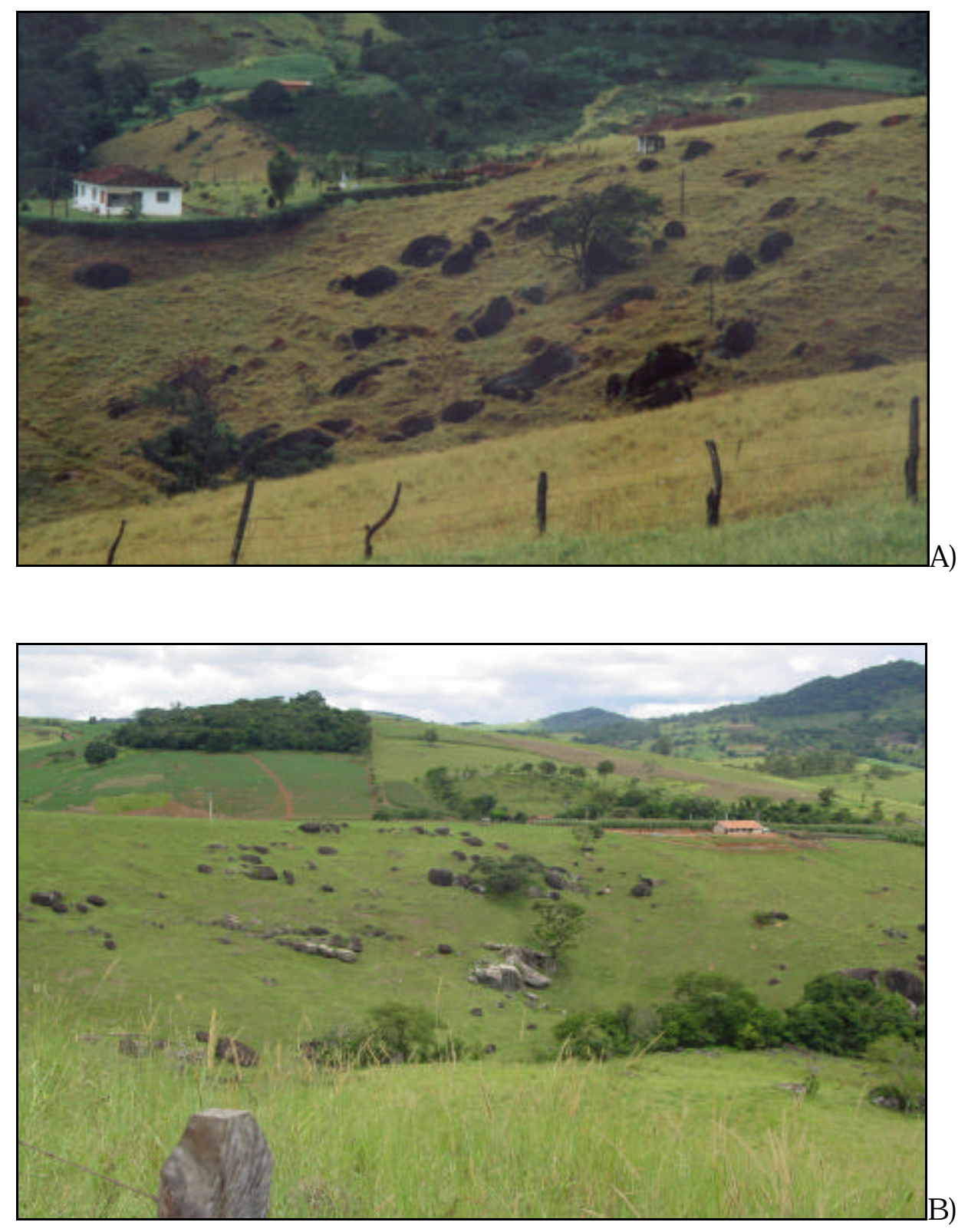

Figura 5.4 a e b - Afloramentos típico de granitos porfiróides. 


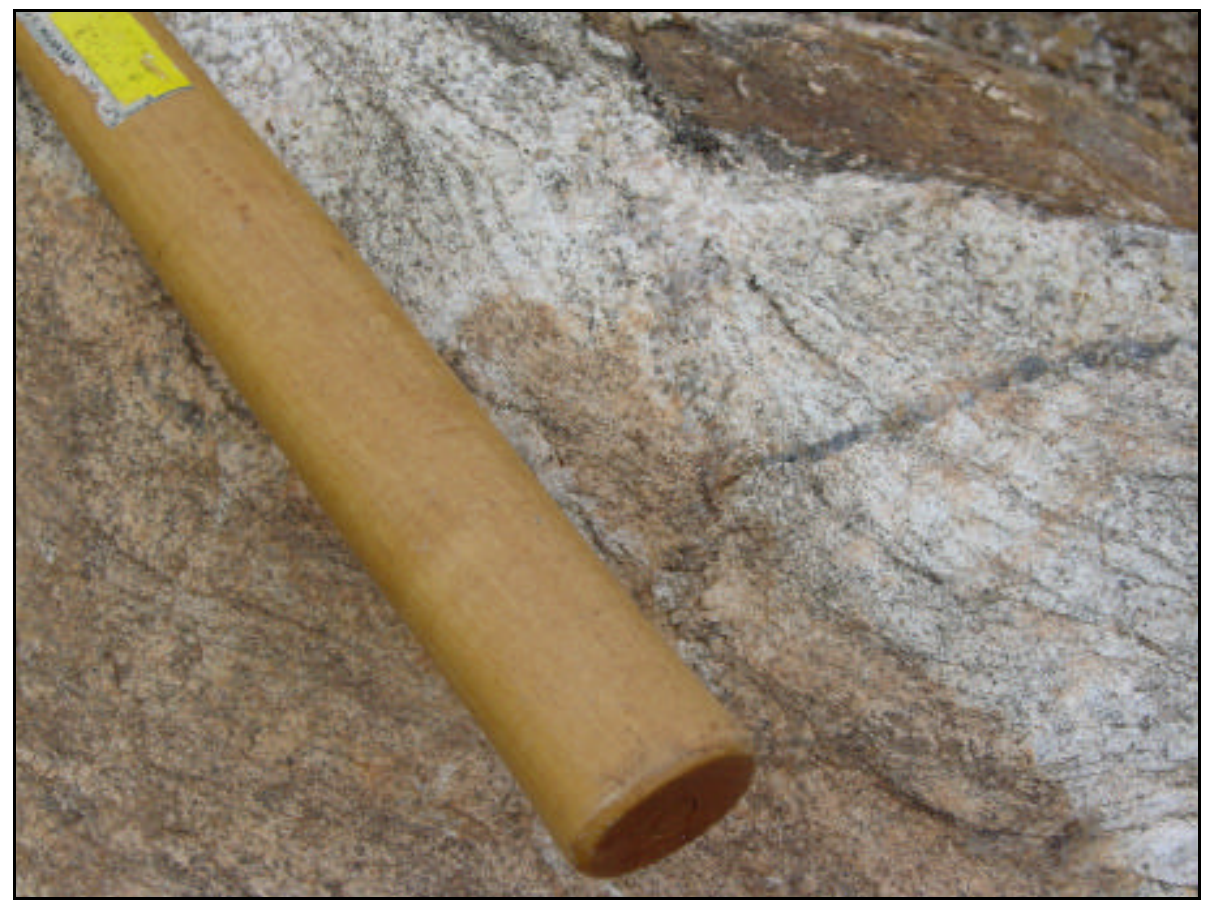

Figura 5.5 - Bandamento típico exibido pelos Granitos-G naisses.

\subsubsection{Rochas Metamónficas}

As rochas metamórficas presentes na área caracterizam uma associação litológica subdividida em quatro unidades: 1) Gnaisses; 2) Quartzitos Impuros; 3) Migmatitos, e 4) Rochas Cataclasadas

\section{Gnaisses}

Estas rochas constituem uma associação litológica subdividida em duas unidades as quais foram, primeiramente, caracterizadas por Mio (1992) e Barison (1995) como G naisses Q uartizíticos e $\mathrm{G}$ naisses Alcalinos. Aqui receberam denominação de $\mathrm{G}$ naisses com intercalações de quartzitos e $\mathrm{G}$ naisses com intercalações de rochas básicas.

\section{G naisses com intercalacọes de $Q$ uartzito $(\mathrm{G} n \mathrm{q})$}

Associação litológica caracterizada por grande heterogeneidade, constituída basicamente por gnaisses do tipo hornblenda e/ ou biotita gnaisses, com intercalações freqüentes de quartzito, e secundárias de biotita xistos, anfibolitos e granitos gnaisses. Comumente afloram como rocha alterada, na qual as intercalações com os quartzitos e biotitas xisto são denotadas por alternância de níveis ou lentes (Figura 5.6 A e B). 
Por vezes, os quartzitos desta unidade afloram na forma lentes com dimensões centimétricas a métricas. A transição dos quartzitos para os gnaisses normalmente é caracterizada pelo incremento na quantidade de biotita e feldspato.

Tem ocorrência limitada à porção da baixa bacia, no extremo oeste como corpos de grande extensão areal. Nas porções sudoeste e centro norte da porção da baixa bacia, estão presentes como corpos alongados, por vezes sinuosos.

Estas litologias condicionam relevo de morros suaves e declividades médias.
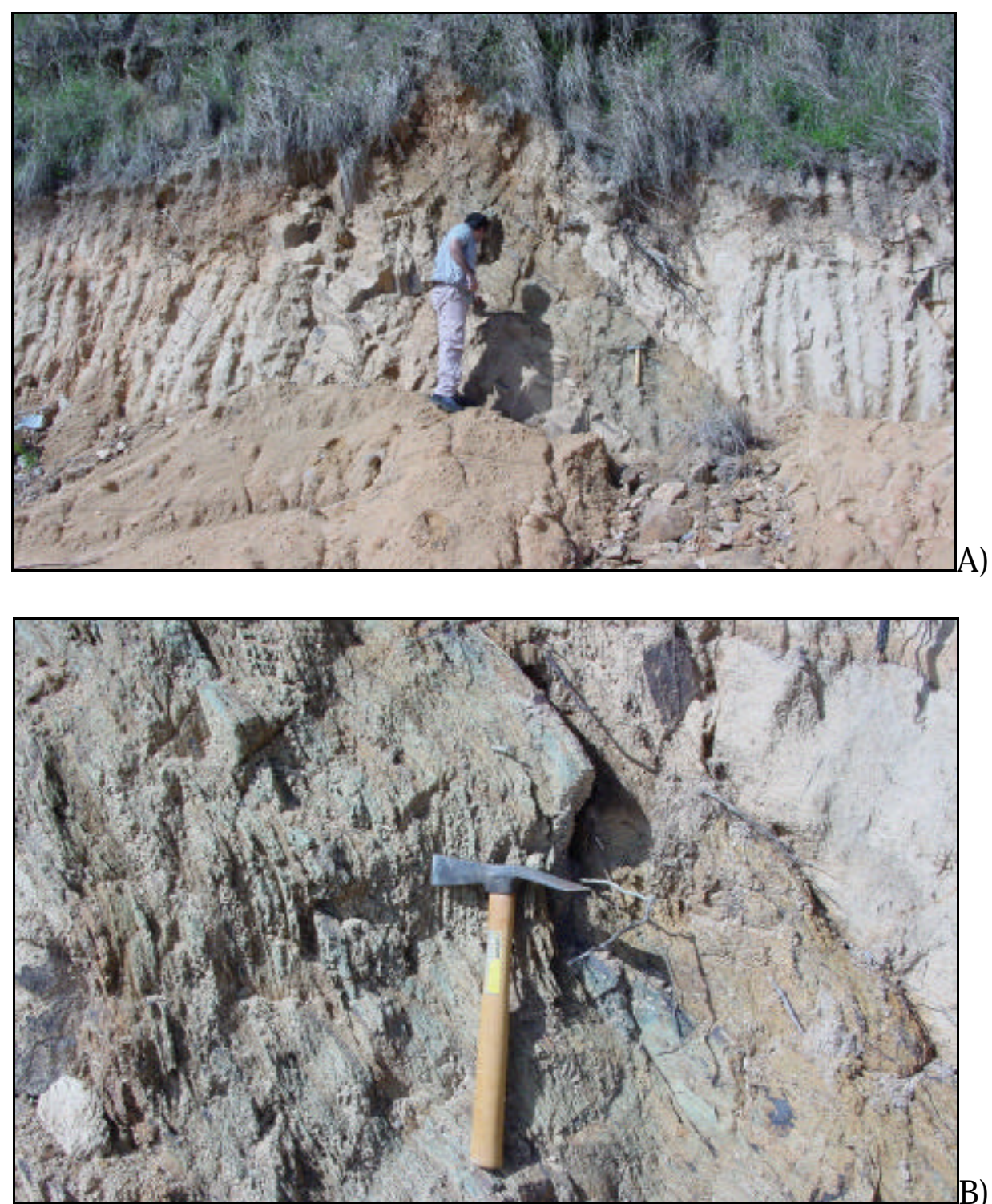

Figura 5.6 -A)Afloramento de G naisse intercaldos com quartzitos e xistos, (B) detalhe da lente de xisto 
$\underline{G \text { naisses om intercalacọes de R ochas Básicas ( } \mathrm{G} \text { nb) }}$

Associação litológica caracterizada pela presença de biotita e hornblenda gnaisse, com freqüentes intercalações de anfibolitos e eventualmente gonditos (Mio, 1992).

O s biotita gnaisses predominam na associação com os hornblenda gnaisses, que ocorrem sob forma de camadas ou lentes de espessura variada. De maneira geral, apresentam estrutura granoblástica e porções gnáissicas, com alternância de tons claros (cinza esbranquiçados) e escuros (cinza esverdeados) e xistosidade marcante.

Segundo Barison (1995), estas rochas são constituídas pelos minerais quartzo, plagioclásio, microclínio, biotita e hornblenda.

Junto as zonas de falha de Monte Sião e Ibitinga, esta associação exibe evidências de catáclase denotada pela cominuição de grãos e heterogeneidade litológica em afloramentos (Figura 5.7).

Os anfibolitos ocorrem intercalados, na forma de níveis centimétricos a métricos, concordantes com a foliação geral, apresentando-se, via de regra, muito alterados. Exibem uma coloração amarela a ocre, e são muito friáveis, assemelhando-se a um solo.

Na porção mediana da bacia e nas proximidades do município de Serra Negra, esta associação caracteriza-se por apresentar veios pegmatíticos (Figura 5.8).

Estas rochas apresentam a maior ocorrência em área na bacia e condicionam relevo desde morros de encostas suaves a serras de vertentes íngremes.

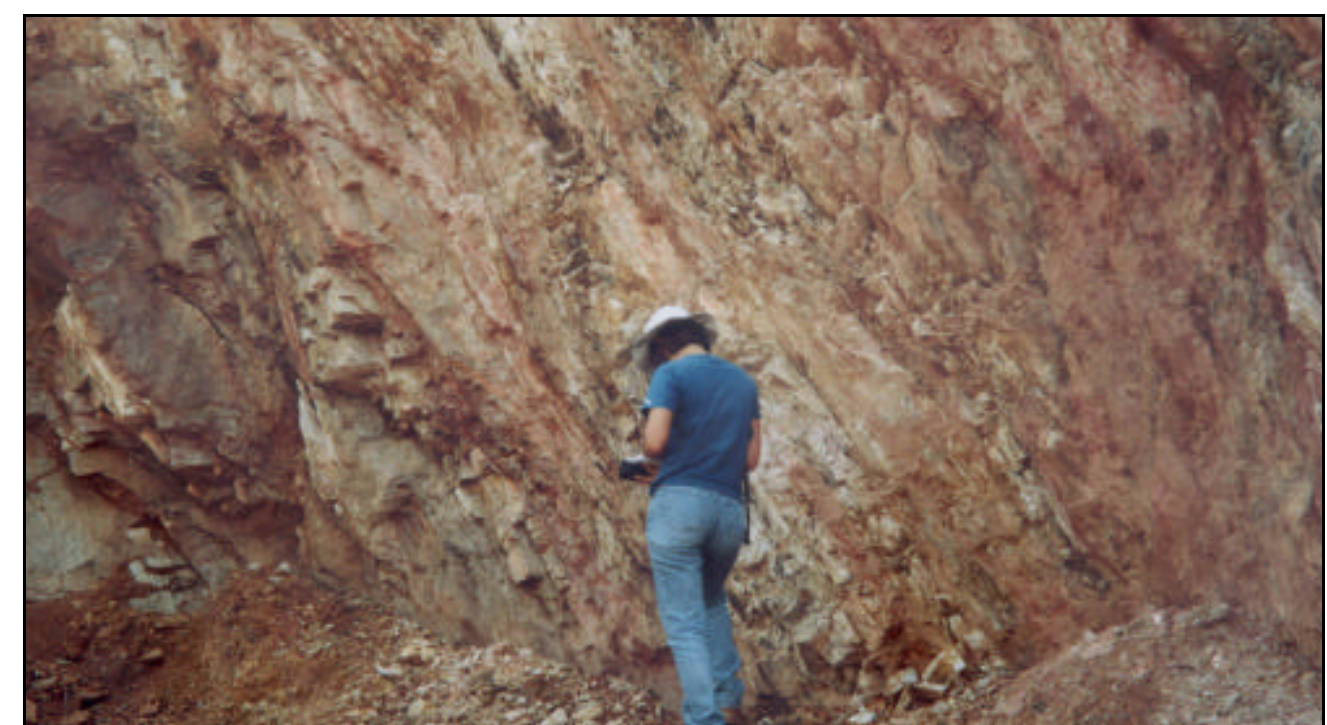

Figura 5.7 - Afloramentos de gnaisses intercalados com rochas básicas, com aspecto cataclasado, apresentando heterogeneidade litológica. 


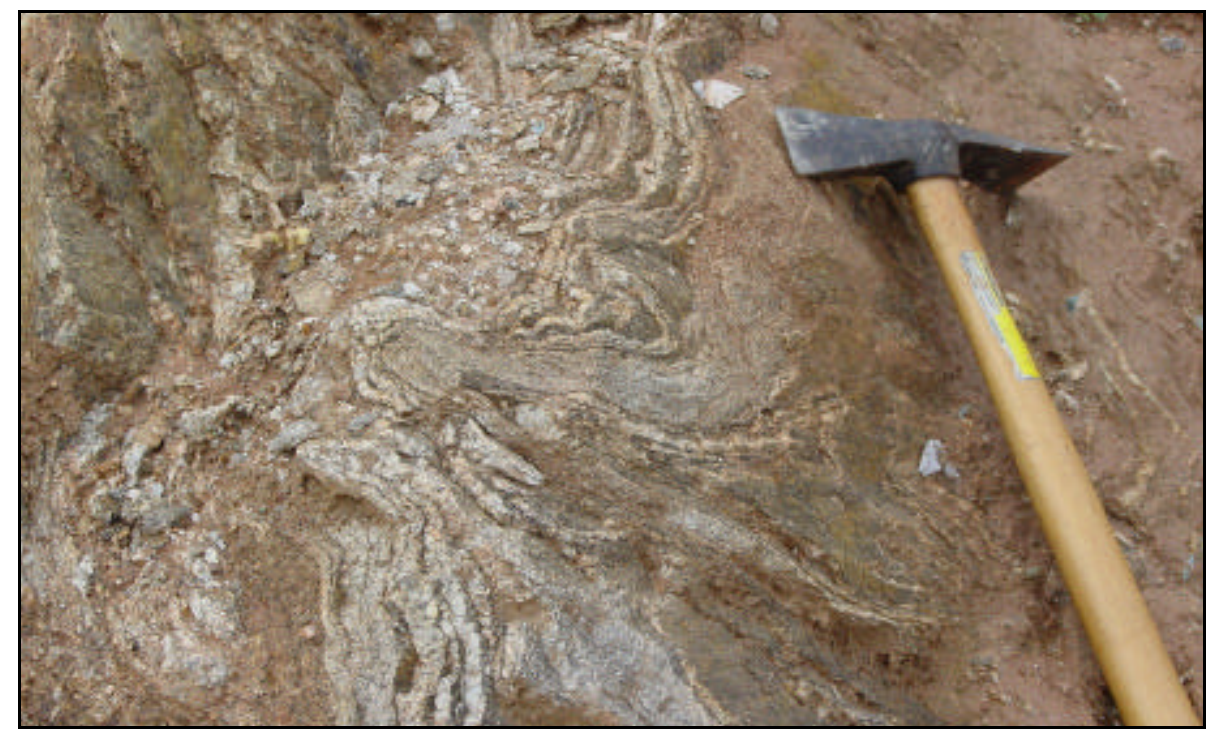

Figura 5.8 - Afloramentos de veios pegmatíticos comum nos gnaisses intercalados com rochas básicas nas proximidades do município de Serra Negra.

\section{Quartzitos Impuros (Qtz)}

Caracterizados anteriormente por Mio (1992) e Saraiva (1995), são constituídos por quartzitos mais ou menos puros (Figuras 5.9 e 5.10). Comumente ocorrem intercalados xistos gnaisse (sericita e biotita), e subordinadamente anfibolitos.

Mio (1992) descreve como principais constituintes destas rochas os minerais de quartzo, feldspatos e micas, anfibólios e granadas em proporções variadas.

A transição entre as litologias desta unidade e os gnaisses intercalados com quartzito é normalmente gradacional, caracterizada pelo aumento ou diminuição da porcentagem de quartzo. Junto a zona de falha de Monte Sião esta litologia apresenta contatos abruptos com as rochas cataclásticas adjacentes.

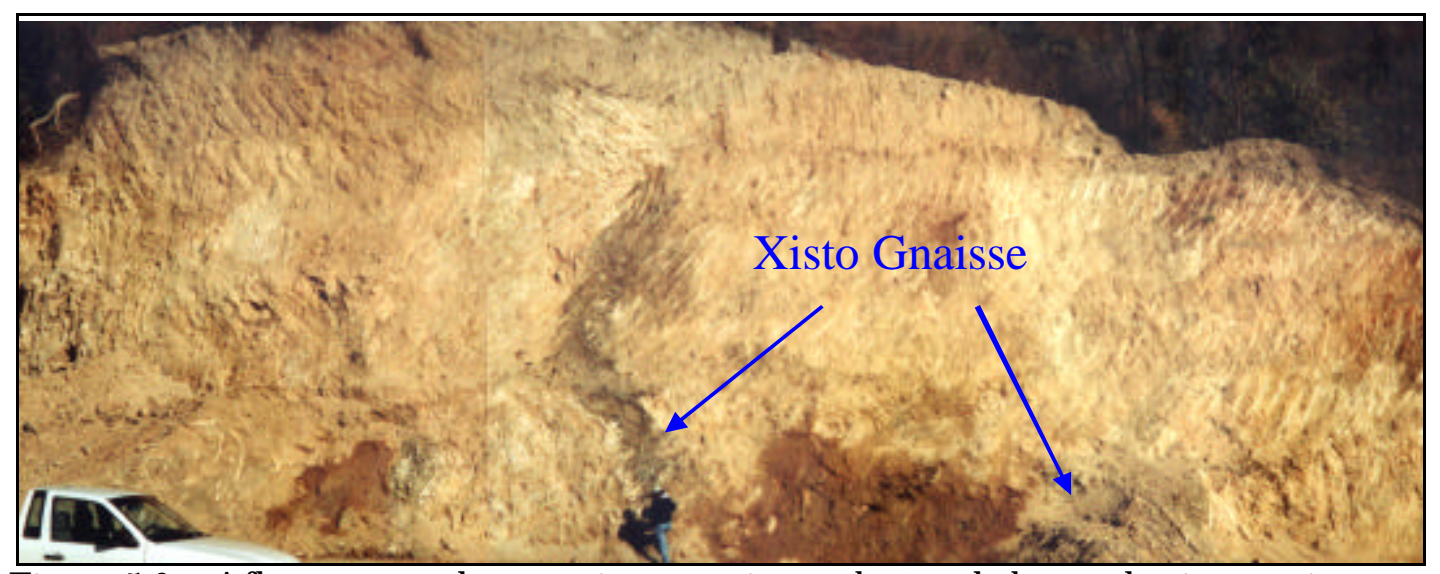

Figura 5.9 - Afloramentos de quartzitos com intercalações de lentes de xisto gnaisse. 


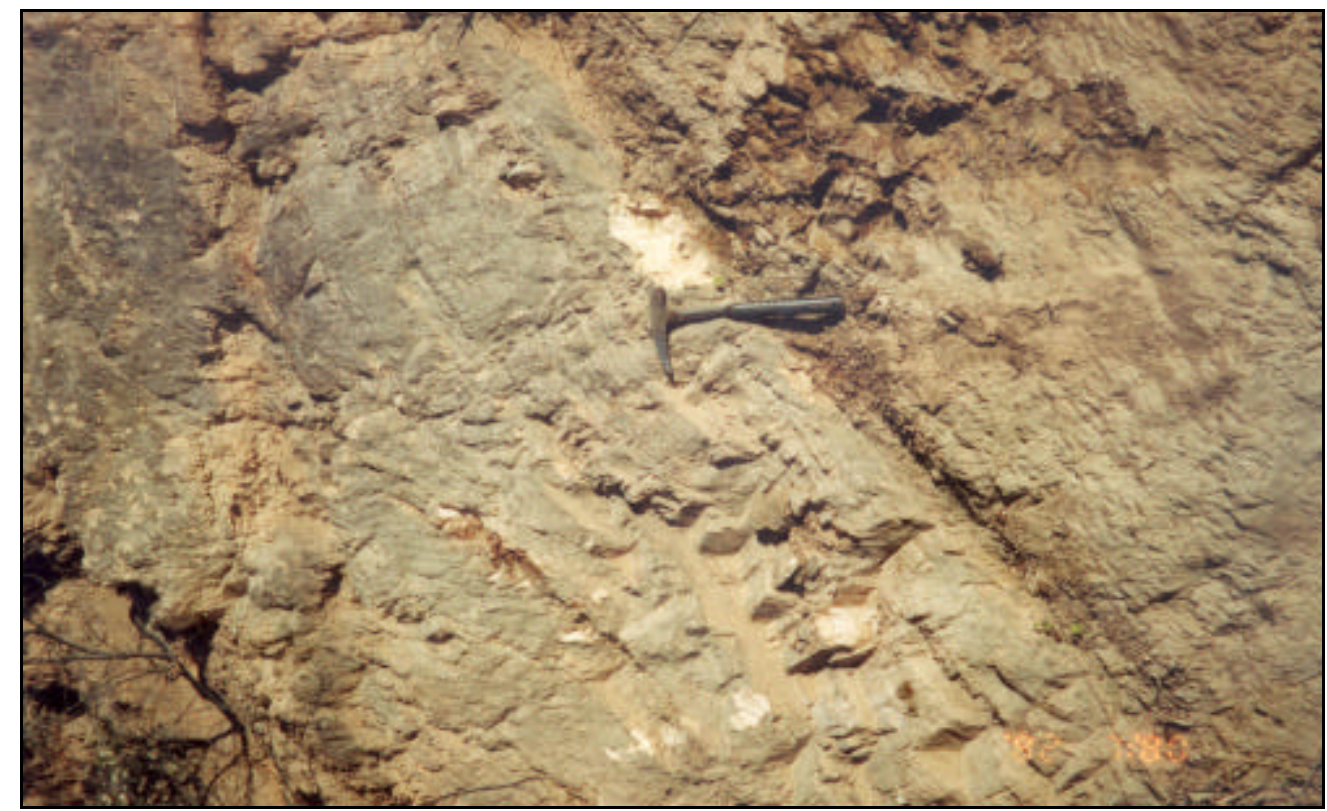

Figura 5.10 - Afloramento de quartzito sem ocorrência de níveis intercalados.

Afloram na forma de corpos arqueados na porção centro-norte da baixa bacia, ora sinuosos, ora alongados na média bacia. Caracterizam relevos mais acidentados e cotas altimétricas mais elevadas. Sustentam relevos montanhosos com cristas bem marcadas.

\section{Migmatitos (MG)}

Estas litologias caracterizam-se por complexidade composicional e estrutural (Mio, 1992; Saraiva, 1995). Exibem bandamento bem marcado, apresentando bandas claras (leucossomas) constituídas de feldspato e quartzo, com $23 \mathrm{~cm}$ de espessura e banda escura (paleossoma) rica em biotita e espessura média de $1 \mathrm{~cm}$. Junto a zona de falha de Monte Sião é comum a ocorrência destas bandas com aspecto dobrado e sinuosos (Figura 5.11 A e B)

Possuem granulometria variada (equi-inequegranular) e preservam resquícios das rochas ígneas originais (granitos rosa a acinzentados). A composição mineral destas rochas tende a ser granítica, com predominância de quartzo, biotita e hornblenda (Saraiva, 1995).

São comuns ocorrências de xistos, quartzitos e anfibolitos, inclusos sob forma de lentes. Em alguns locais ocorrem intercalações com biotita gnaisse 
Estas rochas ocorrem na transição entre baixa e média bacia e na porção centronorte da alta bacia. Condicionam relevos de serras e morros.
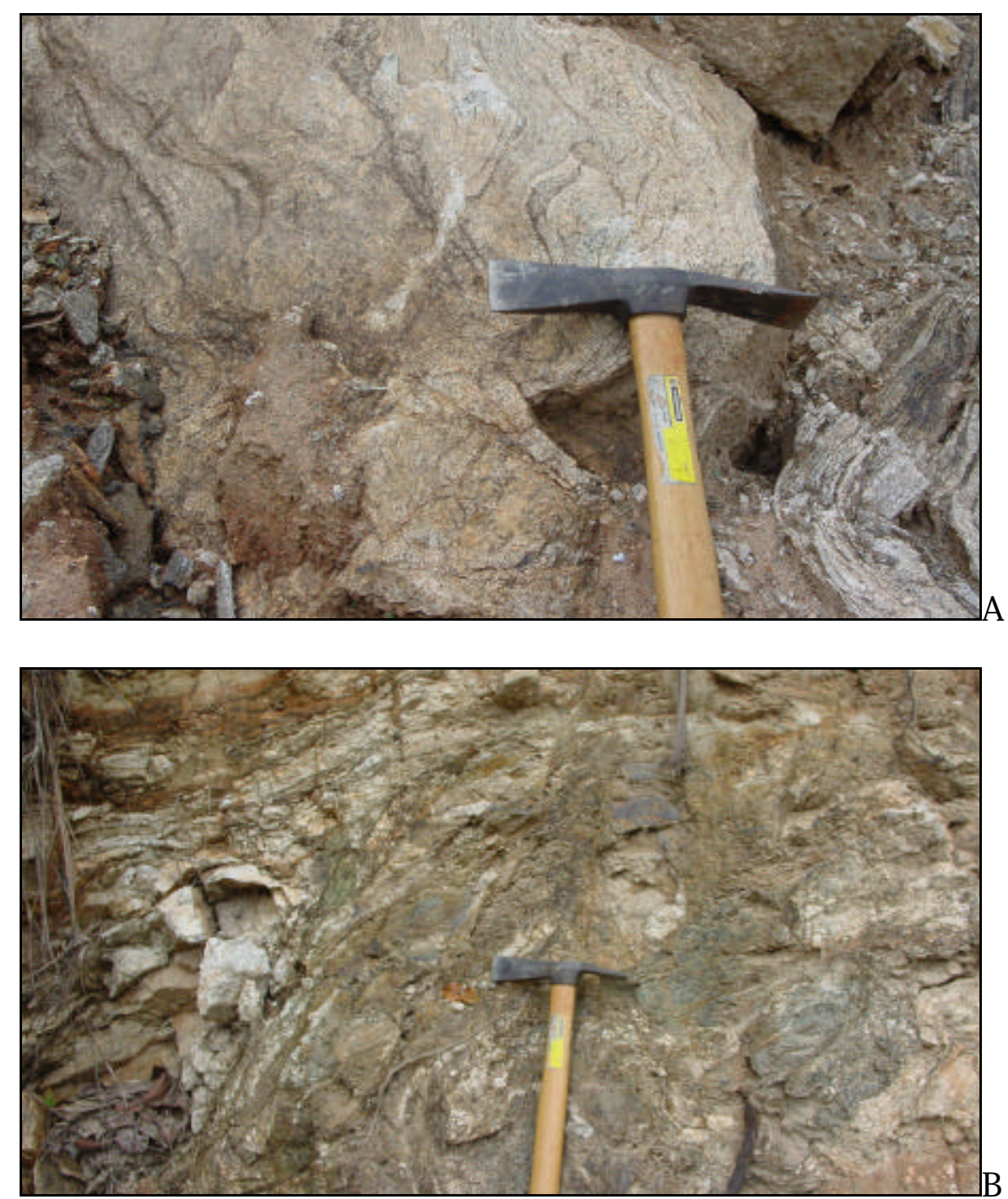

Figura 5.11 A e B) Afloramentos de Migmatitos com leucossomas e paleossomas exibindo aspecto dobrado.

\section{Rochas Cataclasadas}

Anteriormente denominada por Saraiva (1995) como unidades de CataclasitoMigmatito, estas rochas podem ser divididas em função da textura e do grau de cominuição dos grãos em duas unidades:, em Ultramilonitos e Blastomilonitos. 
Sariava (op cit) correlaciona geneticamente estas rochas as zonas de falhas de Monte Sião e Ibitinga. D e acordo com Albercht (1992), estas litologias têm por principal características apresentar uma forte redução granulométrica dos minerais originais, devido a ação dos esforços tectônicos.

Estas litologias condicionam relevos de serras com cristas estreitas e declividade elevada.

Ultramilonitos (U tm)

Têm ocorrência predominante junto à zona de falha de Ibitinga, onde ocorrem com grande extensão areal. De forma secundária ocorrem junto a Falha de Monte Sião.

Dotadas de grande heterogeneidade litológica e grau metamórfico muito elevado, estas rochas são constituídas, principalmente, de ultramilonitos e blastomilonitos de gnaisse acinzentado e migmatitos, e secundariamente de xistos e quartzitos.

As rochas desta unidade tendem a exibir deformações mais elevadas nas porções centrais das zonas de falhas, caracterizada por uma cominuição dos grãos (Figura 5.12).

Saraiva (1995), destaca que devido a ação tectônica a transição entre as várias litologias é gradacional junto a zona de falha de Ibitinga, e brusca junto a zona de falha de Monte Sião e Ibitinga, caracterizada pela existência de falhas (Figura 5.13). Estas variações de contato refletem as diferentes intensidades da cataclase e do processo de metamorfismo. 0 contraste devido às diferenças de deformação e fraturamento impõe heterogeneidades marcantes no comportamento geotécnico desta unidade.

\section{Blastomilonitos (Btm)}

Esta associação apresenta, assim como a unidade de Ultramilonitos, heterogeneidade litológica, porém com grau metamórfico menos acentuado.

As litologias que caracterizam esta associação são blastomilonitos e ultramilonitos (em menor proporção que os primeiros), derivados de granitos e migmatitos. Comumente são observados intercalações com milonito gnaisse rosa a cinzento claro, de estruturas lenticulares dominantes.

As porções de maior deformação restringem-se as adjacências da zona de falha de Ibitinga e, à medida que se distância para leste as rochas passam a exibir uma 
diminuição do grau de cominuição dos grãos, passando a predominar texturas de rochas do tipo gnaisse e granitos com orientação de cristais.

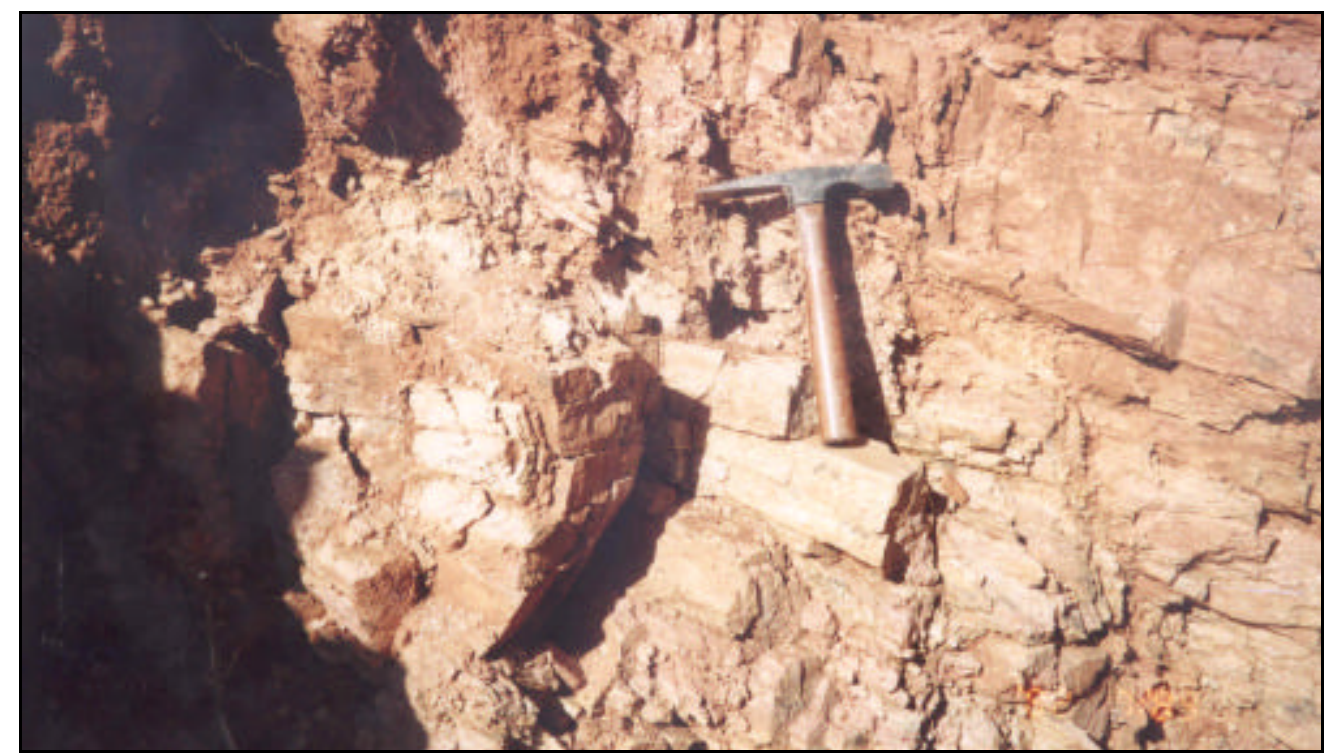

Figura 5.12 - Afloramentos de Ultramilonitos de gnaisse cataclasados.

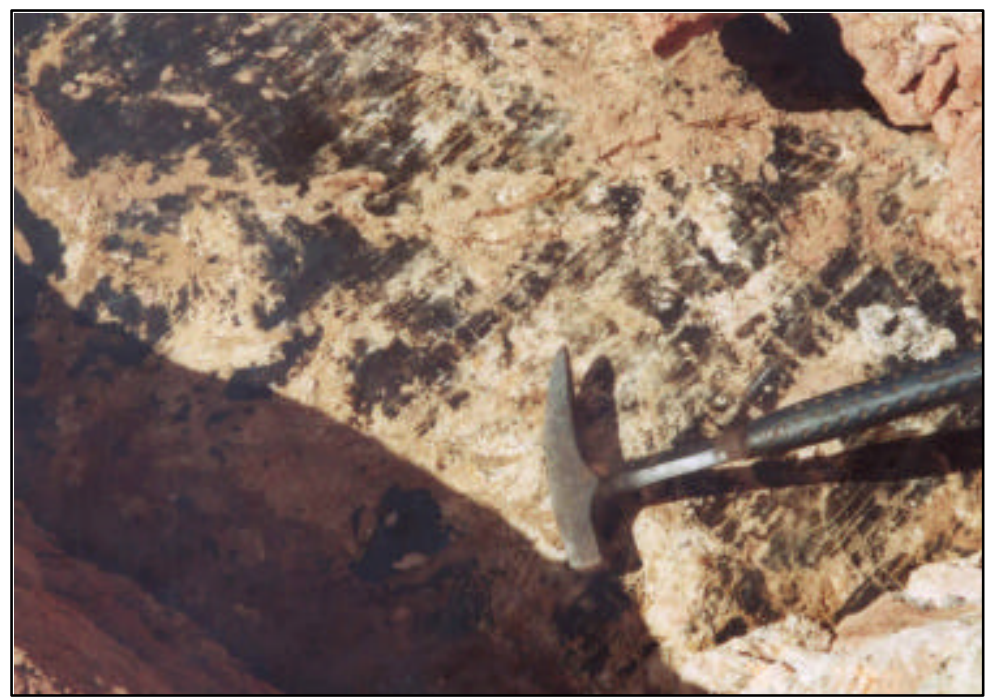

Figura 5.13 Plano de falha comum nos Ultramilonitos presentes junto as zonas de falhas.

A análise do substrato rochoso da Bacia, somada a informações obtidas de fotografias aéreas, trabalhos de campo e dados preexistentes permite tecer algumas considerações sobre o comportamento das litologias presentes na área.

As litologias da Bacia caracterizam-se por apresentarem forte condicionamento estrutural. Fator responsável pela organização espacial das rochas e das relações de contato das mesmas 
De maneira geral, as estruturas tectônicas (falhas e dobramentos) existentes na área controlam a distribuição das diversas litologias na região, especialmente na porção central da bacia, onde se localizam as zonas de falha de Monte Sião e Ibitinga.

O controle estrutural exercido nas rochas da bacia também condiciona a heterogeneidade no comportamento dos maciços rochosos, sendo responsável pelas relações de contato entre as diferentes litologias. A ação da deformação nas unidades do substrato rochoso acarretou a existência de zonas de transição gradacionais e zonas de transição abruptas entre litologias.

As transições gradacionais são caracterizadas ente litotipos que não sofreram ação direta de metamorfismo cataclástico. As transições abruptas caracterizam-se por contatos condicionados por falhamentos, como observado em campo junto as zonas de falha de Monte Sião e Ibitinga.

\subsection{MAPA DE LAN DFORMS (ANEXO III)}

A compartimentação da superfície do terreno em áreas com características dotadas de representatividade e significado é um processo de grande importância que auxilia o zoneamento ambiental. Diversos são os conceitos e técnicas existentes para compartimentação da paisagem. Para realização deste processo o primeiro passo a ser tomado consiste da escolha e determinação de uma técnica que melhor se adeque aos objetivos pretendidos.

Nesta pesquisa optou-se por adotar os conceitos básicos da técnica de compartimentação do terreno sistematizada por Lollo (1995).Técnica de compartimentação em L andforms, a qual consiste em compartimentar uma área com base na linha de avaliação do terreno, considerando as condições naturais do mesmo. Essa linha de avaliação permite dividir a área em unidades cada vez menores, função da escala e da finalidade pretendida, a partir do uso preferencial de sensores remotos e trabalhos de campo, tendo-se como base sua uniformidade em termos de forma de terreno. Permite avaliar a relação forma do terreno X geologia (litologia e estruturas) Assim como com os materiais inconsolidados desenvolvidos sobre o substrato rochoso. Tais unidades dotadas de uniformidade e significado recebem a denominaçõa delandforms

L andform pode ser definido como "porção do terreno originado de processos naturais, distinguível das porções vizinhas (demais landforms) em pelo menos um dos 
seguintes elementos de identificação: forma e posição topográfica; freqüência e organização dos canais; inclinação das vertentes e amplitude de relevo" (Lollo, 1995).

\subsubsection{Procedimentos E mpregados}

O Mapa de Landforms da bacia foi obtido mediante realização de duas fases gerais de trabalho: 1) Levantamento de dados por fotointerpretação, que objetivou fornecer um conhecimento prévio da morfologia do terreno e 2) Trabalhos de campo, que tiveram por objetivo a verificação das relações entre morfologia/ litologia e morfologia/ materiais inconsolidados, que resultou na elaboração do mapa de lanforms da área. A Figura 5.14 apresenta um fluxograma com as etapas desenvolvidas.

Para auxiliar na compartimentação do relevo foram utilizadas informações extraídas das cartas topográficas e dados obtidos de hipsometria da bacia (Figura 5.15), as quais auxiliaram na análise do comportamento das amplitudes das formas de terreno.

A compartimentação da área foi realizada em dois níveis hierárquicos, segundo a proposição de Lollo (1995), a saber:

- Sistema de Terreno (L and System) - são associações de formas de relevo com expressão espacial determinada, e que apresentam condições similares de processos evolutivos e de materiais associados, representando um conjunto de processos ou um intervalo de tempo no qual estes estiveram ativos, esperandose que apresentam uniformidade em nível de substrato rochoso (Lollo, 1995).

- Unidade de Terreno (Land Unit) - são formas individuais do terreno que se distinguem das outras as quais está associada, por indicar um determinado subconjunto de processos do sistema de terreno no qual se situa. As características de cada unidade devem se refletir em nível de diferença em termos do material inconsolidado associado a ela (Lollo, 1995). 


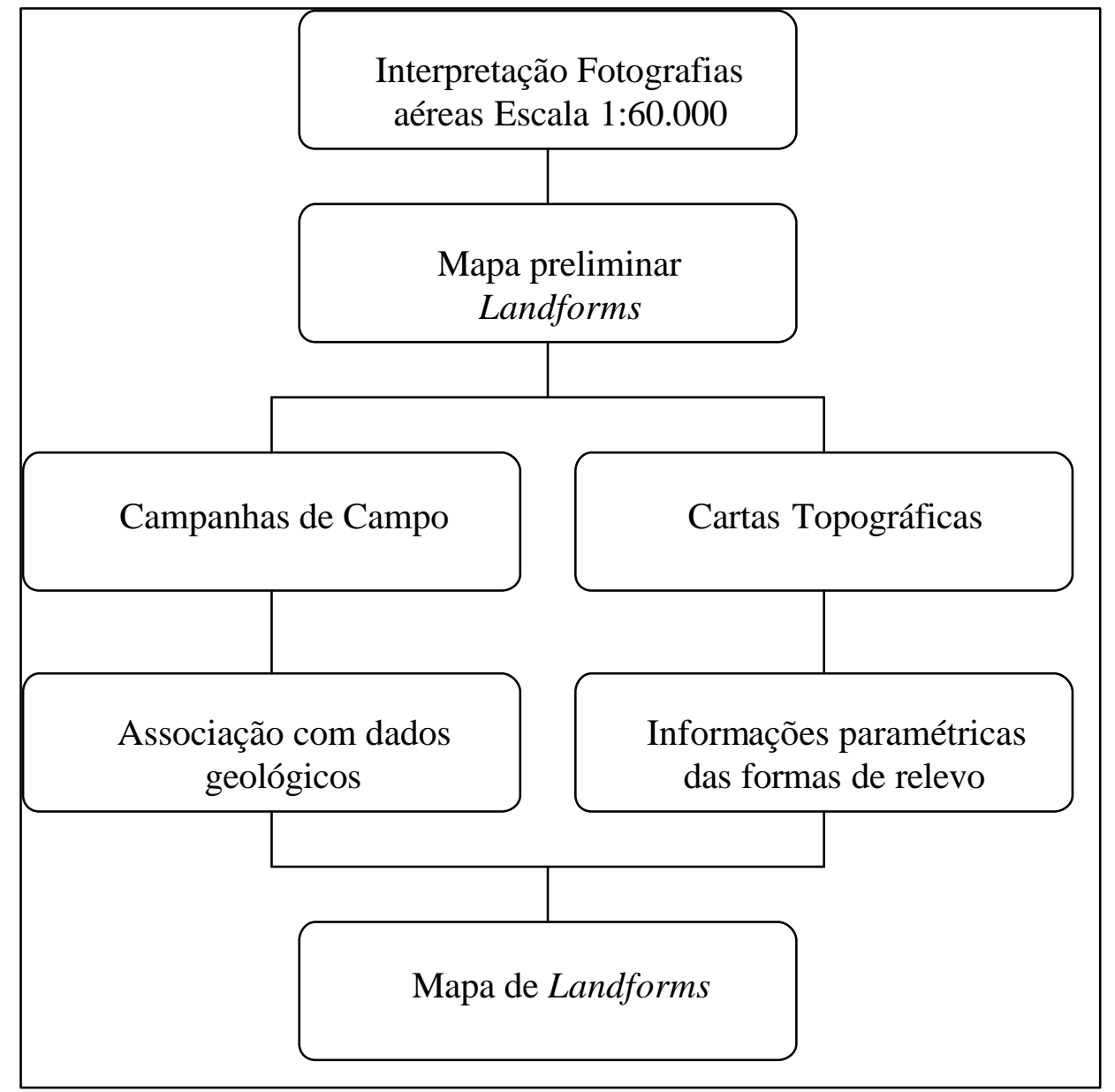

Figura 5.14 - Etapas desenvolvidas na obtenção do Mapa de L andforms da bacia.

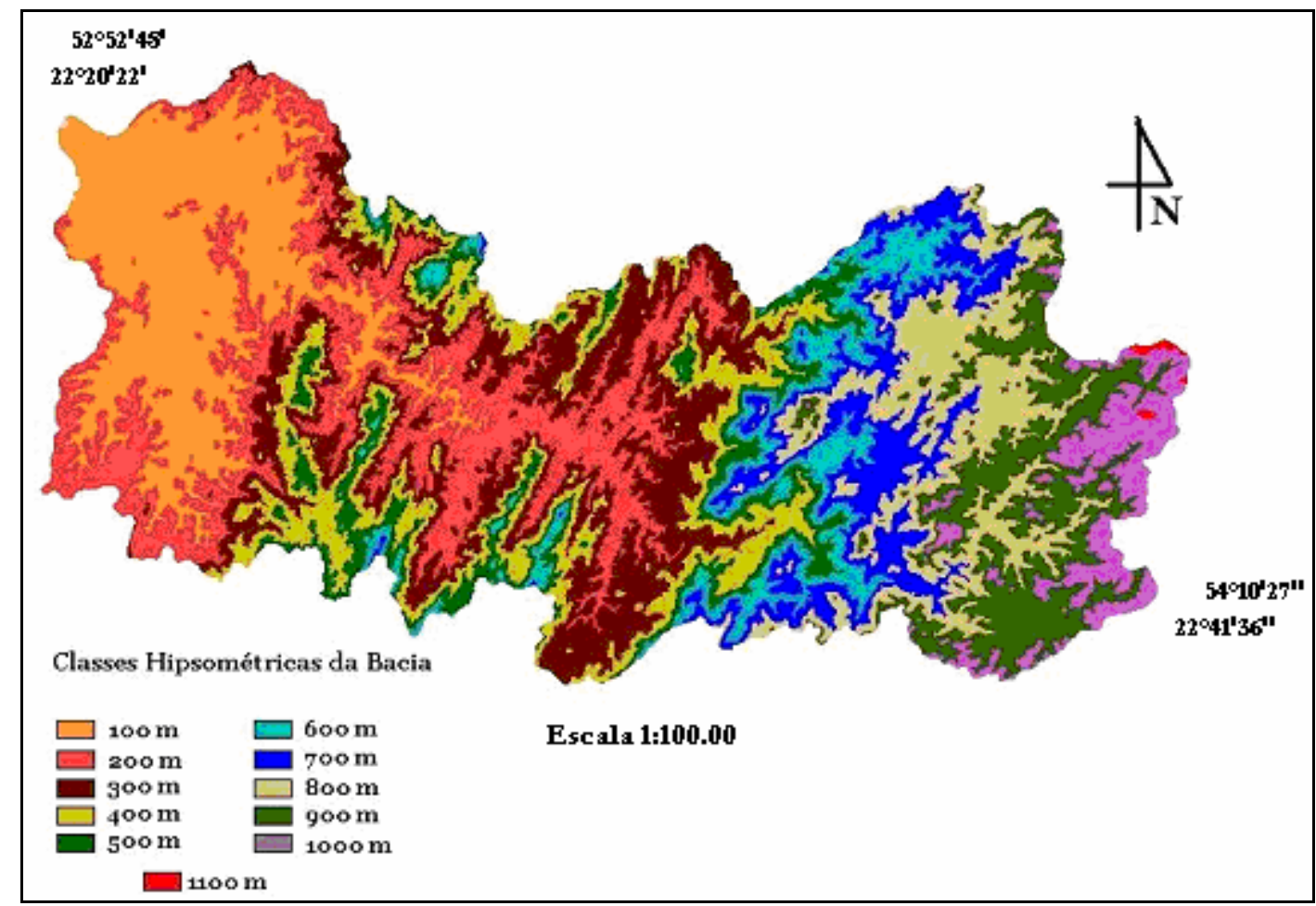

Figura 5.15 - Dados de Hipsometria da bacia. 


\subsubsection{Sistemas e Unidades de Landforms}

A área da bacia foi compartimentada em cinco sistemas de terreno, A, B, C, D e E; os quais foram segmentados em unidades menores (Anexo III, Quadro 5.2).

Para caracterização e sistematização dos landforms foram utilizados atributos sugeridos por IPT (1981) e Saraiva (1995). Estes fazem referência à amplitude local, forma de topo, perfil de encosta, forma de vale, entre outras (Tabelas 5.1 e 5.2).

Tabela 5.1 - Atributos para classificação dos tipos de terreno (IPT, 1981).

\begin{tabular}{c|c|c}
\hline Tipo de Relevo & $\begin{array}{c}\text { Declividade } \\
\text { Predominante }\end{array}$ & \multirow{2}{*}{$<$} \\
\hline Rampa & $<5 \%$ & $<100 \mathrm{~m}$ \\
\hline Colina & $0-20 \%$ & \\
\hline Morrote & $>20 \%$ & \multirow{2}{*}{$100-300 \mathrm{~m}$} \\
\hline $\begin{array}{c}\text { Morro com Encostas } \\
\text { Suavizadas }\end{array}$ & $0-20 \%$ & \\
\hline Morros & $>20 \%$ & $>300 \mathrm{~m}$ \\
\hline Serras & & \\
\hline
\end{tabular}

Tabela 5.2 - Atributos utilizados na caracterização das formas de relevo da bacia (adaptado de Saraiva, 1995).

\begin{tabular}{|c|c|c|c|}
\hline ATRIBUT0 & CATEGORIA & INTERVALO & CONCEITO \\
\hline Amplitude local & $\begin{array}{l}\text { Pequena } \\
\text { média } \\
\text { grande }\end{array}$ & $\begin{array}{l}0-100 \mathrm{~m} \\
100-300 \mathrm{~m} \\
>300 \mathrm{~m}\end{array}$ & $\begin{array}{l}\text { Altura máxima, acima do } \\
\text { assoalho de grandes vales } \\
\text { adjacentes. }\end{array}$ \\
\hline $\begin{array}{ll}\text { Expressão } & \text { em } \\
\text { área* } & \end{array}$ & $\begin{array}{l}\text { Pequena } \\
\text { Média } \\
\text { Ampla }\end{array}$ & $\begin{array}{l}<1 \mathrm{Km}^{2} \\
1-4 \mathrm{Km}^{2} \\
>4 \mathrm{Km}^{2}\end{array}$ & Area de Interflúvio \\
\hline Topo* & $\begin{array}{l}\text { Extensos } \\
\text { Restritos }\end{array}$ & $\begin{array}{l}>2 \mathrm{Km} \\
<2 \mathrm{Km}\end{array}$ & -- \\
\hline Forma do Topo & $\begin{array}{l}\text { Aplainado } \\
\text { Arredondado } \\
\text { Anguloso }\end{array}$ & -- & -- \\
\hline Perfil de Vertente & $\begin{array}{l}\text { Convexo } \\
\text { Retilíneo } \\
\text { Côncavo }\end{array}$ & -- & -- \\
\hline Vales & $\begin{array}{l}\text { Abertos } \\
\text { Fechados }\end{array}$ & -- & -- \\
\hline $\begin{array}{l}\text { Planícies } \\
\text { Aluvionares* }\end{array}$ & $\begin{array}{l}\text { D esenvolvidas } \\
\text { Restritas }\end{array}$ & $\begin{array}{lll}\begin{array}{l}\text { Extensão } \\
>1 \mathrm{KM}\end{array} & \text { área } \\
\begin{array}{l}\text { Extensão } \\
\text { <1KM }\end{array} & & \text { área } \\
<1 \mathrm{M} & & \end{array}$ & -- \\
\hline $\begin{array}{l}\text { Ravinamento nas } \\
\text { Vertentes }\end{array}$ & $\begin{array}{l}\text { Presente } \\
\text { Ausente }\end{array}$ & -- & -- \\
\hline
\end{tabular}




\subsubsection{Sistemas de Terreno A}

Localizado na região mais a oeste da baixa bacia, este sistema corresponde 17,5\% da área total da bacia. É caracterizado por três formas principais de terreno: 1) Vale com ocorrência de planícies aluviais; 2) Relevo de Colinas e 3) Relevo de Morros, segmentados em oito unidades. Apresenta predominância das classes de declividade muito baixa (0-2\%), baixas (2-10\%) e medianamente moderadas (10-20\%), e tem por substrato associado Gnaisses intercalados a rochas básicas e Gnaisses intercalados a quartzitos.

\section{$\underline{\text { Unidade A } 1}$}

Caracteriza-se por um vale aberto com planícies aluvionares desenvolvidas. Tem expressões em áreas que variam de pequena (parte sul) a ampla (próximo a Itapira). Predominam declividades muito baixas (0-2\%).

\section{Unidade A 2}

Presente na porção centro nordeste do sistema, esta configura um relevo de morros de topos angulosos e extensos que definem pequenas cristas com orientações variadas, de forma a configurar um arco (Figura 5.16). Exibem vertentes retilíneas a convexas com predomínio de classes de declividade entre 10 e 20\%, associadas a vales fechados (Figura 5.17). Em campo foi constatada presença de ravinas nas encostas.

As amplitudes locais variam de 160 a 140 metros. Estas formas de relevo apresentam substrato constituído de Quartzitos impuros. 


\begin{tabular}{|c|c|c|}
\hline Sistemas & Unidades & Descricão \\
\hline \multirow{8}{*}{ Sistema A } & A1 & Vale aberto com desenvolvimento de planícies aluvionares. \\
\hline & $\mathrm{A} 2$ & Morros com amplitudes locais entre 160 e 140 metros. Topos angulosos e extensos, vertentes retilíneas a convexas. Declividade entre $10 \mathrm{e} 20 \%$. Substrato constituído de Quartzitos impuros \\
\hline & A3 & $\begin{array}{l}\text { Colinas com amplitude local entre } 60 \text { e } 80 \text { metros. Topos arredondados e restritos, vertentes de perfis convexo-retilíneos, vales abertos e fechados com presença de planícies aluvionares interiores restritas. D eclividade } \\
\text { predominante entre } 10 \mathrm{e} 20 \% \text {. Substrato de cnaisses intercalados com quartzitos. }\end{array}$ \\
\hline & A4 & $\begin{array}{l}\text { Morros com amplitudes locais de } 100 \text { metros. Topos aplainados a ondulados orientados no sentido NE/SW, encostas suavizadas retilíneo-convexas e vales abertos. Declividades entre } 2 \text { e } 20 \% \text {. Substrato de G naisses } \\
\text { intercalados com quartzitos }\end{array}$ \\
\hline & A5 & Morros com amplitude local entre 100 e 160 metros. Topos arredondados restritos, encostas convexas suaves. Substrato de $\mathrm{G}$ naisses intercalados com rochas básicas. \\
\hline & A6 & $\begin{array}{l}\text { Morros com amplitudes locais entre } 120 \text { e } 160 \text { metros. Topos angulosos restritos, dispostos de forma alongada e orientados no sentido NE/ SW. Encostas com perfis retilíneo-convexos. Decclividades entre } 10 \text { e } 20 \% \text {. } \\
\text { Substrato de gnaisses intercalados com quartzitos. }\end{array}$ \\
\hline & A7 & $\begin{array}{l}\text { Morros com amplitudes ente } 100 \text { e } 140 \mathrm{~m} \text {. Topos arredondados a levemente angulosos restritos, orientados na direção NE/ SW. Encostas convexas suaves. Declividades entre } 10 \text { e } 20 \% \text {. Substrato de gnaisses intercalados } \\
\text { com rochas básicas. }\end{array}$ \\
\hline & A8 & Colinas de topos arredondados suaves, perfis de encostas retilíneo-convexas. Declividade $<2 \%$. Substrato de Granitos cataclasados. \\
\hline \multirow{8}{*}{ Sistema B } & B1 & Morros com amplitude local de 180 metros. Topos angulosos restritos, encosta retilíneo-convexos com inclinação moderada. Declividades entre 10 e $45 \%$. Substrato de $\mathrm{G}$ naisses intercalados com rochas básicas. \\
\hline & B2 & Morros de topos arredondados e restritos, com encostas suavizadas de perfil retilíneo-convexas. D eclividades entre $10 \mathrm{e} 20 \%$. Substrato de G naisses intercalados com quartzitos. \\
\hline & B3 & Serras com amplitudes locais de $300 \mathrm{~m}$. Topos angulosos extensos, encostas retilíneo-convexas. Declividade entre $10 \mathrm{e} 30 \%$. Substrato de $\mathrm{G}$ naisses intercalados com rochas básicas. \\
\hline & B4 & Morros com amplitude local de 200 metros. Topos arredondados a angulosos restritos, orientados NW/ SE, encostas convexo-retilíneas de inclinação moderada. \\
\hline & B5 & $\begin{array}{l}\text { Serras com amplitudes locais de } 420 \text { metros. Topos arredondados extenssos, alongados na direção NE/ SW. Encostas voltadas para oeste convexas e extensas; e encostas voltadas para leste com vertentes retilíneo - convexas. } \\
\text { Declividade entre } 20 \mathrm{e} 45 \% \text { Substrato de } \mathrm{G} \text { naisses intercalados com rochas básicas. }\end{array}$ \\
\hline & $\mathrm{B} 6$ & Morros com amplitude local de 280 metros. Topos arredondados agudos, orientados na direcã̃o NW/ SE. Encostas retilíneas, com inclinação moderada. Declividade entre 20 e $30 \%$. Substrato de Migmatitos \\
\hline & B7 & Morros com amplitude local de 140 metros. Topos angulosos estreitos, encostas convexo-retilíneas e vales abertos. Declividade entre $20 \mathrm{e} 30 \%$. Substrato de Migmatitos e $\mathrm{G}$ naisses intercalados com rochas básicas. \\
\hline & B8 & Morros com amplitudes locais de 240 metros. Topos angulosos restritos, encostas retilíneo - convexas. Declividade entre 20 e $30 \%$. Substrato de Q uartzitos impuros. \\
\hline \multirow{7}{*}{ SistemaC } & $\mathrm{C} 1$ & Serras com amplitude local de 360 metros. Topos angulosos estreitos e não contínuos. Vertentes convexo-retilíneas. Declividade entre 30 e $45 \%$. Substrato de Migmatitos. \\
\hline & $\mathrm{C} 2$ & $\begin{array}{l}\text { Conjunto de vales abertos com desenvolvimento de planícies aluvionares localizadas e morros, amplitude locais ente } 100 \text { e } 140 \text { metros. Topos angulosos estreitos, encostas convexas. Declividade entre } 10 \text { e } 20 \% \text { e entre } 20 \text { e } \\
30 \% \text {. Substrato de G naisses intercalados com rochas básicas. }\end{array}$ \\
\hline & C3 & $\begin{array}{l}\text { Serras com amplitude local de } 480 \text { metros. Topos arredondados a angulosos extensos dispostos no sentindo NE/ SW. Econstas desiguais; retilíneo - convexas voltadas para oeste; e retilíneas voltado para leste. D eclividade } \\
\text { entre } 30 \text { e } 45 \% \text {. Substrato de Migmatitos. }\end{array}$ \\
\hline & C4 & $\begin{array}{l}\text { Morros com amplitudes locais entre } 160 \text { e } 240 \text { metros. Topos angulosos, encostas retililíneo - convexas associadas a vales abertos. Declividade entre } 10 \text { e } 45 \% \text {.Substrato de } \mathrm{G} \text { naisses intercalados com rochas básicas, Quartzitos } \\
\text { impuros e Ultramilonitos. }\end{array}$ \\
\hline & C5 & $\begin{array}{l}\text { Serra com amplitude local de } 460 \text { metros. Topos arredondados estreitos, encostas de perfis desiguais, convexo-retilíneas voltadas para oeste e retilíneas voltadas para leste Declividades entre } 30 \text { e } 45 \% \text {. Substrato de } \\
\text { Migmatitos. }\end{array}$ \\
\hline & C6 & $\begin{array}{l}\text { Serras com amplitudes locais de 300m. Topos angulosos estreitos, orientados no sentido NE/ SW . Encostas convexo-retilíneas. Declividades entre } 30 \text { e } 45 \% \text { e, entre } 20 \text { e } 30 \% \text {. Ssubstrato de G naisses intercalados a rochas } \\
\text { básicas e Q uartzitos impuros. }\end{array}$ \\
\hline & C7 & Serras com amplitude local de 300 metros. Topos angulosos estreitos, orientados no sentido NE/ SW. Vertentes retilíneo-convexas. D eclividades entre 30 e $45 \%$. Substrato de Q uartzitos impuros. \\
\hline \multirow{11}{*}{ Sistema D } & D1 & Serras alongadas no sentido NE/ SW, amplitudes locais entre 320 e 400 metros. Topos angulosos estreitos, vertentes retilineo-convexas. Declividade entre 30 e $45 \%$. Substrato de G naisses intercalados a rochas básicas. \\
\hline & D2 & Colinas com amplitudes locais de 80 metros. Topos arredondados, encostas convexas de inclinação suave. D eclividade entre 10 e $20 \%$. Substrato de G naisses intercalados a rochas básicas. \\
\hline & D3 & Morros com amplitude local de 180 metros, associados a vales abertos. Topos arredondados e encostas convexas. Declividade entre $10 \mathrm{e} 20 \%$ junto às encostas e $<2 \%$ nas áreas do vales. Substrato de Ultramilonitos. \\
\hline & D4 & Colinas com amplitude local de 80 metros. Topos arredondados e encostas convexas. D eclividade entre $10 \mathrm{e} 20 \%$. Substrato de Blastomilonitos. \\
\hline & D5 & Morros com amplitudes locais de 100 metros. Topos restritos angulosos, perfis de encosta convexos.Declividade entre 10 e $20 \%$, e entre 20 e $30 \%$. Substrato de Blastomilonitos. \\
\hline & D6 & Morros com amplitudes locais de 200 e 220 metros. Topos arredondados a angulosos estreitos, orientação NE/ SW. Encostas retilíneo-convexas. Declividade entre 10 e $20 \%$, e 20 e $30 \%$. Substrato de G ranito \\
\hline & D7 & Serras com amplitudes locais de 300 metros associadas a vales abertos Perfil de encosta retilíneo. Declividade entre $10 \mathrm{e} 20 \%$. Substrato de Ultramilonitos e Q uartzitos impuros. \\
\hline & D8 & Serras com amplitudes locais de 320m. Topos angulosos e estreitos, encostas retilíneas de inclinação elevada. Declividade entre 30 e $45 \%$ e, entre 20 e $30 \%$. Substrato de Ultramilonitos. \\
\hline & D9 & Serras de topo muito anguloso e alongado no sentido NE/ SW. Perfis convexos retilíneos voltados para oeste, e retilíneos voltados $\mathrm{p}$ \\
\hline & D10 & Morros com amplitudes locais de 120 metros. Topos angulosos, encostas retilíneas, associadas a vales fechados. Declividade entre $10 \mathrm{e} 30 \%$. Substrato de Blastomilonitos. \\
\hline & D11 & Vale aberto com desenvolvimento de planície aluvionar. D eclividades muito baixa, < $2 \%$. Substrato de Ultramilonitos e $\mathrm{G}$ naisses intercalados a rochas básicas. \\
\hline \multirow{8}{*}{ Sistema E } & E1 & vexas. Declividades entre $10 \mathrm{e} 20 \% \mathrm{e}, 20 \mathrm{e} 30 \%$. Substrato de Migmatitos e $\mathrm{G}$ ranitos porfiríticos. \\
\hline & E2 & Serras com amplitudes locais entre 300 e 360 metros. Topos arredondados, restritos a extensos, encostas convexas, por vezes retilíneo - convexas. Declividade entre 10 e $20 \%$ e, 20 e $30 \%$. Substrato de Migmatitos. \\
\hline & E3 & Morros com amplitudes locais de 100m e 200m. Topos arredondados e restritos orientados nas direções NE/ SW e E -W. Encostas convexo- reitlíneas. Declividade entre 10 e $20 \%$. Substrato de Migmatitos. \\
\hline & E4 & $\begin{array}{l}\text { Serras com amplitude local entre } 400 \text { e } 540 \text { metros. Topos agudos extensos, orientados E-W e NE/ SW, encostas voltadas para o sul e leste de perfil convexo-retilíneo, para norte e oeste com perfil retilíneo. D eclividade entre } \\
10 \text { e } 20 \% \text { e, } 20 \text { e } 30 \% \text {. Substrato de Migmatitos. }\end{array}$ \\
\hline & E5 & Morros e vales abertos. Topos angulosos a arredondados, encostas convexas. Declividade entre 10 e $20 \%$ e, 2 e $10 \%$. Substrato de Migmatitos. \\
\hline & E6 & Morros com amplitudes locais de 220 metros. Topos angulosos extensos e encostas retilíneo-convexas. Declividade entre $10 \mathrm{e} 30 \%$. Substrato de G ranitos porfiríticos. \\
\hline & E7 & $\begin{array}{l}\text { Morros com amplitudes entre } 220 \text { e } 240 \text { metros. Topos arredondados e extensos, orientados NE/ SW e NW/ SE. Perfis de encostas convexo-retilíneos suaves Declividade entre } 10 \text { e } 20 \% \text { e, } 20 \text { e } 30 \% \text {. Substrato de } \\
\text { Migmatitos e G ranitos porfiríticos }\end{array}$ \\
\hline & E8 & $\begin{array}{l}\text { Vales abertos com desenvolvimento de planície, associado a colinas. Amplitu } \\
\text { Substrato de G ranitos-gnaisses e Granitos porfiríticos. }\end{array}$ \\
\hline
\end{tabular}




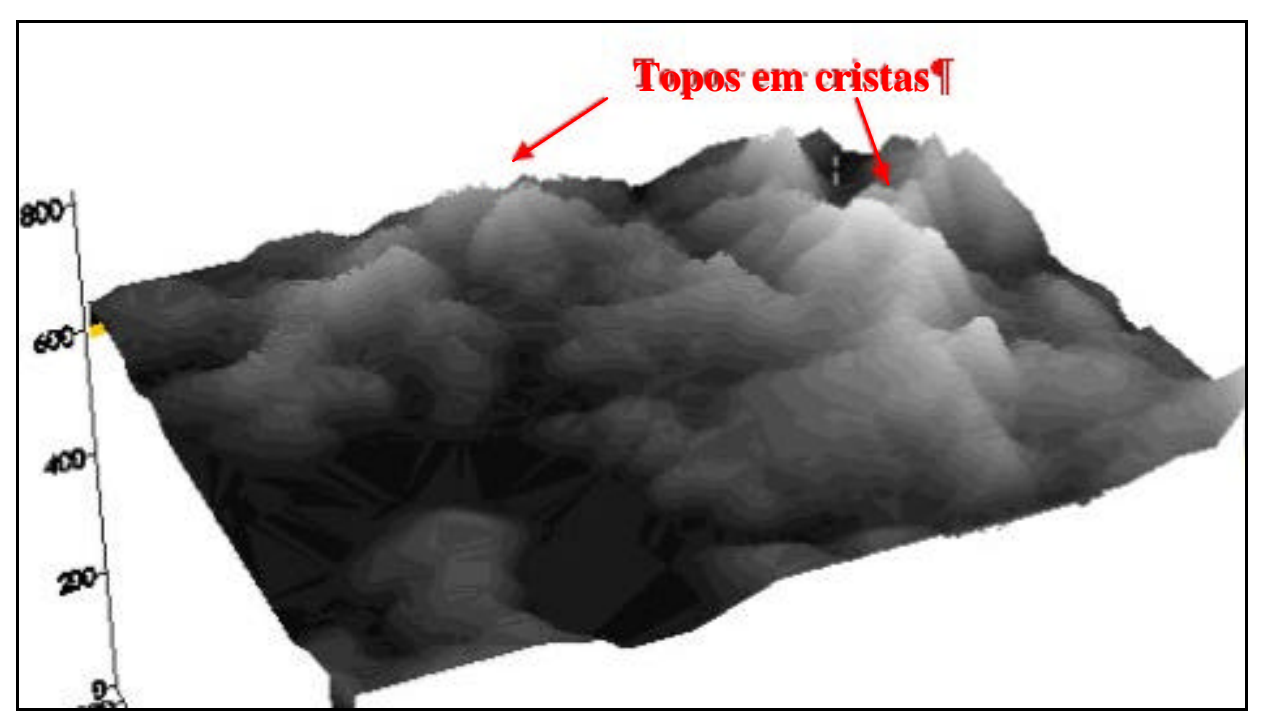

Figura 5.16. D etalhe em Modelo Digital do Terreno da Unidade A2. Notar destaque aos morros de topos angulosos, definindo cristas com disposição em arco.

Figura 5.17. D etalhe perfil de encosta da Unidade A2.

\section{$\underline{\text { Unidade A } 3}$}

Localizada na porção extremo centro-oeste do sistema, caracteriza um relevo de colinas com amplitude local entre 60 e 80 metros, associadas a vales que variam entre abertos e fechados com presença de planícies aluvionares interiores restritas. Exibe topos arredondados e restritos com vertentes de perfis convexo-retilíneos, com declividade predominante entre 10 e 20\% (Figura 5.18).Esta unidade é constituída por gnaisses intercalados com quartzitos. 


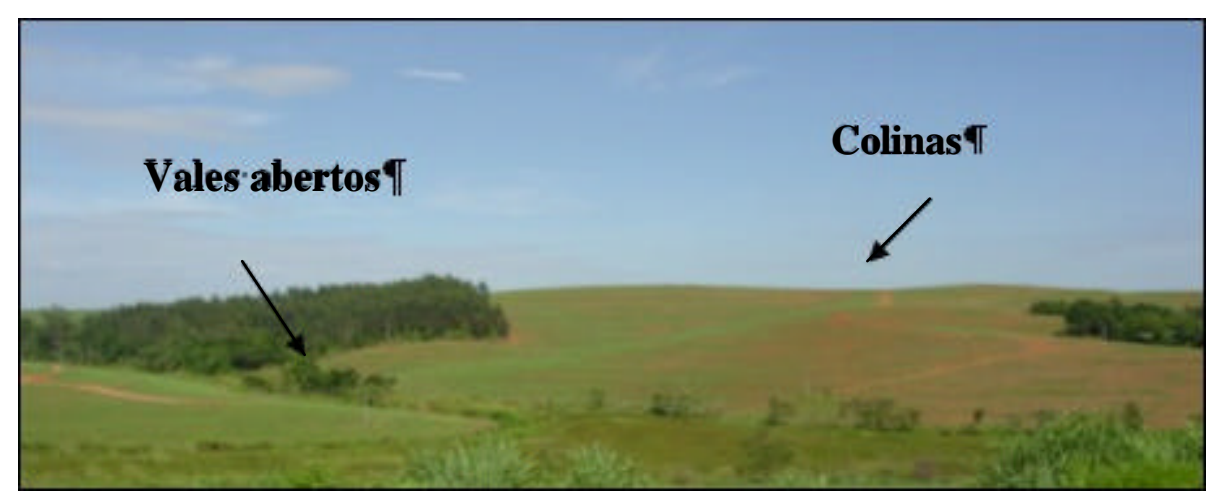

Figura 5.18 Unidade de landform A3. Colinas associadas a vales abertos.

\section{$\underline{\text { Unidade A } 4}$}

Localizada, também, na porção extremo centro-oeste do sistema, esta compreende um relevo de morros com encostas suavizadas, associados a vales abertos e com amplitudes locais de 100 metros. O s topos destas formas de relevo são aplainados a ondulados, orientados no sentido NE/ SW. Os perfis de encosta variam de retilíneos a convexos (Figura 5.19). Predominam declividades entre 2 e $20 \%$.

O substrato que constitui estas formas de relevo são Gnaisses intercalados com quartzitos

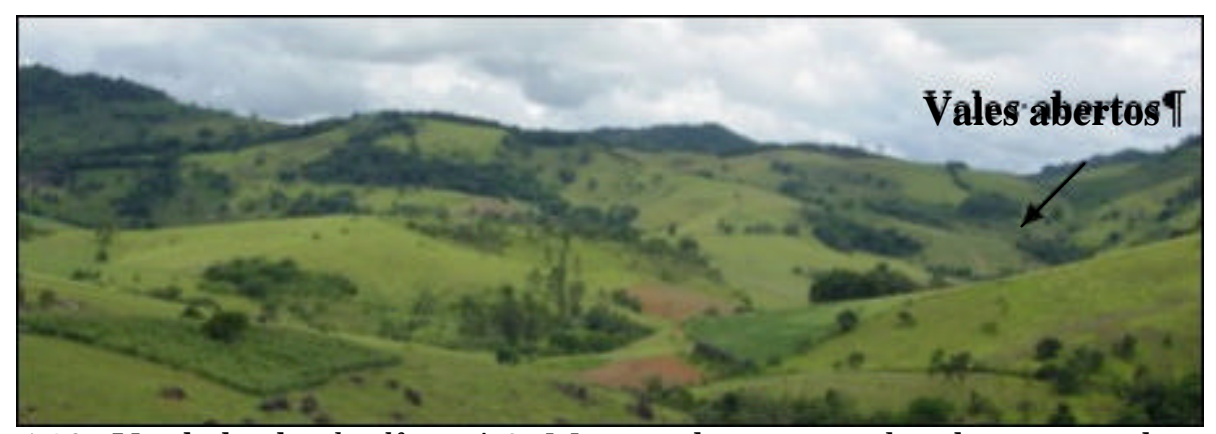

Figura 5.19. Unidade de landform A4. Morros de topos aplinados associadas a vales abertos.

\section{$\underline{\text { Unidade A } 5}$}

Localizada na porção centro norte do sistema, constituem relevo de morros de topos arredondados restritos, com encostas convexas suaves, de amplitude local variando entre 100 e 160 metros (Figura 5.20). 0 substrato associado a estas formas de relevo é constituído de $\mathrm{G}$ naisses intercalados com rochas básicas 


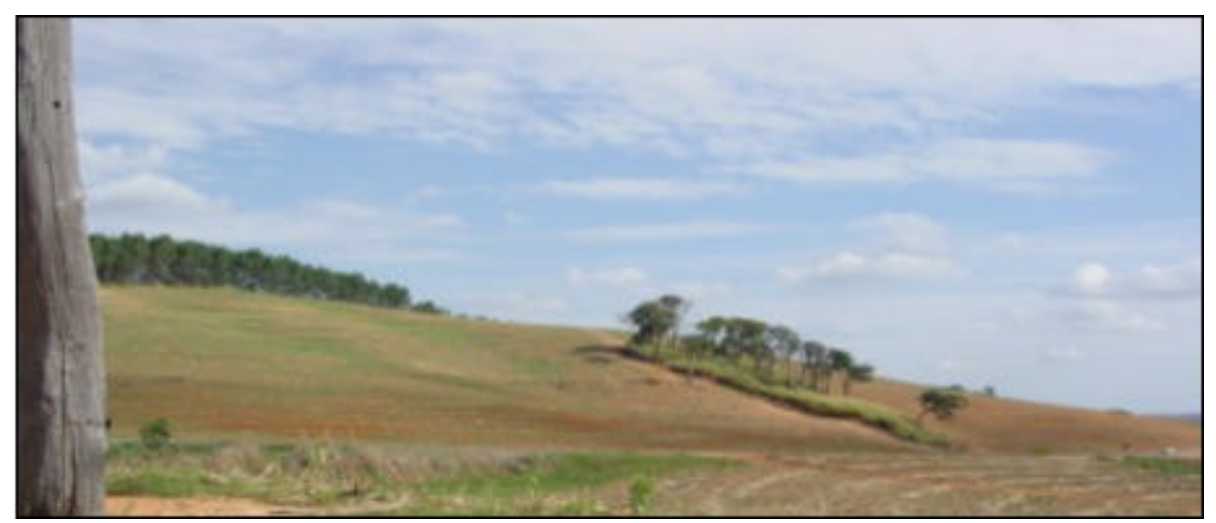

Figura 5.20 - D etalhe Unidade de landform A5. Morro de topos arredondados e vertentes convexas.

$\underline{\text { Unidade A } 6}$

Presente na porção extremo sul do sistema, caracterizam um relevo de morros com topos angulosos restritos, dispostos de forma alongada e orientados no sentido NE/ SW (Figura 5.21). Exibe encostas com perfis retilíneo-convexo, com declividades predominando entre 10 e 20\%. As amplitudes locais desta unidade variam entre 120 e 160 metros.

O substrato que sustenta estas formas corresponde a gnaisses intercalados com quartzitos.

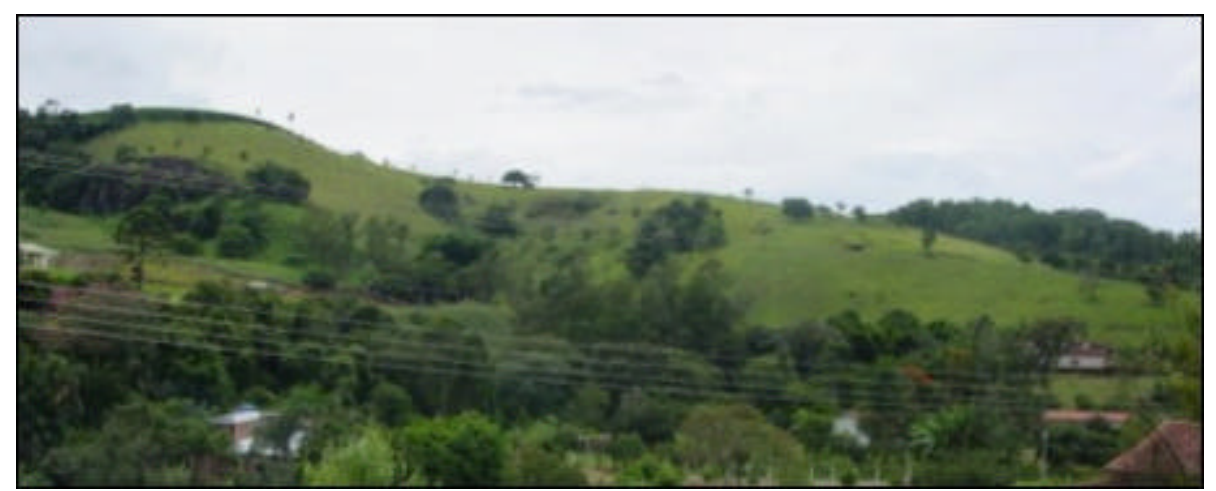

Figura 5.21 - D etalhe Unidade de landform A6. Morro de topos angulosos alongados na direção NE/ SW.

\section{$\underline{\text { Unidade A } 7}$}

Corresponde a quase totalidade da porção sul do sistema. Constitui um relevo de morros com topos arredondados a levemente angulosos restritos (Figura 5.22)., orientados na direção NE/ SW com amplitudes locais ente 120 e 160 metros. Apresenta 
amplitudes locais que variam ente 100 e 140m. Exibe encostas convexas suaves com declividades predominando entre 10 e $20 \%$.

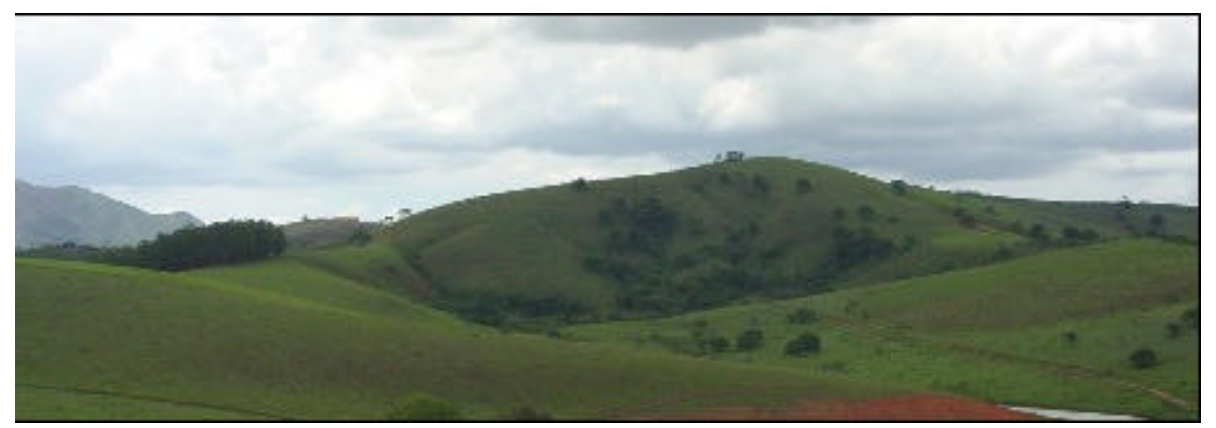

Figura 5.22 - Unidade de landform A7. Morros de topos arredondados a levemente angulosos.

Em campo são observados ravinamentos localizados nas encostas destas formas de relevo. O substrato que constitui estas formas corresponde a gnaisses intercalados a rochas básicas.

\section{$\underline{\text { Unidade A } 8}$}

Localizada na porção extremo noroeste do sistema, esta unidade caracteriza um relevo de colinas de topos arredondados suaves e amplitude local de 60 metros (Figura 5.23). Exibe perfis de encosta retilíneas-convexas, com valores de declividade $<2 \%$. É observada a ocorrência de ravinamentos nas encostas.

Granitos cataclasado correspondem ao substrato que sustenta estas formas de relevo.

Figura 5.23 - Unidade de landform A8. Colinas de topos arredondados suaves. 


\section{3.2.2. Sistemas de Temeno $B$}

Compreende a região mais a leste da baixa bacia, e corresponde a 12,21\% da totalidade da mesma. Caracteniza-se por formas de terreno representadas por morros e secundariamente serras, com as primeiras de ocorrência predominante. As classes de declividade medianamente moderadas $(10-20 \%)$ e alta $(30-45 \%)$ ocorrem em maior proporção.

O sistema é compartimentado em oito unidades, as quais estão associadas a substratos constituídos de gnaisses intercalados com rochas básicas, gnaisses intercalados com quartzitos e migmatitos

\section{$\underline{\text { Unidade B1 }}$}

Presente na porção extremo norte do sistema, caracteriza um relevo de morros com topos angulosos restritos, de amplitude local de 180 metros. Os perfis de encosta são retilíneo-convexos com inclinação moderada (Figura 5.24). São observados ravinamentos localizados. Predominam declividades entre 10 e $45 \%$.

Estas formas de relevo correspondem a ocorrência de G naisses intercalados com rochas básicas.

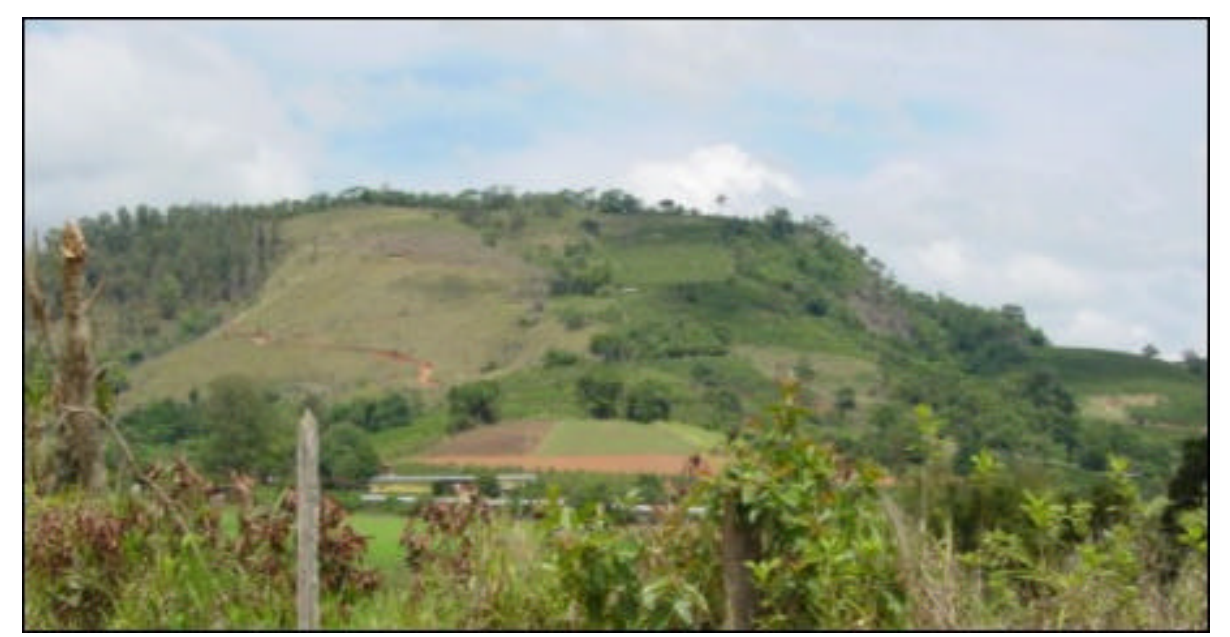

Figura 5.24. Unidade de landform B1. Morros de topos angulosos restritos e encosta retilíneo-convexos. 
$\underline{\text { Unidade B2 }}$

Presente na porção extremo noroeste do sistema, esta unidade caracteriza relevo de morros com amplitude local de 120 metros, de topos arredondados e restritos (Figura 5.25), com encostas suavizadas de perfil retilíneo-convexas.

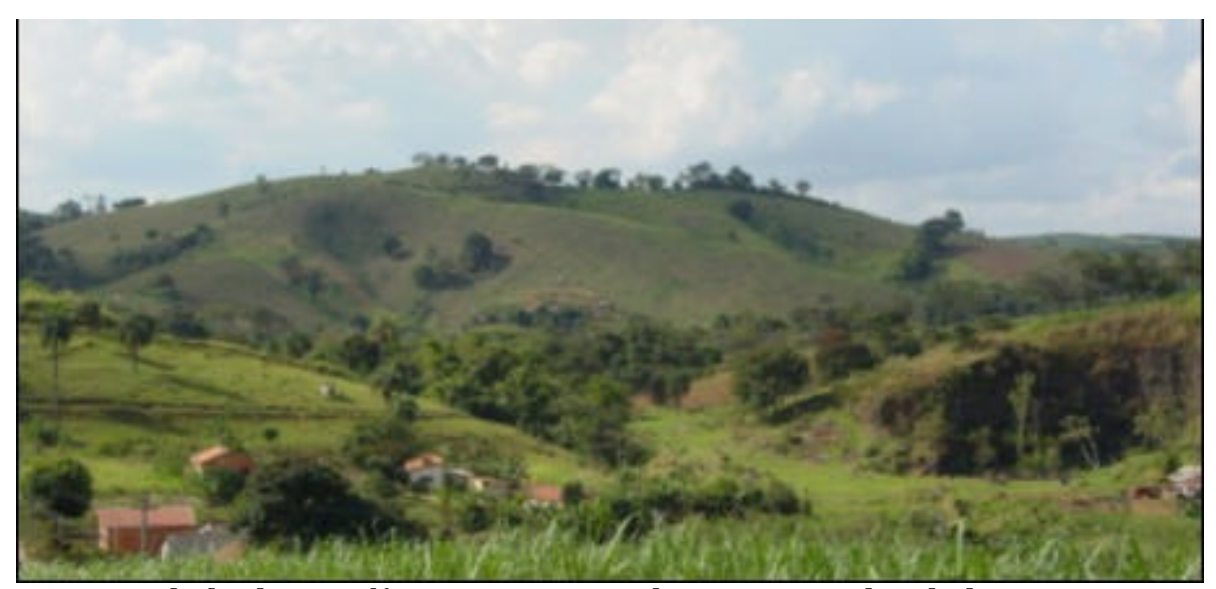

Figura 5.25. Unidade de L andform B2. Morros de topos arredondados e restritos.

Nestas formas de relevo predominam declividades entre 10 e 20\%, e o substrato associado é constituído por gnaisses intercalados com quartzitos.

$\underline{\text { Unidade B3 }}$

Localizada na porção centro norte do sistema, esta constitui um relevo de serras de topos angulosos extensos (Figura 5.26). Exibem amplitudes locais de 220 metros e encostas retilíneo-convexas, e amplitudes locais de 300m.

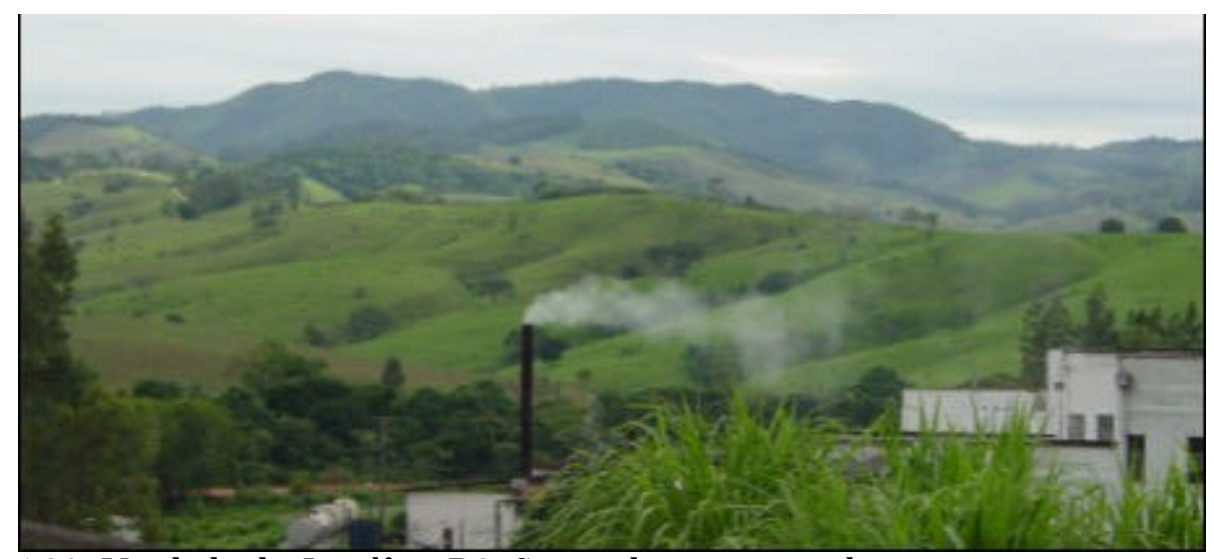

Figura 5.26. Unidade de L andform B3. Serras de topos angulosos extensos. 
Os valores de declividade predominantes variam entre 10 e $30 \%$, e 0 substrato que constitui estas formas de relevo corresponde a $\mathrm{G}$ naisses intercalados com rochas básicas.

$\underline{\text { Unidade B4 }}$

Localizada na porção sudoeste do sistema, constitui relevo de morros com amplitude local de 200 metros. Estas formas caracterizam-se por exibirem, ora topos arredondados ora angulosos e restritos, orientados NW/ SE, com encostas convexoretilíneas de inclinação moderada (Figura 5.27 A e B).
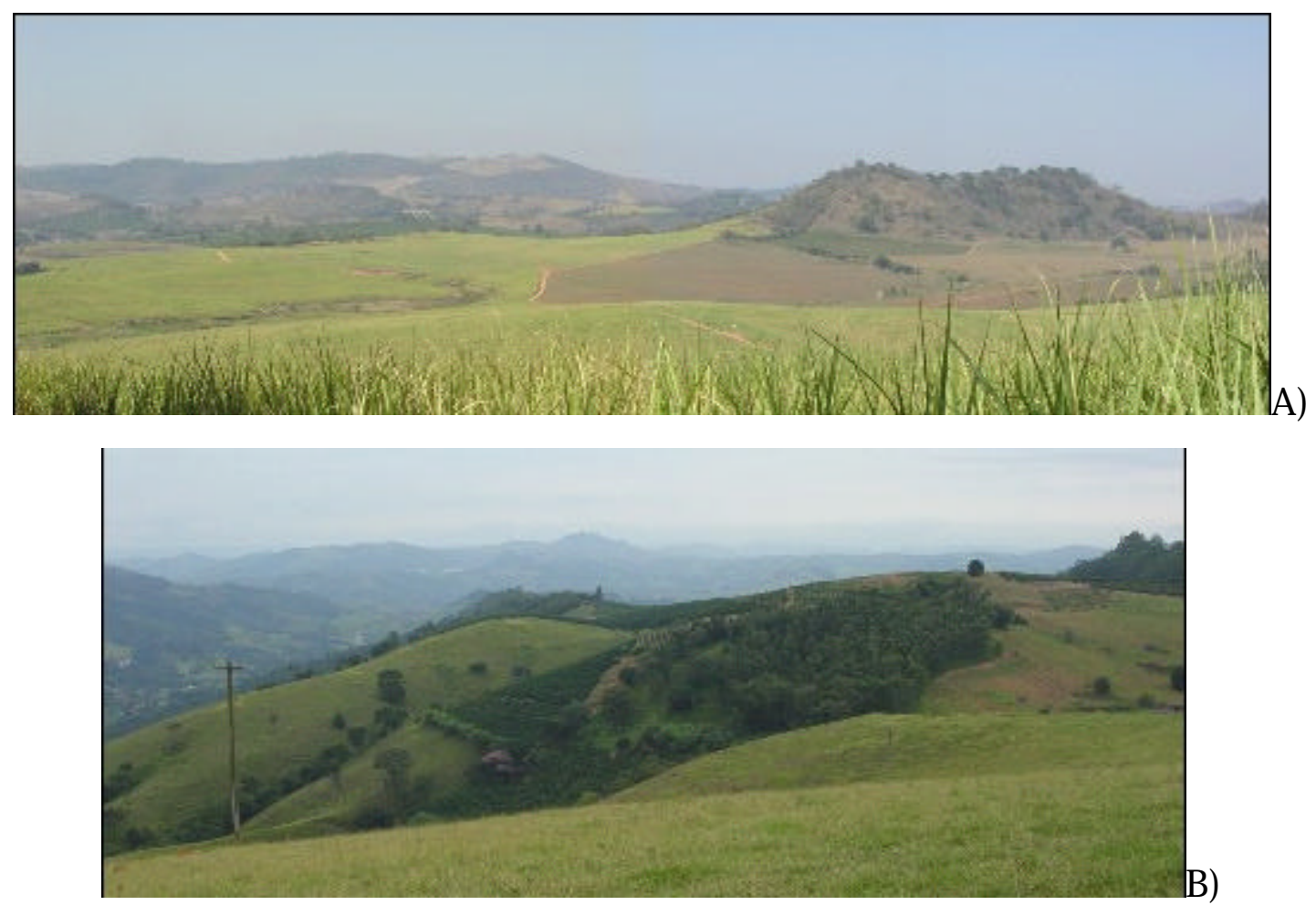

Figura 5.27. Unidade de L andfrom B4. a) Morros com topos angulosos restritos. b) Morros com topos arredondados.

\section{$\underline{\text { Unidade B5 }}$}

Presente na porção contro-leste do sistema, caracteriza um relevo de serras com amplitudes locais de 420 metros. Estas apresentam topos arredondados extenssos, alongados na direção NE/ SW. Encostas voltadas para oeste convexas e extensas (Figura 
5.28), com inclinações moderadas a altas e presença de ravinamentos; e encostas voltadas para leste com vertentes retilíneo-convexas, de inclinação elevada.

\section{Figura 5.28. Unidade de landform B5. D etalhe encostas convexas e extensas voltadas para oeste}

Predominam valores de declividade entre 20 e $45 \%$, e gnaisses intercalados com rochas básicas constituem 0 substrato desta unidade.

\section{$\underline{\text { Unidade B6 }}$}

Localizada na porção extremo sudoeste do sistema, esta unidade de relevo constituem morros com amplitude local de 280 metros, de topos arredondados agudos, orientados na direção NW/ SE (Figura 5.29). Apresentam encostas retilíneas, com inclinação moderada.

Predominam nesta unidade valores de declividade entre 20 e $30 \%$, e apresentam migmatitos como substrato associado.

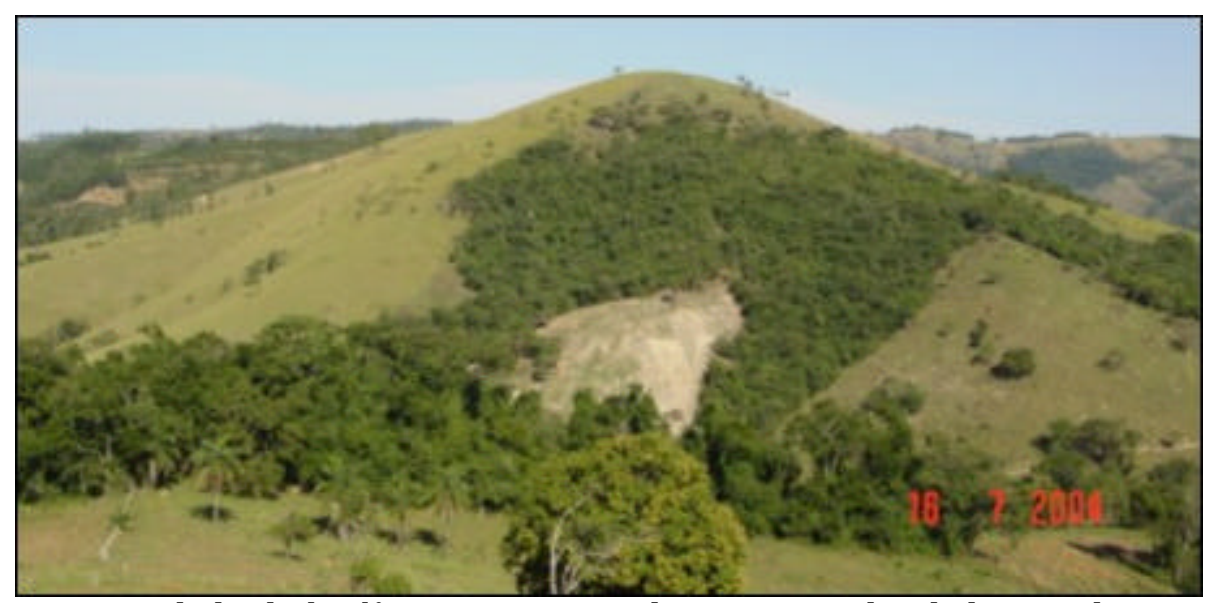

Figura 5.29. Unidade de hndform B6. Morros de topos arredondados agudos e encostas retilíneas. 


\section{$\underline{\text { Unidade B7 }}$}

Presente na porção extremo sudeste do sistema, caracterizam relevo de morros de topos angulosos estreitos, com amplitude local de 140 metros. Apresentam perfis de encostas convexo-retilíneas e vales abertos (Figura 5.30).

Predominam valores de declividade entre 20 e $30 \%$.

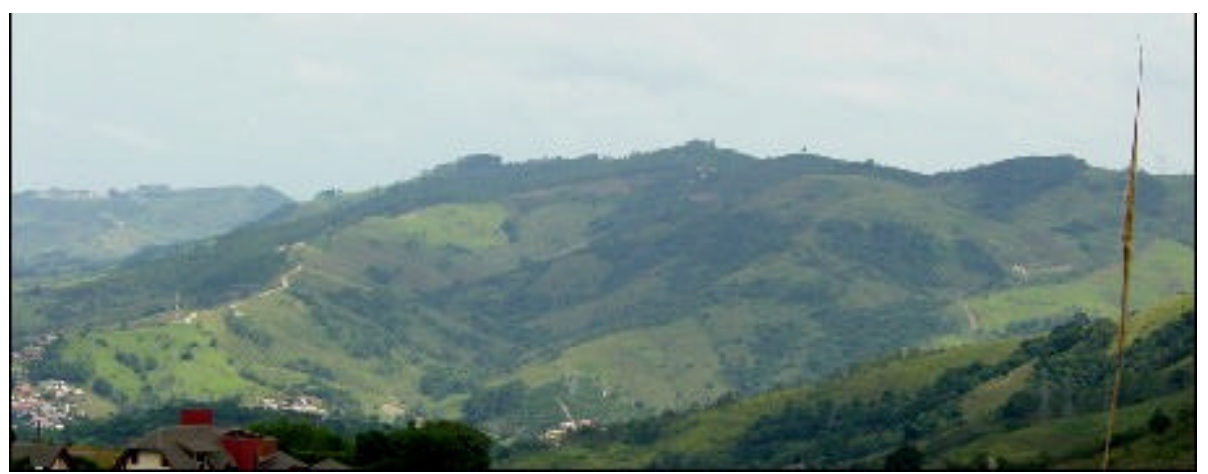

Figura 5.30. Unidade de hndform B7. Morros de topos angulosos estreitos, encostas convexo-retilíneas associadas a vales abertos

O substrato que constitui as formas de relevo desta unidade são migmatitos e gnaisses intercalados com rochas básicas.

\section{$\underline{\text { Unidade B } 8}$}

Localizada na porção centro-norte do sistema, esta unidade é caracterizada por um relevo de morros com amplitudes locais de 240 metros. Estes apresentam topos angulosos restritos e, perfil de encosta retilíneo-convexo.

Os valores de declividade predominante variam entre 20 e $30 \%$ e o substrato associado a estas formas são Q uartzitos impuros.

\subsubsection{Sistemas de Temeno C}

Compreende a região mais a oeste da média bacia, e corresponde a 8,83\% do total da mesma. É caracterizado pela ocorrência de duas formas de terreno: 1) Morros associados a vales extenso e 2) Serras. Predominam neste sistema classes de declividade alta (30-45\%) e moderadas (20-30\%), estes últimos valores mais presentes nas encostas 
das serras e morros. A classe muito alta (>45\%) tem ocorrência restrita, delimitam os topos das Serras.

O sistema é subdividido em sete unidades, as quais têm por substrato associado gnaisses intercalados com rochas básicas e migmatitos.

$\underline{\text { Unidade C1 }}$

Localizada na porção extremo noroeste do sistema, caracteriza um relevo de serras com amplitude local de 360 metros. Exibem topos angulosos estreitos e não contínuos. Vertentes convexo-retilíneas com inclinação alta e vales fechados (Figura 5.31).

Predominam faixas de declividade entre 30 e 45\%. Migmatitos correspondem ao substrato associado a esta unidade.

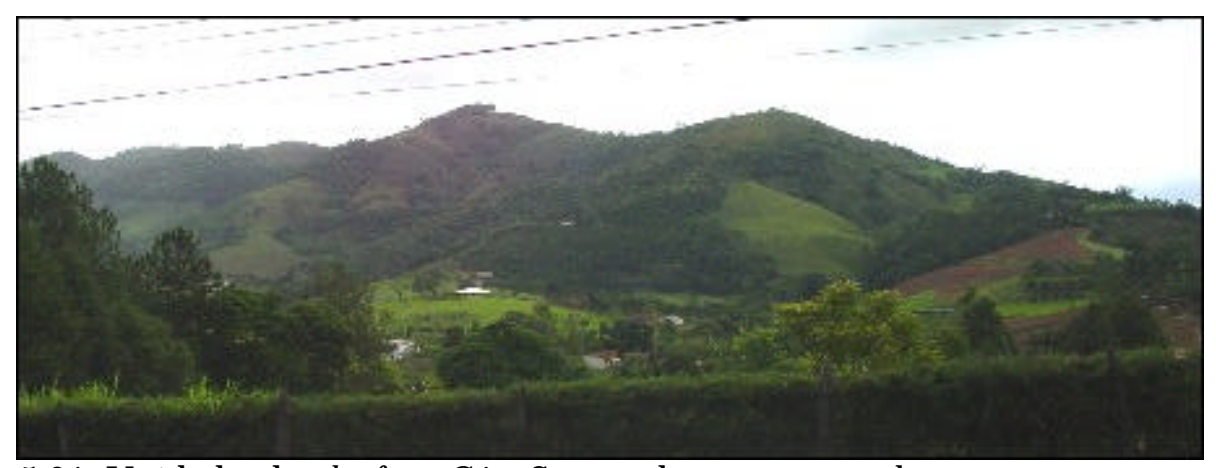

Figura 5.31 Unidade de lanform C1. Serras de topos angulosos, vertentes convexoretilíneas.

\section{$\underline{\text { Unidade C2 }}$}

Presente na porção centro oeste do sistema, constitui um conjunto de vales e morros, com amplitudes locais variando entre 100 e 140 metros (Figura 5.32). Os vales são abertos com desenvolvimento de planícies aluvionares localizadas. Apresenta expressões em áreas que variam de pequena a média. Os morros exibem topos angulosos estreitos, com encostas convexas de inclinação média. 


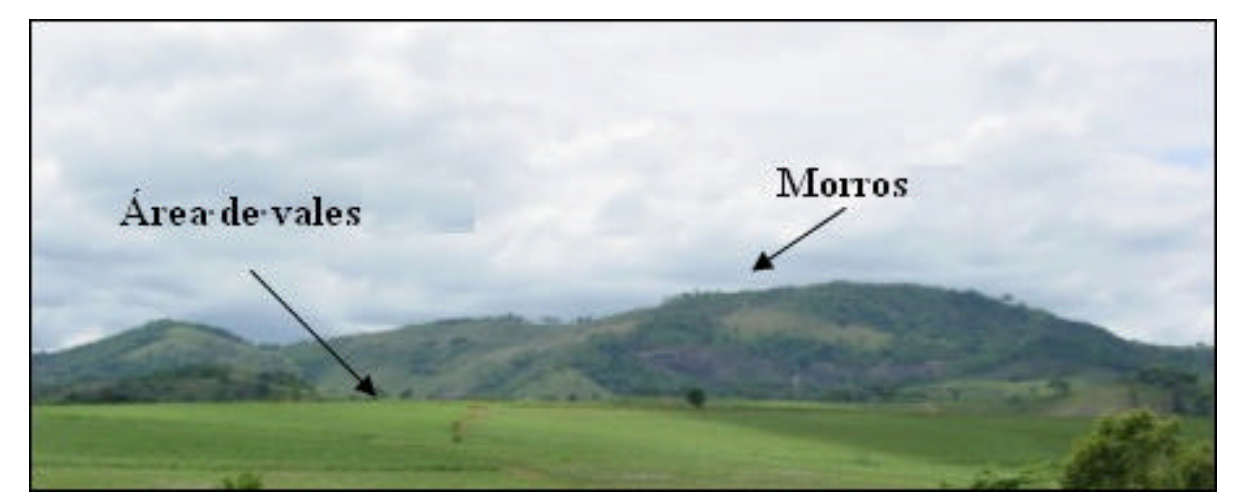

Figura 5.32 Unidade de landform C2. Morros de encostas convexas e topos anguloso, associado a vales abertos.

Predominam valores de declividade entre 10 e $20 \%$ e entre 20 e $30 \%$. o substrato associado a estas formas de terreno corresponde a gnaisses intercalados com rochas básicas.

\section{$\underline{\text { Unidade C3 }}$}

Localizadas na porção centro norte do sistema, caracteriza um relevo de serras de amplitude local de 480 metros. Estas formas de relevo ocorrem dispostas no sentindo NE/SW. Caracterizam feições alongadas, com topos variando de arredondados a angulosos extensos. Exibem encostas com perfis desiguais com ocorrência de ravinamentos; retilíneo-convexas de inclinação moderada a altas voltadas para oeste; e perfil retilíneo e inclinação alta voltadas para leste (Figura 5.33).

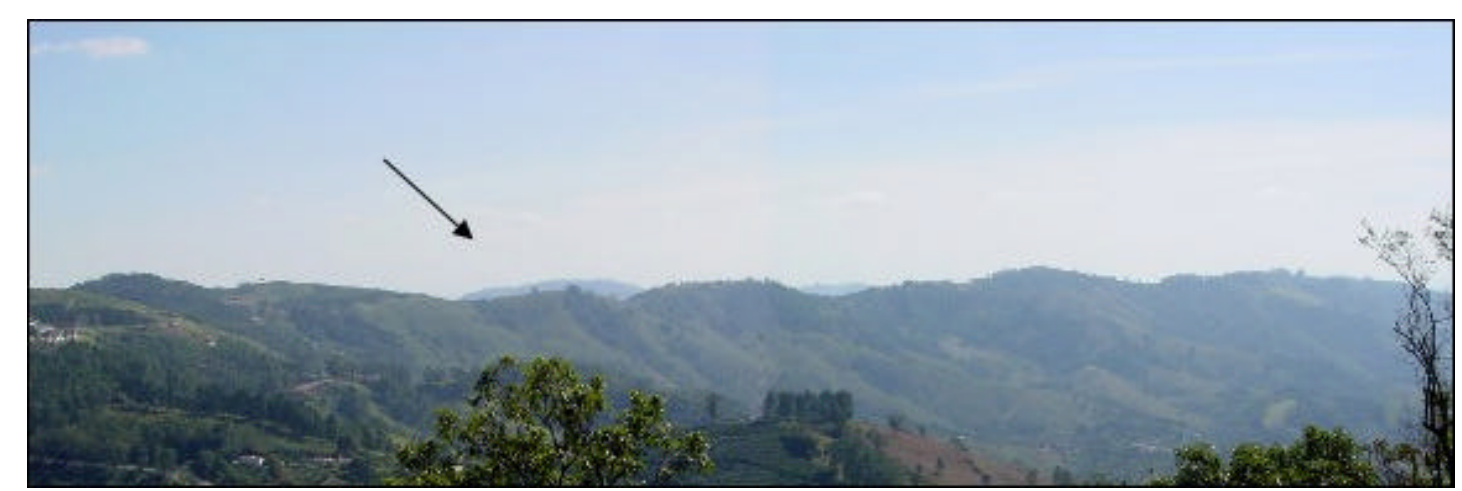

Figura 5.33. Unidade de landform C3. Serras de topos angulosos a arredondados. D etalhe dos perfis de encosta voltados para leste.

As faixas de declividade que predominam nestas formas de relevo variam entre 30 e $45 \%$, e migmatitos constituem o substrato associado. 


\section{$\underline{\text { Unidade C4 }}$}

Presente na porção centro leste do sistema, constituem um relevo de morros com amplitudes variando entre 160 e 240 metros. Estas formas de terreno exibem topos angulosos e encostas retililíneo-convexas associadas a vales abertos (Figura 5.34). Apresentam maior inclinação das vertentes voltadas para leste e declividade variando entre 10 e $45 \%$.

O substrato rochoso associado é constituído de gnaisses intercalados com rochas básicas, quartzitos impuros e ultramilonitos.

Figura 5.34. Unidade de landform C3. D etalhe forma dos topos angulosos e encosta retililíneo-convexas.

\section{$\underline{\text { Unidade C5 }}$}

Localizada na porção sudoeste do sistema, caracteriza um relevo de serra de amplitude local de 460 metros, com topos arredondados estreitos e encostas de inclinação moderada a alta, de perfis desiguais. Convexo-retilíneas voltadas para oeste e retilíneas voltadas para leste (Figura 5.35).

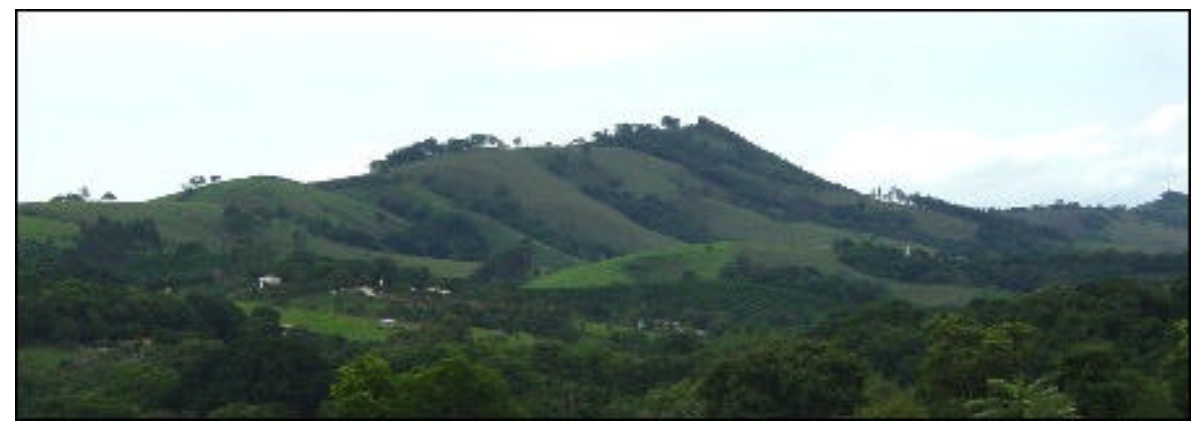

Figura 5.35 Unidade de lanform C5. Serras de topos estreitos.D etalhe encostas retilíneas voltadas para leste. 
Valores entre 30 e $45 \%$ correspondem as declividades predominantes, e migmatitos constituem o substrato que sustenta estas formas de relevo.

\section{$\underline{\text { Unidade } \mathrm{C} 6}$}

Presente na porção centro sul do sistema, caracterizam serras com amplitude local de 300m, de topos angulosos estreitos, orientados no sentido NE/ SW (Figura 5.36). Estas serras exibem encostas convexo-retilíneas, nas quais observa-se presença de ravinas.

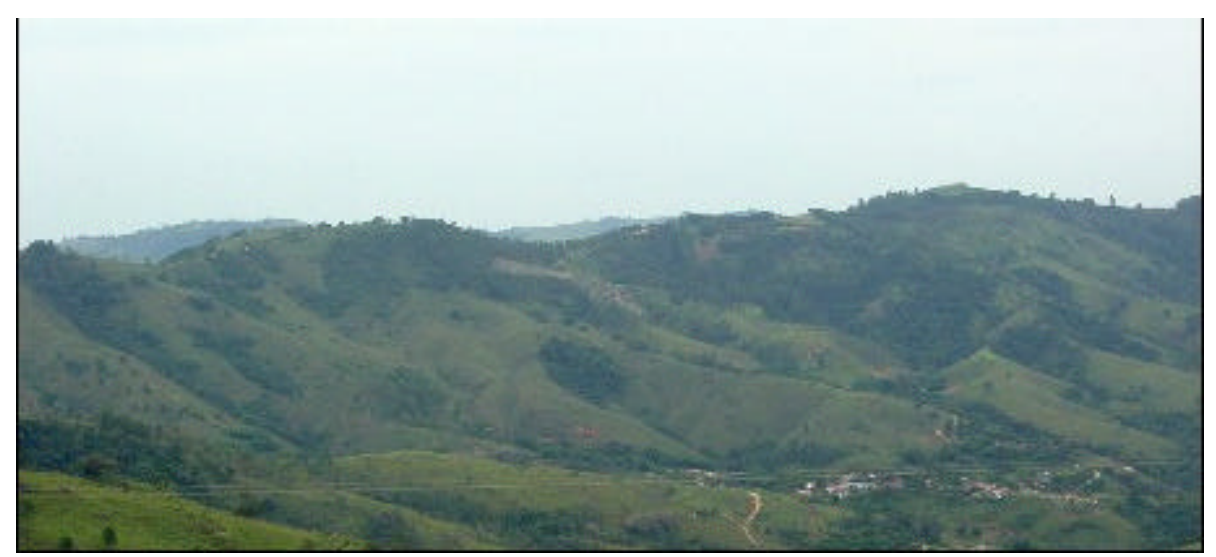

Figura 5.36. Unidade de landform C6. Serras de topos angulosos estreitos, encostas convexo-retilíneas.

Valores entre 30 e $45 \%$ e entre 20 e 30\% caracterizam as classes de declividades predominantes. Constituem o substrato associado gnaisses intercalados a rochas básicas e quartzitos impuros.

\section{$\underline{\text { Unidade C } 7}$}

De ocorrência localizada na porção norte do sistema, constitui um conjunto de serras de amplitude local de 300 metros. As serras exibem topos angulosos estreitos, orientados no sentido NE/SW, com vertentes retilíneo-convexas (Figura 5.37). As inclinações das vertentes são médias a altas, denotadas por valores de declividade entre 30 e $45 \%$.

Estas formas de relevo apresentam quartzitos impuros por substrato associados 


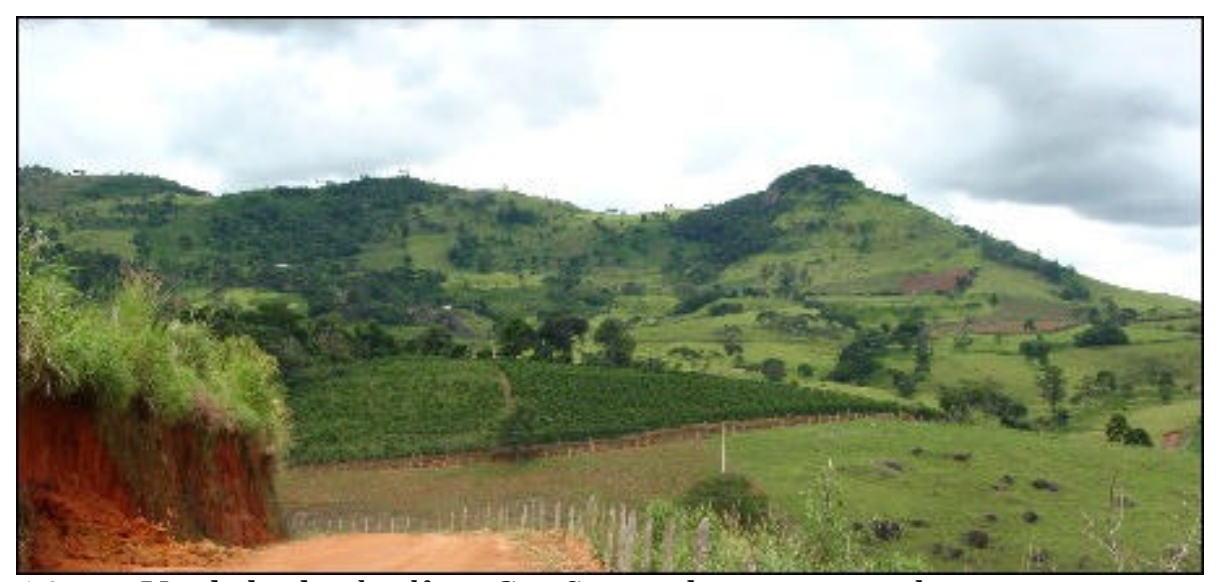

Figura 5.37 - Unidade de landform C7. Serras de topos angulosos restritos, vertentes retilíneo-convexas.

\subsubsection{Sistemas de Terreno D}

Localizado na região mais a leste da média bacia, compreende 19,93\% da área total da mesma, e apresenta $\mathrm{G}$ naisses intercalados a rochas básicas como substrato.

É caracterizado pela ocorrência de três formas principais de terreno: 1) Relevo de vales e morros e 2) Relevo de colinas e 3) Relevo de serras. Predominam classes de declividade medianamente moderadas (10-20\%) nas encostas das serras e nas áreas de morros; e alta (30-45\%) delimitando os topos das serras.

Este sistema é subdivido em 11 unidades de terreno.

$\underline{\text { Unidade D } 1}$

Localizada nas porções extremo norte e sul do sistema, caracterizam um relevo de serras alongadas no sentido NE/ SW, com amplitudes locais variando entre 320 e 400 metros. Estas exibem topos angulosos estreitos e. vertentes retilíneo-convexas, com inclinação alta é observada a ocorrência de ravinamentos (Figura 5.38).

Os valores de declividade predominantes variam entre 30 e $45 \%$, e gnaisses intercalados a rochas básicas constituem o substrato associado. 


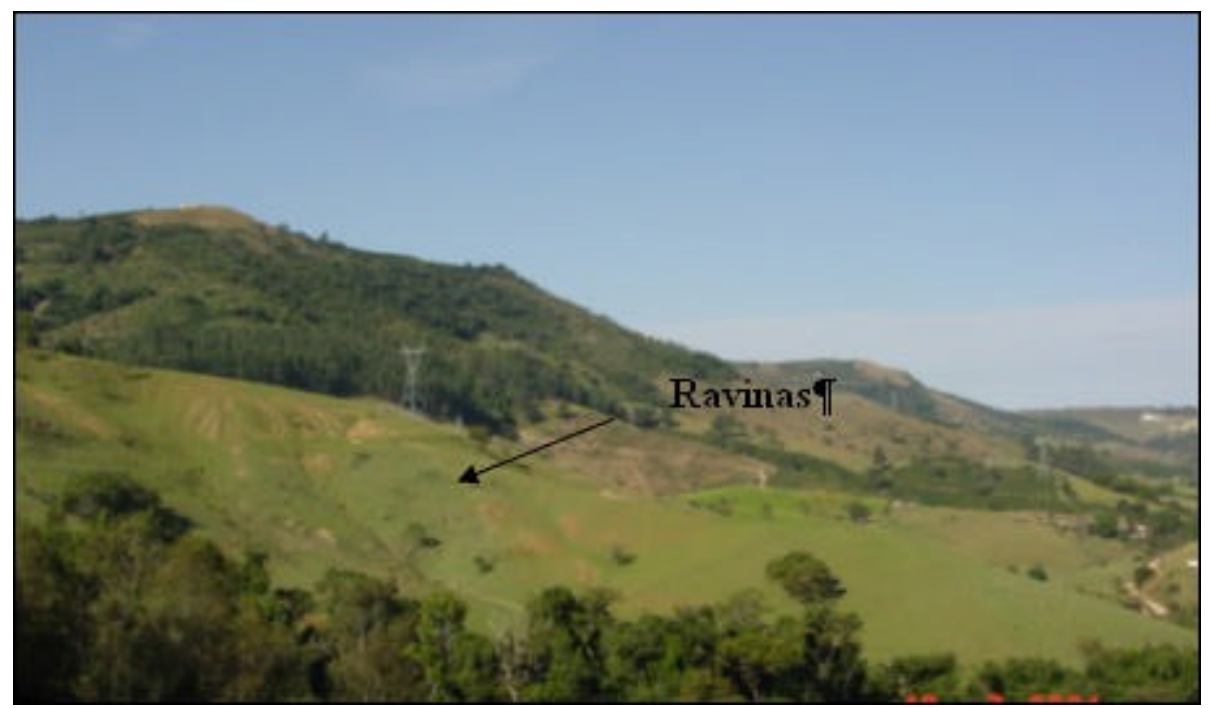

Figura 5.38. D etalhe da Unidade de landfom D 1. Serras de encostas retilíneo-convexas com presença de ravinas.

$\underline{\text { Unidade D } 2}$

Presente na porção centro oeste do sistema, caracteriza um relevo colinas de encostas suavizadas associadas a vales abertos (Figura 5.39). Estas apresentam amplitudes locais de 80 metros.

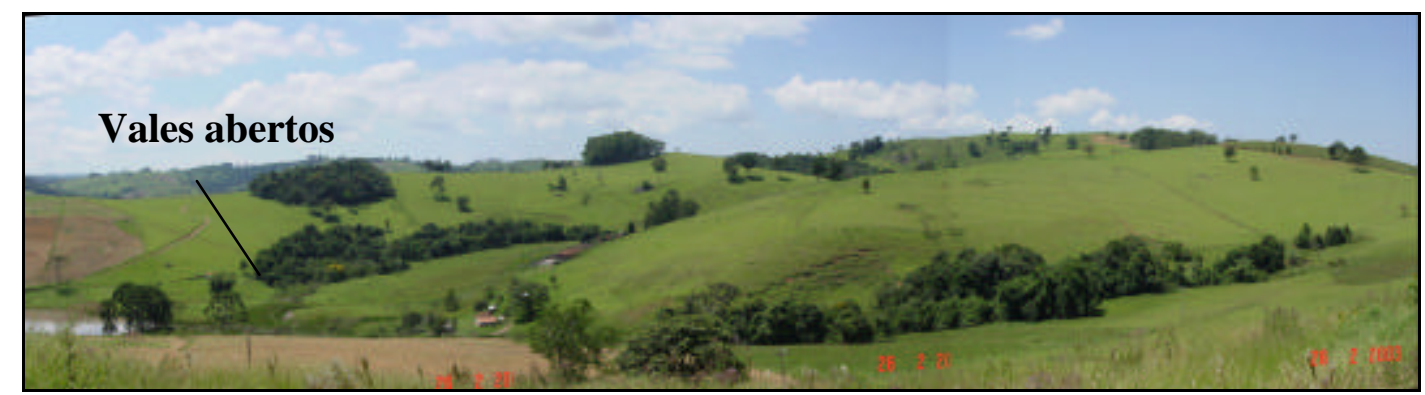

Figura 5.39. Unidade de landfom D2. Colinas de encostas suavizadas associadas a vales abertos.

As colinas apresentam amplitude local de 80 metros e topos arredondados, encostas convexas de inclinação suave, denotado pelo predomínio de valores de declividade entre 10 e $20 \%$.

Como na unidade anterior, gnaisses intercalados a rochas básicas constituem 0 substrato associado a estas formas de relevo. 


\section{U nidade D 3}

Presente na porção nordeste do sistema, caracteriza um relevo morros associados a vales abertos sem desenvolvimento de planícies. Os morros apresentam amplitude local de 180 metros, topos arredondados e encostas convexas de inclinação média (Figura 5.40).

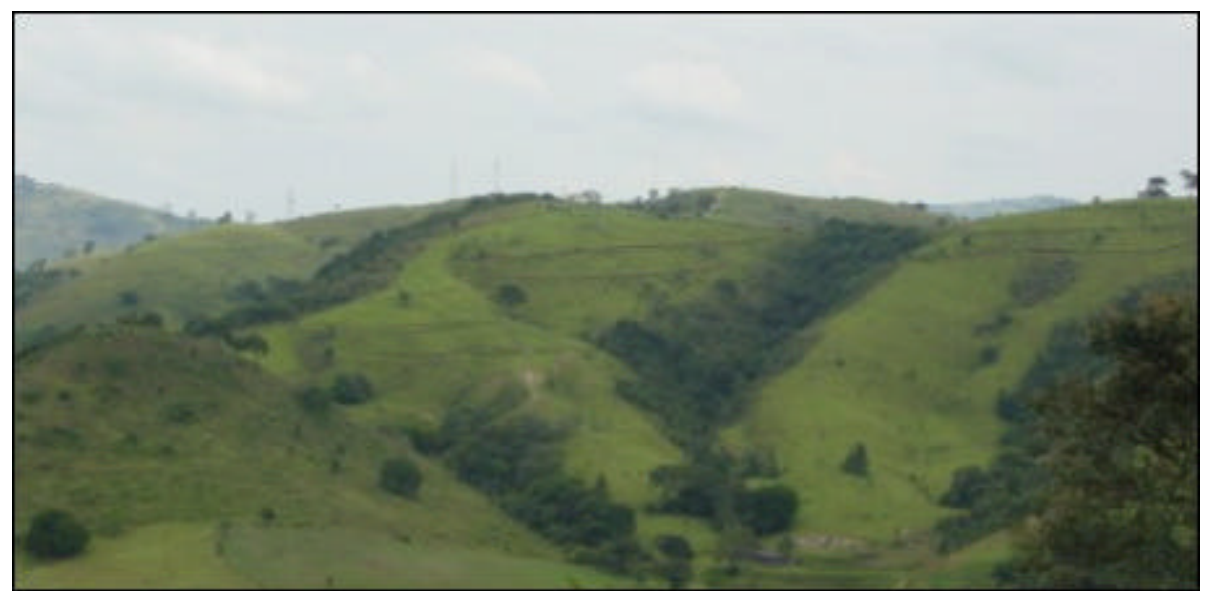

Figura 5.40. Unidade de lanform D 3. Morros de encostas convexas com inclinação média, associados a vales abertos.

Predominam valores de declividade entre 10 e $20 \%$ junto às encostas e $<2 \%$ nas áreas do vales. $\mathrm{O}$ substrato associado é constituído de ultramilonitos.

$\underline{\text { Unidade D } 4}$

Localizada na porção centro-leste e sudeste do sistema, esta unidade constitui um conjunto de colinas com amplitude local de 80 metros, topos arredondados e encostas convexas (Figura 5.41).

Estas formas de relevo estão associadas à ocorrência de blastomilonitos, e valores predominantes de declividade entre 10 e $20 \%$. 


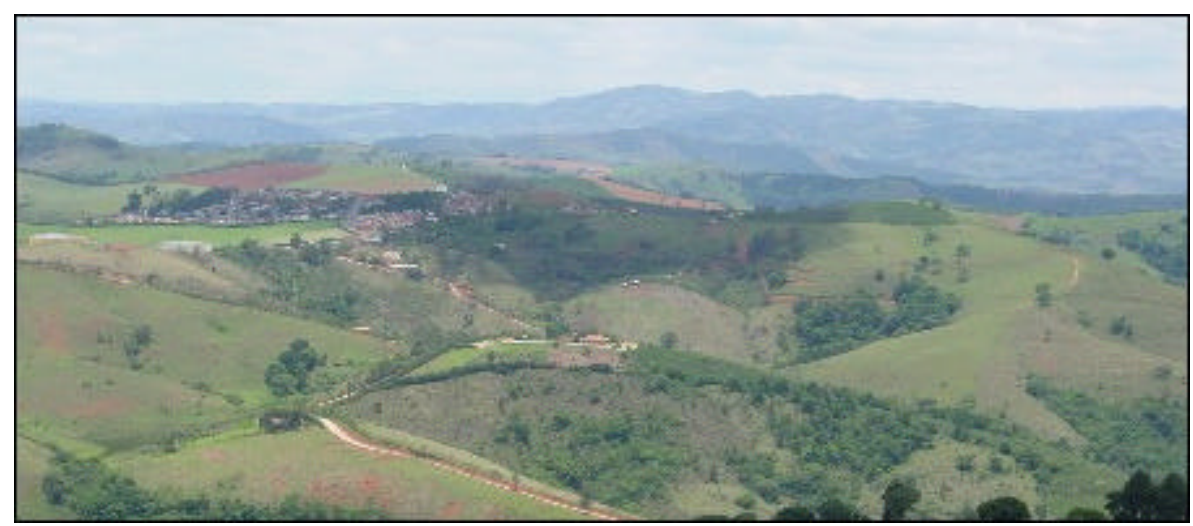

Figura 5.41. Unidade de lanform D4. Colinas de topos arredondados e encostas convexas.

$\underline{\text { Unidade D } 5}$

Localizada no extremo sudeste do sistema, esta unidade caracteriza um relevo de morros com amplitudes locais de 100 metros.

Os morros apresentam topos restritos angulosos, e perfis de encosta convexos (Figura 5.42). Predominam valores de declividade entre 10 e 20\%, e entre 20 e 30\%. Blastomilonitos constituem o substrato associado.

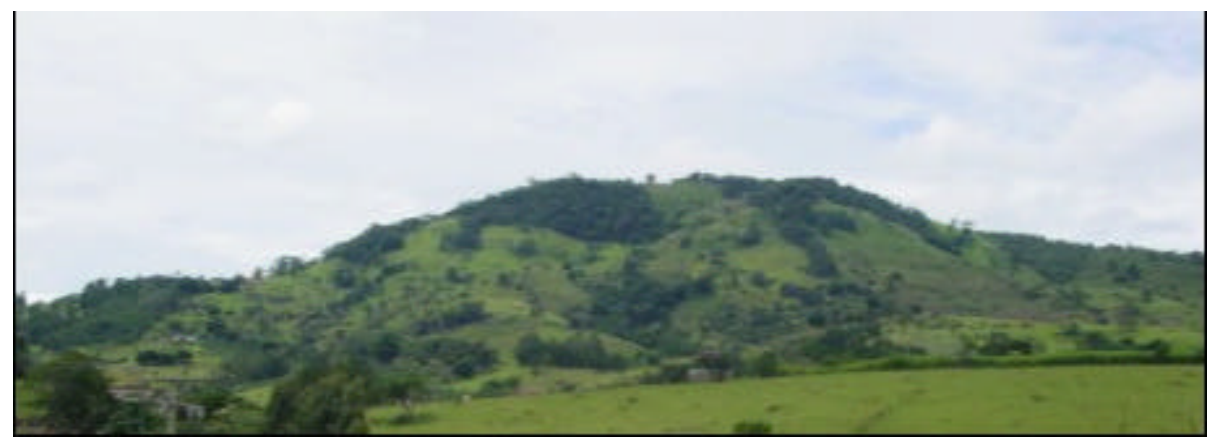

Figura 5.42. Unidade de landform D5. Morros de topos angulosos restritos e encostas convexas.

$\underline{\text { Unidade D } 6}$

Presente na porção centro-leste do sistema, caracteriza-se por um relevo de morros, com amplitudes locais variando entre 200 e 220 metros. Exibem topos arredondados, por vezes angulosos estreitos (Figuras 5.43 a e b), com orientação predominante para NE/SW. Exibem perfis de encosta variando entre retilíneo e convexos suaves. 

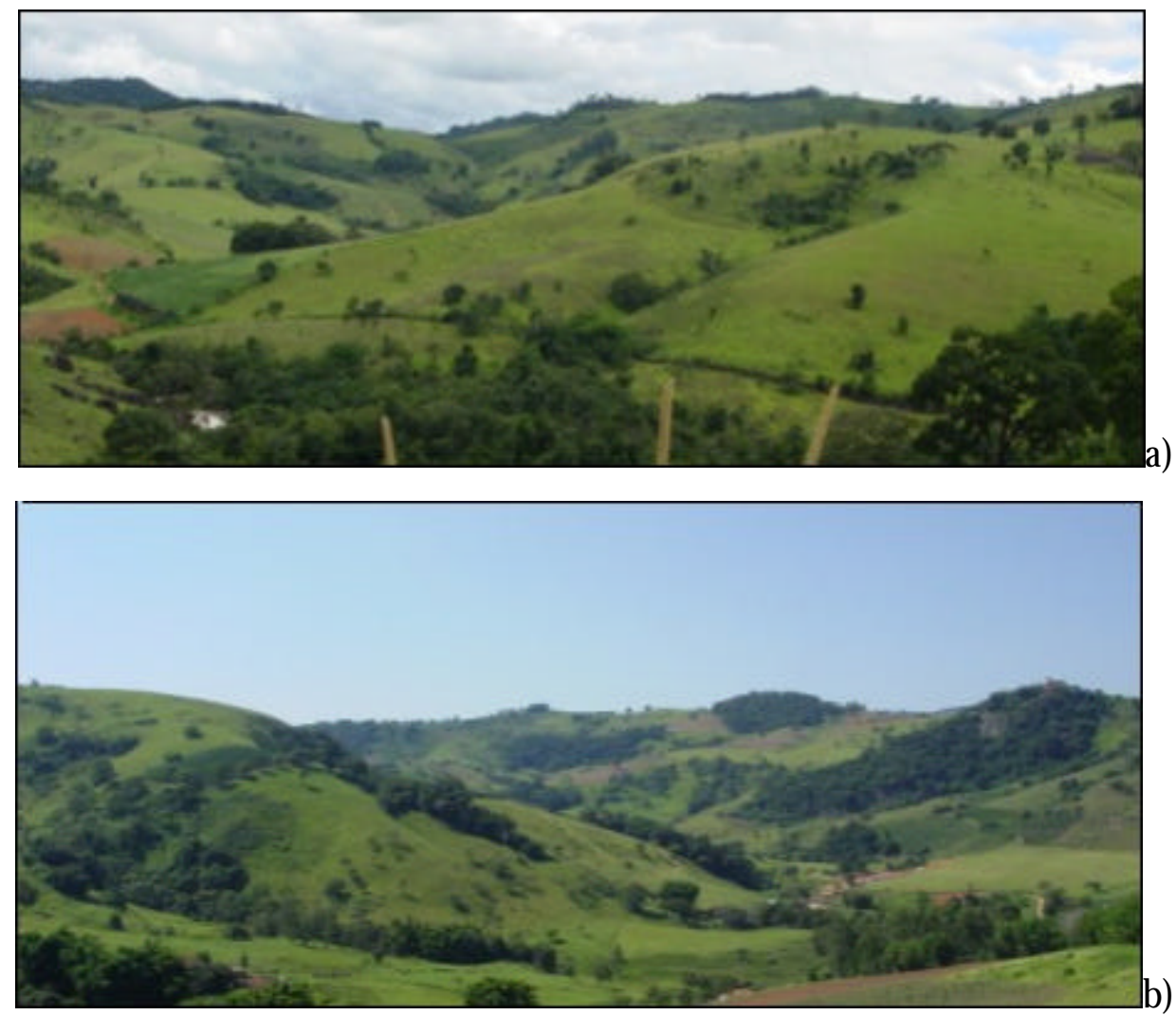

Figura 5.43. Unidade de landform D 6. a) Morros de topos arredondados e b) Morros de topos angulosos.

Predominam valore de declividade entre 10 e $20 \%$, e entre 20 e $30 \%$. 0 substrato associado a estas formas de relevo é constituído de $\mathrm{G}$ ranitos porfirítcos

$\underline{\text { Unidade D } 7}$

Localizada na porção centro-sudoeste do sistema, corresponde a um relevo de serras associadas a vales abertos As serras exibem perfil de encosta retilíneo e amplitudes locais de 300 metros(Figura 5.44 a e b)..

Os valores de declividade predominante nesta unidade variam entre 10 e 20\%, e o substrato associado é constituído por ultramilonitos e quartzitos impuros. 

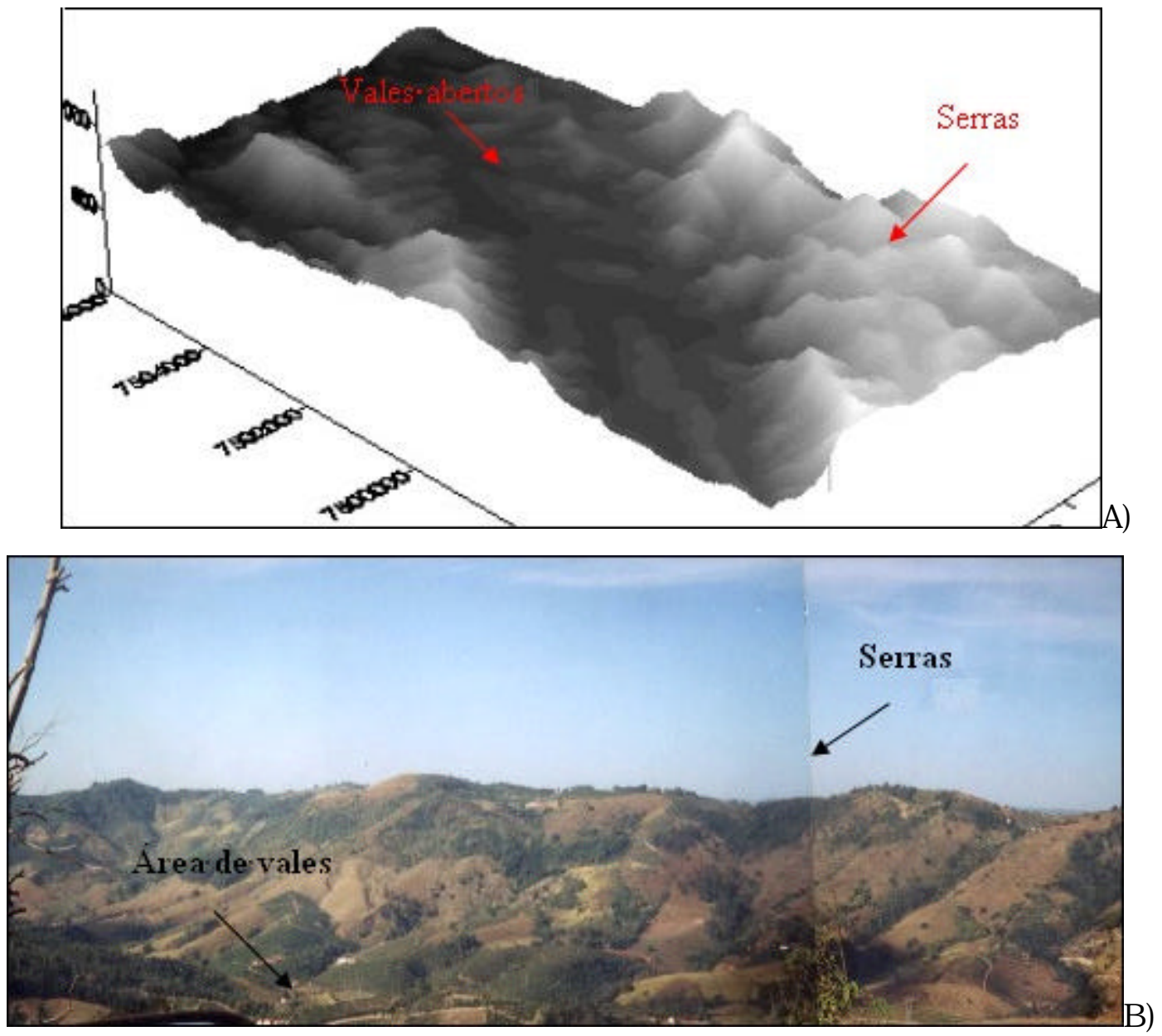

Figura 5.44. Unidade de landform D 7, conjunto de serras associadas a vales abertos. a) Representação em modelo digital do terreno, b) Detalhe encostas retilíneas.

\section{$\underline{\text { Unidade D } 8}$}

Localizada na porção centro-sul do sistema, constitui um relevo de serras com amplitudes locais de 320m, com topos angulosos e estreitos. Encostas retilíneas de inclinação elevada (Figura 5.45). Predominam valores de declividade entre 30 e 45\% e, entre 20 e $30 \%$.

Esta unidades é associada a ocorrência de ultramilonitos. 


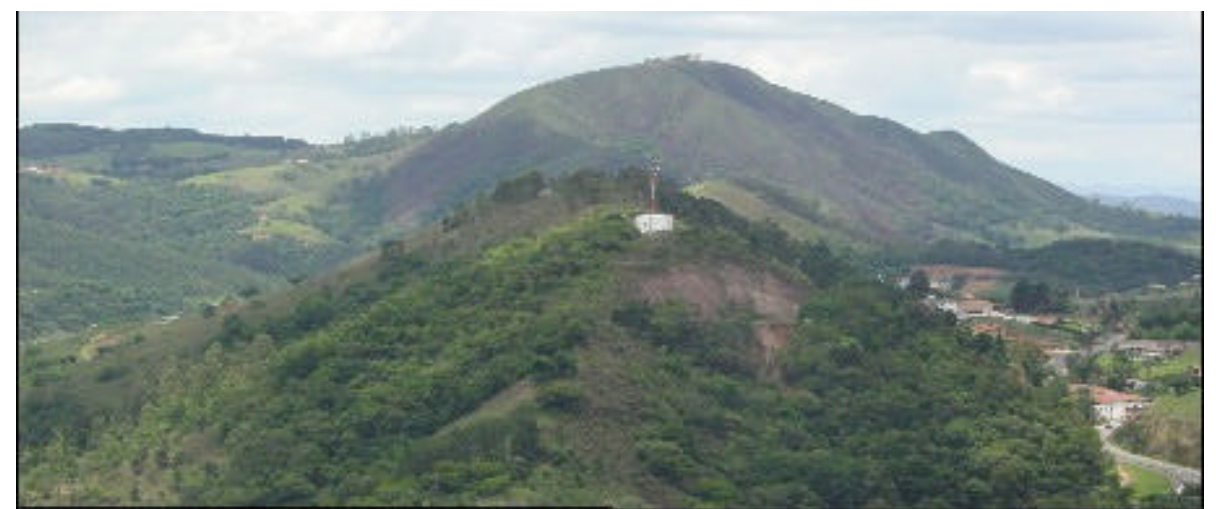

Figura 5.45. Detalhe da unidade de landfom D8. Serras de topo anguloso e encostas retilíneas.

$\underline{\text { Unidade D } 9}$

De ocorrência localizada na porção centro-sul, caracterizam serras de topo muito anguloso e alongado no sentido NE/SW. Apresenta vertentes de inclinação muito elevada e perfis convexos retilíneos voltados para oeste, e retilíneos voltados para leste (Figura 5.46 A e B). Apresenta predominância de valores de declividade entre $30 \mathrm{e}$ $45 \%$, e tem por substrato associados rochas cataclasadas, blastomilonitos.
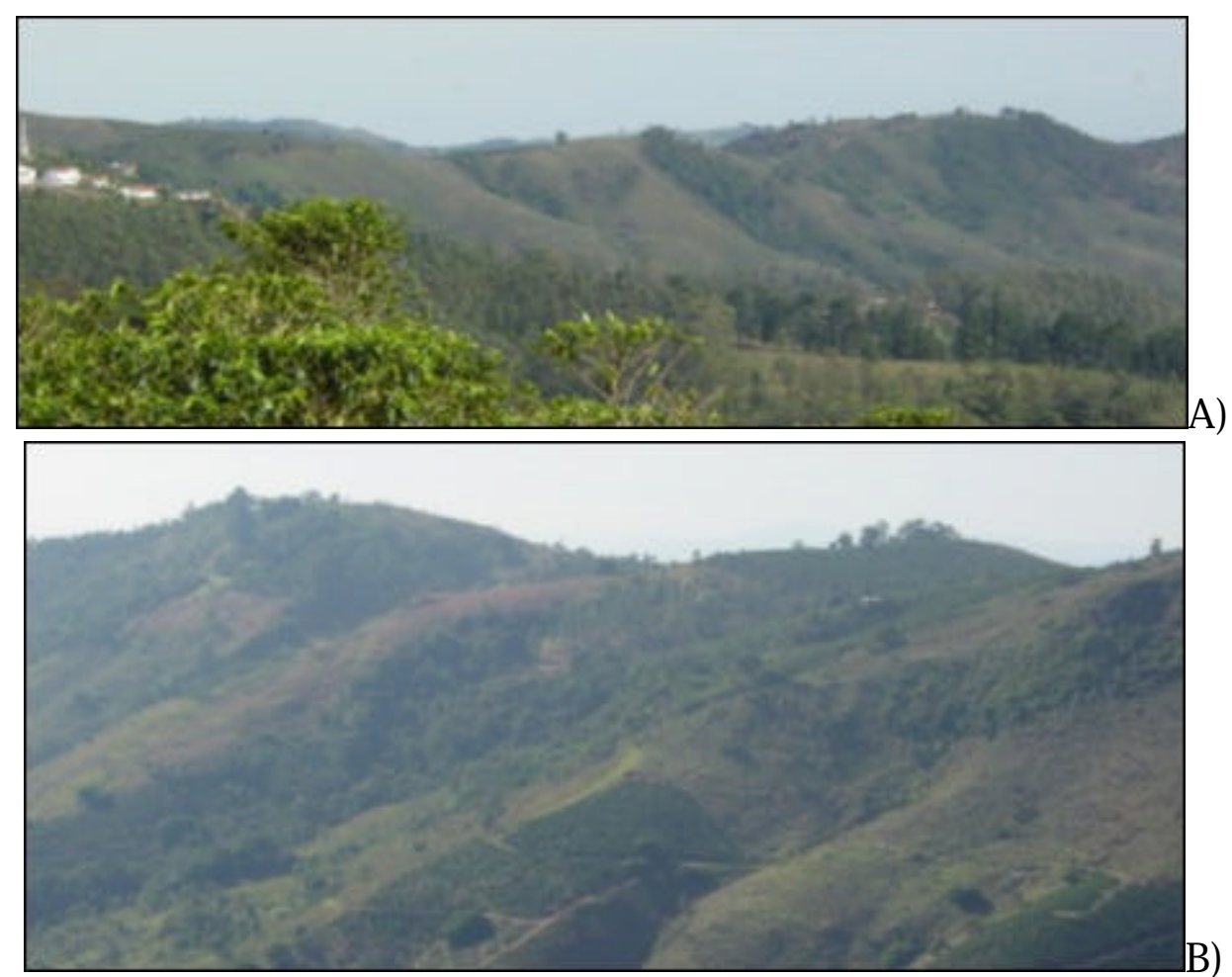

Figura 5.46. Unidade de landfom D 9. Serras de topo anguloso de encostas desiguais. a) Encostas retilíneas e b) Encostas convexas. 


\section{$\underline{\text { Unidade D } 10}$}

Presente na porção sudeste do sistema, constitui um relevo de morros com amplitudes locais de 120 metros. Apresentam topos angulosos e encostas retilíneas, associadas a vales fechados (Figura 5.47).

Nesta unidade os valores de declividade variam entre 10 e 30\%. Blastomilonitos constituem o substrato que sustenta esta unidade.

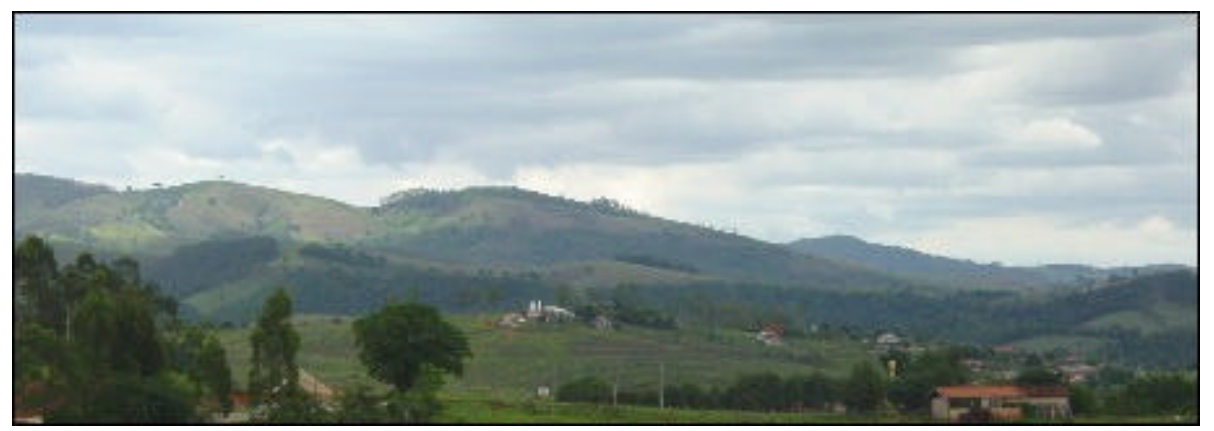

Figura 5.47. Unidade de landfom D 10. Morros de topo anguloso de encostas retilíneas.

\section{$\underline{\text { Unidade D } 11}$}

Localizada na porção central do sistema, caracteriza um vale aberto (Figura 5.48), com desenvolvimento de planície aluvionar. Apresenta valores de declividades muito baixos, $<2 \%$, e ultramilonitos e gnaisses intercalados a rochas básicas por substrato associado, principalmente, e blastomilonitos ocorrendo de forma secundária.

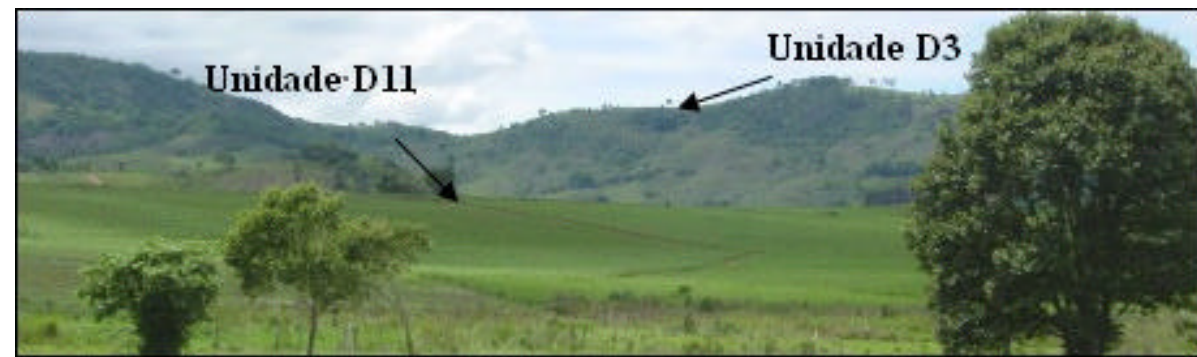

Figura 5.48.Unidade de landfom D 11. Vale abertos com desenvolvimento de planície aluvionar.

\subsubsection{Sistema de Terreno $\mathrm{E}$}

Localizado na porção da alta bacia, corresponde a 41,49\% da área da mesma. É constituído por três formas principais de terreno: 1) Relevo de serras, 2) Relevo de vales 
associados a colinas e 3) Relevo de morros. Predominam neste Sistema classes de declividade entre 10 e $20 \%$ e entre 2 e $10 \%$.

Subdividido em oito unidades de terreno, estas apresentam como substrato associados granitos porfiríticos e migmatitos, com granitos-gnaisses caracterizados por ocorrência secundária.

\section{$\underline{\text { Unidade E } 1}$}

Localizada no extremo oeste do sistema, caracteriza-se por um relevo de morros com amplitude local de 100 metros. Exibem topos angulosos alinhados no sentido NE/ SW. Vertentes retilíneo-convexas de inclinação média, associadas a vales abertos (Figura 5.49).

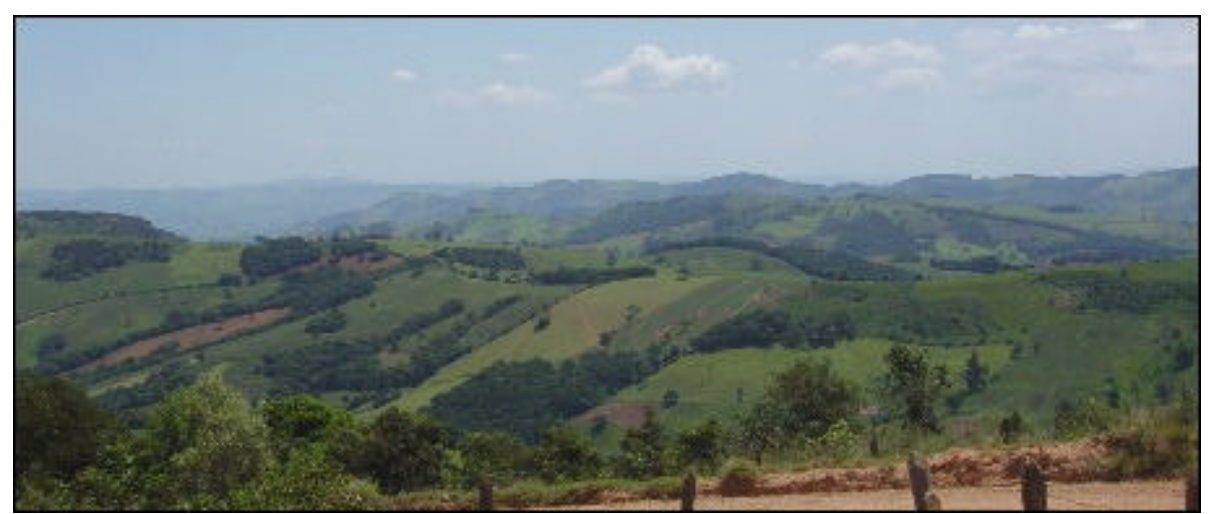

Figura 5.49. Unidade de landform E1. Morros de topos angulosos.

D estacam-se, nesta unidade destacam-se valores de declividades entre 10 e 20\% e, entre 20 e 30\%. Migmatitos constituem o substrato predominante que sustenta estas formas de relevo. De forma secundária, ocorrem granitos porfińticos.

\section{U nidade E 2}

Presente na porção extremo norte e extremo nordeste do sistema, esta unidade constitui um relevo que caracteriza um conjunto de serras com amplitudes locais entre 300 e 360 metros. Estas apresentam topos arredondados que variam entre restritos e extensos. Apresentam encostas convexas, por vezes retilíneo-convexas e inclinação média (Figura 5.50). Associados a estas são observados vales abertos. 


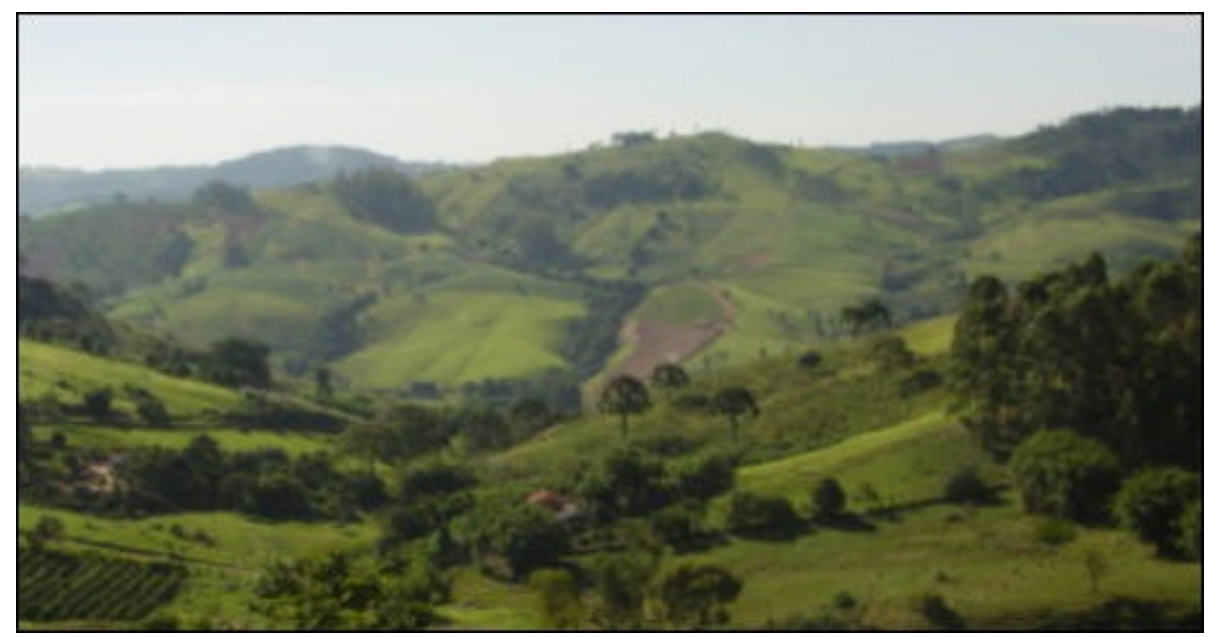

Figura 5.50. Unidade de landform E2. Serras de topos arredanodados associadas a vales abertos.

Nesta unidade predominam valores de declividade entre 10 e $20 \%$ e, entre 20 e $30 \%$. Migmatitos caracterizam o principal substrato que sustenta estas formas de relevo.

\section{$\underline{\text { Unidade E } 3}$}

Localizados na porção centro-norte, constituem dois morros, com amplitudes locais de 100m e 200m, ambos apresentam topos arredondados e restritos (Figura 5.51). Os topos são orientados nas direções NE/ SW e E-W. Exibem encostas convexoreitlíneo, e apresentam valores de dedlividade entre 10 e 20\%. Migmatitos caracterizam o substrato rochoso associado a estas formas de relevo.

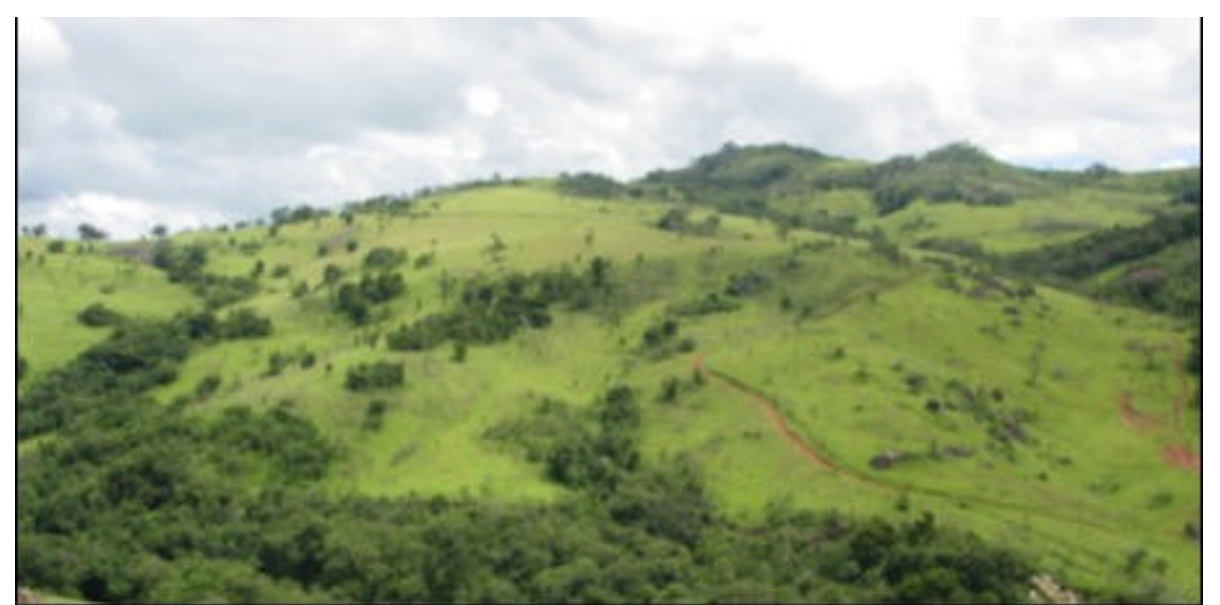

Figura 5.51. Unidade de landform E3. Morors de topos arredanodados e encostas convexo-retilíneas. 


\section{$\underline{\text { Unidade E } 4}$}

Localizada na porção central do sistema, caracteriza um conjunto de serras de amplitude local variando entre 400 e 540 metros. Exibem topos agudos extensos, orientados no sentido E-W e NE/ SW. Apresentam encostas voltadas para o sul e leste de perfil convexo-retilíneo, e voltadas para norte e oeste com perfil retilíneo (Figura 5.52 A e B). Vales fechados ocorrem associados a estas serras.
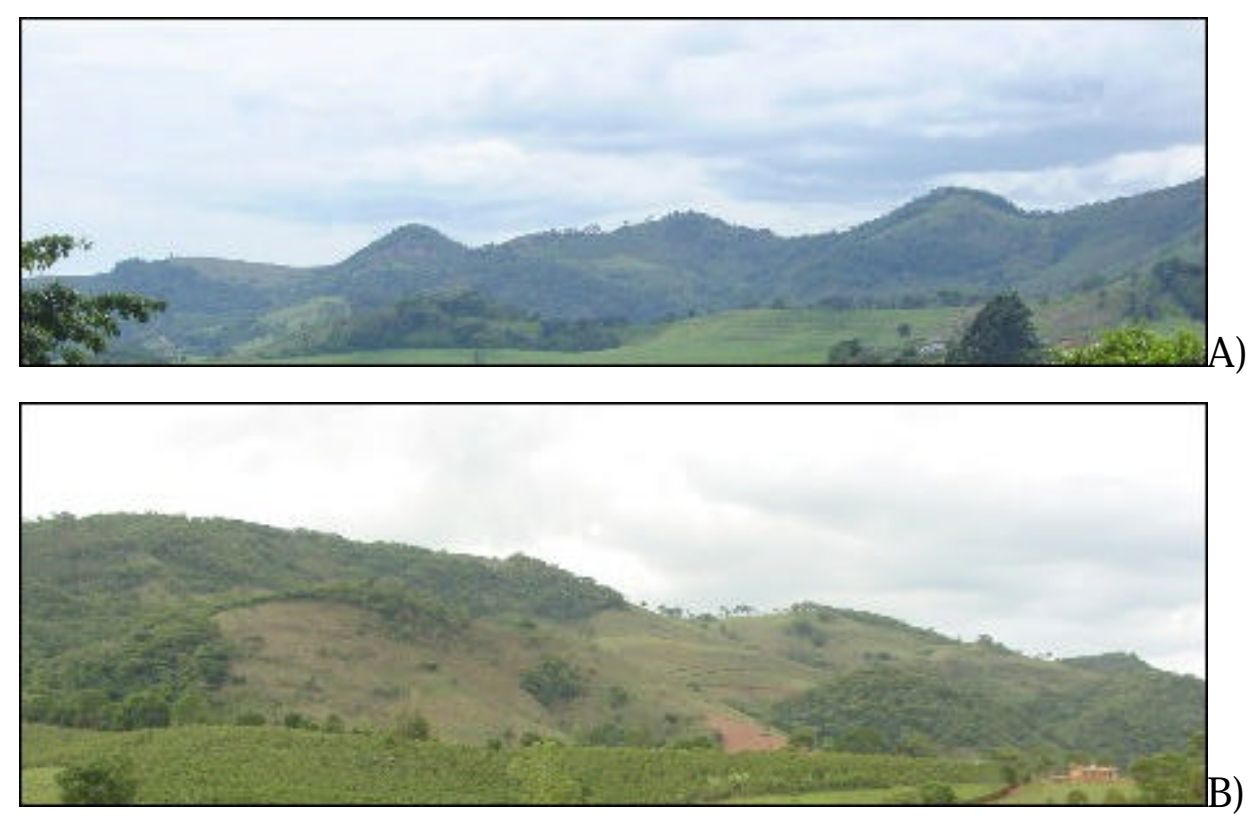

Figura 5.52. Unidade de landform E4. a) Serras com perfil de encostas retilíneo voltado para 0 norte e oeste e b) Perfil convexo-retilíneo voltados para o sul e leste.

Destacam-se valores de declividade entre 10 e $20 \%$ e, entre 20 e $30 \%$. Migmatitos constituem o substrato rochoso associado.

\section{$\underline{\text { Unidade E } 5}$}

Presente na porção central do sistema, esta unidade caracteriza um relevo morros e vales abertos com planícies associadas, onde predominam amplitudes locais de 100 metros (Figura 5.53). Os morros exibem topos angulosos a arredondados, com encostas convexas de inclinação média. Predominam valores de declividade entre 10 e $20 \%$, junto aos morros, e entre 2 e 10\% nas áreas de vale. Assim como na unidade anterior, Migmatitos constituem o substrato rochoso associado. 


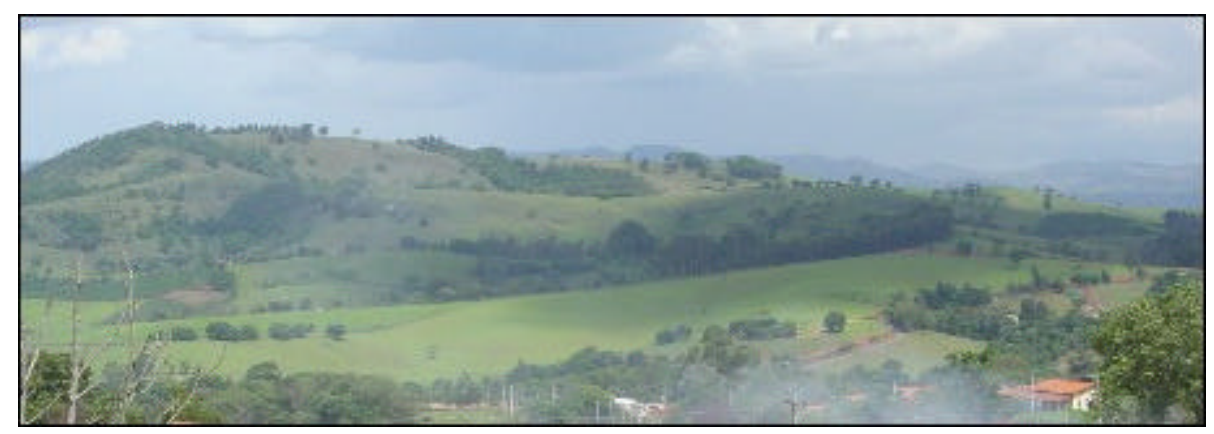

Figura 5. 53. Unidade de landform E5. Morros e vales abertos.

\section{Unidade E 6}

Localizada na porção centro-sul do sistema, constitui um relevo de morros com amplitudes locais de 220 metros. Estas exibem topos angulosos extensos e encostas retilíneo-convexas, de inclinação média a alta (Figura 5.54). Vales fechados orientados NE/ SW e NW/ SE ocorrem associados. São observadas ravinas nas encostas .

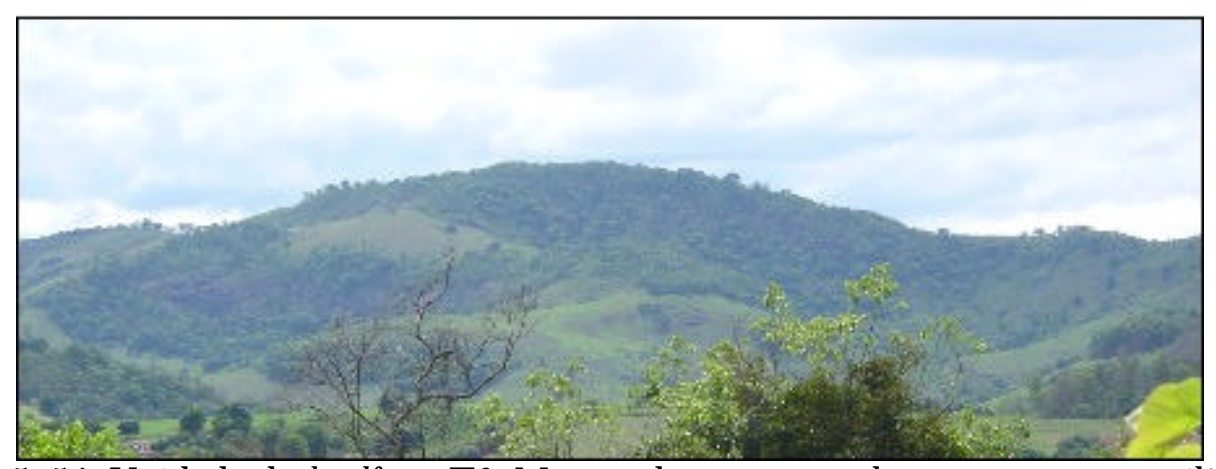

Figura 5. 54. Unidade de landform E6. Morros de topos angulosos e encostas retilíneoconvexas.

\section{$\underline{\text { Unidade E } 7}$}

Presente na porção sudeste do sistema, esta unidade constitui um conjunto de morros com amplitudes locais que variam entre 220 e 240 metros. Apresentam topos arredondados e extensos, orientados nos sentidos NE/ SW e NW/ SE. Os perfis de encostas são convexo-retilíneos suaves (Figura 5.55). Predominam valores de declividade entre 10 e $20 \%$ e, entre 20 e 30\%. Migmatitos e granitos porfiríticos constituem 0 substrato predominante desta unidade. Granitos-gnaisse apresentam ocorrência secundária. 


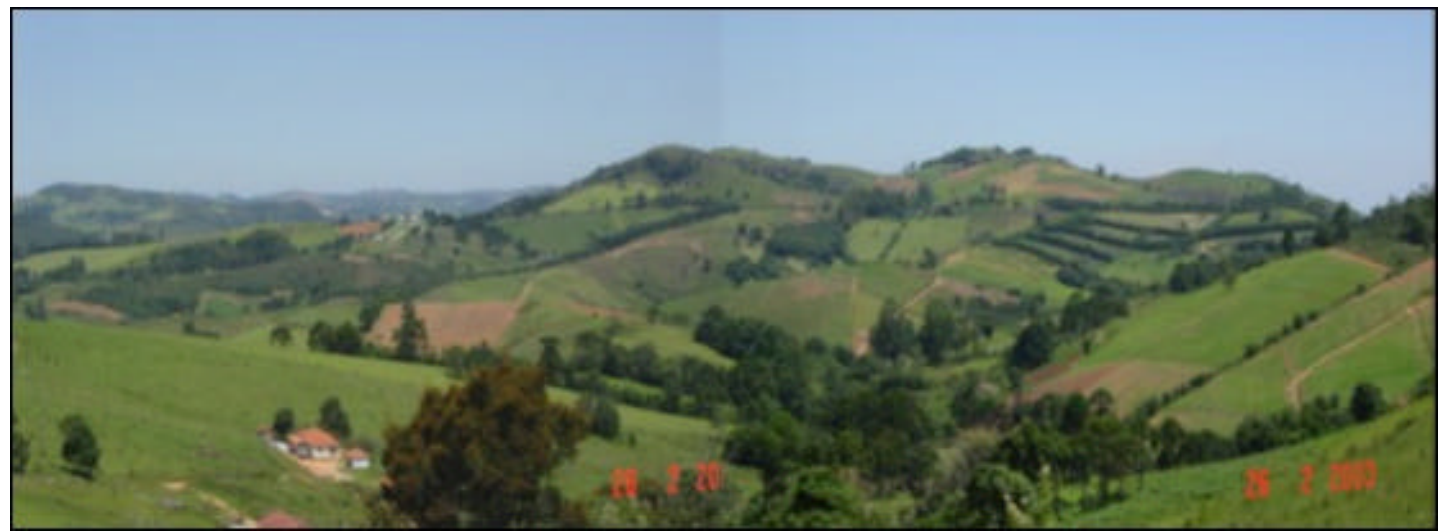

Figura 5.55. Unidade de landform E7. Morros de topos arredondados extensos com perfis de encostas são convexo-retilíneos suaves.

$\underline{\text { Unidade E } 8}$

Localizada na porção extremo sudeste do sistema, esta unidade compreende um relevo de vales abertos e extensos com desenvolvimento de planície, associado a colinas de amplitude local de 60 metros. As colinas apresentam topos arredondados extensos, e encostas convexas suaves com inclinação baixa (Figura 5.56).

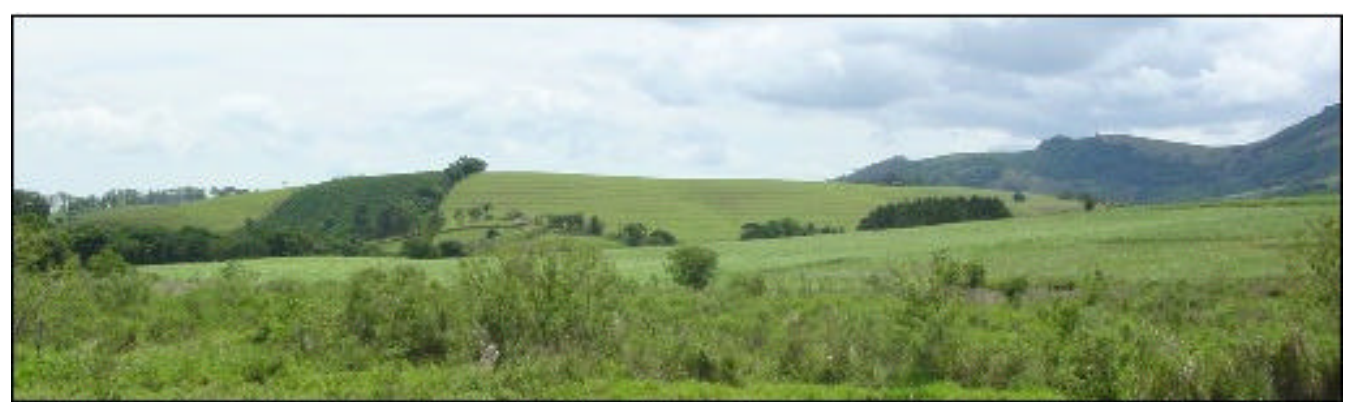

Figura 5.56 - Unidade de lanform E8. Colinas de topos arredondados extensos e encostas convexas suaves.

Predominam nesta unidade valores de declividade entre 2 e 10\%, junto aos relevos de colinas e $<2 \%$ nas áreas de vales.

Granitos-gnaisses e granitos porfiríticos constituem o substrato rochoso que sustenta esta unidade de terreno. 


\subsection{MAPA DE UNIDADES DE MATERIAIS INCONSOLIDADOS (ANEXO}

IV)

De acordo com Mio (1992) sob a designação de materiais inconsolidados incluem-se todos os materiais superficiais, sobrejacentes aos materiais rochosos em estado são ou pouco alterados.

$\mathrm{Na}$ presente pesquisa designam-se como materiais inconsolidados tanto os materiais superficiais produto de retrabalhamento físico e/ ou químico de materiais préexistentes, como os materiais resultantes da alteração intempérica in situ dos materiais rochosos.

\subsubsection{Procedimentos E mpregados}

A caracterização dos materiais inconsolidados da área foi realizada mediante execução conjugada de três atividades: 1) Levantamento de dados, que consistiu no levantamento de informações relativas a trabalhos pré-existentes na área de pesquisa, de modo a fornecer um conhecimento prévio sobre as características principais dos materiais inconsolidados da bacia; 2) Trabalhos de campo, que consistiu de duas etapas. A primeira visando confirmar e/ ou reestruturar as unidades de materiais preliminarmente delimitadas a partir da interpretação de fotografias aéreas e dos dados pré-existentes levantados, e a segunda visando a execução de amostragens de materiais para realização de ensaios de laboratório; e 3) Ensaios de laboratório, que permitiram uma melhor caracterização das unidades de materiais inconsolidados. A Figura 5.57 apresenta um fluxograma com as etapas executadas para obtenção do Mapa de Unidades de Materiais Inconsolidados da bacia.

As informações pré-exiestentes levantadas correspondem, principalmente, aos trabalhos realizados por Mio (1992), Albrecht (1992), Barison (1995) e Saraiva (1995).

Nas primeiras etapas de campo foram executadas descrições gerais dos materiais, onde se procurou destacar características como cor, textura (determinada por meio de avaliação visual e tátil), espessura predominante, relações de contato com 0 substrato rochoso e relações com as formas de terreno. É importante ressaltar que devido a grande heterogeneidade conferida pelo quadro litológico/ estrutural da área a característica cor não pode ser tomada como indicativo de delimitação de unidades de material inconsolidado. 


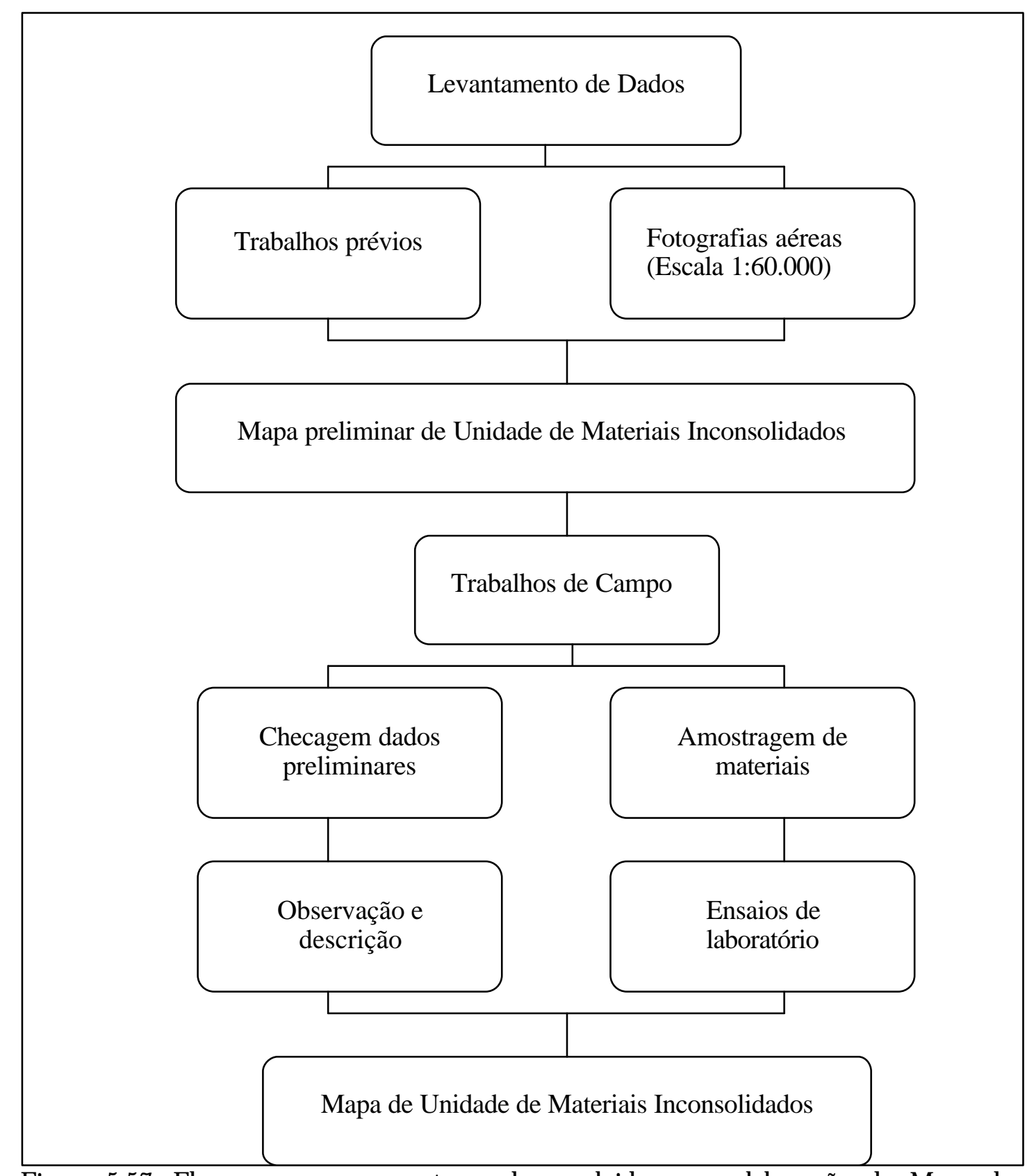

Figura 5.57. Fluxograma com as etapas desenvolvidas para elaboração do Mapa de Unidades de Materiais Inconsolidados.

\subsubsection{E nsaios de Laboratónio Realizados}

Para a caracterização das unidades de materiais inconsolidados da área foram executados os ensaios de granulometria, massa específica dos sólidos ( $\rho)$ ), massa específica seca de campo ( $\rho d)$, adsorção de azul de metileno, absorção de água e perda por imersão, além do cálculo dos indicies de vazios e porosidade natural. 
Análise G ranulométrica, Massa específica dos sólidos (os), Massa específica seca de

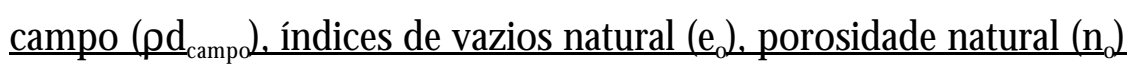

0 ensaio de análise granulométrica foi realizado por sedimentação e peneiramento, segundo a norma técnica ABNT (NBR 7181/ 84).

0 ensaio de determinação da massa específica dos sólidos ( $\rho s$ ) foi executado segundo a norma técnica ABNT (NBR 6508/84)

$0 \rho \mathrm{d}_{\text {campo }} 0 \mathrm{e}_{0}$ e a $\mathrm{\eta}_{\mathrm{o}}$ foram determinados a partir do "Método do Anel" proposto por Zuquette (1987). Neste método são utilizados anéis de pvc rígido de 10 cm x $5 \mathrm{~cm}$ (diâmetro/ altura) para coletas de amostras indeformadas de solos e, a partir de relações de massa de solo seco e volume de solo ocupado no anel, obtém-se valor de $\rho d_{\text {campo }}$ :

$$
\rho_{\text {dcampo }}=\frac{(M)}{V}
$$

onde: $\mathrm{M}$ - massa seca de solo seco $(\mathrm{g})$

$\mathrm{V}$ - volume do anel $\left(\mathrm{cm}^{3}\right)$

A partir dos valores de $\rho d_{\text {campo }}$ e $\rho$ s foram obtidos os índices $e_{0}$ e $\mathrm{n}_{0}$, por meio das expressões:

$$
\begin{gathered}
e=\left(\frac{\rho s}{\rho_{d}}\right)-1 \\
n=\frac{e}{1+e}
\end{gathered}
$$

onde:. $\rho s$ - massa específica dos sólidos $\left(\mathrm{g} / \mathrm{cm}^{3}\right)$

$\rho d$ - massa específica aparente seca de campo $\left(\mathrm{g} / \mathrm{cm}^{3}\right)$ 


\section{Ensaio de Adsorção de Azul de Metileno}

$\mathrm{O}$ azul de metileno é um corante orgânico, de composição $\mathrm{C}_{16} \mathrm{H}_{18} \mathrm{~N}_{3} \mathrm{~S}$ CL. $3 \mathrm{H}_{2} \mathrm{O}$, com nome comercial de cloridato de metiltianina. Caracteriza-se como um corante que em solução aquosa apresenta-se dissociado em ânions cloreto e cátions azul de metileno $\left(\mathrm{C}_{16} \mathrm{H}_{18} \mathrm{~N}_{3} \mathrm{~S}^{+}\right)$. Q uando os cátions azul de metileno entram em contato com os argilo-minerais, ocorre a substituição dos cátions $\mathrm{Na}^{+}, \mathrm{K}^{+}, \mathrm{Mg}^{2+}$ e $\mathrm{H}_{3} \mathrm{O}^{+}$, formando uma monocamada de azul de metileno sobre a superfície dos minerais de argila (Pejon, 1992).

Partindo-se de uma concentração conhecida de azul de metileno (anidro) em solução aquosa, o volume gasto da solução e a área da superfície do cátion de azul de metileno $\left(130 \mathrm{~A}^{2}\right)$, é possível calcular a superfície específica (SE) e a capacidade de troca catiônica (CTC) dos materiais inconsolidados.

São dois os métodos de ensaio para determinação de SE e da CTC por meio do uso do azul de metileno: 1) Método colorimétrico e 2) Método do papel de filtro. Aqui foi utilizado o segundo método, conforme os procedimentos de ensaio apresentados por Pejon (1992).

Para execução do ensaio deve-se utilizar uma massa de 2 a 4 gramas de solo passado em peneira de 2,00mm, em suspensão em um beck er contendo $10 \mathrm{ml}$ de água destilada.

A solução de azul de metileno utilizada foi preparada com uma massa de 1,5 grama de corante anido dissolvido em $1.000 \mathrm{ml}$ de água destilada.

O ensaio consiste em adicionar a solução de azul de metileno, com auxílio de uma bureta graduada, à suspensão de solos mais água previamente preparada e, sob agitação contínua como o uso de um agitador magnético. Adiciona-se $1 \mathrm{ml}$ de solução de azul de metileno e aguarda-se um intervalo de três minutos. Após este intervalo, captura-se uma gota da suspensão (solo/água/ azul de metileno) com auxílio de um bastão de vidro e deposita-se sobre um papel de filtro (Whatmann's 42), observando-se a coloração da mancha formada no papel. Se a mancha formada tiver coloração azulescuro, significa que o azul de metileno foi totalmente adsorvido pelas partículas de solo (resultado negativo) e o ensaio não pode ser encerrado. Deve-se prosseguir o ensaio com nova adição de solução de azul de metileno e aguardando o intervalo de três minutos, para realização de uma nova captura de uma gota da solução solo/ água/ azul 
de metileno. Este procedimento deve ser repetido sucessivamente até que seja atingido o ponto de saturação do solo pelo azul de metileno, o qual é caracterizado pela formação de uma auréola azul-clara em torno da mancha azul-escura (resultado positivo). Nesse ponto deve-se aguardar mais três minutos sem adição de mais solução do corante, para em seguida repetir o teste da mancha, caso se confirme o resultado positivo o ensaio está encerrado. Em caso contrário o procedimento deve continuar até a obtenção do resultado final (Figura 5.58).

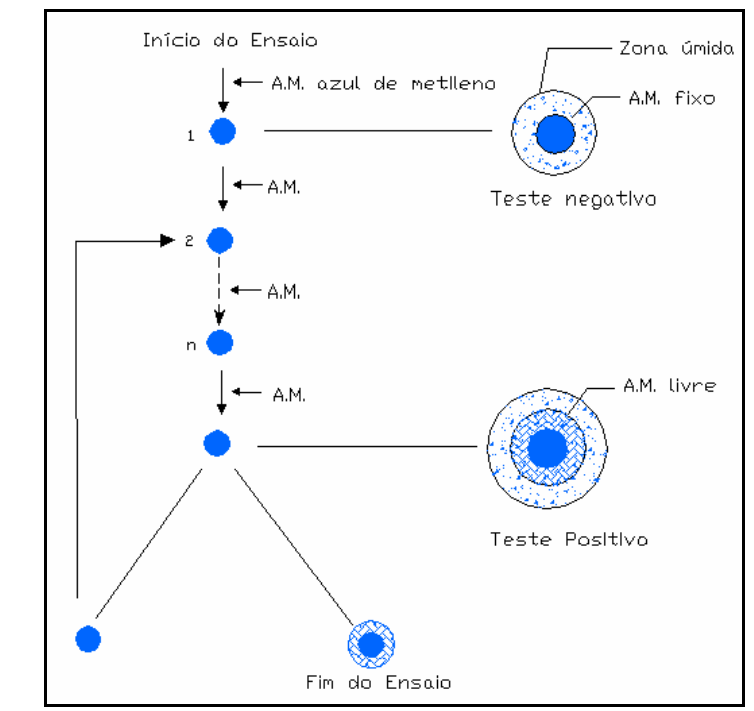

Figura 5.58. Fluxograma do ensaio de adsorção de azul de metileno pelo Método do Papel de Filtro (Pejon, 1992).

Finalizado o ensaio pode-se proceder ao cálculo dos valores de CTC e SE, por meio das expressões:

$$
C T C=\frac{C * V * 100}{M}
$$

onde: CTC - capacidade de troca catiônica $\left(\mathrm{Cmol}^{+} / \mathrm{kg}\right)$

V - volume de solução de azul de metileno gasto (ml) para saturar a suspensão contendo solo.

C - concentração da solução de azul de metileno (normalidade) $=0,0047 \mathrm{~N}$

$\mathrm{M}$ - massa de solo seco

$$
S E=\frac{S * V}{M}
$$

onde: SE - superfície específica

V - volume de solução de azul de metileno necessário para saturar a solução contendo solos seco

$\mathrm{M}$ - massa de solo seco

S - superfície recoberta por $1 \mathrm{ml}$ da solução de azul de metileno a 0,0047 N = $3,67 \mathrm{~m}^{2} / \mathrm{ml}$ 
Ensaios de Absorção de água e Perda de massa por imersão - Erodibilidade dos Materiais Inconsolidados

A caracterização da erodibilidade dos materiais inconsolidados baseia-se em dois ensaios simples, absorção de água e perda de massa por imersão, propostos por Nogami \& Vilibor (1979) e modificado por Pejon (1992).

Para execução deste ensaio são utilizadas amostras indeformadas, obtidas com a cravação no solo de um cilindro de pvc rígido $(4 \mathrm{~cm} \mathrm{x} 2 \mathrm{~cm}$, diâmetro/ altura) de ponta biselada (Figura 5.59). As amostras coletadas são secas ao ar, na sombra, por um período mínimo de sete dias. Após a secagem são realizados os ensaios de absorção de água e perda de massa por imersão, para obtenção do índice de erodibilidade. A descrição destes ensaios é apresentada a seguir.

\section{A bsorção de Á gua}

Na realização deste ensaio utiliza-se um equipamento simples, o qual consiste de um recipiente cilíndrico, com as mesmas dimensões do cilindro de amostragem, ligado a um tubo de vidro horizontal graduado (Figura 5.60). O conjunto é totalmente preenchido com água, e na porção superior do recipiente é fixada uma pedra porosa, a qual é mantida saturada. 0 conjunto amostra mais cilindro de amostragem é pesado e colocado sobre a pedra porosa. Neste momento são realizadas leituras de volume de água absorvida por intervalo de tempo. Os intervalos de tempo em segundos adotados foram: $5,10,15,20,25,30,35,40,45,50,55,60,90,120,240$, até que a amostra estivesse totalmente saturada.

A obtenção do índice de absorção (S) é feita a partir da montagem de um gráfico que relaciona o volume de água absorvido por unidade de área da base do corpo de prova (q) com a raiz quadrada do tempo $(\sqrt{t})$. $\mathrm{O}$ índice $\mathrm{S}$ corresponde ao coeficiente angular da reta, ou seja:

$$
S=\left(\frac{q}{\sqrt{t}}\right)
$$




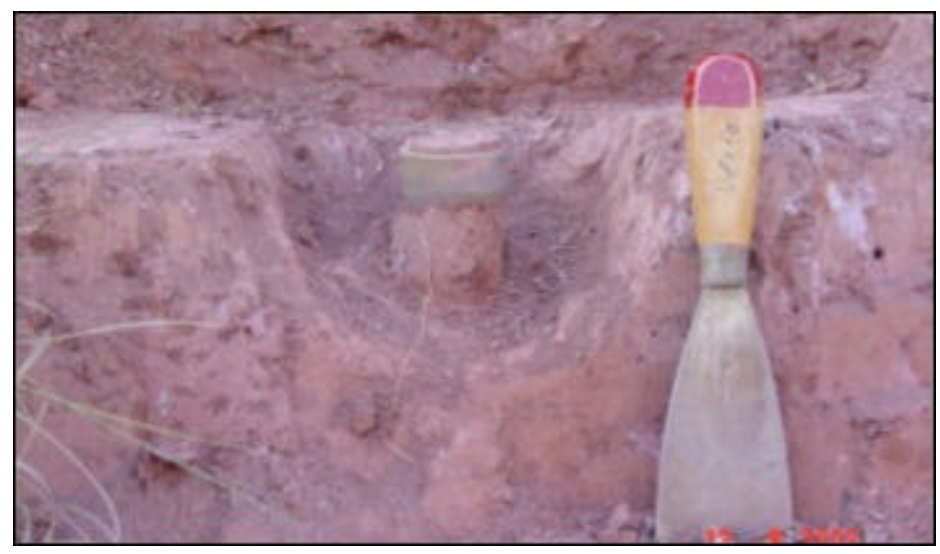

Figura 5.59. Coleta de amostra indeformada para execução dos ensaios de absorção de águas e perda por imersão.

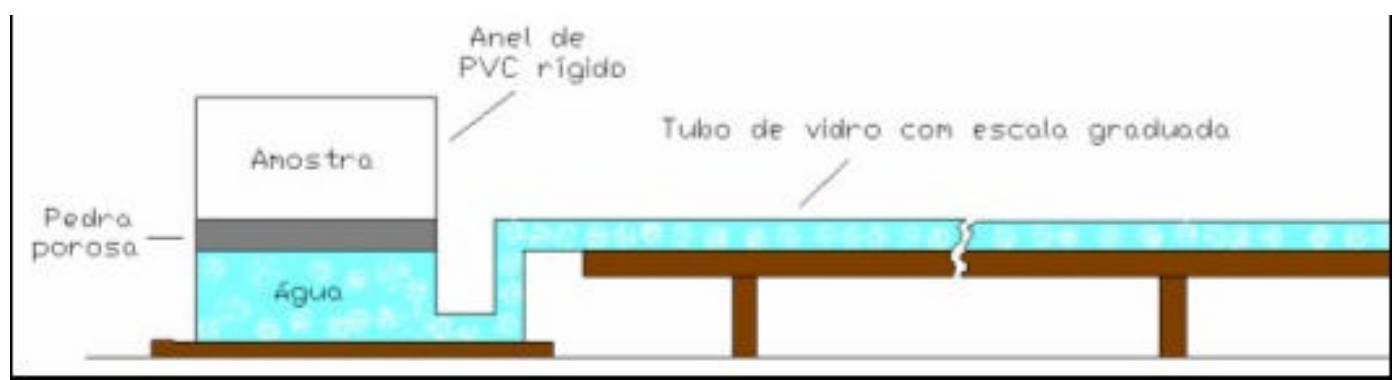

Figura 5.60. Esquema ilustrativo do equipamento utilizado na execução do ensaio de absorção de água (Pejon, 1992).

\section{Perda de massa por Imersão}

Após a realização do ensaio de absorção de água, o cilindro com a amostra é encaixado em uma base de apoio e o conjunto é imerso (na horizontal) em um recipiente com água, até que o topo da amostra fique a $2 \mathrm{~mm}$ abaixo do nível da água. 0 conjunto é mantido nesta posição até a completa saturação. Após este período, imergese totalmente a amostra e em seguida gira-se o conjunto até que a superfície livre da amostra fique na vertical (Figura 5.61). As partículas desprendias das amostras são coletadas em um recipiente menor disposto na base do conjunto. Após 24 horas determina-se a perda de peso em porcentagem do peso inicial da amostra seca (P).

Para o cálculo do índice de erodibilidade foi utilizada a expressão propostas por Nogami \& Villibor (1979) e modificada por Pejon (1992), apresentadas a seguir:

$$
E_{40}=\frac{(40 * S)}{P}
$$

onde: S - índice de absorção de água

$\mathrm{P}$ - índice de perda de massa por imersão 


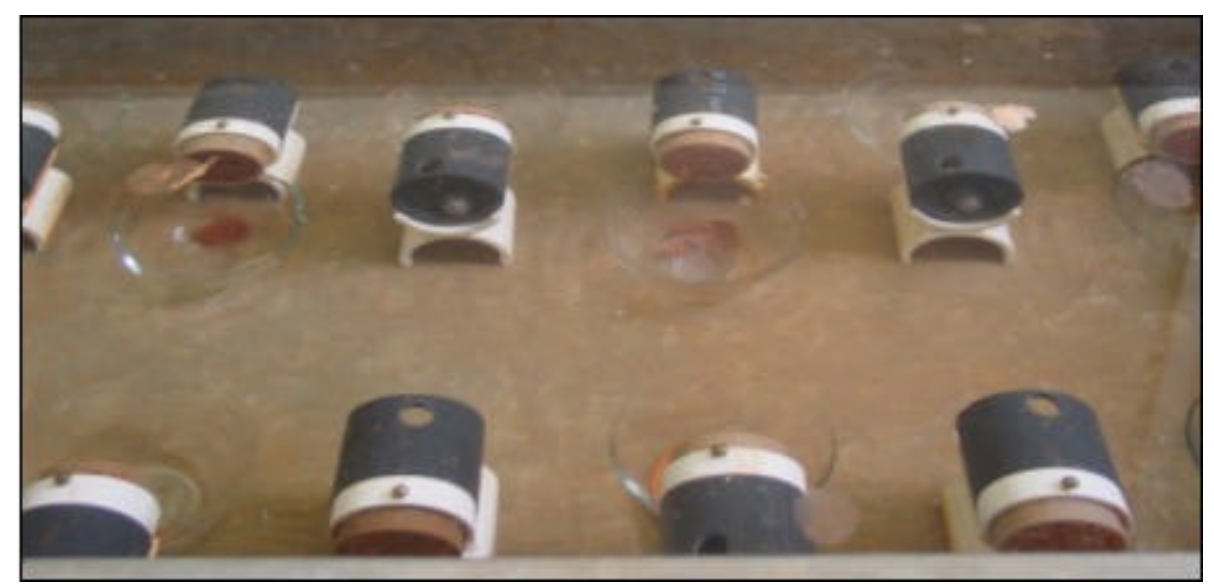

Figura 5.61. Ilustração do conjunto anel/ solo imerso em recipiente com água para execução do ensaio de perda de massa por imersão.

Para os casos onde o valor de E obtido são menores que 1, considera-se que 0 material inconsolidado ensaiados tem alta erodibilidade, e para os caso em que E é maior que um os materiais ensaiados são considerados de baixa erodibilidade.

\subsubsection{Unidades de Materiais Inconsolidados}

As unidades de materiais inconsolidados da bacia apresentam-se divididas em dois grandes grupos, segundo a gênese:

1 - Retrabalhados, os quais são divididos em três unidades: Aluviões, Retrab 1 e Retrab 2

2 -Residuais, os quais são divididos em 12 unidades: quanto a litologia associada. Estas unidades encontram-se subdivididas em 47 subunidades de acordo com aspectos de textura, espessura e landforms.

Um aspecto importante dos materiais da área, ressaltado por Mio (1992) e Saraiva (1995), é a ocorrência de pavimentos líticos de dois tipos: 1) linha de seixos facetados e arredondados, os quais apresentam composição variada (granitos, gnaisses, quartzitos, etc) de tamanhos variados (3-5 cm de diâmetro) e espessura entre 5-10 cm e 2) Linha de fragmentos facetados, constituída por quartzo e quartzito, com espessuras variadas $(3-15 \mathrm{~cm})$.

Mio (1992) ressalta a necessidade de atenção para não confundi-los e classificar todos como linhas de seixos. 
O Anexo IV mostra o Mapa de Materiais Inconsolidados e a Tabela 5.3 apresenta uma caracterização geral das unidades de materiais inconsolidados da bacia Hidrográfica do Rio do Peixe.

\subsubsection{Unidade de Materiais Aluvionares - (Al)}

Constituem depósitos de aluvião das áreas de várzea do Rio do Peixe e de áreas restritas de algumas drenagens secundárias. Apresentam textura e constituição mineralógica bastante variável, refletindo as características das rochas fontes e dos processos de deposição fluvial. Conforme verificação em trabalhos de campo, observase a ocorrência de textura predominantemente arenosa, no entanto na porção da baixa bacia e nas proximidades do município de Socorro é comum a ocorrência de depósitos argilosos, os quais são utilizados na fabricação de tijolos.

\subsubsection{Unidades de Materiais Retrabalhados - (Rt)}

Constituem duas subunidades, Retrab 1 e 2, formadas por processo de retabalhamento de materiais preexistentes (Tabela 5.4). A subunidade Retrab1 apresenta textura argilo-arenosa com silte, coloração vermelha escura, com espessuras variáveis entre 0,5 e 2 metros. A subunidade Retrab2 apresenta textura areno-siltosa e espessuras que variam entre 1 e 4 metros. As cores predominantes são o vermelho e o laranja. As maiores espessuras ocorrem nas porções da média bacia entre as zonas de cisalhamento de Ibitinga e Monte Sião. Nesta porção os materiais retrabalhados exibem textura arenoargilosa. Nas outras porções da bacia as espessuras variam de $0.2 \mathrm{~m}$, e os mesmos se caracterizam por apresentarem textura areno-siltosa.

É comum a ocorrência, em superfícies expostas desta unidade, de uma película superficial de cimentação por silica, a qual segundo Barison (1995), Saraiva (1995) e Mio (1992), pode ser responsável pela estabilidade de alguns cortes e ausência ou baixa incidência de ravinamentos. 
Tabela 5.3 - Caracterização geral das unidades de materiais inconsolidados da Bacia Hidrográfica do Rio do Peixe.

\begin{tabular}{|c|c|c|c|c|c|c|c|c|c|c|c|c|c|}
\hline \multirow[t]{2}{*}{ Unidade } & \multirow[t]{2}{*}{ Gênese } & \multirow{2}{*}{$\begin{array}{c}\text { Espessura } \\
\text { (m) }\end{array}$} & \multicolumn{4}{|c|}{ Textura } & \multirow{2}{*}{$\begin{array}{l}\text { pdcamp } \\
\left(\mathrm{g} / \mathbf{c m}^{3}\right)\end{array}$} & \multirow{2}{*}{$\begin{array}{c}\rho \mathbf{S} \\
\left(\mathbf{g} / \mathbf{c m}^{3}\right)\end{array}$} & \multirow{2}{*}{$\begin{array}{c}n \\
(\%)\end{array}$} & \multirow[t]{2}{*}{$\mathbf{e}_{\mathbf{o}}$} & \multirow{2}{*}{$\begin{array}{c}\text { Erodibilidade } \\
\text { E } 40\end{array}$} & \multirow{2}{*}{$\begin{array}{c}\mathrm{CTC} \\
\mathrm{Cmol}^{+} / \mathrm{kg}\end{array}$} & \multirow{2}{*}{$\begin{array}{c}\mathrm{SE} \\
\mathbf{m}^{2} / \mathbf{g}\end{array}$} \\
\hline & & & $\begin{array}{l}\text { \% Areia } \\
\text { Grossa }\end{array}$ & $\begin{array}{c}\text { \% Areia } \\
\text { Fina }\end{array}$ & $\%$ Silte & $\begin{array}{c}\% \\
\text { Argila }\end{array}$ & & & & & & & \\
\hline Retrab1 & Retrabalhado & $0.5-2$ & -- & 23 & 12 & 65 & 1.38 & 2.66 & 48 & 0.93 & 94.32 & 6.04 & 47.31 \\
\hline Retrab2 & Retrabalhado & $1-4$ & 06 & 50 & 39 & 5 & 1.18 & 2.62 & 55 & 1.22 & 20.32 & 2.17 & 38.72 \\
\hline ReGrC & Residual & $1-2.5$ & 17 & 34 & 39 & 10 & 1.39 & 2.65 & 47.36 & 1.9 & 5.86 & 2.80 & 17.65 \\
\hline ReGrP & Residual & $1-4$ & $11-18$ & $30-48$ & $15-28$ & $12-36$ & $1.19-1.42$ & $2.58-2.63$ & $45-54$ & $0.84-1.20$ & $5.37-173.84$ & $2.85-6.49$ & $16.84-30.36$ \\
\hline ReGr-Gn & Residual & $1-3$ & 03-10 & $47-59$ & $16-28$ & $10-27$ & $1.18-1.38$ & $2.65-2.61$ & $47-55$ & $0.89-1.25$ & $4.87-20.9$ & $2.54-4.19$ & $33.65-24.01$ \\
\hline ReGnb & Residual & $0.5-6$ & $05-15$ & $10-52$ & $11-48$ & $08-63$ & $1.09-1.34$ & $2.61-2.6$ & $49-58$ & $0.96-1.41$ & $0.67-38.12$ & $3.15-6.95$ & $24.65-45.71$ \\
\hline ReGnq & Residual & $0.5-3$ & $12-16$ & $42-49$ & $10-14$ & $25-32$ & $1.26-1.40$ & $2.61-2.62$ & $46-52$ & $0.87-1.07$ & $13.84-17.6$ & $3.55-5.52$ & $39.52-44.01$ \\
\hline$\overline{\operatorname{ReQtz}}$ & Residual & $0.5-1.5$ & 08-19 & $37-84$ & $18-34$ & $10-26$ & $1.41-1.51$ & $2.63-2.65$ & $4.71-42$ & $0.74-0.89$ & $1.65-10.38$ & $2.25-3.56$ & $21.65-30.21$ \\
\hline ReMig & Residual & $0.5-10$ & $04-16$ & $16-44$ & $07-52$ & $12-58$ & $1.28-1.52$ & $2.58-2.63$ & $41-55$ & $0.69-1.24$ & $4.98-93.77$ & $5.19-9.89$ & $21.17-47.21$ \\
\hline ReUtm & Residual & $1-8$ & $14-25$ & $16-46$ & $28-52$ & 08-18 & $1.39-1.53$ & $2.63-2.65$ & $45-48$ & $0.74-0.89$ & $0.43-0.99$ & $7.86-8.4$ & $53.45-68.25$ \\
\hline ReBtm & Residual & $\overline{1-4}$ & $08-10$ & $23-42$ & $45-52$ & $13-17$ & $1.41-1.56$ & $2.62-2.63$ & $43-55$ & $0.73-0.86$ & $0.83-0.94$ & $2.31-4.43$ & $17.24-35.28$ \\
\hline
\end{tabular}


Tabela 5.4. Dados dos ensaios de caracterização realizados em amostra de Materiais Retrabalhados.

\begin{tabular}{|c|c|c|c|c|c|c|c|c|c|c|c|c|}
\hline \multirow[t]{2}{*}{ Subunidade } & \multirow{2}{*}{$\begin{array}{c}\text { Esp. } \\
\text { (m) }\end{array}$} & \multicolumn{4}{|c|}{ Textura } & \multirow{2}{*}{$\begin{array}{c}\text { pdcampo } \\
\left(\mathrm{g} / \mathrm{cm}^{3}\right)\end{array}$} & \multirow{2}{*}{$\begin{array}{c}\rho \mathrm{s} \\
\left(\mathbf{g} / \mathbf{c m}^{3}\right)\end{array}$} & \multirow{2}{*}{$\begin{array}{c}n \\
(\%)\end{array}$} & \multirow[t]{2}{*}{$\mathbf{e}_{\mathbf{o}}$} & \multirow{2}{*}{$\begin{array}{c}\text { Erod. } \\
\mathbf{4 0}\end{array}$} & \multirow[t]{2}{*}{ CTC } & \multirow[t]{2}{*}{ SE } \\
\hline & & $\begin{array}{c}\text { \% Areia } \\
\text { Grossa }\end{array}$ & $\begin{array}{c}\% \\
\text { Areia } \\
\text { Fina }\end{array}$ & $\begin{array}{c}\% \\
\text { Silte }\end{array}$ & $\begin{array}{c}\% \\
\text { Argila }\end{array}$ & & & & & & & \\
\hline Retrab1 & $0,5-2$ & -- & 23 & 12 & 65 & 1,38 & 2,66 & 48 & 0,93 & 94,32 & 6,04 & 47,31 \\
\hline Retrab2 & $1-4$ & 06 & 50 & 39 & 5 & 1,18 & 2,62 & 55 & 1,22 & 20,32 & 2,17 & 38,72 \\
\hline Min-Max & $0,5-4$ & 06 & $23-50$ & $12-39$ & $5-65$ & $1,38-1,18$ & $\begin{array}{l}2,62- \\
2,66\end{array}$ & $\begin{array}{l}48- \\
55\end{array}$ & $\begin{array}{l}0,93- \\
1,22\end{array}$ & $\begin{array}{l}20,32- \\
94,32\end{array}$ & $\begin{array}{l}2,17- \\
6,04\end{array}$ & $\begin{array}{l}38,72- \\
47,31\end{array}$ \\
\hline
\end{tabular}

O s contatos com as unidades de materiais residuais são caracterizados, muitas vezes, pela ocorrência de linhas de seixos (Figura 5.62 A e B).
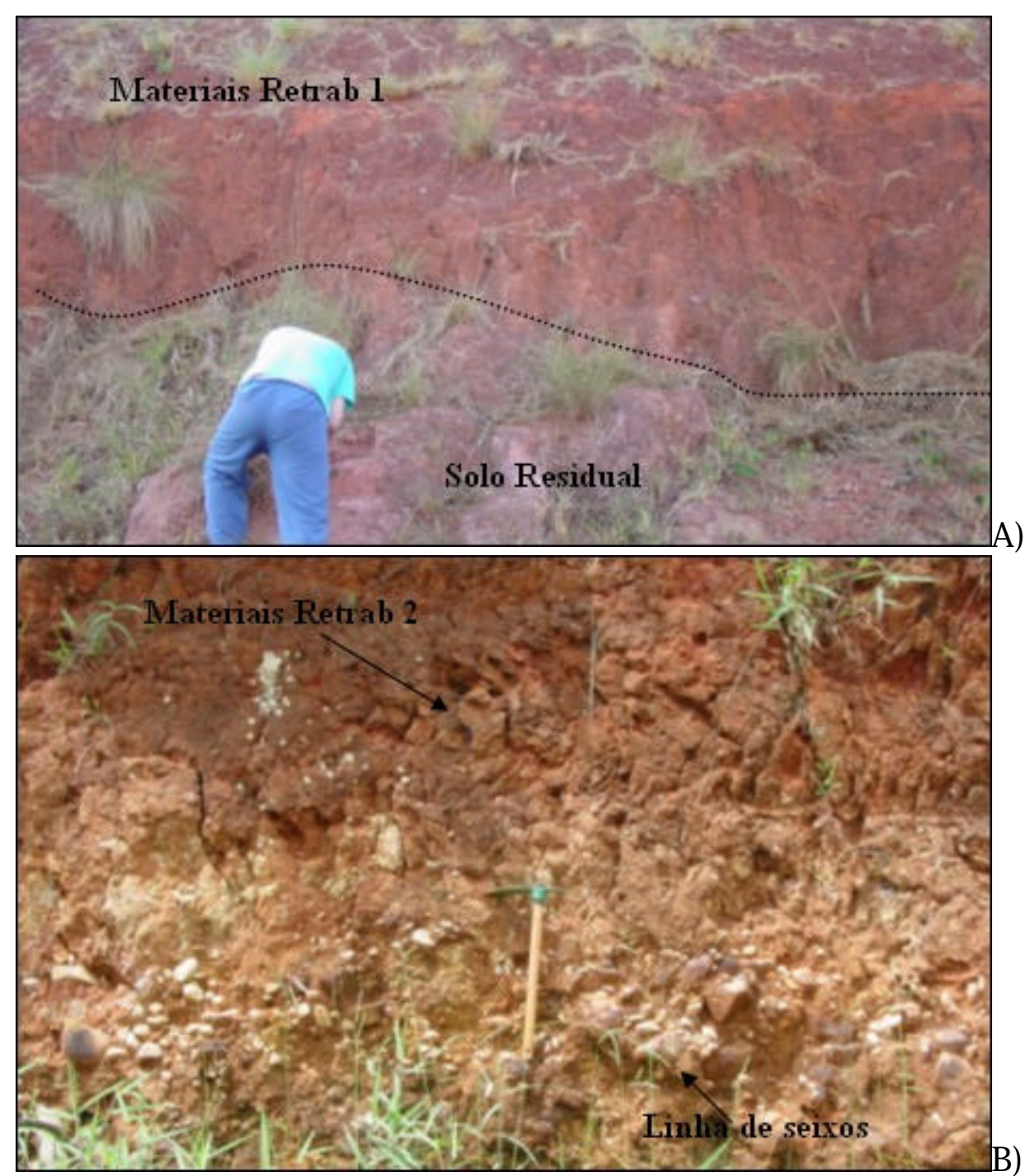

Figura 5.62.A) O corrência de materiais retrabalhados presente sobre residuais sem linha de seixo.B) Linha de seixos separando materiais retrabalhados e residuais. 


\subsubsection{Unidades de Materiais Residuais}

Constituem materiais originados por processo de alteração intempérica in situ do substrato rochoso. Na bacia ocorrem nove classes de unidades materiais residuais. Estas classes são subdividas em 46 subunidades menores. A descrição dessas unidades é apresentada a seguir.

Unidade de Materiais Residuais de $\mathrm{G}$ ranitos $\mathrm{C}$ ataclasados - ( $\mathrm{ReG} \mathrm{rC}$ )

De ocorrência localizada a foz da bacia, estes materiais correlacionam-se à unidade de landforms A8. Os solos desta unidade apresentam um perfil de alteração caracterizado por heterogeneidade e ausência da rocha sã exposta em superfície (Figura 5.63).

O correm com espessura variando de 1-2,5m, textura areno-siltosa com argila e caracterizam-se por baixa erodibilidade (Tabela 5.5). Predominam colorações em tons claros de rosa a laranja.

São comuns as ocorrências de veios de quartzo verticalizados e porções de rochas alteradas em meio ao solo bem desenvolvido.

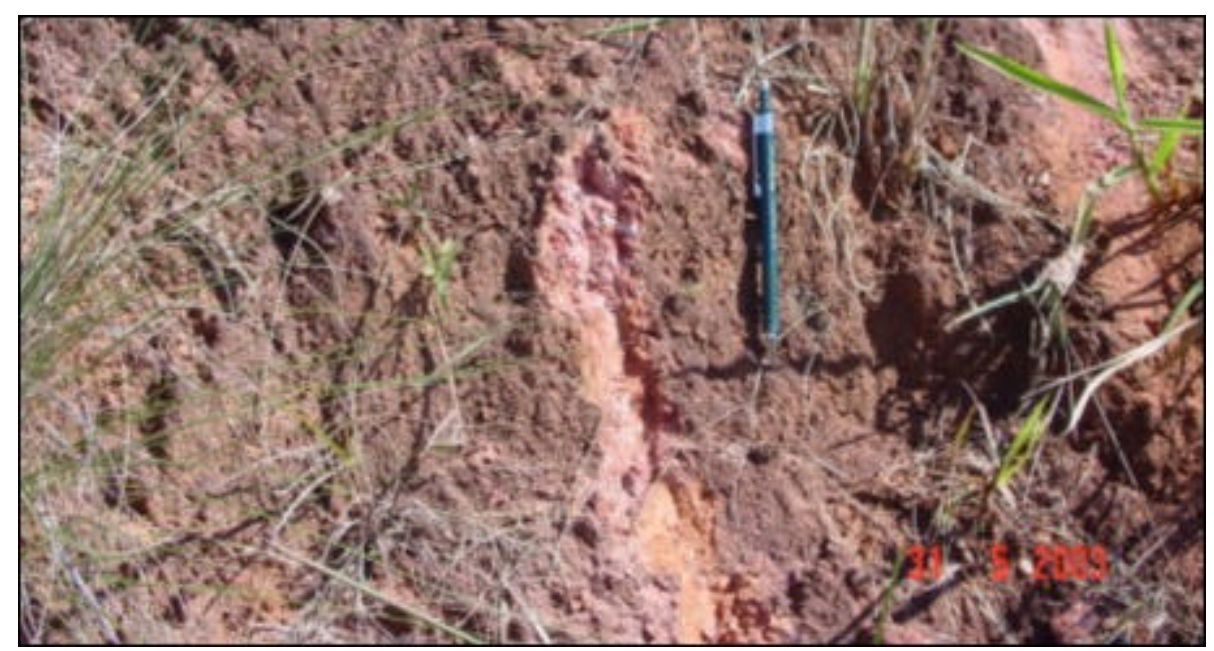

Figura 5.63. D etalhe de afloramento de materiais residuais de G ranitos cataclsaos.

Tabela 5.5. Dados dos ensaios de caracterização realizados em amostra de Materiais Residuais de Granitos Cataclasados.

\begin{tabular}{|c|c|c|c|c|c|c|c|c|c|c|c|}
\hline \multirow{2}{*}{$\begin{array}{c}\text { Esp. } \\
\text { (m) }\end{array}$} & \multicolumn{4}{|c|}{ Textura } & \multirow{2}{*}{$\begin{array}{c}\text { pdcampo } \\
\left(\mathrm{g} / \mathrm{cm}^{3}\right)\end{array}$} & \multirow{2}{*}{$\begin{array}{c}\rho s \\
\left(\mathbf{g} / \mathbf{c m}^{3}\right)\end{array}$} & \multirow[t]{2}{*}{\begin{tabular}{|l|} 
n (\%) \\
\end{tabular}} & \multirow[t]{2}{*}{$\mathbf{e}_{\mathrm{o}}$} & \multirow{2}{*}{$\begin{array}{r}\text { Eno } \\
40\end{array}$} & \multirow[t]{2}{*}{ CT } & \multirow[t]{2}{*}{$\mathrm{SE}$} \\
\hline & $\begin{array}{l}\text { \% Areia } \\
\text { Grossa }\end{array}$ & $\begin{array}{c}\% \\
\text { Areia } \\
\text { Fina }\end{array}$ & $\begin{array}{c}\% \\
\text { Silte }\end{array}$ & \%Argila & & & & & & & \\
\hline $1-2,5$ & 17 & 34 & 39 & 10 & 1,39 & 2,65 & 47,36 & 1,9 & 5,86 & 2 & 17, \\
\hline
\end{tabular}




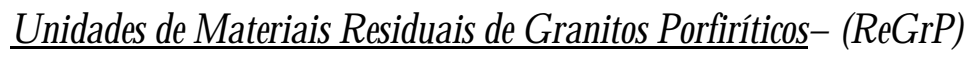

De ocorrência localizada a porção da alta da bacia, estes materiais estão subdivididos em cinco subunidades menores, que apresentam correlação com o sistema de landforms D e E (Tabela 5.6).

Tabela 5.6. Correlação entre subunidade de materiais inconsolidados residuais de granitos porfiríticos e unidades de lanforms.

\begin{tabular}{c|c}
\hline $\begin{array}{c}\text { Subunidade Materiais } \\
\text { Inconsolidados }\end{array}$ & $\begin{array}{c}\text { Unidade } \\
\text { Landform }\end{array}$ \\
\hline Grp1 & D 6 \\
\hline Grp2 & E 4 \\
\hline Grp3 & E 6 \\
\hline Grp4 & E 7 \\
\hline Grp5 & E 8 \\
\hline
\end{tabular}

O perfil típico de alteração destes materiais é extremamente heterogêneo.Por vezes exibem em superfície apenas as variações de rocha muito alterada a solo, e por vezes ocorrem com a presença de matacões de rocha pouco alterada envoltos em solo bem desenvolvido. A presenta textura variando entre areno-argilosa com silte a areno siltosa com argila (Tabela 5.7).

A coloração exibida por estes solos reflete a composição da rocha original, porções mais ricas em feldspato-potássico exibem tons rosa-avermelhados, e porções mais ricas em quartzo exibem tons branco-alaranjados (Figura 5.64).

Tabela 5.7. Dados dos ensaios de caracterização realizados em amostra de Materiais

\begin{tabular}{|c|c|c|c|c|c|c|c|c|c|c|c|c|}
\hline \multirow{2}{*}{$\begin{array}{l}\text { Subunida- } \\
\text { des }\end{array}$} & \multirow{2}{*}{$\begin{array}{l}\text { Esp. } \\
\text { (m) }\end{array}$} & \multicolumn{4}{|c|}{ Textura } & \multirow{2}{*}{$\begin{array}{l}\text { pdcamp } \\
\left(\mathrm{g} / \mathrm{cm}^{3}\right)\end{array}$} & \multirow{2}{*}{$\begin{array}{c}\rho s \\
\left(\mathbf{g} / \mathbf{c m}^{3}\right)\end{array}$} & \multirow{2}{*}{$\begin{array}{c}\mathrm{n} \\
(\%)\end{array}$} & \multirow[t]{2}{*}{$\mathbf{e}_{\mathbf{o}}$} & \multirow{2}{*}{$\begin{array}{c}\text { Erod. } \\
40\end{array}$} & \multirow[t]{2}{*}{ CTC } & \multirow[t]{2}{*}{$\mathrm{SE}$} \\
\hline & & $\begin{array}{c}\text { \% Areia } \\
\text { Grossa }\end{array}$ & $\begin{array}{c}\% \\
\text { Areia } \\
\text { Fina }\end{array}$ & $\begin{array}{c}\% \\
\text { Silte }\end{array}$ & $\begin{array}{c}\% \\
\text { Argila }\end{array}$ & & & & & & & \\
\hline ReGrP1 & $0,5-3$ & 18 & 40 & 15 & 27 & 1,38 & 2,63 & 48 & 0,96 & 6,85 & 3,17 & 23,15 \\
\hline ReGrP2 & $1-4$ & 11 & 45 & 18 & 26 & 1,42 & 2,62 & 45 & 0,84 & 5,37 & 4,12 & 27,17 \\
\hline ReGrP3 & $1-2,5$ & 12 & 48 & 28 & 12 & 1,19 & 2,62 & 54 & 1,20 & 10,04 & 2,85 & 16,84 \\
\hline ReGrP4 & $1-2$ & 11 & 30 & 23 & 36 & 1,40 & 2,62 & 46 & 0,87 & 173,84 & 5,75 & 49,54 \\
\hline ReGrP5 & $1-4$ & 13 & 34 & 19 & 34 & 1,36 & 2,58 & 47 & 0,89 & 88,66 & 6,49 & 30,36 \\
\hline Min-Max & $1-4$ & 11-18 & $30-48$ & $\begin{array}{l}15- \\
28\end{array}$ & $12-36$ & $1,19-1,42$ & $2,58-2,63$ & $45-54$ & $\begin{array}{l}0,84- \\
1,20\end{array}$ & $\begin{array}{l}5,37- \\
173,84\end{array}$ & $\begin{array}{l}2,85- \\
6,49\end{array}$ & $\begin{array}{l}16,84 \\
- \\
30,36\end{array}$ \\
\hline
\end{tabular}

As variações laterais de contato são bem heterogêneas. Nas proximidades da zona de falha de Ibitinga é comum a ocorrência de rocha sã, ou pouco alterada, em contato brusco com solo. 


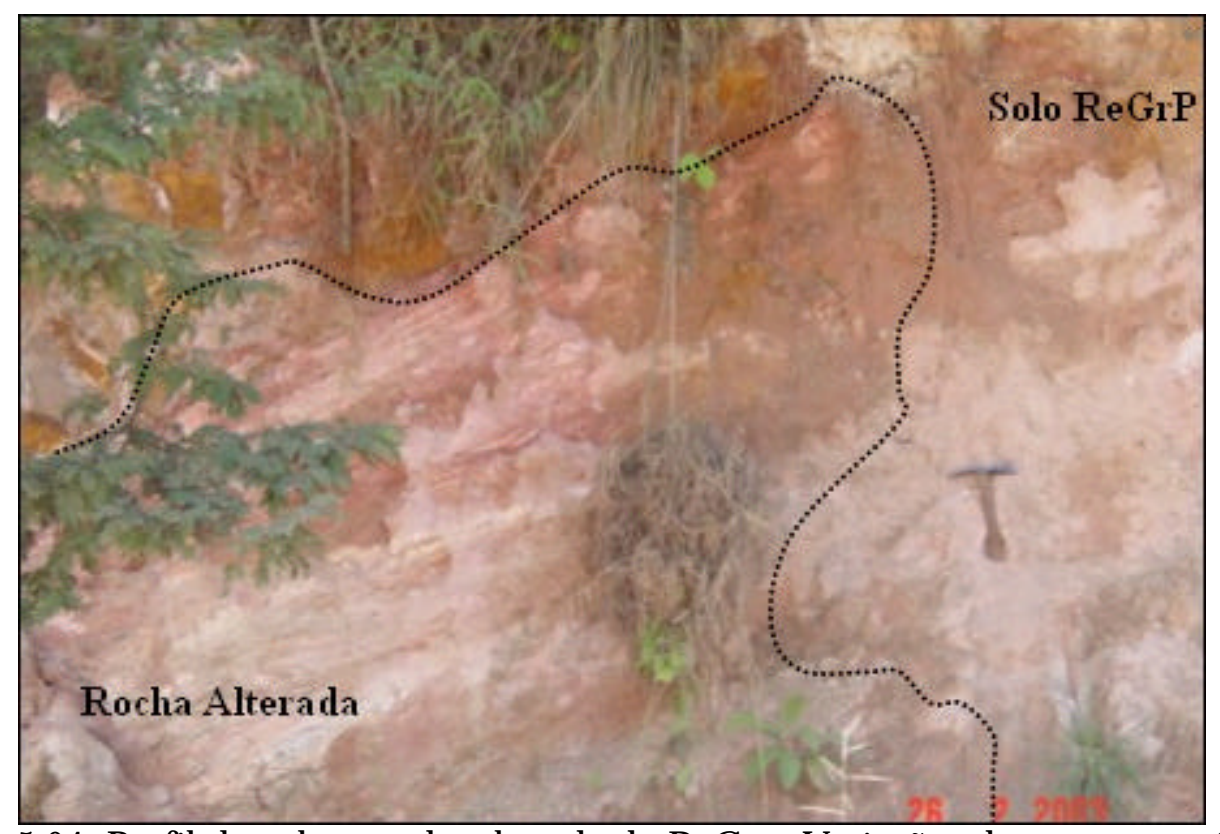

Figura 5.64. Perfil de solo e rocha alterada de ReG rp. Variações de cor caracterizando composição da rocha original.

Unidade de M ateriais Residuais de $\mathrm{G}$ ranitos- $\mathrm{G}$ naisses- ( $\mathrm{ReG} \mathrm{r-G} \mathrm{n}$ )

Com ocorrência localizada na porção de cabeceira da bacia, estes materiais subdividem-se em duas subunidades, que apresentam associação com o sistema de landform E (Tabela 5.8).

Tabela 5.8. Correlação entre unidade de materiais inconsolidados residuais de granitosgnaisses e unidade lanforms.

\begin{tabular}{c|c}
\hline $\begin{array}{c}\text { Subunidade Materiais } \\
\text { Inconsolidados }\end{array}$ & $\begin{array}{c}\text { Unidade } \\
\text { Landform }\end{array}$ \\
\hline $\mathrm{Gr}-\mathrm{Gn} 1$ & $\mathrm{E} 4$ \\
\hline $\mathrm{Gr} \mathrm{Gn} 2$ & $\mathrm{E} 6 \mathrm{eE} 7$ \\
\hline
\end{tabular}

0 perfil típico de alteração desta unidade caracteriza-se por apresentar solos bem desenvolvidos, espessura variável entre $0.5-3 \mathrm{~m}$, de coloração laranja a vermelho escuro, de textura predominantemente arenosa com frações argila e silte (Tabela 5.9). É incomum a ocorrência em superfície de porções de rocha sã. Normalmente observa-se a presença de fragmentos de rocha muito alterada envoltos em meio ao solo (Figura 5.65 A e B). Observa-se, também, com freqüência a presença de solos retrabalhados sotopostos ao solo residual, com contato delimitado por linhas de seixo. Todavia as espessuras reduzidas dos solos retrabalhados não permitem o mapeamento destas unidades. 
Tabela 5.9 Dados dos ensaios de caracterização realizados em amostra de Materiais Residuais de Granitos- $\mathrm{G}$ naisses.

\begin{tabular}{|c|c|c|c|c|c|c|c|c|c|c|c|c|}
\hline \multirow{2}{*}{$\begin{array}{l}\text { Subunida } \\
\text {-de }\end{array}$} & \multirow{2}{*}{$\begin{array}{c}\text { Esp. } \\
\text { (m) }\end{array}$} & \multicolumn{4}{|c|}{ Textura } & \multirow{2}{*}{$\begin{array}{l}\text { pdcamp } \\
\left(\mathrm{g} / \mathrm{cm}^{3}\right)\end{array}$} & \multirow{2}{*}{$\begin{array}{c}\rho s \\
\left(\mathbf{g} / \mathbf{c m}^{3}\right)\end{array}$} & \multirow{2}{*}{$\begin{array}{c}\mathrm{n} \\
\mathbf{( \% )}\end{array}$} & \multirow[t]{2}{*}{$\mathbf{e}_{\mathbf{o}}$} & \multirow{2}{*}{$\begin{array}{c}\text { Erod. } \\
\mathbf{4 0}\end{array}$} & \multirow[t]{2}{*}{ CTC } & \multirow[t]{2}{*}{$\mathrm{SE}$} \\
\hline & & $\begin{array}{c}\% \\
\text { Areia } \\
\text { Grossa }\end{array}$ & $\begin{array}{c}\% \\
\text { Areia } \\
\text { Fina }\end{array}$ & $\begin{array}{c}\% \% \\
\text { Silte }\end{array}$ & $\begin{array}{c}\% \\
\text { Argila }\end{array}$ & & & & & & & \\
\hline $\begin{array}{l}\text { ReGr- } \\
\text { Gn1 }\end{array}$ & $1-3$ & 10 & 47 & 16 & 27 & 1,18 & 2,65 & 55 & 1,25 & 20,90 & 4,19 & 33,65 \\
\hline $\begin{array}{l}\text { ReGr- } \\
\text { Gn2 }\end{array}$ & $0,5-2$ & 03 & 59 & 28 & 10 & 1,38 & 2,61 & 47 & 0,89 & 4,87 & 2,54 & 24,01 \\
\hline Min-Max & $1-3$ & 03-10 & $47-59$ & 16-28 & $10-27$ & $1,18-1,38$ & $2,65-2,61$ & $47-55$ & $\begin{array}{l}0,89- \\
1,25\end{array}$ & $\begin{array}{l}4,87- \\
20,9\end{array}$ & $\begin{array}{l}2,54- \\
4,19\end{array}$ & $\begin{array}{l}33,65 \\
- \\
24,01\end{array}$ \\
\hline
\end{tabular}
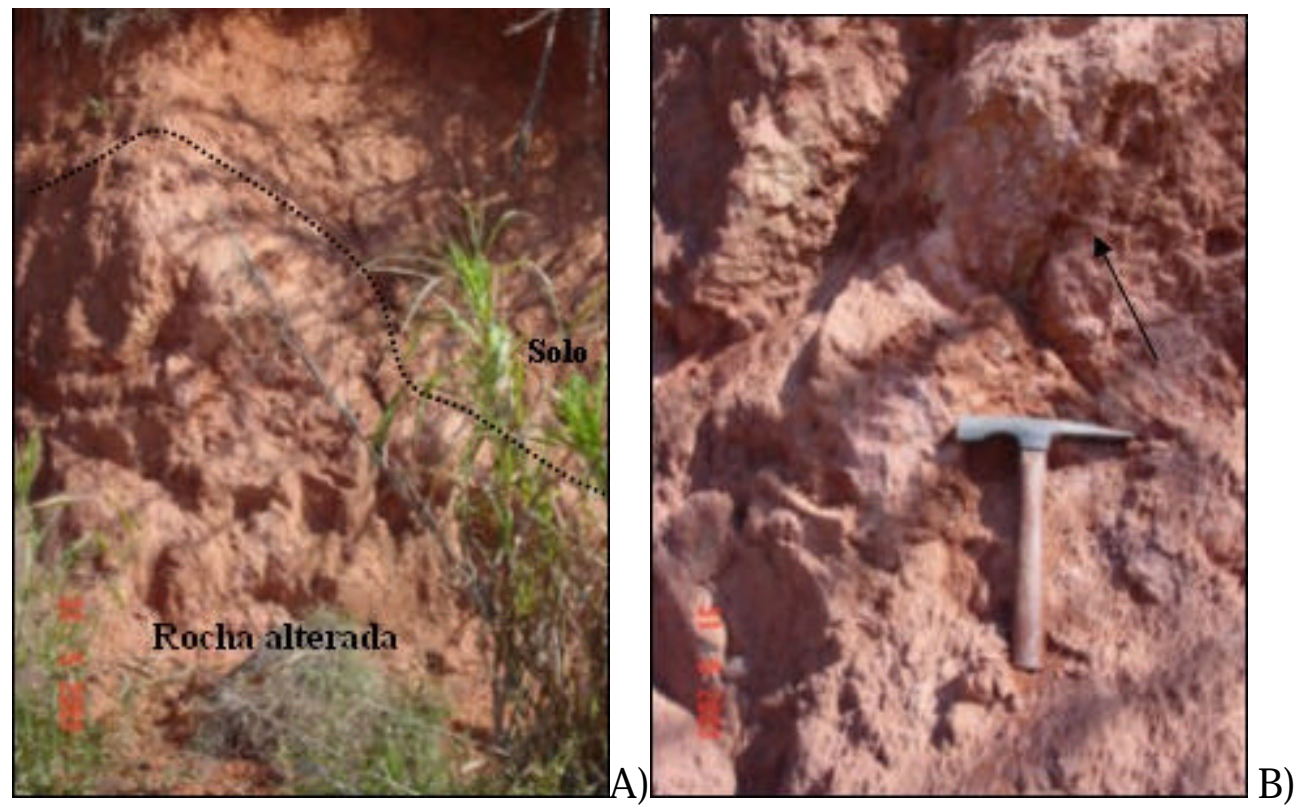

Figura 5.65. A)Perfil de solo e rocha alterada de ReGr-Gn. B) Detalhe rocha alterada diferenças de coloração porção gnaissificada.

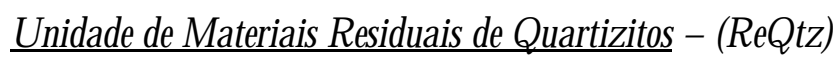

Presente nas porções da baixa e média bacia, estes matérias subdividem-se em três unidades e associam-se aos sistemas de landform A, B e C (Tabela 5.10).

Tabela 5.10. Correlação entre unidade de materiais inconsolidados residuais de quartzitos impuros e unidade lanforms.

\begin{tabular}{c|c}
\hline $\begin{array}{c}\text { Subunidade Materiais } \\
\text { Inconsolidados }\end{array}$ & $\begin{array}{c}\text { Unidade } \\
\text { Landform }\end{array}$ \\
\hline Q tz1 & $\mathrm{A} 2$ \\
\hline Q tz2 & $\mathrm{B} 8$ e C7 \\
\hline Q tz3 & $\mathrm{C} 4$ \\
\hline
\end{tabular}


O s materiais desta unidade exibem, normalmente, espessuras bastante reduzidas, não superiores a 1,5 metros. Constituídos, predominante, de quartzo com teores elevados de muscovitas e eventualmente porções mais feldspáticas, as texturas destes materiais variam entre areno-siltosa com argila a areno-argilosa com silte (Tabela 5.11).

O perfil de alteração se caracteriza pela gradação entre porções de solo bem desenvolvido, de coloração amarelo a laranja claro, e porções de rochas quartzosa pouco alteradas do substrato (Figura 5.66 A e B). Por vezes são observados contatos bruscos entre porções de solo e rocha sã. Isto é muito comum junto à zona de falha de Ibitinga. Também é comum a ocorrência de veio de quartzo de espessura centimétrica $(10-40 \mathrm{~cm})$ cortando os pacotes de solo.

Tabela 5.11 - Dados dos ensaios de caracterização realizados em amostra de Materiais Residuais de Quartzitos Impuros.

\begin{tabular}{|c|c|c|c|c|c|c|c|c|c|c|c|c|}
\hline \multirow{2}{*}{$\begin{array}{l}\text { Subunida- } \\
\text { de }\end{array}$} & \multirow{2}{*}{$\begin{array}{c}\text { Esp. } \\
\text { (m) }\end{array}$} & \multicolumn{4}{|c|}{ Textura } & \multirow{2}{*}{$\begin{array}{l}\text { pdcamp } \\
\left(\mathrm{g} / \mathrm{cm}^{3}\right)\end{array}$} & \multirow{2}{*}{$\begin{array}{l}\rho s \\
\left(\mathbf{g} / \mathbf{c m}^{3}\right)\end{array}$} & \multirow{2}{*}{$\begin{array}{c}\mathrm{n} \\
(\%)\end{array}$} & \multirow[t]{2}{*}{$\mathbf{e}_{\mathbf{o}}$} & \multirow{2}{*}{$\begin{array}{l}\text { Erod. } \\
40\end{array}$} & \multirow[t]{2}{*}{ CTC } & \multirow[t]{2}{*}{$\mathrm{SE}$} \\
\hline & & $\begin{array}{c}\% \\
\text { Areia } \\
\text { Grossa }\end{array}$ & $\begin{array}{c}\% \\
\text { Areia } \\
\text { Fina }\end{array}$ & $\begin{array}{c}\% \\
\text { Silte }\end{array}$ & $\begin{array}{c}\% \% \\
\text { Argila }\end{array}$ & & & & & & & \\
\hline$\overline{\text { ReQ tz1 }}$ & $1-1,5$ & 19 & 37 & 34 & 10 & 1,41 & 2,65 & 47,1 & 0,89 & 1,65 & 2,25 & 21,65 \\
\hline \multirow[t]{2}{*}{ ReQ tz2 } & $\begin{array}{l}0,5- \\
1,5\end{array}$ & 8 & 48 & 18 & 26 & 1,51 & 2,63 & 42 & 0,74 & 10,38 & 3,56 & 30,21 \\
\hline & $\begin{array}{l}0,5- \\
1,5\end{array}$ & 08-19 & $37-84$ & $18-34$ & $10-26$ & $1,41-1,51$ & $2,63-2,65$ & $\begin{array}{l}4,71- \\
42\end{array}$ & $\begin{array}{l}0,74- \\
0,89\end{array}$ & $\begin{array}{l}1,65- \\
10,38\end{array}$ & $\begin{array}{l}2,25- \\
3,56\end{array}$ & $\begin{array}{l}21,65 \\
- \\
30,21\end{array}$ \\
\hline
\end{tabular}

Observações de campo mostram que a subunidade ReQ tz 3 caracteriza-se por apresentar os menores valores de espessura, dentre as três unidades, em geral inferiores a 0,5 metros. Observações visuais e táteis permitem enquadrar a textura desta subunidade como similar a unidade ReQ tz1.

O resultado do ensaio de erodibilidade em amostras de solos da subunidade ReQ tz1 permite caracterizar estas como de alta erodibilidade. Em campo observa-se também a ocorrência comum de movimento gravitacional tipo creeping (Figura 5.67).

Assim como o substrato rochoso, estes solos apresentam relações de contato abrupto com os solos residuais de Gnaisses intercalados a rochas básicas e solos residuais de Ultramilonitos. 

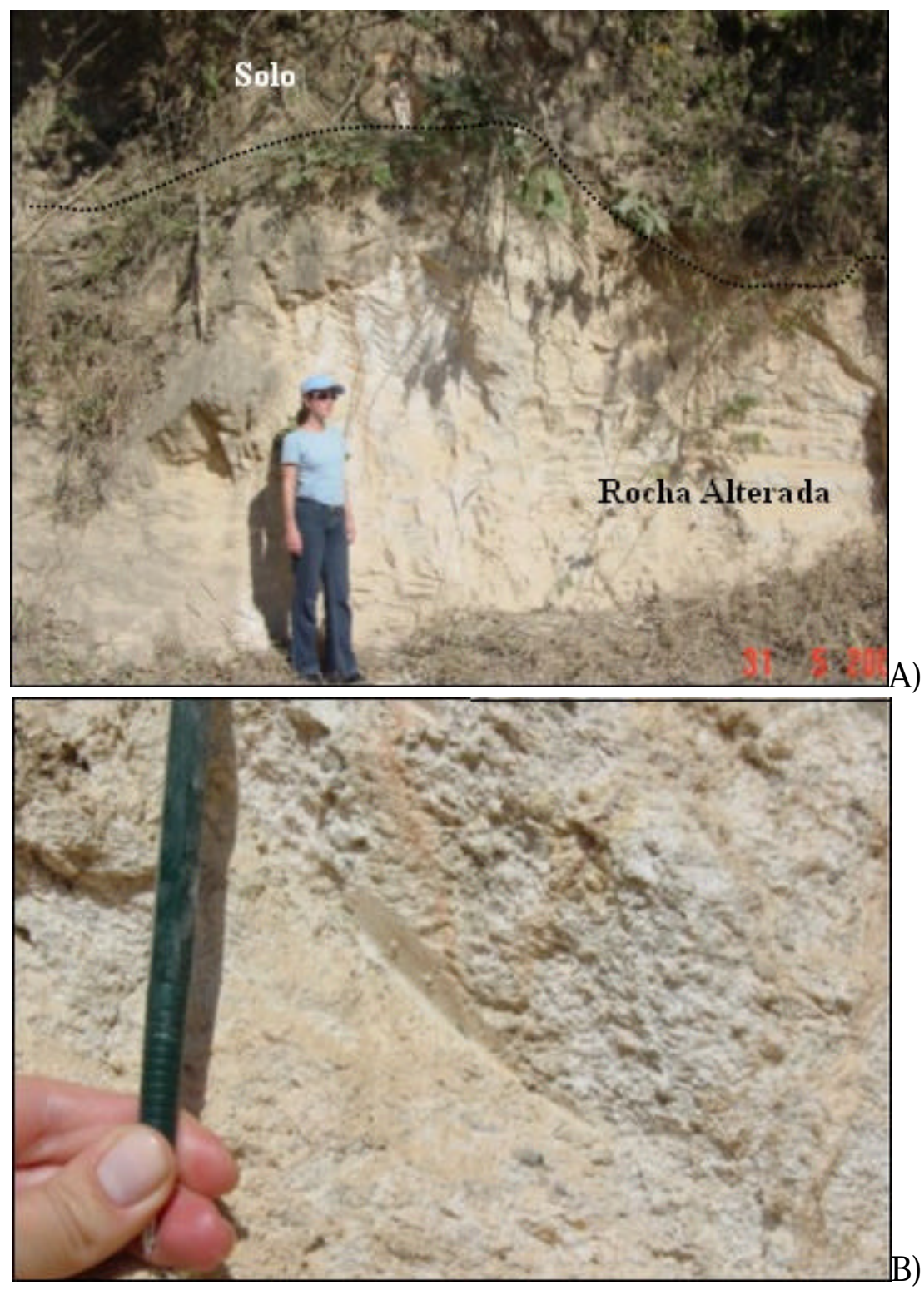

Figura 5.66. A) Perfil de solo ReQtz. Gradação entre rocha alterada e solos bem desenvolvido. B) D etalhe rocha alterada de quartzitos impuros.

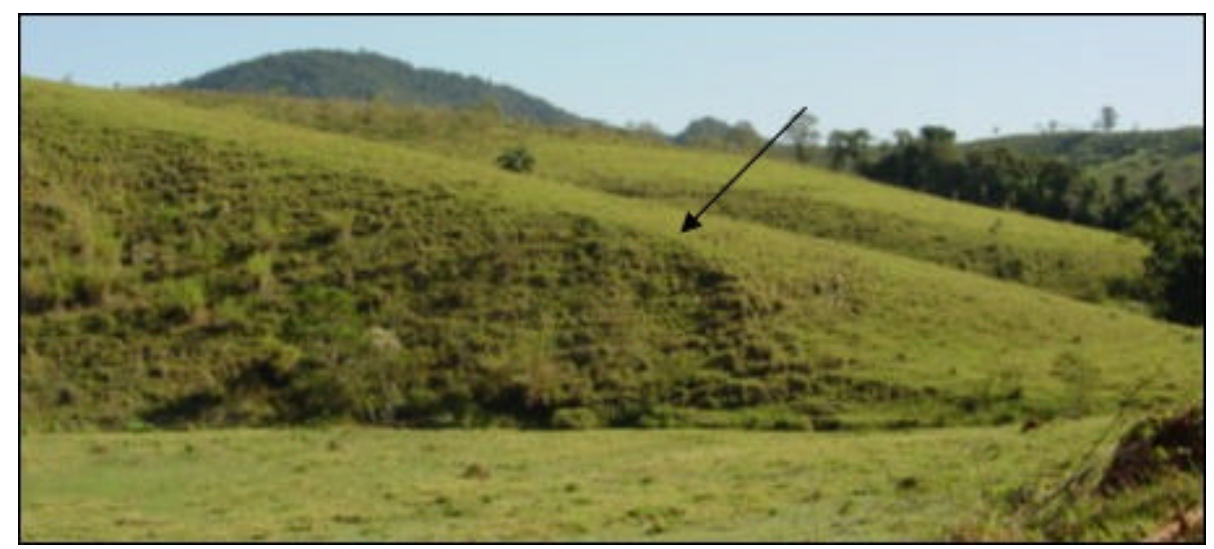

Figura 5.67. Movimento de massa gravitacional tipo creeping comum em solos da unidade ReQtz1. 
Unidade de Materiais Residuais de G naisses Intercalados com Q uartzitos - ( $\mathrm{ReG} \mathrm{nQ}$ )

Presente nas porções da baixa bacia, estes materiais subdividem-se em cinco subunidades, as quais estão associadas as sistemas de landforms A e B (Tabela 5.12)

Tabela 5.12. Correlação entre unidade de materiais inconsolidados residuais de gnaisses intercalados com quartzitos e unidade lanforms.

\begin{tabular}{c|c}
\hline $\begin{array}{c}\text { Subunidade Materiais } \\
\text { Inconsolidados }\end{array}$ & $\begin{array}{c}\text { Unidade } \\
\text { Landform }\end{array}$ \\
\hline Gnq1 & $\mathrm{A} 3$ \\
\hline Gnq2 & $\mathrm{A} 4$ \\
\hline Gnq3 & $\mathrm{B} 1$ \\
\hline Gnq4 & $\mathrm{B} 4$ \\
\hline Gnq5 & $\mathrm{A} 6$ \\
\hline
\end{tabular}

Esta unidade de materiais inconsolidados apresenta um perfil com texturas predominante areno-argilosa com silte e espessuras que variam entre 0,5 e 4,0 metros (Tabela 5.13).

A subunidade ReGnQ 2 apresenta, segundo observações de campo uma textura semelhante a da subunidade ReG nQ1, diferenciando-se desta por apresentar espessuras não superiores a 2,0 metros.

Estes solos exibem variações laterais extremamente bruscas na gradação do perfil de alteração. É comum a ocorrência, em superfície, de rochas alterada exposta junto aos solos residuais bem desenvolvidos, muitas vezes a diferença de cores apresentadas por estas permite denotar 0 contato entre as porções de gnaisse e quartzitos (Figura $5.68 \mathrm{~A}$ e B).

Tabela 5.13. Dados dos ensaios de caracterização realizados em amostras de Materiais Residuais de $\mathrm{G}$ naisses intercalados com Q uartzitos.

\begin{tabular}{|c|c|c|c|c|c|c|c|c|c|c|c|c|}
\hline \multirow{2}{*}{$\begin{array}{l}\text { Subunida- } \\
\text { de }\end{array}$} & \multirow{2}{*}{$\begin{array}{l}\text { Esp. } \\
\text { (m) }\end{array}$} & \multicolumn{4}{|c|}{ Textura } & \multirow{2}{*}{$\begin{array}{l}\text { pdcamp } \\
\left(\mathbf{g} / \mathbf{c m}^{3}\right)\end{array}$} & \multirow{2}{*}{$\begin{array}{c}\rho \mathbf{s} \\
\left(\mathbf{g} / \mathbf{c m}^{3}\right)\end{array}$} & \multirow{2}{*}{$\begin{array}{c}n \\
(\%)\end{array}$} & \multirow[t]{2}{*}{$\mathbf{e}_{0}$} & \multirow{2}{*}{$\begin{array}{c}\text { Erod. } \\
40\end{array}$} & \multirow[t]{2}{*}{ CTC } & \multirow[t]{2}{*}{$\overline{\mathrm{SE}}$} \\
\hline & & $\begin{array}{c}\% \\
\text { Areia } \\
\text { Grossa }\end{array}$ & \begin{tabular}{|c|}
$\%$ \\
Areia \\
Fina
\end{tabular} & $\begin{array}{c}\% \\
\text { Silte }\end{array}$ & $\begin{array}{c}\% \\
\text { Argila }\end{array}$ & & & & & & & \\
\hline ReGnQ1 & $0,5-3$ & 14 & 42 & 14 & 30 & 1,29 & 2,62 & 50 & 1,03 & 14,42 & 5,52 & 43,17 \\
\hline ReGnQ3 & $1-4$ & 13 & 47 & 12 & 28 & 1,26 & 2,61 & 52 & 1,07 & 13,84 & 4,40 & 44,01 \\
\hline ReGnQ4 & $1-2$ & 16 & 49 & 10 & 25 & 1,30 & 2,62 & 50 & 1,01 & 14,61 & 3,55 & 41,35 \\
\hline ReGnQ5 & $0,5-1$ & 12 & 46 & 10 & 32 & 1,40 & 2,62 & 46 & 0,87 & 17,60 & 5,05 & 39,52 \\
\hline Min-Max & $0,5-3$ & 12-16 & \begin{tabular}{|l|}
$42-49$ \\
\end{tabular} & 10-14 & $25-32$ & $1,26-1,40$ & $2,61-2,62$ & 46-52 & $\begin{array}{l}\mathbf{0 , 8 7 -} \\
\mathbf{1 , 0 7}\end{array}$ & $\begin{array}{l}13,84- \\
17,6\end{array}$ & $\begin{array}{l}3,55- \\
5,52\end{array}$ & $\begin{array}{l}39,52 \\
- \\
44,01\end{array}$ \\
\hline
\end{tabular}

De forma menos freqüente, é observada a exposição de pacotes constituídos apenas por solo residual bem desenvolvido (Figura 5. 69). Nestes, por vezes é possível 
observar a presença de fragmentos de feldspatos e micas disseminadas nas porções de solo.

Em outros pontos a espessura do perfil de solo é muito diminuta, ocorrendo quase que a exposição predominante de porções de rochas sã a alterada (Figura 5.70).
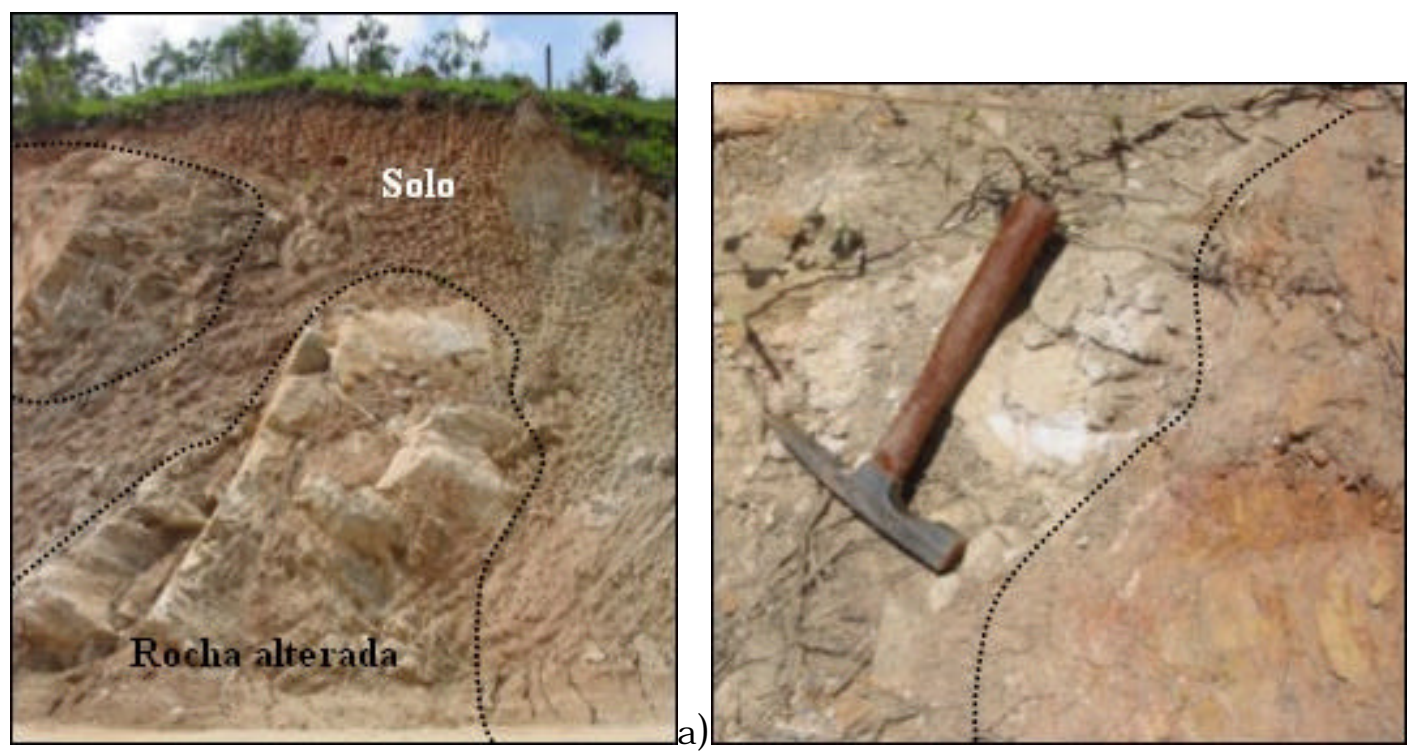

b)

Figura 5.68. A) Exposição de rocha quatzítica e solos residuais de gnaisse intercalados com quartzitos, B) diferença de cores caracterizando porções quartziticas e gnáissicas.

Em observações de campo, constatou-se ser comum a presença de ravinamentos nos perfis de encostas das subunidades destes solos, em especial quando lhes é retirado 0 nível superficial.

Unidade de Materiais Residuais de G naisses intercalados om Rochas Básicas - (ReG nb)

Presentes nas porções da baixa e média bacia, estes solos apresentam grande ocorrência em área e subdividem-se em 11 subunidades, as quais apresentam associação aos Sistemas de landforms A, B, C e D (Tabela 5.14). 


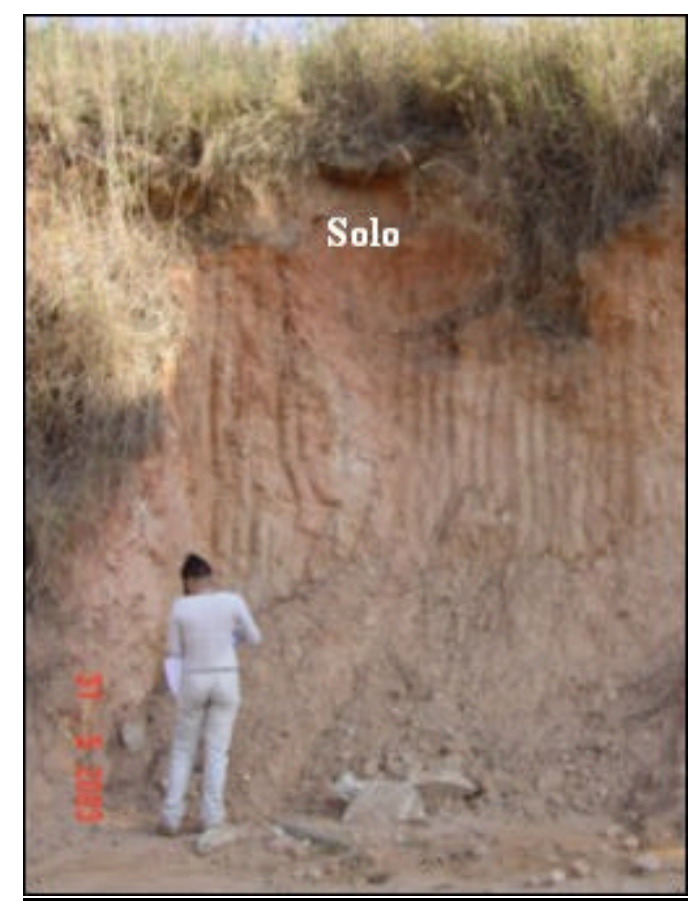

Figura 5.69. Exposição de pacote de solos residuais de gnáissicas intercalados com quatzo.

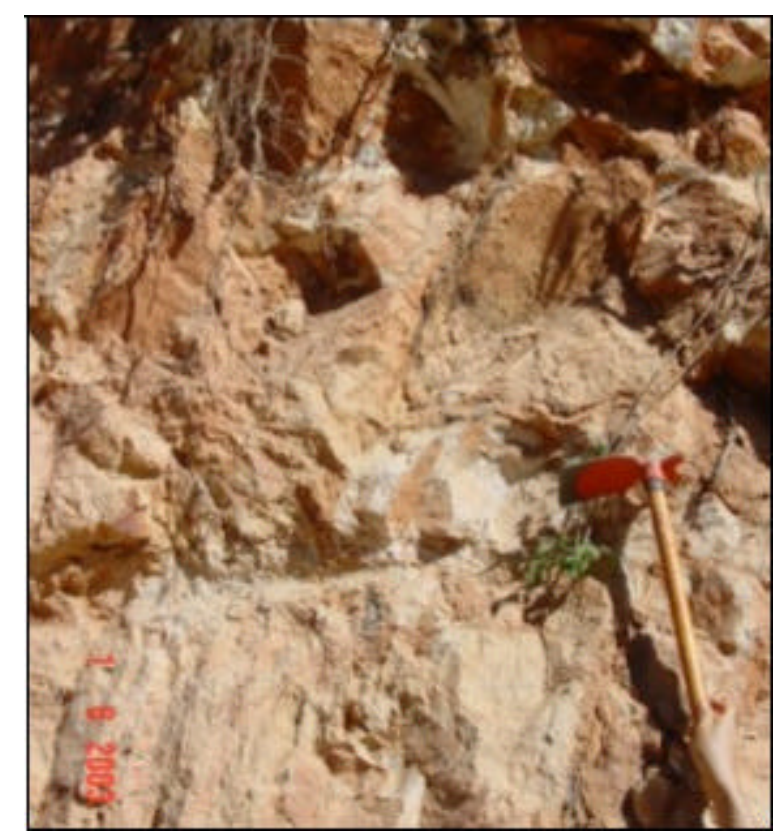

Figura 5.70 Detalhe ocorrência de rocha sã a dterada de gnaisses intercalada com quartzito, sem presença de solos desenvolvidos. 
Tabela 5.14. Correlação entre unidade de materiais inconsolidados residuais de Gnaisses intercalados a rochas básicas e unidade lanforms.

\begin{tabular}{c|c}
\hline $\begin{array}{c}\text { Subunidade Materiais } \\
\text { Inconsolidados }\end{array}$ & $\begin{array}{c}\text { Unidade } \\
\text { Landform }\end{array}$ \\
\hline $\mathrm{Gnb1}$ & $\mathrm{A} 5$ \\
\hline $\mathrm{Gnb2}$ & $\mathrm{A} 7 / \mathrm{A} 5$ \\
\hline $\mathrm{Gnb3}$ & $\mathrm{B} 4$ \\
\hline $\mathrm{Gnb} 4$ & $\mathrm{~B} 5$ \\
\hline $\mathrm{Gnb5}$ & $\mathrm{C} 2$ \\
\hline $\mathrm{Gnb6}$ & $\mathrm{B} 3$ \\
\hline $\mathrm{Gnb7}$ & $\mathrm{C} 1$ \\
\hline $\mathrm{Gnb} 8$ & $\mathrm{C} 4$ \\
\hline $\mathrm{Gnb} 9$ & $\mathrm{~B} 7$ \\
\hline $\mathrm{Gnb} 10$ & $\mathrm{D} 1$ \\
\hline $\mathrm{Gnb} 11$ & $\mathrm{D} 2$ \\
\hline
\end{tabular}

Os materiais desta unidade caracterizam-se por texturas desde argilo-arenosiltosa a areno-siltosa com argila, e espessuras variável entre 0.5 e 6 metros (Tabela 5.15). Nas proximidades do município de Serra Negra os solos desta unidade exibem, espessuras não superiores a $2 \mathrm{~m}$. Apresentam cores que variam de laranja a vermelho, com predomínio de tons escuros.

Os solos das subunidades ReGnb3, ReGnb4, ReGnb6 e ReGnb7, segundo análise visual tátil e observações de campo, caractenizam-se por apresentarem uma textura siltosa, assemelhando-se ao solo ReGnb5 que apresenta textura silto-arenosa. A diferença entre estes solos é determinada pelas variações de valores de espessura, que nos ReG nb5 chega a alcançar mais de 4 metros, e nas outras unidades variam entre 1 e 3 metros.

Normalmente, o perfil de alteração desta unidade não expõe a rocha sã, sendo comum, ora a ocorrência apenas de solos bem desenvolvido em superfície (Figura 5.71), ora a ocorrência da rocha original em estágio de elevada alteração envolto por massa de solo (Figura 5.72).

Tabela 5.15 Dados dos ensaios de caracterização realizados em amostra de Materiais Residuais de $\mathrm{G}$ naisses intercalados Rochas Básicas.

\begin{tabular}{|c|c|c|c|c|c|c|c|c|c|c|c|c|}
\hline \multirow[t]{2}{*}{ Subunidade } & \multirow{2}{*}{$\begin{array}{c}\text { Esp. } \\
\text { (m) }\end{array}$} & \multicolumn{4}{|c|}{ Textura } & \multirow{2}{*}{$\begin{array}{l}\text { pdcamp } \\
\left(\mathrm{g} / \mathrm{cm}^{3}\right)\end{array}$} & \multirow{2}{*}{$\begin{array}{c}\rho s \\
\left(\mathbf{g} / \mathbf{c m}^{3}\right)\end{array}$} & \multirow{2}{*}{$\begin{array}{c}\mathrm{n} \\
(\%)\end{array}$} & \multirow[t]{2}{*}{$\overline{\mathbf{e}_{\mathbf{o}}}$} & \multirow{2}{*}{$\begin{array}{c}\text { Erod } \\
40\end{array}$} & \multirow[t]{2}{*}{ CTC } & \multirow[t]{2}{*}{$\mathrm{SE}$} \\
\hline & & $\begin{array}{c}\% \\
\text { Areia } \\
\text { Grossa }\end{array}$ & $\begin{array}{c}\% \\
\text { Areia } \\
\text { Fina }\end{array}$ & $\begin{array}{c}\% \% \\
\text { Silte }\end{array}$ & $\begin{array}{c}\% \\
\text { Argila }\end{array}$ & & & & & & & \\
\hline$\overline{R e G n B 1}$ & $0,5-5$ & 7 & 20 & 19 & 54 & 1,29 & 2,66 & 51 & 1,06 & 38,12 & 5,42 & 36,42 \\
\hline ReGnB2 & $0,5-5$ & 5 & 23 & 11 & 61 & 1,34 & 2,63 & 49 & 0,96 & 34,87 & 6,95 & 42,52 \\
\hline ReGnB5 & $1-6$ & 17 & 24 & 48 & 11 & 1,28 & 2,62 & 51 & 1,04 & 1,78 & 5,84 & 45,71 \\
\hline ReGnB8 & $1-6$ & 8 & 52 & 31 & 09 & 1,29 & 2,63 & 51 & 1,04 & 0,74 & 3,15 & 24,65 \\
\hline ReGnB9 & $>4$ & 06 & 12 & 26 & 56 & 1,13 & 2,61 & 56 & 1,31 & 34,64 & 4,28 & 33,52 \\
\hline ReGnB10 & $>4$ & 15 & 49 & 28 & 8 & 1,09 & 2,63 & 53 & 1,14 & 0,67 & 5,84 & 45,71 \\
\hline ReGnB11 & $>4$ & 08 & 10 & 19 & 63 & 1,23 & 2,63 & 58 & 1,21 & 5,86 & 6,95 & 40,65 \\
\hline Min-Med & $0,5-6$ & 05-15 & $10-52$ & $\begin{array}{l}\text { 11- } \\
48\end{array}$ & 08-63 & $1,09-1,34$ & $2,61-2,6$ & $49-58$ & $\begin{array}{l}0,96- \\
1,41\end{array}$ & $\begin{array}{l}0,67- \\
38,12\end{array}$ & $\begin{array}{l}\text { 3,15- } \\
6,95\end{array}$ & $\begin{array}{l}24,65- \\
45,71\end{array}$ \\
\hline
\end{tabular}


Nos pontos onde é constatada a ocorrência de solo e rocha alterada, é comum observar exposição de eventuais pseudomorfos de feldspato e elevada concentração de biotitas. As variações de cores apresentadas pelas rochas alteradas permitem identificar a alternância de bandas características da rocha original. Bandas ricas em quartzo e feldspato exibem cores rosas e branco, bandas ricas em biotita caracterizam-se por apresentar cores laranja e vermelho escuro (Figura $5.73 \mathrm{~A} \mathrm{e} \mathrm{B).}$

Veios de quartzo com espessura normalmente entre 10 e $15 \mathrm{~cm}$, dispostos paralelamente a superfície do terreno, são freqüentemente observados nestes solos (Figura 5.74).

Figura 5. 71. Afloramento de solos residuais de Gnaisses intercalados com rochas básicas. 


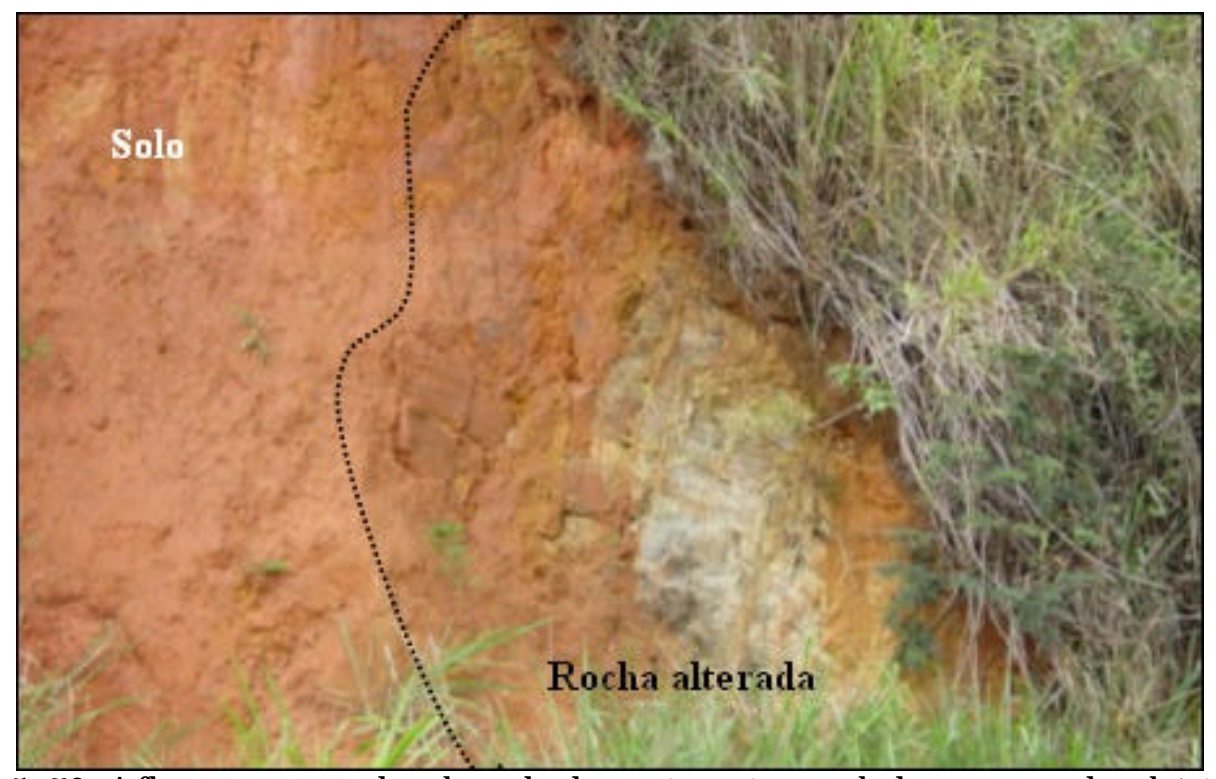

Figura 5. 72. Afloramento rocha alterada de gnaisses intercalados com rochas básicas em envolta em massa de solo.
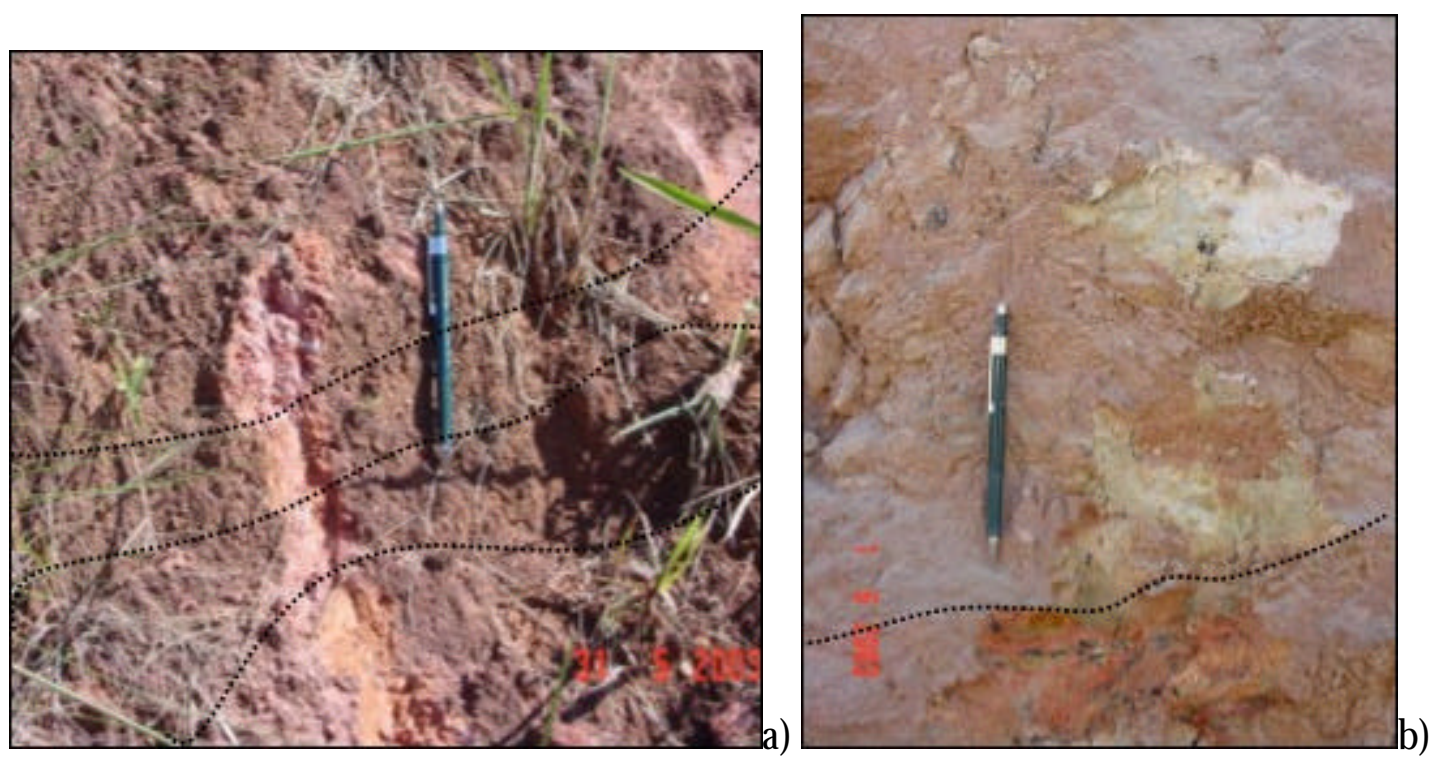

Figura 5. 73 A e B. Exemplos da ocorrência de variações de cores em gnaisses intercalados com rochas básicas alterados, delimitando alternância de bandas mais ricas em quartzo e feldspato, e ricas em biotitas. 


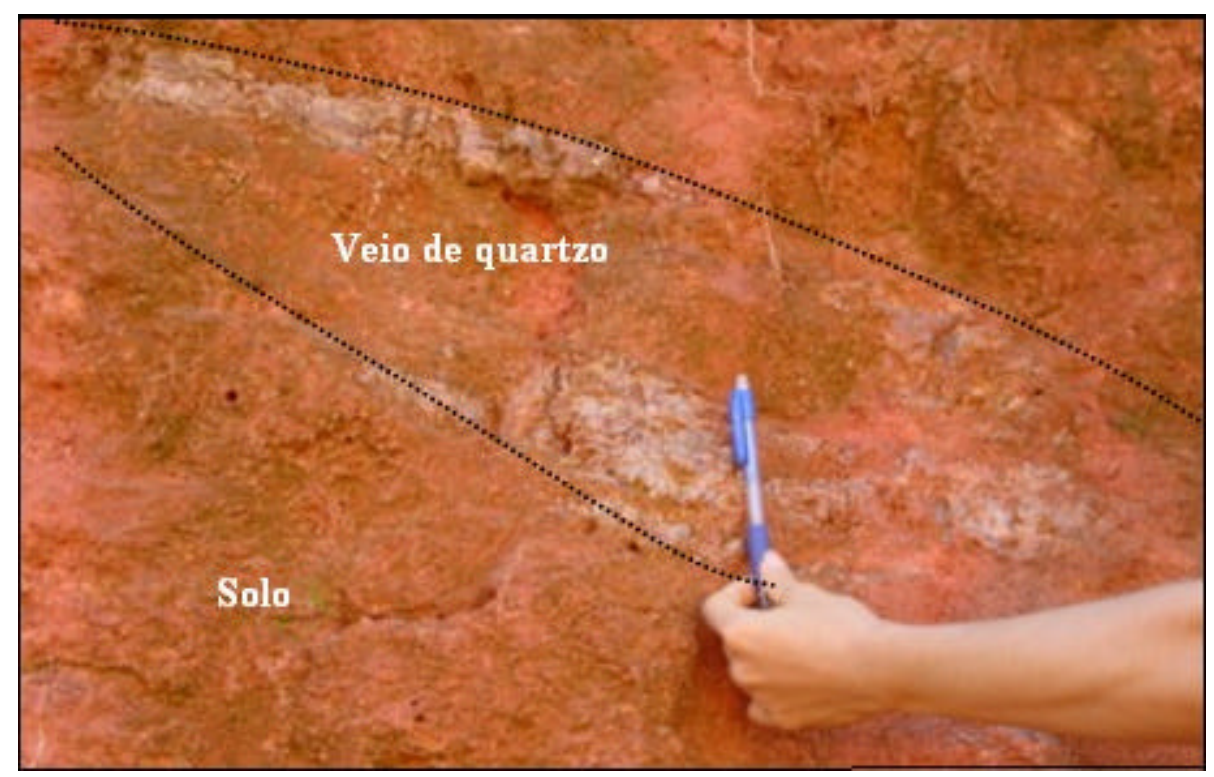

Figura 5.74 Veio de quartzo disposto em meio a massa de solo de gnaisses intercalados com rochas básicas.

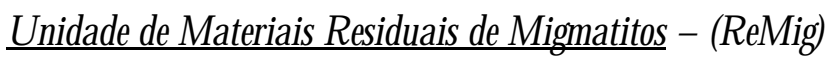

Presentes nas porções entre média e baixa bacia e na área da cabeceira da bacia, apresentam correlação com os Sistemas de landforms B, C e E (Tabela 5.16). os solos desta unidade subdividem-se em nove subunidades.

Tabela 5.16 Correlação entre unidade residuais de materiais inconsolidados de migmatitos e unidade lanforms.

\begin{tabular}{c|c}
\hline $\begin{array}{c}\text { Subunidade Materiais } \\
\text { Inconsolidados }\end{array}$ & $\begin{array}{c}\text { Unidade } \\
\text { Landform }\end{array}$ \\
\hline Mig1 & B4/ B5 \\
\hline Mig2 & B6 \\
\hline Mig3 & E 3 \\
\hline Mig4 & E2 \\
\hline Mig5 & C5 \\
\hline Mig6 & C3 \\
\hline Mig7 & C4 \\
\hline Mig8 & E4 \\
\hline Mig9 & E5 \\
\hline
\end{tabular}

Os materiais desta unidade caracterizam-se por apresentarem texturas que variam entre arenoas a argilosas com espessuras variadas, normalmente entre 3 e 6 metros (Tabela 5.17). 
Tabela 5.17 Dados dos ensaios de caracterização realizados em amostra de Materiais Residuais de Migmatitos.

\begin{tabular}{|c|c|c|c|c|c|c|c|c|c|c|c|c|}
\hline \multirow{2}{*}{$\begin{array}{l}\text { Subunida- } \\
\text { de }\end{array}$} & \multirow{2}{*}{$\begin{array}{c}\text { Esp. } \\
\text { (m) }\end{array}$} & \multicolumn{4}{|c|}{ Textura } & \multirow{2}{*}{$\begin{array}{c}\text { pdcam } \\
\left(\mathrm{g} / \mathrm{cm}^{3}\right. \\
)\end{array}$} & \multirow{2}{*}{$\begin{array}{c}\rho s \\
\left(\mathbf{g} / \mathbf{c m}^{3}\right)\end{array}$} & \multirow{2}{*}{$\begin{array}{c}\mathrm{n} \\
(\%)\end{array}$} & \multirow[t]{2}{*}{$\overline{\mathbf{e}_{0}}$} & \multirow{2}{*}{$\begin{array}{c}\text { Erod. } \\
\mathbf{4 0}\end{array}$} & \multirow[t]{2}{*}{ CTC } & \multirow[t]{2}{*}{$\mathrm{SE}$} \\
\hline & & $\begin{array}{c}\% \\
\text { Areia } \\
\text { Grossa }\end{array}$ & $\begin{array}{c}\% \% \\
\text { Areia } \\
\text { Fina }\end{array}$ & \begin{tabular}{|c|}
$\%$ \\
Silte
\end{tabular} & $\begin{array}{c}\% \% \\
\text { Argila }\end{array}$ & & & & & & & \\
\hline ReMig2 & $0,5-6$ & 8 & 17 & 27 & 48 & 1,40 & 2,61 & 46 & 0,86 & 93,77 & 8,56 & 31,25 \\
\hline ReMig3 & $1-8$ & 8 & 20 & 52 & 20 & 1,39 & 2,63 & 47 & 0,89 & 87,98 & 7,86 & 23,45 \\
\hline ReMig4 & $1-10$ & 6 & 21 & 54 & 19 & 1,38 & 2,63 & 47 & 0,90 & 70,42 & 7,79 & 32,94 \\
\hline ReMig5 & $1-3$ & 8 & 29 & 7 & 56 & 1,52 & 2,58 & 41 & 0,69 & 13,49 & 9,43 & 45,13 \\
\hline ReMig6 & $1-2$ & 4 & 16 & 28 & 52 & 1,18 & 2,65 & 55 & 1,24 & 424,77 & 8,43 & 38,32 \\
\hline ReMig7 & $0,5-3$ & 8 & 15 & 23 & 54 & 1,17 & 2,63 & 55 & 1,24 & 367,73 & 9,89 & 47,21 \\
\hline ReMig8 & $1,5-3$ & 10 & 13 & 19 & 58 & 1,28 & 2,61 & 50 & 1,03 & 65,09 & 9,35 & 40,57 \\
\hline ReMig9 & $1,5-3$ & 16 & 44 & 28 & 12 & 1,52 & 2,62 & 42 & 0,72 & 4,98 & 5,19 & 21,17 \\
\hline Max-Min & $\begin{array}{l}0,5- \\
10\end{array}$ & 04-16 & $16-44$ & \begin{tabular}{|c|}
$07-52$ \\
\end{tabular} & $12-58$ & $\begin{array}{l}1,28- \\
1,52\end{array}$ & $2,58-2,63$ & 41-55 & $\begin{array}{l}0,69- \\
1,24\end{array}$ & $\begin{array}{l}4,98- \\
93,77\end{array}$ & $\begin{array}{l}5,19- \\
9,89\end{array}$ & $\begin{array}{l}21,17 \\
- \\
47,21\end{array}$ \\
\hline
\end{tabular}

Os solos da subunidade ReMig1, mediante observações de campo, são caracterizados por apresentar textura siltosos, semelhante aos solos das subunidades ReMig3 e ReMig4, e espessuras que podem chegar a 8 metros.

Os perfis de alteração destas unidades são, em geral, muito espessos e exibem tonalidades predominantemente rosas e laranjas médios e vermelhos escuros (Figura 5.75 A e B). Apresentam intercalações de níveis e bolsões com elevada concentração de biotita e elevadas concentrações em k-feldspato, o que confere a alguns perfis de solos diferenças de tonalidade, que delimitam bem estes bolsões (Figura 5.76). A ocorrência de blocos inalterados em meio ao solo se da de forma eventual. Freqüentes são as ocorrências de veios de quartzo de orientações variadas em meio ao solo superficial.

Em alguns locais onde a foliação da rocha original apresenta-se verticalizada, e a cobertura original de vegetação foi retirada é comum a ocorrência de movimentos gravitacionais de massa, creeping (Figura 5.77). 


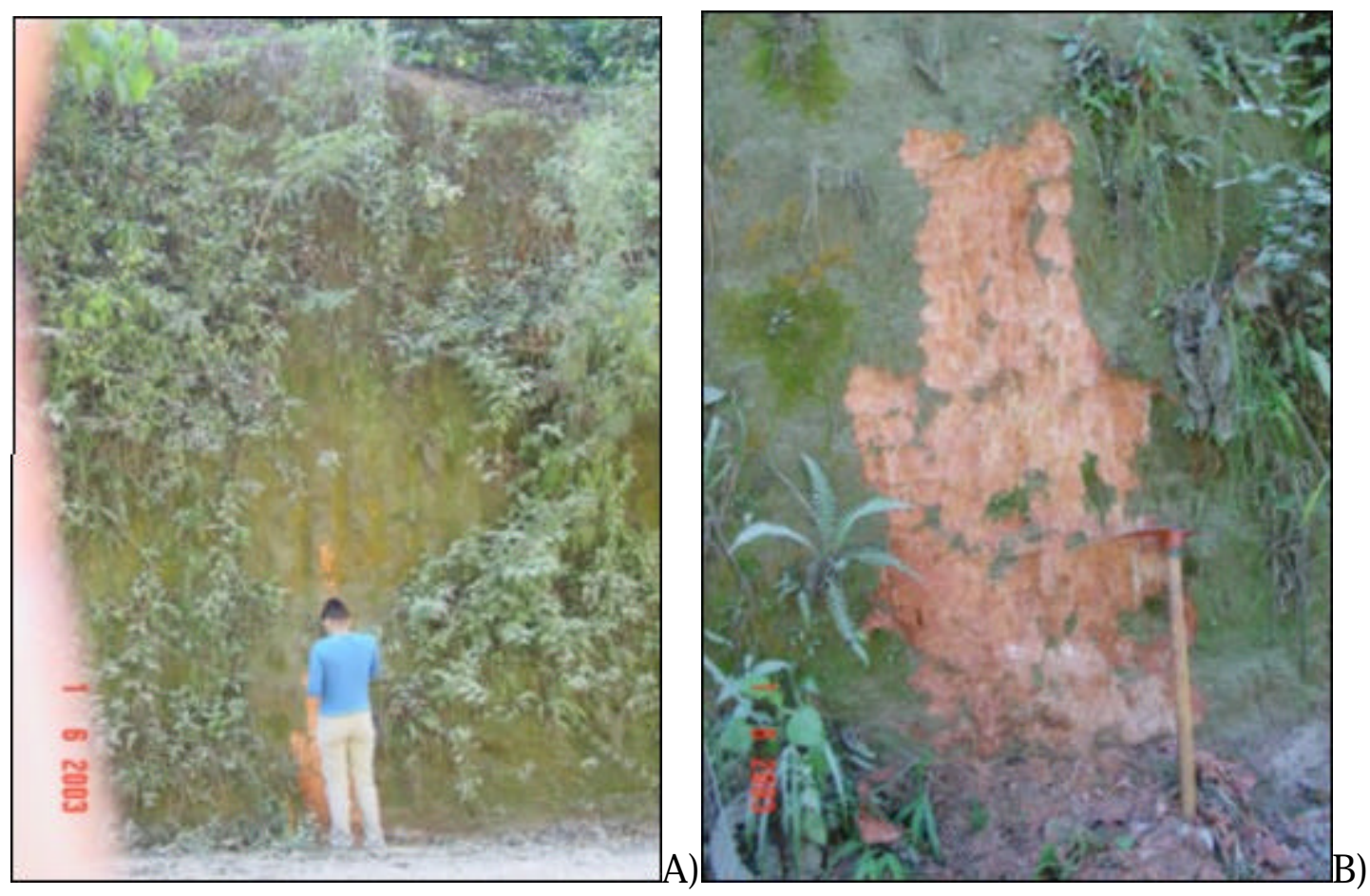

Figura 5. 75 A) Afloramento de solos de migmatitos bem desenvolvidos. B). D etalhe da predominância de tons laranjas.

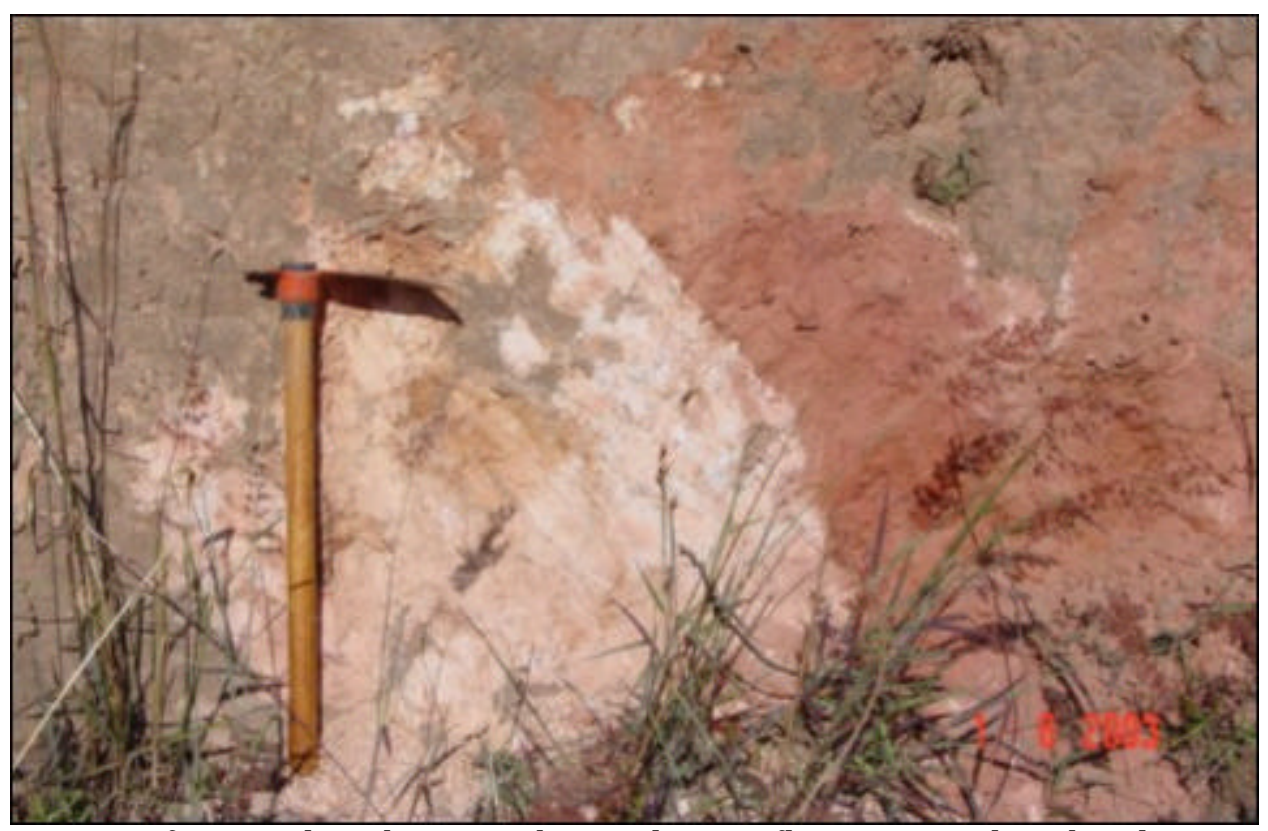

Figura 5.76 Diferença de coloração observada em afloramentos de solos de migmatito resultante das diferenças de concentração mineralógica da rocha. 


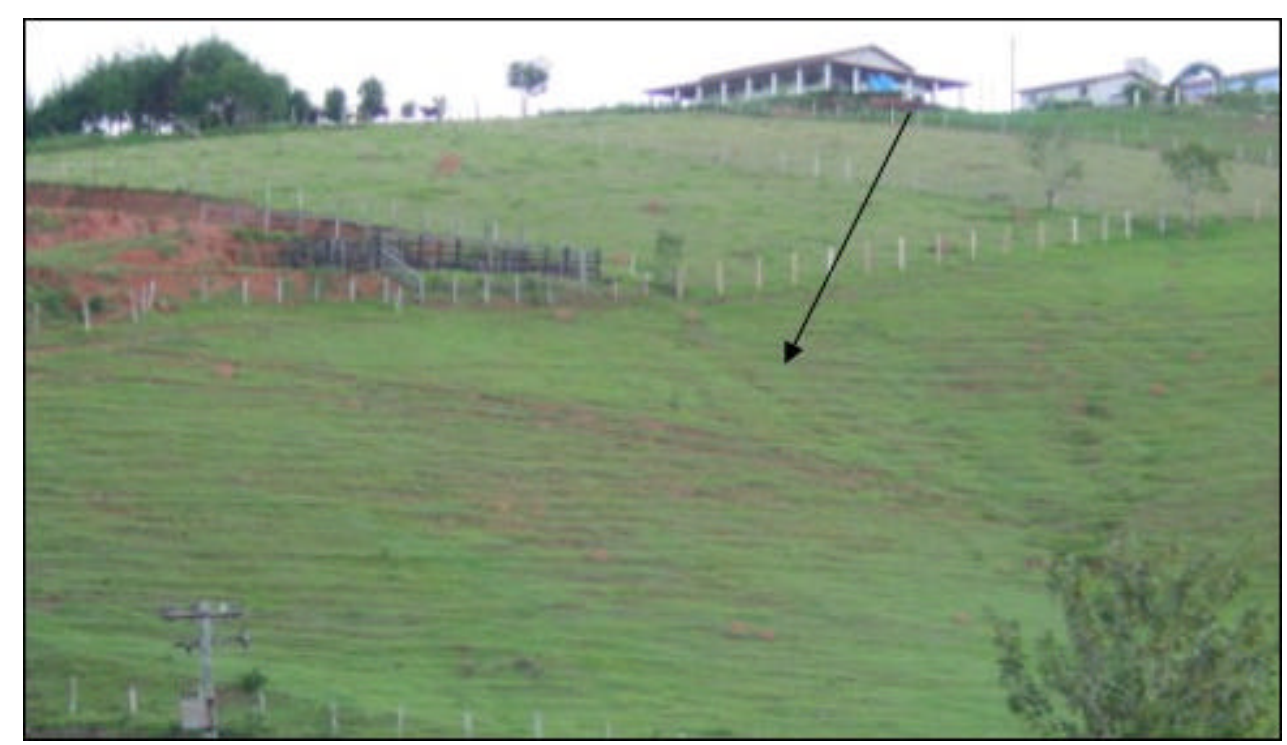

Figura 5. 77 Movimentos de massa gravitacional tipo creeping, comum em solos de migmatito que apresentam foliação verticalizada e vegetação original removida.

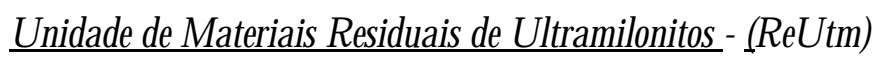

Localizados na porção da média bacia, junto as zonas de falha de Monte Sião e Ibitinga, os solos desta unidade apresentam correlação com os Sistemas de landforms $\mathrm{C}$ e D (Tabela 5.18), e subdividem-se em seis subunidades.

Tabela 5.18 Correlação entre unidade de materiais inconsolidados residuais de ultramilonitos e unidade lanforms.

\begin{tabular}{c|c}
\hline $\begin{array}{c}\text { Subunidade Materiais } \\
\text { Inconsolidados }\end{array}$ & $\begin{array}{c}\text { Unidade } \\
\text { Landform }\end{array}$ \\
\hline Utm1 & D1 \\
\hline Utm2 & D3 \\
\hline Utm3 & D3 \\
\hline Utm4 & D7 \\
\hline Utm5 & D8 \\
\hline Utm6 & C4 \\
\hline
\end{tabular}

Apresentam perfis de solo caracterizados por grande heterogeneidade, com variações laterais bruscas, denotada pela coexistência lado a lado de níveis inalterados de rochas diversas milonitizadas, sem capeamento de solo, com níveis completamente alterados e solos bem desenvolvidos (Figura 5.78 A, B e C). Esta heterogeneidade é bem caracterizada em campo pela grande variabilidade de cores de alteração presentes em um único afloramento. Os solos desta unidade apresentam textura que variam entre silto- 
areno-argilosa e areno-siltosa com argila e espessuras que chegam até a 8 metros (Tabela 5.19).
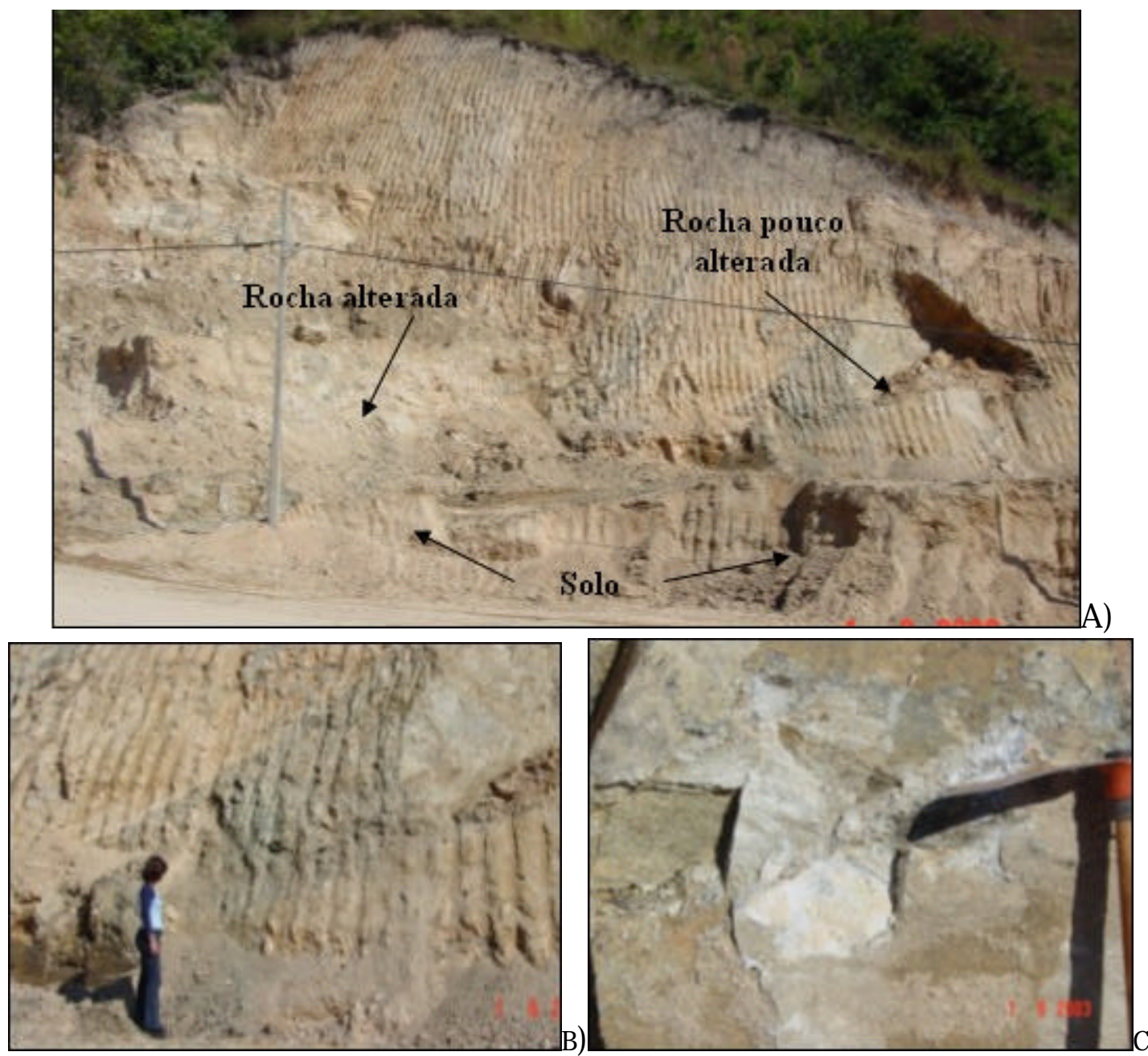

Figura 5.78 A) Afloramento de solos de ultramilonitos caracterizado pela ocorrência de intercalações de pacotes de solo e rochas pouco a muito alteradas B e C) Detalhe de porções pouco alteradas envoltas na massa de solo.

Tabela 5.19 Dados dos ensaios de caracterização realizados em amostra de Materiais Residuais de Ultramilonitos.

\begin{tabular}{|c|c|c|c|c|c|c|c|c|c|c|c|c|}
\hline \multirow{2}{*}{$\begin{array}{l}\text { Subuinda- } \\
\text { de }\end{array}$} & \multirow{2}{*}{$\begin{array}{l}\text { Esp. } \\
\text { (m) }\end{array}$} & \multicolumn{4}{|c|}{ Textura } & \multirow{2}{*}{$\begin{array}{l}\text { pdcamp } \\
\left(\mathbf{g} / \mathbf{c m}^{3}\right)\end{array}$} & \multirow{2}{*}{$\begin{array}{c}\rho \mathbf{s} \\
\left(\mathbf{g} / \mathbf{c m}^{3}\right)\end{array}$} & \multirow{2}{*}{$\begin{array}{c}\mathrm{n} \\
(\%)\end{array}$} & \multirow{2}{*}{$\mathbf{e}_{0}$} & \multirow{2}{*}{$\begin{array}{c}\text { Erod } \\
\dot{40}\end{array}$} & \multirow{2}{*}{\begin{tabular}{|l|l} 
CTC \\
\end{tabular}} & \multirow{2}{*}{$\mathrm{SE}$} \\
\hline & & $\begin{array}{c}\% \\
\text { Areia } \\
\text { Grossa }\end{array}$ & $\begin{array}{c}\% \\
\text { Areia } \\
\text { Fina }\end{array}$ & \begin{tabular}{|c|}
$\%$ \\
Silte
\end{tabular} & $\begin{array}{c}\% \\
\text { Argila }\end{array}$ & & & & & & & \\
\hline ReUtm3 & $1-6$ & 15 & 17 & 52 & 16 & 1,53 & 2,63 & \begin{tabular}{|l|}
48 \\
\end{tabular} & \begin{tabular}{|l|}
0,77 \\
\end{tabular} & \begin{tabular}{|l|}
0,56 \\
\end{tabular} & 8,40 & 60,31 \\
\hline ReUtm4 & $1-8$ & 18 & 46 & 28 & 8 & 1,48 & 2,65 & 44 & \begin{tabular}{|l|}
0,79 \\
\end{tabular} & 0,43 & \begin{tabular}{|l|}
8,36 \\
\end{tabular} & 68,25 \\
\hline \begin{tabular}{|l|} 
ReUtm5 \\
\end{tabular} & $1-8$ & 14 & 20 & 48 & 18 & 1,52 & 2,65 & 45 & \begin{tabular}{|l|}
0,74 \\
\end{tabular} & \begin{tabular}{|l|l|}
0,99 \\
\end{tabular} & \begin{tabular}{|l|}
7,86 \\
\end{tabular} & 53,45 \\
\hline ReUtm6 & $1-4$ & 25 & 16 & 50 & 9 & 1,39 & 2,63 & \begin{tabular}{|l|}
47 \\
\end{tabular} & 0,89 & 0,94 & 8,29 & 58,42 \\
\hline \begin{tabular}{|l} 
Min-Max \\
\end{tabular} & $1-8$ & $14-25$ & $16-46$ & \begin{tabular}{|l|}
$28-52$ \\
\end{tabular} & 08-18 & $1,39-1,53$ & $2,63-2,65$ & \begin{tabular}{|l|}
$45-48$ \\
\end{tabular} & $\begin{array}{l}0,74 \\
0,89\end{array}$ & $\begin{array}{l}0,43- \\
0,99\end{array}$ & \begin{tabular}{|l|}
$7,86-$ \\
8,4
\end{tabular} & $\begin{array}{l}53,45 \\
- \\
68,25\end{array}$ \\
\hline
\end{tabular}


As subunidades ReUtm1 e ReUtm2, caracterizam-se por apresentar, segundo observações feitas em campo espessuras de solo que variam entre 1 - 3 e 1 - 2 metros, respectivamente. Ambas apresentam texturas silto-arenosas como as subunidades ReUtm5 e ReUtm6.

O s solos desta unidade apresentam alta erodibilidade.

Unidade de M ateriais Residuais de Blastomilonitos - (ReBtm)

Localizadas entre a porção da média e alta bacia, estes solos subdividem-se em cinco subunidades, e correlacionam-se aos Sistemas delandforms E e D (Tabela 5.20).

De uma maneira geral, os perfis de solo desta unidade apresentam as mesmas características dos solos ReUtm. G rande heterogeneidade denotada pela variabilidade de intercalações de porções de solo com rochas alteradas (Figura 5.79 A e B). A diferença os solos das duas unidades é relação de espessuras dos perfis, as quais chegam a seis metros, e um menor grau de deformação das porções de rochas presentes e colorações predominantemente mais claras.

Tabela 5.20 Correlação entre unidade de materiais inconsolidados residuais de Blastomilonitos e unidade lanforms.

\begin{tabular}{c|c}
\hline $\begin{array}{c}\text { Subunidade Materiais } \\
\text { Inconsolidados }\end{array}$ & $\begin{array}{c}\text { Unidade } \\
\text { Landform }\end{array}$ \\
\hline Btm1 & E2 \\
\hline Btm2 & D3E1/ D 5 \\
\hline Btm3 & D3D 4 \\
\hline Btm4 & D 7D 10 \\
\hline Btm5 & D 8D 9 \\
\hline
\end{tabular}

Caracterizam-se por apresentarem texturas que variam entre silto-arenosas com argila e areno-siltosas com argila e por espessuras entre 0,5 e 4 metros. Assim como os solos ReUtm, também apresentam alta erodibilidade (Tabela 5.21). 

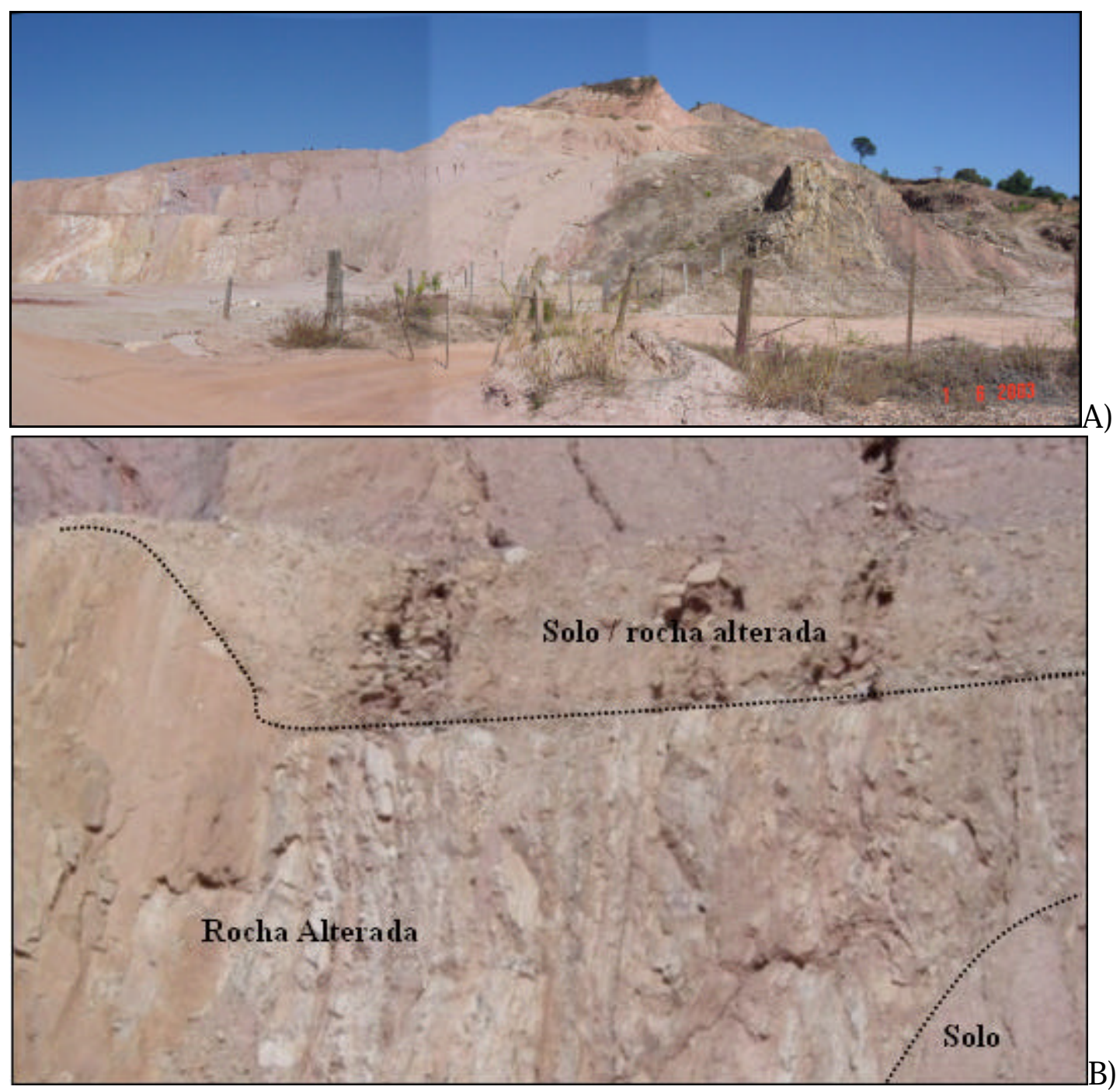

Figura 5.79 A) Afloramento de solos de Blastomilonitos B).D etalhe da ocorrência de rocha alterada ladeada por solo residual.

Tabela 5.21 Dados dos ensaios de caracterização realizados em amostra de Materiais Residuais de Blastomilonitos.

\begin{tabular}{|c|c|c|c|c|c|c|c|c|c|c|c|c|}
\hline \multirow{2}{*}{$\begin{array}{l}\text { Subuinda- } \\
\text { de }\end{array}$} & \multirow{2}{*}{$\begin{array}{c}\text { Esp. } \\
\text { (m) }\end{array}$} & \multicolumn{4}{|c|}{ Textura } & \multirow{2}{*}{$\begin{array}{l}\text { pdcamp } \\
\left(\mathbf{g} / \mathbf{c m}^{3}\right)\end{array}$} & \multirow{2}{*}{$\begin{array}{c}\rho \mathbf{s} \\
\left(\mathbf{g} / \mathbf{c m}^{3}\right)\end{array}$} & \multirow{2}{*}{$\begin{array}{c}\mathrm{n} \\
(\%)\end{array}$} & \multirow[t]{2}{*}{$\mathbf{e}_{\mathbf{o}}$} & \multirow{2}{*}{$\underset{\mathbf{4 0}}{\text { E rod. }}$} & \multirow[t]{2}{*}{ CTC } & \multirow[t]{2}{*}{$\overline{\mathrm{SE}}$} \\
\hline & & $\begin{array}{c}\% \\
\text { Areia } \\
\text { Grossa }\end{array}$ & $\begin{array}{c}\% \\
\text { Areia } \\
\text { Fina }\end{array}$ & \begin{tabular}{|c|}
$\%$ \\
Silte
\end{tabular} & $\begin{array}{c}\% \\
\text { Argila }\end{array}$ & & & & & & & \\
\hline ReBtm1 & $\begin{array}{l}0,5- \\
1,50\end{array}$ & 8 & 42 & 37 & 13 & 1,56 & 2,62 & 55 & 0,74 & 0,83 & 2,31 & 17,24 \\
\hline ReBtm2 & $1-3.5$ & 10 & 28 & 45 & 17 & 1,52 & 2,63 & 43 & 0,73 & 0,91 & 3,42 & 21,36 \\
\hline ReBtm4 & $1-4$ & 10 & 23 & 52 & 15 & 1,41 & 2,63 & 46 & 0,86 & 0,94 & 4,43 & 35,28 \\
\hline Min-Max & $1-4$ & 08-10 & \begin{tabular}{|l|}
$23-42$ \\
\end{tabular} & $45-52$ & 13-17 & $1,41-1,56$ & $2,62-2,63$ & 43-55 & $\begin{array}{l}0,73- \\
0,86\end{array}$ & $\begin{array}{l}0,83- \\
0,94\end{array}$ & $\begin{array}{l}2,31- \\
4,43\end{array}$ & $\begin{array}{l}17,24 \\
- \\
35,28\end{array}$ \\
\hline
\end{tabular}

As subunidades ReBtm3 e ReBtm5, segundo observações em campo, caracterizam-se por apresentarem espessuras que variam entre 1,0-2,0 e 0,5-2,0 metros, respectivamente. As texturas dos solos destas unidades assemelham-se as texturas siltosas com pouca areia das subunidades ReBtm2 e ReBtm4. 


\subsection{MAPA DE USO E OCUPAÇÃO DO TERRENO (ANEXO V)}

O mapa de uso e ocupação pode ser caracterizado como um documento cartográfico que retrata a disposição espacial das atividades existentes no meio físico, para um intervalo de tempo definido (Amorim, 2003; Collares, 2001).

A obtenção deste documento dá-se por meio da interpretação de dados orbitais de sensores remotos, imagens de satélite e fotografias aéreas, e por trabalhos de campo. Para a obtenção das características de uso e ocupação do meio físico da Bacia Hidrográfica do Rio do Peixe utilizou-se como fonte de informações Imagem de Satélite Landsat ETM7,a qual foi processada no software ENVI® 3.6. (E nviromental V isualization Image).

\subsection{1 - Procedimentos E mpregados}

Para interpretação e obtenção deste documento foram utilizadas técnicas de geoprocessamento, processamento digital de imagem de satélite, as quais compreenderam manipulação numérica dos dados extraídos da imagem, e processamento dos mesmos em três etapas básicas: 1) Pré-processamento; 2) Processamento e 3) Pós-processamento.

As etapas envolvidas na obtenção do Mapa de Uso e O cupação da bacia são apresentadas na Figura 5.80, e descritas a seguir.

\subsubsection{Atividades de Pré-processamento}

Envolve procedimentos que visam assegurar que os dados a serem classificados apresentem uma boa qualidade e representatividade do quadro real vigente no meio, para uma referida data.

Foram executados cinco procedimentos: 1) Aquisição da imagem e seleção de bandas; 2) Delimitação da área em enfoque; 3)Correção geométrica da Imagem; 4) Aplicação de contrate e 5) D elimitação de áreas amostrais de treinamento.

Foi utilizada como fonte de dados a Imagem de Satélite Landsat ETM7, datada de 25/ 05/ 2003, com a composição colorida das bandas 4 , 5 e 3, adequada a obtenção de informações de diferenciação do uso da terra (G uia ENVI 2003). 


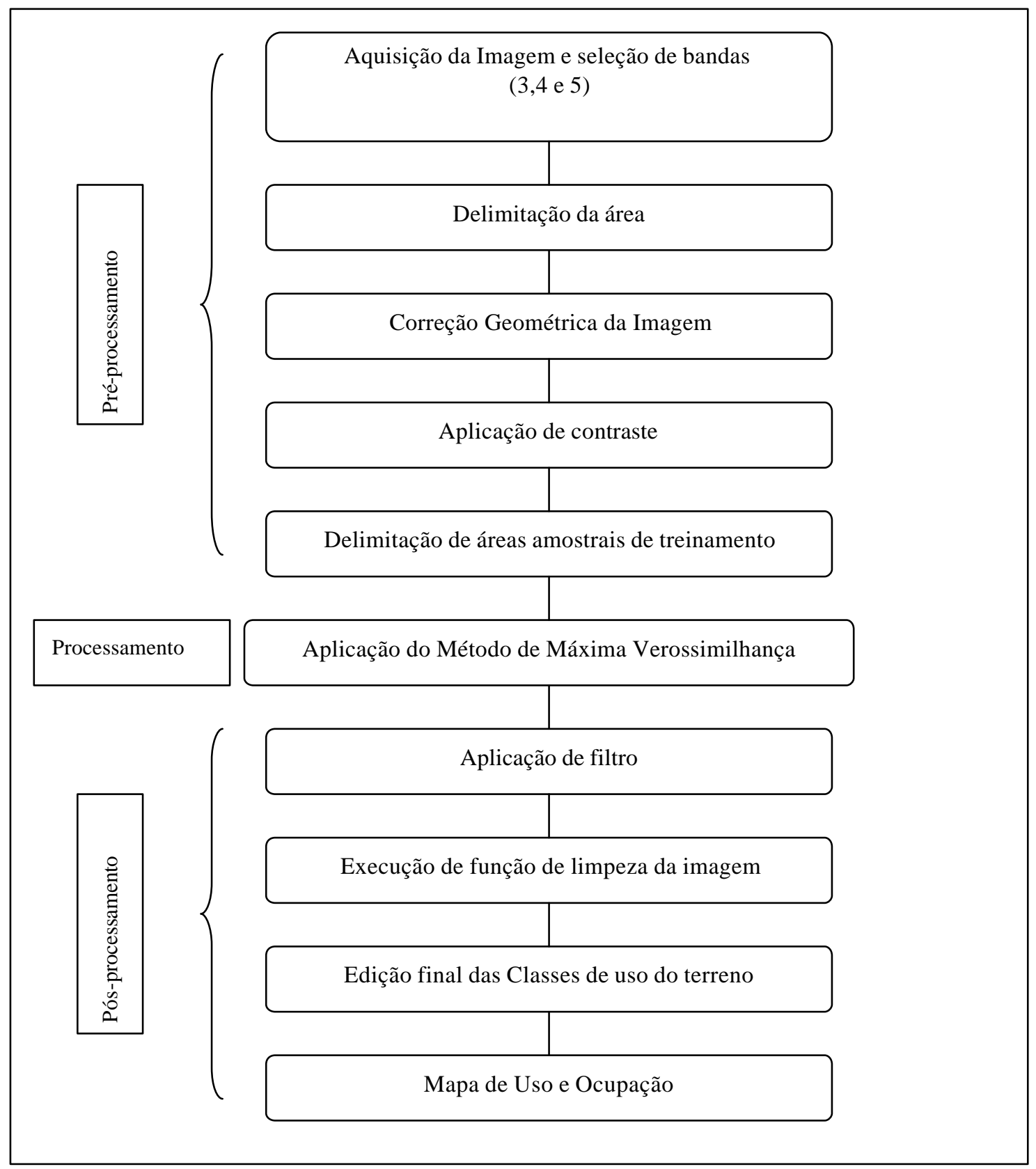

Figura 5.80 - Etapas executadas na obtenção do Mapa de Uso e 0 cupação

O processo de correção geométrica consistiu em georreferenciar a imagem em coordenadas UTM (Universal Transverse Mercator) Córrego Alegre, com base nos mapas topográficos que recobrem a área de pesquisa. Para execução do georreferenciamento foram escolhidos pontos de controle (GCPS - ground ontrol points selection) na imagem e atribuídos aos mesmos os valores de coordenadas UTM das cartas topográficas. 
As amostras de treinamento correspondem a exemplos de atividades de uso e ocupação do terreno, que representam o comportamento médio de cada uma das classes a serem identificadas e mapeadas. Essas são utilizadas pelo sistema para realizar 0 enquadramento de todos os pix els correspondentes a imagem dentre as classes de atividades identificada (Guia ENVI, 2003).

A delimitação das amostras de treinamento foi realizada por meio de atividades de campo nas quais procedeu-se a identificação e determinação de áreas a serem utilizadas como exemplos amostrais. A delimitação destas foi executada com auxílio de fotografias aéreas na escala 1:60.000, mapas topográficos na escala 1:50.000 e um G PS com precisão de 30m. Foram investigadas e demarcadas amostras de treinamento correspondentes aos diferentes tipos de uso e ocupação existentes

Como classes temas das atividades de uso e ocupação vigentes na bacia, foram definidas: 1) Mata Nativa, vegetação de cerrado, 2) Mata Ciliar, presentes ao longo das faixas marginais dos cursos de drenagem; 3) Áreas de pastagem; 4) Áreas de cultivo de café; 5) Áreas de cultivo de cana-de-açúcar; 6) Áreas destinadas a cultivos diversificados (aqui denominada de outras culturas); 7) Áreas de solo exposto, 8) Áreas urbanas, 9) Áreas de reflorestamento; 10) Área de várzea e 11) Corpos d'água (Tabela 5.22). As Figuras 5.81 a 5.89 apresentam exemplos de algumas das classes temáticas identificadas em campo e, a Figura 5.90 (A a J) ilustra exemplos destas classes correspondentes na composição colorida da imagem..

Tabela 5.22 Tipos de uso e ocupação levantados na Bacia do Rio do Peixe para serem utilizados como amostras de treinamento na classificação supervisionada.

\begin{tabular}{l|l}
\hline \multicolumn{1}{c|}{ Tipo de uso e ocupação } & \multicolumn{1}{c}{ Descrição } \\
\hline Area urbana & Cidade e municípios da bacia \\
\hline Cana de açúcar & Área destinada ao cultivo de cana-de-açúcar \\
\hline Café & Área destinada ao cultivo de café \\
\hline O utras culturas & $\begin{array}{l}\text { Áreas destinadas ao cultivo de laranja, batata, milho, } \\
\text { tomate, etc. }\end{array}$ \\
\hline Mata Nativa & Áreas de mata de cerrado preservadas \\
\hline Mata Ciliar & $\begin{array}{l}\text { Áreas de vegetação nativa ao longo das margens dos } \\
\text { rios. }\end{array}$ \\
\hline Reflorestamento & Área com ocorrência de Eucaliptos \\
\hline Pastagem / capoeira & Área de pastagem e capoeira \\
\hline Área de várzea & Área de várzea do Rio do Peixe \\
\hline Corpos d'água & Lagos ou represas \\
\hline Solo exposto & $\begin{array}{l}\text { Área com solo descoberto para área de empréstimo, } \\
\text { disposição de lixo, ou apenas sem cobertura vegetal. }\end{array}$ \\
\hline
\end{tabular}


$\mathrm{Na}$ classe temática mata nativa, foram englobadas as ocorrências de mata nativa muito fechada a mata nativa pouco densa, esparsas.

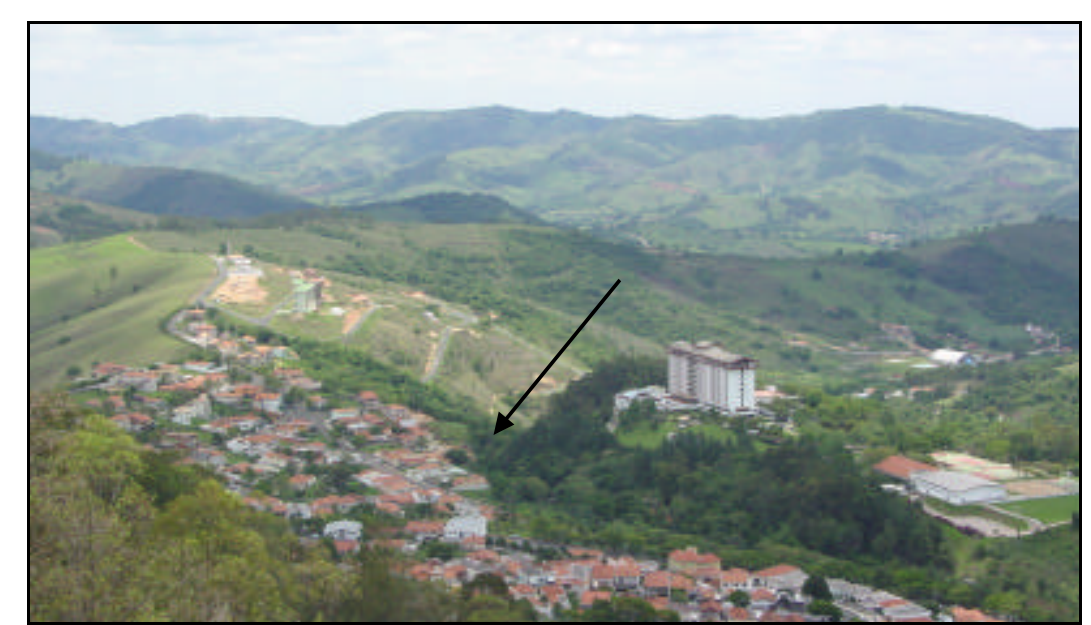

Figura 5.81 - Exemplo de ocorrência em campo da classe temática área urbana.

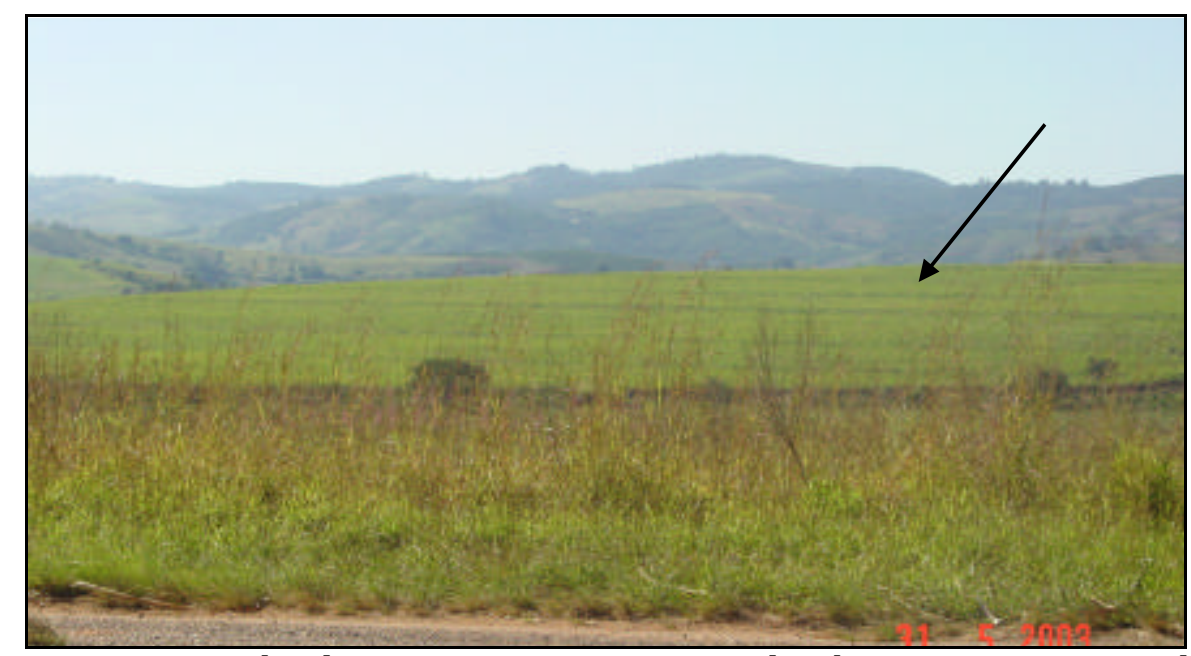

Figura 5.82 - Exemplo de ocorrência em campo da classe temática cana-de-açúcar estágio de crescimento. 


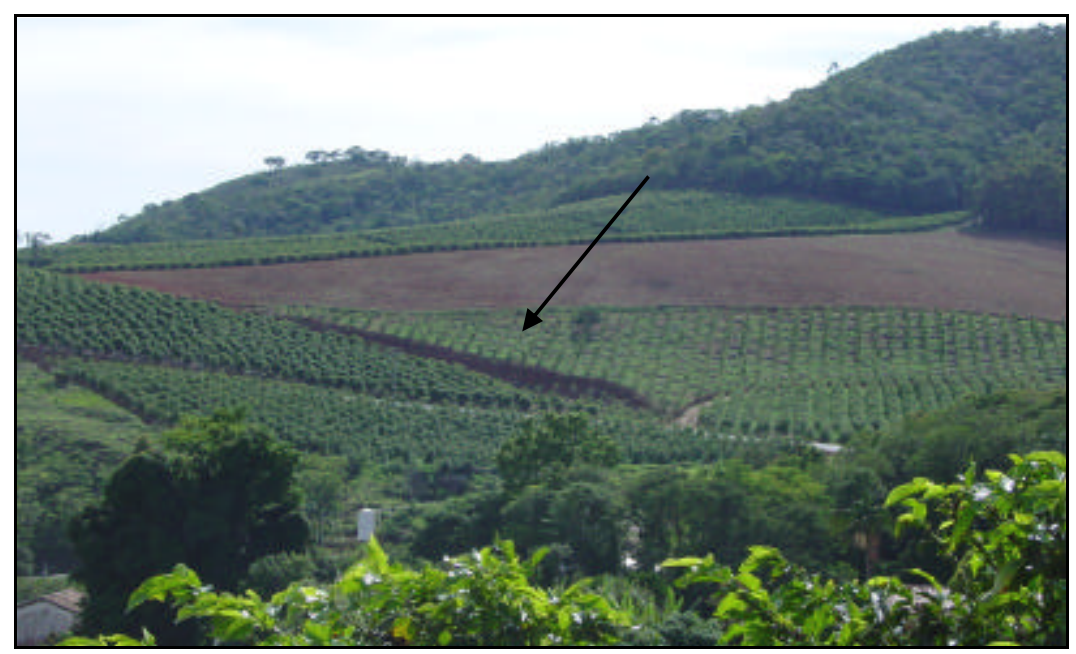

Figura 5.83 - Exemplo de ocorrência em campo da classe temática café.

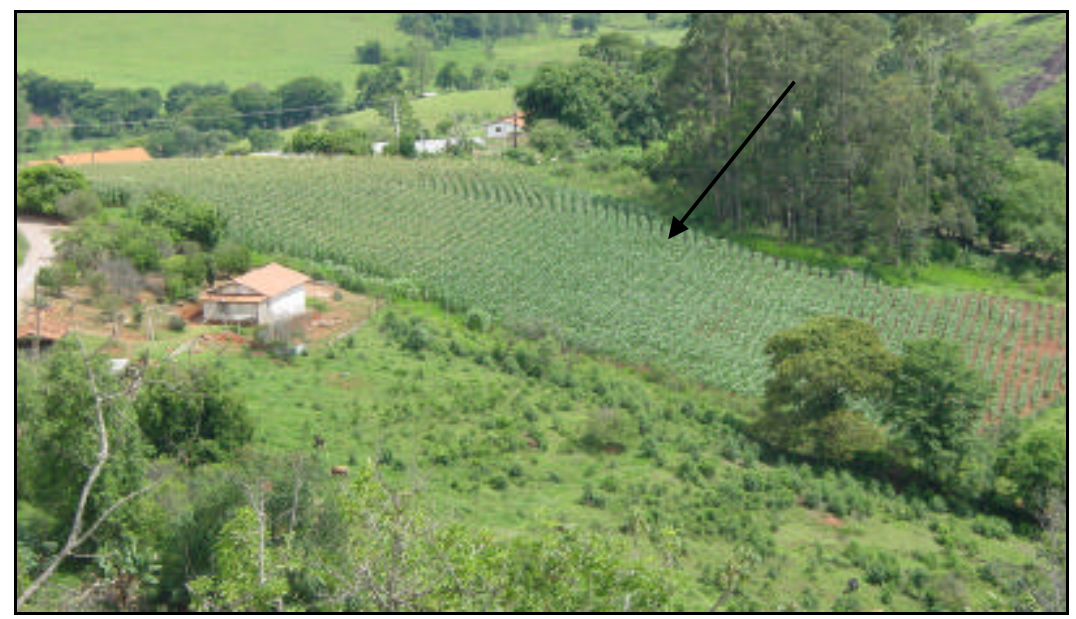

Figura 5.84 - Exemplo de ocorrência em campo da classe temática outras culturas (exemplo milho).
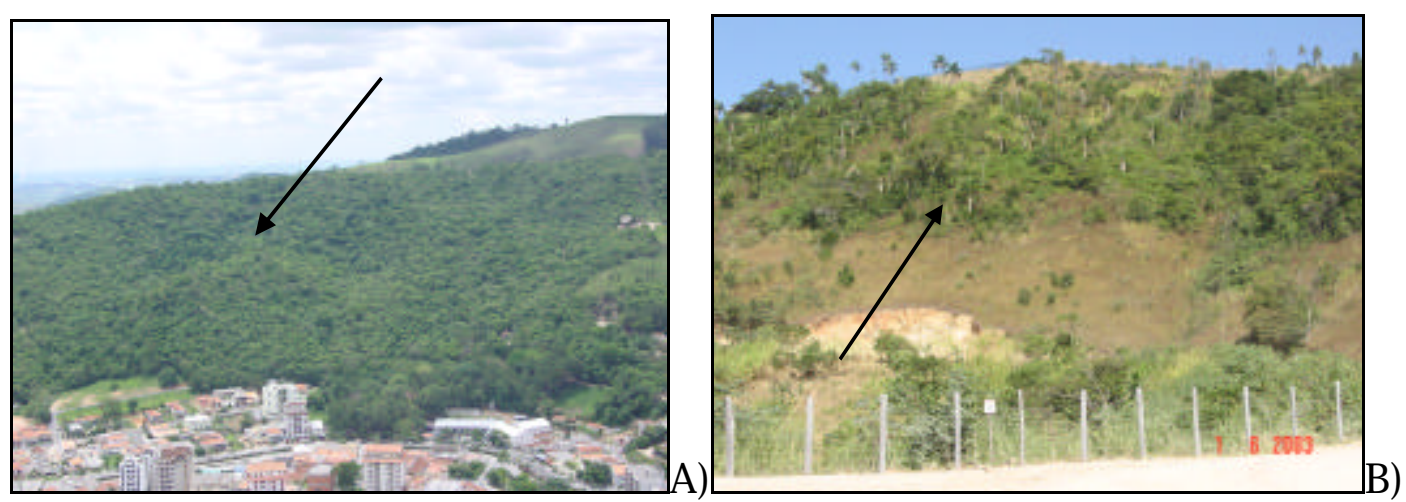

Figura 5.85 -Exemplo de ocorrência em campo da classe temática mata. A) Mata nativa fechada e B)Mata nativa esparsa 


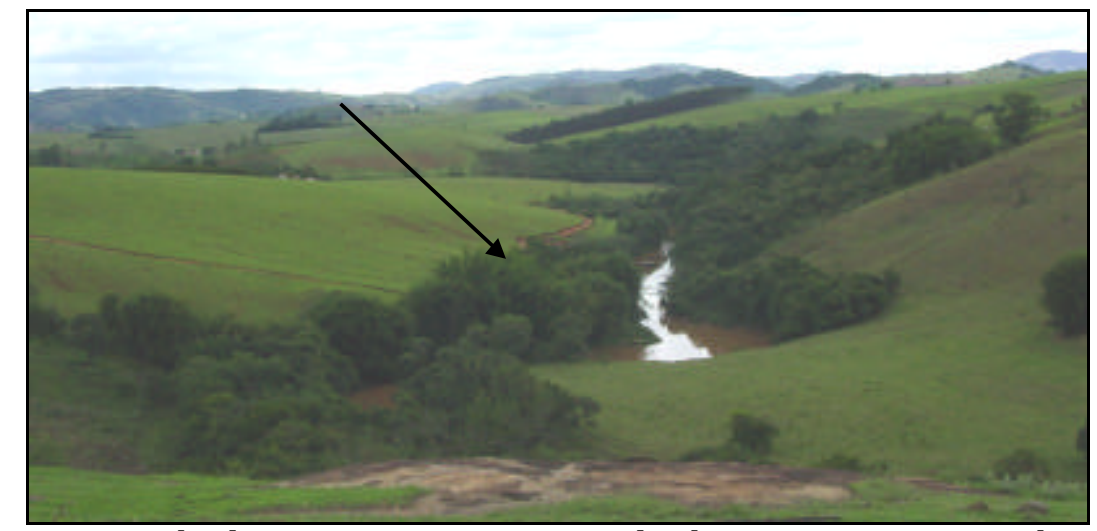

Figura 5.86- Exemplo de ocorrência em campo da classe temática mata ciliar.

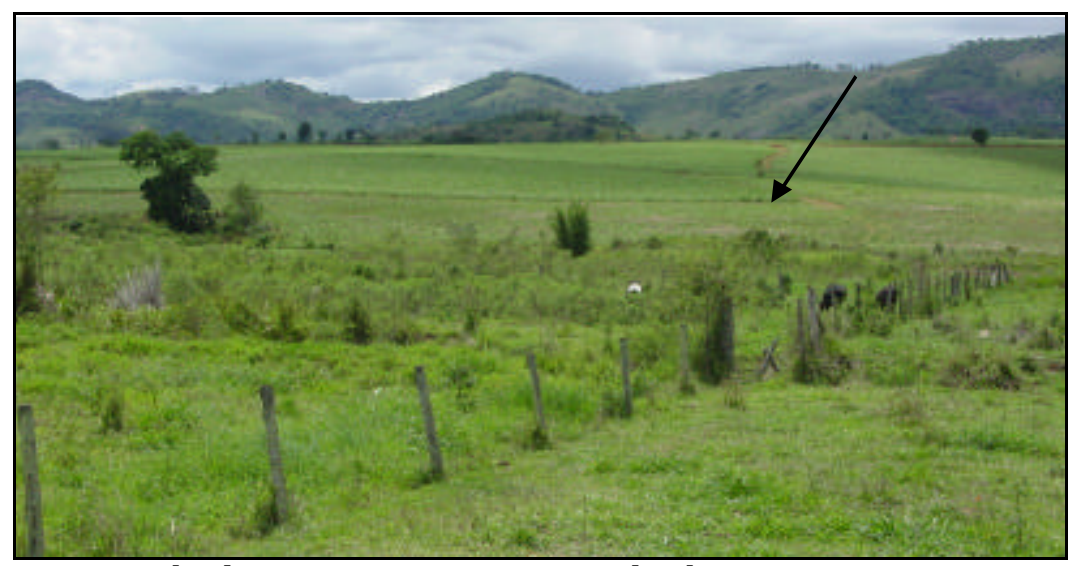

Figura 5.87 - Exemplo de ocorrência em campo da classe temática pastagem.

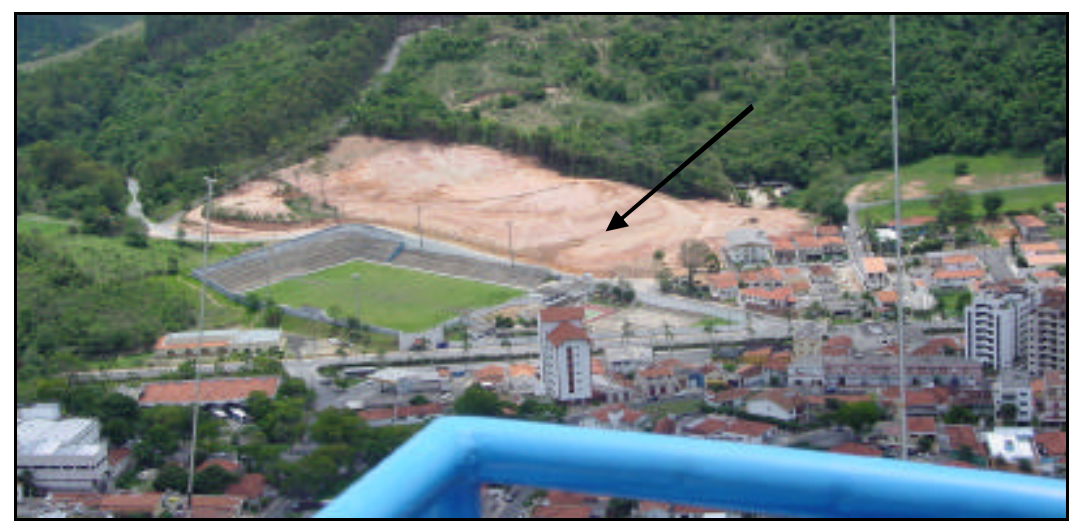

Figura 5.88 - Exemplo de ocorrência em campo da classe temática solo exposto.

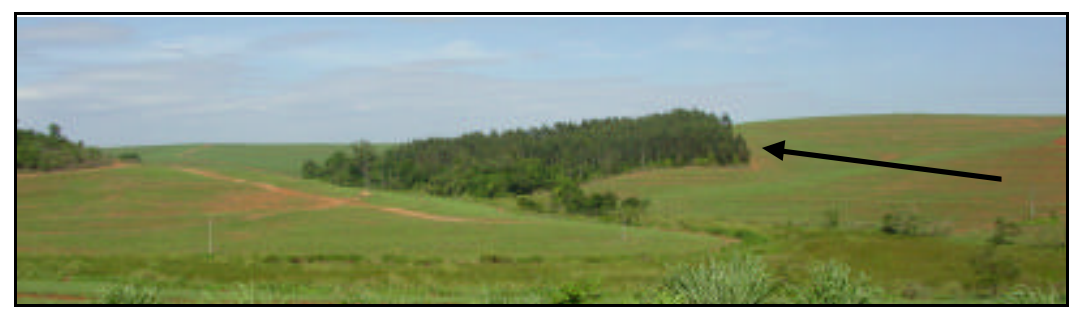

Figura 5.89 - Exemplo de ocorrência em campo da classe temática reflorestamento. 


\subsubsection{Atividades de Processamento}

Envolvem técnicas de processamento matemático com objetivo de atribuir a cada unidade da imagem, pix els, um valor que o caracterize como pertencente a uma determinada classe, dentro de um universo de classes.

O processo matemático de classificação utilizado para cena da área da bacia consistiu da técnica de classificação supervisionada. D e acordo com G uia ENVI (2003), esta é a mais comumente utilizada para extração de informações temáticas referentes ao uso e ocupação do solo. Nesta os pix els da imagem não pertencentes às amostras de treinamento são classificados como pertencentes a uma das classes pré-estabelecidas, 0 que é efetuado por meio da aplicação de métodos matemáticos estatísticos (G uia ENVI, 2003).

O método estatístico escolhido para ser utilizado foi o Método da Máxima Verossimilhança, o qual tem como suporte matemático a estatística paramétrica multivariada, onde as classes são definidas, com base nas amostras de treinamento, pelos vetores das médias e matrizes de covariância. No processo de classificação, cada pix el passa a ser definido por um vetor $\mathrm{X}$, que expressa a sua probabilidade de pertencer a cada uma das classes. 0 pix $\mathrm{e}$ é então classificado como pertencente a classe com a maior probabilidade (Guia ENVI, 2003). D e acordo com Crosta (1993), este método é recomendado quando se conhece bem a região a ser classificada, permitindo a definição de amostras de treinamento bem representativas.

\subsubsection{Atividades de Pós-processamento}

De acordo com Jensen (1986),esta atividade envolve procedimentos que visam 0 refinamento do produto obtido, de forma a segurar a obtenção de um documento cartográfico sem ruídos, como a classificação inadequada de pix els.

O refinamento da cena classificada foi feito por meio de três procedimentos: 1) Aplicação de Filtro; 2) Execução de funções de limpeza da imagem (Funções Clump dasses e Sieve dasses); e 3) Edição final das classes delimitadas pelo processo de classificação. 


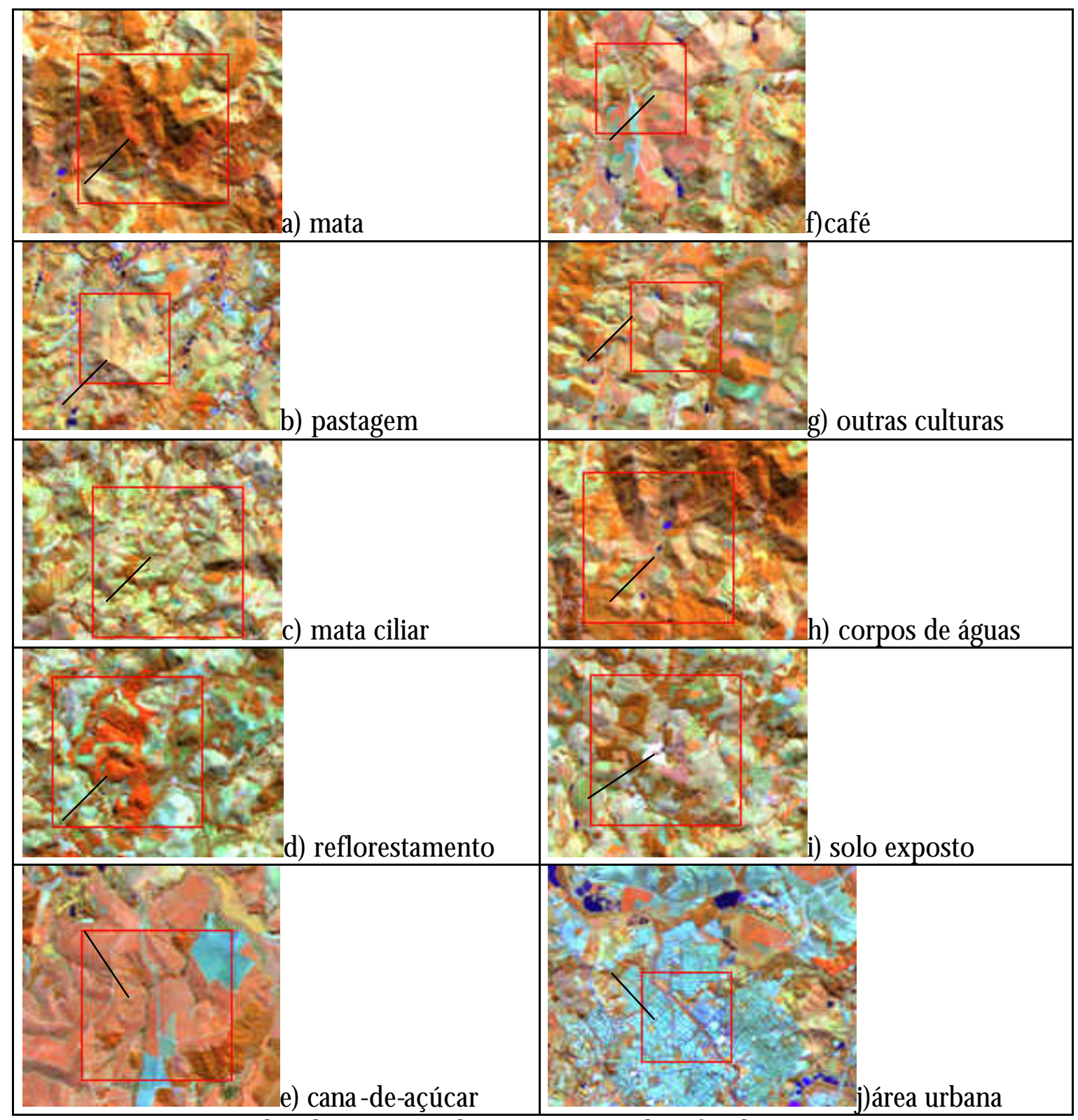

Figura 5.90 - Exemplos de amostras de treinamento identificadas na composição RGB, bandas 4-5-3 (observar áreas demarcadas com o quadrado vermelho).

\subsection{2 - Classes de Uso e 0 cupação do Terreno}

Para Bacia Hidrográfica do Rio do Peixe foram obtidas 11 classes de uso e ocupação do terreno, como resultado do processo de classificação supervisionada (Tabela 5.23, AnexoV).

No processo executado foram classificados $1.624,38 \mathrm{~K} \mathrm{~m}^{2}$, os quais corresponde a 93\% da área total da bacia. 
Tabela 5.23 - Dados referentes à extensão das classes de uso e ocupação na Bacia do Rio do Peixe.

\begin{tabular}{l|c|c}
\hline Classes Temáticas de Uso e Ocupação & Área (km $\mathbf{~}^{\mathbf{2}}$ & Área (\% do total) \\
\hline Pastagem / capoeira & 960,28 & 53,34 \\
\hline Mata Nativa & 349,65 & 20,88 \\
\hline Café & 100,87 & 6,02 \\
\hline Outras culturas & 76,53 & 4,57 \\
\hline Canad eacúcar & 52,74 & 3,15 \\
\hline Mata Ciliar & 30,62 & 1,83 \\
\hline Área urbana & 29,43 & 1,76 \\
\hline Solo exposto & 7,47 & 0,45 \\
\hline Corpos de água & 6,61 & 0,39 \\
\hline Várzea do Rio do Peixe & 5,49 & 0,33 \\
\hline Reflorestamento & 4,70 & 0,28 \\
\hline Área total classificada & 1624,38 & 93 \\
\hline
\end{tabular}

Das classes de uso do terreno caracterizadas por atividades antrópicas, pode-se constatar que a atividade de pastagem apresenta o maior percentual de ocorrência em área (53,34\%). As atividades de desenvolvimento agrícola, café, cana-de-açúcar e outras culturas, apresentam percentual de ocorrência em área de 13,74\%. As classes relativas as áreas que conservam suas condições naturais do meio, mata nativa e mata ciliar perfazem $22.71 \%$ da área da bacia. A classe de ocupação urbana corresponde a um percentual muito pequeno, $1,76 \%$.

Os resultados obtidos permitem classificar a bacia como uma região com predomínio de atividades de desenvolvimento rural. 


\section{CAPÍTULO 6}

\section{DOCUMENTOS CARTOGRÁFICOS FUZZY - CARTAS DERIVADOS}

Elaborar um mapa em formato furyy implica transformar um documento cartográfico de formato temático para o formato numérico (Moreira et al, 2001).

Documentos em formato temático têm por característica conter regiões geográficas definidas por um ou mais polígonos, os quais delimitam a ocorrência espacial de um tema, por exemplo, o uso do solo e a aptidão agrícola de uma região (Manual SPRING). Estes dados, obtidos a partir de levantamento de campo, são inseridos em ambientes computacionais por digitalização ou, de forma mais automatizada, a partir de classificação de imagens.

Nos sistemas de informações geográficas (SIG) tais polígonos recebem a denominação de classes ou geoclasses, que correspondem à especialização de um tema, por exemplo, diferentes tipos de solo. Essas são entendidas e modeladas como representativas de uma distribuição homogênea de propriedades em termos da ocorrência espacial do tema, e exibem contatos rígidos bem definidos.

Documentos numéricos retratam características ou fenômenos que possuem uma variação contínua de seus valores em função de sua posição na superfície. Esta variação é representada por meio de uma superfície contínua, grade numérica, na qual cada ponto apresenta um valor que corresponde a um grau de aceitação de possibilidade de existência da característica ou fenômeno no ponto em questão, com relação a todo o espaço amostral analisado.

Documentos numéricos correspondem, dentro do ambiente dos SIG, a modelos numéricos de terreno (MNT), ou modelos digitais de terreno (MDT). Consiste em uma representação matemática da distribuição espacial de uma determinada 
característica vinculada a uma superfície real. A superfície é em geral contínua e o fenômeno que representa pode ser variado (Manual SPRING). São convencionados os valores entre "0" e "1" para denotar a variação do fenômeno ao longo da superfície.

Os documentos cartográficos furzy elaborados correspondem as cartas derivadas interpretativas. Para obtenção destes documentos fez-se necessário, primeiro, criar uma base de dados básicos fundamentais furzyy. A base de dados é constituída de informações fundamentais a caracterização das potencialidades e restrições do meio físico da região, as quais são retratadas pelos documentos cartográficos derivados interpretativos.

Para obtenção destes documentos foi utilizado o SIG SPRING 4.0 como suporte computacional.

\subsection{SUPORTE COMPUTACIONAL - SISTEMA DE INFORMAÇÃO GEOGRÁFICA SPRING}

O SPRING constitui um sistema desenvolvido pelo Instituto Nacional de Pesquisas Especiais (INPE), para ambientes UNIX e Windows (Manual SPRING). Funciona como um banco de dados geográfico de $2^{\circ}$ geração, concebido para uso em conjunto com ambiente cliente-servidor, o qual funciona acoplado a gerenciadores de bancos de dados relacionais.

De acordo com (Câmara \& Medeiros, 1998) caracteriza-se basicamente por:

- Operar como um banco de dados geográfico sem fronteiras que suporta grande volume de dados, sem limitações de escala, projeção e fuso, e manter a identidade dos objetos geográficos ao longo de todo o banco;

- Administrar tanto dados vetoriais como dados matriciais (raster), e realizar a integração de dados de Sensoriamento Remoto num SIG;

- Prover um ambiente de trabalho amigável e poderoso, por meio da combinação de menus e janelas com uma linguagem espacial facilmente programável pelo usuário, Linguagem Espaço-Geográfica Baseada em Álgebra - LEGAL;

- Conseguir escalonabilidade completa, isto é, operar com toda sua funcionalidade em ambientes que variem desde micro-computadores a estações de trabalho RISC de alto desempenho. 
Para execução de armazenamento, recuperação e modelagem de informações, os dados devem ser estruturados no sistema na forma de um projeto, o qual delimita a área física de trabalho definida pelas coordenadas da região em estudo. As informações referentes ao projeto são armazenadas no banco de dados do sistema, localizado em um diretório, disco rígido (Figura 6.1 A e B).

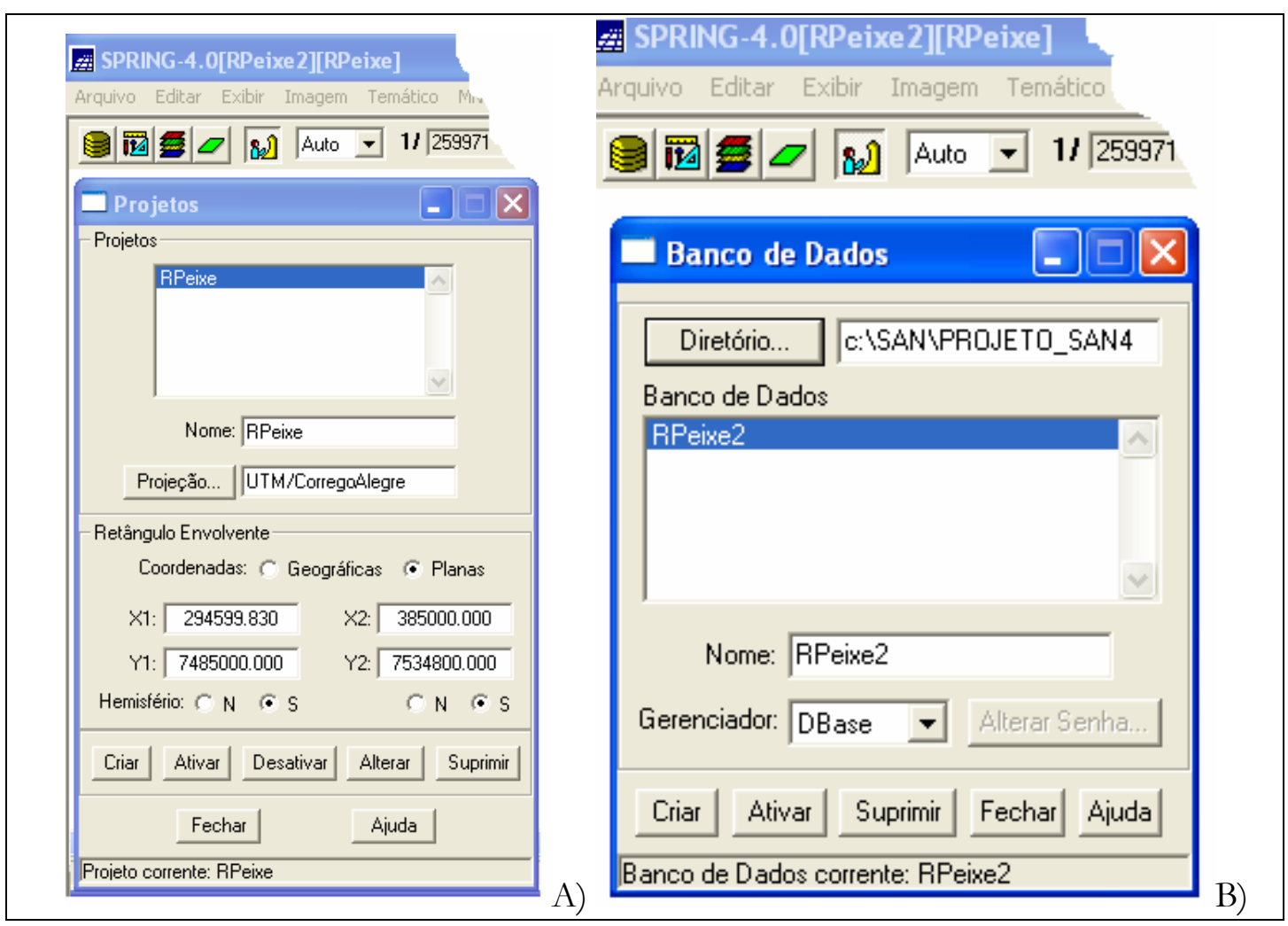

Figura 6.1 A) Projeto criado para informações do meio físico da bacia. B) Banco de Dados associado ao Projeto.

Dentro do projeto as informações são armazenadas segundo "diretórios" denominados de Categorias e "sub-diretórios" denominados de Planos de Informação (PI). A categorias definem o modelo ao qual determinada informação será vinculada, tipo temático, numérico, cadastral, rede, objeto ou não-espacial. Os planos de informação reúnem objetos que tem características básicas em comuns a uma categoria (Manual SPRING). Na edição dos planos de informação são definidos a escala de trabalho, a resolução espacial e o tipo de representação da informação, se matriz, vetor ou texto (Figura 6.2 A e B).

As informações referentes ao meio físico da Bacia Hidrográfica do Rio do Peixe foram organizadas em modelos temáticos e numéricos. 


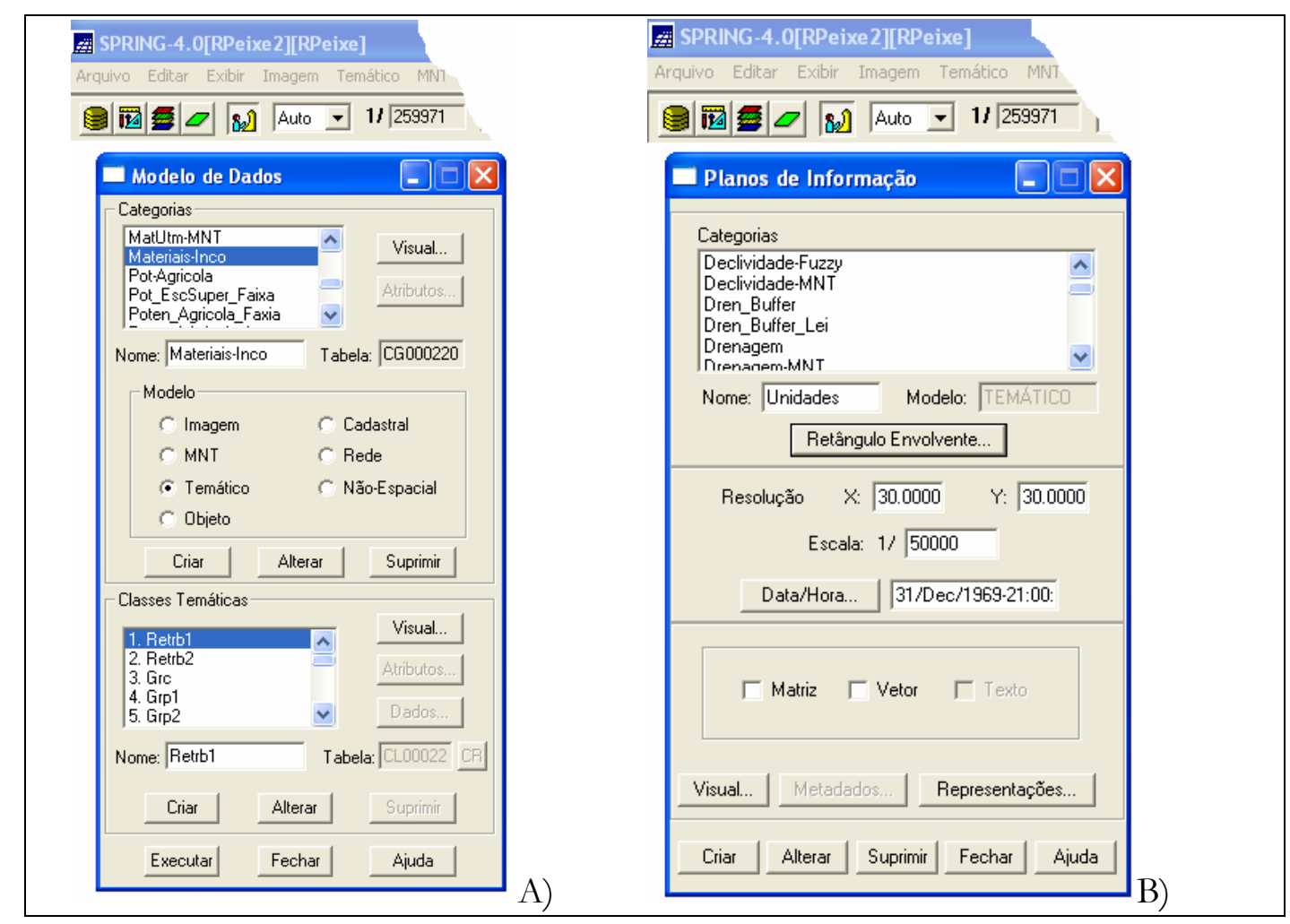

Figura 6.2 Exemplo de criação de modelo temático associado a informações do meio físico da bacia. B) Atribuição de escala e resolução as informações contidas no PI da categoria criada.

\subsubsection{Linguagem de Programação LEGAL}

Normalmente os sistemas de informação geográfica não apresentam aplicativos específicos para executar operações fur:y em mapas. Quando apresentam, estes constituem módulos com regras predefinidas, rígidas, quanto à forma de análise dos dados. Isto não permite que o usuário tenha grande liberdade em alterar as condições de modelagem das informações que deseja analisar.

Em alguns casos, a utilização de rotinas de programação permite estabelecer, por meio da interface usuário/sistema, a liberdade de modificar as condições de modelagem da informação.

A linguagem de programação LEGAL possibilita estabelecer uma interface com o sistema SPRING, para que o mesmo realize diferentes operações sobre dados representados em um projeto de um banco de dados SPRING (Manual SPRING), dentre as quais a modelagem em mapas segundo a técnica da lógica furæy. 
A linguagem LEGAL foi desenvolvida com base no modelo de dados do sistema SPRING e tem por característica ser de fácil utilização (Manual SPRING).

Permite a execução de análises e simulações de fenômenos do mundo real sobre atributos espaciais e não-espaciais. As análises e simulações são realizadas por meio de operações algébricas, descritas segundo expressões similares às utilizadas na matemática para definição de operações aritméticas e booleanas. Tais operações são organizadas segundo regras gramaticais, e envolvem operadores, funções e dados espaciais categorizados segundo o modelo de dados do sistema. A linguagem utiliza operadores que atuam sobre os modelos de dados armazenados.

O sistema considera na interpretação das sentenças de linguagem a coerência entre o modelo de dados e os operadores. Quando não há coerência entre o modelo e os operadores, mensagens de erro são enviadas no display, e o usuário é informado onde se encontra a incoerência (Figura $6.3 \mathrm{~A}$ e B). Isto caracteriza uma grande vantagem do sistema SPRING, pois auxilia o usuário na construção dos modelos e rotinas de programação.

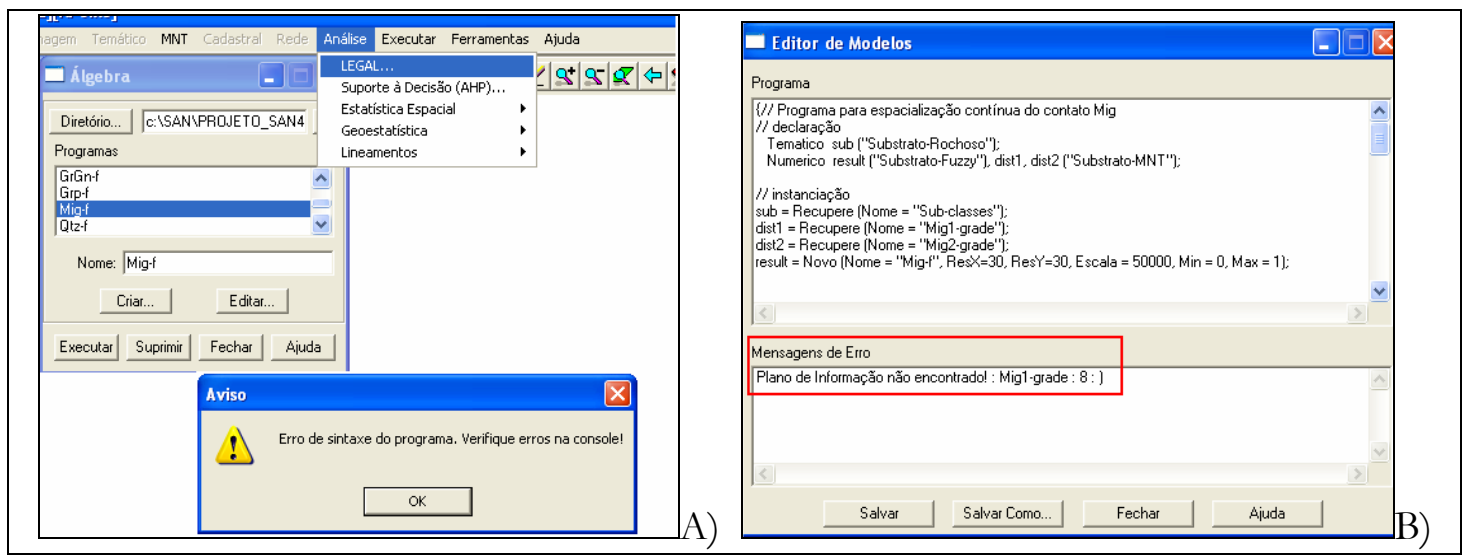

Figura 6.3 A) Mensagem de erro informativa de incoerência no programa a ser executado. B) Informação da linha do programa em que se encontra a incoerência.

\subsubsection{Estruturação de um Programa em LEGAL}

Um programa em LEGAL é constituído de uma lista de sentenças que descreve uma ou mais ações a serem executadas sobre os dados espaciais. Tais ações devem fazer 
sentido no contexto de alguma disciplina de sistema de informação geográfica (Manual SPRING).

As sentenças em LEGAL são estruturadas em três grupos: 1) Declaração de variáveis, 2) Instanciação de variáveis e 3) Operações de álgebra de mapas.

A declaração consiste da definição de variáveis, ou seja, da atribuição de um nome a ser associado aos dados fornecidos ou produzidos no programa. Os dados declarados correspondem a um modelo e uma categoria que irá caracterizar um plano de informação, um mapa cadastral, um objeto ou uma tabela de transformação.

A instanciação consiste efetivamente da associação de planos de informação a variável dos modelos previamente declaradas. $\mathrm{Na}$ instanciação ocorre a manipulação do banco de dados do sistema com a recuperação e/ou criação de planos de informações (PI). O operador novo cria planos de informações, como o que conterá o resultado da execução da rotina, além de tabelas associativas as variáveis previamente declaradas.

As operações de álgebra de mapas correspondem a aplicação de funções, ou de um ou mais operadores sobre as variáveis declaradas e instanciadas. As operações são descritas por expressões algébricas, segundo regras gramaticais que permitem a definição recursiva de operações complexas a partir de outras mais simples, com base nas propriedades dos dados e operadores envolvidos. Cada sentença descreve uma operação específica, a qual consiste de atribuir o resultado da avaliação de uma expressão algébrica a uma variável previamente definida.

O processamento de um programa em LEGAL obedece a um fluxo de execução, que é realizado por comandos de controle. Estes são fundamentais para modelagem de situações que envolvem a execução alternativa, condicional ou repetitiva de conjunto de operações.

No SPRING, os comandos de controle são baseados em constructos de linguagem do tipo: Enquanto (condição)\} operacãa. A condição referida é dada por uma expressão booleana, a qual envolve apenas expressões reais. O comando enquanto aciona uma seqüência de operações que devem ser executadas repetidas vezes até que a avaliação da condição dada pela expressão booleana resulte em uma avaliação verdadeira, de forma a satisfazer uma realidade pretendida pelo usuário.

O Quadro 6.1 apresenta o exemplo de uma seqüência escrita em linguagem LEGAL para uma unidade de mapa, plano de informação - litologia, da categoria Substrato Rochoso, sobre a qual objetiva-se retratar a distribuição de ocorrência espacial 
da mesma, com a caracterização da zona de transição existente entre esta e as unidades adjacente, fronteira fu₹:̌y de gradação.

Quadro 6.1 - Exemplo de programa em LEGAL

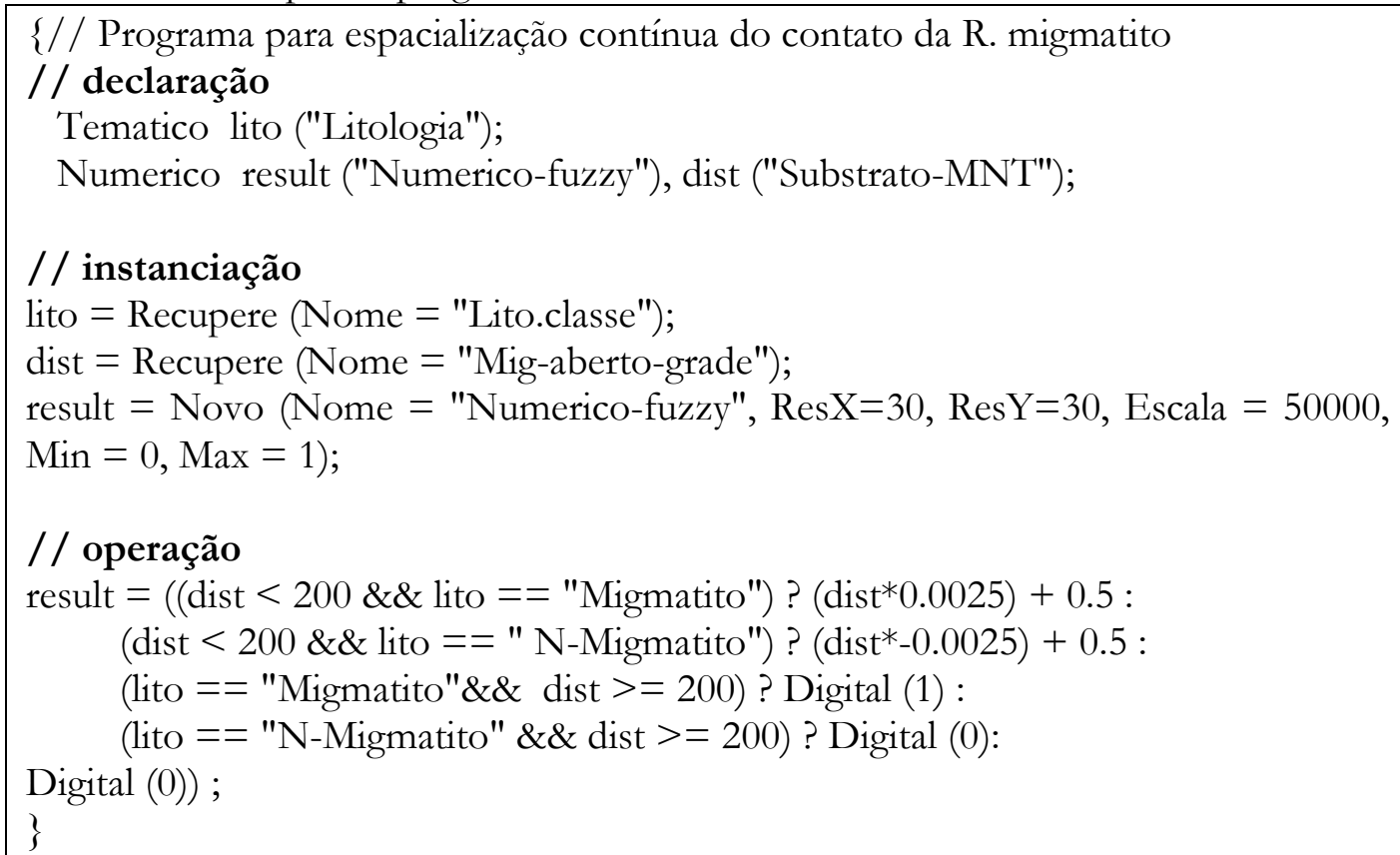

No exemplo acima são declaradas informações pertencentes aos modelos temáticos e numéricos. O modelo temático identifica a ocorrência espacial do tema a ser modelado, e o modelo numérico identifica a superfície contínua, grade de distância, sobre a qual serão aplicadas operações matemáticas que modelaram a variação espacial do tema.

O programa construído realiza diferentes funções condicionais por restrições espaciais. Estas condições são relativas a cada unidade de mapa presente, que delimitam a existência ou não da litologia, classes Migmatito e N-Migmatito. As condições restritivas são estabelecidas a partir da associação de limites determinados por faixas de distâncias e a ocorrência de um tema.

Na execução do programa é realizada, sobre a grade de distância, uma verificação seqüencial ponto a ponto da superfície numérica das condições estabelecidas. Satisfeita uma condição, aplica-se a operação matemática vinculada a mesma. O processo é continuo até que todas as condições sejam satisfeitas. Satisfeitas todas as condições o processo é encerrado. 
No programa apresentado no Quadro 6.1, a primeira e segunda linha da operação caracterizam condições que objetivam expressar o comportamento da zona de contato da litologia Migmatito. As condições determinadas nestas linhas delimitam a região que expressa a gradação entre as unidades no espaço, por meio da variação decrescente de valores, conforme distância da unidade litológica. A terceira e quarta linha da operação objetivam expressar 100\% de existência apenas da litologia Migmatito na unidade de mapa, e 100\% da não existência da litologia fora da unidade de mapa, respectivamente.

Para criação da base de dados básicos fundamentais, e a obtenção das cartas derivadas interpretativas da bacia em formato numérico, furay, foram utilizadas operações de álgebra de mapas descritas por expressões algébricas booleanas condicionais que visaram simular as condições existentes em campo, e operações matemáticas representadas por equações lineares simples, responsáveis pela modelagem da variação espacial dos atributos, ou seja, que traduziram para forma matemática o modo lingüístico de descrever as condições constatadas no meio.

Moreira et al. (2001), recomendam a utilização de equações lineares para ponderação de valores de gradação entre polígonos. Segundo os autores (op cit), o uso de equações lineares é preferido, pois evitam atribuição de complexidade ao sistema, nas fases iniciais de tratamento de dados.

\subsection{BASE DE DADOS BÁSICOS FUNDAMENTAIS FUZZY}

Constituíram os dados básicos fundamentais fuఇæy informações necessárias para obtenção e caracterização das potencialidades e restrições do meio físico da Bacia do Rio do Peixe retratadas nas cartas derivadas. Caracterizam esta base informações de: 1) Declividade do terreno, 2) Densidade de drenagem e 3) Substrato rochoso e materiais inconsolidados.

A criação da base de dados foi realizada por meio de execução de rotinas de programação, as quais transformaram as informações temáticas em numéricas. Estas modelaram os dados iniciais a partir de condições restritivas e operações matemáticas.

As informações referentes a declividade e densidade de drenagem caracterizam dados representados por modelos numéricos, e as informações de substrato rochoso e materiais inconsolidados caracterizam dados representados por modelos associativos temático/numéricos. 


\subsubsection{Declividade}

A declividade pode ser definida como a inclinação da superfície de em terreno em relação ao plano horizontal, e é constituída de duas componentes: o gradiente e a exposição (Manual SPRING). Gradiente é a taxa máxima de variação no valor da elevação, pode ser medido em grau $\left(0\right.$ a $\left.90^{\circ}\right)$ ou em porcentagem (\%), e a exposição é a direção dessa variação medida em graus ( 0 a $\left.360^{\circ}\right)$. No SPRING o componente gradiente é referenciado como declividade.

Nos SIG a declividade é obtida a partir da consideração de um modelo numérico de terreno (MNT), no qual constam dados altimétricos extraídos de uma carta topográfica. Para um determinado ponto $\mathbf{P}$ na superfície, é traçado um plano tangente a este que corresponderá à inclinação do mesmo em relação ao plano horizontal.

O SPRING apresenta módulos que permitem o cálculo das duas componentes, gradiente e aspecto, a partir de derivadas parciais de primeira e segunda ordem obtidas de uma grade numérica, retangular ou triangular, resultante dos valores de altitude da superfície. Para cada ponto desta grade são calculadas as derivadas parciais, computando-se os valores de altitude em uma janela de $3 \times 3$ pontos que se desloca sucessivamente sobre a grade. $\mathrm{O}$ resultado corresponde a duas novas grades, uma de gradiente e outra de exposição (Manual SPRING).

Os resultados constituem informações que apresentam variação ao longo de uma superfície, ou seja, retratam variação espacial contínua de um atributo do meio físico. Portanto caracterizam dados em formato furzy, os quais têm por faixa de variação, não os valores limites convencionais “0” e "1", mas os valores máximos e mínimos de declividade da área em análise.

\subsubsection{Procedimentos Empregados}

O processo de obtenção dos dados declividade fur:y da bacia consistiu de duas etapas (Figura 6.4): 1) Execução de processamentos que resultaram em um documento cartográfico em formato temático, o qual corresponde a carta de declividade da bacia (ANEXO VI), e representa os valores reais dos percentuais de inclinação da declividade da região e 2). Transformação das informações primárias em uma superfície numérica, 
representada por uma faixa entre "1" e "4" de variação do percentual de declividade, por meio de rotina de programação. Esta superfície constitui os dados fundamentais fuгæy de declividade utilizados na elaboração de cartas derivadas.

O processo de tranformação das informações primárias de percentual de declividade em formato fu₹₹y, com distribuição contínuas entre a faixa "1" e "4", visou a obtenção de uma caracterização de distribuição destes valores na bacia, compatível com as classes de potencialidade e restrições adotadas para as cartas derivadas, classe baixa identificada pelo valor " 1 " e classe alta identificada pelo valor "4"

A declividade constitui um atributo do meio que influencia no comportamento de potencialidades e restrições de uma dada região, por exemplo, condiciona de forma direta o escoamento superficial de uma área, que influenciará no desenvolvimento ou não de feições erosivas.

A caracterização da distribuição contínua da declividade de uma área por meio de faixa de variação, como a estabelecia pela faixa acima, constitui uma informação de fácil entendimento e manipulação no processo de modelagem de informações do meio para determinação de potencialidade e restrições. 


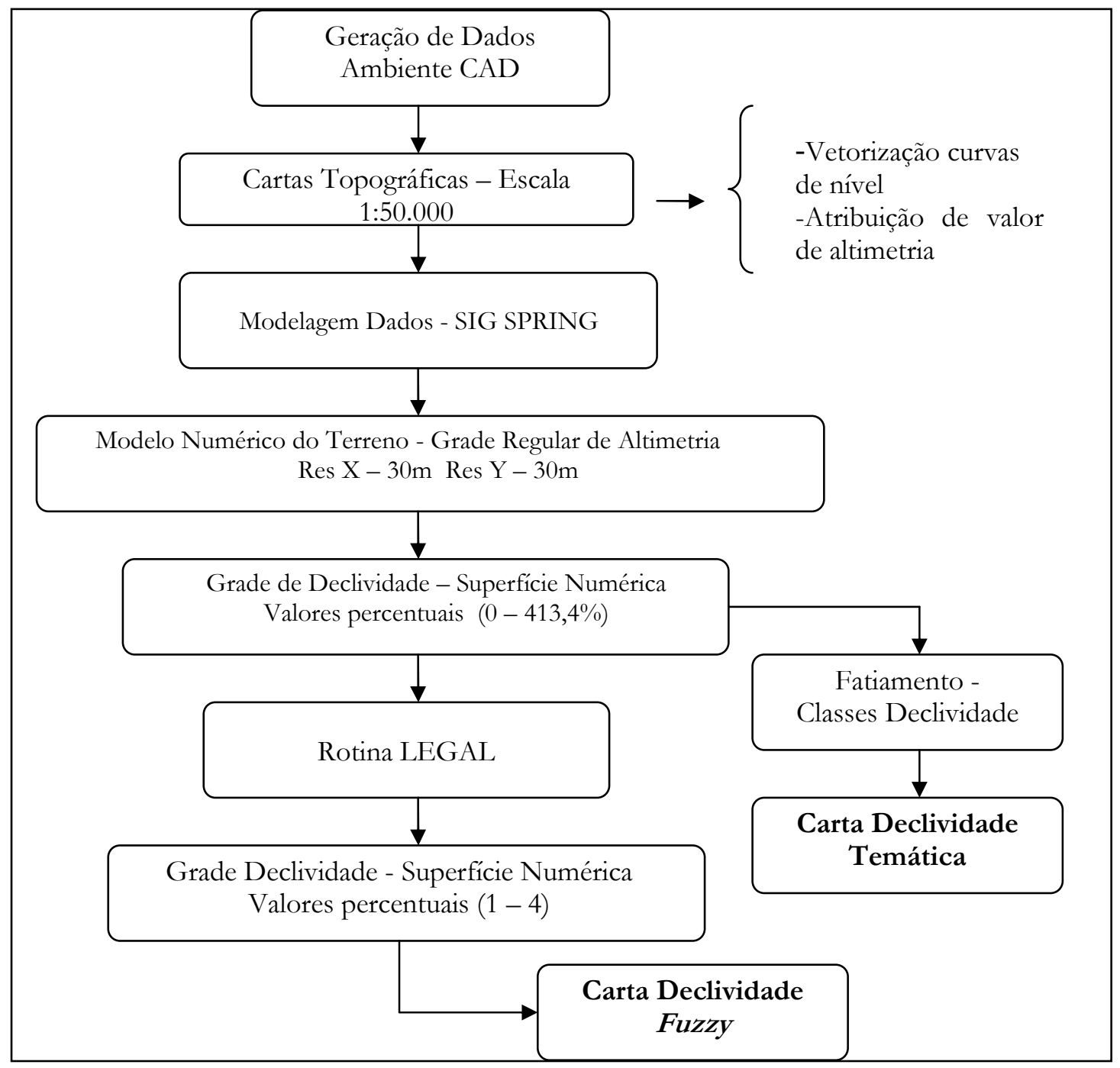

Figura 6.4 - Etapas executadas para obtenção da Carta de Declividade da bacia.

\subsection{Carta de Declividade - Documento Temático}

Para obtenção dos dados de declividade percentual da bacia foi executada a operação de comando declividade, do módulo MNT do sistema SPRING. Nesta operação o usuário escolhe o formato do dado de entrada e saída, e estabelece a unidade de representação, a resolução espacial dos dados, além da categoria e o PI ao qual os dados serão vinculados (Figura 6.5). 


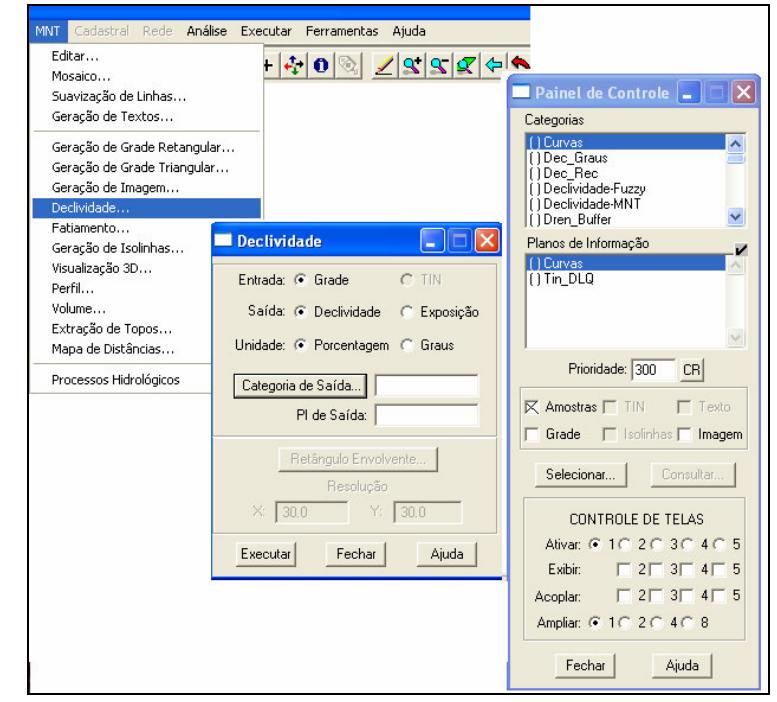

Figura 6.5. Módulo de execução e obtenção de dados de declividade no SPRING.

Esta operação resulta em uma superfície contínua, a qual apresenta valores de declividade percentuais entre 0 e 413,46\%, que corresponde ao mínimo e máximo de declividade percentual da área. Os valores correspondentes em graus são 0 e 76, $4^{0}$.

Com objetivo de obter um documento com dados representativos do meio, e de fácil visualização e entendimento pelo usuário, esta superfície numérica foi submetida a um processo de fatiamento, por meio do módulo MNT (Figura 6.6).

O fatiamento consiste na geração de uma imagem temática a partir de dados numéricos (Manual SPRING). A definição dos intervalos de fatias dependerá da variação dos valores da grade que se deseja destacar. Neste processo o usuário define em quantas faixas deseja representar os dados numéricos, a partir da declaração dos valores iniciais e finais de cada faixa, e associação das mesmas a classes temáticas previamente criadas (Figura 6.6). O resultado obtido tem por significados a representação de aspectos particulares do modelo numérico do terreno na forma de um PI de categoria temática (Figura 6.7).

Os resultados dos valores de declividade percentuais da bacia foram agrupados em seis faixas, $0-2 \% ; 2-10 \% ; 10-20 \% ; 20-30 \% ; 30-45 \%$ e $>45 \%$ (Anexo VI).

A adoção destas faixas baseou-se nos limites propostos por ZUQUETTE (1987). Segundo o Autor (op cit) a adoção de faixas para caracterização da distribuição de declividade facilita a análise individual de áreas frente aos diferentes tipos de ocupação. As faixas propostas são adequadas as condições tropicais, tanto para situação urbana, escalas maiores, como para situações regionais, escalas menores (Tabela 6.1; Quadro 6.2). 


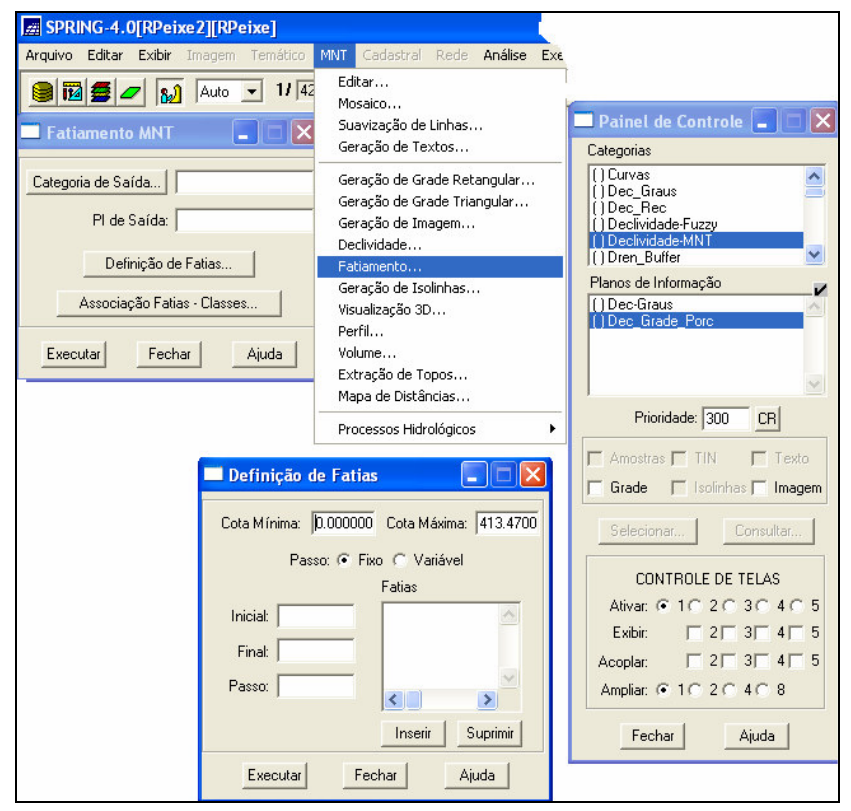

Figura 6.6 - Etapas do procedimento de fatiamento para obtenção de documento temático a partir de superfície numérica.

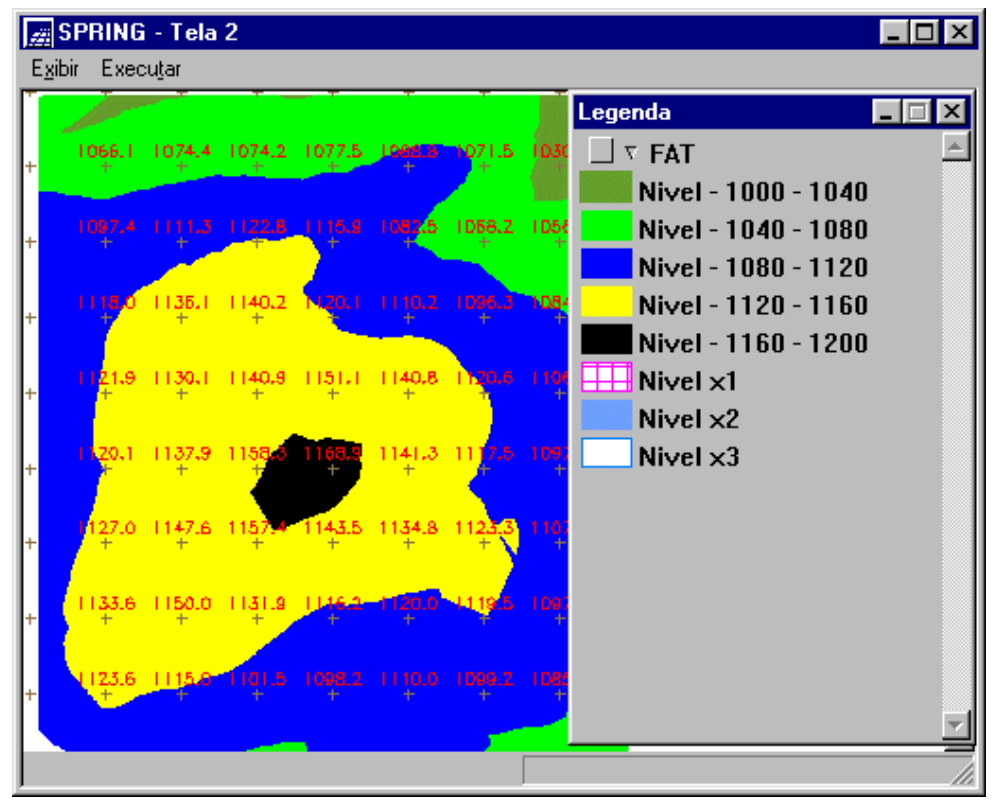

Figura 6.7 - Exemplo do resultado de uma operação de fatiamento de uma grade numérica (manual SPRING). 
Tabela 6.1 - Valores de Declividade (\%) que delimitam a ocupação do meio físico (adaptado de Zuquette, 1987).

\begin{tabular}{|c|c|c|}
\hline & \multicolumn{2}{|c|}{ Situações de ocupação do Meio Físico } \\
\hline \multirow{6}{*}{ 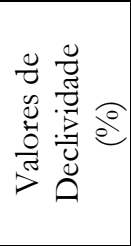 } & Urbana & Regional \\
\hline & $0-2$ & $0-2$ \\
\hline & $2-5$ & $2-10$ \\
\hline & $5-10$ & $10-15$ \\
\hline & $10-15$ & $15-20$ \\
\hline & $>15$ & $>20$ \\
\hline
\end{tabular}

Quadro 6.2 - Resumo dos Limites críticos de ocupação do meio frente os valores de ocupação (adaptado de Zuquette, 1987).

\begin{tabular}{|c|c|c|}
\hline \multicolumn{2}{|c|}{ Classes (\%) } & Ocupações do Meio Físico \\
\hline \multicolumn{2}{|l|}{$0-2$} & Aeroportos internacionais e locais; redes ferroviárias principais. \\
\hline \multicolumn{2}{|l|}{$2-5$} & $\begin{array}{l}\text { Estradas principais, maquinário agrícola de plantio e cultivo; erosão começa a ser } \\
\text { significativa; densidade elevada de ocupação com habitações. }\end{array}$ \\
\hline \multicolumn{2}{|c|}{$5-10$} & $\begin{array}{l}\text { Desenvolvimento urbano e industrial em grande escala, máximo para redes de sistema } \\
\text { de saneamento, máximo absoluto para ferrovias. }\end{array}$ \\
\hline \multicolumn{2}{|c|}{$10-15$} & $\begin{array}{l}\text { Máximo para residências convencionais e para estradas em perímetro urbano; } \\
\text { desenvolvimento urbano; tratores com esteiras e tratores padrões. }\end{array}$ \\
\hline \multicolumn{2}{|c|}{$15-20$} & Absoluta para residências, máquinas e estradas; habitações individuais. \\
\hline \multirow[b]{2}{*}{$>20$} & 25 & Máximo para estruturas de engenharia. \\
\hline & 45 & Máximo para operar veículos tracionados. \\
\hline
\end{tabular}

Dentre as faixas de declividade adotadas, as faixas de $0-2-\%$ e $20-30 \%$ caracterizam as maiores ocorrências em área (Tabela 6.2).

Tabela 6.2 - Classes de Declividade e valores de ocorrência em área.

\begin{tabular}{c|c|c}
\hline CLASSE & DECLIVIDADE (\%) & $\begin{array}{c}\text { OCORRENCIA EM ÁREA } \\
\left(\mathbf{K M}^{\mathbf{2}} \mathbf{~}\right.\end{array}$ \\
\hline 1 - Muito Baixa & $0-2$ & 262.82 \\
\hline 2 - Baixa & $2-10$ & 278.08 \\
\hline 3 - Medianamente Moderada & $10-20$ & 521.87 \\
\hline 4 - Moderada & $20-30$ & 348.22 \\
\hline 5 - Alta & $30-45$ & 214.50 \\
\hline 6 - Muito Alta & $>45$ & 52.19 \\
\hline
\end{tabular}

A observação da distribuição de ocorrência em área das classes de declividades percentuais apresentadas na Tabela 6.2, analisadas com base nos intervalos limites propostos por Zuquette (1987), permite constatar que as classes favoráveis a construção de estradas, ao desenvolvimento urbano e industrial e a operação de maquinários agrícolas (Muito Baixa, Baixa e Medianamente Moderada) perfazem aproximadamente 63\% da área da bacia. Já as classes mais restritivas a ocupação do terreno correspondem a apenas $37 \%$ da área da bacia. 


\subsection{Dados Declividade Fuzzy}

Os dados de declividade percentual da bacia em formato furzy foram obtidos a partir da execução de um uma rotina de programação (Programa LEGAL 1 - Apêndice A), a qual aplicou equações matemáticas a grade numérica primária, segundo condições restritivas numéricas.

Os valores adotados como condições restritivas foram determinados a partir da correspondência estabelecida entre as declividades percentuais e em graus, e da avaliação quantificada de ocorrência em áreas das primeiras. Valores percentuais iguais a 5\% correspondem classes de declividade baixas, e valores iguais ou superiores a $45 \%$ caracterizam classe muito alta de declividade, e correspondem a apenas 3,11\% do total da área da bacia.

Para este intervalo restritivo foi elaborada a equação linear $((f(x)=((x * 0,075))+0,625)$, que permitiu a transformação e espacialização contínua da declividade percentual, contida neste intervalo, para a faixa entre "1" e "4", por meio da expressão:

$M F_{\text {declivida } 14}=($ valor declividade $* 0.075)+0.625$ Se $(($ valor declividade $>5$ E Valor declividade $<45)$

Onde MF corresponde a função que caracteriza a gradação do atributo declividade no espaço, superfície matemática contínua.

De forma a garantir que fora da faixa restritiva não ocorressem valores diferentes da faixa estabelecida, foram elaboradas e aplicadas as equações lineares $(f(x)=(x * 0)+1)$ e $(f(x)=(x * 0)+4)$, executadas na rotina de programação (Programa LEGAL 1 - Apêndice A) pelas expressões:

$$
\begin{aligned}
& M F_{\text {Declividade } 1}=(V \text { alor declividade } * 0)+1 \boldsymbol{S e}(\text { valor declividade } \leq 5) \\
& M F_{\text {Declividade }}=\left(\text { V alor declividade }{ }^{*} 0\right)+4 \boldsymbol{S e}(\text { valor declividade } \geq 45)
\end{aligned}
$$

O resultado da execução da rotina LEGAL de espacialização da declividade consistiu de uma superfície numérica, a qual apresenta para áreas caracterizadas por valores de baixa declividade o número "1", e para as áreas de declividade mais elevadas, o número “4” (Figura 6.8 e Figura 6.9). 


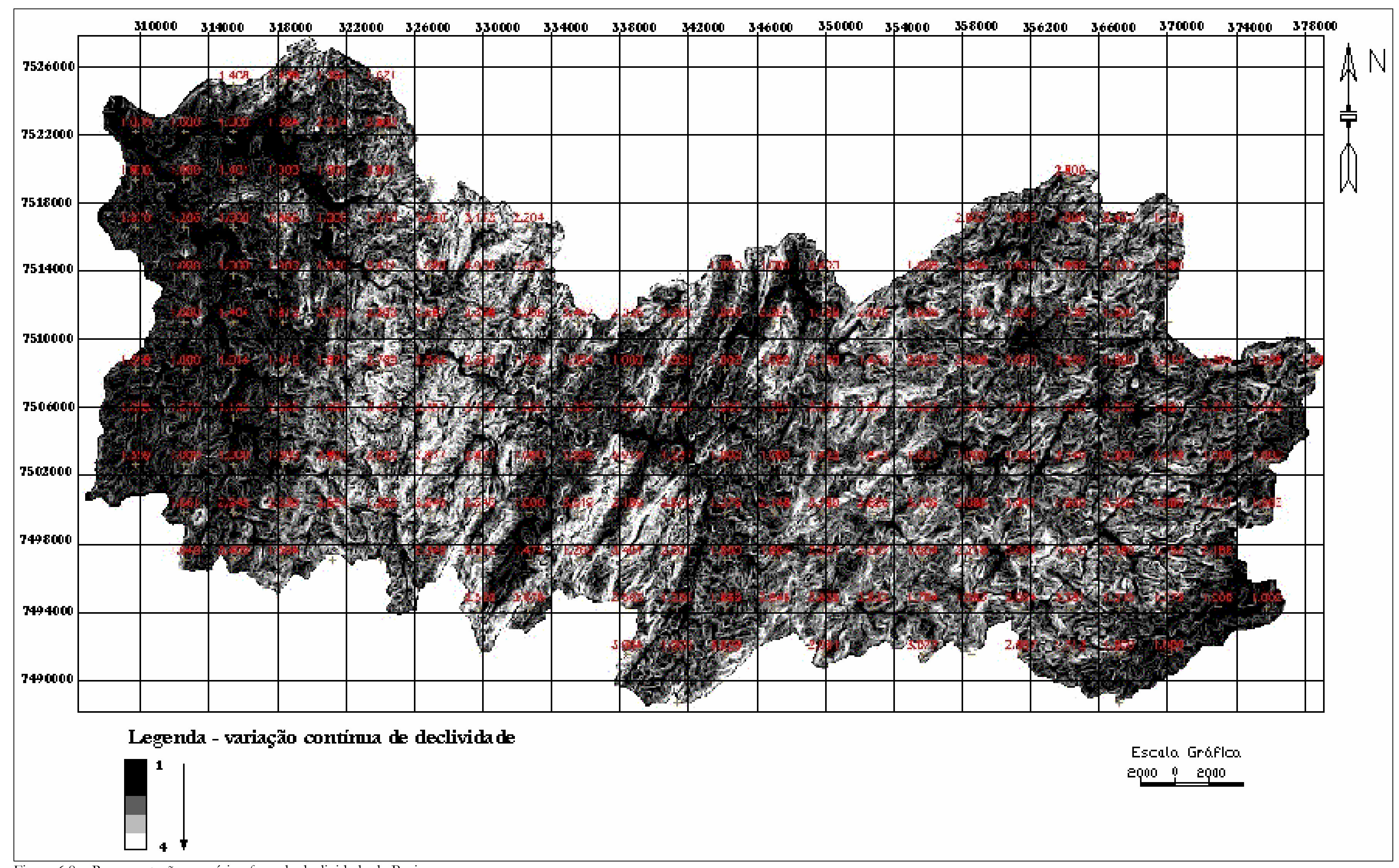

Figura 6.8 - Representação numérica fu₹:̌y da declividade da Bacia. 


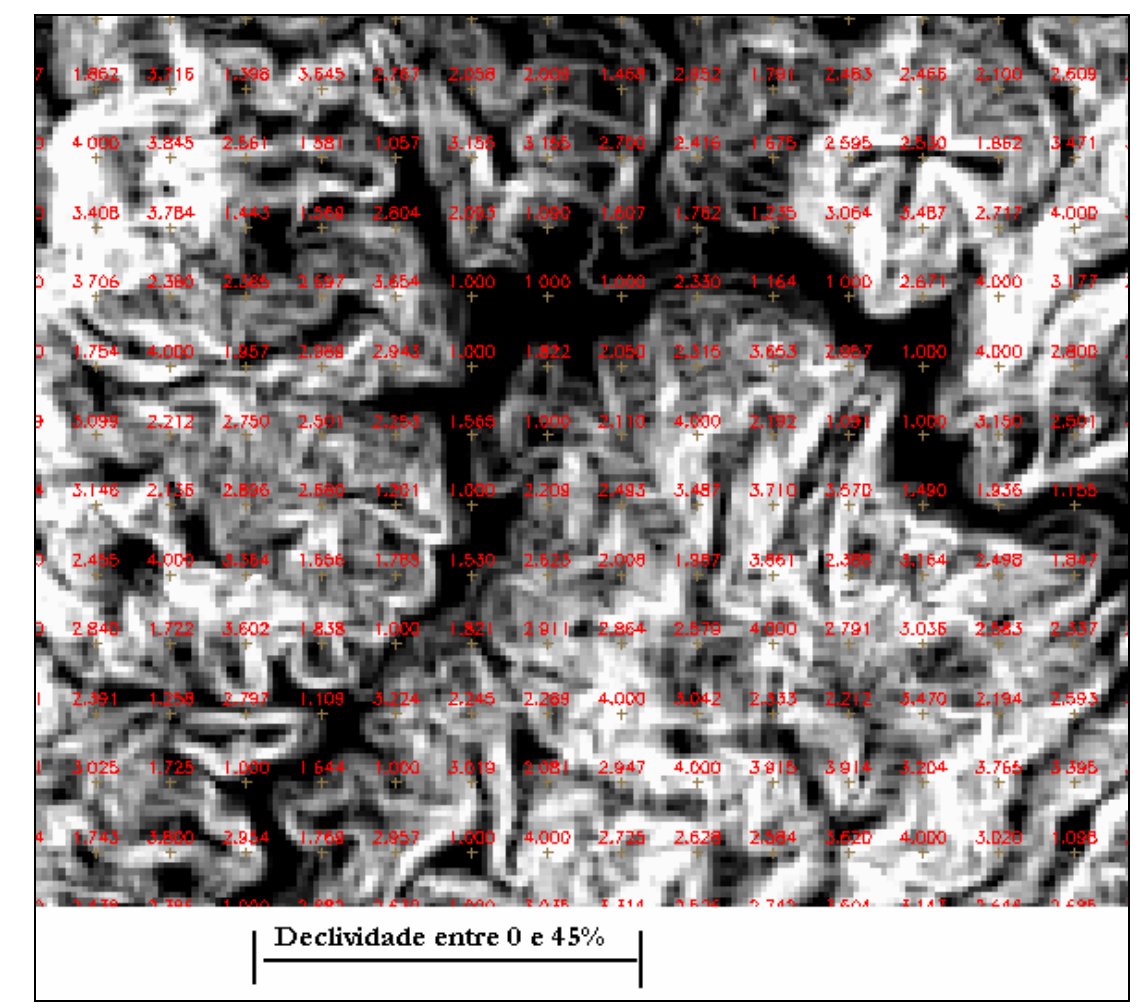

Figura 6.9 - Detalhe da representação numérica fuгży dos valores de declividade da bacia.

\subsubsection{Carta de Extensão do menor Percurso de Água Superficial (CEMPAS)}

Esta carta foi proposta por Lopes (2000), em substituição a carta do número de canais de drenagens por quilômetro linear proposta por Pejon (1992). A CEMPAS fornece informações semelhantes a uma carta de densidade de canais de drenagens por quilômetro linear, no entanto tem a vantagem de ser mais facilmente obtida em ambiente SIG, tornando-a mais precisa e rápida de obter.

O número de canais de drenagem por unidade linear é um parâmetro importante que condiciona diretamente o comportamento de escoamento superficial de uma região, e indiretamente a ocorrência de fenômenos erosivos e o desenvolvimento de atividades agrícolas.

Collares (2000) ressalta que esta variável retrata a disponibilidade de canais para o escoamento linear das águas e materiais detríticos. Desta forma informações relativas a este parâmetro devem retratar a distribuição em área da ocorrência desde baixa a alta de número de canais por unidade linear.

Foram estabelecidas faixas de distância regularmente distribuídas de forma crescente nas laterais dos cursos de drenagem. O estabelecimento destas faixas permitiu 
a delimitação do comportamento de influência deste atributo no escoamento superficial da bacia. Regiões mais distantes dos cursos de drenagem caracterizam áreas de baixa influência no comportamento de escoamento superficial, pelo fato de apresentarem uma longa distância até os canais, favorecendo a infiltração, enquanto que em regiões mais próximas aos cursos de drenagem caracterizam áreas com alta influência no comportamento de escoamento superficial, por que nestas há maior facilidade para a água atingir os canais de drenagem.

\subsubsection{Procedimentos Empregados}

Para obtenção das faixas foi necessária a construção de uma grade contínua de distância simetricamente distribuída a partir dos cursos de drenagem, a qual foi posteriormente fatiada e transformada para o formato fuzæy , superfície contínua com valores entre " 1 " e "4".

A construção da grade foi executada mediante importação dos vetores representativos dos canais de drenagem (Figura 6.10), como amostras MNT, e posterior criação de um mapa de distância (Figura 6.11), o qual consiste de uma matriz com 1558 linhas e 2846 colunas, de resolução espacial 30X30 metros.

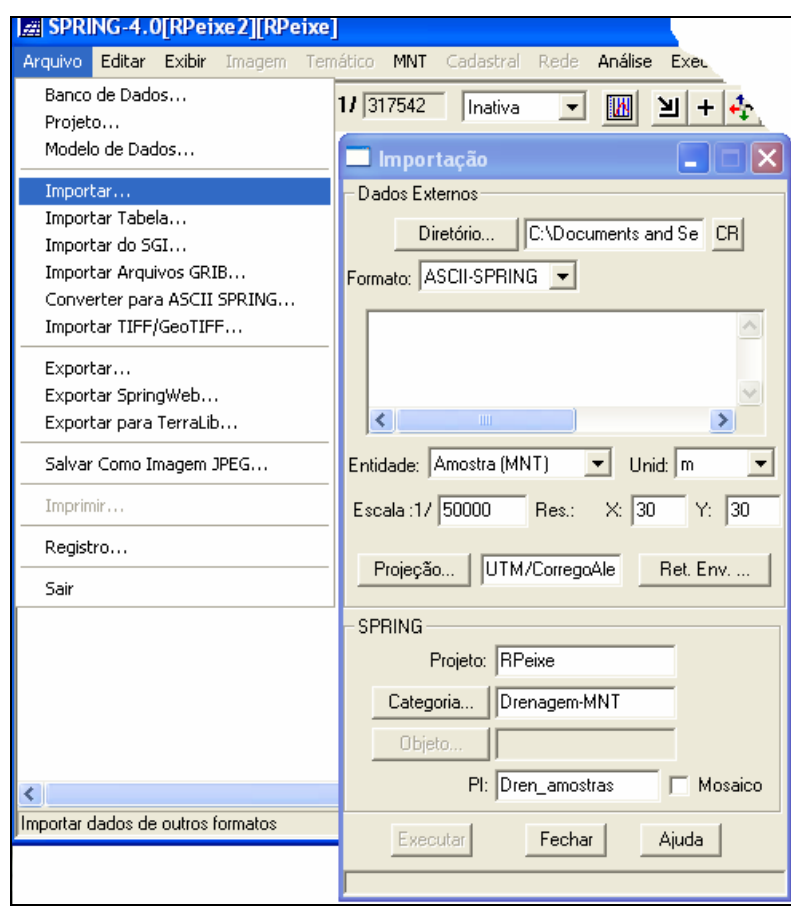

Figura 6.10 - Etapas de importação de dados como Amostras MNT. 


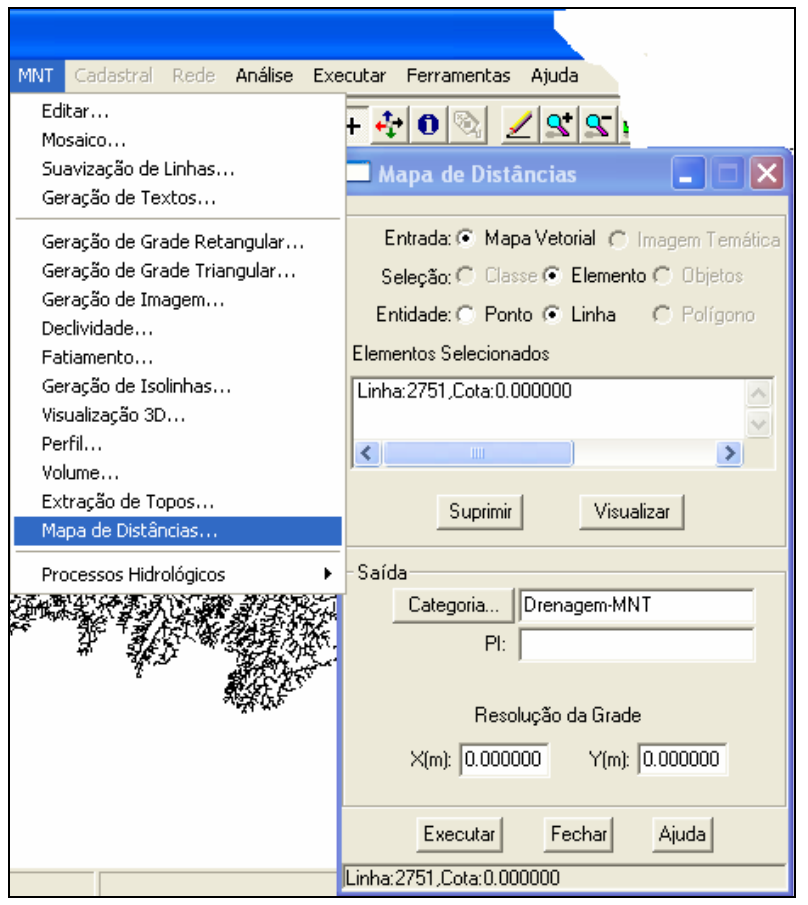

Figura 6.11 - Operação de elaboração de mapa de distancia.

$\mathrm{Na}$ importação dos dados como amostras MNT, são definidos parâmetros que caracterizaram os dados vetoriais importados, como unidade métrica, escala e resolução espacial.

$\mathrm{Na}$ construção do mapa de distância é determinado o formato do dado de entrada, se mapa vetorial ou imagem temática; modo de seleção dos dados e natureza da entidade que será selecionada. Também é estabelecida a resolução espacial da grade a ser gerada.

No processo de execução da grade ocorre a alocação de pontos, que correspondem ao centro dos pixels, em distâncias regulares crescentes, conforme resolução espacial estabelecida, a partir de um ponto inicial o qual é tomado como zero. A partir deste são alocados pontos com distribuição contínua regular para toda área (Figura 6.12).

Foram considerados como pontos iniciais as linhas representativas dos cursos de drenagem e estabelecida como resolução espacial a distribuição de 30 X30 metros. 


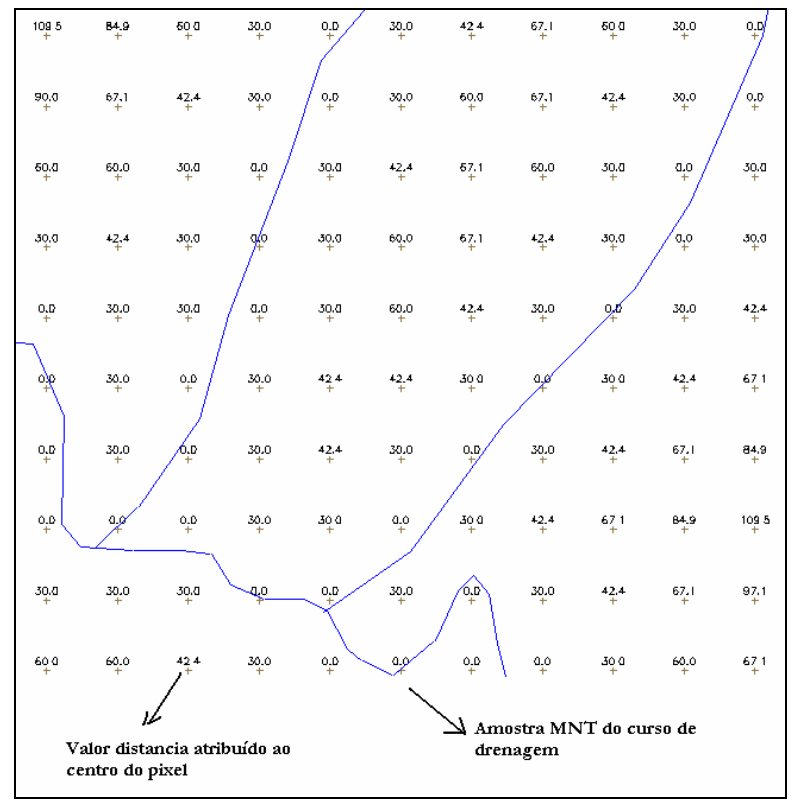

Figura 6.12 - Detalhe da grade de distância construída a partir dos dados representativos da rede de drenagem da bacia.

No processo de fatiamento ao qual a grade foi submetida foram estabelecidas faixas com intervalos de distância regulares de 100 metros, e valores limites de 0 e 300 metros (Figura 6.13). A adoção do valor de 300 metros como limite máximo foi devida constatação de que, para limites de distância superiores a este a distribuição do comportamento da densidade de drenagem para bacia não representaria condições reais. Aos valores máximos e mínimos de distância foram associados os números "4" e "1", respectivamente, como faixa de variação deste atributo.

Determinado o comportamento de influência do atributo para área da bacia, procedeu-se obtenção da superfície contínua fu₹zy representativa do mesmo, por meio de rotina de programação (Programa LEGAL 2 - Anexo XI). O programa executou a transformação de espacialização da faixa entre "4" e "1" com a aplicação da equação linear $\left(f(x)=\left(x^{*}-0,01\right)+4\right)$ a grade numérica, segundo condições restritivas distância. A operação foi executada por meio da expressão:

$$
M F_{d d ~ 1-4}=(\text { valor Distância*-0.01) }+4 \text { Se }((\text { valor distância }<300)
$$

A não existência de valores diferentes da faixa estabelecida além da faixa restritiva de 300 metros foi assegurada pela aplicação da equação linear $(f(x)=(x * 0)+1)$, executada na rotina de programação (Programa LEGAL 2 - Anexo XI) pela expressão:

$$
M F_{d d 1}=(\text { Valor distância*0) }+1 \text { Se (valor distância } \geq 300)
$$


O resultado da rotina LEGAL consistiu de uma superfície numérica contínua representativa da distribuição espacial da densidade de drenagem na área da bacia (Figura 6.14 e Figura 6.15), correspondente a influência no escoamento superficial, ou seja, o valor 1 representando baixa e o valor 4 alta influência no processo de escoamento superficial.

\subsubsection{Substrato Rochoso e Materiais Inconsolidados}

Os dados de substrato rochoso e materiais inconsolidados consistem de informações temáticas importantes à caracterização das potencialidades e restrições naturais de uma área. Estes dados são representados na forma cartográfica por polígonos que constituem diferentes unidades destes compartimentos do meio físico.

As informações representadas por estes polígonos têm por característica exibirem, muitas vezes, uma distribuição espacial não homogênea denotada pela ocorrência de contato gradacional com as unidades adjacentes.

Os diversos polígonos que constituem os compartimentos de substrato rochoso e materiais inconsolidados encerram características diferentes entre si (espessura, textura, natureza genética, etc.), as quais apresentam distribuição espacial ditada pelas relações de contato da unidade ao qual pertencem.

Os dados básicos representados por estes atributos correspondem a representação da ocorrência espacial e das relações de contato dos mesmos em formato furay.

\subsubsection{Procedimentos Empregados}

A obtenção das bases fu₹:y retratadas pelos atributos de substrato rochoso e materiais inconsolidados foi executada em duas etapas: 1) Caracterização das relações de contato entre unidades de cada compartimento, com estabelecimento das faixas de gradação entre unidades e 2) Elaboração e execução de programas LEGAL para espacialização numérica contínua das transições de contato entre unidades. 


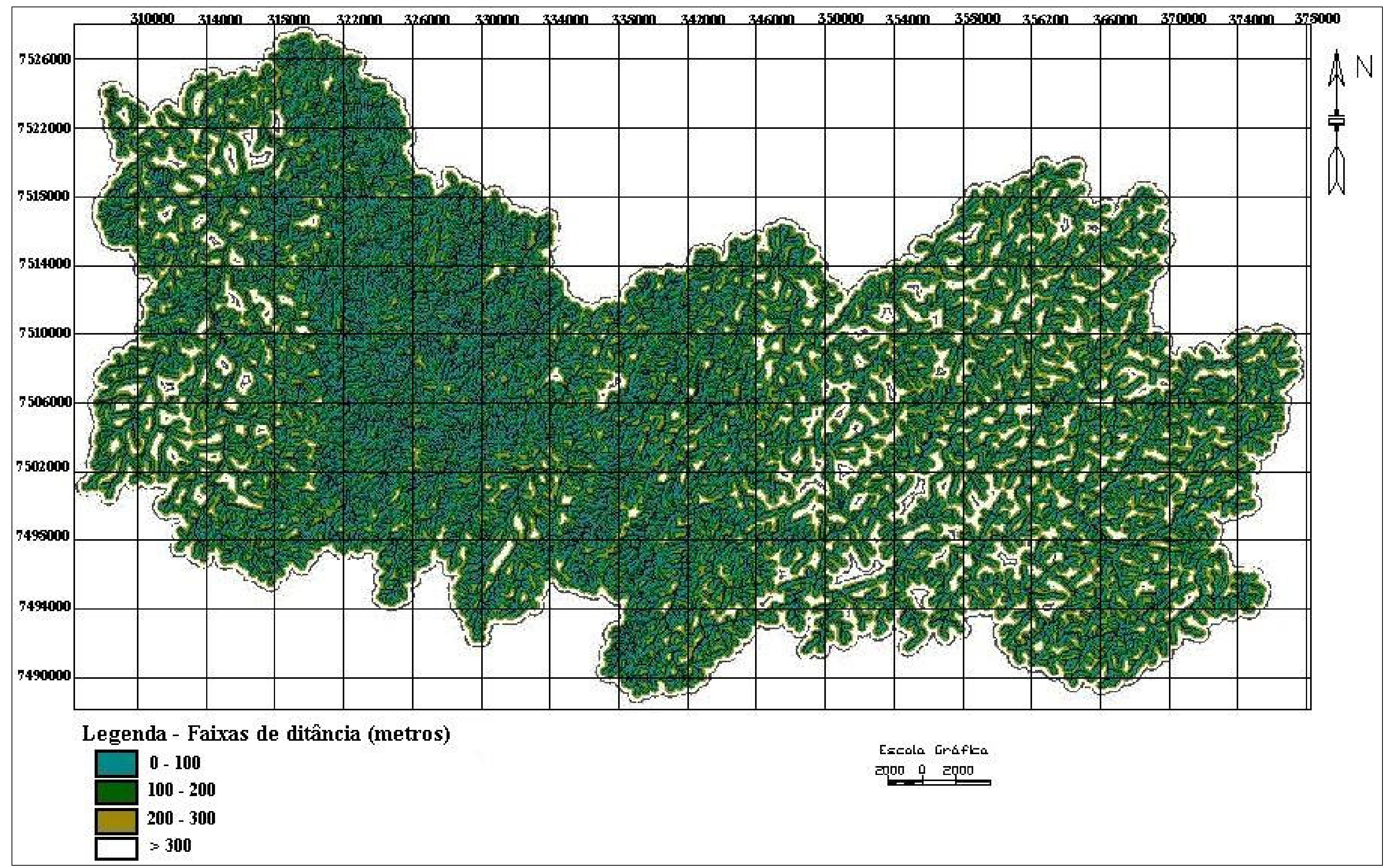

Figura 6.13 - Representação temática das faixas de distância regularmente distribuídas ao longo da rede de drenagem da bacia. 


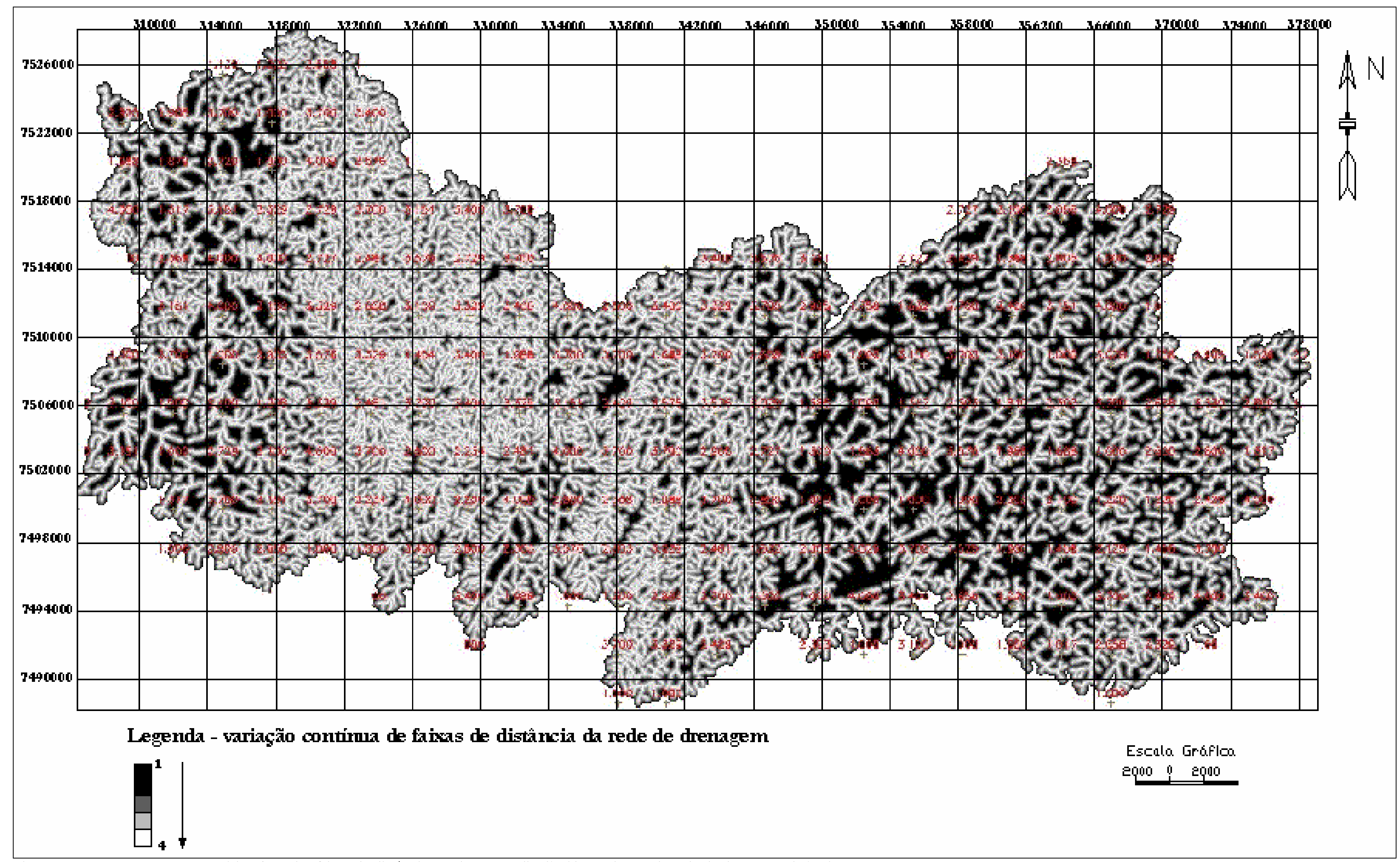

Figura 6.14 - Representação numérica fuそ:̧y das faixas de distância regularmente distribuídas ao longo da rede de drenagem da bacia. 


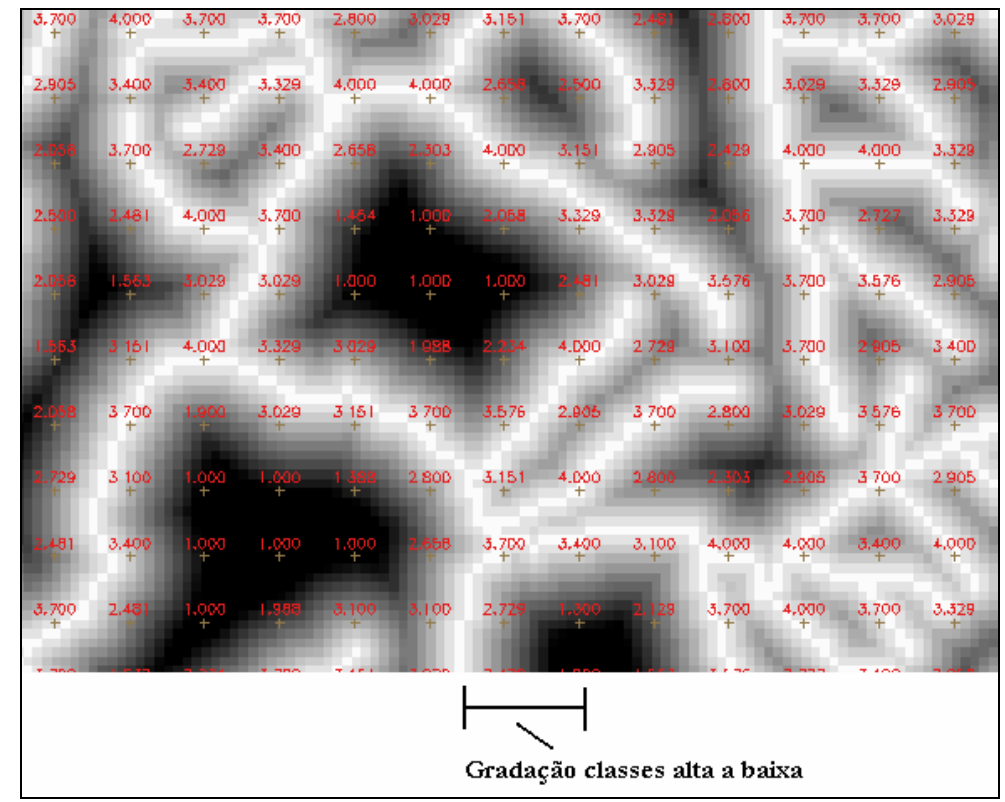

Figura 6.15 - Detalhe da representação numérica fu₹zy dos valores das classes de densidade de drenagem da bacia.

Para facilitar o processo de transformação das informações do substrato rochoso e materiais inconsolidados para formato numérico fuzzy, os polígonos representativos das diferentes unidades constituintes destes compartimentos foram considerados como conjuntos furay.

\section{Conjuntos Furzy}

Moreira et al (2001) definem, matematicamente, um conjunto fuzay como: se Z denota um espaço de objetos, então se entende que o conjunto fužy A em Z é o conjunto expresso pelo par ordenado $-\mathrm{A}=\left(\mathrm{z}, \mathrm{MF}_{\mathrm{A}}(\mathrm{z})\right)$ para todo $\mathrm{z} \in \mathrm{Z}$, onde a função $\mathrm{MF}_{\mathrm{A}}(\mathrm{z})$ caracteriza a "graduação" de z em A. Ou seja, avalia o grau de pertinência do elemento z com relação ao conjunto A, refletindo o grau de compatibilidade de um predicado associado a um conjunto A e ao objeto Z.

A função $\mathrm{MF}_{\mathrm{A}}$ (z) resulta em um número real que normalmente varia de " 0 " a "1", com "1" caracterizando o membro que se encaixa completamente ao conjunto e “ 0 ” o membro que não pertence ao conjunto.

Um aspecto relevante a ser assegurado no processo de elaboração de documentos cartográficos por meio de inferência fuzæy, é que o valor do elemento no 
centro do conjunto tem que ser "1", devendo o mesmo decair de maneira lógica através da fronteira furay, zona de gradação de contato entre polígonos (Moreira et al, 2001).

Conforme os autores (op cit), o ponto onde o valor do elemento é igual a 0.5 caracteriza o ponto de cruzamento, e este deve coincidir com os contatos rígidos dos modelos booleanos.

Burrough e McDonell (1998) destacam que a $\mathrm{MF}_{\mathrm{A}}(\mathrm{z})$ que retrata em linguagem matemática as relações de contato entre unidades deve ser definida de tal modo, que a condição acima citada seja respeitada.

\subsubsection{1- Caracterização das relações de contato}

A caracterização das relações de contato consistiu do levantamento de informações em campo e determinação das transições entre as unidades de substrato rochoso e de materiais inconsolidados.

Das observações das relações de contato em campo, constatou-se que as unidades de substrato rochoso e materiais inconsolidados da bacia do Rio do Peixe exibem diferentes situações de transição de contato, de modo que para uma melhor caracterização destas transições adotou-se a técnica de análise por contato individual, Individual Boundary Aproach (Burrough \& Macdowel,1998). Segundo está técnica, é assumido que um polígono pode apresentar diferentes faixas de gradação ao longo de seus contatos, podendo ser abruptos em algumas parte e difusos em outras, assim como podem apresentar relações difusas variáveis.

A caracterização das relações de contato foi estabelecida primeiramente para as unidades de substrato rochoso, e em seguida para as unidades de materiais inconsolidados.

\section{Substrato Rochoso}

Para as diferentes unidades que constituem este compartimento foram verificadas três situações de gradação:

1. Relação de contato abrupto -não é verificada gradação entre atributos. Entendese que nesta situação a unidade tem grau de pertinência "1" em toda sua 
extensão, e grau de pertinência “0” na região adjacente, logo após a linha de contato booleano.

2. Relação de contato com transição homogênea entre unidades - gradação com faixas de transição simétricas entre unidades adjacentes. Neste tipo de relação, duas unidades adjacentes apresentam faixas de transição com dimensões simétricas, a partir da zona de contato booleano.

3. Relação de contato com transição heterogênea entre unidades - gradação com faixas de transição assimétricas entre unidades adjacentes. As faixas de transição exibem dimensões diferentes a partir da zona de contato booleano.

A região de encontro entre contatos homogêneos e heterogêneos caracteriza a ocorrência de uma zona de transição complexa, aqui denominada de zona tripla. As Figuras 6.16 (A -D) exemplificam as situações de relações de contato descritas acima.

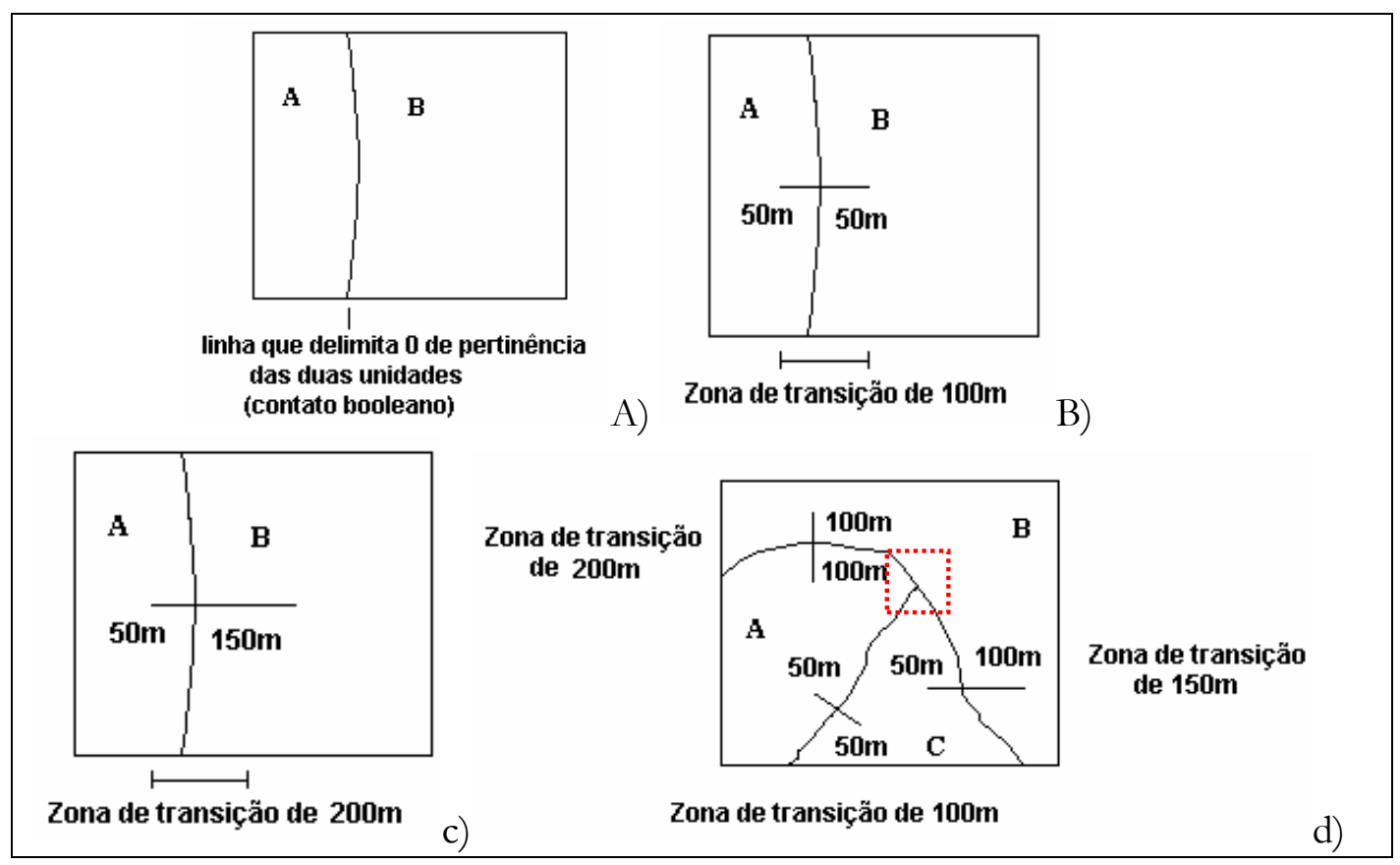

Figura 6.16 -Relações de contato verificadas entre unidades do substrato rochoso da bacia. A) Contato abrupto, B) Contato homogêneo, C) Contato heterogêneo e D) Região de contato complexo - destacada em vermelho.

Foram verificadas, para a maioria das unidades litológicas presentes na área a predominância de ocorrência de relações de contatos gradacionais homogêneos e heterogêneos entre unidades. A ocorrência de contato abrupto foi verificada apenas entre a unidade de quartzitos impuros e as litologias adjacentes a este, presentes nas 
zonas de falhas de Monte Sião e Ibitinga. Nesta localidade a referida unidade exibe contatos condicionados por falhas.

Estabelecidas e caracterizadas as relações de contatos, foram formuladas as funções membro fužy para cada unidade. Estas caracterizam as faixas de gradação de cada unidade individualmente.

Para cada faixa de transição identificada foi elaborada uma função que traduz para a linguagem matemática sua distribuição espacial.

Faixa de gradação de $50 \mathrm{~m}$

Faixa de gradação de $100 \mathrm{~m}$

Faixa de gradação de $200 \mathrm{~m}$

Faixa de gradação de $250 \mathrm{~m}$

Faixa de gradação de $400 \mathrm{~m}$

$$
\begin{array}{r}
F(x)=(0,01 * X)+0,5 \\
F(x)=(0,005 * X)+0,5 \\
F(x)=(0,0025 * X)+0,5 \\
F(x)=(0,002 * X)+0,5 \\
F(x)=(0,00125 * X)+0,5
\end{array}
$$

\section{Materiais Inconsolidados}

As relações de contato entre as unidades deste atributo foram determinadas levando-se em consideração três aspectos:

1. Unidades adjacentes de materiais residuais representativas de litologias diferentes exibem as mesmas faixas de gradação estabelecidas para as unidades de substrato rochosos a que se referem;

2. Unidades adjacentes de materiais residuais representativas de mesma litologia exibem relações de contato determinadas por critérios de textura, espessura e unidades de landforms correspondente;

3. Unidade materiais retrabalhados e aluviões apresentam contatos abruptos com as unidades adjacentes.

Com a adoção destes critérios houve necessidade de caracterização e estabelecimento de relações de contato apenas para as unidades de materiais inconsolidados residuais representativas de mesma litologia (aspecto 2 acima).

Foram adotadas faixas de transição de 50 e 100 metros para caracterizar as zonas de gradação. A caracterização das zonas foi estabelecida a partir da seguinte seqüência de análise: 1) Para situações de mesma textura entre unidades, o comportamento de 
transição foi estabelecido por relações de espessura e 2) Para situações de mesmas texturas e espessuras entre unidades o comportamento de transição foi estabelecido por relações de unidades de lanforms

Aos materiais de texturas argilosas foi atribuído maior valor de faixa de transição, pois entende-se que estes caracterizam materiais mais evoluídos que os arenosos e siltosos, logo devem apresentar uma transição entre unidades adjacentes mais gradacional.

Para os materiais de maiores espessuras atribuiu-se maior valor de faixa de transição, pois estes apresentam perfis com maior distribuição espacial, o que condiciona uma zona de transição mais desenvolvida.

Para as relações de transição estabelecidas a partir de critérios de formas de terreno foram obedecidas as correspondências apresentadas na Tabela 6.3.

Tabela 6.3 - Relações de transição estabelecidas a partir de critérios de formas de terreno

\begin{tabular}{c|c}
\hline Relações de adjacência entre formas & Faixas de transição estabelecidas \\
\hline Morro/Colina & $100 / 50$ \\
\hline Morro/Serra & $50 / 100$ \\
\hline Colina/Serra & $50 / 100$ \\
\hline
\end{tabular}

\subsubsection{2- Elaboração e execução de Programas em LEGAL}

Em função dos atributos de substrato rochoso e materiais inconsolidados apresentarem relações de contato caracterizadas por condições restritivas associadas a modelos temáticos e numéricos, foi necessário primeiro vincular as unidades constituintes destes compartimentos às categorias e PI de modelo temático (MT) e modelo numérico do terreno (MNT).

Em uma etapa posterior forma elaborados os programas em LEGAL. Estes executam diferentes funções condicionais restritivas espaciais, com aplicação de operações pontuais, caracterizadas por uma função membro furæỳ. As funções condicionais restritivas são definidas por variáveis lingüísticas (informações temáticas) associadas as grades de distância (informações numéricas). 


\section{Informacões de Modelo Temáticos}

Os dados associados aos PI das categorias temáticas foram importados como entidades tipo linha com topologia, e submetidos a edição vetorial, que consistiu na atribuição a cada polígono de uma respectiva classe (Figura 6.17). As classes identificam as unidades encontradas em campo.

As classes temáticas dos PI foram transformadas para o formato matriz(Figura 6.18), o que assegurou uma correspondência de resolução espacial, 30 x 30 metros, com as informações dos modelos numéricos. Este procedimento se fez necessário devido ao fato de, no processo de importação das linhas ser passível a atribuição apenas de valores de escala e unidade métrica.

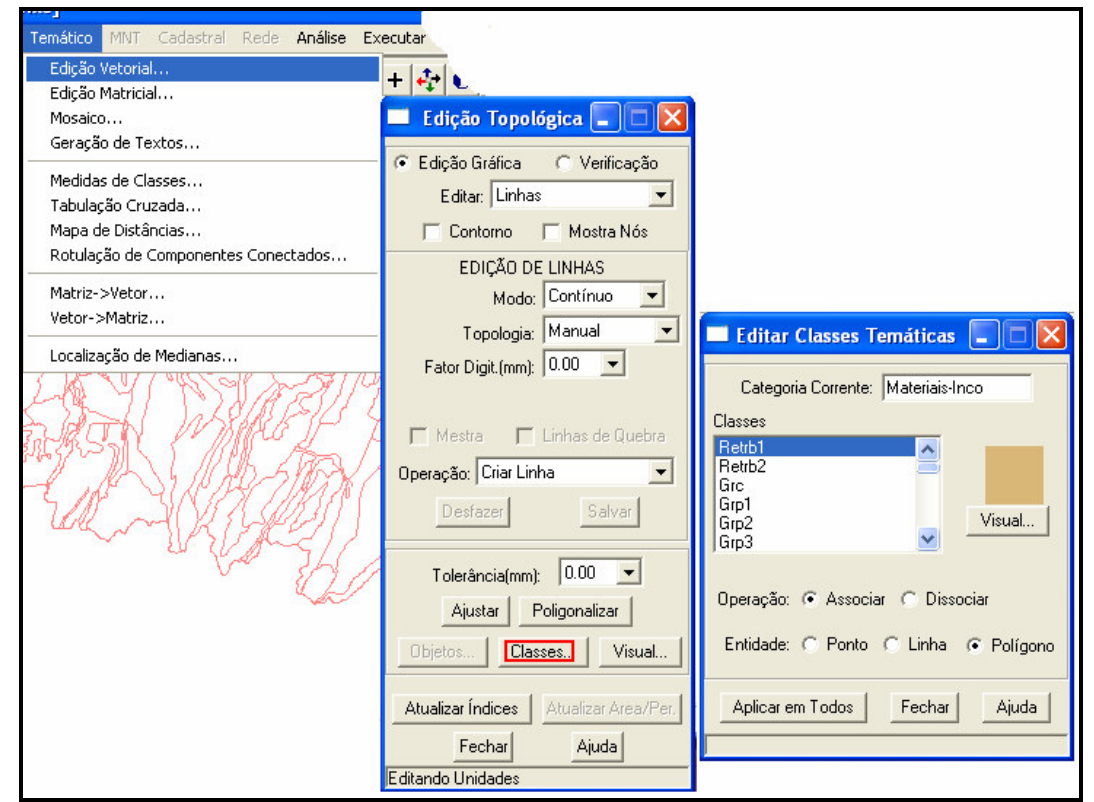

Figura 6.17 - Etapas de edição vetorial de polígonos representativos de unidades temáticas

\section{Informacões de Modelo Numéricos}

As informações associadas aos PI da categoria MNT foram armazenadas sob o formato de grades contínuas de distância, mapas de distância, com resolução espacial $30 \mathrm{X} 30$ metros e 1558 linhas e 2846 colunas.

Em função da diversidade de relações de transição constatadas para as diferentes unidades de substrato rochoso e materiais inconsolidados, caracterizadas por variações 
nas dimensões das faixas de gradação ao longo da extensão dos contatos, foi necessária a geração de grades compartimentadas para caracterização pelos programas em LEGAL das relações de contato. Ou seja, para uma unidade A, que apresenta transições homogêneas e heterogêneas ao longo de toda extensão de sua linha de contato (Figura 6.19), procedeu-se a partição da mesma, de forma que as diferentes partes fossem representativas destas variações espaciais de contato.

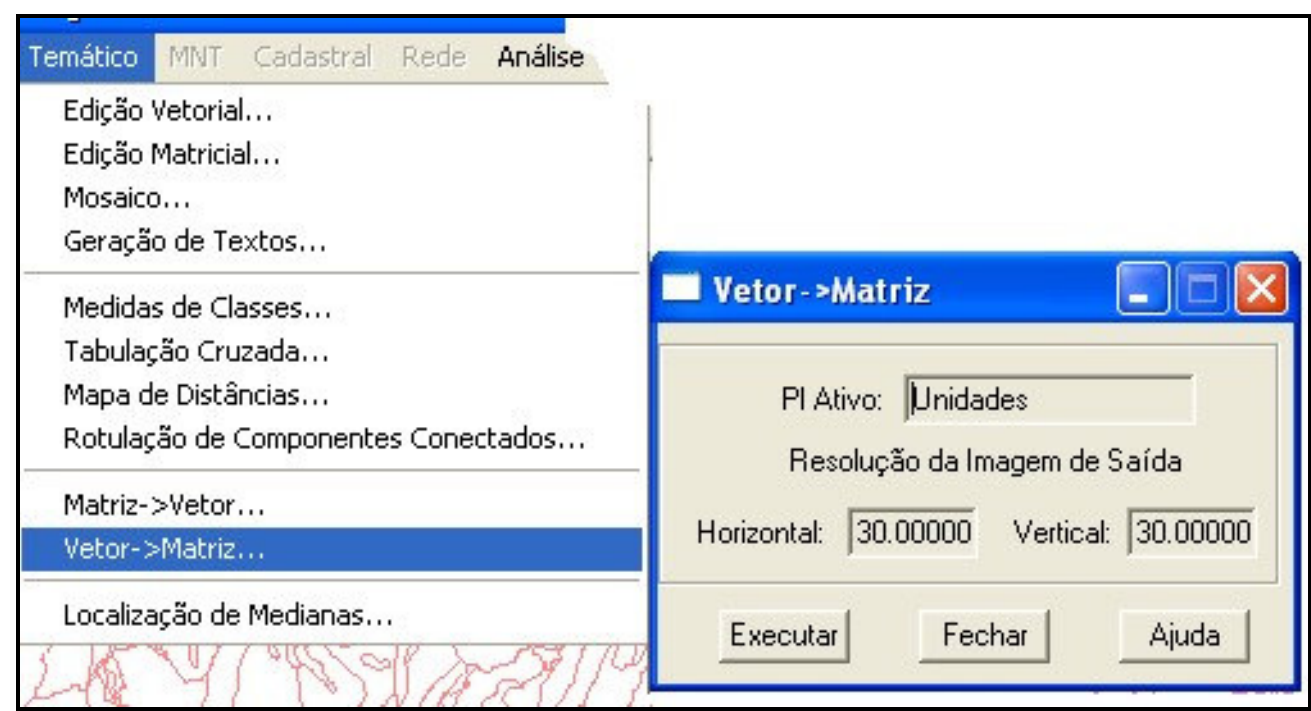

Figura 6.18 - Etapas transformação de dados temáticos vetorias para representação matricial.

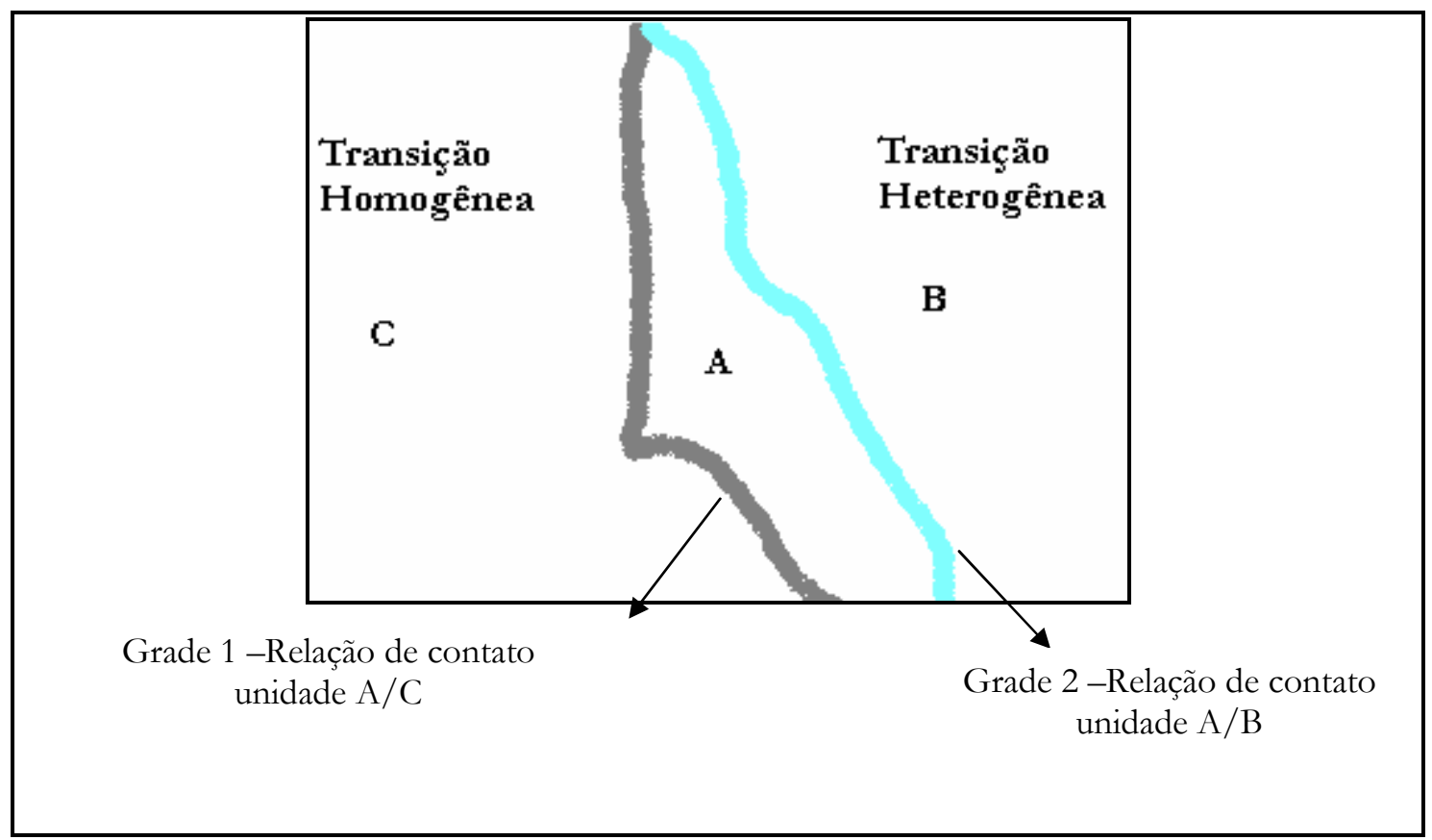

Figura 6.19 - Exemplo de unidade com relações gradativas diferentes ao longo da extensão de sua linha de contato. 
Rotinas em LEGAL

Organizados os dados sob forma de modelos temáticos e numéricos procedeuse a elaboração e execução dos programas (Programas LEGAL 3 a 64, Apêndice A) de espacialização das relações de contato entre as unidades para o formato numérico fuz:yy.

Os programas traduziram para linguagem matemática o comportamento das zonas de transição, de forma a caracterizar a distribuição de ocorrência espacial crescente de uma unidades, denotada pela faixa " 1 a 0 ".

Para relações transicionais os programas executaram operações com aplicação de funções responsáveis pela espacialização gradativa dos contatos primeiramente para as faixas de gradação internas ao polígono, e posteriormente as faixas externas, como exemplificado abaixo:

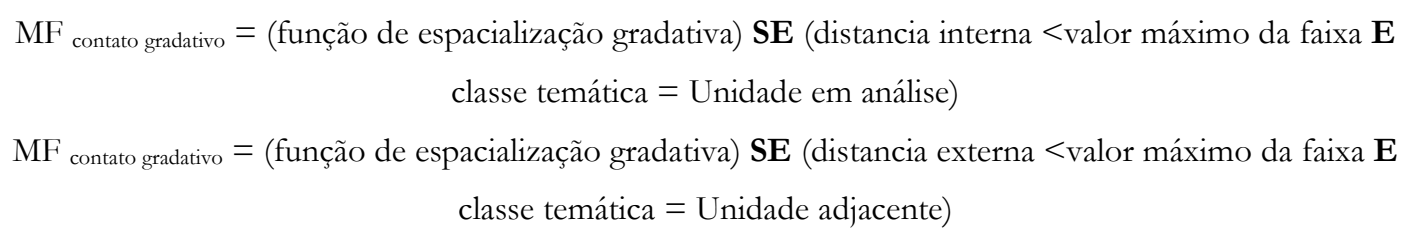

Obtidas as espacializações gradativas, os programas executam funções de atribuição de número inteiro representativos das situações de $100 \%$ e $0 \%$ de existência da unidade, como exemplificado abaixo:

$\mathrm{MF}_{100 \% \text { exeistência }}=($ Valor 1$) \mathbf{S E}$ (distancia interna $\geq$ valor máximo faixa interna $\mathbf{E}$ classe temática $=$ Unidade em análise)

$\mathrm{MF}_{0 \% \text { exeistência }}=($ Valor 0) $\mathbf{S E}$ (distancia externa $\geq$ valor máximo faixa externa $\mathbf{E}$ classe temática $=$ Unidade adjacente)

Para situações de contato abrupto foram executadas operações com aplicação de função que especializa a distribuição da unidade de forma homogênea:

$\mathrm{MF}_{\text {contato abrupto }}=$ (função de espacialização homogênea) $\mathbf{S E}$ (distancia $\geq 0 \mathbf{E}$ classe temática $=$ Unidade em análise)

A seguir são apresentados exemplos de Programas em LEGAL de obtenção da representação fuzæy de relações de contato gradativo e abrupto (Quadro 6.3 e 6.4). 
Quadro 6.3 - Exemplo de programa LEGAL para espacialização contínua de relações de contatos gradativos.

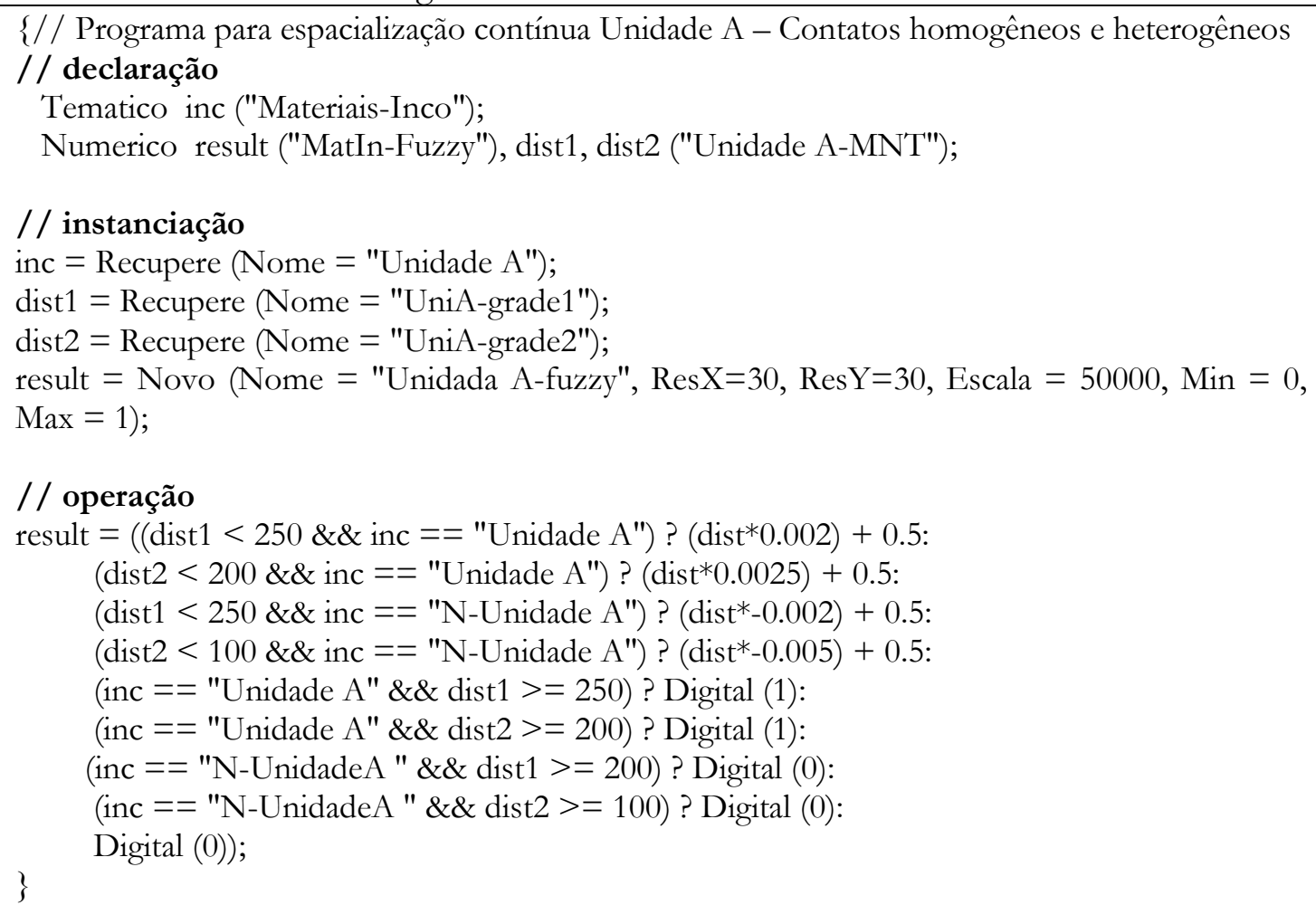

\section{// operação}

result $=(($ dist1 $<250 \& \&$ inc $==$ "Unidade A" $) ?($ dist*0.002) +0.5 :

$($ dist $2<200 \& \&$ inc $==$ "Unidade A") ? (dist*0.0025) + 0.5:

$($ dist $1<250 \& \&$ inc $==$ "N-Unidade A") ? (dist*-0.002) + 0.5:

(dist $2<100 \& \&$ inc $==$ "N-Unidade A") ? (dist*-0.005) + 0.5:

(inc $==$ "Unidade A" \&\& dist1 >= 250) ? Digital (1):

(inc $==$ "Unidade A" \&\& dist2 >= 200) ? Digital (1):

(inc $==" N-$ UnidadeA $" \& \&$ dist1 $>=200)$ ? Digital (0):

(inc $==" N-$ UnidadeA $" \& \&$ dist2 $>=100)$ ? Digital $(0)$ :

Digital (0));

Quadro 6.4 - Exemplo de programa LEGAL para espacialização contínua de relações de contato abrupto.

\{ // Programa para espacialização contínua Unidade B - Contato abrupto

// declaração

Tematico inc ("Materiais-Inco");

Numerico result ("MatIn-Fuzzy"), dist ("MatRetrb-MNT");

\section{// instanciação}

inc $=$ Recupere $($ Nome $=$ "Unidades B");

dist $=$ Recupere $($ Nome $=$ "UniB-grade");

result $=$ Novo $($ Nome $=$ "Unidade B-fuzzy", ResX=30, ResY=30, Escala $=50000$, Min $=0$, $\operatorname{Max}=1)$;

\section{// operação}

result $=(($ dist $>=0 \& \&$ inc $==$ " Unidades B " $)$ ? (dist*1) +1 :

(inc $==" N-$ UnidadeB" \&\& dist $>0)$ ? Digital $(0)$ :

Digital (0)); 
Nas duas rotinas apresentadas nos Quadros 6.3 e 6.4, as seqüências iniciadas pela variável lingǘstica dist expressam o comportamento da zona de contato, e a variável sub o comportamento de ocorrência 100 a $0 \%$ da unidade em análise.

No programa ilustrado no Quadro 6.3, as variáveis dist 1 e 2 fazem referência as duas grades complementares que compõem a linha de contato da unidade. A primeira caracterizada por relações de contatos homogêneos, faixa interna e externa com 250 metros. A segunda caracterizada por relações de contatos heterogêneos, faixa interna e externa com 200/100 metros.

O programa verifica a validade das condições restritivas e aplica as funções associadas, primeiramente para toda extensão interna da área de contato, e posteriormente para toda extensão externa.

Espacializadas para um formato contínuo, as faixas de contato, são atribuídos os valores inteiros " 1 " e " 0 " as regiões internas e externas ao polígono da unidade em análise, de forma a caracterizar as regiões de ocorrência e não existência da unidade.

Para os casos de caracterização de relação de contato abrupto, como apresentado no Quadro 6.4, na primeira expressão condicional restritiva é estabelecida a espacialização homogênea da unidade, em toda sua extensão interna. Estabelece a atribuição do valor "1" a toda extensão interna da unidade. O que determina a partir do contato booleano até o centro do polígono uma ocorrência homogênea para a unidade. A segunda expressão atribui valor de existência nula da unidade, na região externa a linha de contato booleano.

O processo de transformação dos dados de substrato rochosos e materiais inconsolidados resultou na obtenção de 61 polígonos em formato numérico fuそzyy, os quais retratam apenas a distribuição espacial das situações de ocorrência homogênea ou gradativa de cada unidade (Figuras 6.20, 6.21 e 6.22) 


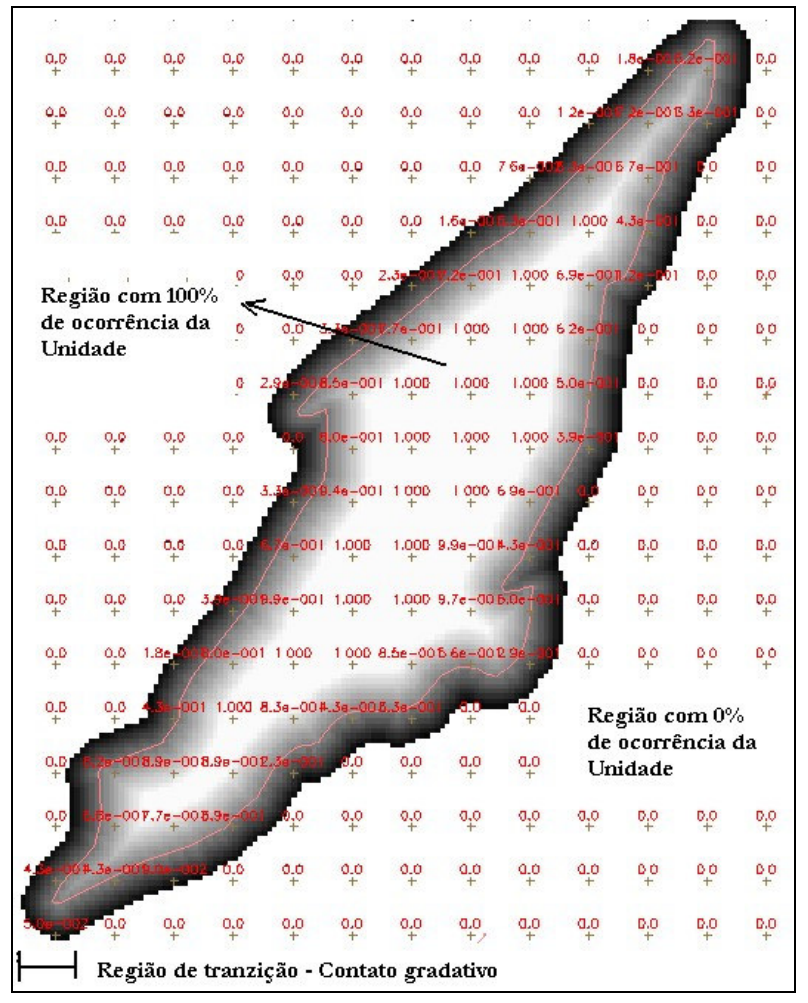

Figura 6.20 Representação numérica fuz:̧y de relações de contato heterogêneo gradativo. Faixa interna 250 metros e externa 200 metros.

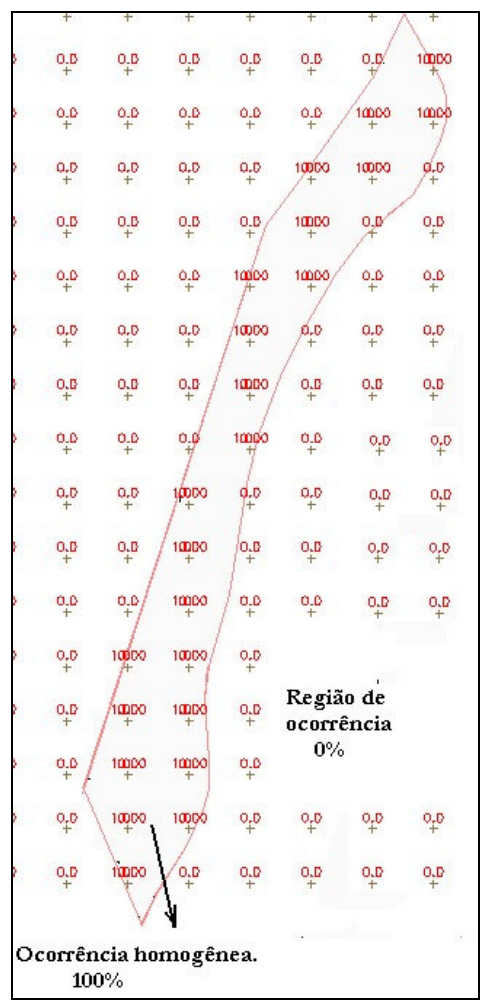

Figura 6.21 -Representação numérica de relação de contato homogêneo abrupto. 


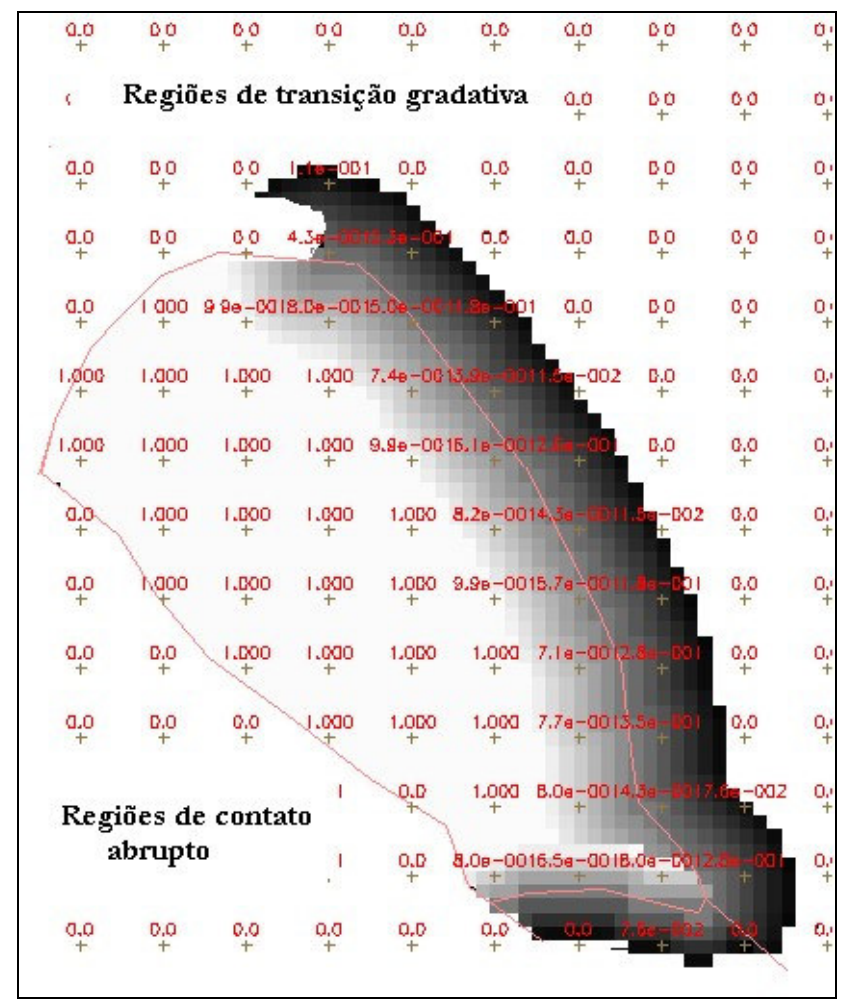

Figura 6.22 -Representação numérica de relação de contato gradativo homogêneo abrupto. Faixas contatos homogêneos interno/externo de 200 metros e 100 metros.

\subsection{CARTAS DERIVADAS INTERPRETIVAS FUZZY}

Obtida a base de dados básicos fundamentais em formato fu₹zy procedeu-se a caracterização das potencialidades e restrições do meio físico da bacia, por meio do cruzamento das informações em formato contínuo, com elaboração de três documentos cartográficos que retratam aptidões e restrições naturais da área quanto aos aspectos de potencial ao escoamento superficial, susceptibilidade a erosão e potencial ao desenvolvimento agrícola. Estes documentos caracterizam o comportamento de variação contínua, entre de limites mínimos e máximos estabelecidos, assim como permitem a delimitação de zonas com comportamento homogêneo quanto as aspectos acima citados.

A obtenção destes documentos envolveu a avaliação e atribuição de peso de importância as diferentes informações que caracterizam a base de dados fundamentais fuг̃y. O processo de atribuição de pesos visou a organização destas informações segundo a menor ou maior influência frente aos fins de restrição e potencialidades pretendidos pelas cartas derivativas. 


\subsection{Procedimentos de elaboração das cartas derivadas}

Para obtenção das cartas derivadas foi realizado um conjunto de procedimentos executados na seguinte seqüência:

1. Seleção das informações básicas fundamentais importantes a caracterização de cada aspecto de potencialidade e susceptibilidade, em separados;

2. Organização das informações básicas segundo ordem de maior a menor influência na caracterização de potencialidade e susceptibilidade;

3. Comparação pareada entre informações para atribuição relativa de pesos de importância;

4. Análise isolada de cada informação para disposição dos atributos que as constituem em ordem crescente de grau de influência, classes de importância, junto aos aspectos de potencialidade e restrições do meio.

5. Cruzamento das informações básicas.

\subsubsection{Comparação pareada entre informações - Técnica AHP}

A comparação pareada entre informações para atribuição relativa de pesos de importância constitui uma técnica de análise proposta por Saaty (1978), denominada Analytic Hierarquy Process (AHP), ou Processo Analítico Hierárquico. Trata-se de uma teoria com bases matemáticas que permite organizar e avaliar a importância relativa entre critérios e medir a consistência dos julgamentos.

Para aplicação da técnica é necessária a estruturação de um modelo hierárquico no qual as informações são organizadas segundo grau de importância relativa destas frente ao aspecto em julgamento. De acordo com Saaty (1978), as diferentes informações que influenciam na caracterização do aspecto a ser retratado são comparadas par a par, e um critério de importância relativa é atribuído ao relacionamento entre estas, conforme uma escala predefinida (Tabela 6.4).

A comparação pareada das informações constituintes da base de dados básicos fundamentais fuz:yy da bacia foi realizada por meio do módulo Análise, com a operação Suporte a decisão (AHP). Nesta as informações representadas pelas categorias são selecionadas por ordem de influência, e avaliadas com atribuição de pesos (Figura 6.23). 
Tabela 6.4 - Escala AHP de comparação par a par (Saaty, 1978)

\begin{tabular}{|c|l|}
\hline $\begin{array}{c}\text { Intensidade de } \\
\text { Importância }\end{array}$ & \multicolumn{1}{|c|}{ Definição e Explicação } \\
\hline 1 & Importância igual - os dois fatores contribuem igualmente para o objetivo \\
\hline 3 & Importância moderada - um fator é ligeiramente mais importante que o outro \\
\hline 5 & Importância essencial - um fator é claramente mais importante que o outro \\
\hline 7 & $\begin{array}{l}\text { Importância demonstrada - um fator é fortemente favorecido e sua maior relevância } \\
\text { foi demonstrada na prática }\end{array}$ \\
\hline 9 & $\begin{array}{l}\text { Importância extrema - a evidência que diferencia os fatores é da maior ordem } \\
\text { possível }\end{array}$ \\
\hline $2,4,6,8$ & Valores intermediários entre julgamentos - possibilidade de compromissos adicionais \\
\hline
\end{tabular}

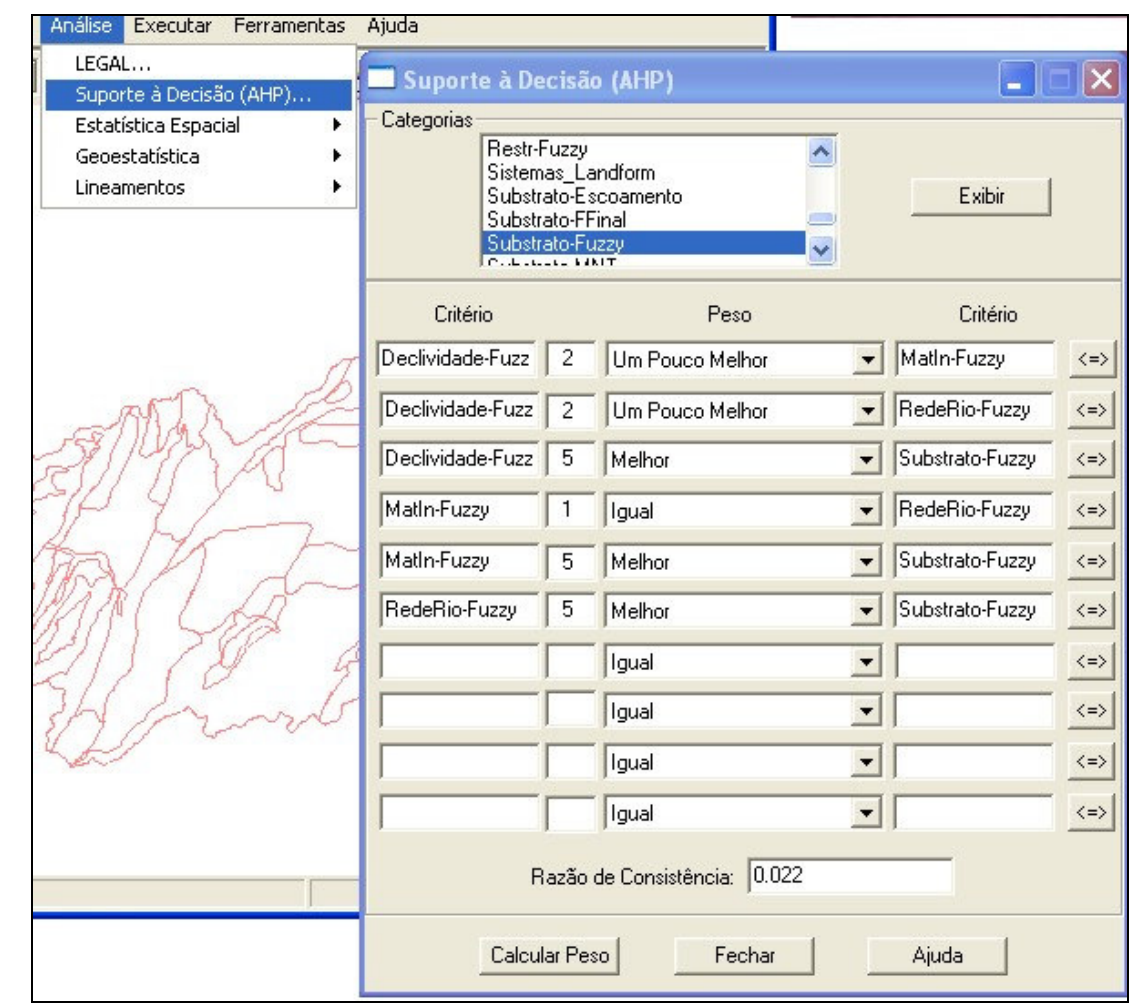

Figura 6.23 - Exemplo de operação de análise AHP no sistema SPRING.

À medida que os pesos são atribuídos as informações, é apresentada a razão de consistência do julgamento tomado. Segundo Saaty (1978), valores de razão de consistência superiores a 0,10 sugerem uma revisão da ordenação adotada ou dos pesos atribuídos.

Obtido um valor de razão de consistência indicativo de um processo de julgamento adequado, o módulo AHP permite o calculo do peso que cada informação tem em relação ao aspecto de potencialidade ou restrição analisado. 


\subsubsection{Disposição dos atributos em classes}

Como cada informação analisada é constituída por diferentes atributos, por exemplo, informação - materiais inconsolidados; atributos - textura, espessura, gênese, etc., e estes influenciam com maior ou menor importância o comportamento das potencialidades e restrições do meio físico, há necessidade de organizá-los em classes que representem a escala de importância da informação.

No processo de análise individual das informações básicas fundamentais, os atributos foram dispostos segundo ordem crescente de importância em quatro classes: Baixa, Média, Alta e Muito alta (Figura 6.24). A estas foram atribuídos os valores "1 a 4", para apresentação destas como superfícies contínuas.

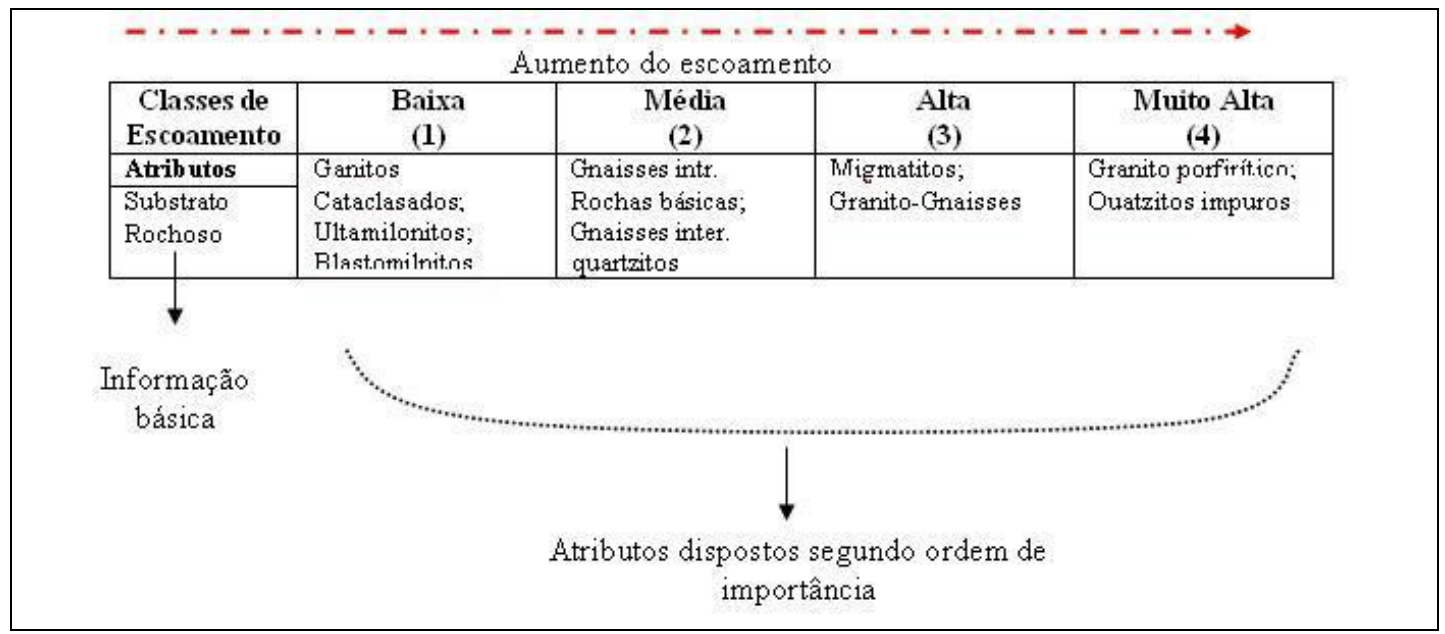

Figura 6.24 - Exemplo de disposição dos atributos constituintes da informação substrato rochoso em classes crescentes de importância quanto ao aumento do escoamento superficial.

As informações relativas a declividade e densidade de drenagem já haviam sido previamente transformadas para o formato numérico representativo destas classes durante o processo de criação da base de dados fundamentais fu₹zy. A disposição dos dados básicos em classes por agrupamento de unidades foi realizada apenas para as informações relativas ao substrato rochoso e aos materiais inconsolidados.

A atribuição do grau de importância a cada agrupamento de unidades foi realizada por programas em LEGAL, por meio da multiplicação do número inteiro representativo de cada classe. Os agrupamentos de unidades representam os atributos constituintes das informações básicas fundamentais. 
A expressão abaixo apresenta a operação de atribuição dos valores inteiros, representativos de uma classe de importância, a um agrupamento de unidades, executada por programa em LEGAL:

// operação

result $=3 *^{*} \operatorname{var} 8+3 * \operatorname{var} 9+3 *^{*} \operatorname{var} 10+3 * \operatorname{var} 11+3 * \operatorname{var} 12+3 * \operatorname{var} 13+3 * \operatorname{var} 14+3 *^{*} \operatorname{var} 15+$ $3 *^{*} \operatorname{var} 16+3 *^{*} \operatorname{var} 17+3{ }^{*} \operatorname{var} 18+3 *^{*} \operatorname{var} 19+3 *^{*} \operatorname{var} 20$

Como resultados desta operação foram obtidas as classes de importância, de forma individual, na forma de superfície contínua para os diferentes atributos das informações básicas fundamentais (Figura 6.25 A e B).

Executada a atribuição dos valores das classes aos respectivos agrupamentos de unidades, procedeu-se a somatória destes e obtenção das superfícies furzy de distribuição, desde baixa a muito alta, das classes de influência de um dado atributo dos compartimentos de substrato rochoso e materiais inconsolidados frente a um aspecto de restrição ou potencialidade do meio (Figura 6.26). Nestas superfícies foram observadas ocorrências de regiões caracterizadas por valores superiores aos limites das classes estabelecidas (Figura 6.27 A e B). Tais regiões ocorrem nas zonas de contato complexo e em áreas onde há recobrimento de zonas de gradação com dimensões diferentes, e caracterizam áreas com valores anômalos de distribuição contínua. Nestes casos, estas áreas foram consideradas com o valor máximo 4.

As superfícies fur:y obtidas foram ponderadas segundo os pesos determinados no processo de comparação pareada, e posteriormente cruzadas para obtenção das cartas derivadas interpretativas.

\subsubsection{Análise das Cartas interpretativas fuzzy}

A análise das superfícies contínuas representativas dos comportamentos de potencial ao escoamento superficial, susceptibilidade a erosão e potencial agrícola da bacia foi realizada por meio da execução de duas operações de quantificação de informações apresentadas no sistema SPRING, estatística de imagem por polígonos e medida de classes temáticas.

A primeira foi executada para as imagens representativas das superfícies contínuas de cada carta. Nessa operação o sistema informa, na forma de um relatório de dados, valores de número de pixel, mínimo, máximo, amplitude, etc. (Figura 6.28). Para 
realização deste procedimento faz-se necessária associação de uma classe temática à superfície continua.
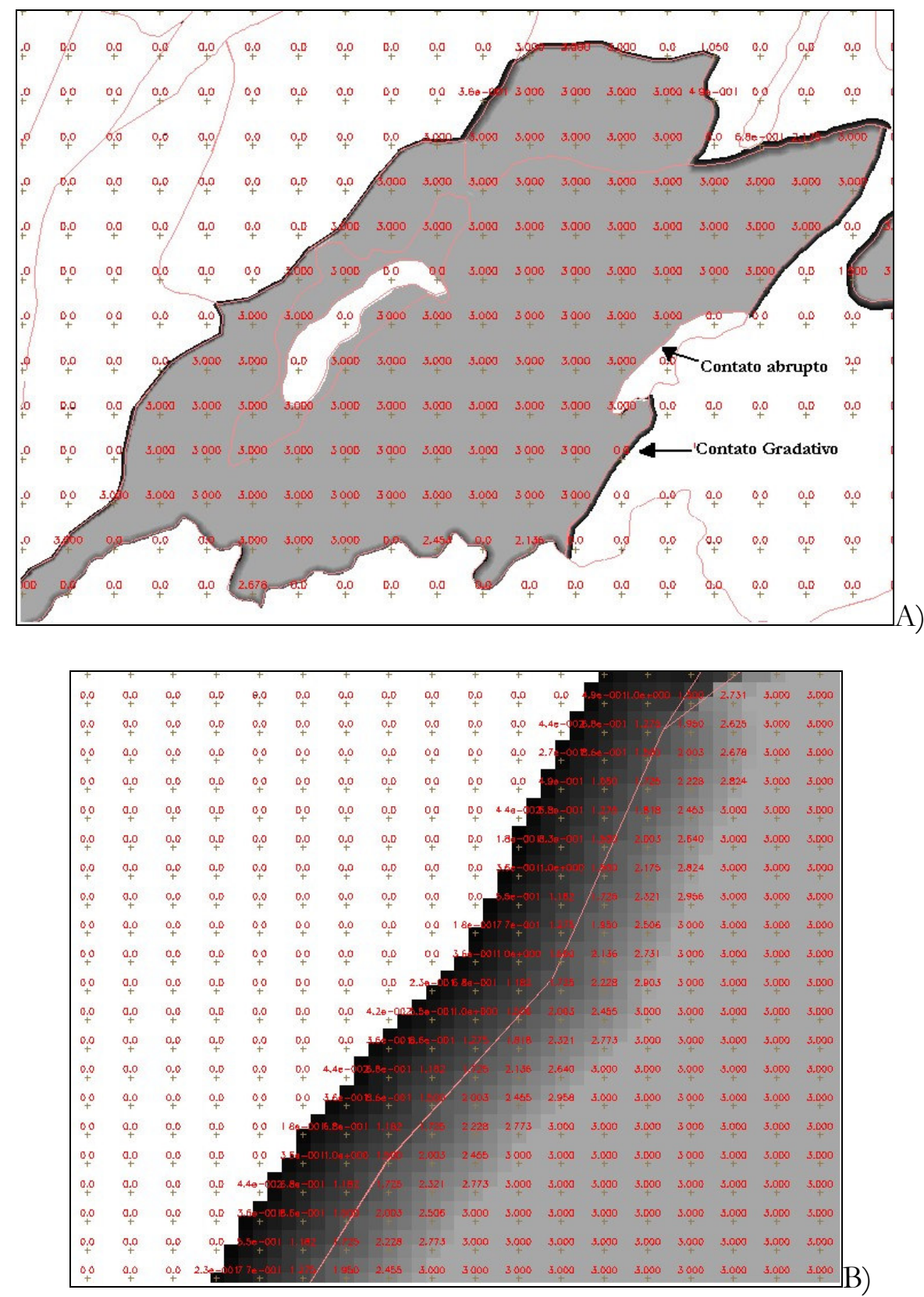

Figura 6.25 - A) Exemplo de agrupamento de unidades representativas de classe de importância alta. B) Detalhe zona de gradação da classe apresentada. 


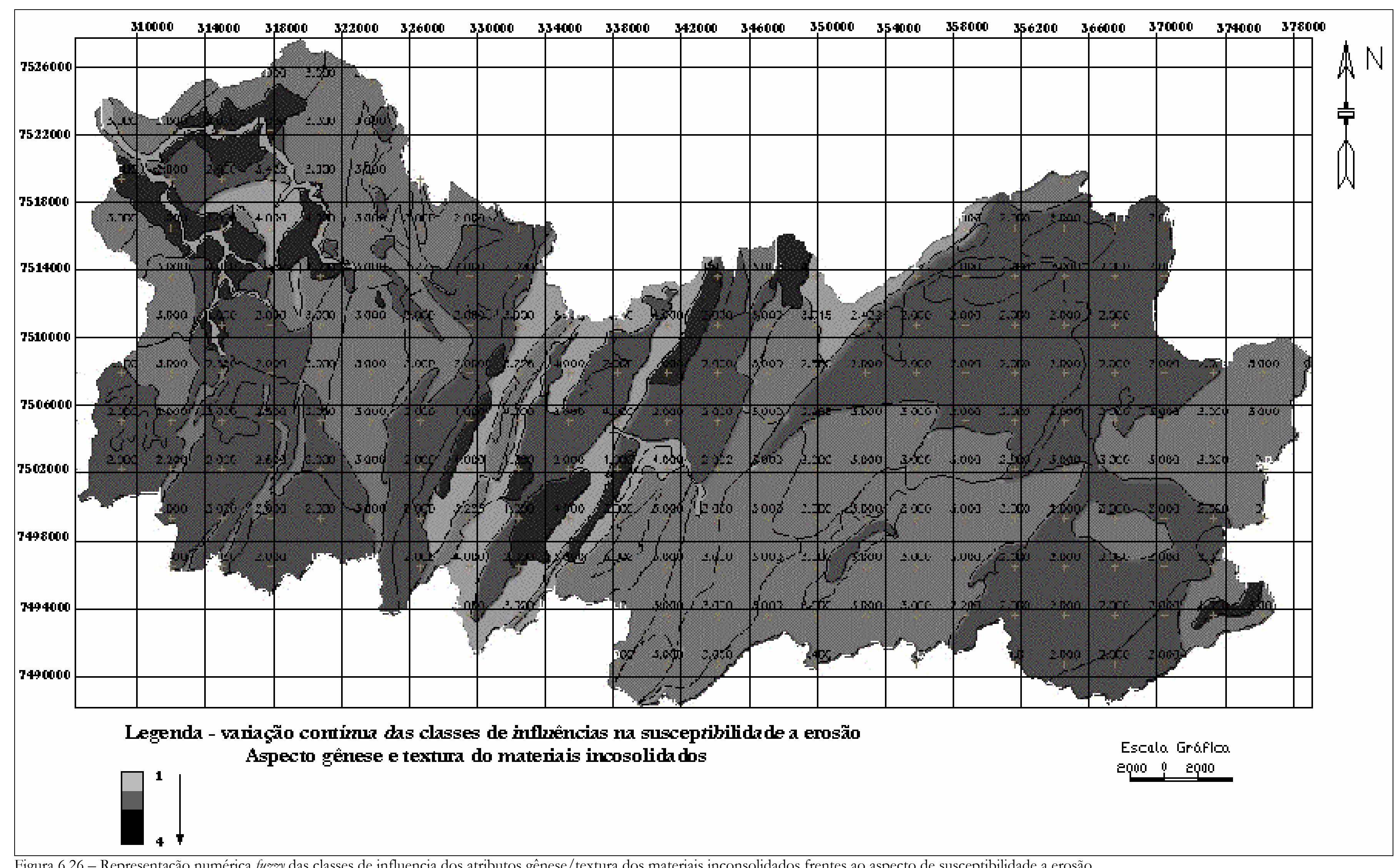

Figura 6.26 - Representação numérica fu₹:yy das classes de influencia dos atributos gênese/textura dos materiais inconsolidados frentes ao aspecto de susceptibilidade a erosão. 

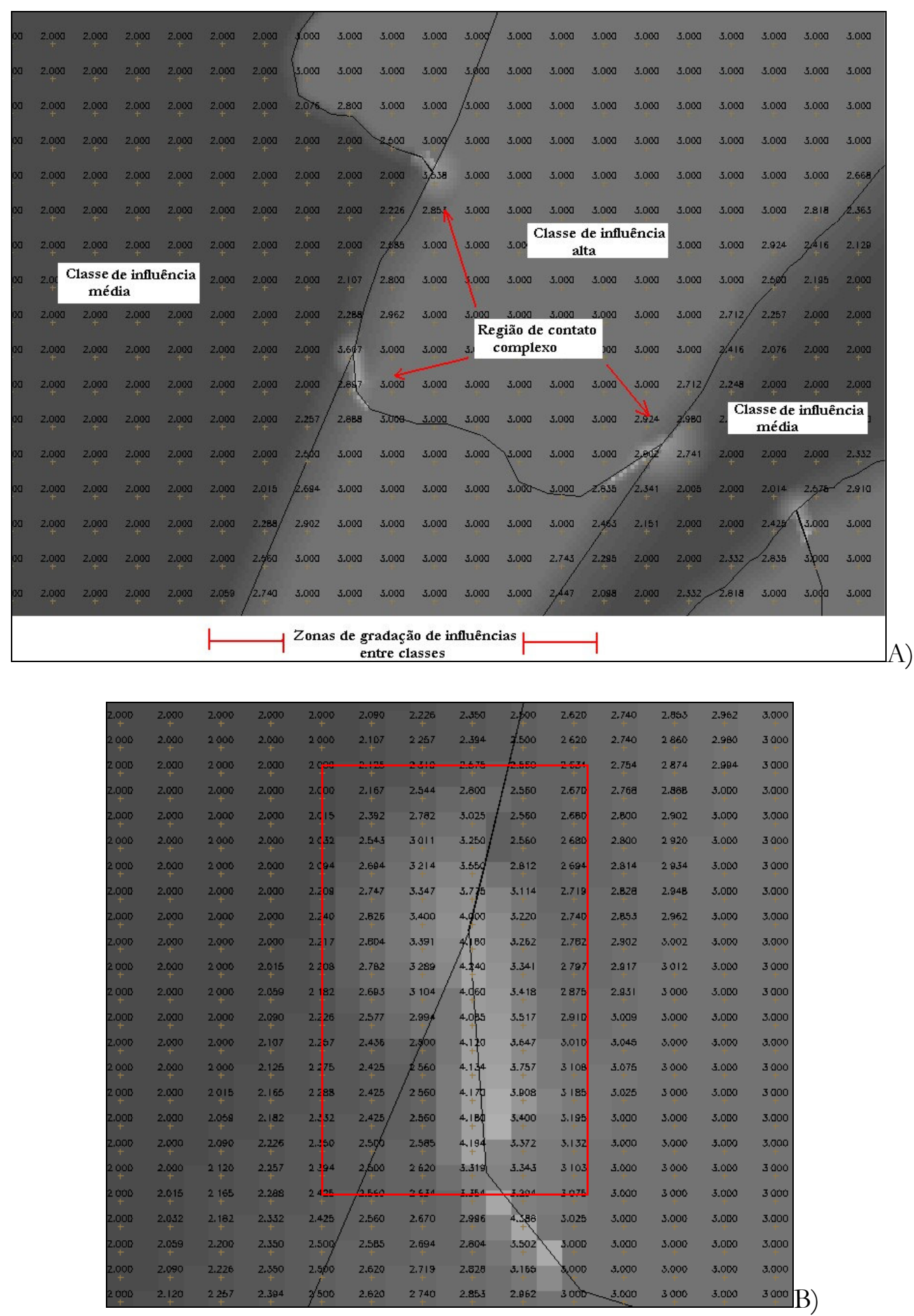

Figura 6.27 - A) Exemplo da ocorrência de regiões anômalas de distribuição contínua de valores entre classes de influência. B) Detalhe de região anômala caracterizada por valores de influência muito alta entre as classes adjacentes, baixa e média. 
A segunda análise foi realizada para as cartas interpretativas apresentadas em formato temático matricial. Esta operação permite o cálculo de ocorrência em área das informações das classes referenciadas nos documentos cartográficos (Figura 6.29).

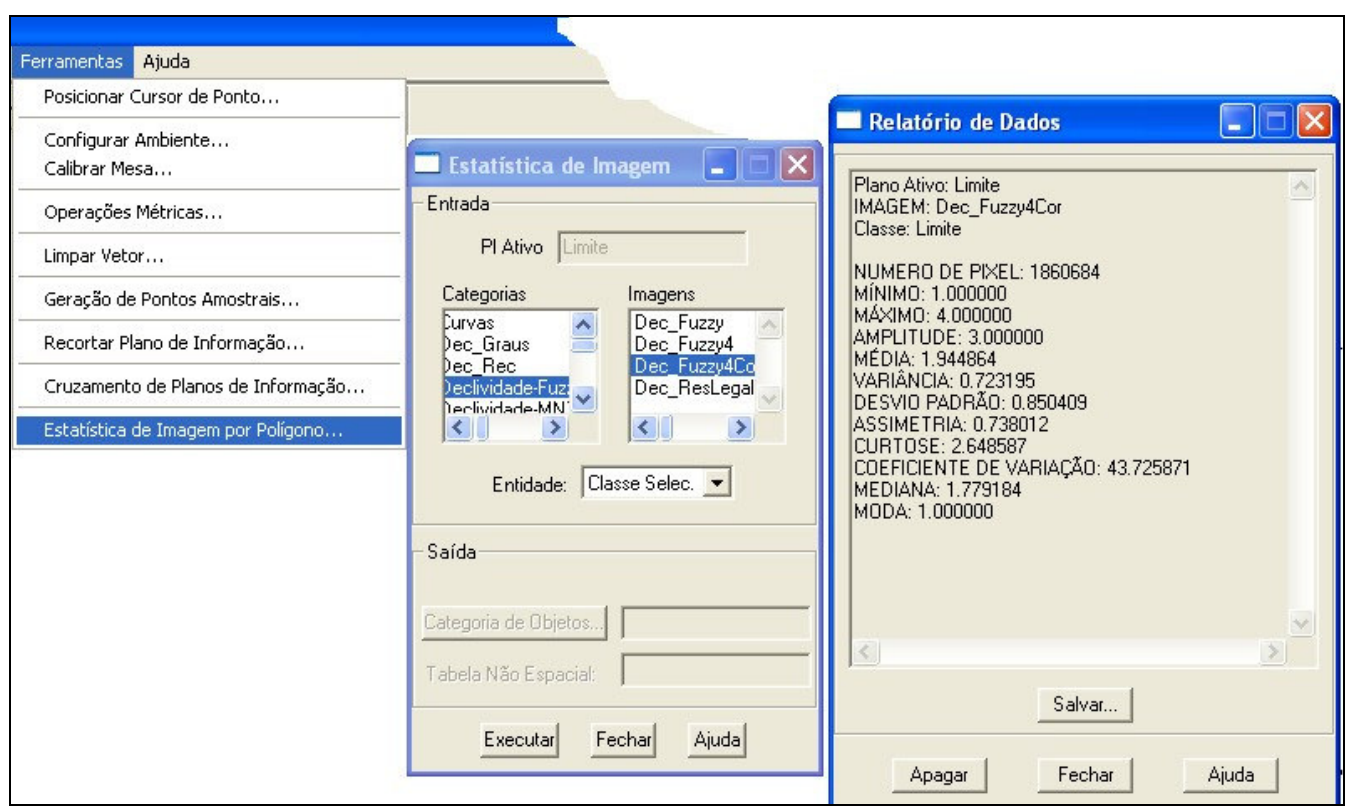

Figura 6.28 - Exemplo de operação de estatística de imagem por polígono.

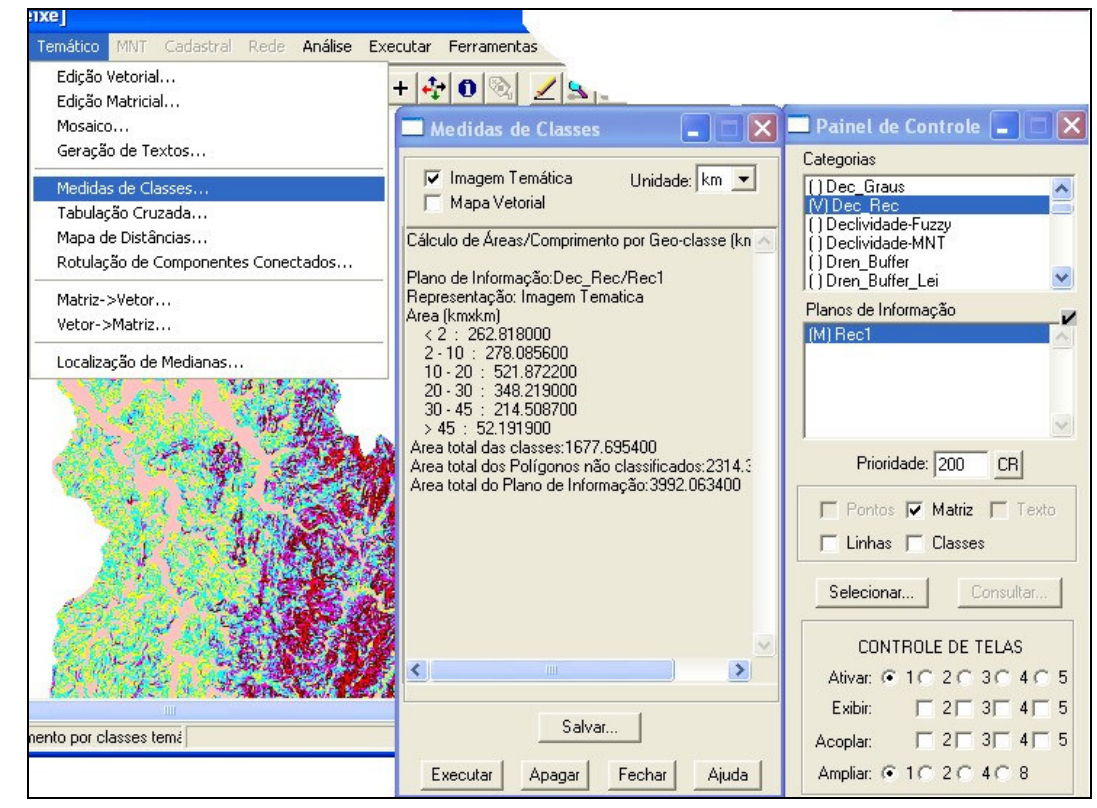

Figura 6.29 - Exemplo operação de medida de classe em imagem temática matricial 


\subsubsection{Carta de Potencial ao Escoamento SuperficiaL (ANEXO VII)}

As informações consideradas para elaboração deste documento e caracterização do potencial ao escoamento da bacia forma: declividade, CEMPAS, materiais inconsolidados e substrato rochoso. A influência das informações dos materiais inconsolidados foi analisada sob os aspectos de textura, gênese e espessura de cada unidade. O substrato rochoso foi analisado sob o aspecto de tipo litológico.

As Tabelas 6.5 e 6.6 apresentam, respectivamente, a ordenação das informações e atributos selecionados por classe de influência no comportamento do escoamento, e a matriz de comparação pareada com pesos obtidos para cada informação.

Tabela 6.5 - Ordenação das informações do meio físico e distribuição dos atributos em classes crescentes de influência.

\begin{tabular}{|c|c|c|c|c|c|c|c|c|c|}
\hline \multicolumn{10}{|c|}{ Aumento do potencial ao escoamento } \\
\hline \multirow{2}{*}{\multicolumn{2}{|c|}{$\begin{array}{l}\text { Informações do } \\
\text { meio físico }\end{array}$}} & \multicolumn{8}{|c|}{ Classes de Escoamento } \\
\hline & & \multicolumn{2}{|r|}{$\begin{array}{c}\text { Baixa } \\
1\end{array}$} & & \multicolumn{2}{|c|}{$\begin{array}{l}\text { Média } \\
2\end{array}$} & \multicolumn{2}{|r|}{$\begin{array}{c}\text { Alta } \\
3 \\
\end{array}$} & $\begin{array}{l}\text { Muito alta } \\
4\end{array}$ \\
\hline \multicolumn{2}{|l|}{ Declividade } & \multicolumn{8}{|c|}{ 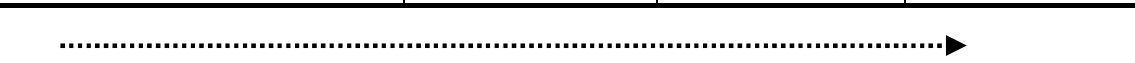 } \\
\hline \multicolumn{2}{|c|}{$\begin{array}{c}\text { Materiais } \\
\text { inconsolidados } \\
\text { Textura / gênese }\end{array}$} & \multicolumn{3}{|c|}{ Retrabalhados arenosos } & \multicolumn{2}{|c|}{$\begin{array}{l}\text { Residuais } \\
\text { arenosos }\end{array}$} & \multicolumn{2}{|c|}{$\begin{array}{c}\text { Residuais } \\
\text { siltosos } \\
\text { Retrabalhados } \\
\text { argilosos }\end{array}$} & $\begin{array}{l}\text { Residuais } \\
\text { argilosos }\end{array}$ \\
\hline \multicolumn{10}{|l|}{ CEMPAS } \\
\hline \multicolumn{2}{|c|}{$\begin{array}{c}\text { Materiais } \\
\text { inconsolidados } \\
\text {.Espessura } \\
\text { (m) }\end{array}$} & \multicolumn{3}{|c|}{$>5,0$} & \multicolumn{2}{|c|}{$5,0-3,0$} & \multicolumn{2}{|r|}{$3,0-1,0$} & $<1,0$ \\
\hline \multicolumn{2}{|c|}{ Substrato rochoso } & \multicolumn{3}{|c|}{$\begin{array}{c}\text { Granitos cataclasados } \\
\text { Milonitos } \\
\text { Ultramilonitos }\end{array}$} & \multicolumn{2}{|c|}{$\begin{array}{l}\text { Gnaisses int. } \\
\text { rochas básicas } \\
\text { Gnaisses inter. } \\
\text { quartzitos }\end{array}$} & \multicolumn{2}{|c|}{$\begin{array}{l}\text { Migmatito } \\
\text { Granito- } \\
\text { gnaisses }\end{array}$} & $\begin{array}{l}\text { Granitos } \\
\text { porfiríticos } \\
\text { Quartzitos } \\
\text { impuros } \\
\end{array}$ \\
\hline \multicolumn{10}{|c|}{ Tabela 6.6 - Matriz de comparação pareada e pesos de ponderação de cada informação. } \\
\hline & \multicolumn{2}{|c|}{ Declividade } & $\begin{array}{l}\text { MI textura } \\
\text { gênese }\end{array}$ & \multicolumn{2}{|c|}{$\begin{array}{l}\text { Densidade } \\
\text { drenagem }\end{array}$} & \multicolumn{2}{|c|}{$\begin{array}{c}\text { MI } \\
\text { espessura }\end{array}$} & Substrato & $\begin{array}{c}\text { Peso } \\
\text { ponderação }\end{array}$ \\
\hline Declividade & \multicolumn{2}{|l|}{1} & 2 & \multicolumn{2}{|l|}{2} & \multicolumn{2}{|l|}{3} & 5 & 0,36607 \\
\hline $\begin{array}{l}\text { MI- textura } \\
\text { gênese }\end{array}$ & \multicolumn{2}{|l|}{$1 / 2$} & 1 & \multicolumn{2}{|l|}{1} & \multicolumn{2}{|l|}{3} & 5 & 0,24221 \\
\hline $\begin{array}{l}\text { Densidade } \\
\text { drenagem }\end{array}$ & \multicolumn{2}{|l|}{$1 / 2$} & 1 & \multicolumn{2}{|l|}{1} & \multicolumn{2}{|l|}{2} & 5 & 0,2174 \\
\hline $\begin{array}{c}\text { MI- } \\
\text { espessura }\end{array}$ & \multicolumn{2}{|c|}{$1 / 3$} & $1 / 3$ & $1 / 2$ & & 1 & & 5 & 0,12875 \\
\hline Substrato & $1 / 5$ & & $1 / 5$ & $1 / 5$ & & $1 / 5$ & & 1 & 0,04557 \\
\hline
\end{tabular}


A matriz apresentada na Tabela 6.7 retrata a avaliação de julgamento de importância entre as informações do meio físico, executada pela operação de suporte a decisão AHP do SPRING. A razão de consistência obtida na operação de comparação par a par foi 0,04 .

A declividade foi considerada como informação de maior importância no processo de escoamento superficial, apresentando influência direta nas condições de mínimo e máximo escoamento. A disposição desta nas classes de influência obedeceu a distribuição dos valores percentuais de declividade, representados sob formato fuz:yy (1 4).

A distribuição em classes de influências da carta CEMPAS também foi retratada sob formato fuгæyy, correspondendo a superfície contínua elaborada na criação da base de dados básicos fundamentais (item 6.2.2).

A informação de materiais inconsolidados relativa aos aspectos de textura e gênese foram distribuídas nas classes crescentes de influência, considerando-se que materiais de gênese retrabalhada com textura caracterizada por mais de $50 \%$ de fração areia favorecem a mínima condição de escoamento, por corresponderem a materiais muito evoluídos que favorecem a infiltração; e materiais de gênese residual associados a texturas com mais de $50 \%$ de fração argila favorecem as condições de máximo escoamento. Matérias com gênese residual e texturas arenosas a siltosas, e de gênese retrabalhada com texturas argilosas foram divididos em classes que caracterizam condições de escoamento médio a alto.

Com relação ao aspecto espessura dos materiais inconsolidados, as unidades constituintes deste compartimento foram distribuídas em classes crescentes de influência a partir da consideração que áreas com materiais pouco espessos $(<1,0$ metro) favorecem as condições de escoamento muito alto, e áreas que apresentam materiais muito espessos (>5,0 metros) favorecem as condições de mínimo escoamento, pois nestas há uma tendência maior a infiltração.

$\mathrm{Na}$ distribuição das unidades do substrato rochoso segundo grau de influência as unidades representadas por granitos cataclasados, milonitos e ultramilonitos foram enquadradas na classe de mínima condição de escoamento, devido a presença de fraturamento e falhamentos em todas, e heterogeneidade composicional das últimas. As unidades representadas por quartzitos impuros e granitos porfiríticos foram classificadas como representativas das condições de escoamento mais elevadas, pois estas apresentam 
maior homogeneidade composicional e textural. As unidades constituintes de gnaisses, migmatitos e granitos-gnaisses foram entendidas como condicionantes de escoamento médios a altos, de acordo com seus aspectos texturais.

As atribuições dos valores associados a cada classe de influência, e a obtenção das superfícies contínuas representativas da distribuição crescente destas nos atributos de materiais inconsolidados e substrato rochoso analisados, foram executadas por rotinas de programação (Programas LEGAL 65 a 75, Apêndice A). A ponderação dos pesos de importância às informações do meio físico analisadas, também foi efetuada por meio de rotinas escritas em LEGAL (Programas LEGAL 76 a 80, Apêndice A).

O mapa de potencial ao escoamento da área foi obtido por meio de somatória das superfícies contínuas das informações classificadas e ponderadas. A operação de somatória destas foi realizada por rotina de programação (Programa LEGAL 81, Apêndice A), e resultou na superfície fuzày representativa do mapa (Figura 6.30).

O entendimento do comportamento de potencial ao escoamento da bacia foi realizado por meio de análises que envolveram observações da superfície continua elaborada, estatística de imagem por polígono e medidas de classes temáticas matriciais associadas ao mapa furay. A medida de classes temáticas foi realiza mediante fatiamento do mapa contínuo em faixas representativas do comportamento de escoamento da área (Anexo VII). As faixas de valores adotadas para representação deste comportamento foram: 1,0 a 2,0 para potenciais de escoamento baixo, 2,0 a 2,5 para potenciais de escoamento médio, 2,5 a 3,5 para potencias de escoamento altos e 3,5 a 4,0 para potencias muito altos de escoamento.

No processo de fatiamento os valores acima de quatro, presentes em regiões de comportamento anômalos foram integrados na classe de escoamento muito alto.

A observação da superfície contínua e os dados da estatística de imagem por polígono (Tabela 6.7) mostram uma predominância de ocorrência de classes de escoamento médio, tendendo a alto. Os valores obtidos da medida de classes temáticas revelam que a bacia caracteriza-se por apresentar potencial ao escoamento médio a alto (Tabela 6.7). 


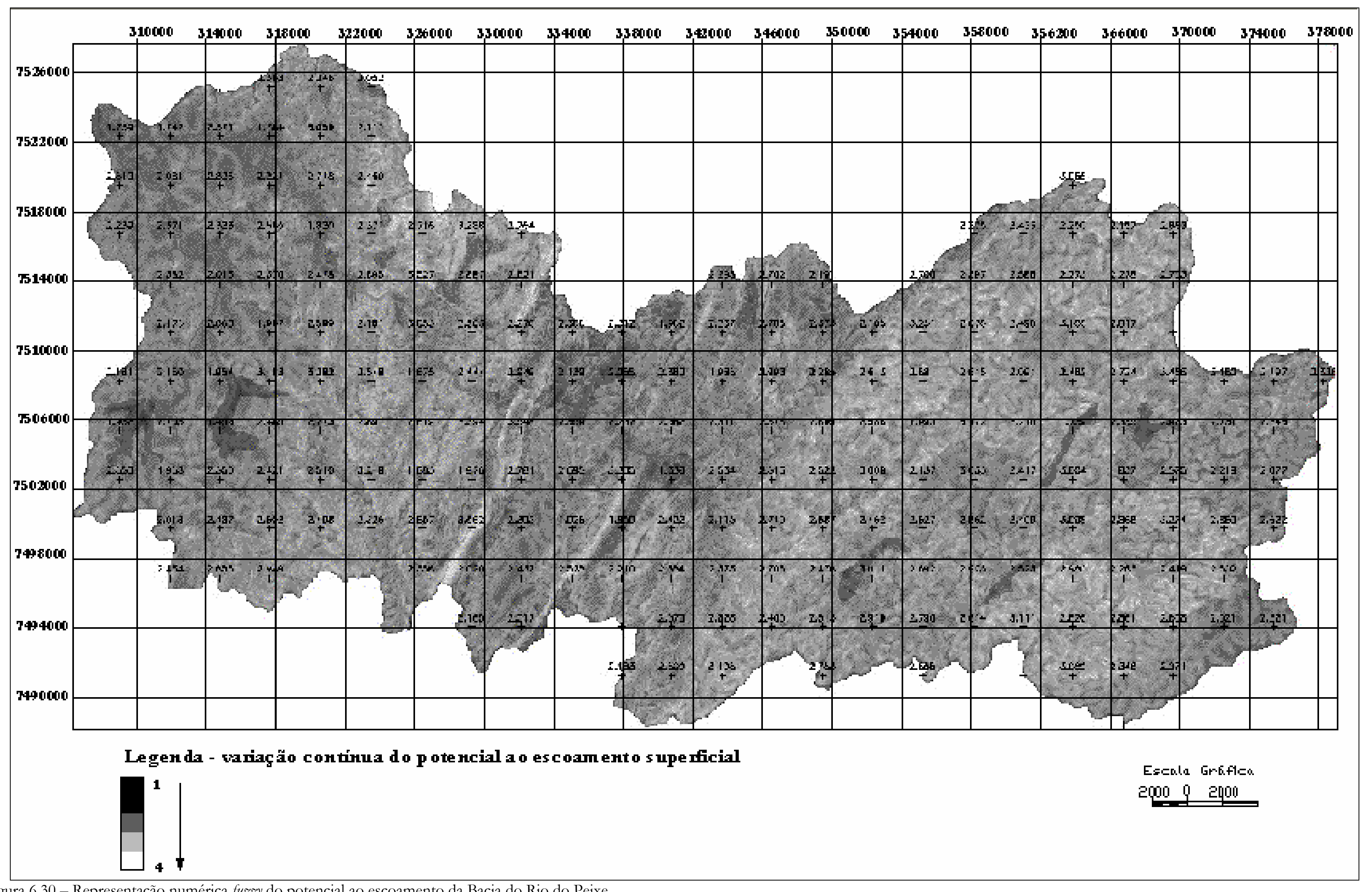

Figura 6.30 - Representação numérica fu₹žy do potencial ao escoamento da Bacia do Rio do Peixe. 
Tabela 6.7 - Valores medida de classe temática e estatística de imagem por polígono

\begin{tabular}{c|c|c}
\hline $\begin{array}{l}\text { Classes de Potencial ao } \\
\text { escoamento }\end{array}$ & Área $\left.\mathbf{( k m}^{2}\right)$ & \% de ocorrência na bacia \\
\hline Baixo & 179,68 & 10,71 \\
\hline Médio & 649,49 & 38,72 \\
\hline Alto & 660,72 & 39,39 \\
\hline Muito Alto & 187,52 & 11,18 \\
\hline \multicolumn{2}{|c}{ Valores de estatísticas de imagem } \\
\hline Numero de Pixels analisados & 1860717 \\
\hline Mínimo & 0,58 \\
\hline Máximo & \multicolumn{2}{c}{2,35} \\
\hline Média & 2,515 \\
\hline Desvio Padrão & 0,40 \\
\hline Moda & 2,37 \\
\hline
\end{tabular}

\subsubsection{Carta de Susceptibilidade a Erosão (ANEXO VIII)}

Foram selecionadas para elaboração deste documento informações referentes a textura, gênese e espessura dos materiais inconsolidados, e as informações do comportamento de escoamento superficial da área, conforme proposta de Pejon (1992).

As Tabelas 6.8 e 6.9 apresentam, respectivamente, a ordenação das informações e atributos selecionados por classe de influência no comportamento a susceptibilidade a erosão, e a matriz de comparação pareada com pesos obtidos para cada informação. A razão de consistência obtida na operação de comparação par a par foi 0,05 .

Tabela 6.8 - Ordenação das informações do meio físico e distribuição dos atributos em classes crescentes de influência.

\begin{tabular}{|c|c|c|c|c|}
\hline \multicolumn{5}{|c|}{ Aumento da susceptibilidade a erosão } \\
\hline \multirow{2}{*}{$\begin{array}{c}\text { Informações do } \\
\text { meio físico }\end{array}$} & \multicolumn{4}{|c|}{ Classes de Escoamento } \\
\hline & $\begin{array}{c}\text { Baixa } \\
1\end{array}$ & $\begin{array}{c}\text { Média } \\
2\end{array}$ & $\begin{array}{c}\text { Alta } \\
3\end{array}$ & $\begin{array}{l}\text { Muito alta } \\
4\end{array}$ \\
\hline $\begin{array}{l}\text { Potencial ao } \\
\text { escoamento }\end{array}$ & \multicolumn{4}{|c|}{ (n) } \\
\hline $\begin{array}{c}\text { Materiais } \\
\text { inconsolidados } \\
\text { Textura / gênese }\end{array}$ & Retrabalhados argilosos & $\begin{array}{c}\text { Retrabalhados } \\
\text { arenosos } \\
\text { Residuais } \\
\text { argilosos }\end{array}$ & $\begin{array}{c}\text { Residuais } \\
\text { arenosos } \\
10-30 \% \text { argila }\end{array}$ & $\begin{array}{c}\text { Residuais } \\
\text { arenosos }<= \\
10 \% \text { argila } \\
\text { Residuais } \\
\text { siltosos }\end{array}$ \\
\hline $\begin{array}{c}\text { Materiais } \\
\text { inconsolidados } \\
\text {.Espessura } \\
(\mathrm{m}) \\
\end{array}$ & $<1,0$ & $1,0-3,0$ & $3,0-5,0$ & $>5,0$ \\
\hline
\end{tabular}

- Atributos com variação contínua. 
Tabela 6.9 - Matriz de comparação pareada e pesos de ponderação de cada informação.

\begin{tabular}{c|l|l|l|c}
\hline & $\begin{array}{c}\text { Potencial } \\
\text { ao } \\
\text { escoamento }\end{array}$ & $\begin{array}{c}\text { MI textura } \\
\text { gênese }\end{array}$ & $\begin{array}{c}\text { MI } \\
\text { espessura }\end{array}$ & $\begin{array}{c}\text { Peso } \\
\text { ponderação }\end{array}$ \\
\hline $\begin{array}{c}\text { Potencial ao } \\
\text { escoamento }\end{array}$ & 1 & 1,333 & 2 & $\mathbf{0 , 4 2 7 0 2}$ \\
\hline $\begin{array}{c}\text { MI- textura } \\
\text { gênese }\end{array}$ & 0,75 & 1 & 3 & $\mathbf{0 , 4 0 3 5 1}$ \\
\hline $\begin{array}{c}\text { MI- } \\
\text { espessura }\end{array}$ & $1 / 2$ & $1 / 3$ & 1 & $\mathbf{0 , 1 6 9 4 6}$ \\
\hline
\end{tabular}

$\mathrm{Na}$ caracterização do comportamento de susceptibilidade a erosão do meio físico da bacia, o potencial ao escoamento foi considerado como informação de maior importância, apresentando grande importância no condicionamento das condições de mínima e máxima susceptibilidade. A disposição desta nas classes de influência obedeceu a distribuição natural dos valores representados sob formato fu₹ży (1 -4).

A declividade não foi selecionada por estar indiretamente retratada pelo mapa de potencial ao escoamento. As informações relativas ao substrato rochoso foram retratadas por meio dos aspectos de gênese e texturas dos materiais inconsolidados, não só pela caracterização quanto a origem residual ou retrabalhado, mas pela distribuição das unidades em classes de influência a partir de considerações da rocha original, quando residuais, e dos resultados obtidos no ensaios de erodibilidade das amostras de solos.

As unidades de materiais caracterizadas por gênese retrabalhada e textura argilosa foram consideradas como responsáveis pelas a mínima condição de erodibilidade, pois corresponderem a materiais muito evoluídos que desfavorecem a situações de elevado escoamento, e segundo dados de ensaios caracterizam-se por baixa erodibilidade. Os materiais de textura arenosa, com mais de $60 \%$ de fração areia, de origem residual de ultramilonitos, blastomilonitos, quartzitos impuros e gnaisses intercalados a rochas básicas foram considerados como responsáveis pelas condições de máxima susceptibilidade a erosão. Estes, conforme ensaios em laboratório caracterizamse por alta erodibilidade. Unidades de matérias de textura argilosa e residuais de granitos porfiríticos, granito-gnaisses, gnaisses intercalados com rochas básicas, migmatitos e ultramilonitos foram considerados como da classe de média influência. $\mathrm{Na}$ classe da alta influência foram enquadrados os materiais residuais de granitos cataclasados, granitos porfiríticos, granito-gnaisses, quartzitos impuros, gnaisses intercalados a rochas básicas e quartzitos, migmatitos, utlamilonitos e blastomilonitos 
que apresentam textura arenosa e siltosa, com percentuais similares destas frações

Com relação a espessura, as unidades pouco espessas $(<1,0$ metro) foram classificadas como de baixa susceptibilidade e as unidades muito espessas ( $>5,0$ metros) como de máxima susceptibilidade, pois nestas os processos erosivos quando instalados atingem grandes proporções.

As atribuições dos valores associados a cada classe de influência, e a obtenção das superfícies contínuas representativas da distribuição crescente destas nos atributos de materiais inconsolidados foram executadas por rotinas de programação (Programas LEGAL 82 a 91, Apêndice A).

Os programas em LEGAL 92 a 95 (Apêndice A) executaram a ponderação dos pesos de importância e a elaboração do mapa de susceptibilidade a erosão furày.

Os dados da estatística de imagem por polígono (Tabela 6.10) e a observação da superfície contínua de distribuição da (Figuras 6.31) mostram uma predominância de ocorrência da classe de alta susceptibilidade. Os valores obtidos da medida de classes apresentadas no mapa temático (Anexo VIII) revelam que a bacia caracteriza-se por apresentar susceptibilidade a erosão alta a média.

Tabela 6.10 - Valores medida de classe temática e estatística de imagem por polígono.

\begin{tabular}{c|c|c}
\hline $\begin{array}{l}\text { Classes de Potencial ao } \\
\text { escoamento }\end{array}$ & Área $\left(\mathbf{k m}^{2}\right)$ & \% de ocorrência na bacia \\
\hline Baixo & 115,80 & 6,90 \\
\hline Médio & 639,34 & 38,11 \\
\hline Alto & 781,58 & 46,59 \\
\hline Muito Alto & 140,70 & 8,39 \\
\hline \multicolumn{2}{c}{ Valores de estatísticas de imagem } \\
\hline Numero de Pixels analisados & 1860717 \\
\hline Mínimo & 0,25 \\
\hline Máximo & 2,46 \\
\hline Dédia & 2,53 \\
\hline Moda Padrão & 0,36 \\
\hline
\end{tabular}




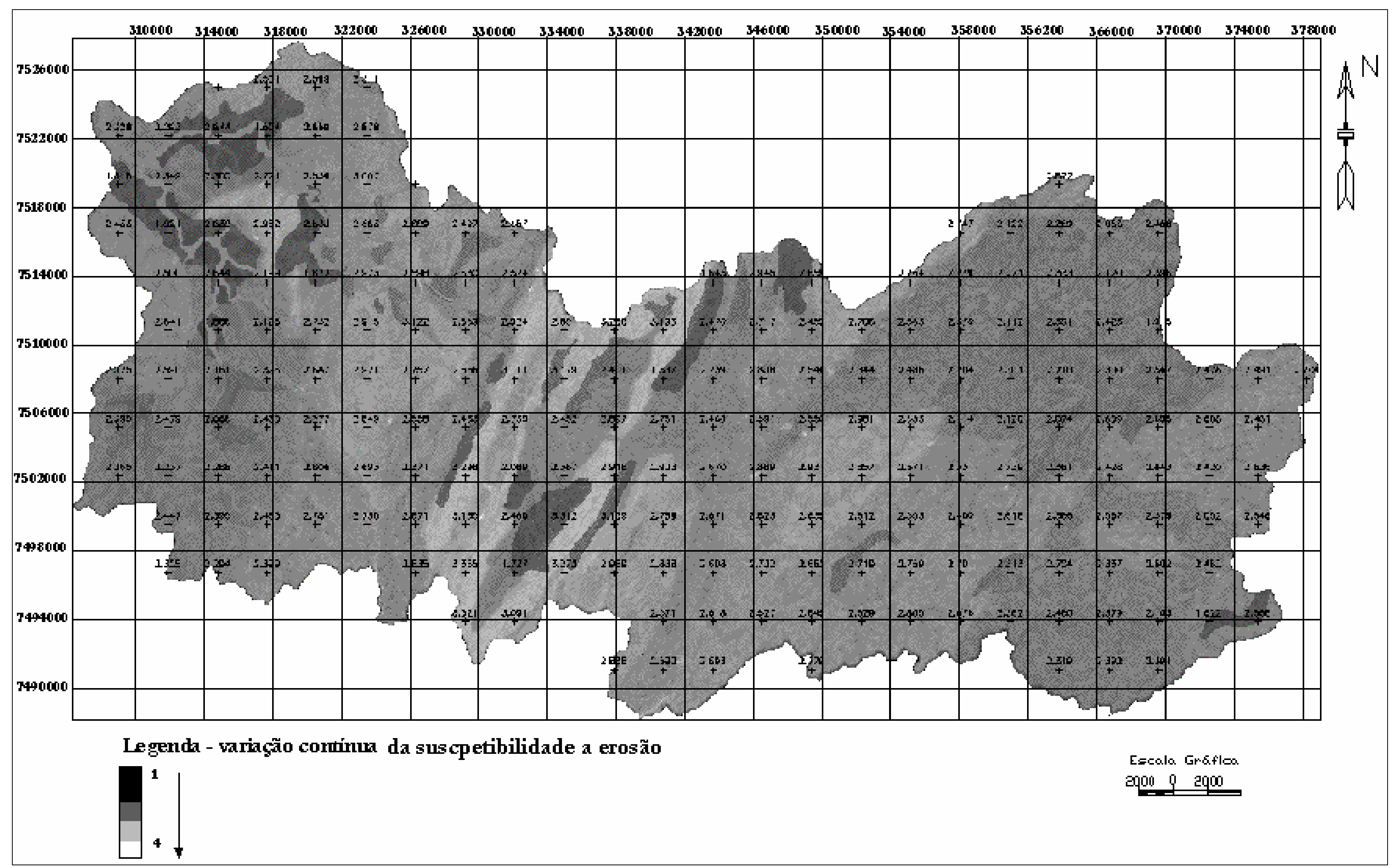

Figura 6.31 - Representação numérica fuح:sy susceptibilidade a erosão da Bacia do Rio do Peixe. 


\subsubsection{Carta de Potencial Agrícola (ANEXO IX)}

Para caracterização do potencial agrícola da bacia foram analisadas as seguintes informações do meio físico: susceptibilidade a erosão, materiais inconsolidados (textura, espessura e capacidade de troca catiônica) e declividade, conforme proposta de Zuquette et al. (1993).

A ordenação das informações e atributos selecionados por classe de influência no comportamento susceptibilidade a erosão, e a matriz de comparação pareada com pesos obtidos para cada informação são apresentadas na Tabelas $6.11 \mathrm{e}$ 6.12, respectivamente. A razão de consistência obtida na operação de comparação par a par foi 0,07 .

Tabela 6.11 - Ordenação das informações do meio físico e distribuição dos atributos em classes crescentes de influência.

\begin{tabular}{|c|c|c|c|c|}
\hline \multicolumn{5}{|c|}{ Aumento do potencial agrícola } \\
\hline \multirow{2}{*}{$\begin{array}{c}\text { Informações do } \\
\text { meio físico }\end{array}$} & \multicolumn{4}{|c|}{ Classes de potencial agrícola } \\
\hline & $\begin{array}{c}\text { Baixa } \\
1\end{array}$ & $\begin{array}{c}\text { Média } \\
2\end{array}$ & $\begin{array}{c}\text { Alta } \\
3\end{array}$ & $\begin{array}{c}\text { Muito alta } \\
4\end{array}$ \\
\hline \multicolumn{5}{|l|}{ Declividade } \\
\hline \multicolumn{5}{|l|}{$\begin{array}{l}\text { Susceptibilidade a } \\
\text { erosão }\end{array}$} \\
\hline $\begin{array}{c}\text { Materiais } \\
\text { inconsolidados } \\
\text {.Espessura } \\
(\mathrm{m})\end{array}$ & $<1,0$ & $1,0-3,0$ & $3,0-5,0$ & $>5,0$ \\
\hline $\begin{array}{c}\text { Materiais } \\
\text { inconsolidados } \\
\text { Textura }\end{array}$ & $\begin{array}{l}\text { Argilosos } \\
\text { Arenosos }\end{array}$ & $\begin{array}{l}\text { Argilo-arenosos } \\
\text { Siltosos }\end{array}$ & $\begin{array}{l}\text { Areno- } \\
\text { argilosos }\end{array}$ & Areno-siltoso \\
\hline $\begin{array}{c}\text { Materiais } \\
\text { inconsolidados } \\
\text { CTC }\end{array}$ & $<3$ & $3-5$ & $5-8$ & $>8$ \\
\hline
\end{tabular}

Atributos com variação contínua.

Tabela 6.12 - Matriz de comparação pareada e pesos de ponderação de cada informação.

\begin{tabular}{c|l|l|l|c|c|c}
\hline & Declividade & $\begin{array}{c}\text { Suscep. } \\
\text { Erosão }\end{array}$ & $\begin{array}{c}\text { MI } \\
\text { espessura }\end{array}$ & $\begin{array}{c}\text { MI textura } \\
\text { gênese }\end{array}$ & MI-CTC & $\begin{array}{c}\text { Peso } \\
\text { ponderação }\end{array}$ \\
\hline Declividade & 1 & 2 & 2 & 4 & 3 & $\mathbf{0 , 4 5}$ \\
\hline $\begin{array}{c}\text { Suscp. } \\
\text { Erosão }\end{array}$ & $1 / 2$ & 1 & 3 & 3 & 2 & $\mathbf{0 , 2 0}$ \\
\hline $\begin{array}{c}\text { MI- } \\
\text { espessura }\end{array}$ & $1 / 2$ & $1 / 3$ & 1 & 4 & $\mathbf{3}$ & $\mathbf{0 , 1 5}$ \\
\hline $\begin{array}{c}\text { MI- textura } \\
\text { gênese }\end{array}$ & $1 / 4$ & $1 / 3$ & $1 / 4$ & $\mathbf{1}$ & $\mathbf{3}$ & $\mathbf{0 , 1 0}$ \\
\hline MI-CTC & $1 / 3$ & $1 / 2$ & $1 / 3$ & $1 / 3$ & 1 & $\mathbf{0 , 1 0}$ \\
\hline
\end{tabular}


Na caracterização do comportamento de potencial agrícola da área a informação referente declividade do meio físico foi considerada como de maior importância, condicionando situações de potencial mínimo e máximo segundo sentido inverso ao aumento da mesma. A influência da declividade no desenvolvimento de atividades agrícolas de uma área é caracterizada, de forma geral, pelos valores mais baixos de declividade como mais favoráveis a prática destas atividades. De acordo com Zuquette et al (1993), valores de declividade percentuais abaixo de oito caracterizam condições de máxima favorabilidade, e acima de 20 já vêm a caracterizar condições restritivas ao desenvolvimento de práticas agrícolas.

A avaliação do comportamento de influência dos valores de declividade percentuais da área segundo maior ou menor favorabilidade ao desenvolvimento de práticas agrícolas obedeceu aos limites destacados por Zuquette $e$ al (op cit). A adoção destas faixas fez-se necessário a elaboração de um novo mapa de declividade fuz:yy, o qual retratasse tais condições de restrição e favorabilidade ((Programa LEGAL 96, Apêndice A). Para este intervalo restritivo foi elaborada a equação linear $((f(x)=((x *-0,25))+6)$, a qual permitiu transformação e espacialização contínua da declividade percentual, contida neste intervalo, para o range "4", "1" por meio da expressão a seguir:

$$
M_{\text {declivida } 4-1}=\left(\text { valor declividade }{ }_{-}-0.25\right)+6 \boldsymbol{S e}((\text { valor declividade }>8 E \text { V alor declividade }<20)
$$

Para garantir que fora da faixa adotada não ocorressem valores diferentes do range estabelecido, foram elaboradas e aplicadas as equações lineares $(f(x)=(x * 0)+1)$ e $\left(f(x)=\left(x^{*} 0\right)+4\right)$, executadas na rotina de programação (Programa LEGAL X Anexo XI) pelas expressões:

$$
\begin{gathered}
M F_{\text {Declividade } 1}=(\text { V alor declividade } * 0)+1 \boldsymbol{S e}(\text { valor declividade } \geq 20) \\
M F_{\text {Declividade }}=(\text { V alor declividade } * 0)+4 \boldsymbol{S e}(\text { valor declividade } \leq 8)
\end{gathered}
$$

A informação de susceptibilidade a erosão foi considerada com a segunda com maior importância no condicionamento a situações de potencial agrícola mínimo e máximo. Para disposição do comportamento de susceptibilidade nas classes de influência ao potencial agrícola fez-se necessário a elaboração de uma nova superfície em formato fuz:yy. Esta foi obtida a partir da inversão dos valores apresentados no mapa contínuo. A inversão do mapa foi executada por rotina de programação (Programa 
LEGAL 97, Apêndice A), a partir da aplicação da função $f(x)=\left(\right.$ valorpixel $\left.\left.^{*}-0,6369\right)+4\right), \quad$ a qual transformou os valores de pixels representativos de susceptibilidade muito alta em baixa.

As unidades de matérias pouco espessas ( $<1,0$ metro) caracterizam condições de baixos potencial ao desenvolvimento agrícola, limitam o desenvolvimento de culturas com raízes profundas. Já as unidades muito espessas ( $>5,0$ metros) favorecem as situações de máximo potencial, pois não correspondem uma condição limitante. Com relação ao aspecto textura, as unidades argilosa e arenosa com percentuais das frações argila e areia correspondentes a mais de $60 \%$, foram consideradas com condicionantes de baixo potencial; unidade com texturas areno-argilosas e areno-siltosas como condicionantes de potenciais alto e muito alto, e a classe de potencial e unidades com textura argilo-arenosa ou siltosa condicionantes de potenciais médios.

Os programas em LEGAL 98 a 118 (Apêndice A) executaram a ponderação dos pesos de importância e a elaboração do mapa de potencial agrícola furåy. A este documento foi, posteriormente, sobreposto as faixas de restrições legais estabelecidas pela Lei Federal 4.771, relativa ao código florestal de 1965, o qual estabelece:

1. Faixas de 30 metros dos cursos de drenagem - áreas de preservação permanente;

2. Faixas de declividades entre $25^{\circ}-45^{\circ}$ - proibida derrubada de florestas para desenvolvimento de qualquer atividade de ocupação do meio;

3. Faixas de declividades $>45^{\circ}$ - área de preservação natural, seja em encosta ou parte da mesma.

Com base nas condições restritivas acima expostas foram executadas rotinas (Programas LEGAL 119 e 120, Apêndice A) as quais permitiram a elaboração de superfícies contínuas, relativas aos aspectos de declividade em graus e distância dos cursos de drenagem, que funcionaram como máscaras. Nestas superfícies valor $\underline{0}$ às regiões com aspectos restritivos e $\underline{1}$, as regiões sem impedimento legal. Estas máscaras foram cruzadas com o mapa de potencial previamente elaborado, resultando em um novo documento, que caracterizou o potencial agrícola da bacia (Programa LEGAL 121, Anexo XI).

Os dados da estatística de imagem por polígono (Tabela 6.13) e a observação da superfície contínua de distribuição da (Figuras 6.32) mostram uma predominância de 
ocorrência da classe de potencial alto. A operação de medida de classes executada para o mapa temático (Anexo IX) confirmam a predominância da classe de alto potencial agrícola.

Tabela 6.13 - Valores medida de classe temática e estatística de imagem por polígono.

\begin{tabular}{c|c|c}
\hline $\begin{array}{l}\text { Classes de Potencial } \\
\text { agrícola }\end{array}$ & Área $\left(\mathbf{k m}^{2}\right)$ & \% de ocorrência na bacia \\
\hline Baixo & 434,43 & 25,92 \\
\hline Médio & 349,68 & 20,87 \\
\hline Alto & 260,01 & 28,52 \\
\hline Muito Alto & 471,89 & 9,54 \\
\hline Restritivo & 159,84 & 1860717 \\
\hline \multicolumn{2}{c}{ Valores de estatísticas de imagem } \\
\hline Numero de Pixels analisados & 0,35 \\
\hline Mínimo & 3,91 \\
\hline Máximo & 2,52 \\
\hline Média & 0,06 \\
\hline Desvio Padrão & 3,29 \\
\hline
\end{tabular}




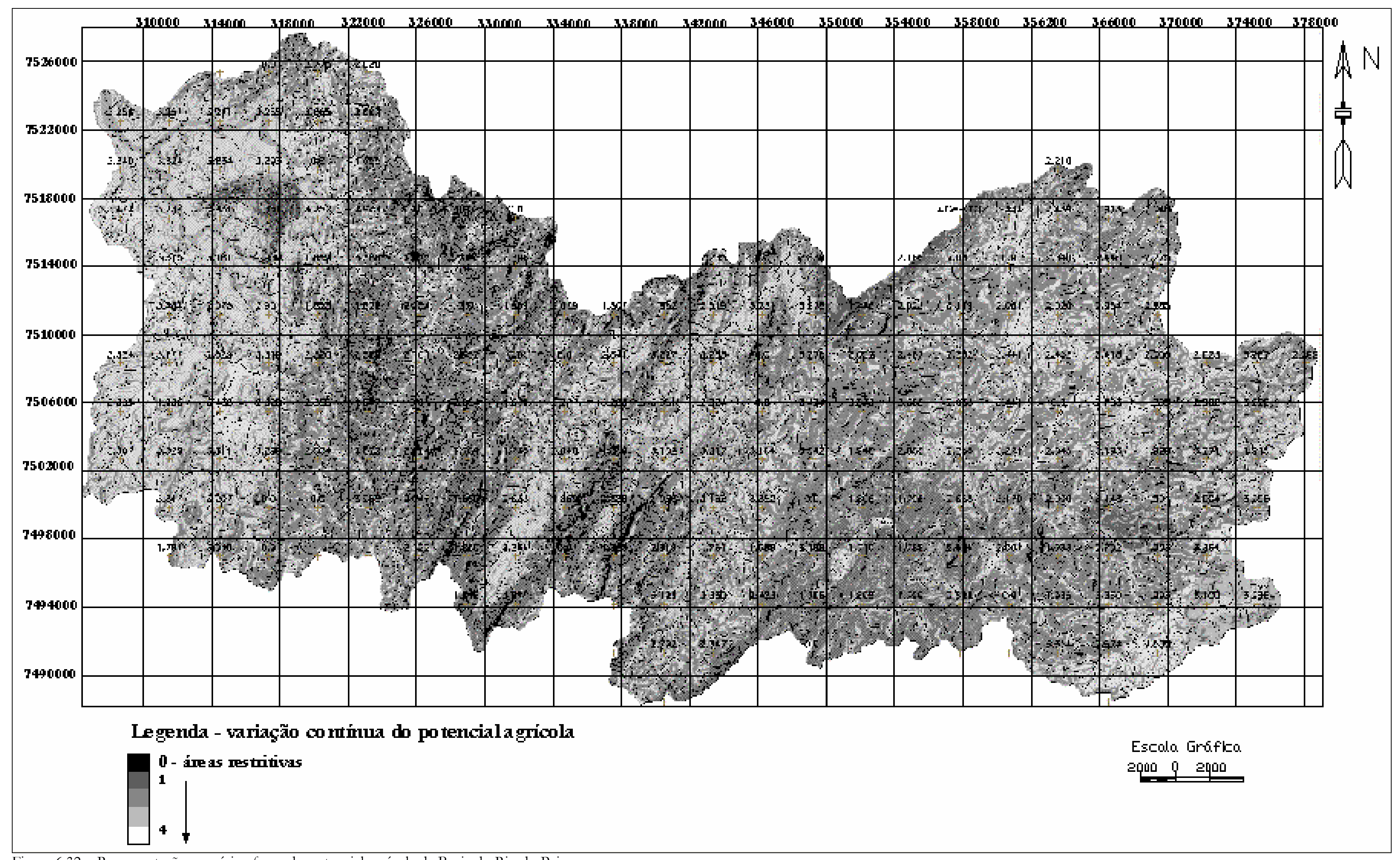

Figura 6.32 - Representação numérica fu₹:y do potencial agrícola da Bacia do Rio do Peixe. 


\section{CAPÍTULO 7}

\section{7. - CARACTERIZAÇÃO DE ALTERAÇÕES DO MEIO - PROPOSTAS DE UM NOVO GEOINDICADOR}

O processo de avaliação de alterações do meio físico introduzidas por atividades transformadoras constitui um método de avaliação ambiental, o qual configura um instrumento do processo planejamento. Processos ou fenômenos do meio utilizados como forma de identificação e quantificação destas alterações recebem a denominação de geoindicadores ambientais.

Com objetivo de identificar e caracterizar alterações ambientais introduzidas no meio físico da bacia do Rio do Peixe devido a prática de atividades agrícolas é proposta a utilização do parâmetro resistência a penetração do solo como geoindicador ambiental.

\section{1 - RESISTÊNCIA A PENETRAÇÃO}

No que se refere a estrutura física do solo, o processo de compactação modifica as condições naturais, implicando na modificação das condições de equilíbrio químico, físico e biológico, e dificultando a translocação de água e nutrientes (Davis e Zhang, 1991).

Vaz et al (2001) citam que a compactação do solo caracteriza-se pela diminuição do volume do mesmo, quando este é submetido a uma pressão externa.

De acordo com Bertoni \& Lombardi Neto (1990), solos com elevado grau de compactação, apresentam uma estruturação que dificulta a infiltração da água e aumenta o escoamento superficial, o que favorece a atuação do processo de erosão pela retirada da camada superficial do solo. Por outro lado, solos com baixo grau de compactação 
apresentam melhor capacidade de infiltração, menor velocidade de escoamento superficial, conseqüentemente menor atuação da erosão.

De modo simplificado pode-se entender que solos compactados têm suas condições naturais de equilíbrio modificadas, o que pode acarretar em implicações no desenvolvimento e rendimento de culturas, além de influenciar na ocorrência de processos erosivos, devido a alteração das condições de infiltração e escoamento.

De uma maneira geral, qualquer modificação nas condições naturais de uso do solo, por exemplo, a remoção da cobertura original para o desenvolvimento de atividade agrícola, tende a alterar as condições primárias de compactação do mesmo, e modificar seu equilíbrio.

O método mais comum de quantificar o estado de compactação do solo é por meio de uso de penetrômetros de solo. Estes medem a resistência à penetração, como a força ou pressão necessária para inserir um cone de tamanho padrão no solo (Bradford, 1986). A inserção do cone no solo pode ser realizada de duas maneiras: 1) o operador força o conjunto contra o solo ou 2) o conjunto é inserido por meio de impactos produzidos pela queda de um peso fixo, em um curso constante (Stolf et al., 1983).

O segundo método de cravação permite que a resistência a penetração de um solo seja inferida, a partir da relação entre o número de impactos executados e o valor de profundidade penetrado.

De acordo com Vaz \& Hopmans (2001) a resistência à penetração é uma propriedade do solo de grande variabilidade espacial, e a técnica de medida de resistência do solo por penetrômetros pode apresentar dificuldade de interpretação e avaliação em termos de valores absolutos, se não forem devidamente considerados parâmetros como a densidade global do solo $(\rho)$ e a umidade $(\theta)$. Os autores (op cit) ressaltam que a determinação destes parâmetros é relevante, pois são os que mais influenciam no comportamento de resistência a penetração do solo, sendo a resistência inversamente proporcional a umidade e diretamente proporcional a densidade do solo.

Vaz et al (2001), com o intuito de melhorar a técnica de penetrometria, desenvolveram um penetrômetro de cone combinado a uma sonda TDR que permite obter, de forma simultânea, medidas de resistência à penetração e umidade do solo, ao longo de um perfil de $60 \mathrm{~cm}$.

Para determinação dos parâmetros resistência a penetração e umidade do solo o equipamento desenvolvido utiliza a técnica de reflectrometria no domínio do tempo. 


\subsubsection{Teoria da Técnica de Reflectrometria no Domínio do Tempo (TDR)}

A reflectrometria no domínio do tempo é uma técnica de medida de umidade, a qual se baseia na medida de velocidade ou no tempo de trânsito de uma onda eletromagnética ao longo de uma sonda metálica de comprimento conhecido inserida no solo (Or et al., 2001). Baseada nas medidas do tempo de transito da onda eletromagnética calcula-se a constante dielétrica do solo que envolve a haste. O cálculo da constante dielétrica é realizado por meio da equação:

$$
\varepsilon_{b}=\left(\frac{c}{v}\right)^{2}=\left(\frac{c t}{2 L}\right)^{2}
$$

onde: $\varepsilon_{\mathrm{b}}$ - constante dielétrica do meio

$\mathrm{c}$ - velocidade da onda eletromagnética no vácuo $\left(3 \times 10^{8} \mathrm{~m} / \mathrm{s}\right)$

$\mathrm{t}$ - tempo de viagem do pulso eletromagnético (seg.)

$\mathrm{L}$ - comprimento da sonda (metros)

$\mathrm{v}$ - velocidade de propagação da onda

Com base no valor da constante obtida é estimado o valor de umidade do solo. O cálculo da umidade é realizado por meio da equação universal de Topp (Topp et al, 1980), a qual corresponde a uma equação empírica polinomial de grau 3, e estabelece a relação entre $\varepsilon_{\mathrm{b}}$ e $\theta$. A equação de Topp é apresentada abaixo:

$$
\theta=5.3 \times 10^{-2}+2.92 \times 10^{-2} \varepsilon_{b}+5.5 \times 10^{-4} \varepsilon^{2}{ }_{b}+4.3 \times 10^{-6} \varepsilon_{b}^{3}
$$

onde: $\theta$ - teor de umidade volumétrica

\subsection{EQUIPAMENTO - PENETRÔMETRO/SONDA-TDR}

Para obtenção dos parâmetros $\varepsilon_{\mathrm{b}}$ e $\theta$, em conjunto as medidas de resistência a penetração, utilizou-se a sonda desenvolvida por Vaz et al. (2001). A mesma consiste de um penetrômetro de solo, com uma sonda TDR de geometria espiral, localizada na base do mesmo, imediatamente acima do cone de penetração. A sonda espiral TDR consiste de dois fios de aço, um condutor e um terra, com comprimento de $26 \mathrm{~cm}$, disposto de forma espiralada em $5 \mathrm{~cm}$. (Figura $7.1 \mathrm{~A} \mathrm{e} \mathrm{B}$ ). 
Os fios são envoltos por um material plástico duro (Kevlar-Nylon), com espaço de $2 \mathrm{~mm}$ entre os mesmos (Vaz e Hopmans, 2001) (Figura 7.2). As medidas do cone de penetração satisfazem aos padrões da Sociedade Americana de Engenharia de Agronomia (ASAE, 1994 apud Vaz e Hopmans, 2001).
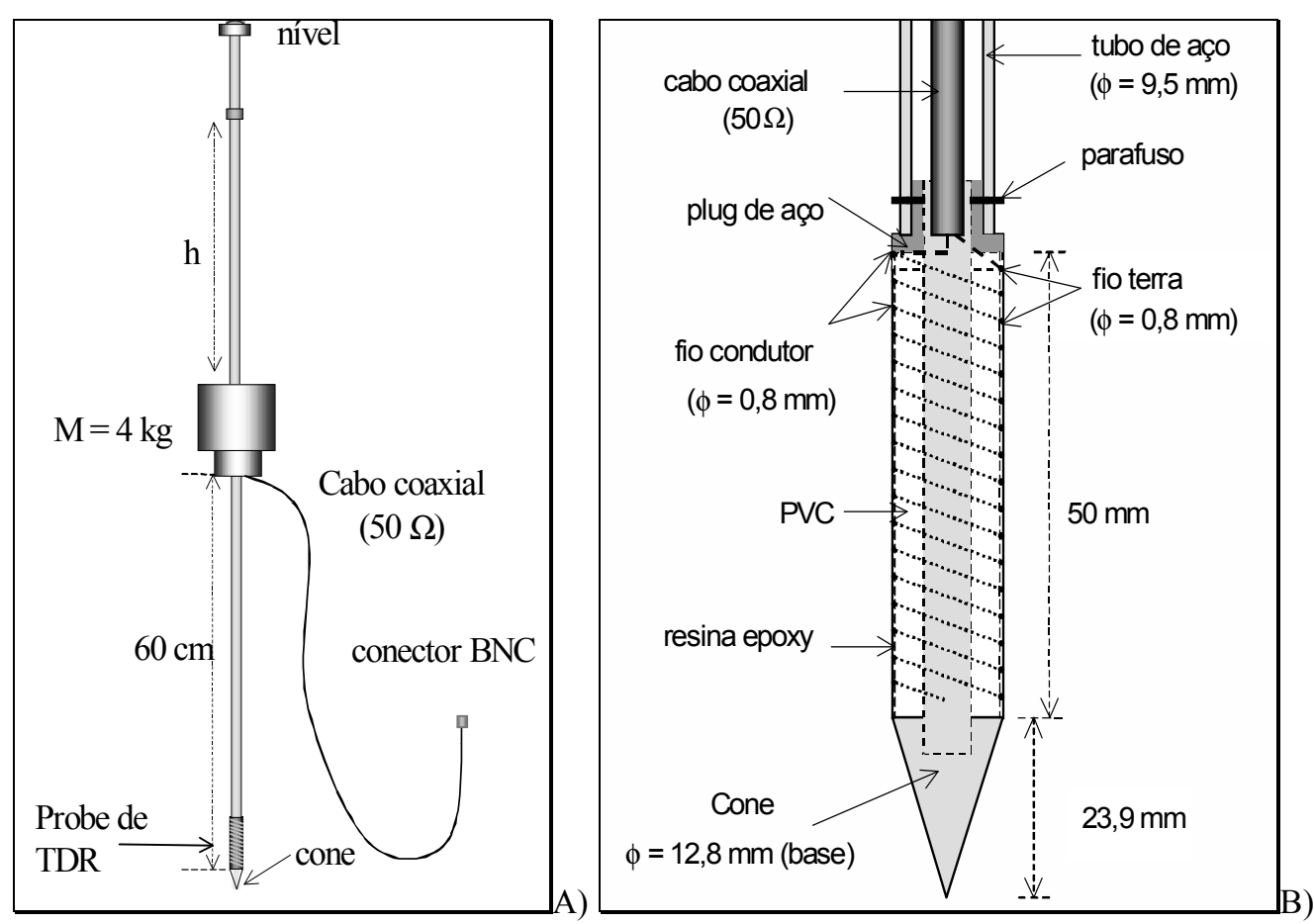

Figura 7.1 - A)Penetrômetro de impacto com sonda espiral de TDR. B) Esquema da haste do penetrômetro de impacto com sonda espiral TDR (Vaz \& Hopmans, 2001).

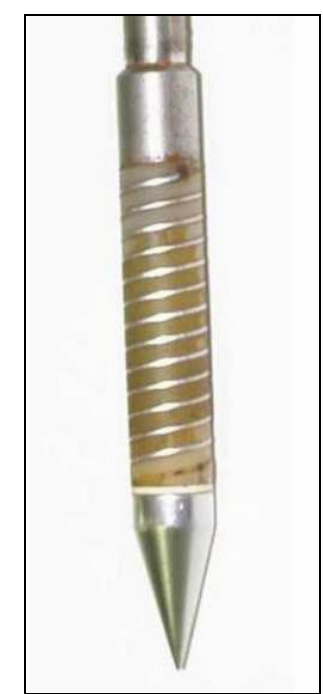

Figura 7.2 - Detalhe da sonda espiral de TDR . Fios metálicos envoltos em um material plástico duro (Kevlar-Nylon). 
A sonda desenvolvida por Vaz et al (2001) utiliza um programa para aquisição das medidas de $\varepsilon_{\mathrm{b}}$ e $\theta$, por meio de processamento em um computador portátil conectado ao penetrômetro e ao TDR (Figura 7.3). O aparelho de TDR utilizado é um Tektronix 1502B, e o programa WinTDR 6.0, o qual é fornecido gratuitamente pelo grupo de Física do solo, Utha University, EUA..

O modelo do penetrômetro utilizado é de impacto (modelo - IAA/Planalsucar - Stolf) desenvolvido para fins de medida de resistência a penetração do solo em áreas destinadas ao desenvolvimento de práticas agrícola.

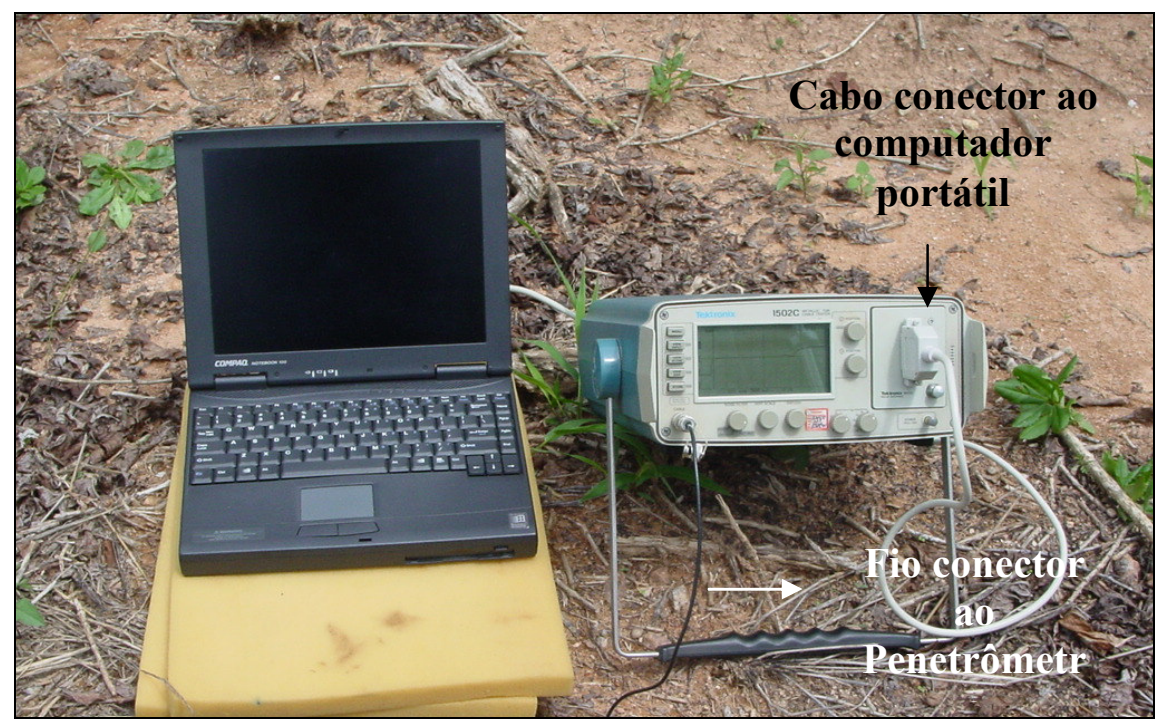

Figura 7.3 - Equipamentos utilizados para aquisição de medidas de $\varepsilon_{\mathrm{b}}$ e $\theta$ em campo.

\subsubsection{WinTDR 6.0}

O princípio básico de determinação dos valores de $\varepsilon_{\mathrm{b}}$ e $\theta$, utilizado pelo WinTDR 6.0, fundamenta-se na análise dos comprimentos de onda eletromagnética que transitam na sonda inserida no solo. A análise das formas de onda geradas permite determinar a distância percorrida pela mesma, a partir de medidas das inflexões apresentadas pela forma de onda visualizada na tela do computador portátil (Figura 7.4). 


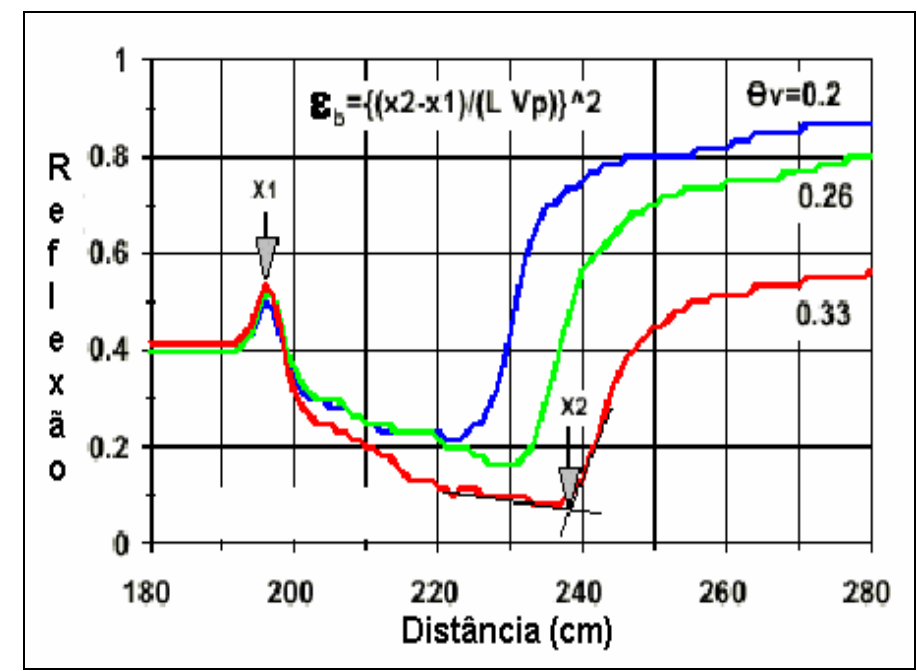

Figura 7.4 - Exemplo de formas de ondas geradas pelo TDR e analisada pelo programa WinTDR 6.0 (Or et al, 2001).

O programa calcula as posições das inflexões x1 (denominada de $1^{\underline{0}}$ pico) e x2 ( $2^{\underline{0}}$ pico ou $2^{\underline{a}}$ inflexão) e a partir da equação abaixo determina a constante dielétrica do meio.

$$
\varepsilon_{b}=\left[\frac{(x 2-x 1)}{L v}\right]^{2}
$$

onde: x1 e x2 - Picos de inflexão apresentados na forma de onda eletromagnética

$\varepsilon_{\beta}$ - constante dielétrica do meio

L - comprimento da sonda (metros)

$\mathrm{v}$ - velocidade relativa de propagação da onda

A Eq 7.3 é similar a Eq 7.1, utilizada na técnica de reflectrometria. Dos valores das constantes dielétricas calculados são obtidos os valores de umidade do solo, por meio da equação universal de Topp (Eq. 7.2).

\subsection{MEDIDAS DE RESISTÊNCIA A PENETRAÇÃO}

A determinação da resistência a penetração do solo, por ensaios de penetrometria pode ser realizada de duas formas: 1) por meio do cálculo do índice de resistência a penetração (IRP) e 2) por meio da quantificação do número total de golpes executados (NTG) para penetrar um valor de profundidade fixo (Stolf et al, 1983). 
O IRP é calculado para diferentes profundidades do perfil ensaiado, e permite caracterizar o comportamento da resistência a penetração de um solo ao longo de um perfil de penetração.

O NTG informa o comportamento de resistência a penetração de um local ensaiado e permite que seja verificado o comportamento da resistência a penetração de um solo frente a diferentes atividades de uso vigentes, por meio da comparação de medidas. O valor de NTG é calculado pela equação abaixo:

$$
N T G=\frac{N G}{x}
$$

onde: NTG - índice de resistência a penetração(número impactos/profundidade).

NG - número total de golpes executados

x. - profundidade do perfil ensaiado $(60 \mathrm{~cm})$

\subsection{PROCEDIMENTOS EMPREGADOS}

Para utilização do parâmetro resistência a penetração como indicador de alterações ambientais do meio físico foram executadas primeiramente experimentos de calibração da sonda-TDR em laboratório, para então serem executados medidas de resistência em campo.

\subsubsection{Experimentos em laboratório}

Consistiu da calibração da sonda-TDR combinada e obtenção de curvas de umidade padrão para os tipos de solos existentes na área.

A obtenção das curvas de calibração compreendeu a execução de medidas de diferentes valores de umidade com a sonda-TDR em três tipos de solos residuais da bacia: 1) Gnaisses intercalados com Rochas Básicas, 2) Gnaisses intercalados com Quartzitos e 3) Migmatitos. Além das curvas obtidas em laboratório foram utilizados também resultados de calibrações executados por Manieri \& Vaz (2003), no laboratório de pesquisa de solos, da unidade da EMBRAPA de São Carlos. 
Os resultados de Manieri \& Vaz (2003), referem-se a solos com grande ocorrência no Estado de São Paulo: Neossolo Quartzarênico órtico (NQo), Latossolo Vermelho distroférrico (LVdf), Latossolo Vermelho Amarelo distrófico (LVAd), Latossolo Vermelho distrófico (LVd), Argissolo Vermelho Amarelo distrófico (PVAd) e Nitossolo Vermelho eutroférrico (Nvef).

As medidas de calibração executadas, tanto para as amostras de solos da bacia como as executadas por Manieri \& Vaz (2003), resultaram na obtenção de curvas padrões de umidade para os solo da bacia.

Para obtenção das curvas foram realizadas medidas em dez pontos diferentes de umidade por solo. Os pontos de umidade foram obtidos a partir do preenchimento de colunas de PVC com amostras de solo de forma que se obtivesse um gradiente de umidade, desde solo seco a totalmente saturado. Preparadas as colunas com o gradiente de umidade, foram executadas medidas com a sonda/TDR combinada a partir da inserção da mesma cuidadosamente no centro do cilindro, para garantir um contato perfeito sonda/solo. Este procedimento permitiu obtenção e correlação de valores de umidade volumétrica $(\theta)$ e constante dielétrica $(\varepsilon)$ para cada ponto de umidade.

Após a realização das medidas, amostras de solo das colunas foram retiradas, pesadas em cápsulas de alumínio e colocadas em estufa a $60^{\circ} \mathrm{C}$ por 24 horas, para nova pesagem e execução do cálculo de umidade gravimétrica. Isto permitiu que os valores das umidades volumétricas medidas com a sonda fossem correlacionadas aos valores de umidades gravimétricas obtidos em estufa, e aos valores das constantes dielétricas, por meio da interpolação de uma função polinomial de terceiro grau $\left(\theta=a+b \varepsilon+c \varepsilon^{2}+d \varepsilon^{3}\right)$, tal como realizado por Topp et al. (1980).

Como resultado foram obtidos os coeficientes de ajuste polinomial para os solos ensaiados, os quais foram divididos em dois grupos de textura: A)solos arenosos e B)solos argilosos (Tabela 7.1).

Tabela 7.1. Coeficientes de determinação $\left(\mathrm{r}^{2}\right)$ e coeficiente de ajuste polinomial de $3^{\circ}$ grau $\left(\theta=a+b \varepsilon+c \varepsilon^{2}+d \varepsilon^{3}\right)$ para solos arenosos e argilosos.

\begin{tabular}{cccccc}
\hline Textura do Solo & $\mathbf{a}$ & $\mathbf{b}$ & $\mathbf{c}$ & $\mathbf{d}$ & $\mathbf{r}^{2}$ \\
\hline Arenosos & $-1,1769$ & 0,5602 & $-0,0762$ & 0,0036 & 0,968 \\
\hline Argilosos & $-1,2510$ & 0,5367 & $-0,6023$ & 0,0024 & 0,905
\end{tabular}


Os valores dos coeficientes obtidos são utilizados na estimativa da umidade a partir da constante dielétrica medida no meio. Os mesmos devem ser inseridos no software WinTDR 6.0 antes da execução de medidas, segundo a textura do solo a ser ensaiados. Em campo, a identificação da textura pode ser feita por avaliação visual/tátil.

\subsubsection{Experimentos em Campo}

Consistiu da execução de 87 medidas in situ com a sonda-TDR combinada. As medidas executadas recobriram seis tipos de solo e cinco tipos de uso e ocupação do terreno vigentes na bacia. A Figura 7.5 apresenta a alocação dos pontos ensaiados e a Tabela 7.2 a relação entre o tipo de solo e o uso do terreno vigente no ponto.

Em cada ponto investigado foram registrados: 1) valores de umidade e profundidade de penetração alcançada a cada dois golpes executados e 2) número total de golpes executados e a umidade média do ponto.

$\mathrm{Na}$ execução do ensaio a profundidade de penetração é lida na própria haste do penetrômetro, a qual é graduada em centímetros (Figura 7. 6). As Figuras 7.7 e 7.8 apresentam exemplos de execuções de ensaios em campo

Em função dos primeiros centímetros de solo formarem uma zona de maior distúrbio e da sonda TDR localizar-se imediatamente após o cone de penetração, a primeira leitura de profundidade foi realizada após a penetração total do conjunto cone/sonda-TDR no solo, por meio da execução de número variável de golpes. As demais leituras foram executadas de forma regular após um número fixo de impactos, dois golpes, até atingir a profundidade de $60 \mathrm{~cm}$.

Dos 87 pontos de medidas ensaiados cinco não foram considerados na análise dos resultados. Em dois, durante o processo de amostragem do perfil de solo ocorreu a perda da sonda-TDR, o que impossibilitou o registro de medidas. Em outros três, devido a valores muito elevados ou muito baixos de umidade do solo as características de resistência a penetração foram anômalas, o que inviabilizou a utilização dos mesmos. 


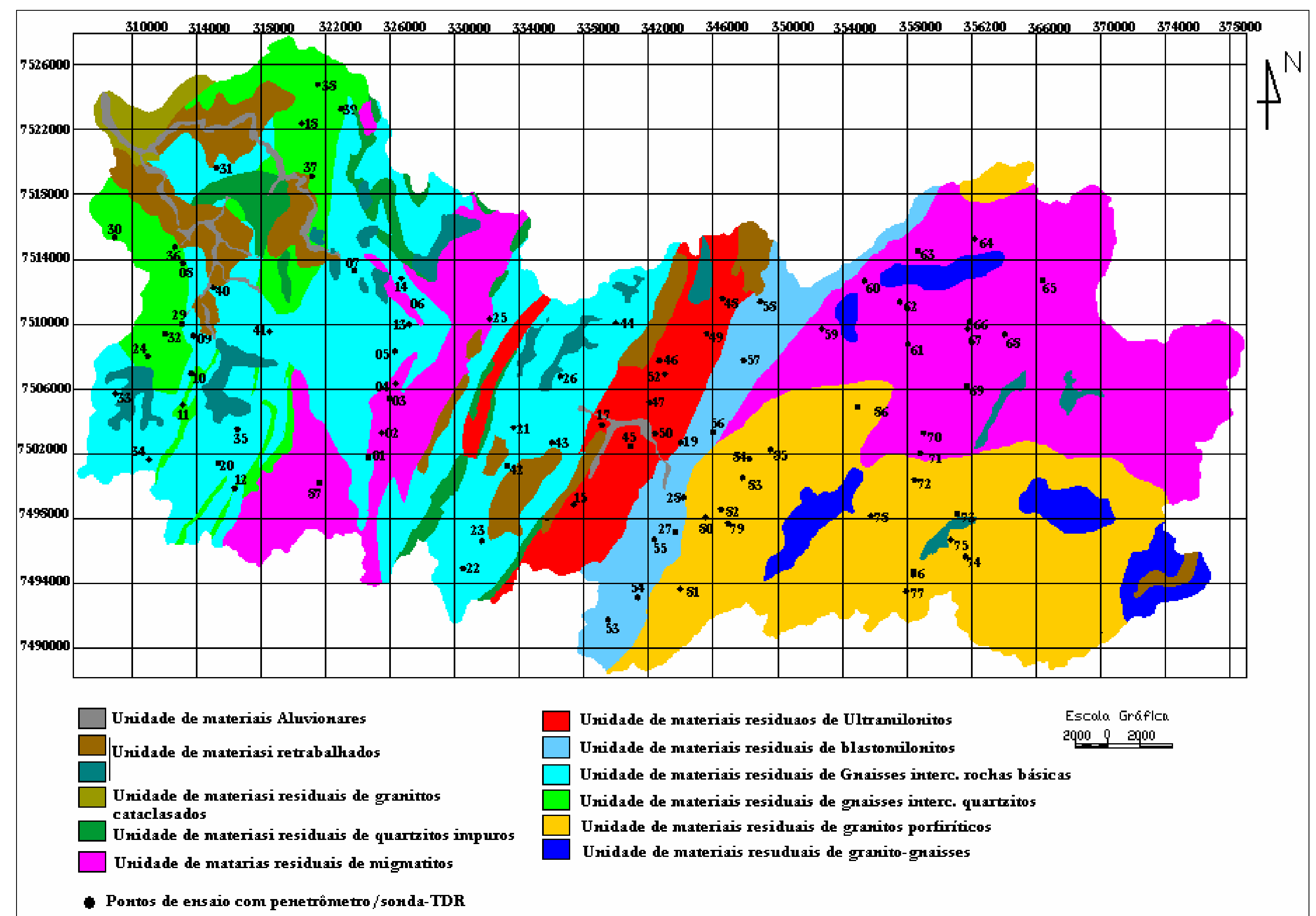

Figura 7.5 - Locação dos pontos de ensaio de resistência a penetração nos solos presentes na Bacia do Rio do Peixe. 
Tabela 7.2 - Relação dos pontos ensaiados por tipo de solo e uso de terreno vigente

\begin{tabular}{l|l|l|l|l|l}
\hline \multirow{2}{*}{ Tipo de Solo } & \multicolumn{6}{|c}{ Uso da Terra } \\
\cline { 2 - 6 } & \multicolumn{1}{|c|}{$\begin{array}{c}\text { Mata } \\
\text { Nativa }\end{array}$} & \multicolumn{1}{|c}{ Pastagem } & \multicolumn{1}{c}{ Café } & \multicolumn{1}{c}{$\begin{array}{c}\text { Cana-de- } \\
\text { açúcar }\end{array}$} & \multicolumn{1}{c}{$\begin{array}{c}\text { Outras } \\
\text { culturas }\end{array}$} \\
\hline ReGnB & 13,14 & $05,07,21,43$ & $\begin{array}{l}23,31,34, \\
41,42\end{array}$ & $\begin{array}{l}09,20,35, \\
40\end{array}$ & $22,26,33,44$ \\
\hline ReGnQ & 11 & $08,12,36,38$ & 29,37 & $\begin{array}{l}10,24,30, \\
32\end{array}$ & 18,39 \\
\hline ReMig & 02,03 & $\begin{array}{l}01,04,06,25,59, \\
63,66,69,71\end{array}$ & $\begin{array}{l}60,61,62, \\
62,87\end{array}$ & -- & $64,67,68$ \\
\hline ReBtm & -- & $53,55,56,57$ & 28,54 & -- & $19,27,58$ \\
\hline ReUtm & -- & $15,51,52$ & $\begin{array}{l}16,45,49, \\
50\end{array}$ & -- & $17,46,47,48$ \\
\hline \multirow{2}{*}{ ReGrP } & & $\begin{array}{l}74,75,78,79,80, \\
85\end{array}$ & $\begin{array}{l}76,81,82, \\
83,84,86\end{array}$ & & $72,73,77$ \\
\hline
\end{tabular}

ReGrP - residuais de Granitos Prfiríticos; ReGnB - residuais de Gnaisses intercalados com rochas Básicas; ReGnQ - residuais de Gnaisses intercalados com Quartzitos; ReMig - residuais de Migmatitos; ReUtm - Residuais de Ultramilonitos; ReBtm - Residuais de Blastomilonitos.

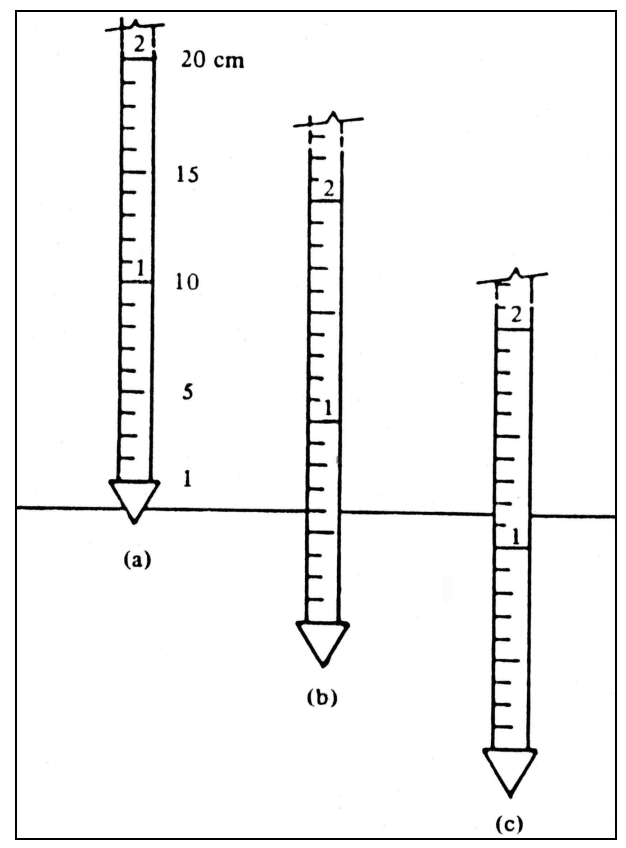

Figura 7.6 - Exemplo de medida de penetração lida na haste do penetrômetro. a) posição inicial; b)posição final da primeira leitura, correspondente a penetração de 0-6 cm; c) posição final da segunda leitura, correspondente a penetração de 6-11,5 cm (Stolf et all, 1983). 


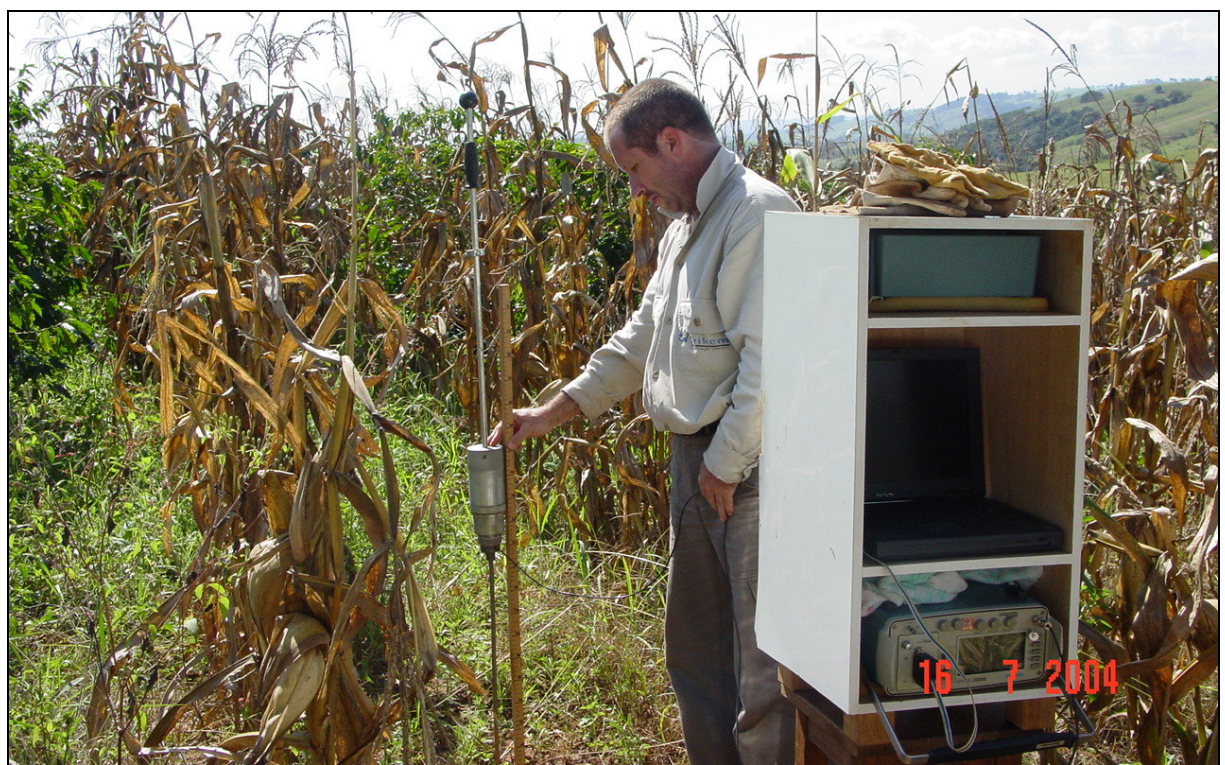

Figura 7.7 - Ensaio de medida de resistência a penetração realizada em campo.

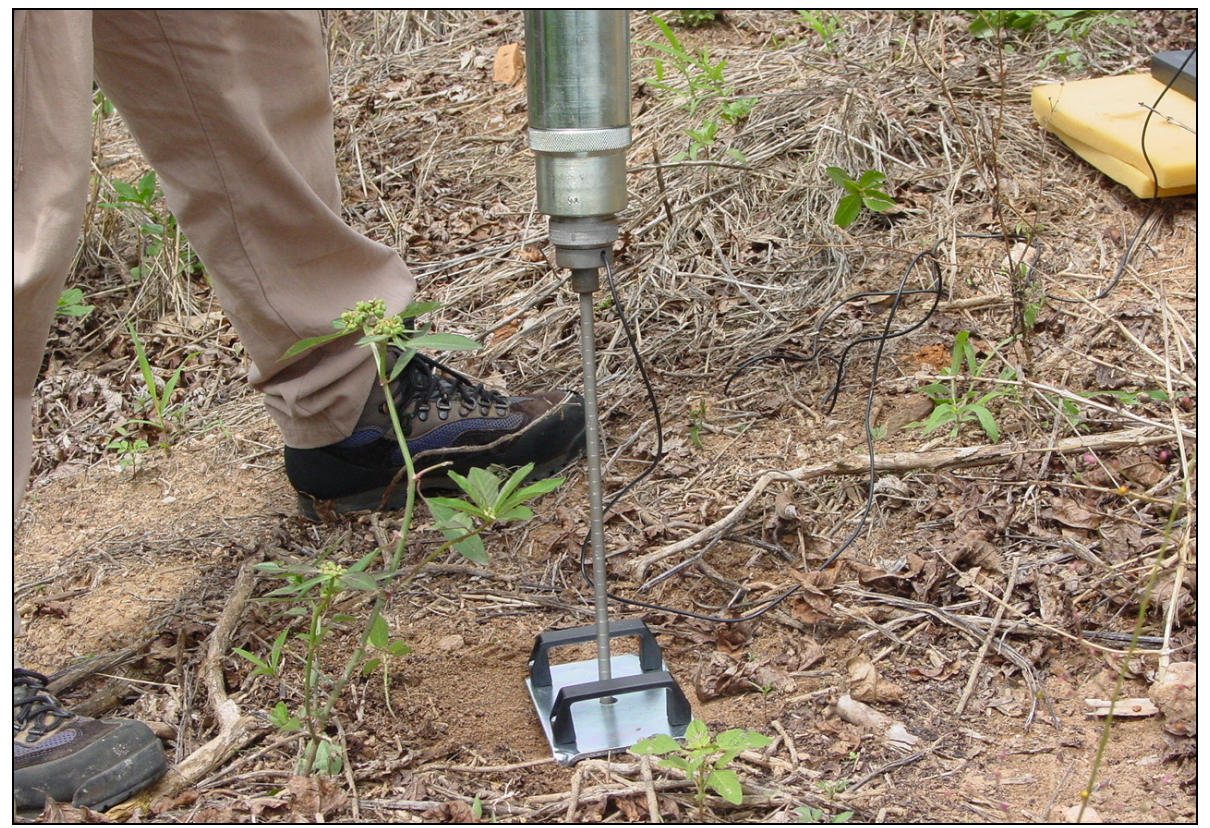

Figura 7.8 - Detalhe cravação do penetrômetro em ensaios de campo. 


\subsection{3 - Uso e ocupação do terreno e solos ensaiados}

Os pontos da bacia onde foram realizadas as medidas de resistência a penetração do solo caracterizam regiões que ainda conservam suas condições naturais, áreas de mata nativa, e regiões com diferentes tipos de uso e ocupação do terreno voltados, principalmente, para o desenvolvimento de práticas agrícolas e atividades de pastagem. As atividades de práticas agrícolas consistem do cultivo de café, cana-de-açúcar, cultura de hortaliças, aqui denominado de outras culturas.

As amostragens foram planejadas de forma a tentar recobrir todos os tipos de solos existentes e as atividades de ocupação do terreno registradas nos mesmo.Porém, dos cinco tipos de uso e ocupação do terreno aqui em destaque, apenas as atividades de pastagem café e outras culturas apresentam registro de ocorrência em todos os solo ensaiados. Isto se deve ao fato da primeira atividade caracterizar a classe de ocupação do terreno com maior ocorrência na bacia, e as demais exibirem uma distribuição mais regular na área. A prática de cana-de-açúcar caracteriza-se por apresentar irregularidade de ocorrência na bacia, estando associada apenas aos solos residuais de gnaisses presentes na parte da baixa bacia.

As regiões com ocorrência de mata nativa acabaram por caracterizar áreas inadequadas a execução dos ensaios de resistência a penetração dos solos, em função da fragilidade da sonda-TDR que foi perdida em dois perfis de medida realizados em regiões com esse tipos de atividade vigente. A fragilidade da sonda é devido ao fato da mesma não apresentar superfície protetora disposta na interface sonda/solo, e como as regiões de mata nativa, caracterizam-se por apresenta grande concentração de raízes, assim como a ocorrência eventual de fragmentos de rochas, na execução de ensaios nestas áreas houve perda dos fios que constituem a sonda TDR pelo atrito com as raízes e fragmentos de rocha.

Os solos ensaiados constituem, solos residuais de Granitos Porfiríticos ReGrP,Gnaisses intercalados com Quartizitos -ReGnQ, Gnaisses intercalados com Rochas Básicas -ReGnB, Migmatitos -ReMig, Ultramilonitos -ReUtm e Blastomilonitos -ReBtm (Figura 7.5). As principais características dos solos ensaiados são apresentadas na Tabela 7.3. 
Tabela 7.3 - Caracterização geral dos solos com registro de ensaio de resistência a penetração.

\begin{tabular}{|c|c|c|c|c|c|c|c|c|c|c|c|c|c|}
\hline \multirow[t]{2}{*}{ Solo } & \multirow[t]{2}{*}{ Gênese } & \multirow{2}{*}{$\begin{array}{c}\text { Espes. } \\
\text { (m) }\end{array}$} & \multicolumn{4}{|c|}{ Textura } & \multirow{2}{*}{$\begin{array}{c}\text { pdcam } \\
\mathrm{p} \\
\left(\mathrm{g} / \mathrm{cm}^{3}\right)\end{array}$} & \multirow{2}{*}{$\begin{array}{c}\rho s \\
(\mathrm{~g} / \mathrm{cm} \\
3)\end{array}$} & \multirow{2}{*}{$\begin{array}{c}\mathrm{n} \\
(\%)\end{array}$} & \multirow[t]{2}{*}{$\mathbf{e}_{o}$} & \multirow{2}{*}{$\begin{array}{c}\text { Erodibilidade } \\
\text { E40 }\end{array}$} & \multirow{2}{*}{$\begin{array}{c}\text { CTC } \\
\mathrm{cmol}^{+} / \mathrm{kg}\end{array}$} & \multirow{2}{*}{$\begin{array}{c}\mathrm{SE} \\
\mathrm{m}^{2} / \mathrm{g}\end{array}$} \\
\hline & & & $\begin{array}{c}\% \\
\text { Areia } \\
\text { Grossa }\end{array}$ & $\begin{array}{c}\% \\
\text { Areia } \\
\text { Fina }\end{array}$ & $\begin{array}{c}\% \\
\text { Silte }\end{array}$ & $\begin{array}{c}\% \% \\
\text { Argila }\end{array}$ & & & & & & & \\
\hline ReGrP & Residual & $1-4$ & $11-18$ & $30-48$ & $15-28$ & $12-36$ & $\begin{array}{l}1,19- \\
1,42\end{array}$ & $\begin{array}{l}2,58- \\
2,63\end{array}$ & $45-54$ & $\begin{array}{l}0,84- \\
1,20\end{array}$ & $5,37-173,84$ & $2,85-6,49$ & $\begin{array}{l}16,84- \\
30,36\end{array}$ \\
\hline ReGnb & Residual & $0,5-6$ & $05-15$ & $10-52$ & $11-48$ & $08-63$ & $\begin{array}{l}1,09- \\
1,34\end{array}$ & $\begin{array}{c}2,61- \\
2,6\end{array}$ & $49-58$ & $\begin{array}{l}0,96- \\
1,41\end{array}$ & $0,67-38,12$ & $3,15-6,95$ & $\begin{array}{l}24,65- \\
45,71\end{array}$ \\
\hline ReGnq & Residual & $0,5-3$ & $12-16$ & $42-49$ & 10-14 & $25-32$ & $\begin{array}{l}1,26- \\
1,40\end{array}$ & $\begin{array}{l}2,61- \\
2,62\end{array}$ & $46-52$ & $\begin{array}{c}0,87- \\
1,07\end{array}$ & $13,84-17,6$ & $3,55-5,52$ & $\begin{array}{l}39,52- \\
44,01\end{array}$ \\
\hline ReMig & Residual & $0,5-10$ & $04-16$ & $16-44$ & $07-52$ & $12-58$ & $\begin{array}{l}1,28- \\
1,52\end{array}$ & $\begin{array}{l}2,58- \\
2,63\end{array}$ & $41-55$ & $\begin{array}{r}0,69- \\
1,24\end{array}$ & $4,98-93,77$ & $5,19-9,89$ & $\begin{array}{l}21,17- \\
47,21\end{array}$ \\
\hline ReUtm & Residual & $1-8$ & $14-25$ & $16-46$ & $28-52$ & 08-18 & $\begin{array}{l}1,39- \\
1,53\end{array}$ & $\begin{array}{l}2,63- \\
2,65\end{array}$ & $45-48$ & $\begin{array}{l}0,74- \\
0,89\end{array}$ & $0,43-0,99$ & $7,86-8,4$ & $\begin{array}{l}53,45- \\
68,25\end{array}$ \\
\hline ReBtm & Residual & $1-4$ & $08-10$ & $23-42$ & $45-52$ & $13-17$ & $\begin{array}{l}1,41- \\
1,56\end{array}$ & $\begin{array}{l}2,62- \\
2,63\end{array}$ & $43-55$ & $\begin{array}{c}0,73- \\
0,86\end{array}$ & $0,83-0,94$ & $2,31-4,43$ & $\begin{array}{r}17,24- \\
35,28\end{array}$ \\
\hline
\end{tabular}




\subsection{CARACTERIZAÇÃO DO COMPORTAMENTO DE RESISTÊNCIA A PENETRAÇÃO}

A análise das medidas de resistência a penetração executadas foi feita por tipo de materiais incosolidados ensaiado, com verificação do comportamento de variação da resistência frente aos diferentes tipos de usos vigentes. Foram considerados os parâmetros NTG e valor de umidade média dos perfis ensaiados na caracterização do comportamento de resistência a penetração dos materiais (Tabela 7.4).

Tabela 7. 4 - Relação de Valores NTG x Umidade volumétrica média, para os diferentes tipos de materiais inconsolidados, e atividades de ocupação do terreno.

\begin{tabular}{|c|c|c|c|c|c|c|c|c|c|c|}
\hline \multirow{3}{*}{$\begin{array}{l}\text { Tipo de Mat. } \\
\text { Inconsolidado }\end{array}$} & \multicolumn{10}{|c|}{ Uso da Terra } \\
\hline & \multicolumn{2}{|c|}{ Mata Nativa } & \multicolumn{2}{|c|}{ Pastagem } & \multicolumn{2}{|c|}{ Café } & \multicolumn{2}{|c|}{$\begin{array}{c}\text { Cana-de- } \\
\text { açúcar }\end{array}$} & \multicolumn{2}{|c|}{$\begin{array}{l}\text { Outras } \\
\text { culturas }\end{array}$} \\
\hline & NTG & $\theta$ méd. & NTG & $\theta$ méd. & NTG & $\theta$ méd. & NTG & $\theta$ méd. & NTG & $\theta$ méd. \\
\hline ReGnB & $\begin{array}{l}26 \\
29\end{array}$ & $\begin{array}{l}23 \\
22\end{array}$ & $\begin{array}{l}53 \\
56 \\
65 \\
59\end{array}$ & $\begin{array}{l}17 \\
16 \\
13 \\
15\end{array}$ & $\begin{array}{l}69 \\
63 \\
63 \\
69 \\
63\end{array}$ & $\begin{array}{l}17 \\
19 \\
19 \\
16 \\
18\end{array}$ & $\begin{array}{l}25 \\
48 \\
45 \\
40\end{array}$ & $\begin{array}{l}23 \\
17 \\
17 \\
19\end{array}$ & $\begin{array}{l}40 \\
39 \\
41\end{array}$ & $\begin{array}{l}19 \\
21 \\
18\end{array}$ \\
\hline ReGnQ & 83 & 17 & $\begin{array}{l}60 \\
61 \\
59 \\
60\end{array}$ & $\begin{array}{l}12 \\
13 \\
15 \\
15\end{array}$ & $\begin{array}{l}30 \\
32\end{array}$ & $\begin{array}{l}17 \\
15\end{array}$ & $\begin{array}{l}45 \\
81 \\
69\end{array}$ & $\begin{array}{l}20 \\
11 \\
17\end{array}$ & $\begin{array}{l}29 \\
25\end{array}$ & $\begin{array}{l}17 \\
18\end{array}$ \\
\hline ReMig & 59 & 11 & $\begin{array}{l}39 \\
26 \\
34 \\
27 \\
46 \\
35 \\
34 \\
33 \\
35 \\
\end{array}$ & $\begin{array}{l}15 \\
19 \\
16 \\
19 \\
13 \\
16 \\
16 \\
17 \\
17 \\
\end{array}$ & $\begin{array}{l}66 \\
60 \\
61 \\
62\end{array}$ & $\begin{array}{l}15 \\
19 \\
19 \\
17\end{array}$ & -- & -- & $\begin{array}{l}24 \\
25 \\
24\end{array}$ & $\begin{array}{l}17 \\
16 \\
17\end{array}$ \\
\hline ReBtm & -- & -- & $\begin{array}{l}49 \\
48 \\
50 \\
51 \\
\end{array}$ & $\begin{array}{l}12 \\
12 \\
11 \\
10 \\
\end{array}$ & $\begin{array}{l}34 \\
36\end{array}$ & $\begin{array}{l}18 \\
17\end{array}$ & -- & -- & $\begin{array}{l}40 \\
43 \\
36\end{array}$ & $\begin{array}{l}13 \\
13 \\
19\end{array}$ \\
\hline ReUtm & -- & -- & $\begin{array}{l}44 \\
42 \\
41\end{array}$ & $\begin{array}{l}19 \\
21 \\
21\end{array}$ & $\begin{array}{l}48 \\
47 \\
42 \\
41 \\
\end{array}$ & $\begin{array}{l}17 \\
17 \\
19 \\
20 \\
\end{array}$ & -- & -- & $\begin{array}{l}65 \\
63 \\
60 \\
64 \\
\end{array}$ & $\begin{array}{l}11 \\
15 \\
17 \\
11 \\
\end{array}$ \\
\hline ReGrP & -- & -- & $\begin{array}{l}60 \\
66 \\
58 \\
62 \\
63 \\
60 \\
\end{array}$ & $\begin{array}{c}17 \\
12 \\
1914 \\
15 \\
16\end{array}$ & $\begin{array}{l}71 \\
64 \\
60 \\
73 \\
68 \\
70\end{array}$ & $\begin{array}{l}14 \\
18 \\
20 \\
14 \\
18 \\
16\end{array}$ & -- & -- & $\begin{array}{l}31 \\
36 \\
33\end{array}$ & $\begin{array}{l}19 \\
14 \\
16\end{array}$ \\
\hline
\end{tabular}

Өméd - Umidade volumétrica média; NTG - número total de golpes em $60 \mathrm{~cm}$ 
Para uma melhor interpretação do comportamento da resistência a penetração, os dados foram plotados em gráficos, os quais representam as variações do NTG e da umidade frente as diferentes atividades de ocupação de um mesmo material (Figuras 7.9 a 7.14$)$

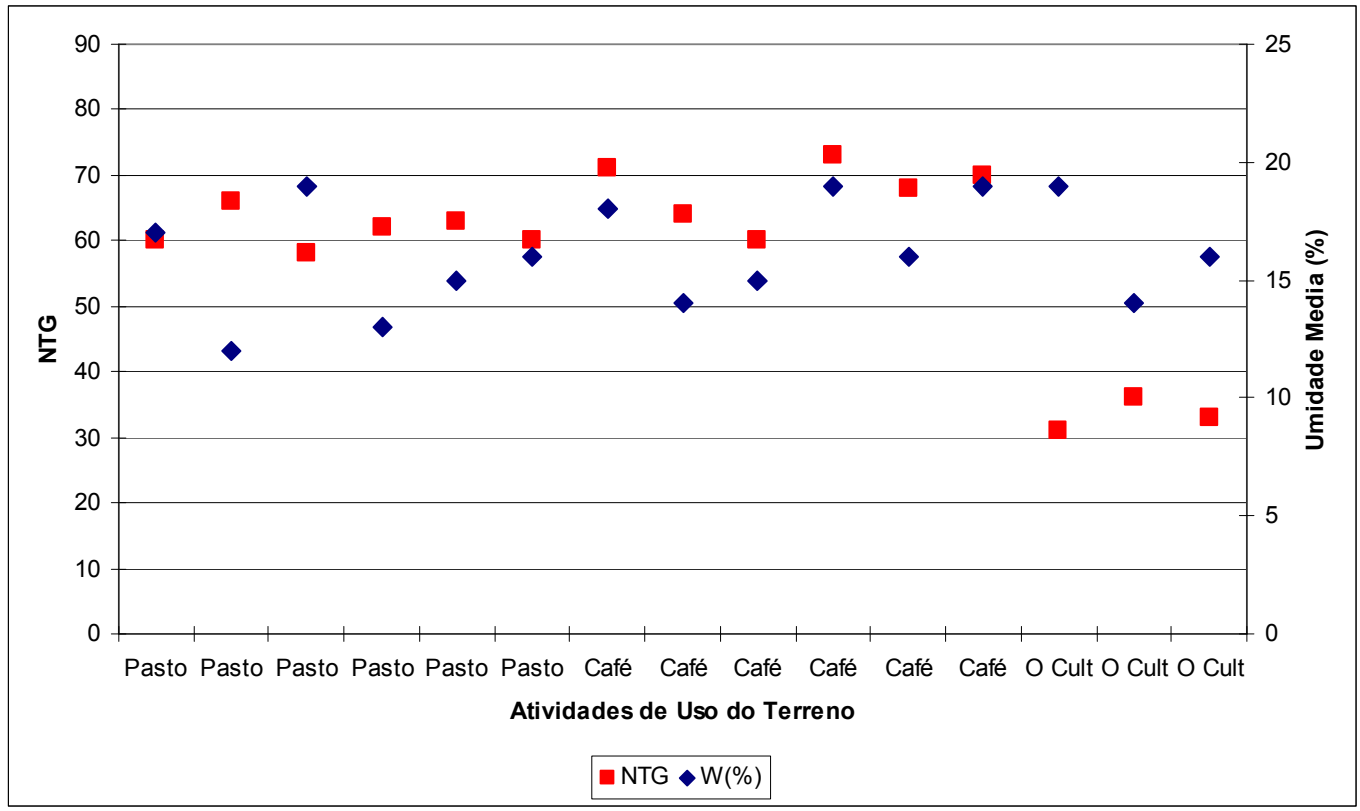

Figura 7.9 - Valores de NTG e umidade média X tipos de ocupação dos materiais residuais de granitos porfiríticos (ReGrP).

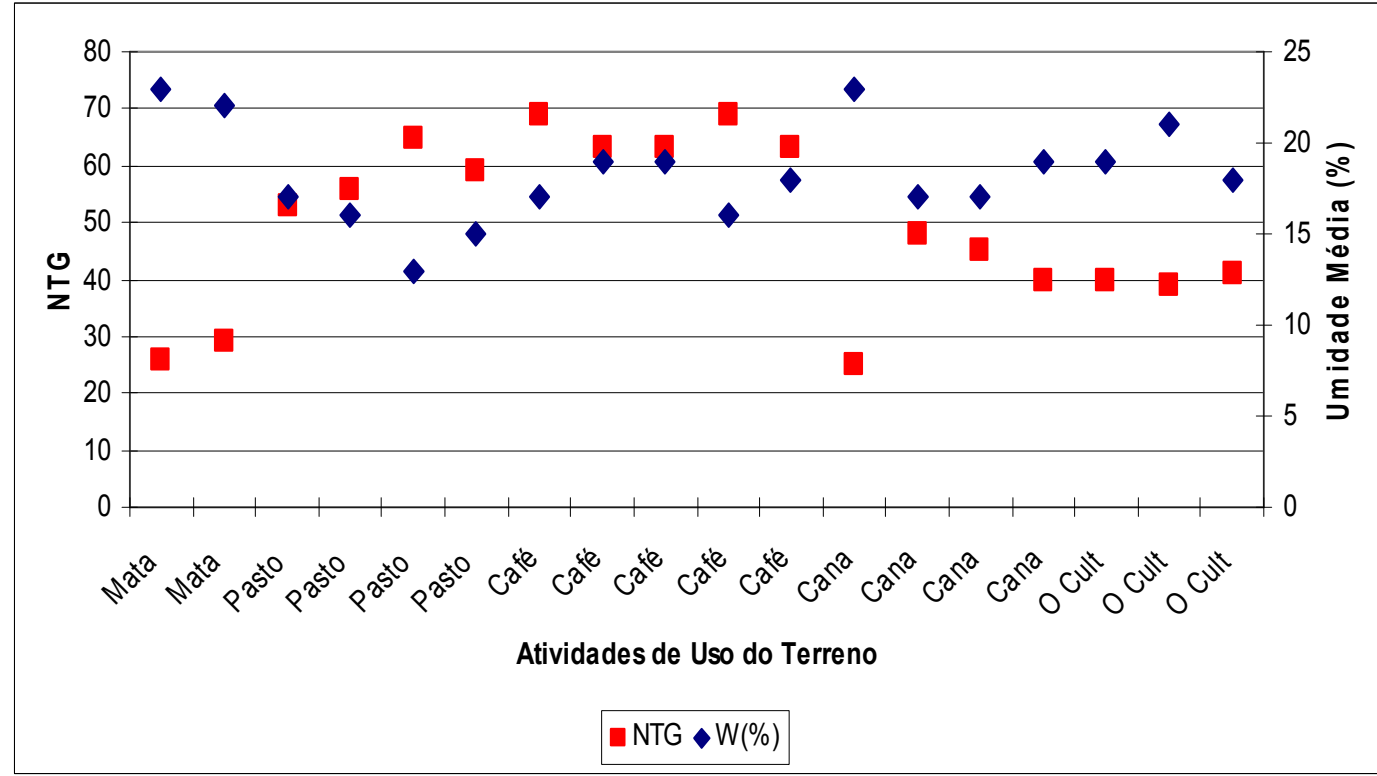

Figura 7.10 - Valores de NTG e umidade média X tipos de ocupação dos materiais residuais de gnaisses intercalados com rochas básicas (ReGnB). 


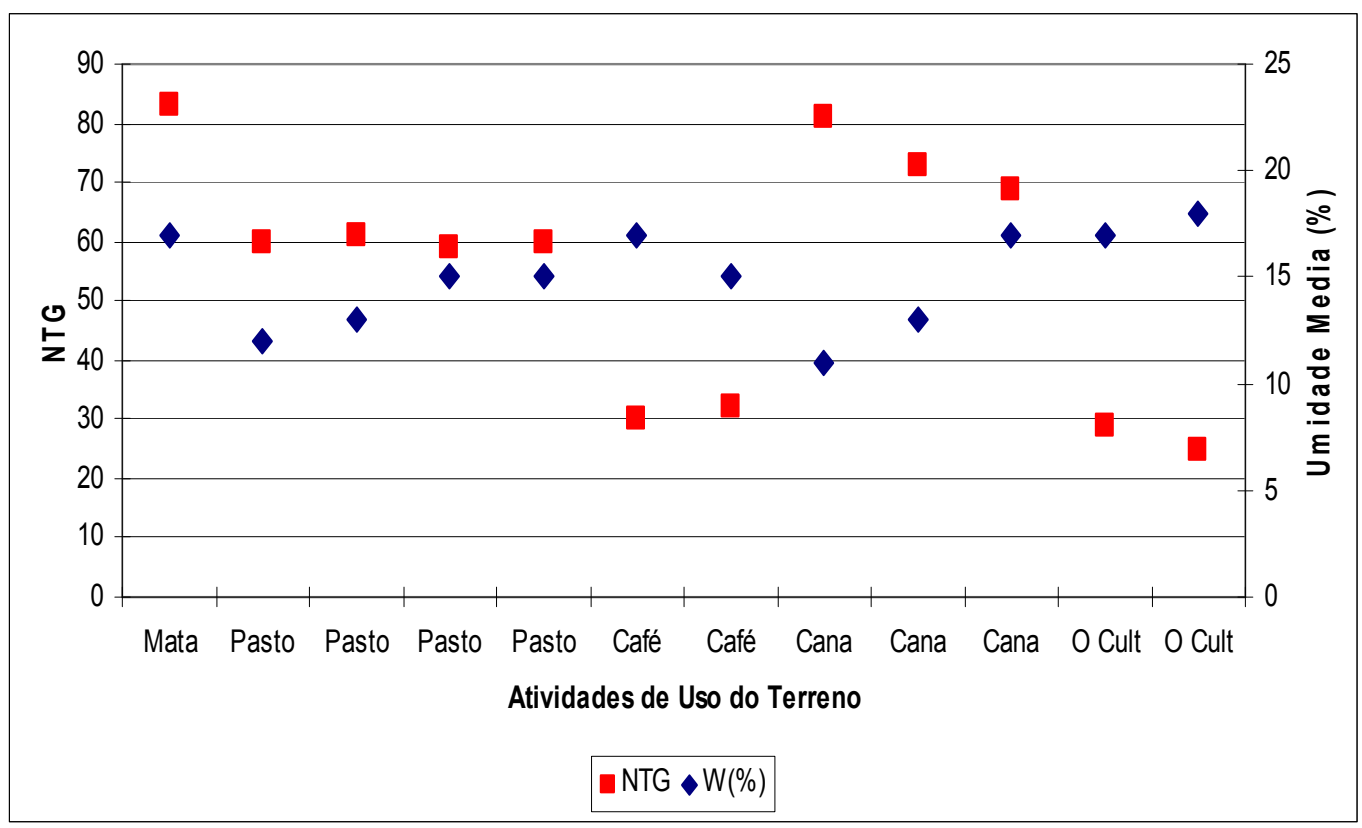

Figura 7.11 - Valores de NTG e umidade média X tipos de ocupação dos materiais residuais intercalados com quartzitos (ReGnQ).

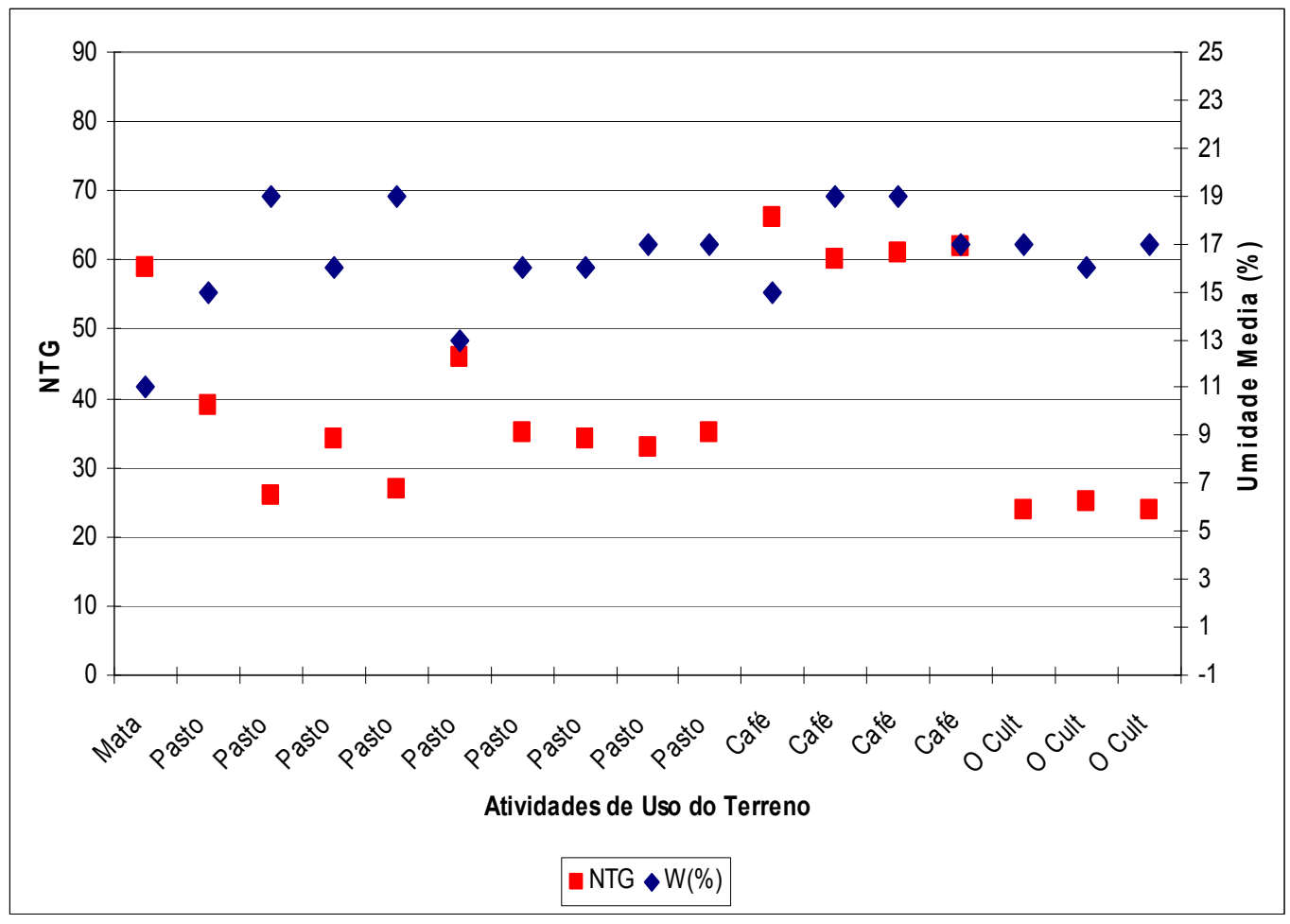

Figura 7.12 - Valores de NTG e umidade média X tipos de ocupação dos materiais residuais de migmatitos (ReMig). 


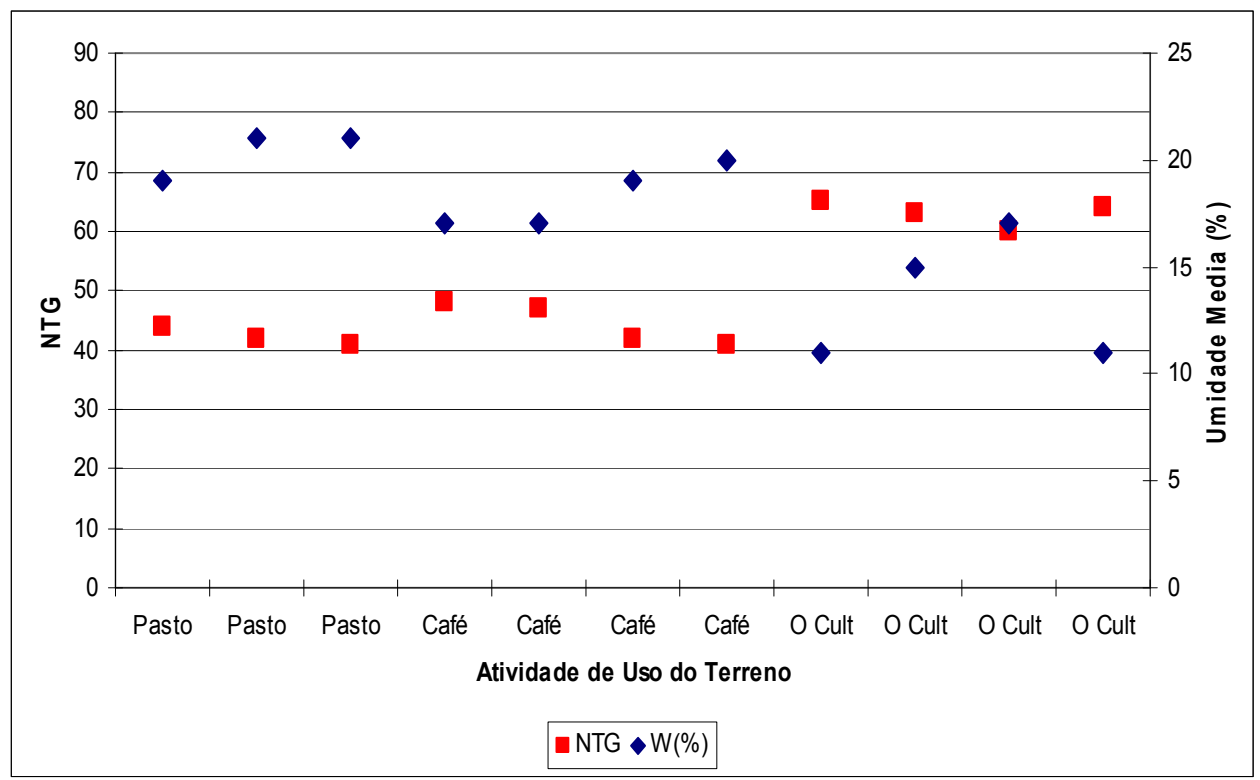

Figura 7.13 - Valores de NTG e umidade média X tipos de ocupação dos materiais residuais de ultramilonitos (ReUtm).

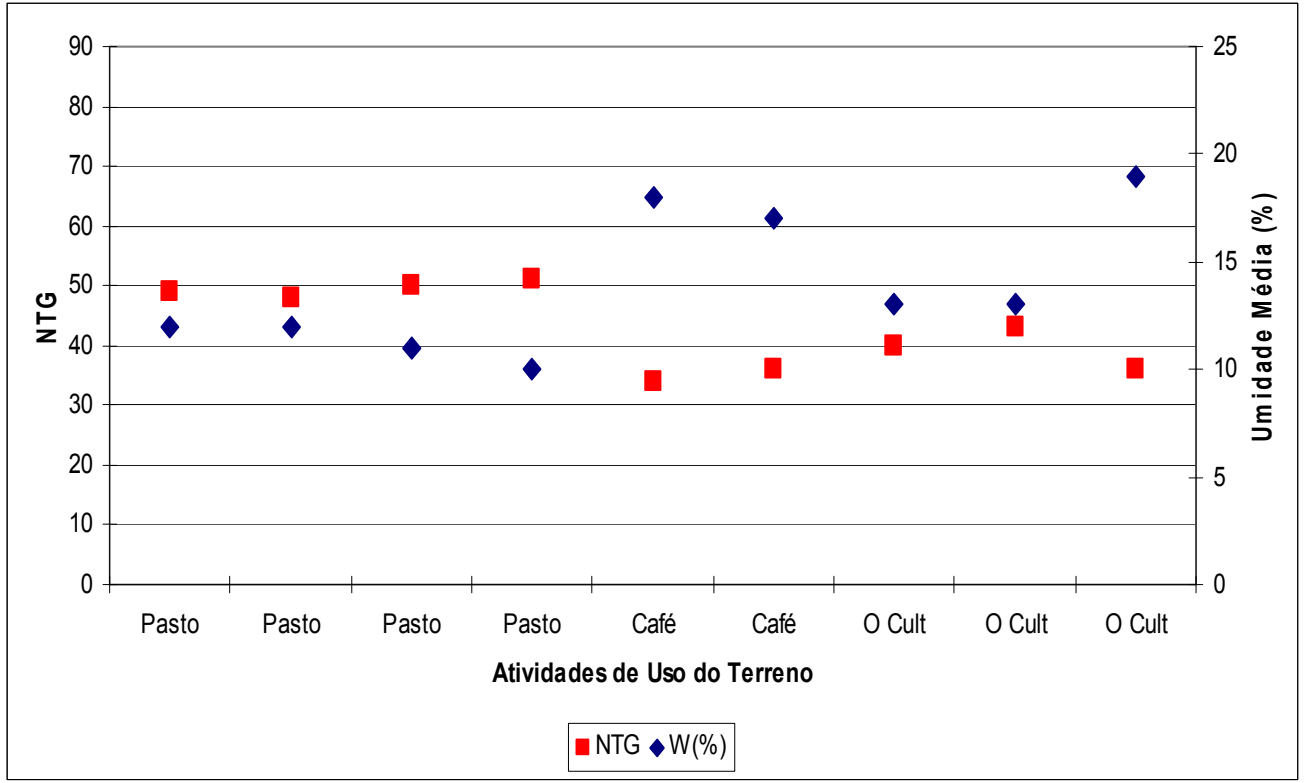

Figura 7.14 - Valores de NTG e umidade média X tipos de ocupação dos materiais residuais de blastomilonitos (ReBtm).

A análise das Figuras 7.9 a 7.14 permitiu constatar que independente do tipo de material inconsolidado e do uso vigente, o NTG varia de forma inversamente proporcional aos teores médios de umidade do material.

Avaliando-se em separado os tipos de materiais, observa-se que o NTG também varia frente as diferentes atividades de uso. Nota-se, para algumas práticas como as atividades de pastagem e o cultivo de café, um comportamento de distribuição dos 
valores de NTG e umidade média mais homogêneos. Isto é bem representado nos materiais ReGnB, ReGnQ ReUtm e ReBtm. Já as práticas de cana-de-açúcar e outras culturas caracterizam-se por um comportamento com maior variabilidade de distribuição dos valores de NTG e umidade média.

Com objetivo de verificar existência de correlação entre o NTG e as medidas de umidade média, foram plotados os valores os valores representativos destes parâmentors por tipo de materiais, sem discriminação dos usos vigentes (Figuras 7.15 a $7.20)$.

Boas correlações foram obtidas apenas para os materiais ReUtm e ReBtm, nos quais foram verificados coeficientes de determinação 0,82 e 0,87 , respectivamente. Nos demais materiais os coeficientes obtidos não indicaram boas correlações. Uma possível causa para má correlação encontrada, pode ser creditada a influência dos diferentes tipos de uso no comportamento da resistência a penetração para um mesmo material inconsolidado. Isto é bem caracterizado nos materiais $\operatorname{ReGnB}$ e $\operatorname{ReGnQ}$, os quais apresentam registros de ensaios em todos os tipos de ocupação do terreno presentes na área. Nestes materiais inconsolidados os valores de $\mathrm{R}^{2}$ são muito baixos, menores que 0,5 .

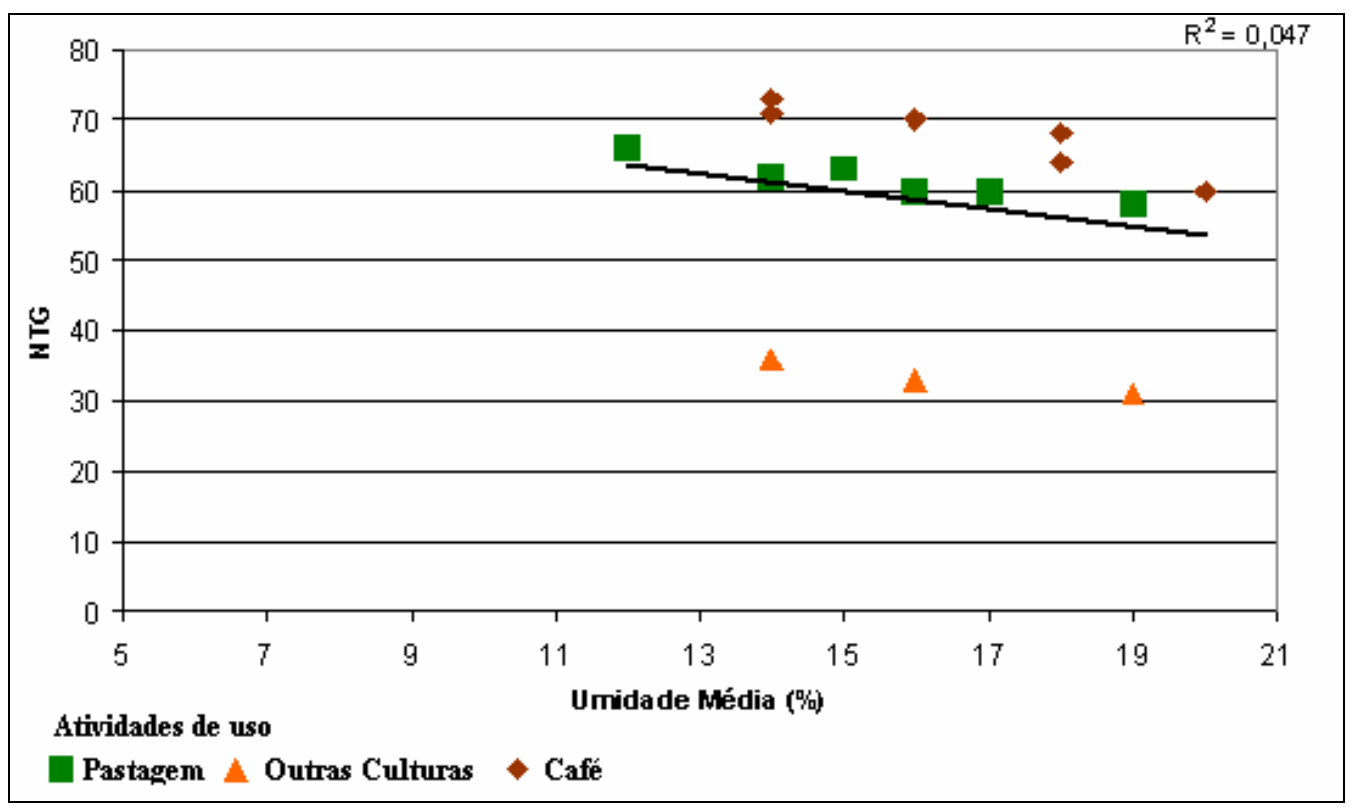

Figura 7.15 - Correlação NGT X Umidade média para os materiais inconsolidados residuais de granitos porfiríticos $(\mathrm{ReGrP})$. 


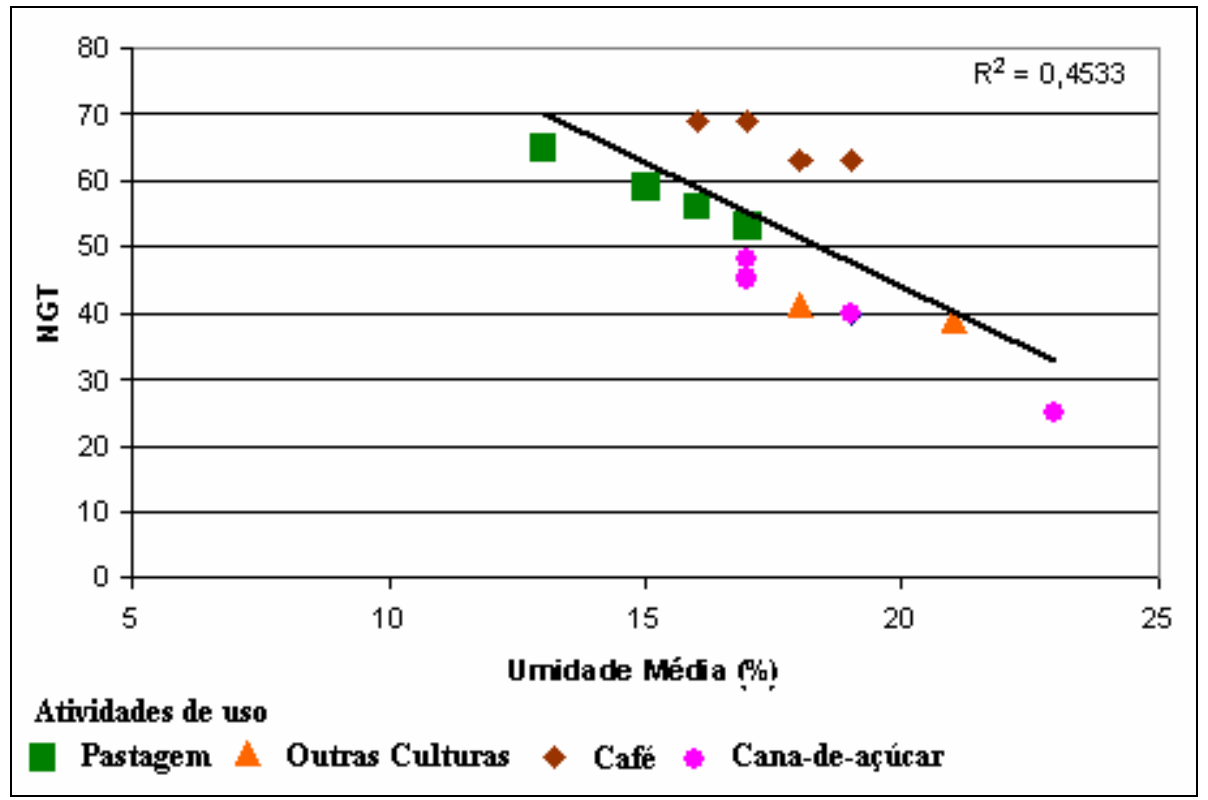

Figura 7.16 - Correlação NGT X Umidade média para os materiais inconsolidados residuais de gnaisses intercalados com rochas básicas (ReGnB).

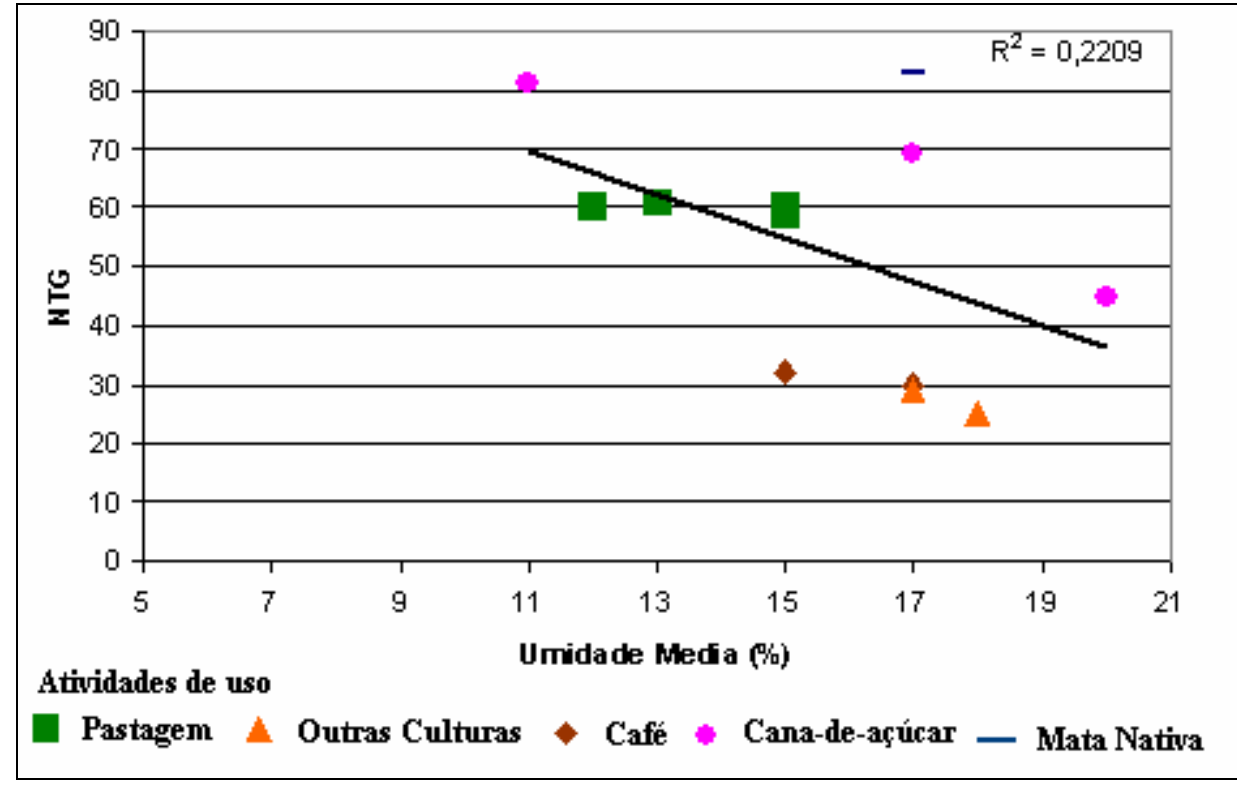

Figura 7.17 - Correlação NGT X Umidade média para os materiais inconsolidados residuais de gnaisses intercalados com quartzitos (ReGnQ). 


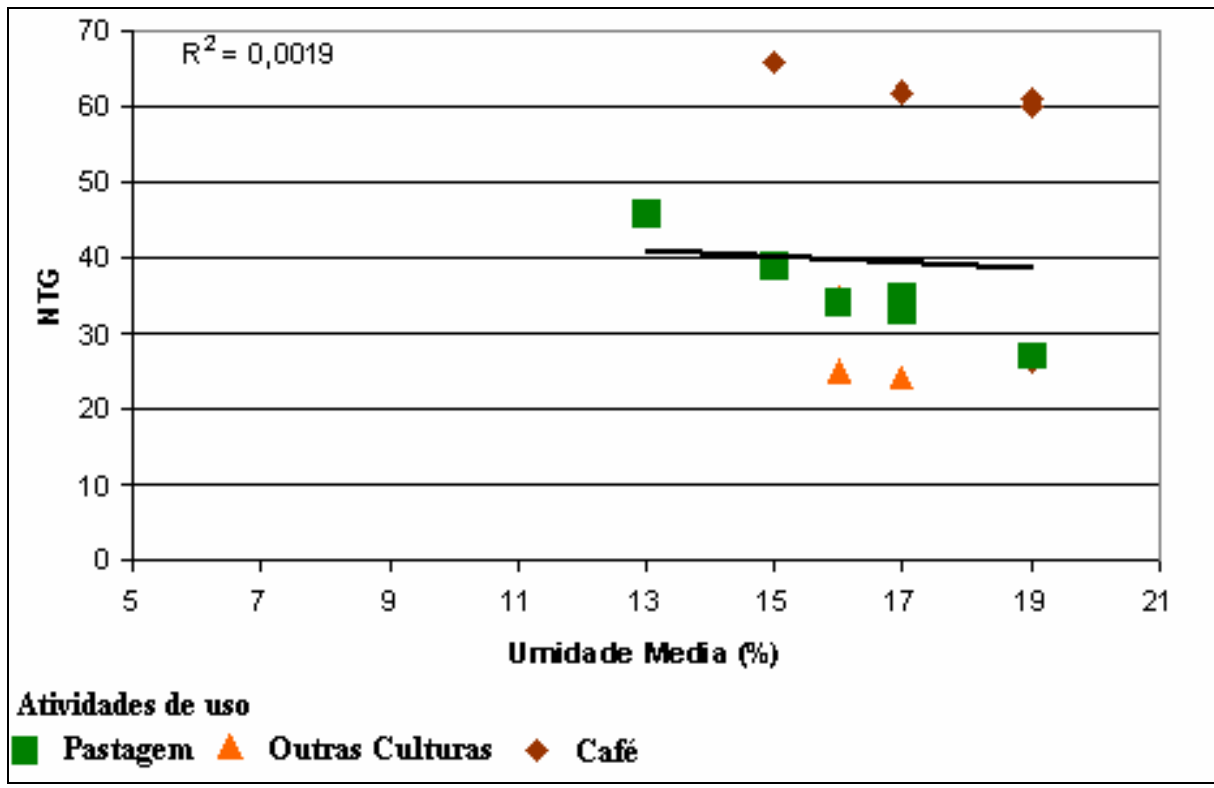

Figura 7.18 - Correlação NGT X Umidade média para os materiais inconsolidados residuais de migmatitos (ReMig).

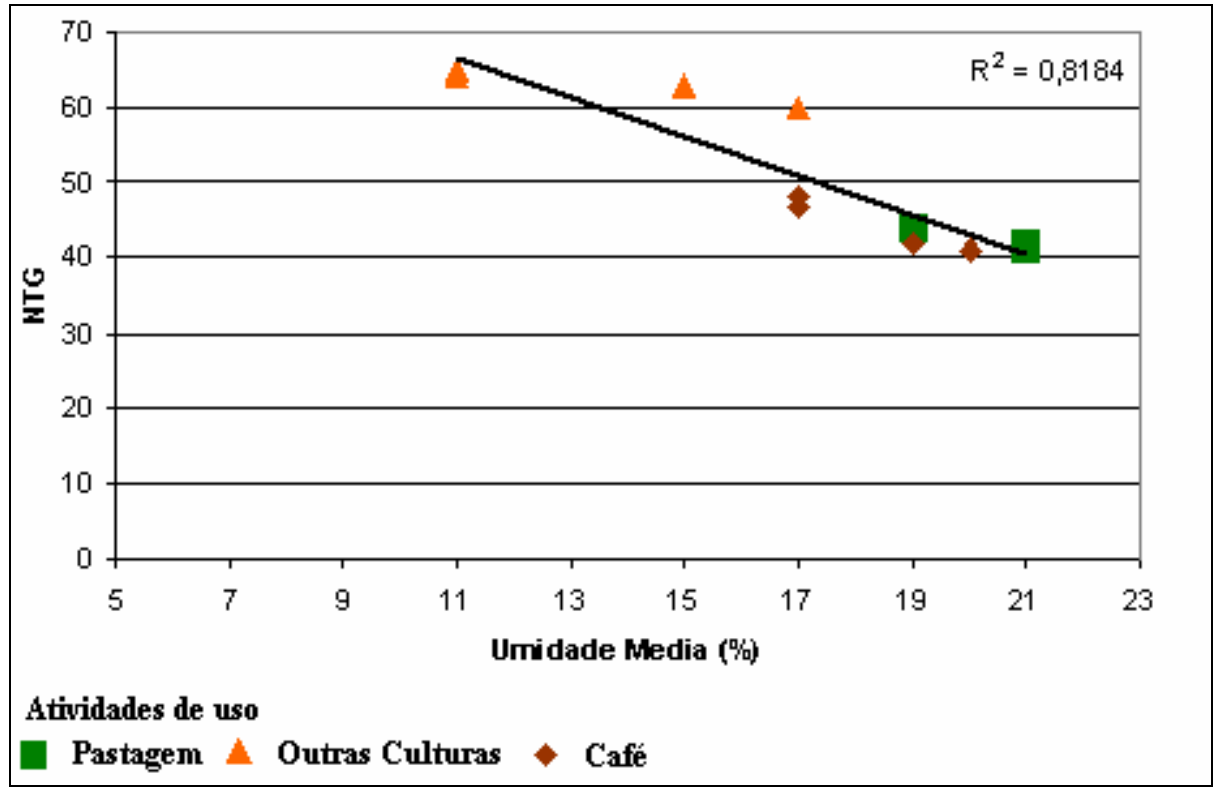

Figura 7.19 - Correlação NGT X Umidade média para os materiais incosolidados residuais de ultramilonitos (ReUtm). 


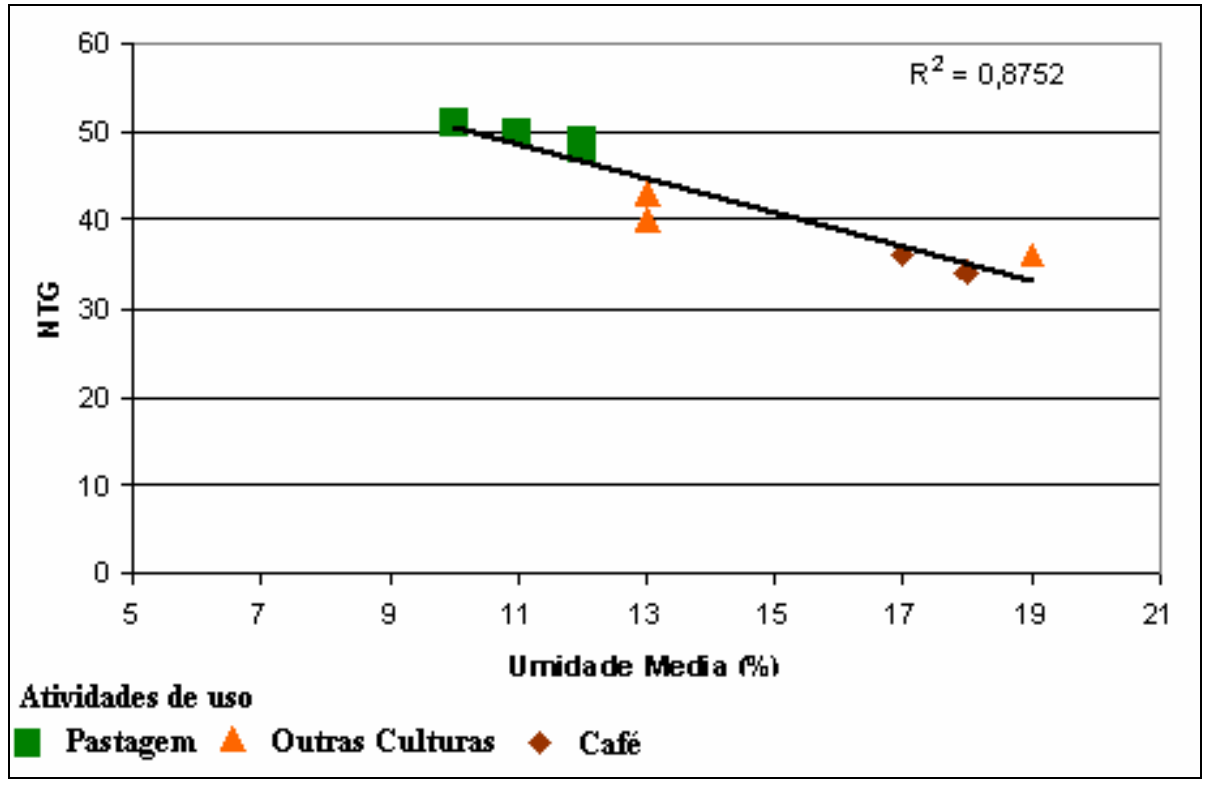

Figura 7.20 - Correlação NGT X Umidade média para os materiais incosolidados residuais de blastomilonitos (ReBtm).

Com objetivo de verificar a influência dos diferentes tipos de uso do terreno no comportamento NTG x Umidade média, por tipo de material, foram calculados coeficientes de correlação destes parâmetros, para cada prática de ocupação do solo. Para os casos das práticas com registro inferior a três pontos ensaiados, como mata nativa nos materiais incosolidados ReGnB, ReGnQ e ReMig; e café nos materiais ReGnQ , os coeficientes de determinação foram obtidos a partir combinação de dados de práticas diferentes como: mata nativa/outras culturas e pastagem/café. Os valores dos $\mathrm{R}^{2}$ obtidos são apresentados na Tabela 7.5.

Este procedimento resultou na obtenção de coeficientes de correlação $\left(\mathrm{R}^{2}\right)$ os quais exibem melhora significativa dos das relações NTG x Umidade média do perfil.

Os valores dos coeficientes mostram que todos os materiais ensaiados, a exceção dos ReGnQ, apresentam bons resultados de correlação dos parâmetros NTG x Umidade média, o que vem a confirmar a influência dos tipos de uso no comportamento de resistência a penetração dos materiais inconsolidados. 
Tabela 7.5 - Valores de correlação NTG x Umidade por tipo de ocupação do terreno.

\begin{tabular}{|c|c|c|c|c|}
\hline $\begin{array}{l}\text { Material } \\
\text { incosoli } \\
\text {-dados }\end{array}$ & Prática de Uso & $\begin{array}{l}\mathrm{N}^{\circ} \text { pontos } \\
\text { ensaiados }\end{array}$ & Coef. $\mathbf{R}^{2}$ & Equações de correlação \\
\hline \multirow{4}{*}{$\operatorname{ReGnB}$} & Mata/O Culturas & 4 & 0,81 & NTG $=-3,7143^{*}($ umidade $)+112,43$ \\
\hline & Pastagem & 4 & 1 & NTG $=-3 *$ (umidade) +104 \\
\hline & Café & 5 & 0,82 & NTG $=-2,2941 *($ umidade $)+106,24$ \\
\hline & Cana-de-açúcar & 3 & 0,98 & NTG $=-3,5833^{*}($ umidade $)+107,42$ \\
\hline \multirow{3}{*}{ ReGrP } & Pastagem & 6 & 0,90 & NTG $=-1,017 *$ (umidade) $+78,57$ \\
\hline & Café & 6 & 0,87 & NTG $=-1,8636^{*}($ umidade $)+98,73$ \\
\hline & Outras Culturas & 3 & 0,95 & NTG $=-0,9737 *$ (umidade $)+49,24$ \\
\hline \multirow{3}{*}{ ReGnQ } & Mata $/{ }^{\circ} \mathrm{OCulturas}$ & 3 & 0,30 & NTG $=-31 *($ umidade $)+583$ \\
\hline & Pastagem/Café & 6 & 0,48 & $\mathrm{NTG}=-5,9032 *($ umidade $)+135,76$ \\
\hline & Cana-de-açúcar & 3 & 0,94 & NTG $=-3,2308^{*}($ umidade $)+118,85$ \\
\hline \multirow{3}{*}{ ReMig } & Mata/O Culturas & 9 & 0,98 & NTG $=-5,9798^{*}($ umidade $)+124,19$ \\
\hline & Pastagem & 5 & 0,95 & NTG $=-3,0945^{*}($ umidade $)+85,22$ \\
\hline & Café & 5 & 0,92 & NTG $=-1,3182 *($ umidade $)+85,32$ \\
\hline \multirow{3}{*}{ ReUtm } & Pastagem & 3 & 0,89 & NTG $=-1,25^{*}($ umidade $)+67,75$ \\
\hline & Café & 4 & 0,96 & NTG $=-2,2963^{*}($ umidade $)+86,407$ \\
\hline & Outras Culturas & 4 & 0,85 & NTG $=-0,6667 *$ (umidade) +72 \\
\hline \multirow{2}{*}{ ReBtm } & Pastagem/Café & 5 & 0,99 & NTG $=-2,381 *($ umidade $)+76,733$ \\
\hline & Outras Culturas & 3 & 0,81 & NTG $=-0,9167 *$ (umidade $)+53,47$ \\
\hline
\end{tabular}

Constatada a influência das diferentes atividades de ocupação do terreno no comportamento de resistência a penetração de um mesmo material, foi realizada análise para verificação dentre as práticas vigentes, e com registro de ensaio, quais são responsáveis pelos valores mais elevados de resistência nos tipos de materiais incosolidados ensaiados.

Em função das atividades de cultivo de café, outras culturas e pastagem apresentarem melhores regularidades de ocorrência na área da bacia, estas foram adotas para determinação, dentre as classes de ocupação com maiores registros de ocorrência na área, quais acarretam maior alteração no comportamento de resistência a penetração nos materiais em análises. Para isto forma analisados os valores de NTG a partir do estabelecimento de quatro teores de umidades comuns a estas práticas (Tabela 7.6), de forma a caracterizar o comportamento da resistência, sem a influência da variabilidade da umidade.

Os valores de umidade fixados correspondem aos teores máximos, mínimos e intermediários registrados nos ensaios. Quando os valores de NTG para estas umidades não foram obtidos diretamente dos ensaios, os mesmos foram calculados a partir das equações de correlação obtidas (Tabela 7.5). 
Tabela 7.6 - Valores de correlação NTG x Umidade por tipo de materiais incosolidados e atividade de ocupação do terreno.

\begin{tabular}{l|c|c|c|c}
\hline $\begin{array}{c}\text { Material/Atividade } \\
\text { de Uso }\end{array}$ & $\boldsymbol{\theta}$ Média 11\% & $\boldsymbol{\theta}$ Média 15\% & $\boldsymbol{\theta}$ Média 19\% & $\boldsymbol{\theta}$ Média21\% \\
\cline { 2 - 5 } & NTG & NTG & NTG & NTG \\
\hline ReGnB-Pastagem & 71 & 59 & 47 & 41 \\
\hline ReGnB-Café & 81,0 & 71,8 & 62,7 & 58,1 \\
\hline ReGnB-O Culturas & 71,6 & 56,7 & 41,9 & 34,4 \\
\hline ReGrP-Pastagem & 67,6 & 63,5 & 59,4 & 57,4 \\
\hline ReGrP-Café & 78,2 & 70,8 & 63,3 & 59,6 \\
\hline ReGrP-O. Culturas & 38,5 & 34,6 & 30,7 & 28,7 \\
\hline ReMig-Pastagem & 70,8 & 65,5 & 60,3 & 57,6 \\
\hline ReMig-Café & 38,5 & 34,6 & 30,7 & 28,8 \\
\hline ReMig-O.Culturas & 58,4 & 34,5 & 10,6 & $-1,4$ \\
\hline ReUtm-Pastagem & 54 & 49 & 44 & 41,5 \\
\hline ReUtm-Café & 61,1 & 52,0 & 42,8 & 38,2 \\
\hline ReUtm-O.Culturas & 64,7 & 62,0 & 59,3 & 58,0 \\
\hline ReBtm Pastagem/Café & 51 & 41 & 31 & 22 \\
\hline RebBtrm O Culturas & 43 & 40 & 36 & 34 \\
\hline
\end{tabular}

\section{Materiais inconsolidados residuais de gnaisses intercalados com rochas básicas (ReGnB)}

Nos materiais inconsolidados ReGnb foi verificado que a atividade de café apresenta os valores mais elevados de resistência a penetração (Figura 7. 21), e as atividades de pastagem e outras culturas são responsáveis pelos menores valores de resistência a penetração. Estas apresentam um comportamento semelhante para os teores mais baixos de umidade média, não sofrendo grandes variações para os valores de umidade média mais altos.

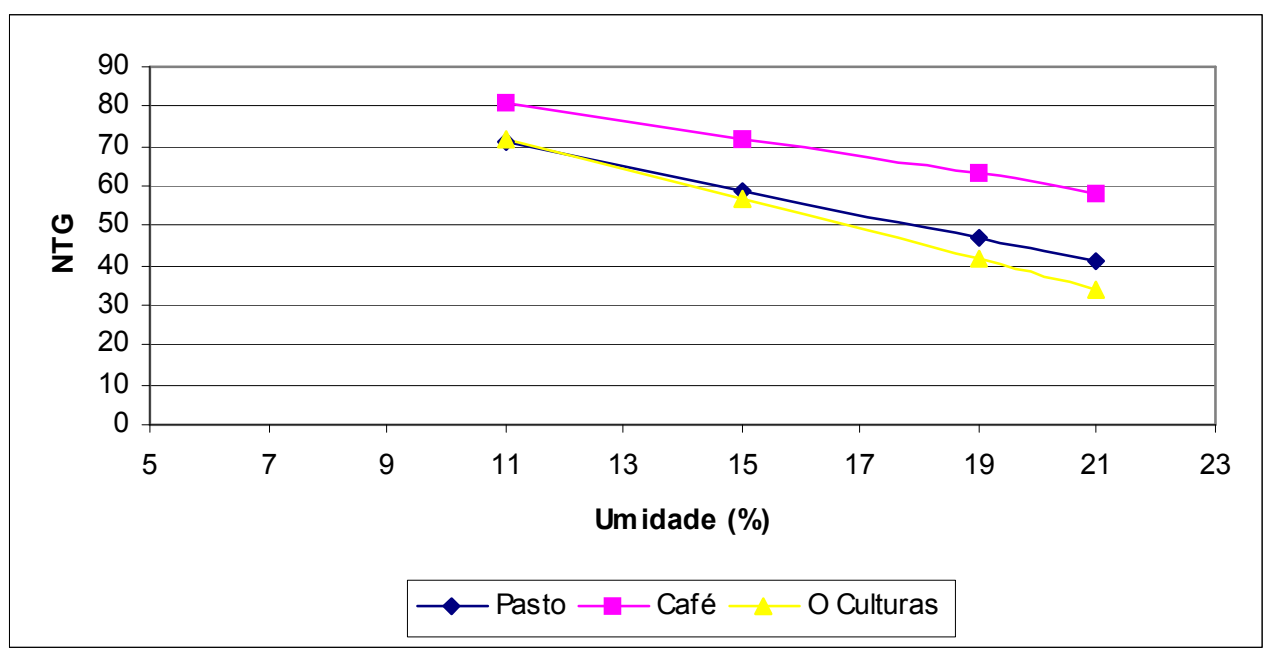

Figura 7.21 - Comportamento da resistência a penetração frente as práticas de pastagem, café e outras culturas nos materiais residuais de gnaisses intercalados com rochas básicas (ReGnB). 


\section{Materiais inconsolidados residuais de granitos porfiriticos (ReGrP)}

Nestes materiais foi verificado, assim como nos ReGnB, que as atividade de cultivo de café são responsáveis pelos maiores valores de resistência a penetração, e que as atividade de cultivo de outras culturas conferem os valores mais baixos de resistência a penetração (Figura 7.22). Observa-se também que para os intervalos de umidade média estabelecidos, as atividades de ocupação do solo por cultivo de café e desenvolvimento de pastagem conferem comportamentos de resistência semelhantes, quando avaliados com relação aos teores mais elevados de umidade.

\section{Materiais inconsolidados residuais de migmatitos (ReMig)}

Para estes foi verificado que as atividades de ocupação por desenvolvimento de pastagens conferem o comportamento de maior resistência a penetração. A atividade de desenvolvimento de outras culturas apresenta um comportamento de resistência particular, com valor de resistência intermediário para os menores teores de umidade, e valor muito baixo, tendendo a um NTG nulo para os teores de umidade mais elevados (Figura 7.23). Este comportamento é verificado em campo pela penetração da sonda combinada devido ao peso do equipamento, ou seja, sem que haja necessidade de execução de golpes iniciais para penetrar a sonda por completo no material.

A atividade de ocupação do terreno por cultivo de café confere aos materiais ReMig um comportamento de resistência a penetração homogêneo,com variação de valores mínimos e máximos de NTG igual a 10.

\section{Materiais inconsolidados residuais de ultramilonitos (ReUtm)}

Os materiais ReUtm apresentaram um comportamento de resistência a penetração inverso aos anteriormente descritos. Nestes materiais, a atividade responsável pelos valores mais elevados de resistência a penetração é a ocupação por desenvolvimento de cultivo de outras culturas (Figura 7.24). Verificou-se que para os teores mais baixos de umidade, as atividades de outras culturas e café apresentam valores de resistência próximos, entretanto, com o aumento dos teores de umidade no perfil de solo as atividade de café e pastagem passam a conferir ao material os valores 
mais baixos de resistência. Observou-se também que a atividade de ocupação por outras culturas exibe um comportamento homogêneo com variações entre valore máximos e mínimos de resistência não superior a NTG igual a 10 .

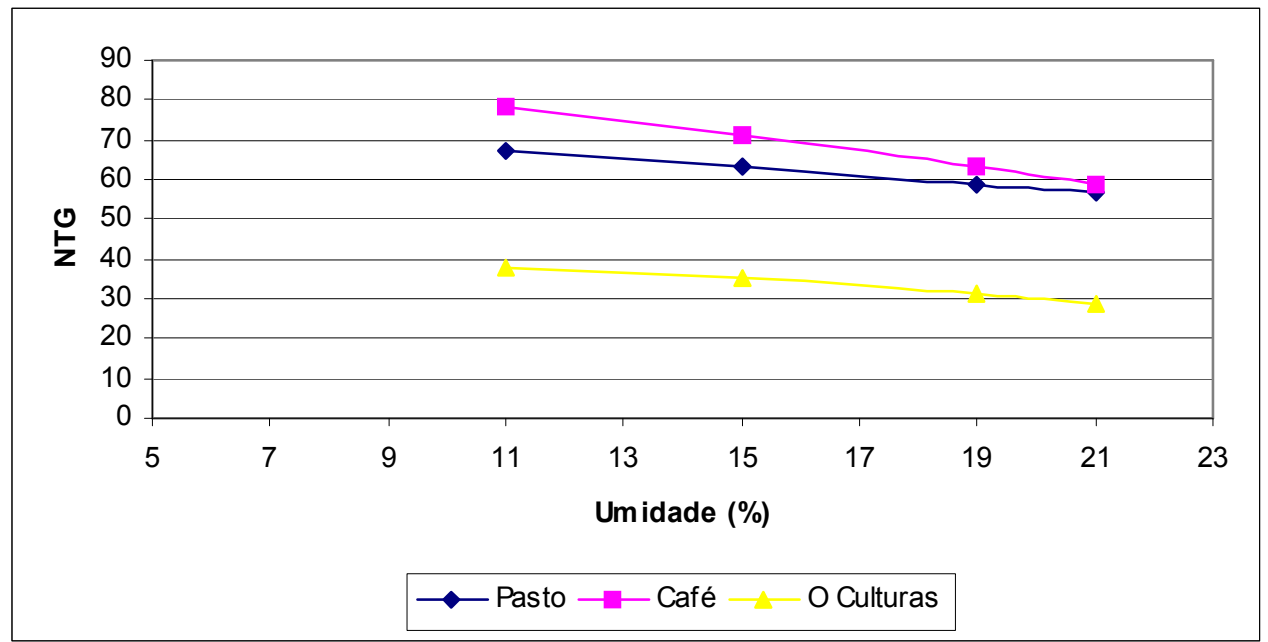

Figura 7.22 - Comportamento da resistência a penetração frente as práticas de pastagem, café e outras culturas nos materiais residuais de granitos porfiríticos (ReGrP).

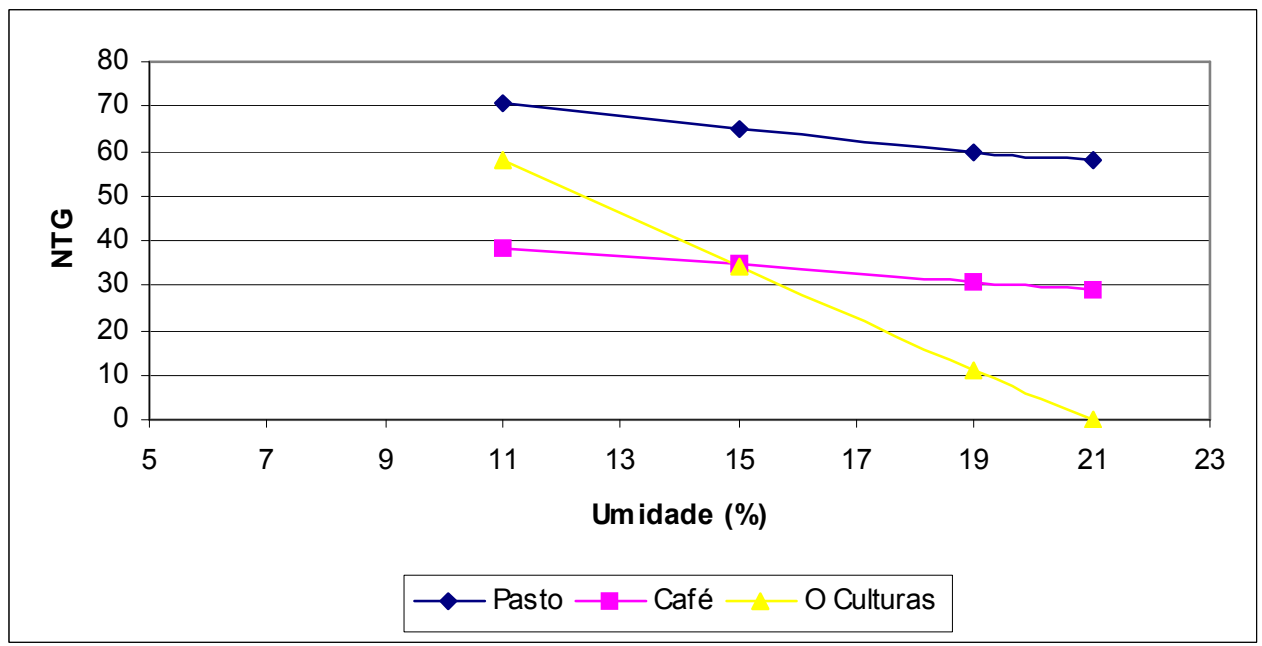

Figura 7.23 - Comportamento da resistência a penetração frente as práticas de pastagem, café e outras culturas nos materiais residuais de migmatitos (ReMig). 


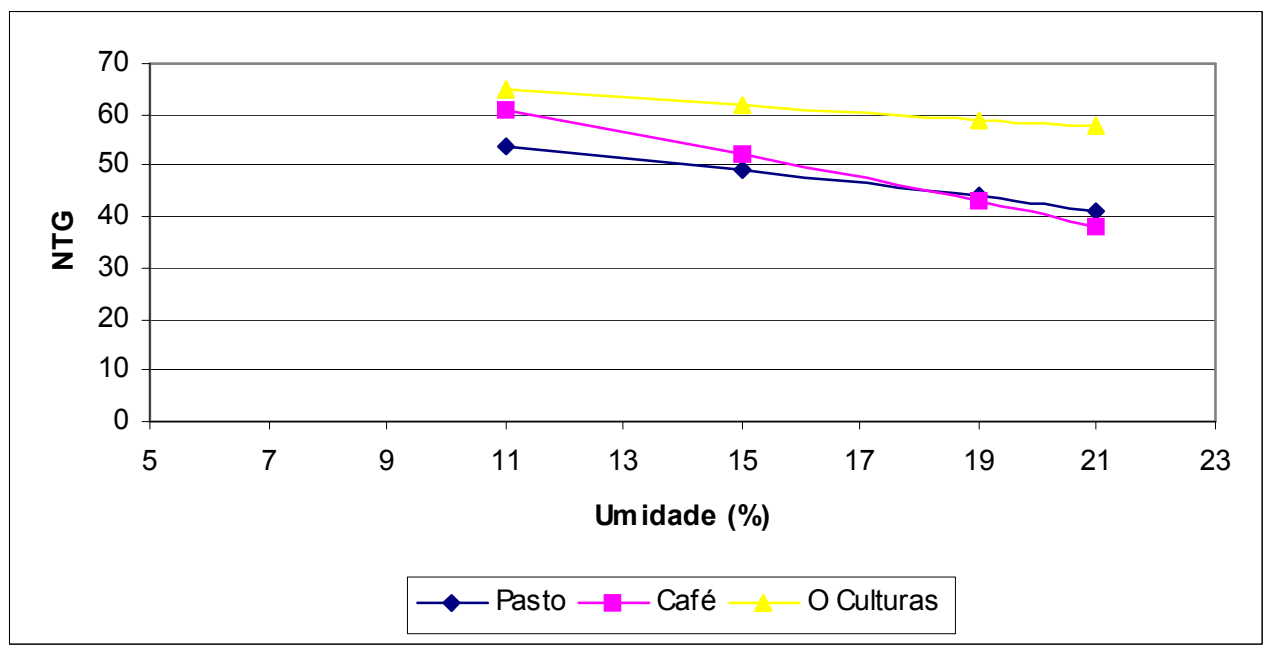

Figura 7.24 - Comportamento da resistência a penetração frente as práticas de pastagem, café e outras culturas nos materiais residuais de ultramilonitos (ReUtm).

\section{Materiais inconsolidados residuais de blastomilonitos (ReBtm)}

Nos materiais ReBtm foi verificado que para os teores mais baixos de unidade as atividades de pastagem e café são responsáveis pelos valores mais elevados de resistência a penetração (Figura 7.25). Já para teores mais altos de umidade ocorre uma inversão, passando a atividade de outras culturas a imprimir valores de resistência mais elevados.

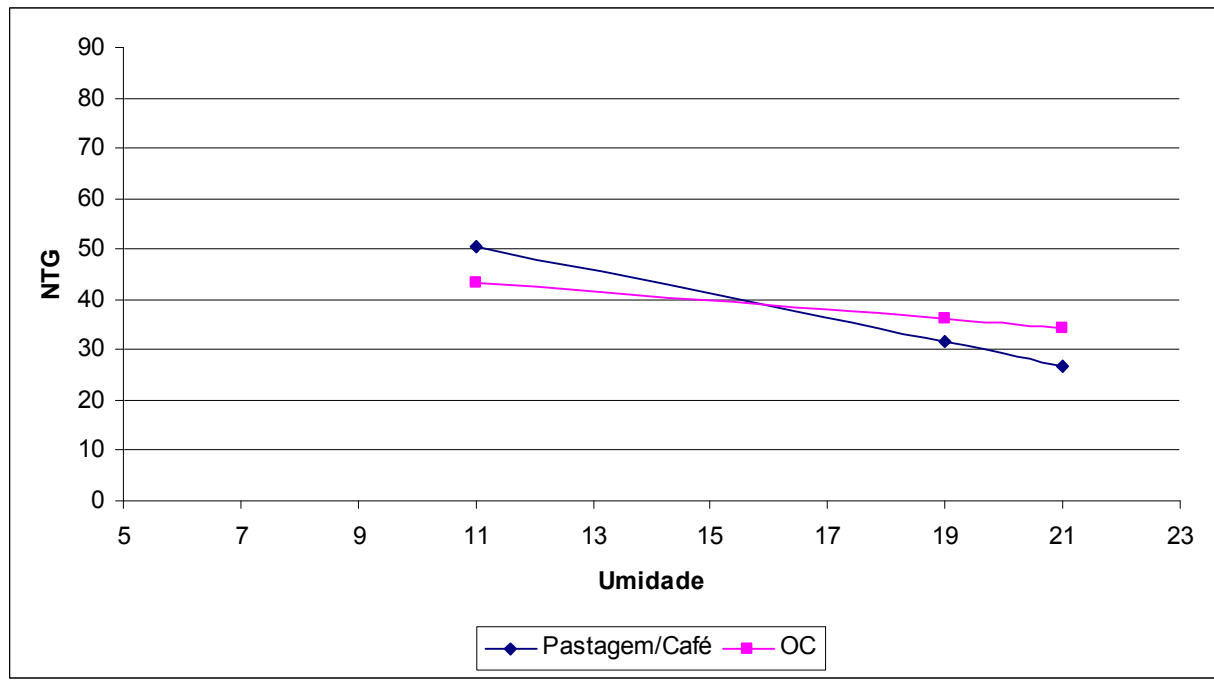

Figura 7.25 - Comportamento da resistência a penetração frente as práticas de pastagem, café e outras culturas nos materiais residuais de blastomilonitos (ReBtm). 
As análises realizadas mostram que as atividades de ocupação do terreno por cultivo de café e desenvolvimento de pastagens são responsáveis pelo comportamento de maiores resistências a penetração para três dos cinco materiais incosolidados analisados, o que permite caracterizá-las como as classes de uso responsáveis pelas maiores alterações no comportamento de resistência a penetração dos materiaiss da bacia.

Os valores mais altos de resistência a penetração encontrados nas práticas de cultivo de café e atividades de pastagem podem ser atribuídos ao fato das mesmas apresentarem baixa rotatividade com atuação de maquinário para aragem e revolvimento do solo em menor freqüência que nas práticas de outras culturas. 
CAPÍTULO 8

\section{8. - ZONEAMENTO GEOAMBIENTAL DA BACIA DO RIO DO PEIXE}

A execução de um zoneamento geoambiental visa caracterizar uma dada região quanto às suas aptidões e restrições frente a atividades em desenvolvimento e/ou prováveis de serem implantadas. Neste processo, as potencialidades e vulnerabilidades do meio quanto ao uso e ocupação são identificadas tomadas como base para análises e diagnósticos das condições do meio físico, de forma a resultar em um plano orientativo a preservação, conservação e desenvolvimento futuro da área. A orientação e a adequação de uso da área, é estabelecida a partir de unidades ambientais que consistem de porções cartográficas do terreno as quais retratam as condições de maior ou menor qualidade ambiental frente a uma determinada solicitação.

Para bacia do Rio do Peixe foram adotadas para estabelecimento do zoneamento as unidades cartográficas de landform - unidade de terreno (land unit), que caracterizam porções dotadas de uniformidade e significado com relação aos diferentes atributos do meio. Trabalhos anteriores, como os de Grecchi (1998), Lopes (2000); Amorim (2003), demonstraram que as unidades de landforms podem ser usadas como base para o zoneamento geoambiental.

Como resultado foi obtido o zoneamento da área em 42 unidades geoambientais, as quais constituem porções individualizadas que reportam os aspectos de potencialidade e susceptibilidade naturais do meio, condicionados pelos atributos presentes, os percentuais de restrições ao uso e ocupação estabelecidas por leis ambientais (Código Florestal - Lei $\mathrm{N}^{\circ}$ 4.771) e as atividades de uso do solo vigentes. 


\section{1 - UNIDADES GEOAMBIENTAIS}

\section{$\underline{\text { Unidade I }}$}

Corresponde a unidade de terreno A1. Apresenta baixo potencial ao escoamento, o qual corresponde a $60 \%$ da unidade e é caracterizado pelo valor médio dos pixels de 1,95, na superfície contínua furay. Em termos dos aspectos de susceptibilidade a erosão e potencial agrícola, apresenta 95\% e $78 \%$ de sua área compreendida na classe alta, respectivamente. A susceptibilidade a erosão exibe valores mínimos dos pixels enquadrados na classe média, e valores de distribuição média na classe alta. O potencial agrícola mostra valores médios de distribuição de 2,19 (Tabela 8.1).

A predominância de valores muito baixos de declividade e a textura muito arenosa do material inconsolidado que constitui esta unidade são os fatores condicionantes do médio potencial ao escoamento (Tabela 8.2). A textura do material e o médio potencial ao escoamento condicionam a alta susceptibilidade erosão. $\mathrm{O}$ alto potencial agrícola apresentado por esta unidade é devido a predominância dos valores de declividade, que caracterizam condições de favorabilidade ao desenvolvimento de atividade agrícolas.

Tabela 8.1 - Características de potencialidade e susceptibilidade do meio para unidade I

\begin{tabular}{|c|c|c|c|c|}
\hline \multicolumn{5}{|c|}{ Potencial ao Escoamento } \\
\hline Classe & Área $\left(\mathrm{Km}^{2}\right)$ & $\%$ área da unidade & \% área da bacia & $\begin{array}{c}\text { Parâmetros estatísticos/Mapas } \\
\text { Numéricos }\end{array}$ \\
\hline Baixa & 10,80 & 59,72 & 6,01 & Mín $-1,38$ \\
\hline Média & 7,14 & 39,48 & 1,10 & Máx -3, 19 \\
\hline Alta & 0,12 & 0,68 & 0,02 & Média $-1,95$ \\
\hline \multirow{2}{*}{ Muito Alta } & \multirow[b]{2}{*}{0,02} & \multirow[b]{2}{*}{0,09} & \multirow[b]{2}{*}{0,01} & Desv Padrão - 0,15 \\
\hline & & & & Moda $-2,01$ \\
\hline \multicolumn{5}{|c|}{ Susceptibilidade a Erosão } \\
\hline Classe & Área $\left(\mathrm{Km}^{2}\right)$ & $\%$ área da unidade & $\%$ área da bacia & $\begin{array}{c}\text { Parâmetros estatísticos/Mapas } \\
\text { Numéricos }\end{array}$ \\
\hline Baixa & 0,00 & 0,00 & 0,00 & Mín - 2,37 \\
\hline Média & 0,77 & 4,23 & 0,12 & Máx $-3,15$ \\
\hline Alta & 17,28 & 95,55 & 2,21 & Média -2,62 \\
\hline \multirow{2}{*}{ Muito Alta } & \multirow[b]{2}{*}{0,03} & \multirow[b]{2}{*}{0,16} & \multirow[b]{2}{*}{0,02} & Desvio Padrão - 0,06 \\
\hline & & & & Moda -2.64 \\
\hline \multicolumn{5}{|c|}{ Potencial Agrícola } \\
\hline Classe & Área $\left(\mathrm{Km}^{2}\right)$ & $\%$ área da unidade & $\%$ área da bacia & $\begin{array}{c}\text { Parâmetros estatísticos/Mapas } \\
\text { Numéricos }\end{array}$ \\
\hline Baixa & 0,59 & 3,26 & 0,14 & Mín $-1,40$ \\
\hline Média & 0,35 & 1,93 & 0,10 & Máx - 3,44 \\
\hline Alta & 14,11 & 78,05 & 5,43 & Média - 2,19 \\
\hline Muito Alta & 0,32 & 1,79 & 0,07 & Desv Padrão - 094 \\
\hline Restritiva & 2,68 & 14,79 & 1,67 & Moda - 2,61 \\
\hline
\end{tabular}


Apesar do alto potencial agrícola apresentado, as classes de uso do solo vigentes que exibem maior percentual de ocorrência são atividade de pastagem, classe de mata nativa e cidades. Atividades correspondentes ao uso voltado ao desenvolvimento agrícola, cultivo de café e outras culturas, têm percentual de ocorrência inferior ao apresentados pela classe de mata nativa (Figura 8.1). Aproximadamente 15\% da unidade constituem regiões com restrições a ocupação. Correspondem a faixas de preservação permanente ao longo do curso do Rio do Peixe.

Tabela 8.2- Atributos do meio físico da unidade I

\begin{tabular}{|c|c|c|c|}
\hline Declividade \% & Área $\left(\mathrm{Km}^{2}\right)$ & $\begin{array}{l}\% \text { área da } \\
\text { unidade }\end{array}$ & $\%$ área da bacia \\
\hline$<2$ & 16,33 & 90,30 & 6,21 \\
\hline $2-10$ & 0,79 & 4,38 & 0,28 \\
\hline $10-20$ & 0,75 & 4,16 & 0,14 \\
\hline $20-30$ & 0,14 & 0,79 & 0,04 \\
\hline $30-45$ & 0,06 & 0,35 & 0,03 \\
\hline$>45$ & 0,00 & 0,02 & 0,01 \\
\hline Geologia & Área $\left(\mathrm{Km}^{2}\right)$ & $\begin{array}{l}\% \text { área da } \\
\text { unidade }\end{array}$ & \% área da bacia \\
\hline Granito Cataclasado & 3,37 & 18,63 & 2,41 \\
\hline Gn Quartzitos & 5,73 & 31,69 & 1,31 \\
\hline Gn Básicas & 8,30 & 45,90 & 18,06 \\
\hline Qartzitos & 0,54 & 3,00 & 0,13 \\
\hline Migmatitos & 0,14 & 0,77 & 0,14 \\
\hline Materiais Inco & Área $\left(\mathrm{Km}^{2}\right)$ & $\begin{array}{c}\% \text { área da } \\
\text { unidade }\end{array}$ & \% área da bacia \\
\hline Aluvião & 18,08 & 100,00 & 139,47 \\
\hline Classes Uso do Solo & Área $\left(\mathrm{Km}^{2}\right)$ & $\begin{array}{c}\% \text { área da } \\
\text { unidade }\end{array}$ & \% área da bacia \\
\hline Área Várzea & 2,04 & 11,26 & 37,51 \\
\hline Café & 1,80 & 9,98 & 1,68 \\
\hline Cidades & 2,06 & 11,37 & 6,51 \\
\hline Corpos d’água & 0,14 & 0,79 & 3,38 \\
\hline Mata Nativa & 3,06 & 16,93 & 0,85 \\
\hline Outras Culturas & 1,05 & 5,81 & 1,42 \\
\hline Cana-de-açúcar & 1,59 & 8,79 & 2,70 \\
\hline Pastagem & 6,34 & 35,07 & 0,64 \\
\hline
\end{tabular}




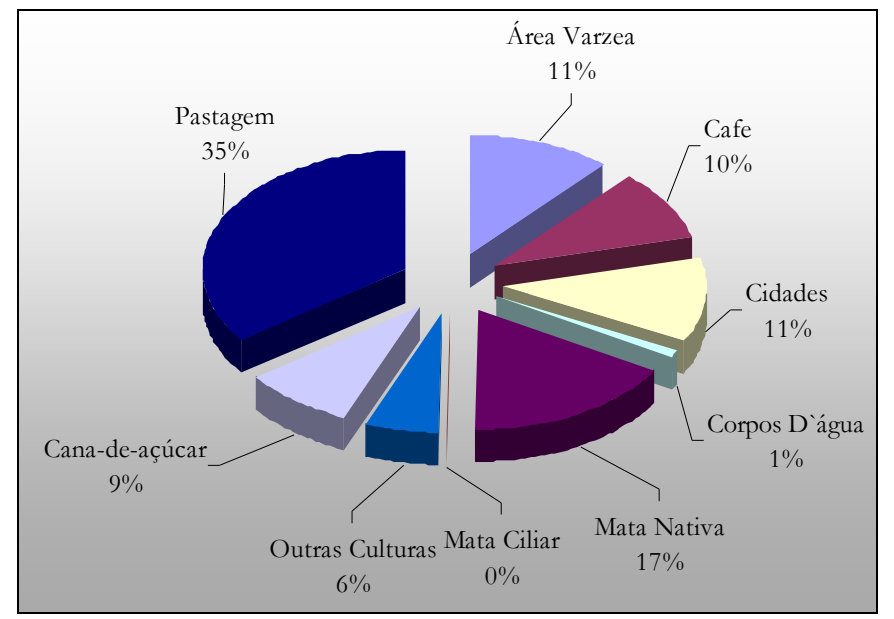

Figura 8.1 - Percentual de ocorrência das classes de uso e ocupação na Unidade Geoambiental I.

\section{$\underline{\text { Unidade II }}$}

Corresponde a unidade de terreno A2, e caracteriza-se por apresentar 54\% de sua área com médio potencial ao escoamento e 34\% com potencial alto. Os pixels da superfície fuzay exibem valores médio de 2,45 , o que confirma a predominância de médio potencial. Com relação a susceptibilidade a erosão, $58 \%$ da área é enquadrada na classe alta e os valores médios superfície contínua são de 2,92. O potencial agrícola varia entre baixo e alto, com predomínio de $48 \%$ da área correspondendo a classe baixa, e $23 \%$ a classe alta. Os valores médios de distribuição da superfície contínua são de 2,0. (Tabela 8.3).

A condição de potencial ao escoamento médio a alto é condicionada pela predominância das classes de declividade medianamente moderada a moderada. A alta susceptibilidade a erosão é favorecida pelas condições de elevado potencial ao escoamento e pelas características dos materiais inconsolidados, residuais de quartzitos impuros, que corresponde a quase totalidade da unidade (Tabela 8.4). Estes apresentam textura arenosa e espessuras não superiores a três metros, características altamente favoráveis ao condicionamento de elevada susceptibilidade a erosão.

As características de declividade moderadas a alta, e a predominância de alta susceptibilidade a erosão vem a caracterizar fator preponderante para ocorrência de classes do baixo potencial agrícola. 
Tabela 8.3 - Características de potencialidade e susceptibilidade do meio para unidade II.

\begin{tabular}{|c|c|c|c|c|}
\hline \multicolumn{5}{|c|}{ Potencial ao Escoamento } \\
\hline Classe & Área $\left(\mathrm{Km}^{2}\right)$ & $\begin{array}{l}\% \text { área da } \\
\text { unidade }\end{array}$ & \% área da bacia & Parâmetros estatísticos/Mapas Numéricos \\
\hline Baixa & 0,79 & 5,31 & 0,44 & Mín - 1,63 \\
\hline Média & 8,00 & 54,00 & 1,23 & Máx $-3,5$ \\
\hline Alta & 5,10 & 34,43 & 0,77 & Média - 2,45 \\
\hline \multirow{2}{*}{ Muito Alta } & \multirow[b]{2}{*}{0,93} & \multirow[b]{2}{*}{6,25} & \multirow[b]{2}{*}{0,49} & Desv Padrão - 0,32 \\
\hline & & & & Moda $-2,22$ \\
\hline \multicolumn{5}{|c|}{ Susceptibilidade a Erosão } \\
\hline Classe & Área $\left(\mathrm{Km}^{2}\right)$ & $\begin{array}{c}\% \text { área da } \\
\text { unidade }\end{array}$ & $\%$ área da bacia & Parâmetros estatísticos/Mapas Numéricos \\
\hline Baixa & 0,55 & 3,7 & 0,47 & Mín - 1,55 \\
\hline Média & 0,02 & 0,14 & 0,00 & Máx - 3,94 \\
\hline Alta & 8,58 & 57,86 & 1,10 & Média - 2,92 \\
\hline \multirow{2}{*}{ Muito Alta } & \multirow[b]{2}{*}{5,67} & \multirow[b]{2}{*}{38,25} & \multirow[b]{2}{*}{4,03} & Desv Padrão - 0,27 \\
\hline & & & & Moda $-2,90$ \\
\hline \multicolumn{5}{|c|}{ Potencial Agrícola } \\
\hline Classe & Área $\left(\mathrm{Km}^{2}\right)$ & $\begin{array}{|ll|}\% \text { área } & \text { da } \\
\text { unidade } & \\
\end{array}$ & \% área da bacia & Parâmetros estatísticos/Mapas Numéricos \\
\hline Baixa & 7,15 & 48,25 & 1,65 & Mín - 1,31 \\
\hline Média & 2,24 & 15,11 & 0,64 & Máx - 3,38 \\
\hline Alta & 3,46 & 23,36 & 1,33 & Média $-2,0$ \\
\hline Muito Alta & 0,43 & 2,88 & 0,09 & Desv Padrão - 0,59 \\
\hline Restritiva & 1,17 & 7,92 & 0,73 & Moda $-2,73$ \\
\hline
\end{tabular}

Tabela 8.4- Atributos do meio físico da unidade II.

\begin{tabular}{|c|c|c|c|}
\hline Declividade \% & Área $\left(\mathrm{Km}^{2}\right)$ & $\begin{array}{c}\% \text { área da } \\
\text { unidade }\end{array}$ & $\%$ área da bacia \\
\hline$<2$ & 1,52 & 10,24 & 0,58 \\
\hline $2-10$ & 2,60 & 17,57 & 0,94 \\
\hline $10-20$ & 5,38 & 36,27 & 1,03 \\
\hline $20-30$ & 3,27 & 22,04 & 0,94 \\
\hline $30-45$ & 1,75 & 11,83 & 0,82 \\
\hline$>45$ & 0,31 & 2,07 & 0,59 \\
\hline Geologia & Área $\left(\mathrm{Km}^{2}\right)$ & $\begin{array}{l}\% \text { área da } \\
\text { unidade }\end{array}$ & $\%$ área da bacia \\
\hline Gn Quartzitos & 0,0774 & 0,52 & 0,06 \\
\hline Qtz & 14,74 & 99,48 & 3,43 \\
\hline Materiais Inco & Área $\left(\mathrm{Km}^{2}\right)$ & $\begin{array}{l}\% \text { área da } \\
\text { unidade }\end{array}$ & $\%$ área da bacia \\
\hline Retrab 1 & 0,56 & 3,78 & 1,12 \\
\hline Qtz1 & 14,26 & 96,22 & 82,15 \\
\hline Classes Uso do Solo & Área $\left(\mathrm{Km}^{2}\right)$ & $\begin{array}{l}\% \text { área da } \\
\text { unidade }\end{array}$ & $\%$ área da bacia \\
\hline Cafe & 1,58 & 10,66 & 1,47 \\
\hline Cidades & 0,47 & 3,14 & 1,47 \\
\hline Corpos D água & 0,02 & 0,10 & 0,36 \\
\hline Mata Nativa & 3,22 & 21,73 & 0,90 \\
\hline Outras Culturas & 0,70 & 4,74 & 0,95 \\
\hline Pastagem & 8,84 & 59,64 & 0,89 \\
\hline
\end{tabular}


As principais classes de uso do solo presentes correspondem a atividade de pastagem, presente em mais de 50\% da área, e mata nativa que ocupa $22 \%$ da unidade (Figura 8.2). Os baixos percentuais de ocorrência das atividades de cultivo de café e outras culturas, se adequam as condições naturais do meio que pouco favorecem ao desenvolvimento de atividades agrícolas.

Áreas com restrições a ocupação compreendem apenas $7 \%$ da unidade e correspondem, principalmente, às faixas de preservação junto aos cursos de drenagem.

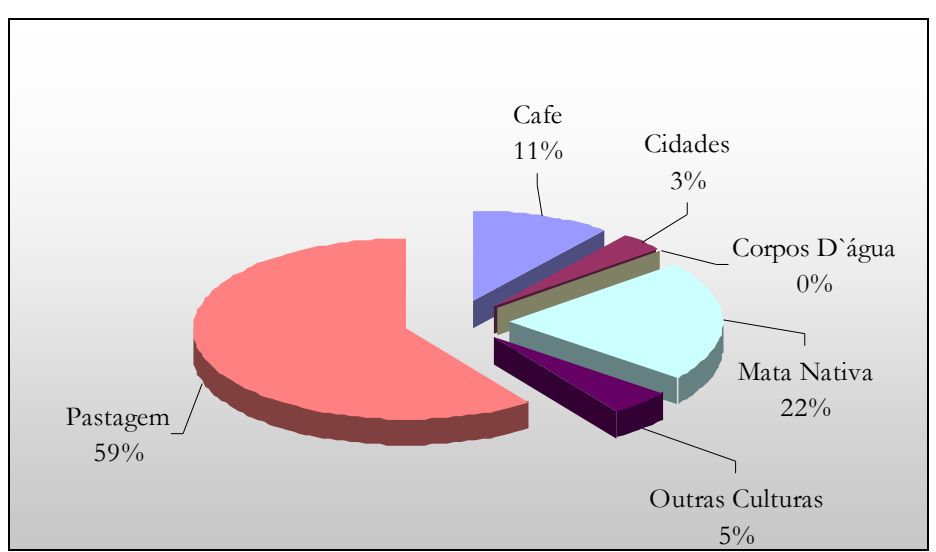

Figura 8.2 - Percentual de ocorrência das classes de uso e ocupação na Unidade Geoambiental II.

\section{Unidade III}

Corresponde a unidade de terreno A3 e caracteriza-se por apresentar $66 \%$ da área com médio potencial ao escoamento e pixels com valor médio de 2,29. Em termos do aspecto de susceptibilidade a erosão $51 \%$ da área corresponde a classe alta e 48\% caracterizam classes de susceptibilidade média a baixa. O valor médio dos pixels da superfície contínua é de 2,31. Caracteriza-se por exibir $80 \%$ da área com elevado potencial agrícola, predominando a classe muito alta, a qual corresponde a $62 \%$ da unidade. O valor médio de distribuição dos pixels na superfície contínua é de 3,95 (Tabela 8.4).

Áreas com restrições a ocupação apresentam baixo percentual de ocorrência, 7\% da unidade, e são restritas a faixas de preservação junto aos cursos de drenagem. 
Tabela 8.5 - Características de potencialidade e susceptibilidade do meio para unidade III.

\begin{tabular}{|c|c|c|c|c|}
\hline \multicolumn{5}{|c|}{ Potencial ao Escoamento } \\
\hline Classe & Área $\left(\mathrm{Km}^{2}\right)$ & $\begin{array}{l}\% \text { área } \mathrm{da} \\
\text { unidade }\end{array}$ & $\begin{array}{c}\% \text { área da } \\
\text { bacia }\end{array}$ & $\begin{array}{c}\text { Parâmetros estatísticos/Mapas } \\
\text { Numéricos }\end{array}$ \\
\hline Baixa & 3,8 & 14,01 & 2,14 & Mín $-1,18$ \\
\hline Média & 18,1 & 66,08 & 2,79 & Máx - 3,39 \\
\hline Alta & 5,36 & 19,53 & 8,12 & Média $-2,29$ \\
\hline \multirow{2}{*}{ Muito Alta } & \multirow[b]{2}{*}{0,1} & \multirow[b]{2}{*}{0,39} & \multirow[b]{2}{*}{0,06} & Desv Padrão - 0,26 \\
\hline & & & & Moda $-2,37$ \\
\hline \multicolumn{5}{|c|}{ Susceptibilidade a Erosão } \\
\hline Classe & Área $\left(\mathrm{Km}^{2}\right)$ & $\begin{array}{l}\text { \% área da } \\
\text { unidade }\end{array}$ & $\begin{array}{c}\% \text { área da } \\
\text { bacia }\end{array}$ & $\begin{array}{c}\text { Parâmetros estatísticos/Mapas } \\
\text { Numéricos }\end{array}$ \\
\hline Baixa & 7,4 & 27,03 & 6,41 & Mín - 1,27 \\
\hline Média & 5,8 & 21,03 & 0,90 & Máx - 3,55 \\
\hline Alta & 14,3 & 51,92 & 1,82 & Média $-2,31$ \\
\hline \multirow{2}{*}{ Muito Alta } & \multirow[b]{2}{*}{0,0} & \multirow[b]{2}{*}{0,02} & \multirow[b]{2}{*}{0,00} & Desv Padrão - 0,39 \\
\hline & & & & Moda $-2,56$ \\
\hline \multicolumn{5}{|c|}{ Potencial Agrícola } \\
\hline Classe & Área $\left(\mathrm{Km}^{2}\right)$ & $\begin{array}{l}\% \text { área da } \\
\text { unidade }\end{array}$ & $\begin{array}{c}\% \text { área da } \\
\text { bacia }\end{array}$ & $\begin{array}{c}\text { Parâmetros estatísticos/Mapas } \\
\text { Numéricos }\end{array}$ \\
\hline Baixa & 0,3 & 0,94 & 0,06 & Mín - 1,84 \\
\hline Média & 3,1 & 11,20 & 0,88 & Máx $-3,71$ \\
\hline Alta & 4,9 & 17,92 & 1,89 & Média - 3,095 \\
\hline Muito Alta & 17,1 & 62,35 & 3,63 & Desv Padrão - 0,43 \\
\hline Restriviva & 2,1 & 7,64 & 1,31 & Moda $-3,47$ \\
\hline
\end{tabular}

A ocorrência de valores percentuais de declividade menores que 20\% (Tabela 8.6) juntamente com as características das matérias inconsolidados presentes, residuais de textura intermediária e retrabalhados de textura arenosa, condicionam a predominância de médio potencial ao escoamento superficial. A ocorrência da classe de alta susceptibilidade a erosão em $50 \%$ da unidade é condicionada pela textura intermediária dos materiais residuais presentes. Esta característica, juntamente com a predominância de declividades inferiores a $20 \%$ constituem fator preponderante a ocorrência do elevado potencial agrícola.

As atividades de pastagem, cultivo de café e cana-de-açúcar, constituem as principais classes de uso dos solos presente, com a primeira correspondendo $33 \%$ da área (Figura 8.3). As classes de café, cana-de-açúcar e outras culturas compreendem 46\% da unidade, o que caracteriza uma condição de adequado aproveitamento do elevado potencial natural ao desenvolvimento agrícola apresentado. 
Tabela 8.6- Atributos do meio físico da unidade III

\begin{tabular}{|c|c|c|c|}
\hline Declividade \% & Área $\left(\mathrm{Km}^{2}\right)$ & $\begin{array}{l}\text { \% área da } \\
\text { unidade }\end{array}$ & $\%$ área da bacia \\
\hline$<2$ & 7,99 & 29,11 & 3,04 \\
\hline $2-10$ & 8,45 & 30,78 & 3,04 \\
\hline $10-20$ & 9,60 & 34,98 & 1,84 \\
\hline $20-30$ & 1,20 & 4,37 & 0,34 \\
\hline $30-45$ & 0,14 & 0,49 & 0,06 \\
\hline$>45$ & 0,00 & 0,00 & 0,00 \\
\hline Geologia & Área $\left(\mathrm{Km}^{2}\right)$ & $\begin{array}{l}\% \text { área da } \\
\text { unidade }\end{array}$ & \% área da bacia \\
\hline Granito Cataclasado & 2,1231 & 7,73 & 1,52 \\
\hline Gn Quartzitos & 25,34 & 92,27 & 5,78 \\
\hline Materiais Inco & Área $\left(\mathrm{Km}^{2}\right)$ & $\begin{array}{c}\% \text { área da } \\
\text { unidade }\end{array}$ & \% área da bacia \\
\hline Retrab 1 & 6,84 & 24,90 & 13,73 \\
\hline Gnq1 & 20,62 & 75,10 & 100,00 \\
\hline Classes Uso do Solo & Área $\left(\mathrm{Km}^{2}\right)$ & $\begin{array}{c}\% \text { área da } \\
\text { unidade }\end{array}$ & \% área da bacia \\
\hline Cafe & 5,87 & 21,37 & 5,48 \\
\hline Cidades & 2,23 & 8,13 & 7,06 \\
\hline Corpos D água & 0,03 & 0,10 & 0,68 \\
\hline Mata Nativa & 2,12 & 7,72 & 0,59 \\
\hline Pastagem & 8,95 & 32,59 & 0,91 \\
\hline Outras Culturas & 1,81 & 6,59 & 2,45 \\
\hline Cana-de-açúcar & 5,26 & 19,15 & 8,95 \\
\hline
\end{tabular}

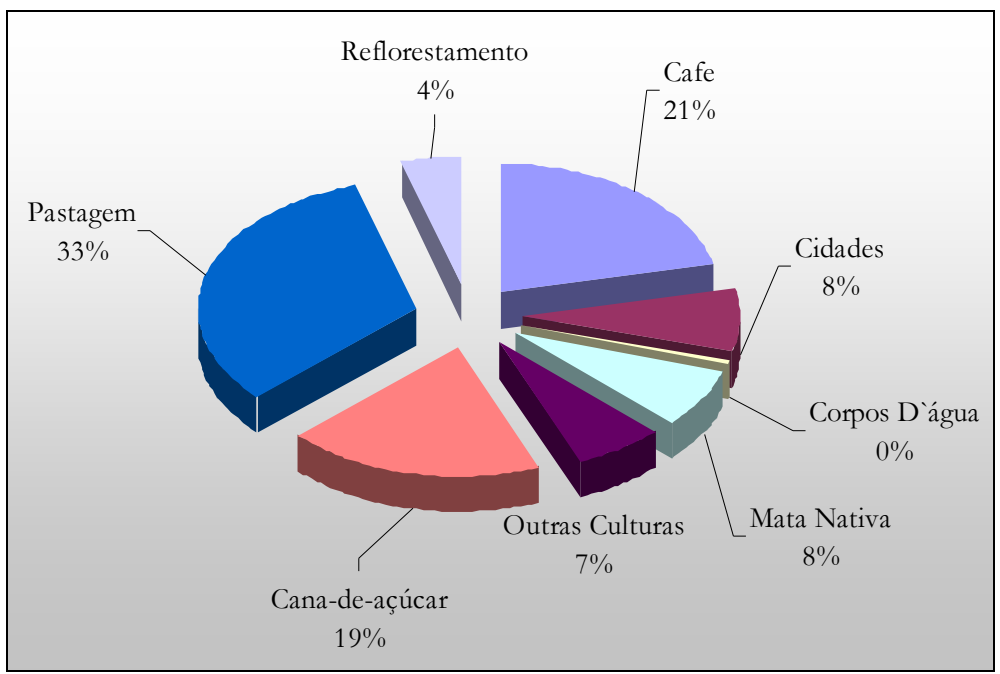

Figura 8.3 - Percentual de ocorrência das classes de uso e ocupação na Unidade Geoambiental III. 


\section{$\underline{\text { Unidade IV }}$}

Corresponde a unidade de terreno A4. Apresenta 85\% de sua área com médio potencial ao escoamento, e valor médio dos pixels de 2,22. Com relação ao aspecto de susceptibilidade a erosão, $42 \%$ da área compreende a classe média e $47 \%$ a classe alta $\mathrm{O}$ valor médio dos pixels é de 2,41. Exibe elevado potencial ao desenvolvimento agrícola, com $63 \%$ da área representada pela faixa de potencial muito alto. A superfície contínua representativa deste aspecto apresenta valor médio para a unidade de 3,05 (Tabela 8.7).

Nesta unidade, regiões com restrições legais a ocupação do meio correspondem a apenas 5\% da mesma, e são restritas a faixas de preservação junto aos cursos de drenagem.

Tabela 8.7 - Características de potencialidade e susceptibilidade do meio para unidade IV.

\begin{tabular}{|c|c|c|c|c|}
\hline \multicolumn{5}{|c|}{ Potencial ao Escoamento } \\
\hline Classe & Área $\left(\mathrm{Km}^{2}\right)$ & $\%$ área da unidade & $\begin{array}{l}\% \text { área } \mathrm{da} \\
\text { bacia }\end{array}$ & $\begin{array}{c}\text { Parâmetros estatísticos/Mapas } \\
\text { Numéricos }\end{array}$ \\
\hline Baixa & 0,16 & 0,80 & 0,09 & Mín - 1,18 \\
\hline Média & 16,93 & 85,28 & 2,61 & Máx - 3,39 \\
\hline Alta & 2,72 & 13,70 & 0,41 & Média - 2,22 \\
\hline \multirow{2}{*}{ Muito Alta } & \multirow[b]{2}{*}{0,01} & \multirow[b]{2}{*}{0,07} & \multirow[b]{2}{*}{0,01} & Desv Padrão - 0,27 \\
\hline & & & & Moda $-1,78$ \\
\hline
\end{tabular}

\begin{tabular}{|c|c|c|c|c|}
\hline \multicolumn{5}{|c|}{ Susceptibilidade a Erosão } \\
\hline Classe & Área $\left(\mathrm{Km}^{2}\right)$ & \% área da unidade & $\begin{array}{l}\% \text { área da } \\
\text { bacia }\end{array}$ & $\begin{array}{c}\text { Parâmetros estatísticos/Mapas } \\
\text { Numéricos }\end{array}$ \\
\hline Baixa & 1,91 & 9,62 & 1,65 & Mín - 1,27 \\
\hline Média & 8,47 & 42,67 & 1,33 & Máx $-3,23$ \\
\hline Alta & 9,47 & 47,70 & 1,21 & Média $-2,41$ \\
\hline \multirow{2}{*}{ Muito Alta } & \multirow[b]{2}{*}{0,00} & \multirow[b]{2}{*}{0,02} & \multirow[b]{2}{*}{0,00} & Desv Padrão - 0,26 \\
\hline & & & & Moda $-2,31$ \\
\hline \multicolumn{5}{|c|}{ Potencial Agrícola } \\
\hline Classe & Área $\left(\mathrm{Km}^{2}\right)$ & $\%$ área da unidade & $\begin{array}{l}\% \text { área da } \\
\text { bacia }\end{array}$ & $\begin{array}{c}\text { Parâmetros estatísticos/Mapas } \\
\text { Numéricos }\end{array}$ \\
\hline Baixa & 0,78 & 3,94 & 0,18 & Mín $-1,80$ \\
\hline Média & 1,78 & 8,98 & 0,51 & Máx - 3,66 \\
\hline Alta & 3,59 & 18,11 & 1,38 & Média $-3,05$ \\
\hline Muito Alta & 12,57 & 63,30 & 2,66 & Desv Padrão - 0,4 \\
\hline Restritiva & 1,10 & 5,52 & 0,69 & Moda $-3,35$ \\
\hline
\end{tabular}

As características apresentadas pelo meio, predominância de declividades inferiores a $20 \%$, materiais inconsolidados residuais de textura intermediária e $42 \%$ da área com média susceptibilidade a erosão constituem fatores que atuam favoravelmente a situação de elevado potencial agrícola. 
A atividade de cultivo de cana-de-açúcar caracteriza a classe de ocupação do solo com maior percentual de ocorrência em área na unidade (Tabela 8.8, Figura 8.4). De forma secundária destacam-se a classe de mata nativa e a ocupação por cidades.

Tabela 8.8- Atributos do meio físico da unidade IV.

\begin{tabular}{|c|c|c|c|}
\hline Declividade \% & Área $\left(\mathrm{Km}^{2}\right)$ & \% área da unidade & $\%$ área da bacia \\
\hline$<2$ & 6,64 & 33,47 & 2,53 \\
\hline $2-10$ & 6,12 & 30,84 & 2,20 \\
\hline $10-20$ & 6,33 & 31,88 & 1,21 \\
\hline $20-30$ & 0,65 & 3,29 & 0,19 \\
\hline $30-45$ & 0,07 & 0,34 & 0,03 \\
\hline$>45$ & 0,02 & 0,09 & 0,03 \\
\hline Geologia & Área $\left(\mathrm{Km}^{2}\right)$ & $\%$ área da unidade & $\%$ área da bacia \\
\hline Gn Quartzitos & 19,7487 & 99,48 & 4,50 \\
\hline Gn Básicas & 0,10 & 0,52 & 0,23 \\
\hline Materiais Inco & Área $\left(\mathrm{Km}^{2}\right)$ & $\%$ área da unidade & $\%$ área da bacia \\
\hline Retrab 1 & 1,7541 & 8,84 & 3,52 \\
\hline Gnq 2 & 18,10 & 91,16 & 133,93 \\
\hline Classes Uso do Solo & Área $\left(\mathrm{Km}^{2}\right)$ & $\%$ área da unidade & $\%$ área da bacia \\
\hline Cafe & 0,77 & 3,86 & 0,71 \\
\hline Cidades & 1,97 & 9,93 & 6,24 \\
\hline Corpos D água & 0,09 & 0,44 & 2,04 \\
\hline Mata Nativa & 2,18 & 10,98 & 0,61 \\
\hline Outras Culturas & 0,38 & 1,92 & 0,52 \\
\hline Cana-de-açúcar & 13,32 & 67,07 & 22,66 \\
\hline
\end{tabular}

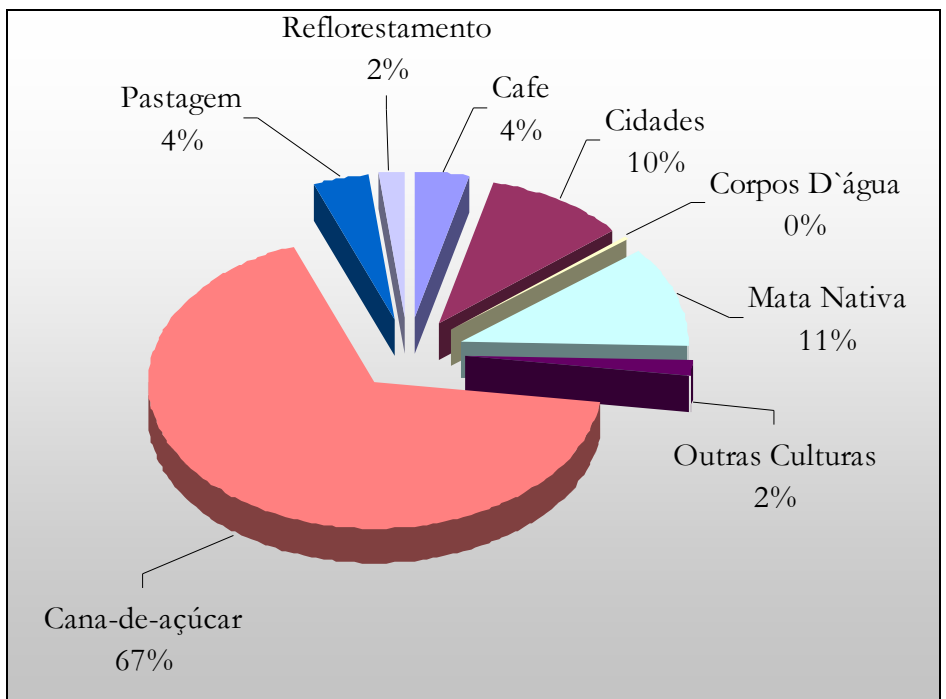

Figura 8.4 - Percentual de ocorrência das classes de uso e ocupação na Unidade Geoambiental IV. 
Juntas, as atividades de cultivo de cana-de-açúcar, café e outras culturas ocupam $73 \%$ da unidade, se adequando a condição natural de elevado potencial agrícola apresentada pelo meio físico.

\section{Unidade $V$}

Corresponde a unidade de terreno A5. Esta unidade geoambiental apresenta condições naturais de médio potencial ao escoamento superficial, com 58\% da sua área representada pela classe média. O valor médio dos pixels da superfície contínua fuzzy é 2,28. A susceptibilidade a erosão é caracterizada pela ocorrência de $42 \%$ da unidade com valores médios e 41\% baixos. A distribuição dos pixels em superfície contínua exibe valor médio de 2,11. As condições de potencial agrícola são predominantemente elevadas, $75 \%$ da área exibe potencial ao desenvolvimento agrícola entre alto e muito alto. Os valores médios de distribuição dos pixels em superfície contínua confirmam a predominância da classe alta (Tabela 8.9)

Regiões com restrições legais a ocupação do meio correspondem a apenas $5 \%$ da unidade, e são restritas a faixas de preservação junto aos cursos de drenagem.

Tabela 8.9 - Características de potencialidade e susceptibilidade do meio para unidade V.

\begin{tabular}{|c|c|c|c|c|}
\hline \multicolumn{5}{|c|}{ Potencial ao Escoamento } \\
\hline Classe & Área $\left(\mathrm{Km}^{2}\right)$ & $\%$ área da unidade & $\%$ área da bacia & $\begin{array}{c}\text { Parâmetros estatísticos/Mapas } \\
\text { Numéricos }\end{array}$ \\
\hline Baixa & 17,85 & 19,43 & 9,93 & Mín $-0,70$ \\
\hline Média & 53,56 & 58,30 & 8,25 & Máx $-3,27$ \\
\hline Alta & 19,21 & 20,90 & 2,91 & Média $-2,28$ \\
\hline \multirow{2}{*}{ Muito Alta } & \multirow{2}{*}{\multicolumn{2}{|c|}{1,37}} & \multirow[b]{2}{*}{0,67} & Desv Padrão - 0,29 \\
\hline & & & & Moda $-1,89$ \\
\hline \multicolumn{5}{|c|}{ Susceptibilidade a Erosão } \\
\hline$\overline{\text { Classe }}$ & Área $\left(\mathrm{Km}^{2}\right)$ & $\%$ área da unidade & $\%$ área da bacia & $\begin{array}{c}\text { Parâmetros estatísticos/Mapas } \\
\text { Numéricos Parâmetros estatísticos }\end{array}$ \\
\hline Baixa & 37,78 & 41,12 & 32,63 & Mín $-0,30$ \\
\hline Média & 38,97 & 42,42 & 6,10 & Máx - 4,27 \\
\hline Alta & 14,32 & 15,59 & 1,83 & Média - 2,11 \\
\hline \multirow{2}{*}{ Muito Alta } & \multirow{2}{*}{\multicolumn{2}{|c|}{0,87}} & \multirow[b]{2}{*}{0,57} & Desv Padrão - 0,40 \\
\hline & & & & Moda $-2,12$ \\
\hline \multicolumn{5}{|c|}{ Potencial Agrícola } \\
\hline Classe & Área $\left(\mathrm{Km}^{2}\right)$ & $\%$ área da unidade & \% área da bacia & $\begin{array}{c}\text { Parâmetros estatísticos/Mapas } \\
\text { Numéricos }\end{array}$ \\
\hline Baixa & 7,51 & 8,18 & 1,73 & Mín - 1,32 \\
\hline Média & 9,99 & 10,87 & 2,86 & Máx - 3,58 \\
\hline Alta & 15,36 & 16,71 & 5,91 & Média - 2,94 \\
\hline Muito Alta & 53,77 & 58,52 & 11,39 & Desv Padrão - 0,48 \\
\hline Restritiva & 5,26 & 5,72 & 3,29 & Moda $-3,32$ \\
\hline
\end{tabular}


A situação de médio potencial ao escoamento é condicionada, principalmente, pela predominância de declividade com valores inferiores a 20\% (Tabela 8.10), pela baixa densidade de drenagem, e pela ocorrência em área de apenas $41 \%$ de materiais inconsolidados com características de gênese e textura, retrabalhados argilosos, que influencia favoravelmente a esta condição.

A condição de média a baixa susceptibilidade a erosão é favorecida pelo médio potencial ao escoamento, e pela característica de textura arenosa dos materiais residuais de gnaisses intercalados a rochas básicas presentes em $42 \%$ da unidade.

O elevado potencial agrícola é condicionado de forma preponderante pelas características de baixos valores de declividade, textura dos materiais retrabalhados e capacidade de troca catiônica deste e dos residuais de gnaisses.

Tabela 8.10- Atributos do meio físico da unidade V.

\begin{tabular}{|c|c|c|c|}
\hline Declividade $\%$ & Área $\left(\mathrm{Km}^{2}\right)$ & $\%$ área da unidade & $\%$ área da bacia \\
\hline$<2$ & 30,58 & 33,29 & 11,64 \\
\hline $2-10$ & 25,33 & 27,57 & 9,11 \\
\hline $10-20$ & 28,15 & 30,64 & 5,39 \\
\hline $20-30$ & 5,50 & 5,99 & 1,58 \\
\hline $30-45$ & 1,93 & 2,10 & 0,90 \\
\hline$>45$ & 0,37 & 0,41 & 0,72 \\
\hline Geologia & Área $\left(\mathrm{Km}^{2}\right)$ & $\%$ área da unidade & $\%$ área da bacia \\
\hline Gn Quartzitos & 29,21 & 31,79 & 6,66 \\
\hline Gn Básicas & 60,05 & 65,36 & 130,67 \\
\hline Qartzitos & 2,62 & 2,85 & 0,61 \\
\hline Materiais Inco & Área $\left(\mathrm{Km}^{2}\right)$ & $\%$ área da unidade & $\%$ área da bacia \\
\hline Retrab 1 & 38,00 & 41,36 & 76,31 \\
\hline Gnq 3 & 3,73 & 4,06 & 8,73 \\
\hline Gnq 4 & 9,96 & 10,84 & 67,99 \\
\hline Gnb 1 & 38,75 & 42,18 & 48,19 \\
\hline Qtz1 & 1,43 & 1,56 & 8,25 \\
\hline Classes Uso do Solo & Área $\left(\mathrm{Km}^{2}\right)$ & $\%$ área da unidade & $\%$ área da bacia \\
\hline Área Varzea & 0,71 & 0,77 & 13,09 \\
\hline Cafe & 16,10 & 17,53 & 15,03 \\
\hline Cidades & 6,44 & 7,01 & 20,37 \\
\hline Corpos D`água & 0,44 & 0,48 & 10,47 \\
\hline Mata Nativa & 28,29 & 30,79 & 7,88 \\
\hline Outras Culturas & 5,01 & 5,45 & 6,77 \\
\hline Cana-de-açúcar & 4,88 & 5,31 & 8,31 \\
\hline Pastagem & 29,64 & 32,26 & 3,00 \\
\hline Solo Exposto & 0,37 & 0,40 & 4,59 \\
\hline
\end{tabular}


As classes de ocupação do solo por pastagem e mata nativa apresentam os maiores percentuais de ocorrência em área, 33\% e 31\% respectivamente (Figura 8.5). Atividades voltadas ao desenvolvimento agrícola ocupam apenas $28 \%$ da unidade, com destaque para o cultivo de café. Esta situação caracteriza um aproveitamento inadequado das condições naturais de alto potencial agrícola apresentada pelo meio físico.

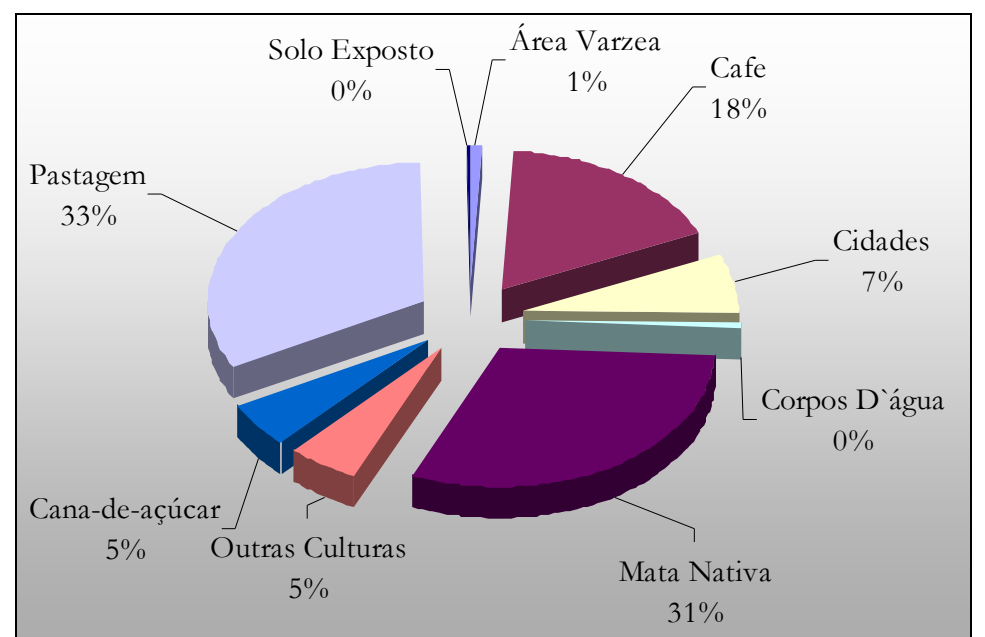

Figura 8.5 - Percentual de ocorrência das classes de uso e ocupação na Unidade Geoambiental V.

\section{$\underline{\text { Unidade VI }}$}

Corresponde a unidade de terreno A6. Apresenta condição de potencial ao escoamento médio a alto, com $41 \%$ da área correspondendo a primeira classe e $43 \%$ a segunda. Os valores médios dos pixels na superfície contínua são de 2,5. A susceptibilidade a erosão caracteriza-se pela predominância da classe média a qual corresponde a $65 \%$ da área. Os valores médios de distribuição dos pixels são de 2,44. O potencial agrícola é caracterizado pela ocorrência de 30\% da área representada pela classe muito alta e 31\% pela classe baixa. O valor médio dos pixels em superfície contínua é de 2,44 (Tabela 8.11).

Áreas com restrições a ocupação correspondem a 6\% da unidade, e constituem áreas com declividade superiores a $25^{\circ}$.

A condição de potencial ao escoamento médio a alto é favorecida pela ocorrência de 38\% em área de declividades medianamente moderadas a muito altas, e 
pela alta influência das características de textura intermediária e gênese residual dos materiais inconsolidados presentes (Tabela 8.12).

Tabela 8.11 - Características de potencialidade e susceptibilidade do meio para unidade VI.

\begin{tabular}{|c|c|c|c|c|}
\hline \multicolumn{5}{|c|}{ Potencial ao Escoamento } \\
\hline Classe & Área $\left(\mathrm{Km}^{2}\right)$ & $\%$ área da unidade & $\%$ área da bacia & $\begin{array}{l}\text { Parâmetros estatísticos/Mapas } \\
\text { Numéricos }\end{array}$ \\
\hline Baixa & 1,04 & 7,00 & 0,58 & Mín - 1,24 \\
\hline Média & 6,07 & 40,87 & 0,93 & Máx $-3,24$ \\
\hline Alta & 6,48 & 43,67 & 0,98 & Média $-2,5$ \\
\hline \multirow{2}{*}{ Muito Alta } & \multirow{2}{*}{\multicolumn{2}{|c|}{7,14}} & \multirow[b]{2}{*}{0,56} & Desv Padrã $-0,320$ \\
\hline & & & & Moda $-2,5$ \\
\hline \multicolumn{5}{|c|}{ Susceptibilidade a Erosão } \\
\hline Classe & Área $\left(\mathrm{Km}^{2}\right)$ & $\%$ área da unidade & $\%$ área da bacia & $\begin{array}{c}\text { Parâmetros estatísticos/Mapas } \\
\text { Numéricos }\end{array}$ \\
\hline Baixa & 0,06 & 0,38 & 0,05 & Mín $-1,22$ \\
\hline Média & 9,64 & 64,90 & 1,51 & Máx - 3,63 \\
\hline Alta & 4,94 & 33,25 & 0,63 & Média $-2,44$ \\
\hline \multirow{2}{*}{ Muito Alta } & \multirow{2}{*}{\multicolumn{2}{|c|}{0,15}} & \multirow[b]{2}{*}{0,02} & Desv Padrão - 0,15 \\
\hline & & & & Moda $-2,44$ \\
\hline \multicolumn{5}{|c|}{ Potencial Agrícola } \\
\hline Classe & Área $\left(\mathrm{Km}^{2}\right)$ & $\%$ área da unidade & $\%$ área da bacia & $\begin{array}{c}\text { Parâmetros estatísticos/Mapas } \\
\text { Numéricos }\end{array}$ \\
\hline Baixa & 4,60 & 30,96 & 1,06 & Mín - 1,62 \\
\hline Média & 2,49 & 16,79 & 0,71 & Máx - 3,48 \\
\hline Alta & 2,35 & 15,86 & 0,91 & Média - 2,44 \\
\hline Muito Alta & 4,33 & 29,20 & 0,92 & Desv Padrão - 0,57 \\
\hline Restritiva & 0,86 & 5,80 & 0,54 & Moda $-3,03$ \\
\hline
\end{tabular}

Tabela 8.12- Atributos do meio físico da unidade VI.

\begin{tabular}{|c|c|c|c|}
\hline Declividade $\%$ & Área $\left(\mathrm{Km}^{2}\right)$ & $\%$ área da unidade & $\%$ área da bacia \\
\hline$<2$ & 2,11 & 14,38 & 0,80 \\
\hline $2-10$ & 3,35 & 22,88 & 1,21 \\
\hline $10-20$ & 5,45 & 37,22 & 1,04 \\
\hline $20-30$ & 2,78 & 18,96 & 0,80 \\
\hline $30-45$ & 0,88 & 6,01 & 0,41 \\
\hline$>45$ & 2,11 & 14,38 & 0,80 \\
\hline Geologia & Área $\left(\mathrm{Km}^{2}\right)$ & $\%$ área da unidade & $\%$ área da bacia \\
\hline Gn Básicas & 14,85 & 100,00 & 3,38 \\
\hline Materiais Inco & Área $\left(\mathrm{Km}^{2}\right)$ & $\%$ área da unidade & $\%$ área da bacia \\
\hline Gnb 5 & 14,85 & 100,00 & 53,40 \\
\hline Classes Uso do Solo & Área $\left(\mathrm{Km}^{2}\right)$ & $\%$ área da unidade & $\%$ área da bacia \\
\hline Cafe & 1,39 & 9,34 & 1,29 \\
\hline Cidades & 0,00 & 0,00 & 0,00 \\
\hline Corpos D água & 0,00 & 0,00 & 0,00 \\
\hline Mata Nativa & 3,94 & 26,54 & 1,10 \\
\hline Outras Culturas & 0,39 & 2,61 & 0,52 \\
\hline Cana-de-açúcar & 2,32 & 15,64 & 3,95 \\
\hline Pastagem & 6,04 & 40,71 & 0,61 \\
\hline Reflorestamento & 0,57 & 3,83 & 11,07 \\
\hline
\end{tabular}


A susceptibilidade a erosão média a alta apresentada é condicionada pelos aspectos de potencial ao escoamento e pelas características de textura e espessura dos materiais inconsolidados. As condições variáveis de potencial agrícola entre as classes baixa e muito alta são controladas pela distribuição dos valores de declividade, que apesar de apresentarem predominância das faixas que favorecem ao desenvolvimento de atividade agrícola, exibem também percentual significativo de classe com severas restrições a implantação das mesmas.

As classes de pastagem e mata nativa destacam-se como as principais atividades de ocupação do solo, com 41\% e 27\% de ocorrência em área respectivamente (Figura 8.6). Atividades voltadas ao desenvolvimento agrícola correspondem a $28 \%$ da área, o que caracteriza um aproveitamento pouco adequado das boas condições naturais de potencial agrícola apresentada por $45 \%$ da unidade.

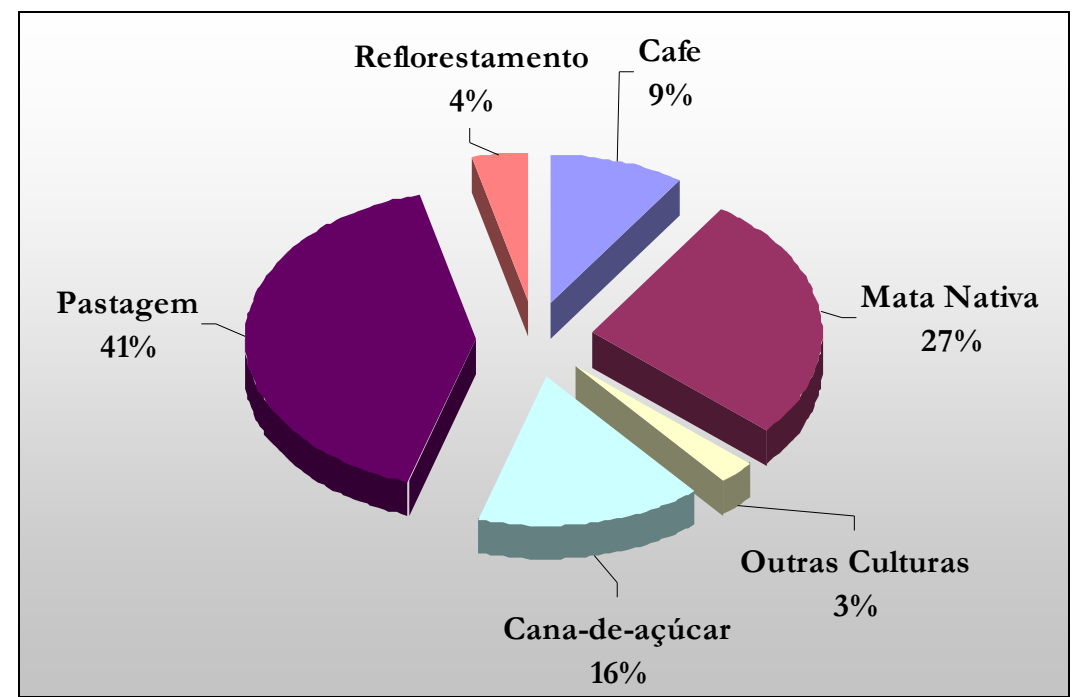

Figura 8.6 - Percentual de ocorrência das classes de uso e ocupação na Unidade Geoambiental VI.

\section{$\underline{\text { Unidade VII }}$}

Corresponde a unidade de terreno A7 e caracteriza-se por apresentar 47\% de sua área com médio potencial ao escoamento, e valores médios de pixels de 2,26. Com relação as condições de susceptibilidade a erosão, 86\% da área constituem a classe média, e a distribuição dos pixels em superfície contínua apresenta valores médio de 2,27. O potencial agrícola é caracterizado pela predominância da classe muito alta, a 
qual corresponde a 54,5\% da unidade. O valor médio de distribuição dos pixels em superfície contínua é de 2,94 (Tabela 8.13).

Regiões com restrições legais a ocupação do meio constituem $6 \%$ da unidade, e caracterizam faixas destinadas a preservação permanente junto aos cursos de drenagem.

Tabela 8.13 - Características de potencialidade e susceptibilidade do meio para unidade VII.

\begin{tabular}{|c|c|c|c|c|}
\hline \multicolumn{5}{|c|}{ Potencial ao Escoamento } \\
\hline Classe & Área $\left(\mathrm{Km}^{2}\right)$ & $\begin{array}{l}\% \text { área da } \\
\text { unidade }\end{array}$ & $\begin{array}{l}\% \text { área da } \\
\text { bacia }\end{array}$ & $\begin{array}{c}\text { Parâmetros estatísticos/Mapas } \\
\text { Numéricos }\end{array}$ \\
\hline Baixa & 23,36 & 24,32 & 13,00 & Mín $-1,17$ \\
\hline Média & 45,54 & 47,41 & 7,01 & Máx - 3,63 \\
\hline Alta & 26,07 & 27,14 & 3,95 & Média - 2,26 \\
\hline \multirow{2}{*}{ Muito Alta } & \multirow[b]{2}{*}{1,10} & \multirow[b]{2}{*}{1,14} & \multirow[b]{2}{*}{0,58} & Desv Padrão - 0,37 \\
\hline & & & & Moda $-2,48$ \\
\hline \multicolumn{5}{|c|}{ Susceptibilidade a Erosão } \\
\hline Classe & Área $\left(\mathrm{Km}^{2}\right)$ & $\begin{array}{l}\% \text { área da } \\
\text { unidade }\end{array}$ & $\begin{array}{l}\% \text { área da } \\
\text { bacia }\end{array}$ & $\begin{array}{c}\text { Parâmetros estatísticos/Mapas } \\
\text { Numéricos }\end{array}$ \\
\hline Baixa & 7,59 & 7,90 & 6,55 & Mín - 1,18 \\
\hline Média & 82,67 & 86,06 & 12,93 & Máx $-3,47$ \\
\hline Alta & 5,79 & 6,03 & 0,74 & Média $-2,27$ \\
\hline \multirow{2}{*}{ Muito Alta } & \multirow[b]{2}{*}{0,01} & \multirow[b]{2}{*}{0,01} & \multirow[b]{2}{*}{0,00} & Desv Padrão - 0,19 \\
\hline & & & & Moda $-2,37$ \\
\hline \multicolumn{5}{|c|}{ Potencial Agrícola } \\
\hline Classe & Área $\left(\mathrm{Km}^{2}\right)$ & $\begin{array}{l}\% \text { área da } \\
\text { unidade }\end{array}$ & $\begin{array}{l}\% \text { área } \mathrm{da} \\
\text { bacia }\end{array}$ & $\begin{array}{c}\text { Parâmetros estatísticos/Mapas } \\
\text { Numéricos }\end{array}$ \\
\hline Baixa & 8,94 & 9,31 & 2,06 & Mín - 1,54 \\
\hline Média & 11,41 & 11,88 & 3,26 & Máx $-3,48$ \\
\hline Alta & 17,33 & 18,04 & 6,66 & Média - 2,94 \\
\hline Muito Alta & 52,36 & 54,51 & 11,10 & Desv Padrão - 0,49 \\
\hline Restritiva & 5,89 & 6,13 & 3,69 & Moda $-3,29$ \\
\hline
\end{tabular}

O médio potencial ao escoamento é condicionado pela predominância de valores percentuais de declividade inferiores a $20 \%$, e pela baixa influência da textura arenosa das matérias residuais de gnaisses intercalados a rochas básicas presentes em 83\% da unidade (Tabela 8.14). A condição de médio potencial ao escoamento controla, de forma preponderante, a média susceptibilidade a erosão apresentada pela unidade. $\mathrm{O}$ elevado potencial agrícola é favorecido pelas características de declividade da área e pelas condições de média susceptibilidade a erosão e elevadas espessuras dos materiais inconsolidados.

A principal classe de ocupação do solo presente nesta unidade é a atividade de pastagem, com ocorrência em 33\% da área (Figura 8.7). 
Tabela 8.14- Atributos do meio físico da unidade VII.

\begin{tabular}{|c|c|c|c|}
\hline Declividade $\%$ & Área $\left(\mathrm{Km}^{2}\right)$ & $\%$ área da unidade & $\%$ área da bacia \\
\hline$<2$ & 27,58 & 28,71 & 10,49 \\
\hline $2-10$ & 26,72 & 27,82 & 9,61 \\
\hline $10-20$ & 33,18 & 34,54 & 6,36 \\
\hline $20-30$ & 7,09 & 7,38 & 2,04 \\
\hline $30-45$ & 1,42 & 1,48 & 0,66 \\
\hline$>45$ & 0,05 & 0,06 & 0,10 \\
\hline Geologia & Área $\left(\mathrm{Km}^{2}\right)$ & $\%$ área da unidade & $\%$ área da bacia \\
\hline Gn Quartzitos & 1,7136 & 1,78 & 0,39 \\
\hline Gn Básicas & 94,3434 & 98,22 & 205,28 \\
\hline Materiais Inco & Área $\left(\mathrm{Km}^{2}\right)$ & $\%$ área da unidade & $\%$ área da bacia \\
\hline Retrab 1 & 0,83 & 0,86 & 1,66 \\
\hline Retrab 2 & 14,30 & 14,89 & 62,87 \\
\hline Gnq 5 & 0,51 & 0,53 & 1,32 \\
\hline Gnb 2 & 80,42 & 83,72 & 690,08 \\
\hline Classes Uso do Solo & Área $\left(\mathrm{Km}^{2}\right)$ & $\%$ área da unidade & $\%$ área da bacia \\
\hline Cafe & 15,90 & 16,55 & 14,84 \\
\hline Corpos D água & 0,08 & 0,08 & 1,79 \\
\hline Mata Nativa & 13,06 & 13,59 & 3,64 \\
\hline Mata Ciliar & 0,45 & 0,47 & 1,34 \\
\hline Outras Culturas & 3,23 & 3,37 & 4,37 \\
\hline Cana-de-açúcar & 27,13 & 28,24 & 46,16 \\
\hline Pastagem & 31,82 & 33,13 & 3,22 \\
\hline Reflorestamento & 0,86 & 0,89 & 16,72 \\
\hline Solo Exposto & 3,54 & 3,68 & 44,03 \\
\hline
\end{tabular}

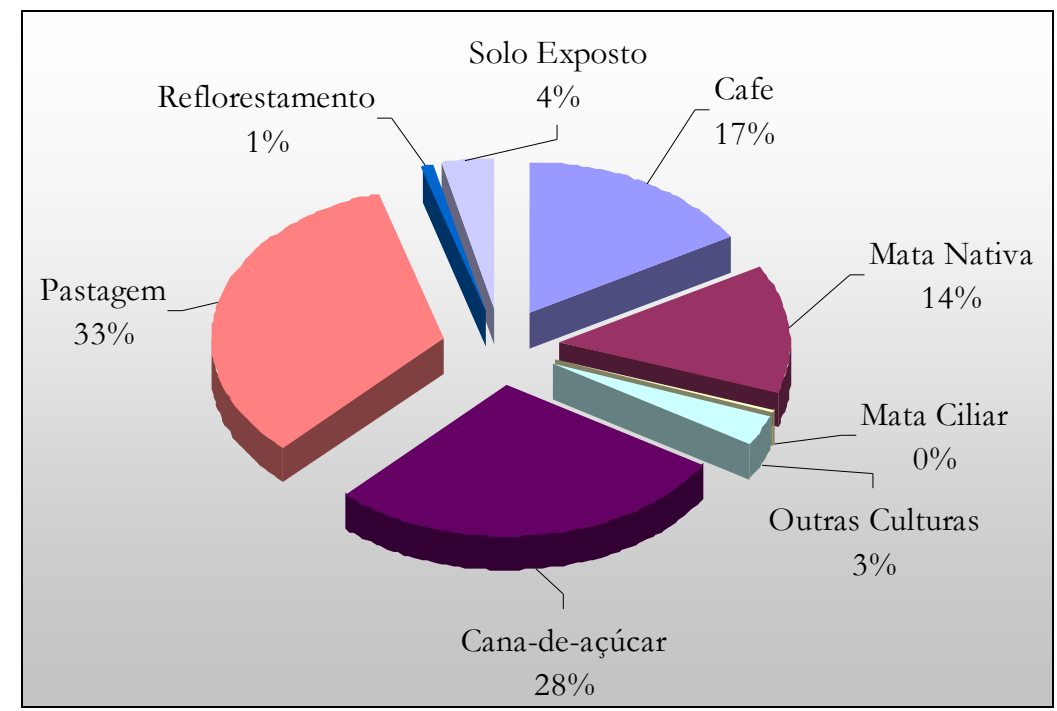

Figura 8.7 - Percentual de ocorrência das classes de uso e ocupação na Unidade Geoambiental VII.

A Figura 8.7 mostra que as classes voltadas ao desenvolvimento agrícola ocupam $48 \%$ da unidade, com predominância das atividades de cultivo de cana-de-açúcar e café. 
A elevada ocorrência destas atividades na área vem a caracterizar um bom aproveitamento das condições naturais oferecidas pelo meio físico.

\section{Unidade VIII}

Corresponde a unidade de terreno A8. Apresenta 51\% da área com médio potencial ao escoamento superficial e $41 \%$ baixo. O s valores médios de pixels de 2,08. A condição de susceptibilidade a erosão é média a alta, caracterizada por $94 \%$ da área, com predomínio da classe média, 61\%. Os valores médios dos pixels são de 2,4. O potencial agrícola é predominantemente elevado, compreendendo a classe muito alta $60 \%$ da unidade. Os valores médios de distribuição dos pixels são de 2,9 (Tabela 8.15)

Regiões com restrições legais a ocupação do meio correspondem a apenas 3\% da unidade. Caracterizam, principalmente, faixas destinadas a preservação permanente junto aos cursos de drenagem.

Tabela 8.15 - Características de potencialidade e susceptibilidade do meio para unidade VIII.

\begin{tabular}{|c|c|c|c|c|}
\hline \multicolumn{5}{|c|}{ Potencial ao Escoamento } \\
\hline Classe & Área $\left(\mathrm{Km}^{2}\right)$ & $\begin{array}{ll}\% \text { área } & \text { da } \\
\text { unidade } & \end{array}$ & $\begin{array}{l}\% \text { área da } \\
\text { bacia }\end{array}$ & $\begin{array}{l}\text { Parâmetros estatísticos/Mapas } \\
\text { Numéricos }\end{array}$ \\
\hline Baixa & 5,33 & 41,10 & 2,97 & Mín $-1,15$ \\
\hline Média & 6,67 & 51,43 & 1,03 & Máx $-3,38$ \\
\hline Alta & 0,88 & 6,81 & 0,13 & Média $-2,08$ \\
\hline \multirow{2}{*}{ Muito Alta } & \multirow[b]{2}{*}{0,09} & \multirow[b]{2}{*}{0,67} & \multirow[b]{2}{*}{0,05} & Desv Padrão - 0,30 \\
\hline & & & & Moda $-1,73$ \\
\hline \multicolumn{5}{|c|}{ Susceptibilidade a Erosão } \\
\hline Classe & Área $\left(\mathrm{Km}^{2}\right)$ & $\begin{array}{l}\% \text { área da } \\
\text { unidade }\end{array}$ & $\begin{array}{c}\% \text { área da } \\
\text { bacia }\end{array}$ & $\begin{array}{c}\text { Parâmetros estatísticos/Mapas } \\
\text { Numéricos }\end{array}$ \\
\hline Baixa & 0,81 & 6,23 & 0,70 & Mín - 1,26 \\
\hline Média & 7,98 & 61,52 & 1,25 & Máx $-3,00$ \\
\hline Alta & 4,18 & 32,24 & 0,53 & Média $-2,40$ \\
\hline \multirow{2}{*}{ Muito Alta } & \multirow[b]{2}{*}{0,00} & \multirow[b]{2}{*}{0,01} & \multirow[b]{2}{*}{0,00} & Desv Padrão - 0,22 \\
\hline & & & & Moda $-2,29$ \\
\hline \multicolumn{5}{|c|}{ Potencial Agrícola } \\
\hline Classe & $\overline{\text { Área }\left(\mathrm{Km}^{2}\right)}$ & $\begin{array}{l}\% \text { área } \mathrm{da} \\
\text { unidade }\end{array}$ & $\begin{array}{ll}\% \text { área da } \\
\text { bacia }\end{array}$ & $\begin{array}{c}\text { Parâmetros estatísticos/Mapas } \\
\text { Numéricos }\end{array}$ \\
\hline Baixa & 1,17 & 9,02 & 0,27 & Mín $-1,51$ \\
\hline Média & 1,43 & 10,99 & 0,41 & Máx $-3,32$ \\
\hline Alta & 2,20 & 17,00 & 0,85 & Média - 2,90 \\
\hline Muito Alta & 7,71 & 59,50 & 1,63 & Desv Padrão - 0,46 \\
\hline Restritiva & 0,45 & 3,43 & 0,28 & Moda $-3,25$ \\
\hline
\end{tabular}

A ocorrência de valores de declividade inferiores a $20 \%$ constitui fator preponderante a condição de médio potencial ao escoamento superficial, e esta vem a controlar situação de média susceptibilidade a erosão. O elevado potencial agrícola é 
favorecido pelas características de declividade além da condição média susceptibilidade a erosão, da forte influência de espessura, entre 1,5 e 2,0 metros, e da textura areno-siltosa dos materiais residuais de granitos cataclasados, que constituem 100\% da unidade (Tabela 8.16).

Trinta e nove por cento da área é ocupada por atividades de uso do solo voltadas ao desenvolvimento agrícola, com destaque para atividade de cultivo de canade-açúcar que ocorre em 30\% da unidade. A atividade de pastagem constitui a classe de ocupação com segunda maior ocorrência em área na unidade, 26\% do total (Figura 8.8). A baixa ocupação da área por atividades voltados ao desenvolvimento agrícola caracteriza situação de aproveitamento inadequado do meio.

Tabela 8.16- Atributos do meio físico da unidade VIII.

\begin{tabular}{|c|c|c|c|}
\hline Declividade $\%$ & Área $\left(\mathrm{Km}^{2}\right)$ & $\%$ área da unidade & $\%$ área da bacia \\
\hline$<2$ & 4,63 & 35,73 & 1,76 \\
\hline $2-10$ & 3,51 & 27,04 & 1,26 \\
\hline $10-20$ & 3,79 & 29,26 & 0,73 \\
\hline $20-30$ & 0,75 & 5,80 & 0,22 \\
\hline $30-45$ & 0,22 & 1,73 & 0,10 \\
\hline$>45$ & 0,04 & 0,33 & 0,08 \\
\hline Geologia & Área $\left(\mathrm{Km}^{2}\right)$ & $\%$ área da unidade & $\%$ área da bacia \\
\hline Granito Cataclasado & 12,97 & 100,00 & 9,28 \\
\hline Materiais Inco & Área $\left(\mathrm{Km}^{2}\right)$ & $\%$ área da unidade & $\%$ área da bacia \\
\hline Grc & 12,97 & 100,00 & 62,87 \\
\hline Classes Uso do Solo & Área $\left(\mathrm{Km}^{2}\right)$ & $\%$ área da unidade & $\%$ área da bacia \\
\hline Área Varzea & 2,68 & 20,68 & 49,38 \\
\hline Cafe & 0,76 & 5,83 & 0,71 \\
\hline Corpos D água & 0,09 & 0,69 & 2,11 \\
\hline Mata Nativa & 1,75 & 13,47 & 0,49 \\
\hline Mata Ciliar & 0,00 & 0,00 & 0,00 \\
\hline Outras Culturas & 0,42 & 3,22 & 0,56 \\
\hline Cana-de-açúcar & 3,96 & 30,58 & 6,75 \\
\hline Pastagem & 3,31 & 25,54 & 0,34 \\
\hline
\end{tabular}

\section{$\underline{\text { Unidade IX }}$}

Corresponde a unidade de terreno B1. Apresenta 47\% da área correspondendo a classe de médio potencial ao escoamento superficial, e 49\% a classe alta. Os pixels exibem valores médios de 2,51. A susceptibilidade a erosão é retratada pela predominância de $81 \%$ da área na classe alta, e por valores médios de pixels de 3,74. O 
potencial agrícola é caracterizado pela ocorrência de $43 \%$ da área na classe baixa. Os pixels exibem valores médios de distribuição de 2,38 (Tabela 8.17).

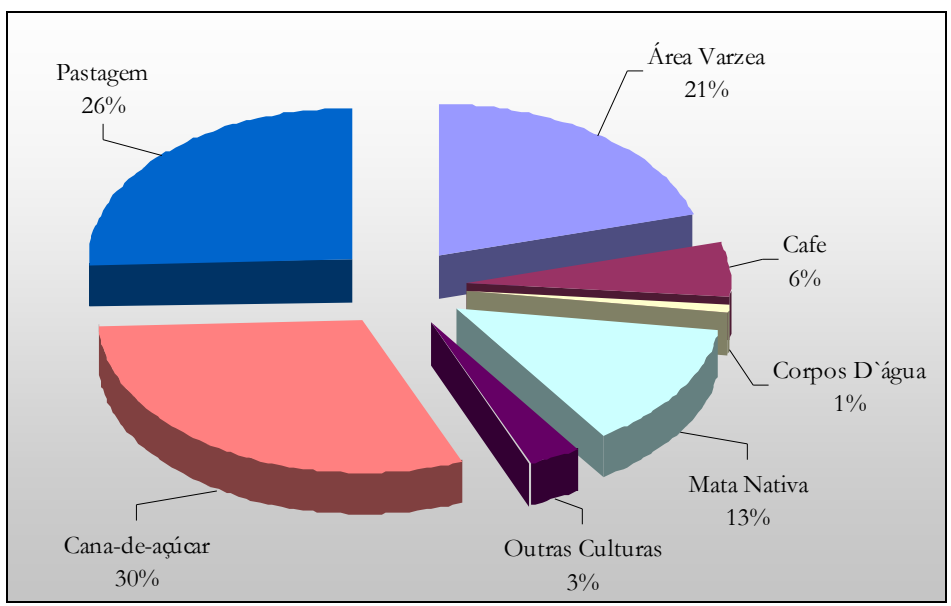

Figura 8.8 - Percentual de ocorrência das classes de uso e ocupação na Unidade Geoambiental VIII.

Tabela 8.17 - Características de potencialidade e susceptibilidade do meio para unidade IX.

\begin{tabular}{|c|c|c|c|c|}
\hline \multicolumn{5}{|c|}{ Potencial ao Escoamento } \\
\hline Classe & Área $\left(\mathrm{Km}^{2}\right)$ & $\begin{array}{c}\% \text { área da } \\
\text { unidade }\end{array}$ & $\begin{array}{c}\% \text { área da } \\
\text { bacia }\end{array}$ & Parâmetros estatísticos/Mapas Numéricos \\
\hline Baixa & 0,23 & 2,33 & 0,13 & Mín - 1,11 \\
\hline Média & 4,70 & 46,87 & 0,72 & Máx - 3,41 \\
\hline Alta & 4,93 & 49,15 & 0,75 & Média - 2,51 \\
\hline Muito & \multirow[b]{2}{*}{0,16} & \multirow[b]{2}{*}{1,59} & \multirow[b]{2}{*}{0,08} & Desv Padrão - 0,36 \\
\hline Alta & & & & Moda $-2,24$ \\
\hline \multicolumn{5}{|c|}{ Susceptibilidade a Erosão } \\
\hline Classe & Área $\left(\mathrm{Km}^{2}\right)$ & $\begin{array}{c}\% \text { área da } \\
\text { unidade }\end{array}$ & $\begin{array}{c}\% \text { área da } \\
\text { bacia }\end{array}$ & Parâmetros estatísticos/Mapas Numéricos \\
\hline Baixa & 0,46 & 4,61 & 0,40 & Mín - 1,33 \\
\hline Média & 0,50 & 5,01 & 0,08 & Máx - 2,16 \\
\hline Alta & 8,09 & 80,72 & 1,04 & Média - 3,74 \\
\hline \multirow{2}{*}{$\begin{array}{c}\text { Muito } \\
\text { Alta }\end{array}$} & \multirow[b]{2}{*}{0,96} & \multirow[b]{2}{*}{9,58} & \multirow[b]{2}{*}{0,68} & Desv Padrão - 0,28 \\
\hline & & & & Moda $-2,67$ \\
\hline \multicolumn{5}{|c|}{ Potencial Agrícola } \\
\hline Classe & Área $\left(\mathrm{Km}^{2}\right)$ & $\begin{array}{ll}\% \text { área } & \mathrm{da} \\
\text { unidade } & \\
\end{array}$ & $\begin{array}{l}\% \text { área da } \\
\text { bacia }\end{array}$ & Parâmetros estatísticos/Mapas Numéricos \\
\hline Baixa & 4,31 & 43,03 & 0,99 & Mín - 1,55 \\
\hline Média & 1,53 & 15,26 & 0,44 & Máx - 3,39 \\
\hline Alta & 1,21 & 12,09 & 0,47 & Média $-2,38$ \\
\hline $\begin{array}{c}\text { Muito } \\
\text { Alta }\end{array}$ & 1,81 & 18,05 & 0,38 & Desv Padrão - 0,54 \\
\hline Restritiva & 1,15 & 11,47 & 0,72 & Moda $-3,35$ \\
\hline
\end{tabular}

Áreas com restrições legais a ocupação do meio correspondem a $11 \%$ da unidade e correspondem, principalmente, as faixas destinadas à preservação permanente 
junto aos cursos de drenagem, e secundariamente a regiões com valores de declividade superiores a $25^{\circ}$.

A condição de potencial de escoamento superficial médio a alto é controlada de forma preponderante pela predominância de valores de declividade superiores a $20 \%$ e pela textura intermediaria dos materiais residuais de gnaisses intercalados com quartzitos presente em 97\% da unidade (Tabela 8.18). A condição de potencial ao escoamento somada as características de textura e espessura, entre 3 e 5 metros, apresentadas pelos materiais inconsolidados presentes condicionam favoravelmente a situação de alta susceptibilidade a erosão. As de alta susceptibilidade a erosão e predominância de elevada declividade condicionam ao baixo potencial agrícola exibido pela unidade.

Tabela 8.18- Atributos do meio físico da unidade IX.

\begin{tabular}{|c|c|c|c|}
\hline Declividade $\%$ & Área $\left(\mathrm{Km}^{2}\right)$ & \% área da unidade & $\%$ área da bacia \\
\hline$<2$ & 0,61 & 6,11 & 0,23 \\
\hline $2-10$ & 1,28 & 12,75 & 0,46 \\
\hline $10-20$ & 3,00 & 29,97 & 0,58 \\
\hline $20-30$ & 2,53 & 25,29 & 0,73 \\
\hline $30-45$ & 2,16 & 21,54 & 1,01 \\
\hline$>45$ & 0,43 & 4,26 & 0,82 \\
\hline Geologia & Área $\left(\mathrm{Km}^{2}\right)$ & \% área da unidade & $\%$ área da bacia \\
\hline Gn Quartzitos & 10,02 & 100,00 & 7,17 \\
\hline Materiais Inco & Área $\left(\mathrm{Km}^{2}\right)$ & \% área da unidade & $\%$ área da bacia \\
\hline Retrab 1 & 0,24 & 2,43 & 0,26 \\
\hline Gnq 3 & 9,78 & 97,57 & 72,37 \\
\hline Classes Uso do Solo & Área $\left(\mathrm{Km}^{2}\right)$ & $\%$ área da unidade & $\%$ área da bacia \\
\hline Cafe & 0,26 & 2,59 & 0,24 \\
\hline Mata Nativa & 5,38 & 53,72 & 1,50 \\
\hline Outras Culturas & 0,24 & 2,35 & 0,32 \\
\hline Pastagem & 4,06 & 40,51 & 0,41 \\
\hline Solo Exposto & 0,08 & 0,82 & 1,02 \\
\hline
\end{tabular}

Destacam-se como principais classes de uso presente na unidade, mata nativa com 53\% de ocorrência em área, e pastagem com 40\% (Figura 8.9). Atividades voltadas ao desenvolvimento de práticas agrícolas ocupam apenas $5 \%$ da área, demonstrando aproveitamento adequado da condição natural de baixo potencial agrícola oferecida pela unidade. 


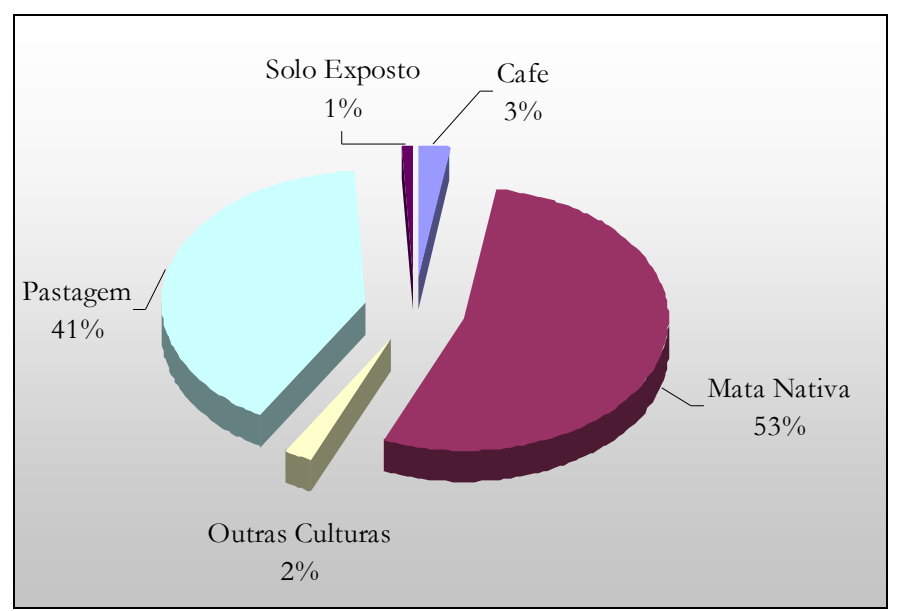

Figura 8.9 - Percentual de ocorrência das classes de uso e ocupação na Unidade Geoambiental IX.

\section{Unidade X}

Corresponde a unidade de terreno B2. Apresenta 57\% de sua área correspondendo a classe de médio potencial ao escoamento, e 35\% a classe alta. A distribuição de pixels em superfície contínua apresenta valores médios de 2,42. A susceptibilidade a erosão é caracteriza pela ocorrência de $78 \%$ da unidade na classe alta, os valores médios de pixels de 2,75. O potencial agrícola é retratado pela ocorrência de $42 \%$ da unidade na classe muito alta, e $21 \%$ na classe média. A superfície fuzzy representativa deste aspecto exibe valores médios dos pixels de 3,06 (Tabela 8.19).

Áreas com restrições legais a ocupação do meio correspondem a 9\% da unidade, e constituem faixas destinadas a preservação permanente junto aos cursos de drenagem.

A situação de potencial ao escoamento médio a alto é condicionada, principalmente, pelas características de textura intermediaria dos materiais residuais de gnaisses intercalados a rochas quatziticas presentes em $98 \%$ da unidade, haja vista que apenas $21 \%$ da unidade exibe valores de declividade acima de $20 \%$ (Tabela 8.20). A alta susceptibilidade a erosão é controlada pelas características de escoamento superficial e aspectos de textura e espessura dos materiais inconsolidados. O elevado potencial agrícola é favorecido pela predominância de faixas de declividade inferiores a $20 \%$ e pelas características dos materiais inconsolidados. 
Tabela 8.19 - Características de potencialidade e susceptibilidade do meio para unidade $\mathrm{X}$.

\begin{tabular}{|c|c|c|c|c|}
\hline \multicolumn{5}{|c|}{ Potencial ao Escoamento } \\
\hline Classe & $\begin{array}{c}\text { Área } \\
\left(\mathrm{Km}^{2}\right)\end{array}$ & $\begin{array}{l}\% \text { área } \mathrm{da} \\
\text { unidade }\end{array}$ & $\begin{array}{l}\% \text { área } \mathrm{da} \\
\text { bacia }\end{array}$ & $\begin{array}{c}\text { Parâmetros estatísticos/Mapas } \\
\text { Numéricos }\end{array}$ \\
\hline Baixa & 2,41 & 7,22 & 1,34 & Mín $-1,18$ \\
\hline Média & 19,07 & 57,01 & 2,94 & Máx - 3,52 \\
\hline Alta & 10,66 & 31,87 & 1,61 & Média $-2,42$ \\
\hline \multirow{2}{*}{ Muito Alta } & \multirow[b]{2}{*}{1,30} & \multirow[b]{2}{*}{3,89} & \multirow[b]{2}{*}{0,69} & Desv Padrão - 030 \\
\hline & & & & Moda $-2,17$ \\
\hline \multicolumn{5}{|c|}{ Susceptibilidade a Erosão } \\
\hline Classe & $\begin{array}{c}\text { Área } \\
\left(\mathrm{Km}^{2}\right)\end{array}$ & $\begin{array}{l}\% \text { área da } \\
\text { unidade }\end{array}$ & $\begin{array}{l}\% \text { área da } \\
\text { bacia }\end{array}$ & $\begin{array}{c}\text { Parâmetros estatísticos/Mapas } \\
\text { Numéricos }\end{array}$ \\
\hline Baixa & 0,41 & 1,22 & 0,35 & Mín - 1,27 \\
\hline Média & 6,88 & 20,57 & 1,08 & Máx - 3,69 \\
\hline Alta & 26,10 & 78,05 & 3,34 & Média $-2,57$ \\
\hline \multirow{2}{*}{ Muito Alta } & \multirow[b]{2}{*}{0,05} & \multirow[b]{2}{*}{0,16} & \multirow[b]{2}{*}{0,04} & Desv Padrão - 0,16 \\
\hline & & & & Moda $-2,56$ \\
\hline \multicolumn{5}{|c|}{ Potencial Agrícola } \\
\hline Classe & $\begin{array}{l}\text { Área } \\
\left(\mathrm{Km}^{2}\right)\end{array}$ & $\begin{array}{l}\% \text { área } \mathrm{da} \\
\text { unidade }\end{array}$ & $\begin{array}{l}\% \text { área } \mathrm{da} \\
\text { bacia }\end{array}$ & $\begin{array}{c}\text { Parâmetros estatísticos/Mapas } \\
\text { Numéricos }\end{array}$ \\
\hline Baixa & 3,25 & 9,73 & 0,75 & Mín $-1,85$ \\
\hline Média & 7,14 & 21,34 & 2,04 & Máx - 3,46 \\
\hline Alta & 5,77 & 17,24 & 2,22 & Média $-2,82$ \\
\hline Muito Alta & 14,28 & 42,69 & 3,03 & Desv Padrão - 0,56 \\
\hline Restritiva & 3,04 & 9,08 & 1,90 & Moda $-3,37$ \\
\hline
\end{tabular}

Tabela 8.20- Atributos do meio físico da unidade X.

\begin{tabular}{c|r|r|r}
\hline Classes Declivid \% & Área $\left(\mathbf{K m}^{2}\right)$ & \% área da unidade & \% área da bacia \\
\hline$<2$ & 7,87 & 23,53 & 2,99 \\
\hline $2-10$ & 6,94 & 20,77 & 2,50 \\
\hline $10-20$ & 11,91 & 35,60 & 2,28 \\
\hline $20-30$ & 4,71 & 14,07 & 1,35 \\
\hline $30-45$ & 1,92 & 5,75 & 0,90 \\
\hline$>45$ & 0,11 & 0,31 & 0,20 \\
\hline Geologia & Área $\left.\mathbf{( K m}^{2}\right)$ & \% área da unidade & \% área da bacia \\
\hline Gn Quartzitos & 33,44 & 100,00 & 23,93 \\
\hline Materiais Inco & Área $\left(\mathbf{K m}^{\mathbf{2}}\right)$ & \% área da unidade & \% área da bacia \\
\hline Retrab 2 & 0,64 & 1,93 & 1,29 \\
\hline Gnq 4 & 32,80 & 98,07 & 76,70 \\
\hline Classes Uso do Solo & Área $\left(\mathbf{K m}^{\mathbf{2}}\right)$ & \% área da unidade & \% área da bacia \\
\hline Café & 3,33 & 9,95 & 3,11 \\
\hline Mata Nativa & 8,35 & 24,97 & 2,33 \\
\hline Outras Culturas & 3,02 & 9,02 & \\
\hline Pastagem & 18,32 & 54,78 & 1,85 \\
\hline Solo Exposto & 0,43 & 1,28 & 5,32 \\
\hline
\end{tabular}

As atividades de pastagem e a classe de mata nativa destacam-se como principais tipos de uso e ocupação do solo presentes na unidade, correspondendo a $54 \%$ de $25 \%$, respectivamente (Figura 8.10). Atividades voltadas ao desenvolvimento de práticas 
agrícolas ocupam apenas $18 \%$ da área, o que retrata aproveitamento inadequado da condição natural de elevado potencial agrícola oferecida pela unidade.

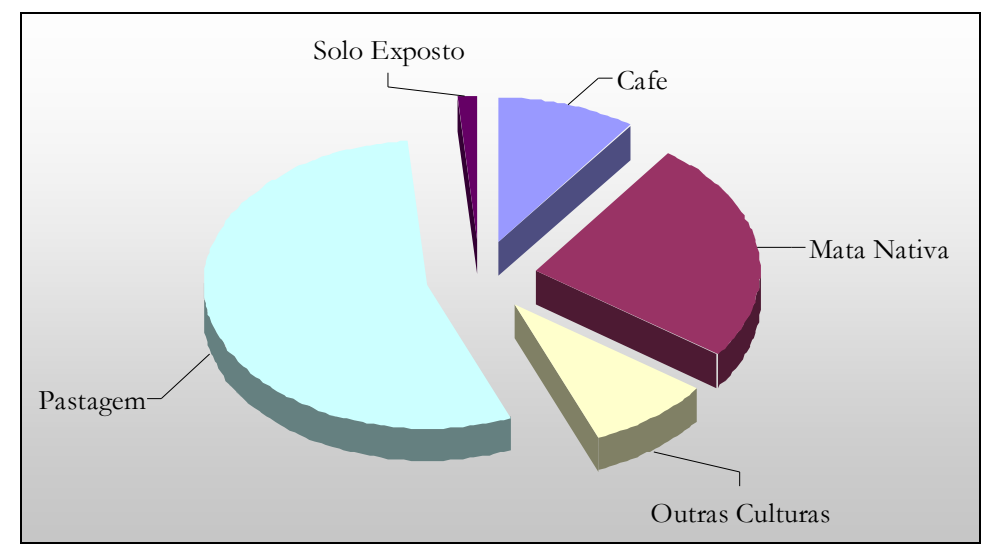

Figura 8.10 - Percentual de ocorrência das classes de uso e ocupação na Unidade Geoambiental X.

\section{$\underline{\text { Unidade XI }}$}

Corresponde a unidade de terreno B3. Apresenta 69\% da área compreendendo as classes de média a alto potencial ao escoamento. A superfície fuz:̧y representativa deste aspecto exibe valores médios de pixels de 2,62. (Tabela 8.21)

Tabela 8.21 - Características de potencialidade e susceptibilidade do meio para unidade XI.

\begin{tabular}{|c|c|c|c|c|}
\hline \multicolumn{5}{|c|}{ Potencial ao Escoamento } \\
\hline Classe & Área $\left(\mathrm{Km}^{2}\right)$ & $\begin{array}{l}\% \text { área } \mathrm{da} \\
\text { unidade }\end{array}$ & $\begin{array}{l}\% \text { área da } \\
\text { bacia }\end{array}$ & Parâmetros estatísticos/Mapas Numéricos \\
\hline Baixa & 0,31 & 1,00 & 0,17 & Mín $-1,23$ \\
\hline Média & 10,89 & 35,32 & 1,68 & Máx - 3,79 \\
\hline Alta & 10,43 & 33,82 & 1,58 & Média $-2,62$ \\
\hline \multirow{2}{*}{ Muito Alta } & \multirow{2}{*}{\multicolumn{2}{|c|}{3,84}} & \multirow[b]{2}{*}{0,63} & Desv Padrão - 0,33 \\
\hline & & & & Moda $-2,37$ \\
\hline \multicolumn{5}{|c|}{ Susceptibilidade a Erosão } \\
\hline Classe & Área $\left(\mathrm{Km}^{2}\right)$ & $\begin{array}{c}\% \text { área da } \\
\text { unidade }\end{array}$ & $\begin{array}{c}\% \text { área da } \\
\text { bacia }\end{array}$ & Parâmetros estatísticos/Mapas Numéricos \\
\hline Baixa & 0,28 & 0,91 & 0,24 & Mín - 1,30 \\
\hline Média & 3,30 & 10,71 & 0,52 & Máx-4,01 \\
\hline Alta & 26,82 & 86,97 & 3,43 & Média $-2,65$ \\
\hline \multirow{2}{*}{ Muito Alta } & \multirow{2}{*}{\multicolumn{2}{|c|}{1,23}} & \multirow[b]{2}{*}{0,27} & Desv Padrão - 0,18 \\
\hline & & & & Moda $-2,56$ \\
\hline \multicolumn{5}{|c|}{ Potencial Agrícola } \\
\hline Classe & Área $\left(\mathrm{Km}^{2}\right)$ & $\begin{array}{l}\% \text { área } \mathrm{da} \\
\text { unidade }\end{array}$ & $\begin{array}{l}\% \text { área da } \\
\text { bacia }\end{array}$ & Parâmetros estatísticos/Mapas Numéricos \\
\hline Baixa & 7,65 & 24,80 & 1,76 & Mín-1,51 \\
\hline Média & 8,81 & 28,57 & 2,52 & Máx - 3,69 \\
\hline Alta & 4,28 & 13,89 & 1,65 & Média - 2,47 \\
\hline Muito Alta & 6,25 & 20,26 & 1,32 & Desv Padrão - 0,56 \\
\hline Restritiva & 3,84 & 12,45 & 2,40 & Moda $-3,37$ \\
\hline
\end{tabular}


A susceptibilidade a erosão é retratada pela ocorrência de $87 \%$ da área da unidade na classe alta, com valores médios de pixels de 2,65. Com relação ao potencial ao desenvolvimento de atividades agrícola, a unidade exibe $53 \%$ de sua área compreendem as classes baixa a média, e valores médios de pixels de 2,47.

Áreas com restrições legais a ocupação do meio correspondem a $12 \%$ da unidade e correspondem, principalmente, faixas destinadas à preservação permanente junto aos cursos de drenagem, e secundariamente a regiões com valores de declividade superiores a $25^{\circ}$.

A ocorrência em $41 \%$ da área de valores de declividade superiores a $20 \%$ somada a predominância dos materiais residuais de gnaisses intercalados a rochas básicas (Tabela 8.22), os quais exibem textura intermediária condicionam o potencial ao escoamento médio a alto em mais de $50 \%$ da unidade. Este aspecto dos materiais inconsolidados e as condições de potencial ao escoamento favorecem a situação de elevada susceptibilidade a erosão constatada na área. O potencial agrícola médio a baixo é condicionado pela ocorrência de valores de declividade acima a $20 \%$ em $42 \%$ da unidade, e pela condição de elevada susceptibilidade a erosão. As características de espessuras superiores a 2 metros e os valores de capacidade de troca catiônica apresentados pelos materiais inconsolidados presentes, juntamente com os valores de declividade inferiores a $20 \%$, em $52 \%$ da área favorecem as elevado potencial agrícola em $34 \%$ da área.

A atividade de pastagem caracteriza a classe de ocupação do solo com maior ocorrência em área na unidade, 57\%. De forma secundária ocorrem mata nativa, com $21 \%$ de ocorrência em área, e café com 18\% (Figura 8.11). A ocupação de apenas 20\% da unidade por atividade voltados as práticas agrícolas caracteriza um aproveitamento adequado das condições naturais de potencial agrícola pouco favorável ao desenvolvimento destas atividades. 
Tabela 8.22 - Atributos do meio físico da unidade XI.

\begin{tabular}{|c|c|c|c|}
\hline Declividade $\%$ & Área $\left(\mathrm{Km}^{2}\right)$ & $\%$ área da unidade & $\%$ área da bacia \\
\hline$<2$ & 2,63 & 8,54 & 1,00 \\
\hline $2-10$ & 4,04 & 13,09 & 1,45 \\
\hline $10-20$ & 10,71 & 34,74 & 2,05 \\
\hline $20-30$ & 8,21 & 26,63 & 2,36 \\
\hline $30-45$ & 4,55 & 14,77 & 2,12 \\
\hline$>45$ & 0,68 & 2,22 & 1,31 \\
\hline Geologia & Área $\left(\mathrm{Km}^{2}\right)$ & $\%$ área da unidade & $\%$ área da bacia \\
\hline Gn Básicas & 28,19 & 91,41 & 6,43 \\
\hline Qartzitos & 0,58 & 1,89 & 1,27 \\
\hline Migmatitos & 2,07 & 6,70 & 0,48 \\
\hline Materiais Inco & Área $\left(\mathrm{Km}^{2}\right)$ & $\%$ área da unidade & $\%$ área da bacia \\
\hline Retrab 2 & 1,14 & 3,71 & 2,30 \\
\hline Gnb 6 & 27,12 & 87,96 & 97,56 \\
\hline Mig 1 & 2,01 & 6,52 & 12,73 \\
\hline Qtz 2 & 0,56 & 1,81 & 3,22 \\
\hline Classes Uso do Solo & Área $\left(\mathrm{Km}^{2}\right)$ & $\%$ área da unidade & $\%$ área da bacia \\
\hline Cafe & 5,56 & 18,04 & 5,19 \\
\hline Mata Nativa & 6,42 & 20,82 & 1,79 \\
\hline Mata Ciliar & 0,21 & 0,68 & 0,62 \\
\hline Outras Culturas & 0,55 & 1,79 & 0,74 \\
\hline Pastagem & 17,73 & 57,48 & 1,79 \\
\hline Solo Exposto & 0,37 & 1,19 & 4,58 \\
\hline
\end{tabular}

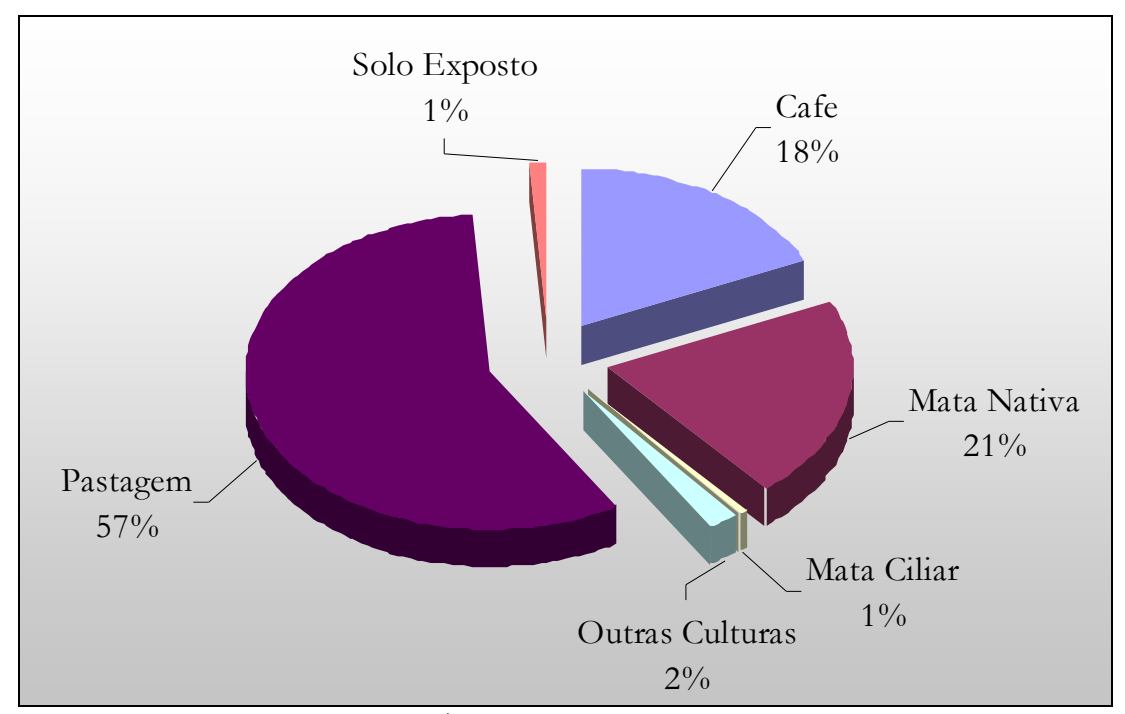

Figura 8.11 - Percentual de ocorrência das classes de uso e ocupação na Unidade Geoambiental XI. 


\section{$\underline{\text { Unidade XII }}$}

Corresponde a unidade de terreno B4. Apresenta 56\% da área compreendida pela classe médio potencial ao escoamento e $41 \%$ pela classe alta. Os valores médios dos pixels são de 2,84. A susceptibilidade a erosão é retratada pela ocorrência de $72 \%$ da unidade na classe alta, com valores médios dos pixels de 2,58. O potencial agrícola é caracterizado pela ocorrência de $28 \%$ da área na classe média e $23 \%$ na classe baixa. Os valores médios dos pixels são de 2,47 (Tabela 8.23).

Regiões com restrições legais a ocupação do meio correspondem a 10\% da unidade e constituem, principalmente, faixas destinadas a preservação permanente junto aos cursos de drenagem.

Tabela 8.23 - Características de potencialidade e susceptibilidade do meio para unidade XII.

\begin{tabular}{|c|c|c|c|c|}
\hline \multicolumn{5}{|c|}{ Potencial ao Escoamento } \\
\hline Classe & Área $\left(\mathrm{Km}^{2}\right)$ & $\%$ área da unidade & \% área da bacia & $\begin{array}{c}\text { Parâmetros estatísticos/Mapas } \\
\text { Numéricos }\end{array}$ \\
\hline Baixa & 1,17 & 6,16 & 0,65 & Mín - 1,06 \\
\hline Média & 8,93 & 46,84 & 1,37 & Máx - 3,56 \\
\hline Alta & 7,79 & 40,86 & 1,18 & Média $-2,48$ \\
\hline \multirow{2}{*}{ Muito Alta } & \multirow{2}{*}{\multicolumn{2}{|c|}{6,14}} & \multirow[b]{2}{*}{0,62} & Desv Padrão - 0,31 \\
\hline & & & & Moda $-2,37$ \\
\hline \multicolumn{5}{|c|}{ Susceptibilidade a Erosão } \\
\hline Classe & Área $\left(\mathrm{Km}^{2}\right)$ & $\%$ área da unidade & $\%$ área da bacia & $\begin{array}{c}\text { Parâmetros estatísticos/Mapas } \\
\text { Numéricos }\end{array}$ \\
\hline Baixa & 0,03 & 0,16 & 0,03 & Mín - 1,45 \\
\hline Média & 5,02 & 26,34 & 0,79 & Máx $-3,74$ \\
\hline Alta & 13,83 & 72,51 & 1,77 & Média - 2,58 \\
\hline \multirow{2}{*}{ Muito Alta } & \multirow[b]{2}{*}{0,15} & \multirow[b]{2}{*}{0,79} & \multirow[b]{2}{*}{0,11} & Desv Padrão - 0,17 \\
\hline & & & & Moda \\
\hline \multicolumn{5}{|c|}{ Potencial Agrícola } \\
\hline Classe & Área $\left(\mathrm{Km}^{2}\right)$ & $\%$ área da unidade & $\%$ área da bacia & $\begin{array}{c}\text { Parâmetros estatísticos/Mapas } \\
\text { Numéricos }\end{array}$ \\
\hline Baixa & 4,50 & 23,59 & 1,04 & Mín - 0,36 \\
\hline Média & 5,47 & 28,69 & 1,56 & Máx - 3,97 \\
\hline Alta & 2,98 & 15,61 & 1,14 & Média - 2,47 \\
\hline Muito Alta & 4,20 & 22,03 & 0,89 & Desv Padrão - 0,56 \\
\hline Restritiva & 1,90 & 9,99 & 1,19 & Moda - 3,22 \\
\hline
\end{tabular}

A condição de potencial ao escoamento médio a alto é favorecida pela ocorrência de valores de declividades superiores a $20 \%$, em $37 \%$ da unidade, e pela textura intermediária dos materiais residuais de migmatitos e gnaisses intercalados a rochas básicas, os quais corresponde a mais de $90 \%$ da área (Tabela 8.24). A alta susceptibilidade a erosão é condicionada pela situação predominante de médio a alto potencial ao escoamento e pelas características de texturas dos materiais residuais de 
gnaisses intercalados a rochas básicas, e de espessuras destes e dos residuais de migmatitos. A condição de elevada susceptibilidade a erosão e a ocorrência de valores de declividade acima de $20 \%$, em $37 \%$ da área vêm a controlar o potencia médio a baixo ao desenvolvimento agrícola exibido pela unidade.

Tabela 8.24- Atributos do meio físico da unidade XII.

\begin{tabular}{c|r|r|r}
\hline Declividade $\%$ & Área $\left(\mathbf{K m}^{2}\right)$ & \% área da unidade & \% área da bacia \\
\hline$<2$ & 1,73 & 9,09 & 0,66 \\
\hline $2-10$ & 3,01 & 15,79 & 1,08 \\
\hline $10-20$ & 7,11 & 37,30 & 1,36 \\
\hline $20-30$ & 4,89 & 25,67 & 1,41 \\
\hline $30-45$ & 2,13 & 11,18 & 0,99 \\
\hline$>45$ & 0,19 & 0,99 & 0,36 \\
\hline Geologia & Área $\left.\mathbf{( K m}^{2}\right)$ & \% área da unidade & \% área da bacia \\
\hline Gn Básicas & 11,67 & 61,23 & 2,66 \\
\hline Migmatitos & 7,39 & 38,77 & 1,72 \\
\hline Materiais Inco & Área $\left(\mathbf{K m}^{2}\right)$ & \% área da unidade & \% área da bacia \\
\hline Retrab 2 & 0,86 & 4,50 & 1,72 \\
\hline Gnb 3 & 11,65 & 61,12 & 100,00 \\
\hline Gnb 4 & 0,01 & 0,06 & 0,03 \\
\hline Mig 1 & 0,56 & 34,41 & 41,55 \\
\hline Mig 2 & 0,07 & 0,38 & 0,22 \\
\hline Classes Uso do Solo & Área $\left(\mathbf{K m}^{2}\right)$ & \% área da unidade & \% área da bacia \\
\hline Café & 2,26 & 11,87 & 2,11 \\
\hline Corpos d’água & 0,06 & 0,31 & 1,40 \\
\hline Mata Nativa & 7,52 & 39,46 & 2,10 \\
\hline Pastagem & 9,22 & 48,36 & 0,93 \\
\hline
\end{tabular}

As classes de pastagem e mata nativa destacam-se como as principais atividades de ocupação do terreno vigentes na unidade. Estas correspondem, respectivamente, a $49 \%$ e $39 \%$ da área. A atividade de café constitui a única prática agrícola vigente na unidade. Corresponde a apenas $20 \%$ da área, e se adequa as condições potencial natural de desenvolvimento agrícola apresentado pela unidade. 


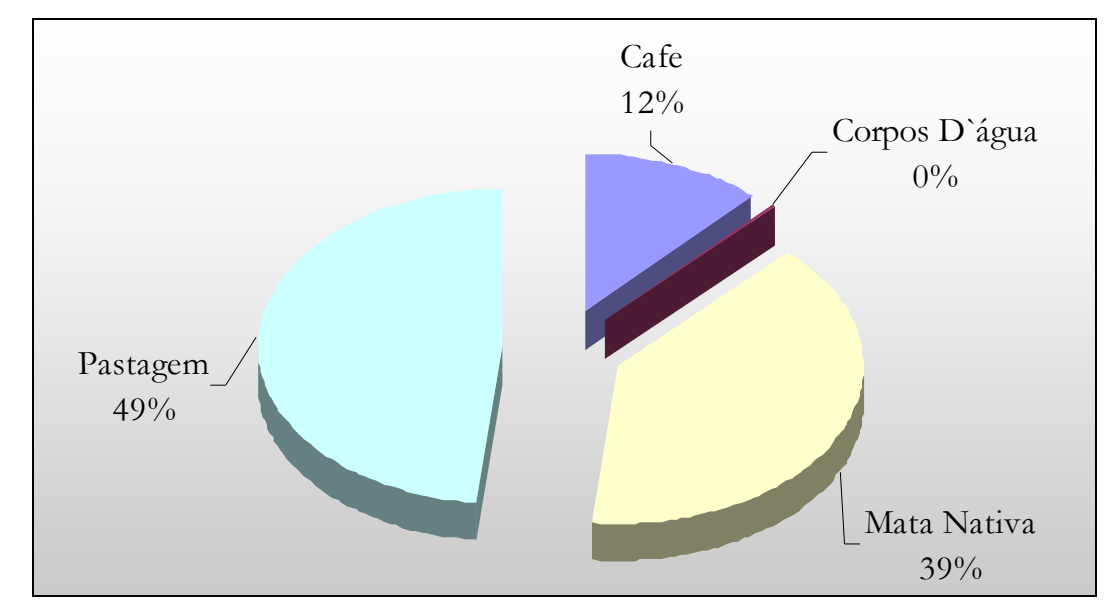

Figura 8.12 - Percentual de ocorrência das classes de uso e ocupação na Unidade Geoambiental XII.

\section{Unidade XIII}

Corresponde a unidade de terreno B5. Caracteriza-se por apresentar 48\% de sua área correspondendo a classe de alto potencial ao escoamento, e 30\% a classe média. Os valores médios de pixels são de 2,65. A susceptibilidade a erosão é retratada pela ocorrência de $76 \%$ da unidade na classe alta, com valores médios dos pixels de 2,8 . O potencial agrícola é caracterizado pela ocorrência de $50 \%$ da área na classe baixa. Os valores médios dos pixels são de 2,15 (Tabela 8.25).

Regiões com restrições legais a ocupação do meio correspondem a $15 \%$ da unidade e constituem faixas destinadas a preservação permanente junto aos cursos de drenagem.

A ocorrência de $48 \%$ da unidade com alto potencial ao escoamento é devido a predominância de valores de declividade acima de $20 \%$, e a ocorrência dos materiais residuais de gnaisses intercalados a rochas básicas, os quais compreende 85\% e caracterizam-se por exibir texturas intermediarias (Tabela 8.26). A condição do potencial ao escoamento e as características de textura destes materiais condicionam a alta susceptibilidade a erosão da unidade. O potencial agrícola predominantemente baixo é resultado dos elevados valores de declividade presentes na área e da influência moderada exercida pelos aspectos de textura dos materiais inconsolidados. 
Tabela 8.25 - Características de potencialidade e susceptibilidade do meio para unidade XIII.

\begin{tabular}{|c|c|c|c|c|}
\hline \multicolumn{5}{|c|}{ Potencial ao Escoamento } \\
\hline Classe & Área $\left(\mathrm{Km}^{2}\right)$ & $\%$ área da unidade & $\%$ área da bacia & $\begin{array}{c}\text { Parâmetros estatísticos/Mapas } \\
\text { Numéricos }\end{array}$ \\
\hline Baixa & 1,59 & 3,39 & 0,89 & Mín $-1,38$ \\
\hline Média & 14,21 & 30,30 & 2,19 & Máx - 3,63 \\
\hline Alta & 22,66 & 48,32 & 3,43 & Média $-2,65$ \\
\hline \multirow{2}{*}{ Muito Alta } & \multirow[b]{2}{*}{8,43} & 17,98 & 4,50 & Desv Padrão - 0,65 \\
\hline & & & & Moda $-3,33$ \\
\hline \multicolumn{5}{|c|}{ Susceptibilidade a Erosão } \\
\hline Classe & Área $\left(\mathrm{Km}^{2}\right)$ & $\%$ área da unidade & $\%$ área da bacia & $\begin{array}{c}\text { Parâmetros estatísticos/Mapas } \\
\text { Numéricos }\end{array}$ \\
\hline Baixa & 0,23 & 0,50 & 0,20 & Mín - 1,69 \\
\hline Média & 2,92 & 6,22 & 0,46 & Máx - 4,08 \\
\hline Alta & 35,94 & 76,64 & 4,60 & Média - 2,80 \\
\hline \multirow{2}{*}{ Muito Alta } & \multirow[b]{2}{*}{7,80} & 16,63 & 5,54 & Desv Padrão - 0,21 \\
\hline & & & & Moda $-3,14$ \\
\hline \multicolumn{5}{|c|}{ Potencial Agrícola } \\
\hline Classe & Área $\left(\mathrm{Km}^{2}\right)$ & $\%$ área da unidade & $\%$ área da bacia & $\begin{array}{c}\text { Parâmetros estatísticos/Mapas } \\
\text { Numéricos }\end{array}$ \\
\hline Baixa & 23,64 & 50,41 & 5,44 & Mín $-1,79$ \\
\hline Média & 7,42 & 15,82 & 2,12 & Máx $-3,63$ \\
\hline Alta & 3,73 & 7,96 & 1,44 & Média $-2,15$ \\
\hline Muito Alta & 4,81 & 10,25 & 1,02 & Desv Padrão - 0,49 \\
\hline Restritiva & 7,29 & 15,55 & 4,56 & Moda $-1,76$ \\
\hline
\end{tabular}

Tabela 8.26- Atributos do meio físico da unidade XIII.

\begin{tabular}{c|r|r|r}
\hline Declividade $\%$ & Área $\left(\mathbf{K m}^{2}\right)$ & \% área da unidade & \% área da bacia \\
\hline$<2$ & 1,95 & 4,16 & 0,74 \\
\hline $2-10$ & 3,78 & 8,06 & 1,36 \\
\hline $10-20$ & 11,53 & 24,59 & 2,21 \\
\hline $20-30$ & 13,85 & 29,53 & 3,98 \\
\hline $30-45$ & 12,55 & 26,76 & 5,85 \\
\hline$>45$ & 3,23 & 6,88 & 6,18 \\
\hline Geologia & Área $\left.\mathbf{( K m}^{\mathbf{2}}\right)$ & \% área da unidade & \% área da bacia \\
\hline Gn Básicas & 40,83 & 87,08 & 9,31 \\
\hline Migmatitos & 6,06 & 12,92 & 1,41 \\
\hline Materiais Inco & Área $\left(\mathbf{K m}^{2}\right)$ & \% área da unidade & \% área da bacia \\
\hline Retrab 1 & 0,32 & 0,67 & 0,33 \\
\hline Retrab 2 & 1,28 & 2,73 & 2,57 \\
\hline Gnb 4 & 40,08 & 85,49 & 95,73 \\
\hline Mig 1 & 5,12 & 10,93 & 32,44 \\
\hline Mig 2 & 0,09 & 0,18 & 0,26 \\
\hline Classes Uso do Solo & Área $\left(\mathbf{K m}^{2}\right)$ & \% área da unidade & \% área da bacia \\
\hline Cafe & 0,82 & 1,76 & 0,77 \\
\hline Cidades & 0,01 & 0,02 & 0,03 \\
\hline Corpos D água & 0,03 & 0,06 & 0,70 \\
\hline Mata Nativa & 19,97 & 42,60 & 5,57 \\
\hline Outras Culturas & 0,02 & 0,03 & 0,02 \\
\hline Pastagem & 26,04 & 55,53 & 2,64 \\
\hline
\end{tabular}


As classes de pastagem e mata nativa destacam-se como principais atividades de ocupação do terreno vigentes na unidade. Estas correspondem, respectivamente, a 55\% e 43\% da área. A atividade de café constitui a única prática agrícola vigente na unidade, e exibe percentual de ocorrência pouco significativo, o que vem a se adequar ao baixo potencial natural de desenvolvimento agrícola apresentado pela unidade (Figura 8.13).

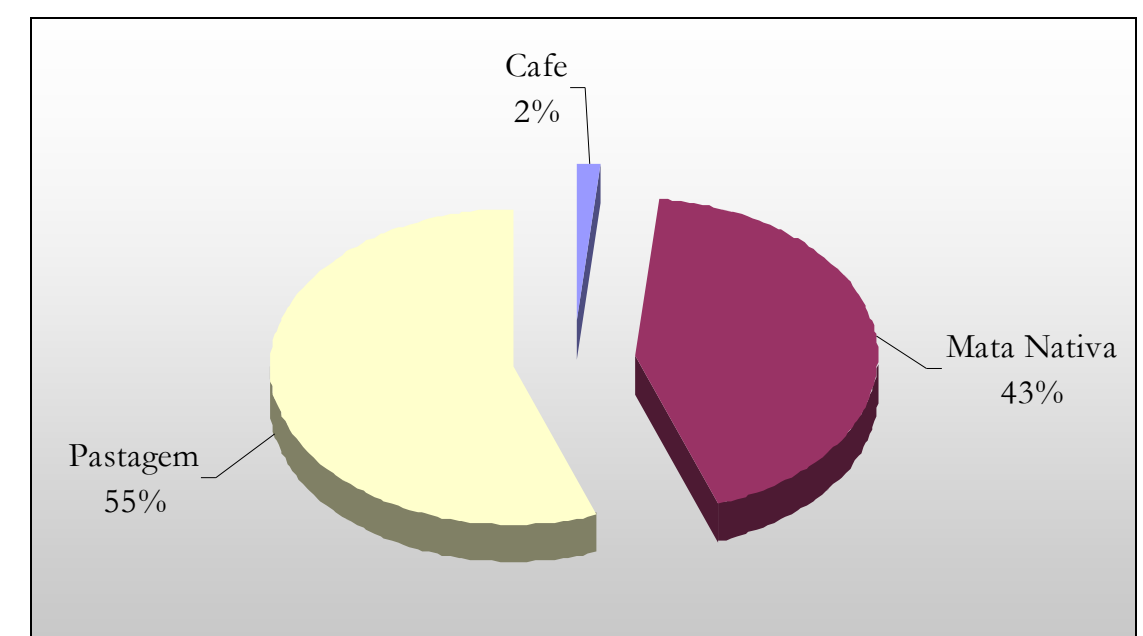

Figura 8.13 - Percentual de ocorrência das classes de uso e ocupação na Unidade Geoambiental XIII.

\section{Unidade XIV}

Corresponde a unidade de terreno B6. Apresenta 54\% da área enquadrada na classe de alto potencial ao escoamento e 31\% na classe média. Os valores médios dos pixels são de 2,64. A susceptibilidade a erosão é caracterizadas pela ocorrência de $82 \%$ da área na classe alta, e valores médio dos pixels de 2,6. O potencial agrícola é representado pela ocorrência de 58\% da área nas classes média a baixa, com valores médios de pixels de 2,43 (Tabela 8.27).

Regiões com restrições legais a ocupação do meio correspondem a $10 \%$ da unidade e constituem faixas destinadas a preservação permanente junto aos cursos de drenagem.

O alto potencial ao escoamento é condicionado pelos valores de declividade superiores a $20 \%$ em $47 \%$ da área, e pela textura argilosa dos materiais residuais de migmatito, que compreendem $98 \%$ da unidade (Tabela 8.28). A condição de escoamento e a característica de elevada espessura destes materiais favorecem a alta 
susceptibilidade a erosão. O médio a baixo potencial agrícola é controlado pelos valoresde declividade, e pela condição de susceptibilidade a erosão.

Tabela 8.27 - Características de potencialidade e susceptibilidade do meio para unidade XIV.

\begin{tabular}{|c|c|c|c|c|}
\hline \multicolumn{5}{|c|}{ Potencial ao Escoamento } \\
\hline Classe & Área $\left(\mathrm{Km}^{2}\right)$ & $\%$ área da unidade & $\%$ área da bacia & $\begin{array}{c}\text { Parâmetros estatísticos/Mapas } \\
\text { Numéricos }\end{array}$ \\
\hline Baixa & 0,83 & 2,47 & 0,46 & Mín $-1,20$ \\
\hline Média & 10,46 & 31,22 & 1,61 & Máx $-3,55$ \\
\hline Alta & 17,99 & 53,71 & 2,72 & Média - 2,64 \\
\hline \multirow{2}{*}{ Muito Alta } & \multirow[b]{2}{*}{4,22} & \multirow[b]{2}{*}{12,59} & \multirow[b]{2}{*}{2,25} & Desv Padrão - 0,31 \\
\hline & & & & Moda $-2,40$ \\
\hline \multicolumn{5}{|c|}{ Susceptibilidade a Erosão } \\
\hline Classe & Área $\left(\mathrm{Km}^{2}\right)$ & $\%$ área da unidade & $\%$ área da bacia & $\begin{array}{c}\text { Parâmetros estatísticos/Mapas } \\
\text { Numéricos }\end{array}$ \\
\hline Baixa & 0,57 & 1,70 & 0,49 & Mín - 1,25 \\
\hline Média & 5,50 & 16,43 & 0,86 & Máx - 3,31 \\
\hline Alta & 27,40 & 81,79 & 3,51 & Média $-2,60$ \\
\hline \multirow{2}{*}{ Muito Alta } & \multirow[b]{2}{*}{0,03} & \multirow[b]{2}{*}{0,08} & \multirow[b]{2}{*}{0,02} & Desv Padrão - 0,17 \\
\hline & & & & Moda $-2,51$ \\
\hline \multicolumn{5}{|c|}{ Potencial Agrícola } \\
\hline Classe & Área $\left(\mathrm{Km}^{2}\right)$ & \% área da unidade & $\%$ área da bacia & $\begin{array}{c}\text { Parâmetros estatísticos/Mapas } \\
\text { Numéricos }\end{array}$ \\
\hline Baixa & 5,27 & 15,74 & 1,21 & Mín - 1,56 \\
\hline Média & 14,20 & 42,39 & 4,06 & Máx $-3,52$ \\
\hline Alta & 4,39 & 13,10 & 1,69 & Média $-2,43$ \\
\hline Muito Alta & 6,20 & 18,51 & 1,31 & Desv Padrão - 0,54 \\
\hline Restritiva & 3,31 & 9,88 & 2,07 & Moda $-3,38$ \\
\hline
\end{tabular}

Tabela 8.28- Atributos do meio físico da unidade XIV.

\begin{tabular}{|c|c|c|c|}
\hline Declividade $\%$ & Área $\left(\mathrm{Km}^{2}\right)$ & $\%$ área da unidade & $\%$ área da bacia \\
\hline$<2$ & 2,41 & 7,20 & 0,92 \\
\hline $2-10$ & 4,00 & 11,95 & 1,44 \\
\hline $10-20$ & 11,16 & 33,31 & 2,14 \\
\hline $20-30$ & 10,52 & 31,41 & 3,02 \\
\hline $30-45$ & 4,99 & 14,91 & 2,33 \\
\hline$>45$ & 0,42 & 1,25 & 0,80 \\
\hline Geologia & Área $\left(\mathrm{Km}^{2}\right)$ & $\%$ área da unidade & $\%$ área da bacia \\
\hline Gn Básicas & 0,48 & 1,44 & 0,11 \\
\hline Migmatitos & 33,02 & 98,56 & 7,67 \\
\hline Materiais Inco & Área $\left(\mathrm{Km}^{2}\right)$ & $\%$ área da unidade & $\%$ área da bacia \\
\hline Gnb 4 & 0,48 & 1,44 & 1,15 \\
\hline Mig 2 & 33,02 & 98,56 & 99,50 \\
\hline Classes Uso do Solo & Área $\left(\mathrm{Km}^{2}\right)$ & $\%$ área da unidade & $\%$ área da bacia \\
\hline Cafe & 0,75 & 2,25 & 0,70 \\
\hline Cidades & 0,37 & 1,11 & 1,18 \\
\hline Mata Nativa & 14,31 & 42,72 & 3,99 \\
\hline Outras Culturas & 0,77 & 2,29 & 1,04 \\
\hline Pastagem & 17,29 & 51,62 & 1,75 \\
\hline
\end{tabular}


As classes de pastagem e mata nativa destacam-se como principais atividades de ocupação do terreno vigentes na unidade. Estas correspondem, respectivamente, a 52\% e $43 \%$ da área. As atividades de café e outras culturas constituem as classes voltadas ao desenvolvimento de prática agrícola vigentes na unidade. Exibem percentual de ocorrência pouco significativo, caracterizado pela ocupação de menos de $5 \%$ da área. Esta situação mostra o aproveitamento correto das condições naturais de potencial agrícola médio a baixo apresentado pela unidade (Figura 8.14).

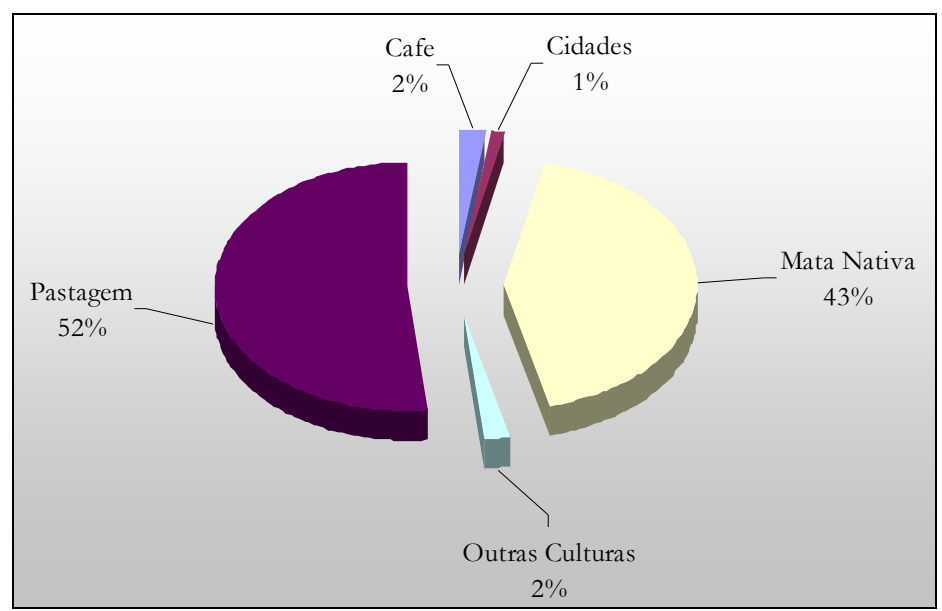

Figura 8.14 - Percentual de ocorrência das classes de uso e ocupação na Unidade Geoambiental XIV.

\section{Unidade XV}

Corresponde a unidade de terreno B7. Caracteriza-se pela ocorrência de $47 \%$ da unidade com médio potencial ao escoamento, e 39\% com potencial alto. Os valores médios dos pixels são de 2,49 (Tabela 8.29). A susceptibilidade a erosão é retratada pela predominância na área, da classe alta $(66 \%)$ e da classe média (30\%), com valores médios dos pixels de 2,56. A condição de potencial agrícola é retratada pela presença de $30 \%$ da unidade na classe baixa e $26 \%$ na classe média. Os valores médios dos pixels são de 2,39 .

Regiões com restrições legais a ocupação do meio correspondem a 10\% da unidade e constituem faixas destinadas a preservação permanente junto aos cursos de drenagem. 
Tabela 8.29 - Características de potencialidade e susceptibilidade do meio para unidade XV.

\begin{tabular}{|c|c|c|c|c|}
\hline \multicolumn{5}{|c|}{ Potencial ao Escoamento } \\
\hline Classe & Área $\left(\mathrm{Km}^{2}\right)$ & $\%$ área da unidade & $\%$ área da bacia & $\begin{array}{c}\text { Parâmetros estatísticos/Mapas } \\
\text { Numéricos }\end{array}$ \\
\hline Baixa & 0,86 & 5,50 & 0,48 & Mín $-1,07$ \\
\hline Média & 7,43 & 47,47 & 1,14 & Máx - 3,51 \\
\hline Alta & 6,19 & 39,58 & 0,94 & Média - 2,49 \\
\hline \multirow{2}{*}{ Muito Alta } & \multirow[b]{2}{*}{1,17} & \multirow[b]{2}{*}{7,45} & \multirow[b]{2}{*}{0,62} & Desv Padrão - 0,33 \\
\hline & & & & Moda $-2,35$ \\
\hline \multicolumn{5}{|c|}{ Susceptibilidade a Erosão } \\
\hline Classe & Área $\left(\mathrm{Km}^{2}\right)$ & $\%$ área da unidade & $\%$ área da bacia & $\begin{array}{c}\text { Parâmetros estatísticos/Mapas } \\
\text { Numéricos }\end{array}$ \\
\hline Baixa & 0,29 & 1,82 & 0,25 & Mín $-1,20$ \\
\hline Média & 4,78 & 30,57 & 0,75 & Máx - 3,86 \\
\hline Alta & 10,34 & 66,09 & 1,32 & Média $-2,56$ \\
\hline \multirow{2}{*}{ Muito Alta } & \multirow[b]{2}{*}{0,24} & \multirow[b]{2}{*}{1,54} & \multirow[b]{2}{*}{0,17} & Desv Padrão - 0,21 \\
\hline & & & & Moda $-2,49$ \\
\hline \multicolumn{5}{|c|}{ Potencial Agrícola } \\
\hline Classe & Área $\left(\mathrm{Km}^{2}\right)$ & $\%$ área da unidade & $\%$ área da bacia & $\begin{array}{c}\text { Parâmetros estatísticos/Mapas } \\
\text { Numéricos } \\
\end{array}$ \\
\hline Baixa & 4,72 & 30,15 & 1,09 & Mín - 1,5 \\
\hline Média & 4,13 & 26,36 & 1,18 & Máx - 3,84 \\
\hline Alta & 2,22 & 14,20 & 0,85 & Média - 2,39 \\
\hline Muito Alta & 2,98 & 19,06 & 0,63 & Desv Padrão - 0,56 \\
\hline Restritiva & 1,57 & 10,06 & 0,98 & Moda $-3,18$ \\
\hline
\end{tabular}

O médio potencial ao escoamento é condicionado pela ocorrência de declividades superiores a $20 \%$ em apenas $42 \%$ da área (Tabela 8.30), e pelas características de texturas intermediária e argilosa das unidades residuais de materiais inconsolidados presentes na unidade. A susceptibilidade média a alta apresentada é condicionada por esta característica dos materiais e pela condição de potencial ao escoamento. O baixo potencial agrícola é condicionado pelos valores de declividade superiores a $20 \%$ e pelas características de elevadas susceptibilidade a erosão.

As classes de pastagem e cidade destacam-se como principais atividades de ocupação do terreno vigentes na unidade. Estas correspondem, respectivamente, a 44\% e $29 \%$ da área (Figura 8.14). As atividades voltadas ao desenvolvimento de práticas agrícolas não ocorrem na unidade. Esta situação mostra o aproveitamento pouco adequado das condições naturais de potencial agrícola apresentado pela unidade, haja vista que $33 \%$ da ares exibem elevado potencial. 
Tabela 8.30- Atributos do meio físico da unidade XV.

\begin{tabular}{|c|c|c|c|}
\hline Declividade \% & Área $\left(\mathrm{Km}^{2}\right)$ & $\%$ área da unidade & $\%$ área da bacia \\
\hline$<2$ & 1,32 & 8,47 & 0,50 \\
\hline $2-10$ & 2,21 & 14,13 & 0,79 \\
\hline $10-20$ & 5,51 & 35,18 & 1,05 \\
\hline $20-30$ & 3,93 & 25,14 & 1,13 \\
\hline $30-45$ & 2,33 & 14,88 & 1,09 \\
\hline$>45$ & 0,35 & 2,25 & 0,68 \\
\hline Geologia & Área $\left(\mathrm{Km}^{2}\right)$ & $\%$ área da unidade & $\%$ área da bacia \\
\hline Gn Básicas & 9,63 & 61,51 & 2,19 \\
\hline Migmatitos & 6,03 & 38,51 & 1,40 \\
\hline Materiais Inço & Área $\left(\mathrm{Km}^{2}\right)$ & $\%$ área da unidade & $\%$ área da bacia \\
\hline Gnb 4 & 1,30 & 8,28 & 3,09 \\
\hline Gnb 9 & 8,51 & 54,36 & 99,92 \\
\hline Mig 2 & 0,01 & 0,05 & 0,02 \\
\hline Mig 3 & 5,84 & 37,34 & 20,12 \\
\hline Classes Uso do Solo & Área $\left(\mathrm{Km}^{2}\right)$ & $\%$ área da unidade & $\%$ área da bacia \\
\hline Cidades & 4,62 & 29,51 & 14,61 \\
\hline Mata Nativa & 4,00 & 25,57 & 1,12 \\
\hline Pastagem & 7,03 & 44,92 & 0,71 \\
\hline
\end{tabular}

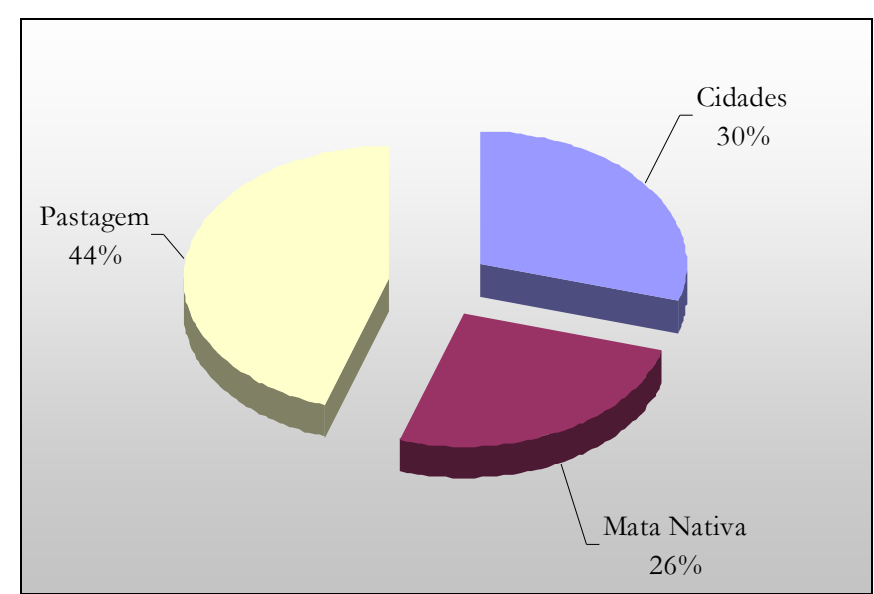

Figura 8.15 - Percentual de ocorrência das classes de uso e ocupação na Unidade Geoambiental XV.

\section{$\underline{\text { Unidade XVI }}$}

Corresponde a unidade de terreno B8. Caracteriza-se por apresentar $42 \%$ de sua área com alto potencial ao escoamento, e 36\% com potencial médio. Os pixels presentes na superfície contínua representativa deste aspecto exibem valores médios de 2,64. (Tabela 8.31). A susceptibilidade a erosão é retratada pela ocorrência de $46 \%$ da unidade na classe alta e 40\% na classe média. Os valores médios dos pixels são de 2,58. 
Tabela 8.31 - Características de potencialidade e susceptibilidade do meio para unidade XVI.

\begin{tabular}{|c|c|c|c|c|}
\hline \multicolumn{5}{|c|}{ Potencial ao Escoamento } \\
\hline Classe & Área $\left(\mathrm{Km}^{2}\right)$ & $\%$ área da unidade & $\%$ área da bacia & $\begin{array}{c}\text { Parâmetros estatísticos/Mapas } \\
\text { Numéricos }\end{array}$ \\
\hline Baixa & 0,53 & 3,50 & 0,29 & Mín $-1,25$ \\
\hline Média & 5,50 & 36,62 & 0,85 & Máx - 3,85 \\
\hline Alta & 6,38 & 42,45 & 0,97 & Média $-2,64$ \\
\hline \multirow{2}{*}{ Muito Alta } & \multirow[b]{2}{*}{2,58} & \multirow[b]{2}{*}{17,18} & \multirow[b]{2}{*}{1,38} & Desv Padrão - 0,58 \\
\hline & & & & Moda $-1,84$ \\
\hline \multicolumn{5}{|c|}{ Susceptibilidade a Erosão } \\
\hline Classe & Área $\left(\mathrm{Km}^{2}\right)$ & $\%$ área da unidade & \% área da bacia & $\begin{array}{c}\text { Parâmetros estatísticos/Mapas } \\
\text { Numéricos }\end{array}$ \\
\hline Baixa & 0,18 & 1,22 & 0,16 & Mín - 1,27 \\
\hline Média & 5,98 & 39,84 & 0,94 & Máx - 3,59 \\
\hline Alta & 7,03 & 46,82 & 0,90 & Média $-2,58$ \\
\hline \multirow{2}{*}{ Muito Alta } & \multirow[b]{2}{*}{1,82} & \multirow[b]{2}{*}{12,12} & \multirow[b]{2}{*}{1,29} & Desv Padrão - 0,35 \\
\hline & & & & Moda $-2,10$ \\
\hline \multicolumn{5}{|c|}{ Potencial Agrícola } \\
\hline Classe & Área $\left(\mathrm{Km}^{2}\right)$ & \% área da unidade & $\%$ área da bacia & $\begin{array}{c}\text { Parâmetros estatísticos/Mapas } \\
\text { Numéricos }\end{array}$ \\
\hline Baixa & 4,43 & 29,52 & 1,02 & Mín - 1,59 \\
\hline Média & 3,87 & 25,76 & 1,11 & Máx $-3,7$ \\
\hline Alta & 1,57 & 10,46 & 0,60 & Média $-2,31$ \\
\hline Muito Alta & 2,69 & 17,88 & 0,57 & Desv Padrão - 0,62 \\
\hline Restritiva & 2,43 & 16,20 & 1,52 & Moda - 3,41 \\
\hline
\end{tabular}

O potencial agrícola é caracterizado pela ocorrência de $29 \%$ da unidade na classe Baixa, e 26\% na classe média, com valores médios dos pixels de 2,31.

Regiões com restrições legais a ocupação do meio correspondem a $16 \%$ da unidade e constituem, principalmente, faixas destinadas a preservação permanente junto aos cursos de drenagem.

As condições de potencial a escoamento médio a alto são favorecidas principalmente pela ocorrência em metade da unidade de valores de declividade superiores a $20 \%$ (tabela 8.32). A condição de susceptibilidade a erosão, também média a alta, é condicionada pelas características do potencial ao escoamento, pela textura areno-argilosa dos materiais resíduas de quartzitos que constituem $54 \%$ da unidade, e arenosa dos materiais retrabalhados presentes em $40 \%$ da unidade, além dos valores de espessuras apresentados por estes últimos.

A ocorrência de $55 \%$ da área com potencial agrícola baixo a médio é devida aos valores de declividade superiores a $20 \%$, que ocorrem em aproximadamente metade da área, além da condição de elevada susceptibilidade a erosão. 
Tabela 8.32- Atributos do meio físico da unidade XVI.

\begin{tabular}{|c|c|c|c|}
\hline Declividade $\%$ & Área $\left(\mathrm{Km}^{2}\right)$ & $\%$ área da unidade & $\%$ área da bacia \\
\hline$<2$ & 1,40 & 9,31 & 0,53 \\
\hline $2-10$ & 1,80 & 11,97 & 0,65 \\
\hline $10-20$ & 4,27 & 28,42 & 0,82 \\
\hline $20-30$ & 3,67 & 24,46 & 1,06 \\
\hline $30-45$ & 2,83 & 18,84 & 1,32 \\
\hline$>45$ & 1,05 & 6,99 & 2,01 \\
\hline Geologia & Área $\left(\mathrm{Km}^{2}\right)$ & $\%$ área da unidade & $\%$ área da bacia \\
\hline Gn Básicas & 0,93 & 6,21 & 0,21 \\
\hline Qartzitos & 12,50 & 83,21 & 27,19 \\
\hline Migmatitos & 1,62 & 10,76 & 0,38 \\
\hline Gn Básicas & 0,93 & 6,21 & 0,21 \\
\hline Materiais Inco & Área $\left(\mathrm{Km}^{2}\right)$ & $\%$ área da unidade & $\%$ área da bacia \\
\hline Retrab 2 & 6,06 & 40,37 & 12,18 \\
\hline Gnb 6 & 0,31 & 2,06 & 1,11 \\
\hline Gnb 7 & 0,01 & 0,08 & 0,12 \\
\hline Mig 1 & 0,18 & 1,23 & 1,17 \\
\hline Mig 4 & 0,24 & 1,62 & 0,79 \\
\hline Qtz 2 & 8,21 & 54,64 & 47,27 \\
\hline Classes Uso do Solo & Área $\left(\mathrm{Km}^{2}\right)$ & $\%$ área da unidade & $\%$ área da bacia \\
\hline Café & 1,24 & 8,28 & 1,16 \\
\hline Mata Nativa & 3,68 & 24,52 & 1,03 \\
\hline Mata Ciliar & 0,06 & 0,38 & 0,17 \\
\hline Pastagem & 10,04 & 66,82 & 1,02 \\
\hline
\end{tabular}

As classes de pastagem e mata nativa destacam-se como principais atividades de ocupação do terreno vigentes na unidade. Correspondem, respectivamente, a 67\% e $25 \%$ da área (Figura 8.16). A ocorrência pouco significativa, apenas $8 \%$, da atividade de cultivo de café retrata um aproveitamento adequado das condições naturais de potencial agrícola exibidas pela unidade.

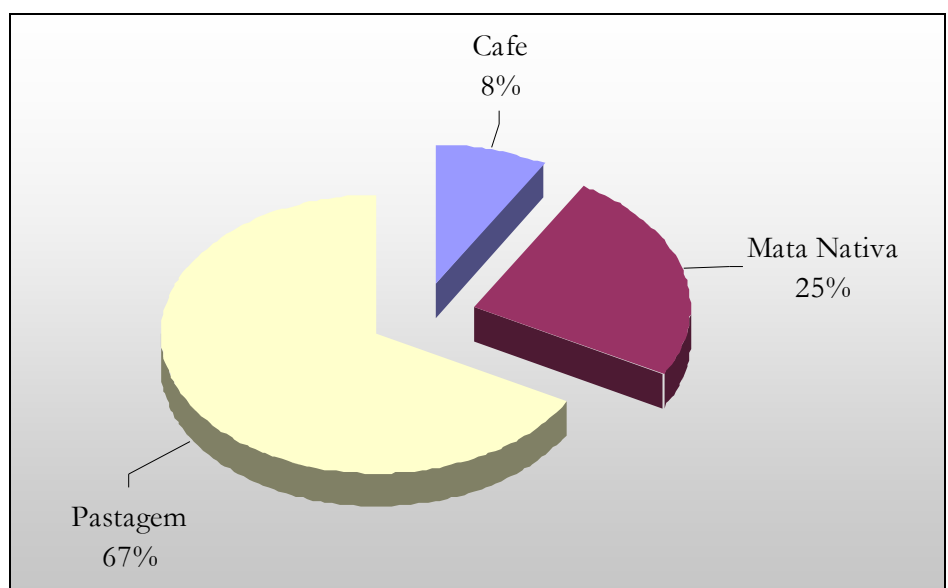

Figura 8.16 - Percentual de ocorrência das classes de uso e ocupação na Unidade Geoambiental XVI. 


\section{Unidade XVII}

Corresponde a unidade de terreno C1. Apresenta potencial ao escoamento caracterizado por $40 \%$ correspondendo a classe alta, com valores médios de pixels de 2,89. A susceptibilidade a erosão é caracterizada por $87 \%$ da unidade estar compreendida na classe alta, e apresentar valores médio de pixels de 2,77. O potencial agrícola é constituído por predominância da classe baixa, correspondendo à ocorrência em área de 59\%, e por valores médios de pixels de 2,04 (Tabela 8.33).

Tabela 8.33 - Características de potencialidade e susceptibilidade do meio para unidade XVII.

\begin{tabular}{|c|c|c|c|c|}
\hline \multicolumn{5}{|c|}{ Potencial ao Escoamento } \\
\hline Classe & Área $\mathrm{Km}^{2}$ ) & $\begin{array}{l}\% \text { área } \mathrm{da} \\
\text { unidade }\end{array}$ & $\%$ área da bacia & $\begin{array}{c}\text { Parâmetros estatísticos/Mapas } \\
\text { Numéricos }\end{array}$ \\
\hline Baixa & 0,18 & 1,64 & 0,10 & Mín - 1,81 \\
\hline Média & 1,63 & 14,90 & 0,25 & Máx - 3,74 \\
\hline Alta & 4,39 & 40,07 & 0,66 & Média - 2,89 \\
\hline \multirow{2}{*}{ Muito Alta } & \multirow[b]{2}{*}{4,75} & \multirow[b]{2}{*}{43,38} & \multirow[b]{2}{*}{2,53} & Desv Padrão - 0,38 \\
\hline & & & & Moda $-3,46$ \\
\hline \multicolumn{5}{|c|}{ Susceptibilidade a Erosão } \\
\hline Classe & Área $\left(\mathrm{m}^{2}\right)$ & $\begin{array}{l}\text { \% área da } \\
\text { unidade }\end{array}$ & $\%$ área da bacia & $\begin{array}{c}\text { Parâmetros estatísticos/Mapas } \\
\text { Numéricos }\end{array}$ \\
\hline Baixa & 0,15 & 1,34 & 0,13 & Mín - 1,28 \\
\hline Média & 0,53 & 4,83 & 0,08 & Máx - 3,77 \\
\hline Alta & 9,57 & 87,38 & 1,22 & Média - 2,77 \\
\hline \multirow{2}{*}{ Muito Alta } & & \multirow[b]{2}{*}{6,42} & \multirow[b]{2}{*}{0,50} & Desv Padrão - 0,20 \\
\hline & 0,70 & & & Moda $-3,02$ \\
\hline \multicolumn{5}{|c|}{ Potencial Agrícola } \\
\hline Classe & Área $\mathrm{Km}^{2}$ ) & $\begin{array}{l}\% \text { área } \mathrm{da} \\
\text { unidade }\end{array}$ & $\%$ área da bacia & $\begin{array}{c}\text { Parâmetros estatísticos/Mapas } \\
\text { Numéricos }\end{array}$ \\
\hline Baixa & 6,46 & 58,95 & 1,49 & Mín - 1,48 \\
\hline Média & 0,81 & 7,42 & 0,23 & Máx - 3,43 \\
\hline Alta & 0,59 & 5,42 & 0,23 & Média - 2,04 \\
\hline Muito Alta & 0,75 & 6,83 & 0,16 & Desv Padrão - 0,42 \\
\hline Restritiva & 2,35 & 21,43 & 1,47 & Moda $-1,81$ \\
\hline
\end{tabular}

Regiões com restrições legais a ocupação do meio correspondem a 21\% da unidade e constituem, tanto faixas destinadas à preservação permanente junto aos cursos de drenagem com áreas coma valores de declividade acima de $25^{\circ}$.

A ocorrência de valores elevados de declividade em $73 \%$ da unidade e a predominância dos materiais residuais de gnaisses intercalados com rochas básicas (Tabela 8.34), os quais exibem textura residual intermediária e espessuras entre 1 e 3 metros caracterizam os fatores responsáveis pelo alto potencial ao escoamento da unidade. A condição de escoamento e a textura dos materiais inconsolidados favorecem a situação de elevada susceptibilidade a erosão. 
Tabela 8.34- Atributos do meio físico da unidade XVII.

\begin{tabular}{|c|c|c|c|}
\hline Declividade \% & Área $\left(\mathrm{Km}^{2}\right)$ & $\%$ área da unidade & $\%$ área da bacia \\
\hline$<2$ & 0,28 & 2,52 & 0,10 \\
\hline $2-10$ & 0,67 & 6,15 & 0,24 \\
\hline $10-20$ & 1,88 & 17,20 & 0,36 \\
\hline $20-30$ & 2,39 & 21,84 & 0,69 \\
\hline $30-45$ & 4,03 & 36,80 & 1,88 \\
\hline$>45$ & 1,70 & 15,53 & 3,26 \\
\hline Geologia & Área $\left(\mathrm{Km}^{2}\right)$ & $\%$ área da unidade & $\%$ área da bacia \\
\hline Gn Básicas & 10,95 & 100,00 & 2,50 \\
\hline Materiais Inco & Área $\left(\mathrm{Km}^{2}\right)$ & $\%$ área da unidade & $\%$ área da bacia \\
\hline Retrab 2 & 0,01 & 0,12 & 0,03 \\
\hline Gnb 7 & 10,9 & 99,88 & 99,88 \\
\hline Classes Uso do Solo & Área $\left(\mathrm{Km}^{2}\right)$ & $\%$ área da unidade & $\%$ área da bacia \\
\hline Mata Nativa & 3,30 & 30,17 & 0,92 \\
\hline Pastagem & 7,65 & 69,83 & 0,77 \\
\hline
\end{tabular}

O baixo potencial agrícola é condicionado pela predominância de valores de declividade acima de $20 \%$, fator que impõem sérias restrições ao desenvolvimento de práticas agrícolas, além das características pouco favoráveis de textura dos materiais inconsolidados.

Nesta unidade é registrada a ocorrência de apenas duas classes de ocupação do solo, pastagem e mata nativa (Figura 8.17).

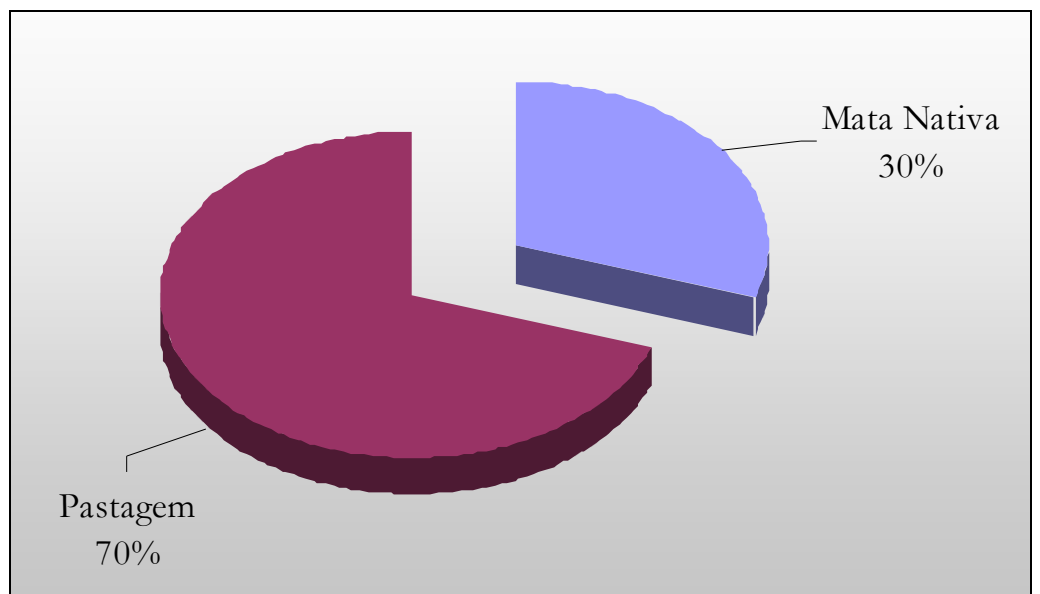

Figura 8.17 - Percentual de ocorrência das classes de uso e ocupação na Unidade Geoambiental XVII. 


\section{Unidade XVIII}

Corresponde unidade de terreno C2. Apresenta condição de potencial ao escoamento caracterizado pela ocorrência de $54 \%$ da unidade na classe média e 34\% na classe alta, com valores médios de pixels de 2,44. A susceptibilidade a erosão é retratada pela ocorrência de $74 \%$ da unidade na classe alta, com valores médios de pixels de 2,84. O potencial agrícola da unidade é representado pela ocorrência de $34 \%$ da área compreendida na classe baixa e $22 \%$ na classe muito alta, com valores médios dos pixels de 2,47 (Tabela 8.35).

Regiões com restrições legais a ocupação do meio correspondem a 15\% da unidade e constituem, principalmente, faixas destinadas a preservação permanente junto aos cursos de drenagem, e secundariamente a áreas com valores de declividade acima de $25^{\circ}$

Tabela 8.35 - Características de potencialidade e susceptibilidade do meio para unidade XVIII.

\begin{tabular}{|c|c|c|c|c|}
\hline \multicolumn{5}{|c|}{ Potencial ao Escoamento } \\
\hline Classe & Área $\left(\mathrm{Km}^{2}\right)$ & \% área da unidade & $\begin{array}{l}\% \text { área } \mathrm{da} \\
\text { bacia }\end{array}$ & $\begin{array}{c}\text { Parâmetros estatísticos/Mapas } \\
\text { Numéricos }\end{array}$ \\
\hline Baixa & 1,02 & 5,31 & 0,57 & Mín - 1,52 \\
\hline Média & 10,41 & 54,40 & 1,60 & Máx - 3,55 \\
\hline Alta & 6,45 & 33,71 & 0,98 & Média $-2,44$ \\
\hline \multirow{2}{*}{ Muito Alta } & \multirow[b]{2}{*}{1,26} & \multirow[b]{2}{*}{6,57} & \multirow[b]{2}{*}{0,67} & Desv Padrão - 0,32 \\
\hline & & & & Moda - 2,11 \\
\hline \multicolumn{5}{|c|}{ Susceptibilidade a Erosão } \\
\hline Classe & Área $\left(\mathrm{Km}^{2}\right)$ & $\%$ área da unidade & $\begin{array}{c}\% \text { área da } \\
\text { bacia }\end{array}$ & $\begin{array}{c}\text { Parâmetros estatísticos/Mapas } \\
\text { Numéricos }\end{array}$ \\
\hline Baixa & 0,02 & 0,10 & 0,02 & Mín - 1,42 \\
\hline Média & 0,97 & 5,04 & 0,15 & Máx - 3,98 \\
\hline Alta & 14,20 & 74,21 & 1,82 & Média - 2,84 \\
\hline \multirow{2}{*}{ Muito Alta } & \multirow[b]{2}{*}{3,95} & \multirow[b]{2}{*}{20,63} & \multirow[b]{2}{*}{2,81} & Desv Padrão - 0,19 \\
\hline & & & & Moda - 2,79 \\
\hline \multicolumn{5}{|c|}{ Potencial Agrícola } \\
\hline Classe & Área $\left(\mathrm{Km}^{2}\right)$ & $\%$ área da unidade & $\begin{array}{l}\% \text { área da } \\
\text { bacia }\end{array}$ & $\begin{array}{c}\text { Parâmetros estatísticos/Mapas } \\
\text { Numéricos }\end{array}$ \\
\hline Baixa & 6,64 & 34,69 & 1,53 & Mín - 1,56 \\
\hline Média & 3,36 & 17,57 & 0,96 & Máx - 3,79 \\
\hline Alta & 2,08 & 10,87 & 0,80 & Média $-2,47$ \\
\hline Muito Alta & 4,17 & 21,78 & 0,88 & Desv Padrão - 0,58 \\
\hline Restritiva & 2,88 & 15,02 & 1,80 & Moda - 3,34 \\
\hline
\end{tabular}

A presença em metade da unidade de valores de declividade superiores a 20\% (Tabela 8.36), somada as características de textura intermediária exibidas pelos materiais residuais de gnaisses intercalados a rocha básicas, os quais compreende $83 \%$ da 
unidade condicionam o potencial médio a alto do escoamento superficial, e a alta susceptibilidade a erosão apresentada pela unidade. O potencial agrícola variável da unidade é controlado, predominantemente, pelas características de declividade.

Tabela 8.36- Atributos do meio físico da unidade XVIII.

\begin{tabular}{|c|c|c|c|}
\hline Declividade $\%$ & Área $\left(\mathrm{Km}^{2}\right)$ & $\%$ área da unidade & $\%$ área da bacia \\
\hline$<2$ & 2,62 & 13,69 & 1,00 \\
\hline $2-10$ & 2,22 & 11,58 & 0,80 \\
\hline $10-20$ & 5,26 & 27,46 & 1,01 \\
\hline $20-30$ & 4,87 & 25,45 & 1,40 \\
\hline $30-45$ & 3,38 & 17,64 & 1,57 \\
\hline$>45$ & 0,81 & 4,21 & 1,54 \\
\hline Geologia & Área $\left(\mathrm{Km}^{2}\right)$ & $\%$ área da unidade & $\%$ área da bacia \\
\hline Gn Básicas & 16,07 & 83,99 & 3,66 \\
\hline Migmatitos & 3,06 & 16,01 & 0,71 \\
\hline Materiais Inco & Área $\left(\mathrm{Km}^{2}\right)$ & $\%$ área da unidade & $\%$ área da bacia \\
\hline Gnb 5 & 15,70 & 82,05 & 100,00 \\
\hline Gnb 6 & 0,37 & 1,93 & 1,33 \\
\hline Mig 1 & 1,91 & 9,99 & 12,11 \\
\hline $\operatorname{Mig} 4$ & 1,51 & 7,91 & 4,90 \\
\hline Classes Uso do Solo & Área $\left(\mathrm{Km}^{2}\right)$ & $\%$ área da unidade & $\%$ área da bacia \\
\hline Cafe & 3,17 & 16,55 & 2,96 \\
\hline Corpos D água & 0,05 & 0,24 & 1,06 \\
\hline Mata Nativa & 3,28 & 17,12 & 0,91 \\
\hline Mata Ciliar & 0,50 & 2,59 & 1,48 \\
\hline Pastagem & 12,15 & 63,51 & 1,23 \\
\hline
\end{tabular}

Nesta unidade, a atividade de pastagem caracteriza-se como a classe com maior destaque na ocupação do solo (Figura 8.18). Atividades voltadas a prática agrícola constituem apenas 17\%, o que caracteriza um aproveitamento adequado as condições variáveis de potencial agrícola oferecida pelo meio. 


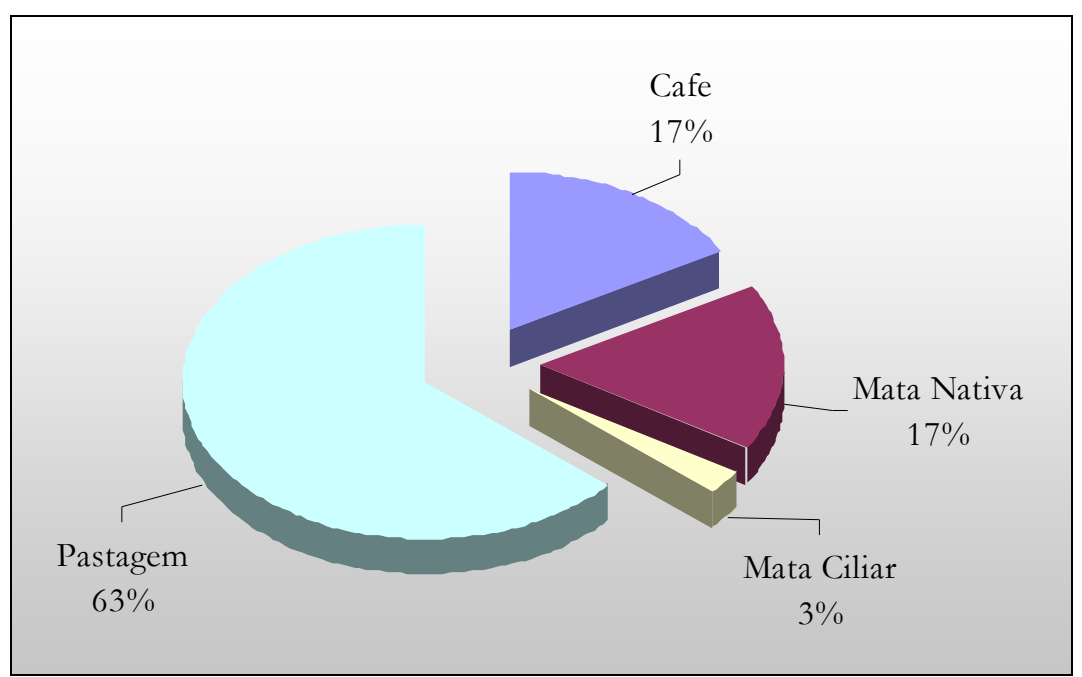

Figura 8.18 - Percentual de ocorrência das classes de uso e ocupação na Unidade Geoambiental XVIII.

\section{$\underline{\text { Unidade XIX }}$}

Corresponde a unidade de terreno C3. Apresenta condição de potencial ao escoamento é caracterizada pela ocorrência de 46\% da unidade na classe alta, e 29\% na classe média, com valores médios dos pixels 2,56. O aspecto de susceptibilidade a erosão é retratados pela predominância da classe alta, $74 \%$ da área, com valores médios dos pixels de 3,6. O potencial agrícola é representado pela ocorrência de $50 \%$ da unidade na classe média, com valores médios dos pixels de 2,22 (Tabela 8.37).

Regiões com restrições legais a ocupação do meio correspondem a $20 \%$ da unidade e constituem, tanto faixas destinadas a preservação permanente junto aos cursos de drenagem, como a áreas com valores de declividade acima de $25^{\circ}$.

O elevado potencial ao escoamento é condicionado pela predominância de valores de declividade acima de $20 \%$ (Tabela 8.38), e pela característica de textura intermediária dos materiais residuais de migmatitos presentes na área. A condição de elevado escoamento superficial e os valores de espessura dos materiais inconsolidados, acima de 5,0 metros, constituem os fatores preponderantes á situação de alta susceptibilidade a erosão. A ocorrência de classe predominante de médio potencial agrícola é devida as características de declividade, além elevada susceptibilidade a erosão.

As classes de pastagem e mata nativa destacam-se como principais atividades de ocupação do terreno vigentes na unidade. Correspondem, respectivamente, a 55\% e $42 \%$ da área (Figura 8.19). O aproveitamento inadequado das condições naturais de 
médio potencial agrícola apresentado é retratado pela inexistência de atividades voltadas ao desenvolvimento de práticas agrícolas.

Tabela 8.37 - Características de potencialidade e susceptibilidade do meio para unidade XIX.

\begin{tabular}{|c|c|c|c|c|}
\hline \multicolumn{5}{|c|}{ Potencial ao Escoamento } \\
\hline Classe & Área $\left(\mathrm{Km}^{2}\right)$ & $\%$ área da unidade & $\%$ área da bacia & $\begin{array}{c}\text { Parâmetros estatísticos/Mapas } \\
\text { Numéricos }\end{array}$ \\
\hline Baixa & 1,17 & 4,84 & 0,65 & Mín - 1,57 \\
\hline Média & 7,02 & 29,00 & 1,08 & Máx - 3,68 \\
\hline Alta & 11,23 & 46,39 & 1,70 & Média $-2,56$ \\
\hline \multirow{2}{*}{ Muito Alta } & \multirow[b]{2}{*}{4,78} & \multirow[b]{2}{*}{19,76} & \multirow[b]{2}{*}{2,55} & Desv Padrão - 0,36 \\
\hline & & & & Moda $-3,24$ \\
\hline \multicolumn{5}{|c|}{ Susceptibilidade a Erosão } \\
\hline Classe & Área $\left(\mathrm{Km}^{2}\right)$ & $\%$ área da unidade & \% área da bacia & $\begin{array}{c}\text { Parâmetros estatísticos/Mapas } \\
\text { Numéricos }\end{array}$ \\
\hline Baixa & 0,10 & 0,41 & 0,09 & Mín - 1,43 \\
\hline Média & 5,99 & 24,76 & 0,94 & Máx - 2,85 \\
\hline Alta & 18,08 & 74,68 & 2,31 & Média $-3,60$ \\
\hline \multirow{2}{*}{ Muito Alta } & \multirow[b]{2}{*}{0,03} & \multirow[b]{2}{*}{0,14} & \multirow[b]{2}{*}{0,02} & Desv Padrão - 0,18 \\
\hline & & & & Moda $-2,87$ \\
\hline \multicolumn{5}{|c|}{ Potencial Agrícola } \\
\hline Classe & Área $\left(\mathrm{Km}^{2}\right)$ & \% área da unidade & $\%$ área da bacia & $\begin{array}{c}\text { Parâmetros estatísticos/Mapas } \\
\text { Numéricos }\end{array}$ \\
\hline Baixa & 3,31 & 13,69 & 0,76 & Mín - 1,54 \\
\hline Média & 12,20 & 50,39 & 3,49 & Máx $-3,7$ \\
\hline Alta & 1,73 & 7,13 & 0,66 & Média $-2,22$ \\
\hline Muito Alta & 2,13 & 8,80 & 0,45 & Desv Padrão - 0,43 \\
\hline Restritiva & 4,86 & 20,06 & 3,04 & Moda - 1,98 \\
\hline
\end{tabular}

Tabela 8.38- Atributos do meio físico da unidade XIX.

\begin{tabular}{|c|c|c|c|}
\hline Declividade \% & Área $\left(\mathrm{Km}^{2}\right)$ & $\%$ área da unidade & $\%$ área da bacia \\
\hline$<2$ & 0,63 & 2,59 & 0,24 \\
\hline $2-10$ & 1,38 & 5,69 & 0,50 \\
\hline $10-20$ & 4,81 & 19,88 & 0,92 \\
\hline $20-30$ & 6,52 & 26,93 & 1,87 \\
\hline $30-45$ & 7,86 & 32,49 & 3,67 \\
\hline$>45$ & 3,01 & 12,43 & 5,76 \\
\hline Geologia & Área $\left(\mathrm{Km}^{2}\right)$ & $\%$ área da unidade & $\%$ área da bacia \\
\hline Qartzitos & 0,19 & 0,78 & 0,41 \\
\hline Migmatitos & 24,02 & 99,22 & 5,58 \\
\hline Materiais Inco & Área $\left(\mathrm{Km}^{2}\right)$ & $\%$ área da unidade & $\%$ área da bacia \\
\hline Retrab 2 & 1,02 & 4,20 & 2,04 \\
\hline Mig 4 & 23,17 & 95,73 & 74,95 \\
\hline Qtz 2 & 0,02 & 0,07 & 0,09 \\
\hline Classes Uso do Solo & Área $\left(\mathrm{Km}^{2}\right)$ & $\%$ área da unidade & $\%$ área da bacia \\
\hline Cafe & 0,09 & 0,39 & 0,09 \\
\hline Cidades & 0,60 & 2,49 & 1,91 \\
\hline Mata Nativa & 10,04 & 41,49 & 2,80 \\
\hline Pastagem & 13,46 & 55,63 & 1,36 \\
\hline
\end{tabular}




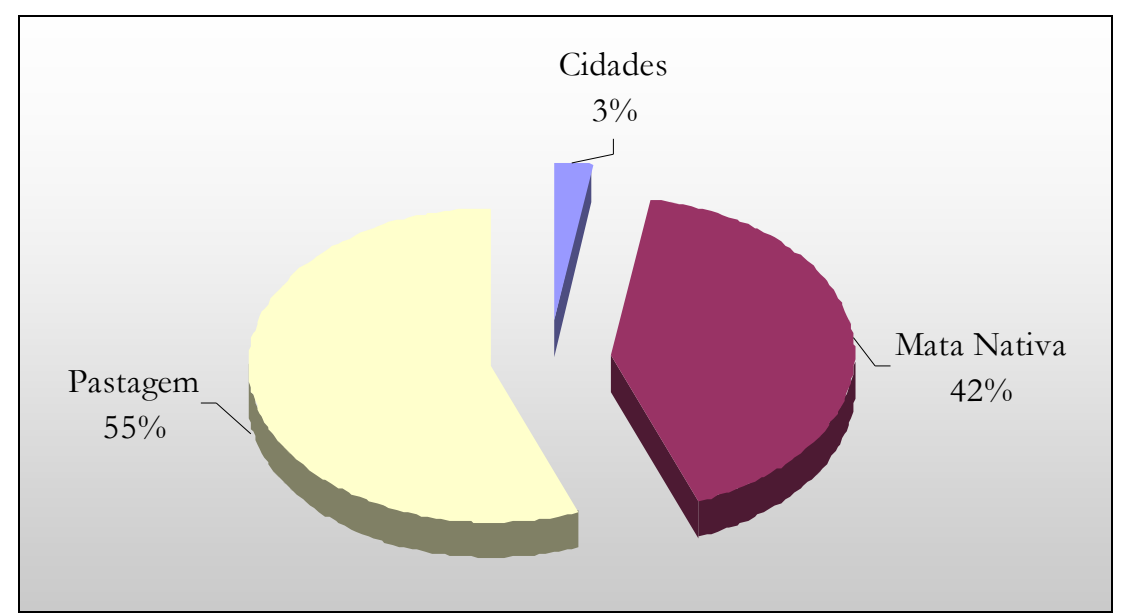

Figura 8.19 - Percentual de ocorrência das classes de uso e ocupação na Unidade Geoambiental XIX.

\section{$\underline{\text { Unidade XX }}$}

Corresponde a unidade de terreno C4. Caracteriza-se por apresentar 33\% de sua área com médio potencial ao escoamento, e 34\% com alto potencial. Os valores médios dos pixels são de 2,53 (Tabela 8.39).

Tabela 8.39 - Características de potencialidade e susceptibilidade do meio para unidade XX.

\begin{tabular}{|c|c|c|c|c|}
\hline \multicolumn{5}{|c|}{ Potencial ao Escoamento } \\
\hline Classe & Área $\left(\mathrm{Km}^{2}\right)$ & $\begin{array}{ll}\% \text { área } & \mathrm{da} \\
\text { unidade } & \\
\end{array}$ & $\%$ área da bacia & $\begin{array}{c}\text { Parâmetros estatísticos/Mapas } \\
\text { Numéricos }\end{array}$ \\
\hline Baixa & 8,09 & 19,17 & 4,50 & Mín - 0,98 \\
\hline Média & 13,99 & 33,14 & 2,15 & Máx - 4,34 \\
\hline Alta & 14,36 & 34,01 & 2,17 & Média $-2,53$ \\
\hline \multirow{2}{*}{ Muito Alta } & \multirow{2}{*}{\multicolumn{2}{|c|}{21,09}} & \multirow[b]{2}{*}{4,75} & Desv Padrão - 0,53 \\
\hline & & & & Moda $-1,87$ \\
\hline \multicolumn{5}{|c|}{ Susceptibilidade a Erosão } \\
\hline Classe & Área $\left(\mathrm{Km}^{2}\right)$ & $\begin{array}{l}\% \text { área da } \\
\text { unidade }\end{array}$ & $\%$ área da bacia & $\begin{array}{l}\text { Parâmetros estatísticos/Mapas } \\
\text { Numéricos }\end{array}$ \\
\hline Baixa & 1,75 & 4,15 & 1,51 & Mín-1,13 \\
\hline Média & 5,96 & 14,11 & 0,93 & Máx - 4,39 \\
\hline Alta & 17,12 & 40,57 & 2,19 & Média $-2,87$ \\
\hline \multirow{2}{*}{ Muito Alta } & & \multirow[b]{2}{*}{48,59} & \multirow[b]{2}{*}{14,58} & Desv Padrão $-0,4$ \\
\hline & 20,51 & & & Moda $-3,09$ \\
\hline \multicolumn{5}{|c|}{ Potencial Agrícola } \\
\hline Classe & Área $\left(\mathrm{Km}^{2}\right)$ & $\begin{array}{ll}\% \text { área } & \mathrm{da} \\
\text { unidade }\end{array}$ & $\%$ área da bacia & $\begin{array}{c}\text { Parâmetros estatísticos/Mapas } \\
\text { Numéricos }\end{array}$ \\
\hline Baixa & 15,30 & 36,25 & 3,52 & Mín - 1,4 \\
\hline Média & 10,12 & 23,98 & 2,89 & Máx - 3,84 \\
\hline Alta & 4,83 & 11,45 & 1,86 & Média - 2,27 \\
\hline Muito Alta & 7,66 & 18,14 & 1,62 & Desv Padrão - 0,59 \\
\hline Restritiva & 7,36 & 17,44 & 4,60 & Moda $-3,10$ \\
\hline
\end{tabular}


A condição de susceptibilidade a erosão é caracterizada pela ocorrência de $48 \%$ da área na classe muito alta e 40\% na classe alta, com valores médios dos pixels de 2,87. O potencial agrícola é caracterizado pela ocorrência de 53\% da área na classe alta, e 24\% na classe média, e 36\% na baixa. Os valores médios dos pixels são de 2,27.

Regiões com restrições legais a ocupação do meio correspondem a 17\% da unidade e constituem, principalmente, faixas destinadas a preservação permanente junto aos cursos de drenagem, e secundariamente a áreas com valores de declividade acima de $25^{\circ}$.

A ocorrência do potencial escoamento médio a alto é condicionado pela predominância de valores de declividade acima de $20 \%$, e pela influência da variação de texturas apresentadas pelos materiais inconsolidados presentes na área (Tabela 8.40). A elevada susceptibilidade a erosão é condicionada pelo aspecto de potencial ao escoamento, e principalmente pela forte influência das características de textura arenosa e intermediária apresentadas pelos materiais inconsolidados presentes em maiores percentuais na unidade, residuais de gnaisses intercalados a rochas básicas e ultramilonitos, respectivamente. O potencial agrícola médio a baixo é condicionado de pelas as características de declividade do terreno, que constituem fator restritivo ao desenvolvimento de práticas voltadas a este fim.

As classes de pastagem e mata nativa destacam-se como principais atividades de ocupação do terreno vigentes na unidade (Figura 8.20). Com ocorrência secundária observa-se a ocupação por cidades. Atividades voltadas ao desenvolvimento de práticas agrícolas ocorrem com percentuais poucos significativos, o que é devido a predominância de valores elevados de declividade, condição restritiva a instalação de atividades voltadas a estes fins.

\section{Unidade XXI}

Corresponde a unidade de terreno C5. Apresenta potencial ao escoamento caracterizado pela ocorrência de $40 \%$ da unidade na classe alta, e $28 \%$ na classe média, com valores médios dos pixels de 2,68 (Tabela 8.41). 
Tabela 8.40- Atributos do meio físico da unidade XX.

\begin{tabular}{|c|c|c|c|}
\hline Classes Declivid \% & Área $\left(\mathrm{Km}^{2}\right)$ & $\%$ área da unidade & $\%$ área da bacia \\
\hline$<2$ & 3,74 & 8,85 & 1,42 \\
\hline $2-10$ & 5,64 & 13,37 & 2,03 \\
\hline $10-20$ & 12,45 & 29,50 & 2,39 \\
\hline $20-30$ & 10,27 & 24,34 & 2,95 \\
\hline $30-45$ & 9,53 & 22,59 & 4,44 \\
\hline$>45$ & 3,70 & 8,77 & 7,10 \\
\hline Geologia & Área $\left(\mathrm{Km}^{2}\right)$ & $\%$ área da unidade & $\%$ área da bacia \\
\hline Gn Básicas & 20,52 & 48,62 & 4,68 \\
\hline Qartzitos & 9,44 & 22,37 & 20,54 \\
\hline Migmatitos & 6,70 & 15,87 & 1,56 \\
\hline Ultramilonitos & 8,68 & 20,56 & 8,68 \\
\hline Gn Básicas & 20,52 & 48,62 & 4,68 \\
\hline Materiais Inco & Área $\left(\mathrm{Km}^{2}\right)$ & $\%$ área da unidade & $\%$ área da bacia \\
\hline Retrab 1 & 1,41 & 3,35 & 1,49 \\
\hline Retrab 2 & 2,38 & 5,64 & 4,78 \\
\hline Gnb 8 & 17,91 & 42,44 & 59,59 \\
\hline Mig 4 & 0,04 & 0,09 & 0,12 \\
\hline Mig 5 & 5,26 & 12,45 & 100,00 \\
\hline Qtz 2 & 6,31 & 14,94 & 36,33 \\
\hline Qtz 3 & 3,13 & 7,42 & 60,32 \\
\hline Utm 6 & 8,90 & 21,08 & 100,00 \\
\hline Classes Uso do Solo & Área $\left(\mathrm{Km}^{2}\right)$ & $\%$ área da unidade & $\%$ área da bacia \\
\hline Cafe & 1,23 & 2,91 & 1,15 \\
\hline Cidades & 5,13 & 12,15 & 16,22 \\
\hline Corpos D água & 0,29 & 0,69 & 6,92 \\
\hline Mata Nativa & 12,76 & 30,24 & 3,56 \\
\hline Mata Ciliar & 0,09 & 0,22 & 0,28 \\
\hline Outras Culturas & 0,25 & 0,60 & 0,34 \\
\hline Pastagem & 22,29 & 52,81 & 2,26 \\
\hline Solo Exposto & 0,16 & 0,38 & 2,00 \\
\hline
\end{tabular}

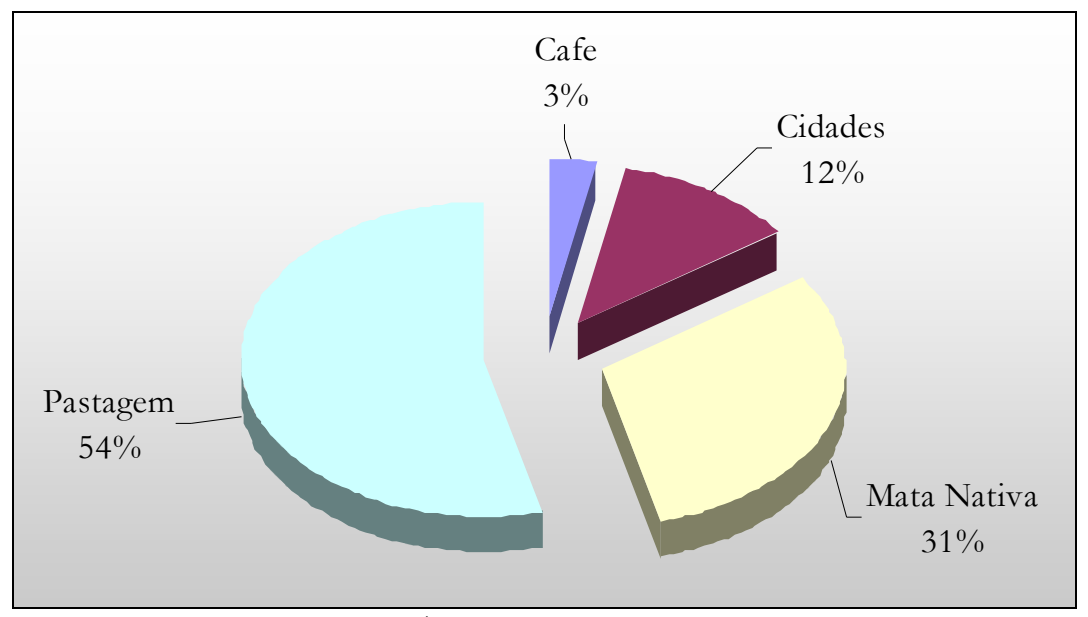

Figura 8.20 - Percentual de ocorrência das classes de uso e ocupação na Unidade Geoambiental XX. 
Tabela 8.41 - Características de potencialidade e susceptibilidade do meio para unidade XXI.

\begin{tabular}{|c|c|c|c|c|}
\hline \multicolumn{5}{|c|}{ Potencial ao Escoamento } \\
\hline Classe & Área $\left(\mathrm{Km}^{2}\right)$ & $\begin{array}{l}\% \text { área } \mathrm{da} \\
\text { unidade }\end{array}$ & $\%$ área da bacia & $\begin{array}{c}\text { Parâmetros estatísticos/Mapas } \\
\text { Numéricos }\end{array}$ \\
\hline Baixa & 0,67 & 2,88 & 0,37 & Mín - 1,57 \\
\hline Média & 6,50 & 28,02 & 1,00 & Máx - 3,48 \\
\hline Alta & 11,17 & 48,10 & 1,69 & Média $-2,68$ \\
\hline \multirow{2}{*}{ Muito Alta } & \multirow[b]{2}{*}{4,87} & \multirow[b]{2}{*}{20,99} & \multirow[b]{2}{*}{2,60} & Desv Padrão - 0,34 \\
\hline & & & & Moda $-3,24$ \\
\hline \multicolumn{5}{|c|}{ Susceptibilidade a Erosão } \\
\hline Classe & Área $\left(\mathrm{Km}^{2}\right)$ & $\begin{array}{l}\text { \% área da } \\
\text { unidade }\end{array}$ & $\%$ área da bacia & $\begin{array}{c}\text { Parâmetros estatísticos/Mapas } \\
\text { Numéricos }\end{array}$ \\
\hline Baixa & 0,00 & 0,00 & 0,00 & Mín-2,15 \\
\hline Média & 4,52 & 19,49 & 0,71 & Máx - 3,95 \\
\hline Alta & 18,62 & 80,22 & 2,38 & Média $-2,64$ \\
\hline \multirow{2}{*}{ Muito Alta } & \multirow[b]{2}{*}{0,07} & \multirow[b]{2}{*}{0,28} & \multirow[b]{2}{*}{0,05} & Desv Padrão - 0,15 \\
\hline & & & & Moda - 2,87 \\
\hline \multicolumn{5}{|c|}{ Potencial Agrícola } \\
\hline$\overline{\text { Classe }}$ & Área $\left(\mathrm{Km}^{2}\right)$ & $\begin{array}{l}\% \text { área da } \\
\text { unidade }\end{array}$ & $\%$ área da bacia & $\begin{array}{c}\text { Parâmetros estatísticos/Mapas } \\
\text { Numéricos }\end{array}$ \\
\hline Baixa & 4,18 & 17,99 & 0,96 & Mín - 1,88 \\
\hline Média & 10,83 & 46,66 & 3,10 & Máx - 3,56 \\
\hline Alta & 1,50 & 6,45 & 0,58 & Média $-2,22$ \\
\hline Muito Alta & 2,02 & 8,69 & 0,43 & Desv Padrão - 0,43 \\
\hline Restritiva & 4,69 & 20,20 & 2,93 & Moda $-1,98$ \\
\hline
\end{tabular}

A susceptibilidade a erosão é caracterizada pela ocorrência de $80 \%$ da unidade na classe alta, com valores médios dos pixels de 2,64. Com relação ao potencial agrícola, $46 \%$ da área se enquadram na classe média, com valores médios dos pixels de 2,22.

Regiões com restrições legais a ocupação do meio correspondem a $20 \%$ da unidade e constituem, tanto faixas destinadas a preservação permanente junto aos cursos de drenagem, como a áreas com valores de declividade acima de $25^{\circ}$.

A condição de alto potencial ao escoamento é favorecida pela predominância de valores de declividade acima de $20 \%$ (Tabela 8.42), e pela textura intermediaria dos materiais resíduas de migmatitos, os quais compreendem 100\% da unidade.

A alta susceptibilidade a erosão é condicionada pela condição do escoamento superficial, somada as características de textura e espessura dos materiais inconsolidados. Estes aspectos somados as características de textura e espessura dos materiais inconsolidados, além os valores de capacidade de troca catiônica constituem fator preponderante a ocorrência do médio potencial agrícola. 
Tabela 8.42- Atributos do meio físico da unidade XXI.

\begin{tabular}{|c|c|c|c|}
\hline Declividade $\%$ & Área $\left(\mathrm{Km}^{2}\right)$ & $\%$ área da unidade & $\%$ área da bacia \\
\hline$<2$ & 0,74 & 3,21 & 0,28 \\
\hline $2-10$ & 1,35 & 5,82 & 0,49 \\
\hline $10-20$ & 4,04 & 17,41 & 0,77 \\
\hline $20-30$ & 5,48 & 23,62 & 1,57 \\
\hline $30-45$ & 8,49 & 36,57 & 3,96 \\
\hline$>45$ & 3,10 & 13,37 & 5,95 \\
\hline Geologia & Área $\left(\mathrm{Km}^{2}\right)$ & $\%$ área da unidade & $\%$ área da bacia \\
\hline Migmatitos & 23,21 & 100,00 & 5,39 \\
\hline Materiais Inco & Área $\left(\mathrm{Km}^{2}\right)$ & $\%$ área da unidade & $\%$ área da bacia \\
\hline Mig 3 & 23,21 & 100,00 & 79,91 \\
\hline Classes Uso do Solo & Área $\left(\mathrm{Km}^{2}\right)$ & $\%$ área da unidade & $\%$ área da bacia \\
\hline Cafe & 1,14 & 4,93 & 1,07 \\
\hline Cidades & 0,07 & 0,29 & 0,21 \\
\hline Mata Nativa & 10,72 & 46,17 & 2,99 \\
\hline Outras Culturas & 1,10 & 4,73 & 1,49 \\
\hline Pastagem & 10,15 & 43,75 & 1,03 \\
\hline Solo Exposto & 0,0288 & 0,12 & 0,36 \\
\hline
\end{tabular}

As classes de mata nativa e pastagem destacam-se como principais atividades de ocupação do terreno vigentes na unidade. Correspondem, respectivamente, a 46\% e 44\% da área (Figura 8.21). O sub aproveitamento das condições naturais de médio potencial agrícola é retratado pela ocorrência de $10 \%$, de práticas agrícolas.

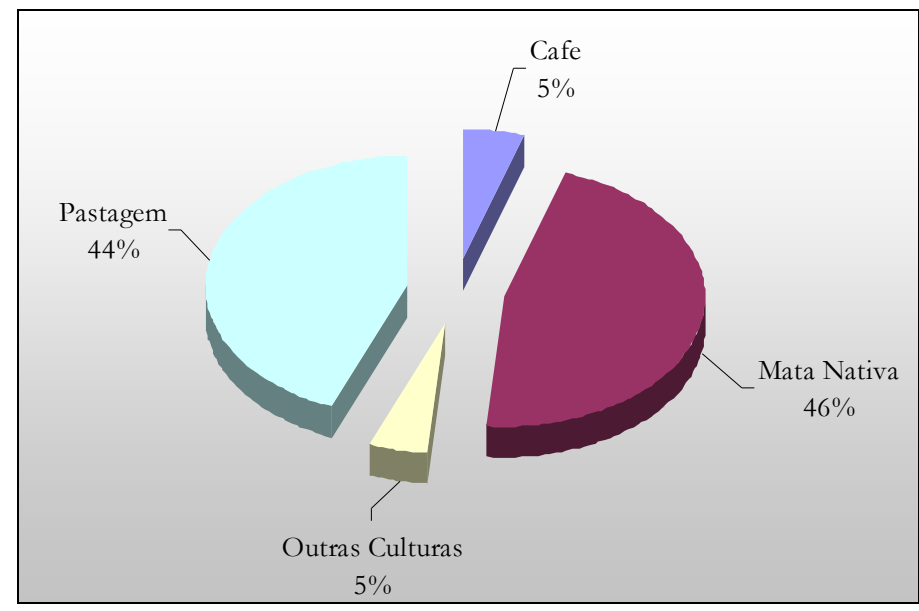

Figura 8.21 - Percentual de ocorrência das classes de uso e ocupação na Unidade Geoambiental XXI. 


\section{$\underline{\text { Unidade XXII }}$}

Corresponde a unidade de terreno C6. Caracteriza-se pela ocorrência de $41 \%$ da área com médio potencial ao escoamento, e 41\% com alto potencial. Os valores médios dos pixels são de 2,47 (Tabela 8.43)

Tabela 8.43 - Características de potencialidade e susceptibilidade do meio para unidade XXII.

\begin{tabular}{|c|c|c|c|c|}
\hline \multicolumn{5}{|c|}{ Potencial ao Escoamento } \\
\hline Classe & Área $\left(\mathrm{Km}^{2}\right)$ & $\begin{array}{l}\% \text { área da } \\
\text { unidade }\end{array}$ & $\%$ área da bacia & $\begin{array}{c}\text { Parâmetros estatísticos/Mapas } \\
\text { Numéricos }\end{array}$ \\
\hline Baixa & 2,39 & 10,48 & 1,33 & Mín - 1,36 \\
\hline Média & 9,38 & 41,22 & 1,44 & Máx - 3,63 \\
\hline Alta & 9,41 & 41,35 & 1,42 & Média $-2,47$ \\
\hline \multirow{2}{*}{ Muito Alta } & \multirow[b]{2}{*}{1,58} & \multirow[b]{2}{*}{6,94} & \multirow[b]{2}{*}{0,84} & Desv Padrão - 0,36 \\
\hline & & & & Moda $-2,15$ \\
\hline \multicolumn{5}{|c|}{ Susceptibilidade a Erosão } \\
\hline Classe & Área $\left(\mathrm{Km}^{2}\right)$ & $\begin{array}{l}\% \text { área da } \\
\text { unidade }\end{array}$ & $\%$ área da bacia & $\begin{array}{l}\text { Parâmetros estatísticos/Mapas } \\
\text { Numéricos }\end{array}$ \\
\hline Baixa & 3,22 & 14,16 & 2,78 & Mín - 1,59 \\
\hline Média & 2,87 & 12,62 & 0,45 & Máx - 4,18 \\
\hline Alta & 5,30 & 23,28 & 0,68 & Média $-2,82$ \\
\hline \multirow{2}{*}{ Muito Alta } & \multirow[b]{2}{*}{11,36} & \multirow[b]{2}{*}{49,93} & \multirow[b]{2}{*}{8,07} & Desv Padrão - 0,29 \\
\hline & & & & Moda $-2,74$ \\
\hline \multicolumn{5}{|c|}{ Potencial Agrícola } \\
\hline Classe & Área $\left(\mathrm{Km}^{2}\right)$ & $\begin{array}{l}\% \text { área } \mathrm{da} \\
\text { unidade }\end{array}$ & $\%$ área da bacia & $\begin{array}{c}\text { Parâmetros estatísticos/Mapas } \\
\text { Numéricos }\end{array}$ \\
\hline Baixa & 10,04 & 44,14 & 2,31 & Mín - 1,66 \\
\hline Média & 4,51 & 19,83 & 1,29 & Máx - 3,84 \\
\hline Alta & 1,81 & 7,93 & 0,69 & Média - 2,17 \\
\hline Muito Alta & 2,82 & 12,40 & 0,60 & Desv Padrão - 0,54 \\
\hline Restritiva & 3,54 & 15,58 & 2,22 & Moda - 3,39 \\
\hline
\end{tabular}

Apresenta 49\% da área caracterizada por muito alta susceptibilidade a erosão, e $23 \%$ alta, com valores médio dos pixels de 2,82. O potencial agrícola é caracterizado pela ocorrência de $44 \%$ da unidade na classe baixa, e 19\% na classe média. Exibe valores médios de pixels de 2,17.

Regiões com restrições legais a ocupação do meio correspondem a 15\% da unidade e correspondem, principalmente, as faixas destinadas a preservação permanente junto aos cursos de drenagem, e secundariamente a áreas com valores de declividade acima de $25^{\circ}$.

O potencial ao escoamento superficial médio a alto é caracterizado pela predominância de valores de declividade acima de $20 \%$, e pela influência pouco 
significativa da textura arenosa dos materiais residuais de gnaisses intercalados a rochas básicas, os quais compreende mais de 50\% da unidade (Tabela 8.44).

Tabela 8.44- Atributos do meio físico da unidade XXII.

\begin{tabular}{c|r|r|r}
\hline Declividade $\%$ & Área $\left(\mathbf{K m}^{2}\right)$ & \% área da unidade & \% área da bacia \\
\hline$<2$ & 1,48 & 6,49 & 0,56 \\
\hline $2-10$ & 2,12 & 9,32 & 0,76 \\
\hline $10-20$ & 5,27 & 23,17 & 1,01 \\
\hline $20-30$ & 6,06 & 26,65 & 1,74 \\
\hline $30-45$ & 6,29 & 27,65 & 2,93 \\
\hline$>45$ & 1,52 & 6,69 & 2,92 \\
\hline Geologia & Área $\left.\mathbf{( K m}^{2}\right)$ & \% área da unidade & \% área da bacia \\
\hline Gn Básicas & 13,65 & 59,99 & 3,11 \\
\hline Qartzitos & 1,39 & 6,12 & 3,03 \\
\hline Migmatitos & 7,71 & 33,88 & 1,79 \\
\hline Materiais Inco & Área $\left(\mathbf{K m}^{2}\right)$ & \% área da unidade & \% área da bacia \\
\hline Retrab 1 & 4,29 & 18,86 & 4,52 \\
\hline Gnb 8 & 12,15 & 53,40 & 40,41 \\
\hline Mig 4 & 6,31 & 27,74 & 20,41 \\
\hline Classes Uso do Solo & Área $\left(\mathbf{K m}^{2}\right)$ & \% área da unidade & \% área da bacia \\
\hline Cafe & 0,12 & 0,54 & 0,11 \\
\hline Cidades & 0,92 & 4,06 & 2,92 \\
\hline Corpos D`água & 0,02 & 0,08 & 0,43 \\
\hline Mata Nativa & 8,14 & 35,80 & 2,27 \\
\hline Mata Ciliar & 0,00 & 0,00 & 0,00 \\
\hline Outras Culturas & 0,35 & 1,55 & 0,48 \\
\hline Pastagem & 13,19 & 57,97 & 1,33 \\
\hline
\end{tabular}

As elevadas condições de susceptibilidade a erosão da unidade são condicionadas pelas características de potencial ao escoamento médio a alto, pela textura arenosa dos materiais residuais de gnaisses intercalados a rochas básicas, e pelas elevadas espessuras exibidas por estes e pelos residuais de migmatitos. A condição de potencial agrícola baixo a médio é condicionada de forma preponderante pelas características de declividade.

As classes de pastagem e mata nativa destacam-se como principais atividades de ocupação do terreno vigentes na unidade. Correspondem, respectivamente, a 58\% e $36 \%$ da área (Figura 8.22). O aproveitamento adequado das condições naturais de baixo potencial agrícola apresentado é retratado pela ocorrência de apenas $2 \%$ em área de práticas agrícolas, caracterizada pelo cultivo de outras culturas. 


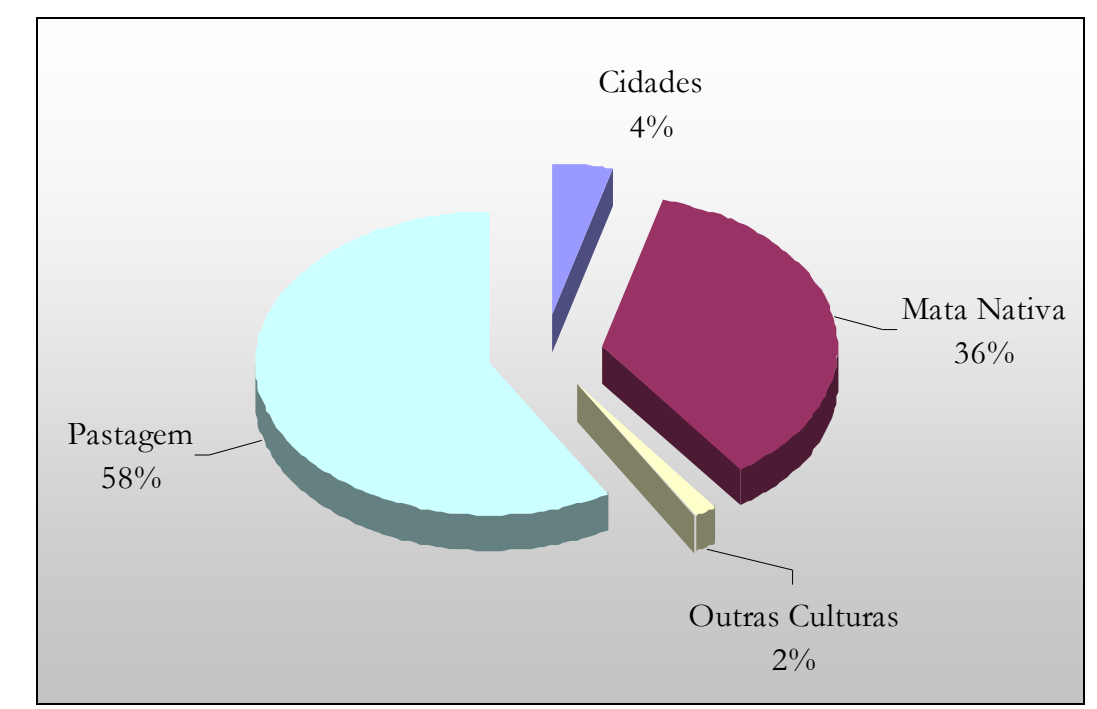

Figura 8.22 - Percentual de ocorrência das classes de uso e ocupação na Unidade Geoambiental XXII.

\section{Unidade XXIII}

Corresponde a unidade de terreno C7. Caracteriza-se por apresentar elevadas condições de potencial ao escoamento superficial, com ocorrência de $71 \%$ da unidade na classe muito alta, e 21\% na classe alta. Apresenta valores médios de pixels de 3,22. O aspecto de susceptibilidade a erosão é caracterizado pela ocorrência de $87 \%$ da área nas classes alta a muito alta, com valores médios de pixels de 2,86. O potencial agrícola da unidade é caracterizado pela presença de $50 \%$ da área na classe baixa. Os valores médios dos pixels são de 1,81 (Tabela 8.45).

Regiões com restrições legais a ocupação do meio correspondem a 37\% da unidade e correspondem, principalmente, a áreas com valores de declividade acima de $25^{\circ}$, e secundariamente as faixas destinadas a preservação permanente junto aos cursos de drenagem.

A condição de elevado potencial ao escoamento superficial é condicionada pela predominância dos valores de declividade acima de 30\%, e pelas características textura arenosa e baixas espessuras dos materiais residuais de quartzitos impuros, os quais constituem 100\% da unidade (Tabela 8.46). 
Tabela 8.45 - Características de potencialidade e susceptibilidade do meio para unidade XXIII.

\begin{tabular}{|c|c|c|c|c|}
\hline \multicolumn{5}{|c|}{ Potencial ao Escoamento } \\
\hline Classe & Área $\left(\mathrm{Km}^{2}\right)$ & \% área da unidade & $\%$ área da bacia & $\begin{array}{c}\text { Parâmetros estatísticos/Mapas } \\
\text { Numéricos }\end{array}$ \\
\hline Baixa & 0,04 & 1,35 & 0,02 & Mín $-1,39$ \\
\hline Média & 0,17 & 6,04 & 0,03 & Máx - 3,95 \\
\hline Alta & 0,59 & 20,95 & 0,09 & Média $-3,22$ \\
\hline \multirow{2}{*}{ Muito Alta } & \multirow[b]{2}{*}{2,00} & \multirow[b]{2}{*}{71,02} & \multirow[b]{2}{*}{1,07} & Desv Padrão - 0,44 \\
\hline & & & & Moda $-3,79$ \\
\hline \multicolumn{5}{|c|}{ Susceptibilidade a Erosão } \\
\hline Classe & Área $\left(\mathrm{Km}^{2}\right)$ & \% área da unidade & $\%$ área da bacia & $\begin{array}{c}\text { Parâmetros estatísticos/Mapas } \\
\text { Numéricos }\end{array}$ \\
\hline Baixa & 0,11 & 4,05 & 0,10 & Mín $-1,37$ \\
\hline Média & 0,24 & 8,52 & 0,04 & Máx - 3,90 \\
\hline Alta & 1,25 & 44,28 & 0,16 & Média - 2,86 \\
\hline \multirow{2}{*}{ Muito Alta } & \multirow[b]{2}{*}{1,22} & \multirow[b]{2}{*}{43,14} & \multirow[b]{2}{*}{0,86} & Desv Padrão - 0,33 \\
\hline & & & & Moda $-3,16$ \\
\hline \multicolumn{5}{|c|}{ Potencial Agrícola } \\
\hline Classe & Área $\left(\mathrm{Km}^{2}\right)$ & \% área da unidade & $\%$ área da bacia & $\begin{array}{c}\text { Parâmetros estatísticos/Mapas } \\
\text { Numéricos }\end{array}$ \\
\hline Baixa & 1,43 & 50,74 & 0,33 & Mín - 1,39 \\
\hline Média & 0,13 & 4,79 & 0,04 & Máx - 3,24 \\
\hline Alta & 0,11 & 3,86 & 0,04 & Média - 1,81 \\
\hline Muito Alta & 0,07 & 2,46 & 0,01 & Desv Padrão - 0,36 \\
\hline Restritiva & 1,06 & 37,78 & 0,67 & Moda $-1,64$ \\
\hline
\end{tabular}

Tabela 8.46- Atributos do meio físico da unidade XXIII.

\begin{tabular}{|c|c|c|c|}
\hline Declividade $\%$ & Área $\left(\mathrm{Km}^{2}\right)$ & $\%$ área da unidade & $\%$ área da bacia \\
\hline$<2$ & 0,03 & 0,89 & 0,01 \\
\hline $2-10$ & 0,13 & 4,73 & 0,05 \\
\hline $10-20$ & 0,34 & 12,14 & 0,07 \\
\hline $20-30$ & 0,45 & 15,88 & 0,13 \\
\hline $30-45$ & 0,89 & 31,45 & 0,41 \\
\hline$>45$ & 0,98 & 34,74 & 1,87 \\
\hline Geologia & Área $\left(\mathrm{Km}^{2}\right)$ & $\%$ área da unidade & $\%$ área da bacia \\
\hline Qartzitos & 2,82 & 100,00 & 6,13 \\
\hline Materiais Inco & Área $\left(\mathrm{Km}^{2}\right)$ & $\%$ área da unidade & $\%$ área da bacia \\
\hline Qtz 2 & 2,82 & 100,00 & 16,22 \\
\hline Classes Uso do Solo & Área $\left(\mathrm{Km}^{2}\right)$ & $\%$ área da unidade & $\%$ área da bacia \\
\hline Cidades & 0,28 & 9,97 & 0,89 \\
\hline Mata Nativa & 1,35 & 47,94 & 0,38 \\
\hline Pastagem & 1,19 & 42,09 & 0,12 \\
\hline
\end{tabular}

A elevada condição de susceptibilidade a erosão é determinada pelo elevado escoamento superficial, somados aos aspectos de textura dos materiais inconsolidados. Estes aspectos e a predominância de valores de declividade muito elevados condicionam o potencial agrícola baixo exibido pela unidade.

As classes de mata nativa e pastagem destacam-se como principais atividades de ocupação do terreno vigentes. Correspondem, respectivamente, a 48\% e 42\% da área 
(Figura 8.23). A inexistência de atividade voltadas ao desenvolvimento de práticas agrícola caracteriza situação de adequação as baixas potencialidades naturais apresentadas pelo meio físico.

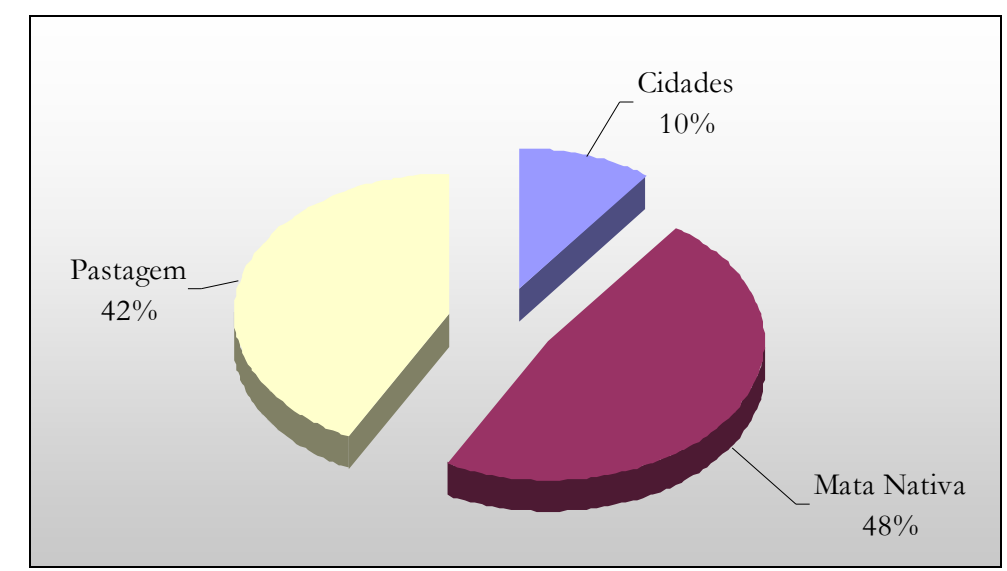

Figura 8.23 - Percentual de ocorrência das classes de uso e ocupação na Unidade Geoambiental XXIII.

\section{Unidade XXIV}

Corresponde a unidade de terreno D1. Apresenta condição de potencial ao escoamento caracterizado pela ocorrência de $47 \%$ da unidade na média, e $31 \%$ na classe alta, com valores médios de pixels de 2,32. O aspecto de susceptibilidade a erosão é caracterizado pela ocorrência de $76 \%$ da unidade nas classe muito alta, com valores médios dos pixels de 3,05. O potencial agrícola é caracterizado pela presença de $52 \%$ da unidade na classe baixa e 14\% na classe muito alta, com valores médios de pixels de 2,17 (Tabela 8.47).

Regiões com restrições legais a ocupação do meio correspondem a $16 \%$ da unidade e correspondem as faixas destinadas a preservação permanente junto aos cursos de drenagem.

O médio a alto potencial de escoamento superficial é condicionado, de forma preponderante pela predominância de valores de declividade acima de 20\% (Tabela 8.48). A elevada susceptibilidade a erosão é favorecida pela condição de escoamento superficial e, principalmente, pela textura arenosa dos materiais residuais de gnaisses intercalado a rochas básicas, os quais compreendem $82 \%$ da unidade. O baixo potencial agrícola é condicionado pelas características restritivas apresentadas pela declividade e pela textura dos materiais inconsolidados. 
Tabela 8.47 - Características de potencialidade e susceptibilidade do meio para unidade XXIV.

\begin{tabular}{|c|c|c|c|c|}
\hline \multicolumn{5}{|c|}{ Potencial ao Escoamento } \\
\hline Classe & Área $\left(\mathrm{Km}^{2}\right)$ & $\%$ área da unidade & $\%$ área da bacia & $\begin{array}{c}\text { Parâmetros estatísticos/Mapas } \\
\text { Numéricos }\end{array}$ \\
\hline Baixa & 13,60 & 19,96 & 7,57 & Mín $-0,82$ \\
\hline Média & 31,96 & 46,90 & 4,92 & Máx $-3,48$ \\
\hline Alta & 21,32 & 31,29 & 3,23 & Média $-2,32$ \\
\hline \multirow{2}{*}{ Muito Alta } & \multirow{2}{*}{\multicolumn{2}{|c|}{1,84}} & \multirow[b]{2}{*}{0,67} & Desv Padrão - 0,87 \\
\hline & & & & Moda $-2,32$ \\
\hline \multicolumn{5}{|c|}{ Susceptibilidade a Erosão } \\
\hline Classe & Área $\left(\mathrm{Km}^{2}\right)$ & $\%$ área da unidade & $\%$ área da bacia & $\begin{array}{c}\text { Parâmetros estatísticos/Mapas } \\
\text { Numéricos }\end{array}$ \\
\hline Baixa & 6,92 & 10,15 & 5,97 & Mín $-0,35$ \\
\hline Média & 1,35 & 1,99 & 0,21 & Máx $-4,45$ \\
\hline Alta & 8,00 & 11,74 & 1,02 & Média $-3,05$ \\
\hline \multirow{2}{*}{ Muito Alta } & \multirow[b]{2}{*}{51,87} & \multirow[b]{2}{*}{76,12} & \multirow[b]{2}{*}{36,87} & Desv Padrão - 0,50 \\
\hline & & & & Moda $-1,73$ \\
\hline \multicolumn{5}{|c|}{ Potencial Agrícola } \\
\hline Classe & Área $\left(\mathrm{Km}^{2}\right)$ & $\%$ área da unidade & $\%$ área da bacia & $\begin{array}{c}\text { Parâmetros estatísticos/Mapas } \\
\text { Numéricos }\end{array}$ \\
\hline Baixa & 35,33 & 51,85 & 8,13 & Mín - 1,42 \\
\hline Média & 6,51 & 9,55 & 1,86 & Máx - 3,59 \\
\hline Alta & 5,44 & 7,98 & 2,09 & Média - 2,17 \\
\hline Muito Alta & 9,43 & 13,84 & 2,00 & Desv Padrão - 0,52 \\
\hline Restritiva & 11,33 & 16,62 & 7,09 & Moda $-3,22$ \\
\hline
\end{tabular}

Tabela 8.48- Atributos do meio físico da unidade XXIV.

\begin{tabular}{|c|c|c|c|}
\hline Declividade $\%$ & Área $\left(\mathrm{Km}^{2}\right)$ & \% área da unidade & $\%$ área da bacia \\
\hline$<2$ & 5,33 & 7,81 & 2,03 \\
\hline $2-10$ & 5,81 & 8,53 & 2,09 \\
\hline $10-20$ & 15,14 & 22,21 & 2,90 \\
\hline $20-30$ & 16,36 & 24,01 & 4,70 \\
\hline $30-45$ & 17,90 & 26,27 & 8,34 \\
\hline$>45$ & 7,60 & 11,15 & 14,55 \\
\hline Geologia & Área $\left(\mathrm{Km}^{2}\right)$ & \% área da unidade & $\%$ área da bacia \\
\hline Gn Básicas & 56,12 & 82,36 & 12,79 \\
\hline Ultramilonitos & 5,7789 & 8,48 & 5,78 \\
\hline Blastomilonitos & 6,2406 & 9,16 & 5,85 \\
\hline Materiais Inco & Área $\left(\mathrm{Km}^{2}\right)$ & $\%$ área da unidade & $\%$ área da bacia \\
\hline Retrab 1 & 6,83 & 10,09 & 7,20 \\
\hline Gnb 10 & 56,1 & 82,36 & 100,00 \\
\hline Utm 1 & 4,9 & 7,24 & 100,00 \\
\hline Utm 2 & 0,2 & 0,31 & 3,45 \\
\hline Classes Uso do Solo & Área $\left(\mathrm{Km}^{2}\right)$ & $\%$ área da unidade & $\%$ área da bacia \\
\hline Cafe & 1,56 & 2,28 & 1,45 \\
\hline Corpos D`água & 0,42 & 0,62 & 9,98 \\
\hline Mata Nativa & 24,67 & 36,20 & 6,87 \\
\hline Mata Ciliar & 0,67 & 0,98 & 2,00 \\
\hline Outras Culturas & 0,40 & 0,59 & 0,54 \\
\hline Pastagem & 40,36 & 59,23 & 4,09 \\
\hline Solo Exposto & 0,06 & 0,09 & 0,79 \\
\hline
\end{tabular}


As classes de pastagem e mata nativa destacam-se como principais atividades de ocupação do terreno vigentes. Correspondem, respectivamente, a 60\% e 37\% da área (Figura 8.24). A ocorrência de apenas $2 \%$ em área pela atividade de cultivo de café, de caracteriza uma situação a qual mostra conformidade com as baixas potencialidade naturais apresentadas pelo meio físico.

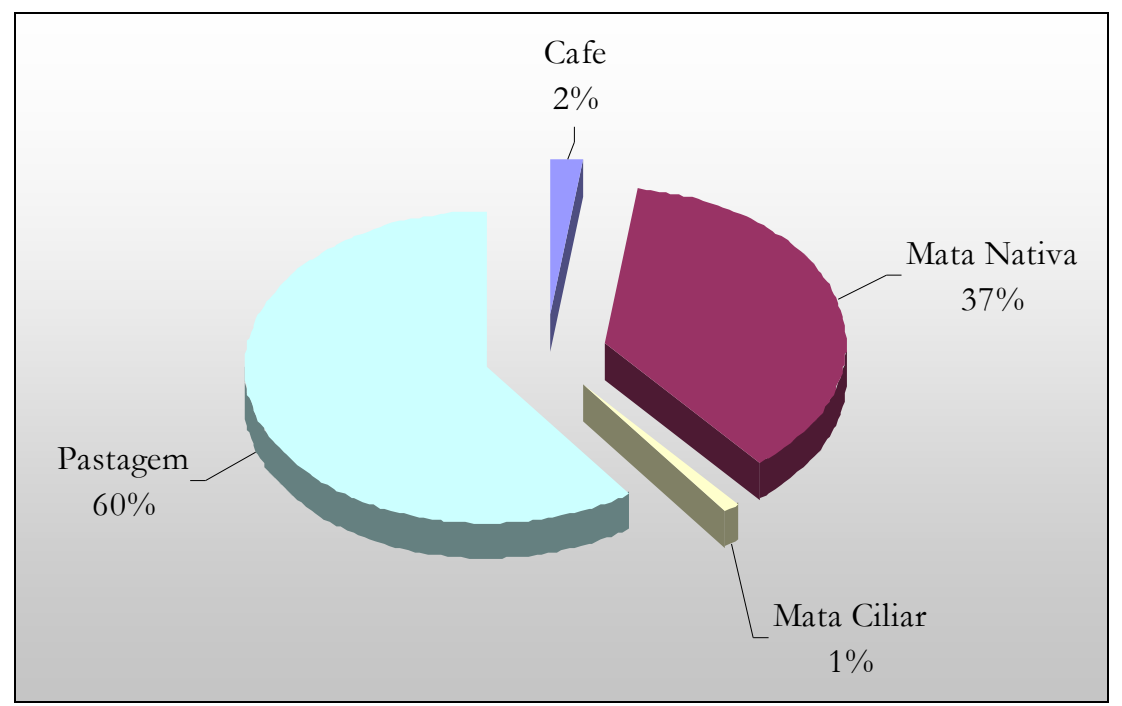

Figura 8.24 - Percentual de ocorrência das classes de uso e ocupação na Unidade Geoambiental XXIV.

\section{Unidade XXV}

Corresponde a unidade de terreno D2. Caracteriza-se por apresentar 55\% da área com médio potencial ao escoamento superficial e $22 \%$ alto, e valores médios dos pixels de 2,30. O aspecto de susceptibilidade a erosão é caracterizado pela ocorrência de $43 \%$ da área na classe média e 31\% na classe alta, com valores médios dos pixels de 2,27. A condição de potencial agrícola da unidade é caracterizada pela ocorrência de $43 \%$ da área na classe muito alta e 30\% nas classe média a baixa, com valores médios dos pixels de 2,91 (Tabela 8.49).

Regiões com restrições legais a ocupação do meio correspondem a apenas $8 \%$ da unidade e compreendem, principalmente, a áreas com valores de declividade acima de $25^{\circ}$ 
Tabela 8.49 - Características de potencialidade e susceptibilidade do meio para unidade XXV.

\begin{tabular}{|c|c|c|c|c|}
\hline \multicolumn{5}{|c|}{ Potencial ao Escoamento } \\
\hline Classe & $\overline{\text { Área }\left(\mathrm{Km}^{2}\right)}$ & $\%$ área da unidade & $\%$ área da bacia & $\begin{array}{c}\text { Parâmetros estatísticos/Mapas } \\
\text { Numéricos }\end{array}$ \\
\hline Baixa & 11,11 & 19,06 & 6,18 & Mín - 1,17 \\
\hline Média & 32,57 & 55,86 & 5,01 & Máx $-3,52$ \\
\hline Alta & 13,23 & 22,69 & 2,00 & Média $-2,30$ \\
\hline \multirow{2}{*}{ Muito Alta } & \multirow[b]{2}{*}{1,39} & \multirow[b]{2}{*}{2,38} & \multirow[b]{2}{*}{0,74} & Desv Padrão $-0,3$ \\
\hline & & & & Moda $-2,35$ \\
\hline \multicolumn{5}{|c|}{ Susceptibilidade a Erosão } \\
\hline Classe & Área $\left(\mathrm{Km}^{2}\right)$ & \% área da unidade & $\%$ área da bacia & $\begin{array}{c}\text { Parâmetros estatísticos/Mapas } \\
\text { Numéricos }\end{array}$ \\
\hline Baixa & 14,98 & 25,69 & 12,93 & Mín $-1,5$ \\
\hline Média & 25,10 & 43,05 & 3,93 & Máx $-3,6$ \\
\hline Alta & 18,07 & 31,00 & 2,31 & Média $-2,27$ \\
\hline \multirow{2}{*}{ Muito Alta } & \multirow[b]{2}{*}{0,15} & \multirow[b]{2}{*}{0,25} & \multirow[b]{2}{*}{0,10} & Desv Padrão - 0,35 \\
\hline & & & & Moda - 2,49 \\
\hline \multicolumn{5}{|c|}{ Potencial Agrícola } \\
\hline Classe & Área $\left(\mathrm{Km}^{2}\right)$ & $\%$ área da unidade & $\%$ área da bacia & $\begin{array}{c}\text { Parâmetros estatísticos/Mapas } \\
\text { Numéricos }\end{array}$ \\
\hline Baixa & 9,87 & 16,93 & 2,27 & Mín - 1,79 \\
\hline Média & 7,90 & 13,55 & 2,26 & Máx - 3,46 \\
\hline Alta & 10,51 & 18,03 & 4,04 & Média $-2,78$ \\
\hline Muito Alta & 25,26 & 43,32 & 5,35 & Desv Padrão - 0,55 \\
\hline Restritiva & 4,79 & 8,21 & 2,99 & Moda $-3,28$ \\
\hline
\end{tabular}

O médio potencial do escoamento superficial é devido as características de declividade, predominância dos valores inferiores a $20 \%$, e a influência dos materiais residuais de gnaisses intercalados a rochas básicas, os quais compreendem $60 \%$ da unidade (Tabela 8.50). Estes materiais apresentam textura argilosa e espessuras muito elevadas, o que favorece ao elevado escoamento superficial.

A condição de média a alta susceptibilidade a erosão é condicionada pelas características do escoamento superficial e pelas espessuras dos materiais inconsolidados presentes, residuais e retrabalhados, haja vista que as características de textura apresentam baixa influência. Os valores de espessura, a capacidade de troca catiônica e as características de declividade favoráveis, presentes em $46 \%$ da unidade condicionam o comportamento de elevado potencial agrícola. 
Tabela 8.50- Atributos do meio físico da unidade XXV.

\begin{tabular}{c|r|r|r}
\hline Declividade $\mathbf{0}$ & Área $\left(\mathbf{K m}^{2}\right)$ & \% área da unidade & \% área da bacia \\
\hline$<2$ & 13,61 & 23,34 & 5,18 \\
\hline $2-10$ & 13,65 & 23,41 & 4,91 \\
\hline $10-20$ & 20,90 & 35,86 & 4,01 \\
\hline $20-30$ & 7,15 & 12,26 & 2,05 \\
\hline $30-45$ & 2,66 & 4,57 & 1,24 \\
\hline$>45$ & 13,61 & 23,34 & 5,18 \\
\hline Geologia & Área $\left.\mathbf{( K m}^{2}\right)$ & \% área da unidade & \% área da bacia \\
\hline Gn Básicas & 58,30 & 100,00 & 13,29 \\
\hline Materiais Inco & Área $\left(\mathbf{K m}^{2}\right)$ & \% área da unidade & \% área da bacia \\
\hline Retrab 1 & 14,97 & 25,68 & 15,78 \\
\hline Retrab 2 & 6,45 & 11,06 & 12,95 \\
\hline Gnb 11 & 36,88 & 63,26 & 100,00 \\
\hline Classes Uso do Solo & Área $\left(\mathbf{K m}^{\mathbf{2}}\right)$ & \% área da unidade & \% área da bacia \\
\hline Cafe & 13,08 & 22,43 & 12,20 \\
\hline Corpos D água & 0,29 & 0,50 & 6,94 \\
\hline Mata Nativa & 5,68 & 9,75 & 1,58 \\
\hline Mata Ciliar & 0,64 & 1,09 & 1,90 \\
\hline Outras Culturas & 3,85 & 6,60 & 5,20 \\
\hline Pastagem & 34,84 & 59,75 & 3,53 \\
\hline Solo Exposto & 0,57 & 0,97 & 7,05 \\
\hline
\end{tabular}

Destacam-se como principais atividades de ocupação do terreno vigentes as classes de pastagem e as atividades voltadas ao desenvolvimento de práticas agrícola, presentes em, respectivamente, a $59 \%$ e $29 \%$ da área (Figura 8.25). A ocorrência destas atividades com segunda classe de destaque, mesmo que com baixos percentuais, caracteriza uma situação de correto aproveitamento das condições naturais apresentadas pelo meio físico.

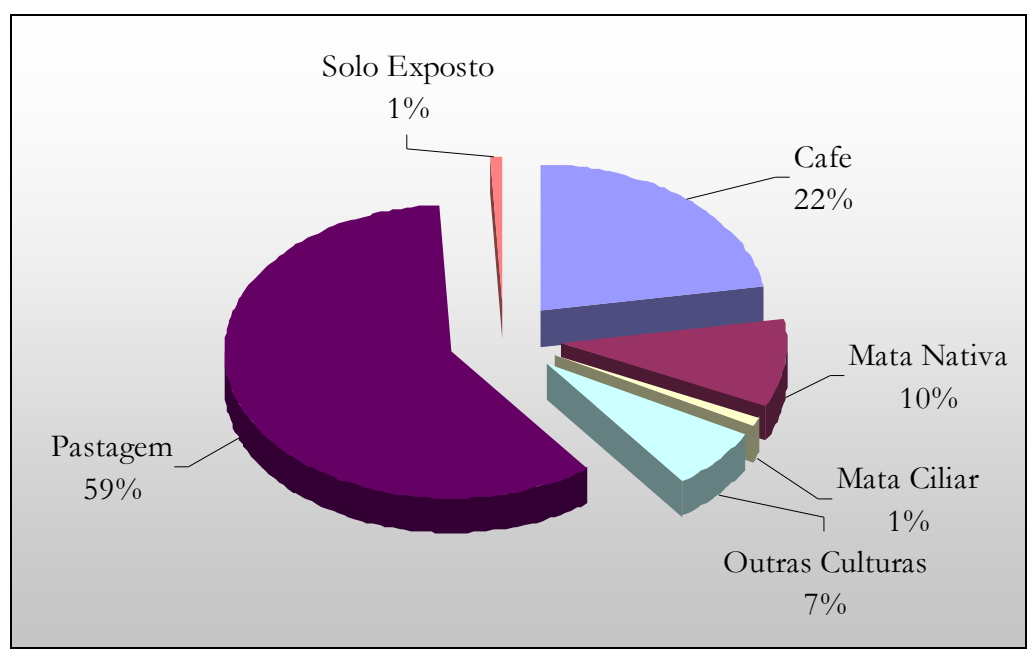

Figura 8.25 - Percentual de ocorrência das classes de uso e ocupação na Unidade Geoambiental XXV. 


\section{Unidade XXVI}

Corresponde a unidade de terreno D3. Caracteriza-se por apresentar 60\% de sua área com médio potencial ao escoamento, e valores médio de pixels de 2,37. A susceptibilidade a erosão é retratada pela ocorrência de $48 \%$ da área na classe média, e $37 \%$ na classe alta, com valores médios dos pixels de 2,73. (Tabela 8.51).O potencial agrícola caracteriza-se por apresentar 38\% da área enquadrada na classe muito alta e 225 na baixa, com valores médios dos pixels de 2,68.

Regiões com restrições legais a ocupação do meio correspondem a $10 \%$ da unidade e caracterizam faixas destinadas a preservação permanente junto aos cursos de drenagem.

Tabela 8. 51 - Características de potencialidade e susceptibilidade do meio para unidade XXVI.

\begin{tabular}{|c|c|c|c|c|}
\hline \multicolumn{5}{|c|}{ Potencial ao Escoamento } \\
\hline Classe & Área $\left(\mathrm{Km}^{2}\right)$ & $\%$ área da unidade & $\%$ área da bacia & $\begin{array}{c}\text { Parâmetros estatísticos/Mapas } \\
\text { Numéricos }\end{array}$ \\
\hline Baixa & 6,51 & 11,16 & 3,62 & Mín - 1,12 \\
\hline Média & 34,88 & 59,83 & 5,37 & Máx - 3,52 \\
\hline Alta & 14,73 & 25,27 & 2,23 & Média - 2,37 \\
\hline \multirow{2}{*}{ Muito Alta } & \multirow[b]{2}{*}{2,68} & \multirow[b]{2}{*}{4,59} & \multirow[b]{2}{*}{1,43} & Desv Padrão $-0,3$ \\
\hline & & & & Moda $-2,31$ \\
\hline \multicolumn{5}{|c|}{ Susceptibilidade a Erosão } \\
\hline Classe & Área $\left(\mathrm{Km}^{2}\right)$ & $\%$ área da unidade & $\%$ área da bacia & $\begin{array}{c}\text { Parâmetros estatísticos/Mapas } \\
\text { Numéricos }\end{array}$ \\
\hline Baixa & 9,29 & 15,93 & 8,02 & Mín - 1,24 \\
\hline Média & 27,86 & 47,79 & 4,36 & Máx - 3,81 \\
\hline Alta & 21,47 & 36,83 & 2,75 & Média - 2,37 \\
\hline \multirow{2}{*}{ Muito Alta } & \multirow[b]{2}{*}{0,17} & \multirow[b]{2}{*}{0,29} & \multirow[b]{2}{*}{0,12} & Desv Padrão - 0,31 \\
\hline & & & & Moda $-2,47$ \\
\hline \multicolumn{5}{|c|}{ Potencial Agrícola } \\
\hline Classe & Área $\left(\mathrm{Km}^{2}\right)$ & $\%$ área da unidade & $\%$ área da bacia & Parâmetros estatísticos \\
\hline Baixa & 12,93 & 22,18 & 2,98 & Mín-1,51 \\
\hline Média & 8,24 & 14,13 & 2,36 & Máx - 3,56 \\
\hline Alta & 9,57 & 16,42 & 3,68 & Média $-2,68$ \\
\hline Muito Alta & 22,25 & 38,16 & 4,71 & Desv Padrão - 0,58 \\
\hline Restritiva & 5,84 & 10,01 & 3,65 & Moda $-3,281$ \\
\hline
\end{tabular}

O médio potencial do escoamento superficial é condicionado pelas características de declividade, predominância dos valores inferiores a $20 \%$, e a de textura dos materiais residuais de ultramilonitos, os quais compreende $78 \%$ da unidade (Tabela 8.52). Estes materiais apresentam textura intermediária a argilosa, porém exibem espessuras muito elevadas, o que influencia contrariamente ao elevado escoamento superficial.A condição de média susceptibilidade a erosão é devida às características de 
escoamento superficial e textura dos materiais residuais e retrabalhados presentes. $\mathrm{O}$ comportamento variável de potencial agrícola é condicionado, principamente, pelas características de declividade da unidade.

Tabela 8.52- Atributos do meio físico da unidade XXVI.

\begin{tabular}{|c|c|c|c|}
\hline Declividade $\%$ & Área $\left(\mathrm{Km}^{2}\right)$ & $\%$ área da unidade & $\%$ área da bacia \\
\hline$<2$ & 12,76 & 21,69 & 4,85 \\
\hline $2-10$ & 11,77 & 20,02 & 4,23 \\
\hline $10-20$ & 19,74 & 33,57 & 3,78 \\
\hline $20-30$ & 8,76 & 14,90 & 2,52 \\
\hline $30-45$ & 4,58 & 7,80 & 2,14 \\
\hline$>45$ & 1,19 & 2,02 & 2,28 \\
\hline Geologia & Área $\left(\mathrm{Km}^{2}\right)$ & $\%$ área da unidade & $\%$ área da bacia \\
\hline Gn Básicas & 7,99 & 13,59 & 1,82 \\
\hline Ultramilonitos & 46,16 & 78,50 & 46,15 \\
\hline Blastomilonitos & 4,65 & 7,91 & 4,36 \\
\hline Materiais Inco & Área $\left(\mathrm{Km}^{2}\right)$ & $\%$ área da unidade & $\%$ área da bacia \\
\hline Retrab 1 & 9,44 & 16,05 & 9,95 \\
\hline Retrab 2 & 3,15 & 5,36 & 6,33 \\
\hline Utm 2 & 5,87 & 9,97 & 96,55 \\
\hline Utm 3 & 40,35 & 68,62 & 96,01 \\
\hline Classes Uso do Solo & Área $\left(\mathrm{Km}^{2}\right)$ & $\%$ área da unidade & $\%$ área da bacia \\
\hline Cafe & 5,79 & 9,85 & 5,40 \\
\hline Cidades & 0,23 & 0,39 & 0,73 \\
\hline Corpos D água & 0,45 & 0,77 & 10,69 \\
\hline Mata Nativa & 7,28 & 12,38 & 2,03 \\
\hline Mata Ciliar & 1,71 & 2,91 & 5,12 \\
\hline Outras Culturas & 5,12 & 8,71 & 6,92 \\
\hline Pastagem & 37,83 & 64,34 & 3,83 \\
\hline Solo Exposto & 0,38 & 0,65 & 4,74 \\
\hline
\end{tabular}

Destacam-se como principais atividades de ocupação do terreno as classes de pastagem e as atividades voltadas ao desenvolvimento de práticas agrícola, presentes em, respectivamente, a 64\% e 19\% da área (Figura 8.26). A ocorrência de atividades voltadas ao desenvolvimento agrícola como segunda classe de destaque, mesmo que com baixos percentuais, caracteriza uma situação de correto aproveitamento das condições naturais apresentadas pelo meio físico, onde 38\% apresenta potencial muito alto. 


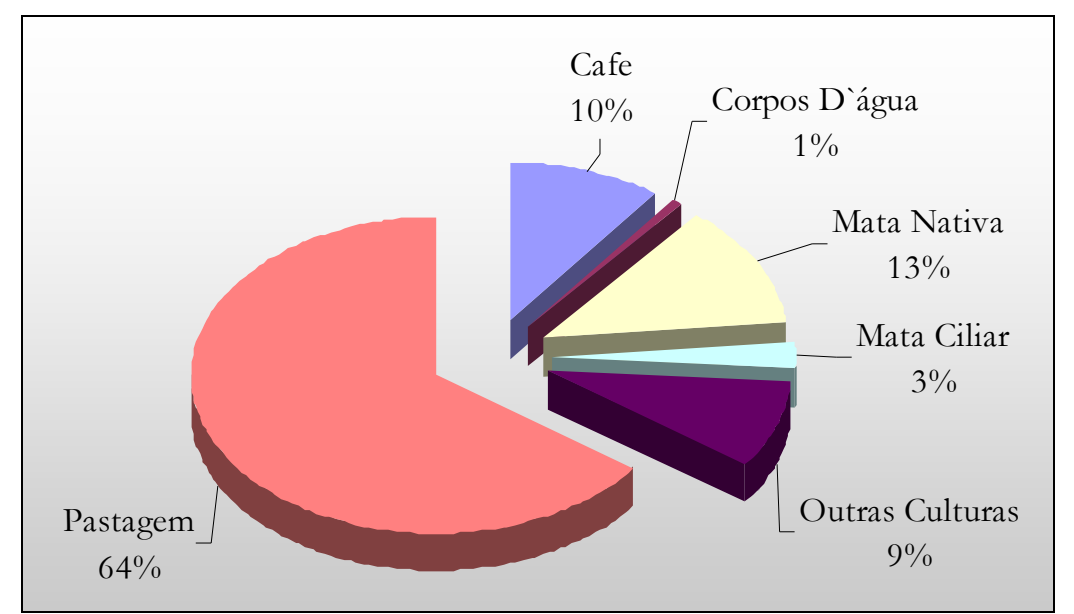

Figura 8.26 - Percentual de ocorrência das classes de uso e ocupação na Unidade Geoambiental XXVI.

\section{Unidade XXVII}

Corresponde a unidade de terreno D4. Caracteriza-se por apresentar $62 \%$ de sua área com médio potencial ao escoamento, e $29 \%$ com alto potencial. Os valores médios de pixels são de 2,4. A susceptibilidade a erosão é retratada pela ocorrência de $75 \%$ da área na classe alta, com valores médios dos pixels de 2,57. O potencial agrícola caracteriza-se por apresentar $34 \%$ da área enquadrada na classe muito alta, e $24 \%$ na classe baixa. Exibe valores médios dos pixels de 2,57 (Tabela 8.53)

Regiões com restrições legais a ocupação do meio correspondem a apenas $8 \%$ da unidade e constituem faixas destinadas a preservação permanente junto aos cursos de drenagem.

O médio potencial do escoamento superficial é condicionado pelas características de declividade, predominância dos valores inferiores a 20\%, e a de textura intermediária e valores de espessuras entre 1 e 3 metros, dos materiais residuais de blastomilonitos, os quais compreende $100 \%$ da unidade (Tabela 8.54). As características de densidade de drenagem vêm a influenciar contrariamente o desenvolvimento de elevado escoamento superficial. A condição de alta susceptibilidade a erosão é devida às características de escoamento superficial e textura dos materiais inconsolidados presentes. O comportamento de elevado potencial agrícola constatado em 50\% da unidade é condicionado pelos valores de espessura e capacidade de troca catiônica dos materiais inconsolidados, e pela ocorrência em $42 \%$ da área de faixas de declividade que favorecem ao desenvolvimento potencial agrícola da unidade. 
Tabela 8.53 - Características de potencialidade e susceptibilidade do meio para unidade XXVII.

\begin{tabular}{|c|c|c|c|c|}
\hline \multicolumn{5}{|c|}{ Potencial ao Escoamento } \\
\hline Classe & Área $\left(\mathrm{Km}^{2}\right)$ & \% área da unidade & \% área da bacia & $\begin{array}{c}\text { Parâmetros estatísticos/Mapas } \\
\text { Numéricos }\end{array}$ \\
\hline Baixa & 1,70 & 6,30 & 0,94 & Mín $-1,73$ \\
\hline Média & 16,69 & 62,00 & 2,57 & Máx - 3,69 \\
\hline Alta & 7,98 & 29,63 & 1,21 & Média $-2,4$ \\
\hline \multirow{2}{*}{ Muito Alta } & \multirow[b]{2}{*}{0,56} & \multirow[b]{2}{*}{2,08} & \multirow[b]{2}{*}{0,30} & Desv Padrão \\
\hline & & & & Moda \\
\hline \multicolumn{5}{|c|}{ Susceptibilidade a Erosão } \\
\hline Classe & Área $\left(\mathrm{Km}^{2}\right)$ & $\%$ área da unidade & \% área da bacia & $\begin{array}{c}\text { Parâmetros estatísticos/Mapas } \\
\text { Numéricos }\end{array}$ \\
\hline Baixa & 0,00 & 0,00 & 0,00 & Mín - 2,21 \\
\hline Média & 6,49 & 24,12 & 1,02 & Máx - 3,58 \\
\hline Alta & 20,37 & 75,67 & 2,61 & Média - 2,57 \\
\hline \multirow{2}{*}{ Muito Alta } & \multirow[b]{2}{*}{0,06} & \multirow[b]{2}{*}{0,21} & \multirow[b]{2}{*}{0,04} & Desv Padrão - 0,12 \\
\hline & & & & Moda $-2,54$ \\
\hline \multicolumn{5}{|c|}{ Potencial Agrícola } \\
\hline Classe & Área $\left(\mathrm{Km}^{2}\right)$ & \% área da unidade & \% área da bacia & $\begin{array}{c}\text { Parâmetros estatísticos/Mapas } \\
\text { Numéricos }\end{array}$ \\
\hline Baixa & 6,61 & 24,56 & 1,52 & Mín - 1,59 \\
\hline Média & 4,41 & 16,40 & 1,26 & Máx - 3,62 \\
\hline Alta & 4,46 & 16,55 & 1,71 & Média - 2,57 \\
\hline Muito Alta & 9,22 & 34,24 & 1,95 & Desv Padrão - 0,55 \\
\hline Restritiva & 2,23 & 8,29 & 1,40 & Moda $-3,12$ \\
\hline
\end{tabular}

Tabela 8.54- Atributos do meio físico da unidade XXVII.

\begin{tabular}{|c|c|c|c|}
\hline Declividade $\%$ & Área $\left(\mathrm{Km}^{2}\right)$ & $\%$ área da unidade & $\%$ área da bacia \\
\hline$<2$ & 5,72 & 21,23 & 2,18 \\
\hline $2-10$ & 5,68 & 21,10 & 2,04 \\
\hline $10-20$ & 10,06 & 37,38 & 1,93 \\
\hline $20-30$ & 4,37 & 16,21 & 1,25 \\
\hline $30-45$ & 1,06 & 3,93 & 0,49 \\
\hline$>45$ & 0,04 & 0,15 & 0,08 \\
\hline Geologia & Área $\left(\mathrm{Km}^{2}\right)$ & $\%$ área da unidade & $\%$ área da bacia \\
\hline Blastomilonitos & 26,92 & 100,00 & 25,22 \\
\hline Materiais Inco & Área $\left(\mathrm{Km}^{2}\right)$ & $\%$ área da unidade & $\%$ área da bacia \\
\hline Btm 3 & 26,92 & 100,00 & 100,00 \\
\hline Classes Uso do Solo & Área $\left(\mathrm{Km}^{2}\right)$ & $\%$ área da unidade & $\%$ área da bacia \\
\hline Cafe & 2,24 & 8,32 & 2,09 \\
\hline Cidades & 3,59 & 13,34 & 11,37 \\
\hline Corpos D água & 0,12 & 0,44 & 2,81 \\
\hline Mata Nativa & 1,73 & 6,44 & 0,48 \\
\hline Mata Ciliar & 0,30 & 1,11 & 0,89 \\
\hline Outras Culturas & 1,51 & 5,61 & 2,04 \\
\hline Pastagem & 17,36 & 64,49 & 1,76 \\
\hline Solo Exposto & 0,06 & 0,24 & 0,79 \\
\hline
\end{tabular}


Destacam-se como principais atividades de ocupação do terreno as classes de pastagem, as atividades voltadas ao desenvolvimento de práticas agrícola e a ocupação por cidades, presentes em, respectivamente, a $66 \%, 14 \%$ e $13 \%$ da área (Figura 8.27). A ocorrência de atividades voltadas ao desenvolvimento agrícola como segunda classe de destaque, mesmo que com baixos percentuais, caracteriza uma situação de correto, porém não total aproveitamento das condições naturais apresentadas pelo meio físico.

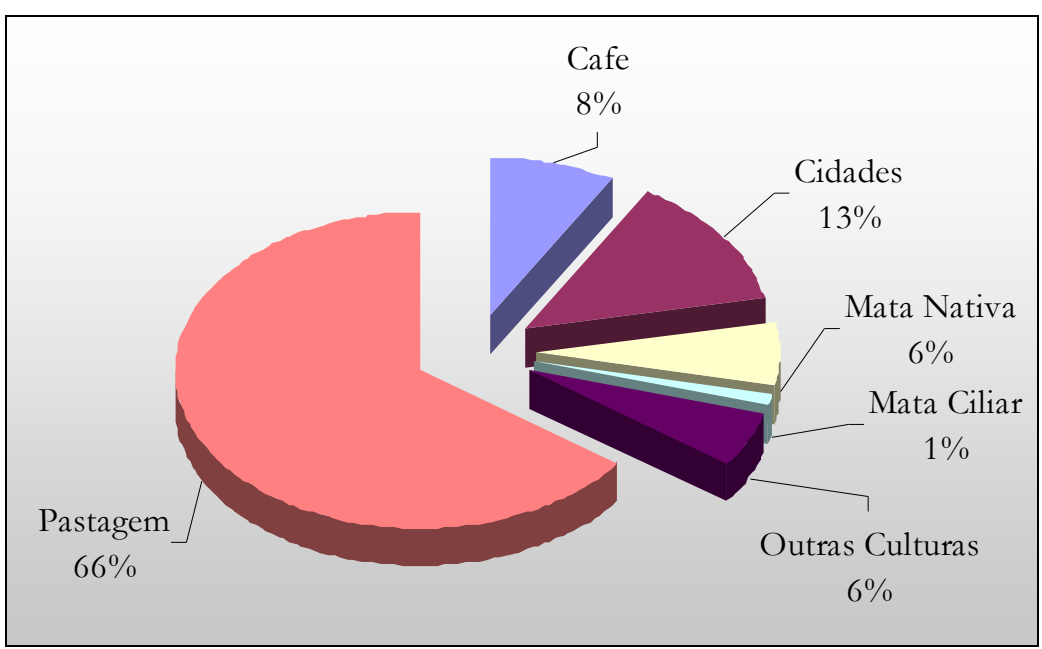

Figura 8.27 - Percentual de ocorrência das classes de uso e ocupação na Unidade Geoambiental XXVII.

\section{Unidade XXVIII}

Corresponde a unidade de terreno D5. Caracteriza-se por apresentar 54\% de sua área com médio potencial ao escoamento, e 37\% com alto potencial. Os valores médios de pixels são de 2,46. A susceptibilidade a erosão é retratada pela ocorrência de $83 \%$ da área na classe alta, com valores médios dos pixels de 2,59. O potencial agrícola caracteriza-se por apresentar $29 \%$ da área enquadrada na classe baixa e $28 \%$ na muito alta, com valores médios dos pixels de 2,58 (Tabela 8.55).

Regiões com restrições legais a ocupação do meio correspondem a apenas $9 \%$ da unidade e constituem faixas destinadas a preservação permanente junto aos cursos de drenagem. 
Tabela 8.55 - Características de potencialidade e susceptibilidade do meio para unidade XXVIII.

\begin{tabular}{|c|c|c|c|c|}
\hline \multicolumn{5}{|c|}{ Potencial ao Escoamento } \\
\hline Classe & Área $\left(\mathrm{Km}^{2}\right)$ & $\%$ área da unidade & $\%$ área da bacia & $\begin{array}{c}\text { Parâmetros estatísticos/Mapas } \\
\text { Numéricos }\end{array}$ \\
\hline Baixa & 0,40 & 4,71 & 0,22 & Mín - 1,26 \\
\hline Média & 4,53 & 53,73 & 0,70 & Máx $-3,41$ \\
\hline Alta & 3,16 & 37,44 & 0,48 & Média $-2,46$ \\
\hline \multirow{2}{*}{ Muito Alta } & \multirow[b]{2}{*}{0,35} & \multirow[b]{2}{*}{4,09} & \multirow[b]{2}{*}{0,18} & Desv Padrão - 0,28 \\
\hline & & & & Moda $-2,32$ \\
\hline \multicolumn{5}{|c|}{ Susceptibilidade a Erosão } \\
\hline Classe & Área $\left(\mathrm{Km}^{2}\right)$ & $\%$ área da unidade & $\%$ área da bacia & $\begin{array}{c}\text { Parâmetros estatísticos/Mapas } \\
\text { Numéricos }\end{array}$ \\
\hline Baixa & 0,09 & 1,06 & 0,08 & Mín $-0,77$ \\
\hline Média & 1,31 & 15,57 & 0,21 & Máx - 3,57 \\
\hline Alta & 7,00 & 83,03 & 0,90 & Média - 2,59 \\
\hline \multirow{2}{*}{ Muito Alta } & \multirow[b]{2}{*}{0,03} & \multirow[b]{2}{*}{0,32} & \multirow[b]{2}{*}{0,02} & Desv Padrão - 0,15 \\
\hline & & & & Moda $-2,54$ \\
\hline \multicolumn{5}{|c|}{ Potencial Agrícola } \\
\hline Classe & Área $\left(\mathrm{Km}^{2}\right)$ & $\%$ área da unidade & \% área da bacia & $\begin{array}{c}\text { Parâmetros estatísticos/Mapas } \\
\text { Numéricos }\end{array}$ \\
\hline Baixa & 2,51 & 29,84 & 0,58 & Mín - 0,35 \\
\hline Média & 1,28 & 15,19 & 0,37 & Máx $-3,57$ \\
\hline Alta & 1,40 & 16,63 & 0,54 & Média $-2,58$ \\
\hline Muito Alta & 2,43 & 28,85 & 0,52 & Desv Padrão - 0,57 \\
\hline Restritiva & 0,81 & 9,60 & 0,51 & Moda $-3,27$ \\
\hline
\end{tabular}

O comportamento de potencial do escoamento superficial médio a alto da unidade é condicionado favoravelmente pelas características de textura intermediária e valores de espessuras entre 1 e 3 metros, dos materiais residuais de blastomilonitos, os quais compreende $100 \%$ da unidade(Tabela 8.56). As características de declividade, predominância dos valores inferiores a $20 \%$, não favorecem ao elevado escoamento superficial. A condição de alta susceptibilidade a erosão é devida às características de escoamento superficial e de textura dos materiais inconsolidados presentes. O comportamento de alto potencial agrícola exibido por $45 \%$ da unidade é condicionado pelos elevados valores de espessura e pelas características de declividade da unidade.

Destacam-se como principais atividades de ocupação do terreno as classes de pastagem, as atividades voltadas ao desenvolvimento de práticas agrícola e a ocorrência de mata nativa, presentes em $78 \%, 10 \%$ e $10 \%$ da área, respectivamente (Figura 8.28). A ocorrência de baixos percentuais de atividades voltadas ao desenvolvimento agrícola caracteriza uma situação de não aproveitamento total das condições naturais apresentadas pelo meio físico, as quais favorecem a ocupação de $45 \%$ meio por estas práticas. 
Tabela 8.56- Atributos do meio físico da unidade XXVIII.

\begin{tabular}{c|r|r|r}
\hline Declividade $\%$ & Área $\left(\mathbf{K m}^{\mathbf{2}}\right)$ & \% área da unidade & \% área da bacia \\
\hline$<2$ & 1,35 & 15,98 & 0,51 \\
\hline $2-10$ & 1,49 & 17,71 & 0,54 \\
\hline $10-20$ & 3,18 & 37,73 & 0,61 \\
\hline $20-30$ & 1,84 & 21,88 & 0,53 \\
\hline $30-45$ & 0,54 & 6,44 & 0,25 \\
\hline$>45$ & 0,02 & 0,20 & 0,03 \\
\hline Geologia & Área $\left.\mathbf{( K m}^{\mathbf{2}}\right)$ & \% área da unidade & \% área da bacia \\
\hline Blastomilonitos & 8,43 & 100,00 & 7,89 \\
\hline Materiais Inco & Área $\left(\mathbf{K m}^{2}\right)$ & \% área da unidade & \% área da bacia \\
\hline Btm 2 & 8,43 & 100,00 & 30,25 \\
\hline Classes Uso do Solo & Área $\left(\mathbf{K m}^{\mathbf{2}}\right)$ & \% área da unidade & \% área da bacia \\
\hline Cafe & 0,61 & 7,25 & 0,57 \\
\hline Mata Nativa & 0,82 & 9,69 & 0,23 \\
\hline Mata Ciliar & 0,21 & 2,48 & 0,62 \\
\hline Outras Culturas & 0,25 & 2,93 & 0,33 \\
\hline Pastagem & 6,54 & 77,65 & 0,66 \\
\hline
\end{tabular}

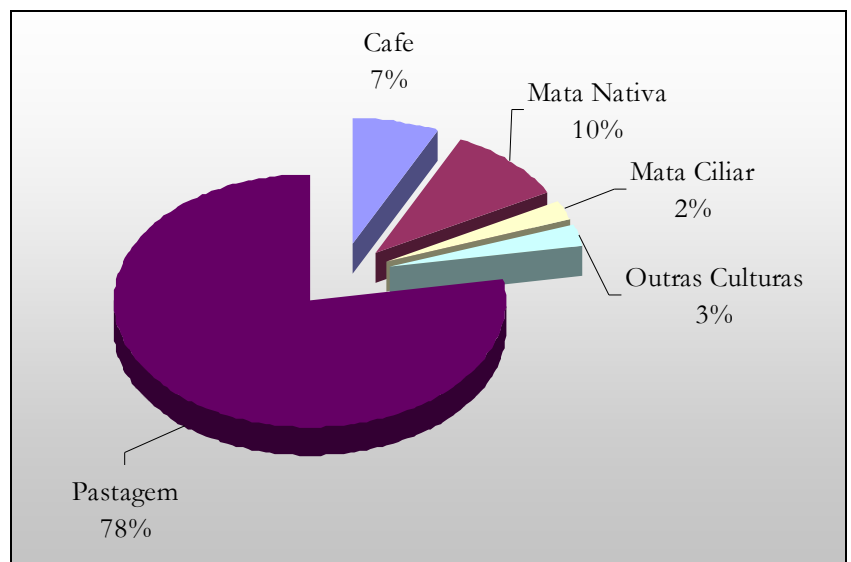

Figura 8.28 - Percentual de ocorrência das classes de uso e ocupação na Unidade Geoambiental XXVIII.

\section{Unidade XXIX}

Corresponde a unidade de terreno D6. Caracteriza-se por apresentar 63\% de sua área com médio potencial ao escoamento, e valores médios de pixels são de 2,77. A susceptibilidade a erosão é retratada pela ocorrência de 94\% da área na classe alta, com valores médios dos pixels de 2,73. O potencial agrícola caracteriza-se por apresentar $48 \%$ da área enquadrada nas classe alta a muito alta, com valores médios dos pixels de 2,63 (Tabela 8.57). 
Tabela 8.57 - Características de potencialidade e susceptibilidade do meio para unidade XXIX.

\begin{tabular}{|c|c|c|c|c|}
\hline \multicolumn{5}{|c|}{ Potencial ao Escoamento } \\
\hline Classe & Área $\left(\mathrm{Km}^{2}\right)$ & $\%$ área da unidade & $\%$ área da bacia & $\begin{array}{c}\text { Parâmetros estatísticos/Mapas } \\
\text { Numéricos }\end{array}$ \\
\hline Baixa & 0,01 & 0,02 & 0,01 & Mín - 1,95 \\
\hline Média & 7,31 & 15,44 & 1,12 & Máx - 4,31 \\
\hline Alta & 30,10 & 63,62 & 4,56 & Média $-2,77$ \\
\hline \multirow{2}{*}{ Muito Alta } & \multirow[b]{2}{*}{9,89} & \multirow[b]{2}{*}{20,91} & \multirow[b]{2}{*}{5,28} & Desv Padrão $-0,28$ \\
\hline & & & & Moda $-2,70$ \\
\hline \multicolumn{5}{|c|}{ Susceptibilidade a Erosão } \\
\hline Classe & Área $\left(\mathrm{Km}^{2}\right)$ & $\%$ área da unidade & \% área da bacia & $\begin{array}{c}\text { Parâmetros estatísticos/Mapas } \\
\text { Numéricos }\end{array}$ \\
\hline Baixa & 0,00 & 0,00 & 0,00 & Mín - 2,25 \\
\hline Média & 1,33 & 2,81 & 0,21 & Máx - 4,77 \\
\hline Alta & 44,65 & 94,38 & 5,71 & Média $-2,73$ \\
\hline \multirow{2}{*}{ Muito Alta } & \multirow[b]{2}{*}{1,33} & \multirow[b]{2}{*}{2,80} & \multirow[b]{2}{*}{0,94} & Desv Padrão - 0,13 \\
\hline & & & & Moda $-2,74$ \\
\hline \multicolumn{5}{|c|}{ Potencial Agrícola } \\
\hline Classe & Área $\left(\mathrm{Km}^{2}\right)$ & $\%$ área da unidade & \% área da bacia & $\begin{array}{c}\text { Parâmetros estatísticos/Mapas } \\
\text { Numéricos }\end{array}$ \\
\hline Baixa & 12,28 & 25,96 & 2,83 & Mín - 1,84 \\
\hline Média & 9,04 & 19,11 & 2,59 & Máx $-3,88$ \\
\hline Alta & 8,28 & 17,50 & 3,18 & Média - 2,63 \\
\hline Muito Alta & 14,40 & 30,43 & 3,05 & Desv Padrão - 0,56 \\
\hline Restritiva & 3,32 & 7,01 & 2,08 & Moda $-3,35$ \\
\hline
\end{tabular}

Regiões com restrições legais a ocupação do meio correspondem a apenas 7\% da unidade e constituem faixas destinadas a preservação permanente junto aos cursos de drenagem.

O comportamento de alto potencial do escoamento superficial da unidade é condicionado favoravelmente pelas características de textura areno-argilosa e valores de espessuras entre 1 e 3 metros, dos materiais residuais de granitos porfiríticos, os quais compreende 100\% da unidade (Tabela 8.58). As características de declividade, predominância dos valores inferiores a $20 \%$, não favorecem tanto ao elevado escoamento superficial. A condição de alta susceptibilidade a erosão é devidamente condicionada pelas características de escoamento superficial e de textura dos materiais inconsolidados presentes. O comportamento elevado do potencial agrícola da unidade é condicionado, principalmente, pelos elevados valores de espessura e características de declividade da unidade, que favorecem ao elevado potencial agrícola, secundariamente influenciam os aspectos de textura dos materiais inconsolidados. 
Tabela 8.58- Atributos do meio físico da unidade XXIX.

\begin{tabular}{c|r|r|r}
\hline Declividade $\%$ & Área $\left(\mathbf{K m}^{2}\right)$ & \% área da unidade & \% área da bacia \\
\hline$<2$ & 6,17 & 13,05 & 2,35 \\
\hline $2-10$ & 8,44 & 17,85 & 3,04 \\
\hline $10-20$ & 18,38 & 38,86 & 3,52 \\
\hline $20-30$ & 11,03 & 23,31 & 3,17 \\
\hline $30-45$ & 3,16 & 6,69 & 1,47 \\
\hline$>45$ & 0,12 & 0,24 & 0,22 \\
\hline Geologia & Área $\mathbf{( \mathbf { K m } ^ { 2 } )}$ & \% área da unidade & \% área da bacia \\
\hline Granitos Porfiríticos & 47,31 & 100,00 & 14,07 \\
\hline Materiais Inco & Área $\mathbf{( \mathbf { K m } ^ { 2 } )}$ & \% área da unidade & \% área da bacia \\
\hline Grp 1 & 47,31 & 100,00 & 100,00 \\
\hline Classes Uso do Solo & Área $\mathbf{( \mathbf { K m } ^ { 2 } )}$ & \% área da unidade & \% área da bacia \\
\hline Cafe & 4,41 & 9,32 & 4,11 \\
\hline Cidades & 0,02 & 0,03 & 0,05 \\
\hline Corpos Dágua & 0,07 & 0,15 & 1,68 \\
\hline Mata Nativa & 8,03 & 16,98 & 2,24 \\
\hline Mata Ciliar & 0,75 & 1,58 & 2,24 \\
\hline Outras Culturas & 3,38 & 7,14 & 4,57 \\
\hline Pastagem & 30,66 & 64,81 & 3,10 \\
\hline
\end{tabular}

Destacam-se como principais atividades de ocupação do terreno as classes de pastagem, a ocorrência de mata nativa e as atividades voltadas ao desenvolvimento de práticas agrícola, presentes em $65 \%, 17 \%$ e $16 \%$ da área, respectivamente (Figura 8.29). A ocorrência de baixos percentuais de atividades voltadas ao desenvolvimento agrícola retrata o não aproveitamento total das condições naturais apresentadas pelo meio físico, as quais favorecem a ocupação de $48 \%$ do meio por estas práticas.

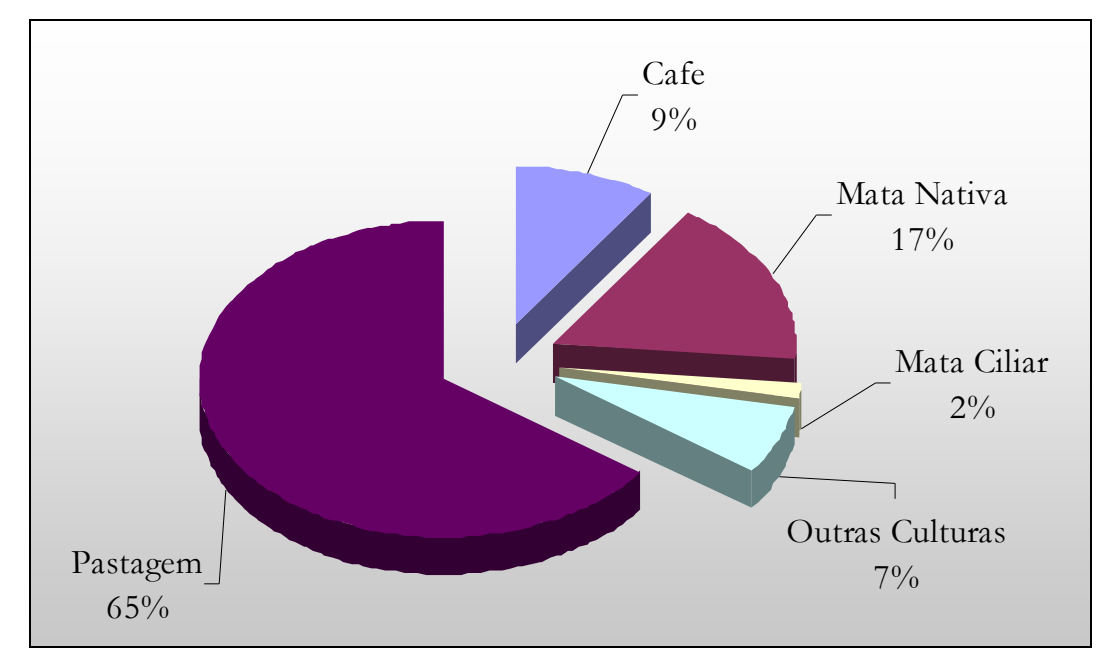

Figura 8.29 - Percentual de ocorrência das classes de uso e ocupação na Unidade Geoambiental XXIX. 


\section{Unidade XXX}

Corresponde a unidade de terreno D7. Caracteriza-se por apresentar 34\% de sua área com baixo potencial ao escoamento e $27 \%$ médio. Os valores médios de pixels são de 2,37. A susceptibilidade a erosão é retratada pela ocorrência de $46 \%$ da área na classe muito alta, com valores médios dos pixels de 2,70. O potencial agrícola caracteriza-se por apresentar 35\% da área enquadrada na classe baixa e 25\% na alta, com valores médios dos pixels de 2,45 (Tabela 8.59).

Regiões com restrições legais a ocupação do meio correspondem $15 \%$ da unidade e constituem, principalmente, faixas destinadas a preservação permanente junto aos cursos de drenagem, e de forma secundária, áreas presentes em regiões com declividades acima de $25^{\circ}$.

Tabela 8.59 - Características de potencialidade e susceptibilidade do meio para unidade XXX.

\begin{tabular}{|c|c|c|c|c|}
\hline \multicolumn{5}{|c|}{ Potencial ao Escoamento } \\
\hline Classe & Área $\left(\mathrm{Km}^{2}\right)$ & \% área da unidade & $\%$ área da bacia & $\begin{array}{c}\text { Parâmetros estatísticos/Mapas } \\
\text { Numéricos }\end{array}$ \\
\hline Baixa & 5,99 & 34,71 & 3,34 & Mín - 0,99 \\
\hline Média & 4,73 & 27,38 & 0,73 & Máx $-3,85$ \\
\hline Alta & 3,63 & 21,04 & 0,55 & Média - 2,37 \\
\hline \multirow{2}{*}{ Muito Alta } & & \multirow[b]{2}{*}{19,17} & \multirow[b]{2}{*}{1,77} & Desv Padrão - 0,58 \\
\hline & 3,31 & & & Moda $-1,82$ \\
\hline \multicolumn{5}{|c|}{ Susceptibilidade a Erosão } \\
\hline Classe & Área $\left(\mathrm{Km}^{2}\right)$ & $\%$ área da unidade & $\%$ área da bacia & $\begin{array}{c}\text { Parâmetros estatísticos/Mapas } \\
\text { Numéricos }\end{array}$ \\
\hline Baixa & 2,67 & 15,44 & 2,30 & Mín -0,54 \\
\hline Média & 2,91 & 16,86 & 0,46 & Máx - 3,56 \\
\hline Alta & 4,14 & 23,95 & 0,53 & Média $-2,70$ \\
\hline \multirow{2}{*}{ Muito Alta } & \multirow{2}{*}{\multicolumn{2}{|c|}{46,05}} & \multirow[b]{2}{*}{5,65} & Desv Padrão - 0,51 \\
\hline & & & & Moda - 3,07 \\
\hline \multicolumn{5}{|c|}{ Potencial Agrícola } \\
\hline Classe & Área $\left(\mathrm{Km}^{2}\right)$ & $\%$ área da unidade & $\%$ área da bacia & $\begin{array}{c}\text { Parâmetros estatísticos/Mapas } \\
\text { Numéricos }\end{array}$ \\
\hline Baixa & 6,13 & 35,48 & 1,41 & Mín $-1,56$ \\
\hline Média & 2,01 & 11,62 & 0,57 & Máx $-3,35$ \\
\hline Alta & 2,51 & 14,52 & 0,96 & Média $-2,45$ \\
\hline Muito Alta & 4,40 & 25,45 & 0,93 & Desv Padrão - 0,60 \\
\hline Restritiva & 2,58 & 14,92 & 1,61 & Moda $-3,3$ \\
\hline
\end{tabular}

O comportamento de baixo a médio potencial do escoamento superficial da unidade é condicionado pelas características de declividade, predominância dos valores superiores a $20 \%$ presente em $34 \%$ da área, além da textura areno-argilosa dos materiais residuais de quartzitos impuros e ultramilonitos (Utm3) e retrabalhados, os quais compreende $49 \%$ da unidade (Tabela 8.60). A condição de elevada susceptibilidade a 
erosão é condicionada pelas características de escoamento superficial e pela textura arenosa dos materiais inconsolidados residuais de ultramilonitos (Utm 4), presentes 53\% da unidade. O comportamento variável do potencial agrícola da unidade é condicionado, principalmente, pelas características de declividade da unidade, os quais apresentam-se com faixas bem distribuídas .

Destacam-se como principais atividades de ocupação do terreno as classes de pastagem, a ocorrência de mata nativa e as atividades voltadas ao desenvolvimento de práticas agrícola, presentes em 75\%,13\% e 11\% da área, respectivamente (Figura 8.30). A ocorrência de baixos percentuais de atividades voltadas ao desenvolvimento agrícola caracteriza o não aproveitamento total das condições naturais apresentadas pelo meio físico, as quais favorecem a ocupação de $40 \%$ meio por estas práticas.

Tabela 8.60- Atributos do meio físico da unidade XXX.

\begin{tabular}{c|r|r|r}
\hline Declividade $\%$ & Área $\left(\mathbf{K m}^{\mathbf{2}}\right)$ & \% área da unidade & \% área da bacia \\
\hline$<2$ & 2,30 & 13,34 & 0,88 \\
\hline $2-10$ & 2,81 & 16,28 & 1,01 \\
\hline $10-20$ & 5,47 & 31,69 & 1,05 \\
\hline $20-30$ & 3,13 & 18,11 & 0,90 \\
\hline $30-45$ & 2,86 & 16,55 & 1,33 \\
\hline$>45$ & 1,10 & 6,35 & 2,10 \\
\hline Geologia & Área $\left.\mathbf{( K m}^{\mathbf{2}}\right)$ & \% área da unidade & \% área da bacia \\
\hline Qartzitos & 3,14 & 18,17 & 6,83 \\
\hline Ultramilonitos & 14,13 & 81,83 & 14,13 \\
\hline Materiais Inco & Área $\left(\mathbf{K m}^{\mathbf{2}}\right)$ & \% área da unidade & \% área da bacia \\
\hline Retrab 1 & 4,83 & 27,98 & 5,09 \\
\hline Qtz 3 & 2,06 & 11,93 & 39,68 \\
\hline Utm 3 & 1,63 & 9,42 & 3,87 \\
\hline Utm 4 & 9,15 & 52,99 & 99,59 \\
\hline Classes Uso do Solo & Área $\left(\mathbf{K m}^{\mathbf{2}}\right)$ & \% área da unidade & \% área da bacia \\
\hline Cafe & 0,66 & 3,79 & 0,61 \\
\hline Corpos D água & 0,15 & 0,87 & 3,55 \\
\hline Mata Nativa & 2,19 & 12,67 & 0,61 \\
\hline Mata Ciliar & 0,05 & 0,31 & 0,16 \\
\hline Outras Culturas & 1,16 & 6,71 & 1,57 \\
\hline Pastagem & 13,06 & 75,64 & 1,32 \\
\hline
\end{tabular}




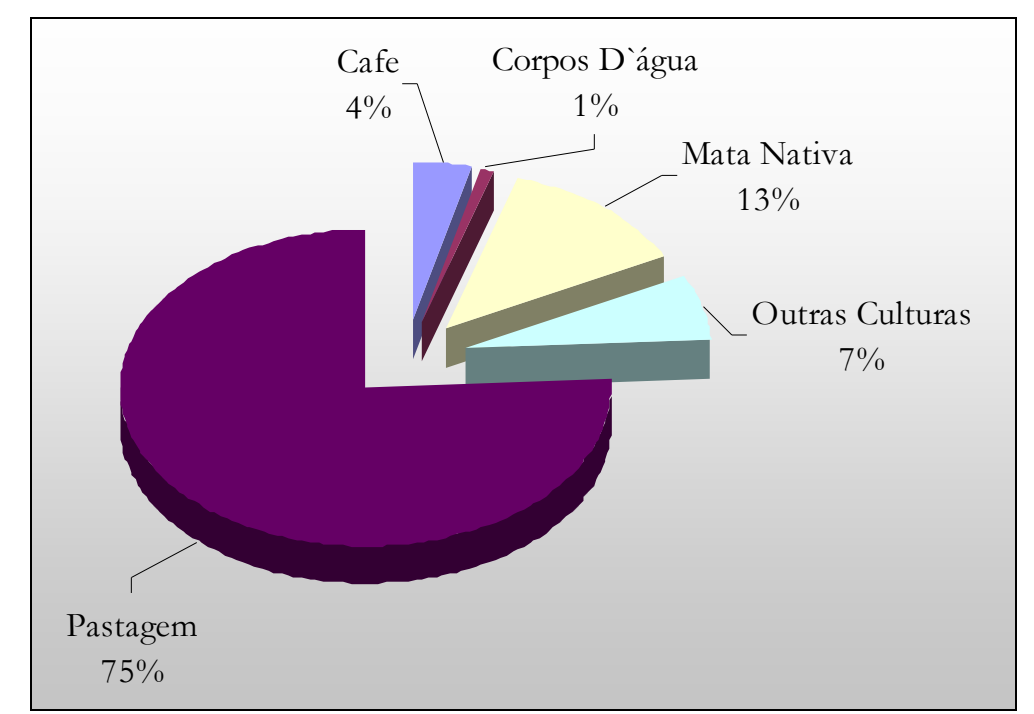

Figura 8.30 - Percentual de ocorrência das classes de uso e ocupação na Unidade Geoambiental XXX.

\section{$\underline{\text { Unidade XXXI }}$}

Corresponde a unidade de terreno D8. Caracteriza-se por apresentar 39\% de sua área com médio potencial ao escoamento e 39\% alto, com valores médios de pixels são de 2,53. A susceptibilidade a erosão é retratada pela ocorrência de $69 \%$ da área na classe alta e $27 \%$ na muito alta, com valores médios dos pixels de 2,88. O potencial agrícola caracteriza-se por apresentar $51 \%$ da área enquadrada na classe baixa valores médios dos pixels de 2,2 (Tabela 8.61).

Regiões com restrições legais a ocupação do meio correspondem a $19 \%$ da unidade e constituem, tanto faixas destinadas a preservação permanente junto aos cursos de drenagem, como áreas presentes em regiões com declividades acima de $25^{\circ}$.

O comportamento de potencial do escoamento superficial médio a alto da unidade é condicionado favoravelmente pelas características de declividade, predominância dos valores superiores a $20 \%$ em $65 \%$ da área, somado as características de textura intermediária, areno-siltosa e silto-arenosa, dos materiais residuais de ultramilonitos e blastomilonitos, os quais compreendem 100\% da unidade (Tabela 8.62). A condição de alta susceptibilidade a erosão é condicionada pelas características de escoamento superficial e pela textura dos materiais inconsolidados presentes na unidade.

O comportamento de baixo potencial agrícola exibido por metade da unidade é condicionado pelas características de declividade superioresres a $20 \%$ constatados em pequena parcela desta, 66\%, da área. 
Tabela 8.61 - Características de potencialidade e susceptibilidade do meio para unidade XXXI.

\begin{tabular}{|c|c|c|c|c|}
\hline \multicolumn{5}{|c|}{ Potencial ao Escoamento } \\
\hline Classe & Área $\left(\mathrm{Km}^{2}\right)$ & $\%$ área da unidade & \% área da bacia & $\begin{array}{c}\text { Parâmetros estatísticos/Mapas } \\
\text { Numéricos }\end{array}$ \\
\hline Baixa & 2,25 & 8,31 & 1,25 & Mín - 1,12 \\
\hline Média & 10,61 & 39,10 & 1,63 & Máx - 3,48 \\
\hline Alta & 10,59 & 39,04 & 1,60 & Média $-2,53$ \\
\hline \multirow{2}{*}{ Muito Alta } & \multirow[b]{2}{*}{3,68} & \multirow[b]{2}{*}{13,55} & \multirow[b]{2}{*}{1,96} & Desv Padrão - 0,39 \\
\hline & & & & Moda $-2,06$ \\
\hline \multicolumn{5}{|c|}{ Susceptibilidade a Erosão } \\
\hline Classe & Área $\left(\mathrm{Km}^{2}\right)$ & $\%$ área da unidade & \% área da bacia & $\begin{array}{c}\text { Parâmetros estatísticos/Mapas } \\
\text { Numéricos }\end{array}$ \\
\hline Baixa & 0,19 & 0,70 & 0,16 & Mín $-1,42$ \\
\hline Média & 0,67 & 2,45 & 0,10 & Máx - 3,37 \\
\hline Alta & 18,90 & 69,66 & 2,42 & Média - 2,88 \\
\hline \multirow{2}{*}{ Muito Alta } & \multirow[b]{2}{*}{7,37} & \multirow[b]{2}{*}{27,16} & \multirow[b]{2}{*}{5,24} & Desv Padrão - 0,19 \\
\hline & & & & Moda $-2,77$ \\
\hline \multicolumn{5}{|c|}{ Potencial Agrícola } \\
\hline Classe & Área $\left(\mathrm{Km}^{2}\right)$ & \% área da unidade & \% área da bacia & $\begin{array}{c}\text { Parâmetros estatísticos/Mapas } \\
\text { Numéricos }\end{array}$ \\
\hline Baixa & 13,91 & 51,27 & 3,20 & Mín $-1,53$ \\
\hline Média & 2,59 & 9,54 & 0,74 & Máx - 3,44 \\
\hline Alta & 2,26 & 8,34 & 0,87 & Média - 2,2 \\
\hline Muito Alta & 3,15 & 11,60 & 0,67 & Desv Padrão - 0,5 \\
\hline Restritiva & 5,18 & 19,09 & 3,24 & Moda - 3,34 \\
\hline
\end{tabular}

Tabela 8.62- Atributos do meio físico da unidade XXXI.

\begin{tabular}{|c|c|c|c|}
\hline Declividade $\%$ & Área $\left(\mathrm{Km}^{2}\right)$ & $\%$ área da unidade & $\%$ área da bacia \\
\hline$<2$ & 1,23 & 4,52 & 0,47 \\
\hline $2-10$ & 2,11 & 7,76 & 0,76 \\
\hline $10-20$ & 6,05 & 22,31 & 1,16 \\
\hline $20-30$ & 6,81 & 25,10 & 1,96 \\
\hline $30-45$ & 7,43 & 27,39 & 3,46 \\
\hline$>45$ & 3,51 & 12,94 & 6,73 \\
\hline Geologia & Área $\left(\mathrm{Km}^{2}\right)$ & $\%$ área da unidade & $\%$ área da bacia \\
\hline Ultramilonitos & 21,48 & 79,17 & 21,48 \\
\hline Blastomilonitos & 5,65 & 20,83 & 5,30 \\
\hline Materiais Inco & Área $\left(\mathrm{Km}^{2}\right)$ & $\%$ área da unidade & $\%$ área da bacia \\
\hline Utm 5 & 21,48 & 79,17 & 100,00 \\
\hline Btm 5 & 5,65 & 20,83 & 100,00 \\
\hline Classes Uso do Solo & Área $\left(\mathrm{Km}^{2}\right)$ & $\%$ área da unidade & $\%$ área da bacia \\
\hline Cafe & 4,95 & 18,26 & 4,62 \\
\hline Cidades & 0,05 & 0,20 & 0,17 \\
\hline Corpos D água & 0,03 & 0,13 & 0,81 \\
\hline Mata Nativa & 4,28 & 15,76 & 1,19 \\
\hline Outras Culturas & 0,85 & 3,12 & 1,15 \\
\hline Pastagem & 16,95 & 62,46 & 1,72 \\
\hline Solo Exposto & 0,02 & 0,07 & 0,24 \\
\hline
\end{tabular}


Destacam-se como principais atividades de ocupação do terreno as classes de pastagem, as atividades voltadas ao desenvolvimento de práticas agrícola e a ocorrência de mata nativa, presentes em 63\%, 21\% e 16\% da área, respectivamente (Figura 8.31). A ocorrência das atividades voltadas ao desenvolvimento agrícola em $21 \%$ da área caracteriza o aproveitamento total das condições naturais apresentadas pelo meio físico, as quais favorecem a ocupação por estas práticas em $20 \%$ da área.

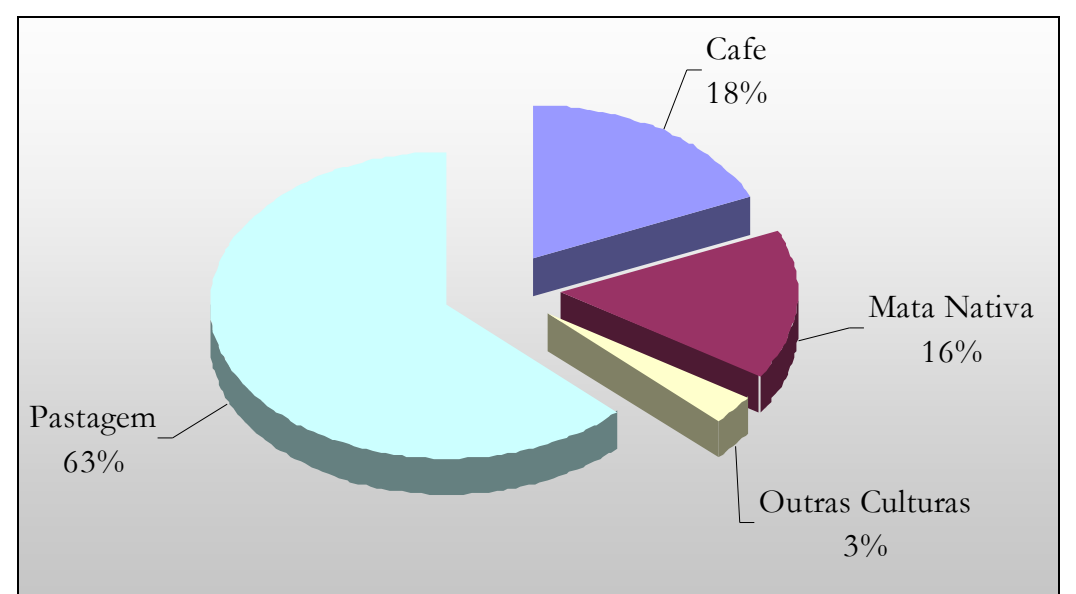

Figura 8.31 - Percentual de ocorrência das classes de uso e ocupação na Unidade Geoambiental XXXI.

\section{Unidade XXXII}

Corresponde a unidade de terreno D9. Caracteriza-se por apresentar $43 \%$ de sua área com alto potencial ao escoamento e 39\% muito alto. Os valores médios de pixels de 2,83. A susceptibilidade a erosão é retratada pela ocorrência de $82 \%$ da área na classe alta, com valores médios dos pixels de 2,81. O potencial agrícola caracteriza-se por apresentar 59\% da área enquadrada na classe baixa, com valores médios dos pixels de 1,09 (Tabela 8.63).

Regiões com restrições legais a ocupação do meio correspondem a $27 \%$ da unidade e constituem, principalmente áreas presentes em regiões com declividades acima de $25^{\circ}$.

O comportamento de elevado potencial do escoamento superficial da unidade é condicionado favoravelmente pelas características de declividade, predominância dos valores superiores a $20 \%$ em $84 \%$ da área, somado as características de textura 
intermediária, silto-arenosa, dos materiais residuais de ultramilonitos, que compreende $100 \%$ da unidade (Tabela 8.64). A condição de alta susceptibilidade a erosão é condicionada pelas características de escoamento superficial e pela textura dos materiais inconsolidados. O comportamento de baixo potencial agrícola é condicionado, principalmente, pelas características de declividade que impõem serias restrições ao desenvolvimento de práticas voltadas a estes fins.

Tabela 8.63 - Características de potencialidade e susceptibilidade do meio para unidade XXXII.

\begin{tabular}{|c|c|c|c|c|}
\hline \multicolumn{5}{|c|}{ Potencial ao Escoamento } \\
\hline Classe & Área $\left(\mathrm{Km}^{2}\right)$ & $\%$ área da unidade & \% área da bacia & $\begin{array}{c}\text { Parâmetros estatísticos/Mapas } \\
\text { Numéricos }\end{array}$ \\
\hline Baixa & 0,23 & 4,05 & 0,13 & Mín $-1,73$ \\
\hline Média & 0,76 & 13,37 & 0,12 & Máx - 3,48 \\
\hline Alta & 2,44 & 43,11 & 0,37 & Média $-2,83$ \\
\hline \multirow{2}{*}{ Muito Alta } & \multirow[b]{2}{*}{2,23} & \multirow[b]{2}{*}{39,45} & \multirow[b]{2}{*}{1,19} & Desv Padrão - 0,37 \\
\hline & & & & Moda $-2,73$ \\
\hline \multicolumn{5}{|c|}{ Susceptibilidade a Erosão } \\
\hline Classe & Área $\left(\mathrm{Km}^{2}\right)$ & \% área da unidade & \% área da bacia & $\begin{array}{c}\text { Parâmetros estatísticos/Mapas } \\
\text { Numéricos }\end{array}$ \\
\hline Baixa & 0,00 & 0,00 & 0,00 & Mín - 2,29 \\
\hline Média & 0,40 & 7,09 & 0,06 & Máx - 3,15 \\
\hline Alta & 4,65 & 82,26 & 0,59 & Média $-2,81$ \\
\hline \multirow{2}{*}{ Muito Alta } & \multirow[b]{2}{*}{0,60} & \multirow[b]{2}{*}{10,63} & \multirow[b]{2}{*}{0,43} & Desv Padrão - 0,17 \\
\hline & & & & Moda $-2,29$ \\
\hline \multicolumn{5}{|c|}{ Potencial Agrícola } \\
\hline Classe & Área $\left(\mathrm{Km}^{2}\right)$ & \% área da unidade & $\%$ área da bacia & $\begin{array}{c}\text { Parâmetros estatísticos/Mapas } \\
\text { Numéricos }\end{array}$ \\
\hline Baixa & 3,37 & 59,67 & 0,78 & Mín - 1,71 \\
\hline Média & 0,25 & 4,49 & 0,07 & Máx - 3,24 \\
\hline Alta & 0,18 & 3,24 & 0,07 & Média - 1,9 \\
\hline Muito Alta & 0,28 & 4,92 & 0,06 & Desv Padrão - 0,35 \\
\hline Restritiva & 1,57 & 27,68 & 0,98 & Moda $-3,15$ \\
\hline
\end{tabular}

Tabela 8.64- Atributos do meio físico da unidade XXXII.

\begin{tabular}{|c|c|c|c|}
\hline Declividade $\%$ & Área $\left(\mathrm{Km}^{2}\right)$ & $\%$ área da unidade & $\%$ área da bacia \\
\hline$<2$ & 0,11 & 1,94 & 0,04 \\
\hline $2-10$ & 0,20 & 3,58 & 0,07 \\
\hline $10-20$ & 0,56 & 9,93 & 0,11 \\
\hline $20-30$ & 1,11 & 19,60 & 0,32 \\
\hline $30-45$ & 2,09 & 37,02 & 0,98 \\
\hline$>45$ & 1,59 & 28,07 & 3,04 \\
\hline Geologia & Área $\left(\mathrm{Km}^{2}\right)$ & $\%$ área da unidade & $\%$ área da bacia \\
\hline Blastomilonitos & 5,65 & 100,00 & 5,30 \\
\hline Materiais Inco & Área $\left(\mathrm{Km}^{2}\right)$ & $\%$ área da unidade & $\%$ área da bacia \\
\hline Btm 5 & 5,65 & 100,00 & 100,00 \\
\hline Classes Uso do Solo & Área $\left(\mathrm{Km}^{2}\right)$ & $\%$ área da unidade & $\%$ área da bacia \\
\hline Cafe & 0,22 & 3,81 & 0,20 \\
\hline Mata Nativa & 2,28 & 40,33 & 0,64 \\
\hline Outras Culturas & 0,11 & 1,86 & 0,14 \\
\hline Pastagem & 3,05 & 54,00 & 0,31 \\
\hline
\end{tabular}


Destacam-se como principais atividades de ocupação do terreno as classes de pastagem e mata nativa, presentes em 54\% e 40\% da área, respectivamente (Figura 8.32). Atividades voltadas ao desenvolvimento agrícola ocorrem em apenas $6 \%$ da área. Esta ocorrência pouco significativa destas práticas se adequa as condições de baixo potencial exibidas pelo meio, sendo creditada as sérias restrições impostas pelas características de declividade do terreno.

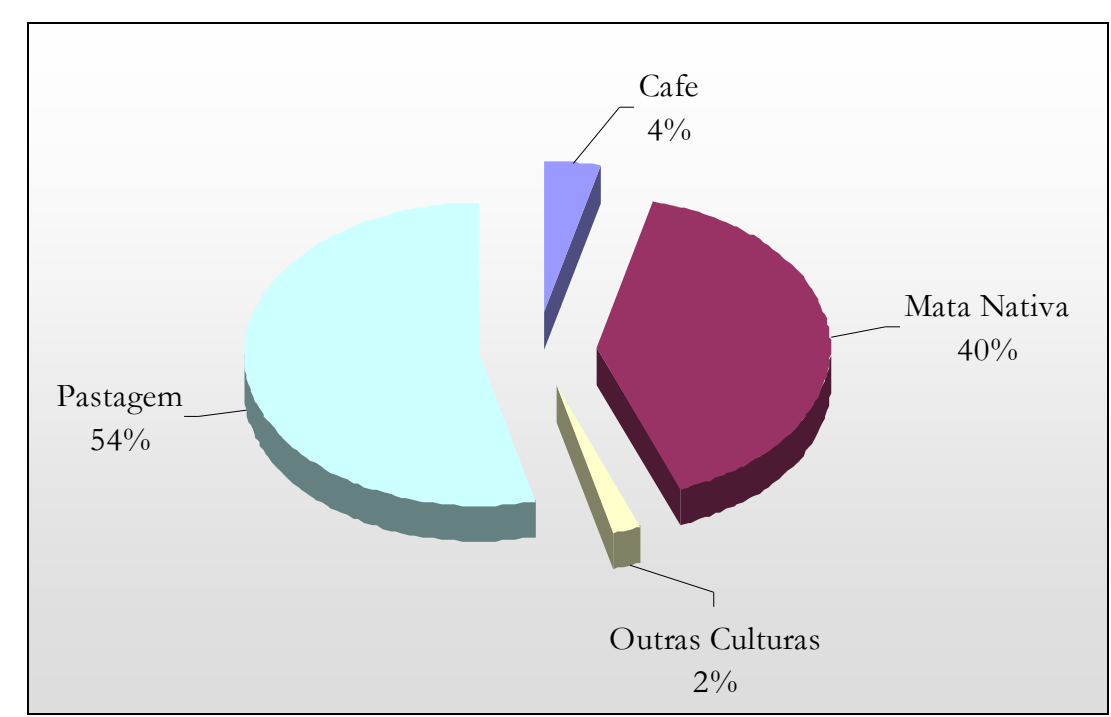

Figura 8.32 - Percentual de ocorrência das classes de uso e ocupação na Unidade Geoambiental XXXII.

\section{Unidade XXXIII}

Corresponde a unidade de terreno D10. Caracteriza-se por apresentar $46 \%$ de sua área com alto potencial ao escoamento, $35 \%$ com médio potencial e valores médios de pixels de 2,17(Tabela 8.65). A susceptibilidade a erosão é retratada pela ocorrência de $83 \%$ da área na classe alta, com valores médios dos pixels de 3,08. O potencial agrícola caracteriza-se por apresentar $50 \%$ da área enquadrada na classe baixa, com valores médios dos pixels de 2,19.

Regiões com restrições legais a ocupação do meio correspondem a 15\% da unidade e constituem, tanto áreas presentes em regiões com declividades acima de $25^{\circ}$, como faixas destinadas a preservação permanente junto aos cursos de drenagem. 
Tabela 8.65 - Características de potencialidade e susceptibilidade do meio para unidade XXXIII.

\begin{tabular}{|c|c|c|c|c|}
\hline \multicolumn{5}{|c|}{ Potencial ao Escoamento } \\
\hline Classe & Área $\left(\mathrm{Km}^{2}\right)$ & $\%$ área da unidade & $\%$ área da bacia & $\begin{array}{c}\text { Parâmetros estatísticos/Mapas } \\
\text { Numéricos }\end{array}$ \\
\hline Baixa & 0,86 & 5,30 & 0,48 & Mín - 1,16 \\
\hline Média & 5,79 & 35,63 & 0,89 & Máx - 3,46 \\
\hline Alta & 7,50 & 46,22 & 1,14 & Média - 2,17 \\
\hline \multirow{2}{*}{ Muito Alta } & \multirow[b]{2}{*}{2,09} & \multirow[b]{2}{*}{12,84} & \multirow[b]{2}{*}{1,11} & Desv Padrão - 0,35 \\
\hline & & & & Moda $-2,19$ \\
\hline \multicolumn{5}{|c|}{ Susceptibilidade a Erosão } \\
\hline Classe & Área $\left(\mathrm{Km}^{2}\right)$ & $\%$ área da unidade & $\%$ área da bacia & $\begin{array}{c}\text { Parâmetros estatísticos/Mapas } \\
\text { Numéricos }\end{array}$ \\
\hline Baixa & 0,24 & 1,47 & 0,21 & Mín - 1,35 \\
\hline Média & 0,35 & 2,18 & 0,06 & Máx - 2,88 \\
\hline Alta & 13,51 & 83,22 & 1,73 & Média $-3,08$ \\
\hline \multirow{2}{*}{ Muito Alta } & \multirow[b]{2}{*}{2,13} & \multirow[b]{2}{*}{13,13} & \multirow[b]{2}{*}{1,51} & Desv Padrã $-0,20$ \\
\hline & & & & Moda $-2,65$ \\
\hline \multicolumn{5}{|c|}{ Potencial Agrícola } \\
\hline Classe & Área $\left(\mathrm{Km}^{2}\right)$ & $\%$ área da unidade & \% área da bacia & $\begin{array}{c}\text { Parâmetros estatísticos/Mapas } \\
\text { Numéricos }\end{array}$ \\
\hline Baixa & 8,73 & 53,78 & 2,01 & Mín $-1,5$ \\
\hline Média & 1,84 & 11,36 & 0,53 & Máx $-3,32$ \\
\hline Alta & 1,48 & 9,08 & 0,57 & Média $-2,19$ \\
\hline Muito Alta & 1,73 & 10,64 & 0,37 & Desv Padrão - 0,48 \\
\hline Restritiva & 2,43 & 14,95 & 1,52 & Moda $-3,26$ \\
\hline
\end{tabular}

O comportamento de médio a alto potencial do escoamento superficial da unidade é condicionado favoravelmente pelas características de elevados valores de declividade em $60 \%$ da área, somado as características de textura intermediária, siltoarenosa, dos materiais residuais de blastomilonitos, que compreende $100 \%$ da unidade (Tabela 8.66). A condição de alta susceptibilidade a erosão é condicionada pelas características de escoamento superficial e pela textura dos materiais inconsolidados. $\mathrm{O}$ baixo potencial agrícola é condicionado, principalmente, pelas características de declividade, as quais impõem restrições ao desenvolvimento de práticas voltadas a estes fins.

Destacam-se como principais atividades de ocupação do terreno as classes de pastagem e mata nativa, presentes em $65 \%$ e $21 \%$ da área, respectivamente (Figura 8.33). Atividades voltadas ao desenvolvimento agrícola correspondem a apenas $12 \%$ da unidade. A ocorrência pouco significativa destas práticas é creditada, principalmente, as sérias restrições impostas pelas características de declividade do terreno, porém mostra o aproveitamento quase que total das condições naturais do meio, as quais permitem a ocupação de $19 \%$ da área por atividades voltadas a estes fins.. 
Tabela 8.66- Atributos do meio físico da unidade XXXIII.

\begin{tabular}{c|r|r|r}
\hline Declividade $\%$ & Área $\left(\mathbf{K m}^{\mathbf{2}}\right)$ & \% área da unidade & \% área da bacia \\
\hline$<2$ & 0,66 & 4,06 & 0,25 \\
\hline $2-10$ & 1,38 & 8,49 & 0,50 \\
\hline $10-20$ & 4,35 & 26,77 & 0,83 \\
\hline $20-30$ & 4,46 & 27,45 & 1,28 \\
\hline $30-45$ & 4,13 & 25,43 & 1,92 \\
\hline$>45$ & 1,17 & 7,20 & 2,24 \\
\hline Geologia & Área $\left.\mathbf{( K m}^{\mathbf{2}}\right)$ & \% área da unidade & \% área da bacia \\
\hline Blastomilonitos & 16,24 & 100,00 & 15,21 \\
\hline Materiais Inco & Área $\mathbf{( \mathbf { K m } ^ { 2 } )}$ & \% área da unidade & \% área da bacia \\
\hline Btm 4 & 16,24 & 100,00 & 100,00 \\
\hline Classes Uso do Solo & Área $\left(\mathbf{K m}^{\mathbf{2}}\right)$ & \% área da unidade & \% área da bacia \\
\hline Cafe & 0,90 & 5,57 & 0,84 \\
\hline Cidades & 0,18 & 1,13 & 0,58 \\
\hline Mata Nativa & 3,43 & 21,11 & 0,96 \\
\hline Outras Culturas & 1,16 & 7,12 & 1,56 \\
\hline Pastagem & 10,56 & 65,07 & 1,07 \\
\hline
\end{tabular}

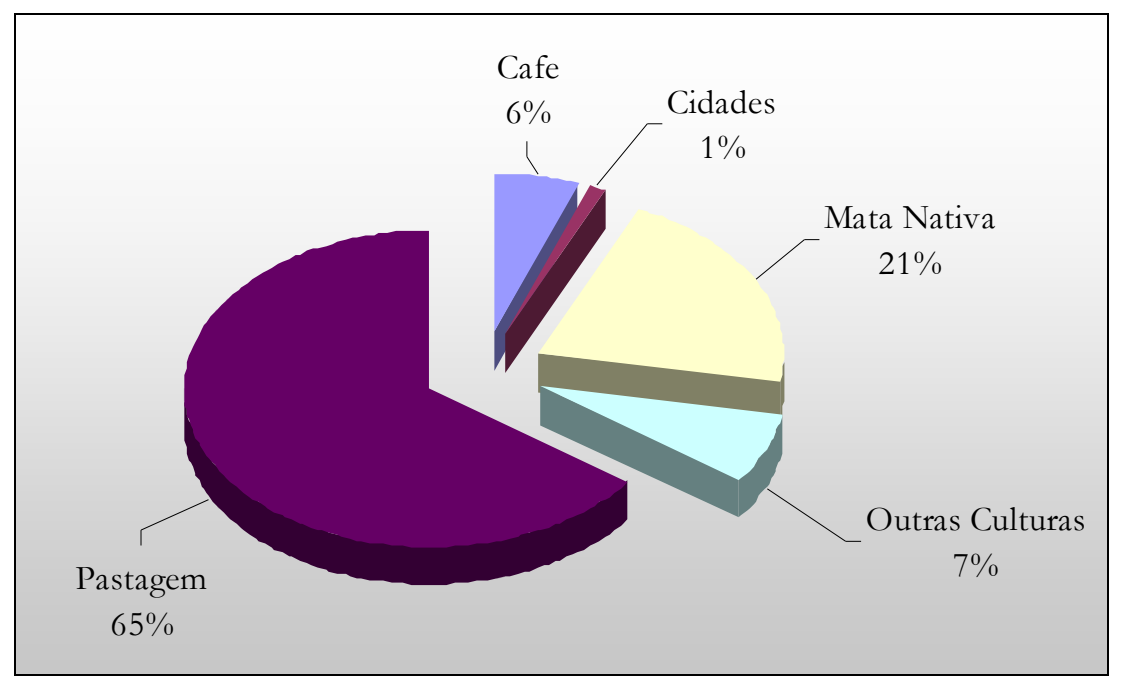

Figura 8.33 - Percentual de ocorrência das classes de uso e ocupação na Unidade Geoambiental XXXIII.

\section{$\underline{\text { Unidade XXXIV }}$}

Corresponde a unidade de terreno D11. Caracteriza-se por apresentar $74 \%$ de sua área com baixo potencial ao escoamento, e valores médios de pixels de 1,91 A susceptibilidade a erosão é retratada pela ocorrência de $91 \%$ da área na classe alta, com valores médios dos pixels de 2,59. O potencial agrícola caracteriza-se por apresentar 
68\% da área enquadrada na classe alta, com valores médios dos pixels de 2,49 (Tabela 8.67).

Regiões com restrições legais a ocupação do meio correspondem a $12 \%$ da unidade e constituem faixas destinadas a preservação permanente junto aos cursos de drenagem.

Tabela 8.67 - Características de potencialidade e susceptibilidade do meio para unidade XXXIV.

\begin{tabular}{|c|c|c|c|c|}
\hline \multicolumn{5}{|c|}{ Potencial ao Escoamento } \\
\hline Classe & Área $\left(\mathrm{Km}^{2}\right)$ & \% área da unidade & \% área da bacia & $\begin{array}{c}\text { Parâmetros estatísticos/Mapas } \\
\text { Numéricos }\end{array}$ \\
\hline Baixa & 3,49 & 74,21 & 1,94 & Mín - 1,01 \\
\hline Média & 1,20 & 25,49 & 0,18 & Máx - 2,94 \\
\hline Alta & 0,01 & 0,28 & 0,00 & Média $-1,91$ \\
\hline \multirow{2}{*}{ Muito Alta } & \multirow[b]{2}{*}{0,00} & \multirow[b]{2}{*}{0,00} & \multirow[b]{2}{*}{0,00} & Desv Padrão - 0,16 \\
\hline & & & & Moda $-1,97$ \\
\hline \multicolumn{5}{|c|}{ Susceptibilidade a Erosão } \\
\hline Classe & Área $\left(\mathrm{Km}^{2}\right)$ & $\%$ área da unidade & \% área da bacia & $\begin{array}{c}\text { Parâmetros estatísticos/Mapas } \\
\text { Numéricos }\end{array}$ \\
\hline Baixa & 0,02 & 0,32 & 0,01 & Mín $-0,43$ \\
\hline Média & 0,36 & 7,74 & 0,06 & Máx - 1,82 \\
\hline Alta & 0,43 & 91,38 & 0,55 & Média - 0,59 \\
\hline \multirow{2}{*}{ Muito Alta } & \multirow[b]{2}{*}{0,03} & \multirow[b]{2}{*}{0,53} & \multirow[b]{2}{*}{0,02} & Desv Padrão - 0,14 \\
\hline & & & & Moda $-1,22$ \\
\hline \multicolumn{5}{|c|}{ Potencial Agrícola } \\
\hline Classe & Área $\left(\mathrm{Km}^{2}\right)$ & \% área da unidade & \% área da bacia & $\begin{array}{c}\text { Parâmetros estatísticos/Mapas } \\
\text { Numéricos }\end{array}$ \\
\hline Baixa & 0,41 & 8,72 & 0,09 & Mín $-0,76$ \\
\hline Média & 0,37 & 7,82 & 0,11 & Máx - 3,31 \\
\hline Alta & 3,20 & 68,02 & 1,23 & Média $-2,49$ \\
\hline Muito Alta & 0,13 & 2,83 & 0,03 & Desv Padrão - 0,32 \\
\hline Restritiva & 0,57 & 12,12 & 0,36 & Moda $-2,61$ \\
\hline
\end{tabular}

O comportamento de médio potencial do escoamento superficial é condicionado predominância de valores muito baixos de declividade e a textura muito arenosa do material inconsolidado que constitui esta (Tabela 8.68). A condição alta susceptibilidade a erosão é condicionada pelas características de escoamento superficial e pela textura dos materiais inconsolidados. O comportamento de alto potencial agrícola é condicionado, principalmente, pelas características de declividade e pelos elevados valores de espessura dos dois materiais residuais presentes.

Destacam-se como principais atividades de ocupação do terreno as classes de pastagem e cidade, presentes em 68\% e 15\% da área, respectivamente (Figura 8.34). Atividades voltadas ao desenvolvimento agrícola correspondem a apenas $9 \%$ da unidade. A ocorrência pouco significativa destas práticas, apesar do alto potencial 
exibido pelo meio, pode ser creditada, principalmente, as características de textura muito arenosa e aos baixos valores de espessura dos materiais inconsolidados.

Tabela 8.68- Atributos do meio físico da unidade XXXIV.

\begin{tabular}{|c|c|c|c|}
\hline Declividade $\%$ & Área $\left(\mathrm{Km}^{2}\right)$ & $\%$ área da unidade & $\%$ área da bacia \\
\hline$<2$ & 3,23 & 68,64 & 1,23 \\
\hline $2-10$ & 0,70 & 14,94 & 0,25 \\
\hline $10-20$ & 0,66 & 14,08 & 0,13 \\
\hline $20-30$ & 0,09 & 1,99 & 0,03 \\
\hline $30-45$ & 0,01 & 0,25 & 0,01 \\
\hline$>45$ & 0,00 & 0,10 & 0,01 \\
\hline Geologia & Área $\left(\mathrm{Km}^{2}\right)$ & $\%$ área da unidade & $\%$ área da bacia \\
\hline Gn Básicas & 0,30 & 6,47 & 0,07 \\
\hline Ultramilonitos & 3,71 & 78,76 & 3,70 \\
\hline Blastomilonitos & 0,69 & 14,77 & 0,65 \\
\hline Materiais Inco & Área $\left(\mathrm{Km}^{2}\right)$ & \% área da unidade & $\%$ área da bacia \\
\hline Aluvião & 4,70 & 100,00 & 20,68 \\
\hline Classes Uso do Solo & Área $\left(\mathrm{Km}^{2}\right)$ & \% área da unidade & $\%$ área da bacia \\
\hline Cafe & 0,13 & 2,75 & 0,12 \\
\hline Cidades & 0,70 & 14,88 & 2,22 \\
\hline Corpos D`água & 0,06 & 1,36 & 1,51 \\
\hline Mata Nativa & 0,14 & 2,87 & 0,04 \\
\hline Mata Ciliar & 0,21 & 4,44 & 0,62 \\
\hline Outras Culturas & 0,27 & 5,64 & 0,36 \\
\hline Pastagem & 3,20 & 68,05 & 0,32 \\
\hline
\end{tabular}

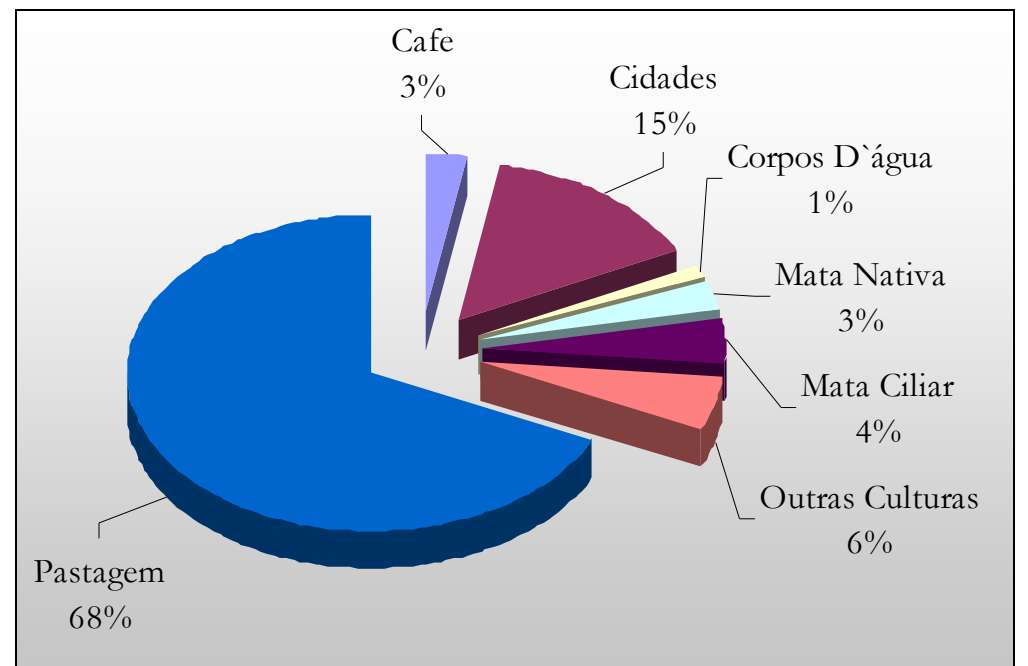

Figura 8.34 - Percentual de ocorrência das classes de uso e ocupação na Unidade Geoambiental XXXIV. 


\section{$\underline{\text { Unidade XXXV }}$}

Corresponde a unidade de terreno E1. Caracteriza-se por apresentar 51\% de sua área com médio potencial ao escoamento, 35\% com alto potencial e valores médios de pixels de 2,46. A susceptibilidade a erosão é retratada pela ocorrência de $77 \%$ da área na classe alta, com valores médios dos pixels de 2,6,. O potencial agrícola caracteriza-se por apresentar $40 \%$ da área enquadrada na classe baixa, e $24 \%$ na classe alta com valores médios dos pixels de 2,44 (Tabela 8.69).

Regiões com restrições legais a ocupação do meio correspondem a $8 \%$ da unidade e constituem, principalmente, faixas destinadas a preservação permanente junto aos cursos de drenagem, e secundariamente a regiões com valores de declividade superiores a $25^{\circ}$.

Tabela 8.69 - Características de potencialidade e susceptibilidade do meio para unidade XXXV.

\begin{tabular}{|c|c|c|c|c|}
\hline \multicolumn{5}{|c|}{ Potencial ao Escoamento } \\
\hline Classe & Área $\left(\mathrm{Km}^{2}\right)$ & \% área da unidade & $\%$ área da bacia & $\begin{array}{c}\text { Parâmetros estatísticos/Mapas } \\
\text { Numéricos }\end{array}$ \\
\hline Baixa & 1,32 & 6,80 & 0,74 & Mín - 1,66 \\
\hline Média & 10,03 & 51,60 & 1,54 & Máx $-3,55$ \\
\hline Alta & 6,87 & 35,35 & 1,04 & Média - 2,46 \\
\hline \multirow{2}{*}{ Muito Alta } & \multirow[b]{2}{*}{1,21} & \multirow[b]{2}{*}{6,24} & \multirow[b]{2}{*}{0,65} & Desv Padrão - 0,33 \\
\hline & & & & Moda $-2,32$ \\
\hline \multicolumn{5}{|c|}{ Susceptibilidade a Erosão } \\
\hline Classe & Área $\left(\mathrm{Km}^{2}\right)$ & $\%$ área da unidade & \% área da bacia & $\begin{array}{c}\text { Parâmetros estatísticos/Mapas } \\
\text { Numéricos }\end{array}$ \\
\hline Baixa & 0,00 & 0,00 & 0,00 & Mín - 2,19 \\
\hline Média & 4,24 & 21,83 & 0,66 & Máx - 3,84 \\
\hline Alta & 15,05 & 77,44 & 1,93 & Média - 2,6 \\
\hline \multirow{2}{*}{ Muito Alta } & \multirow[b]{2}{*}{0,14} & \multirow[b]{2}{*}{0,73} & \multirow[b]{2}{*}{0,10} & Desv Padrão - 0,14 \\
\hline & & & & Moda $-2,54$ \\
\hline \multicolumn{5}{|c|}{ Potencial Agrícola } \\
\hline Classe & Área $\left(\mathrm{Km}^{2}\right)$ & $\%$ área da unidade & \% área da bacia & $\begin{array}{c}\text { Parâmetros estatísticos/Mapas } \\
\text { Numéricos }\end{array}$ \\
\hline Baixa & 7,82 & 40,25 & 1,80 & Mín - 1,67 \\
\hline Média & 2,66 & 13,67 & 0,76 & Máx - 3,75 \\
\hline Alta & 2,60 & 13,36 & 1,00 & Média - 2,44 \\
\hline Muito Alta & 4,80 & 24,68 & 1,02 & Desv Padrão - 0,57 \\
\hline Restritiva & 1,57 & 8,07 & 0,98 & Moda $-3,27$ \\
\hline
\end{tabular}

O comportamento de médio a alto potencial do escoamento superficial é condicionado pela predominância de valores elevados de declividade em $42 \%$ da área e a textura intermediária, silto-arenosa, do material inconsolidado residual de blatomilonitos que constitui 100\% desta (Tabela 8.70). A condição alta susceptibilidade a erosão é condicionada pelas características de escoamento superficial e pela textura dos materiais 
inconsolidados. O comportamento de potencial agrícola médio a muito alto em $51 \%$ da área é condicionado, principalmente, pelas características de declividade inferiores a $20 \%$ constatadas em mais da metade da unidade e pelos elevados valores de espessura dos dois materiais residuais.

Destacam-se como principais atividades de ocupação do terreno as classes de pastagem e mata nativa, presentes em 68\% e 15\% da área, respectivamente (Figura 8.35). Atividades voltadas ao desenvolvimento agrícola correspondem a apenas $7 \%$ da unidade. A ocorrência pouco significativa destas práticas, apesar do bom potencial exibido pó metade da área, mostra o aproveitamento inadequado das condições naturais exibidas pelo meio.

Tabela 8.70- Atributos do meio físico da unidade XXXV.

\begin{tabular}{|c|c|c|c|}
\hline Declividade $\%$ & Área $\left(\mathrm{Km}^{2}\right)$ & $\%$ área da unidade & $\%$ área da bacia \\
\hline$<2$ & 2,58 & 13,26 & 0,98 \\
\hline $2-10$ & 2,62 & 13,49 & 0,94 \\
\hline $10-20$ & 6,09 & 31,32 & 1,17 \\
\hline $20-30$ & 4,82 & 24,79 & 1,38 \\
\hline $30-45$ & 2,73 & 14,03 & 1,27 \\
\hline$>45$ & 0,61 & 3,14 & 1,17 \\
\hline Geologia & Área $\left(\mathrm{Km}^{2}\right)$ & \% área da unidade & $\%$ área da bacia \\
\hline Blastomilonitos & 19,4301 & 100,00 & 18,20 \\
\hline Materiais Inco & Área $\left(\mathrm{Km}^{2}\right)$ & \% área da unidade & $\%$ área da bacia \\
\hline Btm 2 & 19,4 & 100,00 & 69,75 \\
\hline Classes Uso do Solo & Área $\left(\mathrm{Km}^{2}\right)$ & \% área da unidade & $\%$ área da bacia \\
\hline Cafe & 0,45 & 2,29 & 0,42 \\
\hline Mata Nativa & 4,06 & 20,92 & 1,13 \\
\hline Outras Culturas & 0,94 & 4,81 & 1,26 \\
\hline Pastagem & 13,88 & 71,45 & 1,41 \\
\hline Solo Exposto & 0,06 & 0,30 & 0,72 \\
\hline
\end{tabular}

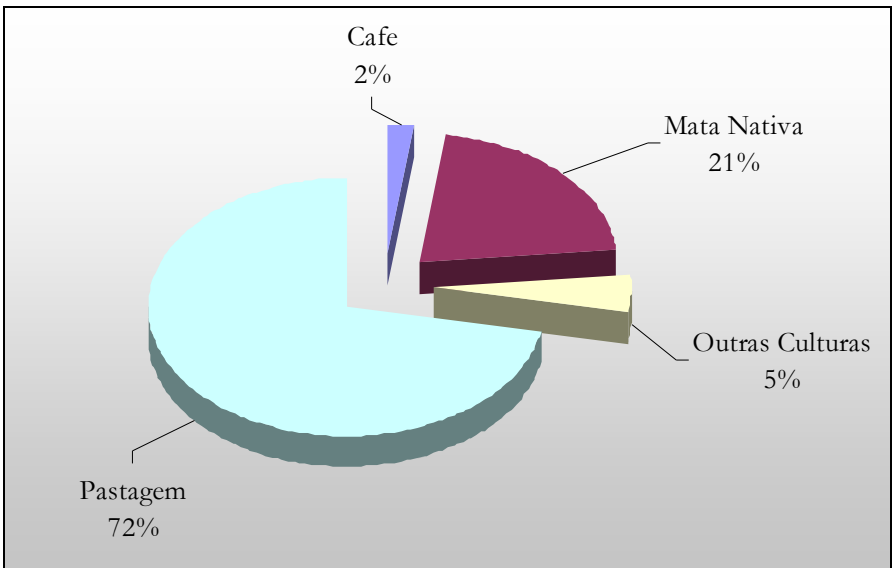

Figura 8.35 - Percentual de ocorrência das classes de uso e ocupação na Unidade Geoambiental XXXV. 


\section{Unidade XXXVI}

Corresponde a unidade de terreno E2. Caracteriza-se por apresentar 29\% de sua área com médio potencial ao escoamento, 50\% com alto potencial e valores médios de pixels de 2,61. A susceptibilidade a erosão é retratada pela ocorrência de $71 \%$ da área na classe media, com valores médios dos pixels de 2,39. O potencial agrícola caracteriza-se por predominância das classes média (335) e muito alta (26\%), com valores médios dos pixels de 2,5 (Tabela 8.71).

Regiões com restrições legais a ocupação do meio correspondem a apenas 6\% da unidade e constituem, principalmente, faixas destinadas a preservação permanente junto aos cursos de drenagem.

Tabela 8.71 - Características de potencialidade e susceptibilidade do meio para unidade XXXVI.

\begin{tabular}{|c|c|c|c|c|}
\hline \multicolumn{5}{|c|}{ Potencial ao Escoamento } \\
\hline Classe & Área $\left(\mathrm{Km}^{2}\right)$ & $\%$ área da unidade & $\%$ área da bacia & $\begin{array}{l}\text { Parâmetros estatísticos/Mapas } \\
\text { Numéricos }\end{array}$ \\
\hline Baixa & 6,74 & 5,38 & 3,75 & Mín - 1,03 \\
\hline Média & 36,26 & 28,99 & 5,58 & Máx $-4,13$ \\
\hline Alta & 62,92 & 50,31 & 9,52 & Média - 2,61 \\
\hline \multirow{2}{*}{ Muito Alta } & \multirow[b]{2}{*}{19,14} & \multirow[b]{2}{*}{15,30} & \multirow[b]{2}{*}{10,21} & Desv Padrão - 0,38 \\
\hline & & & & Moda $-2,65$ \\
\hline \multicolumn{5}{|c|}{ Susceptibilidade a Erosão } \\
\hline Classe & Área $\left(\mathrm{Km}^{2}\right)$ & $\%$ área da unidade & $\%$ área da bacia & $\begin{array}{c}\text { Parâmetros estatísticos/Mapas } \\
\text { Numéricos }\end{array}$ \\
\hline Baixa & 2,86 & 2,29 & 2,47 & Mín - 1,13 \\
\hline Média & 88,90 & 71,07 & 13,90 & Máx - 3,82 \\
\hline Alta & 29,61 & 23,68 & 3,79 & Média - 2,39 \\
\hline \multirow{2}{*}{ Muito Alta } & \multirow{2}{*}{\multicolumn{2}{|c|}{3,10}} & \multirow[b]{2}{*}{2,76} & Desv Padrão - 0,27 \\
\hline & & & & Moda $-2,28$ \\
\hline \multicolumn{5}{|c|}{ Potencial Agrícola } \\
\hline Classe & Área $\left(\mathrm{Km}^{2}\right)$ & $\%$ área da unidade & $\%$ área da bacia & $\begin{array}{c}\text { Parâmetros estatísticos/Mapas } \\
\text { Numéricos }\end{array}$ \\
\hline Baixa & 22,01 & 17,59 & 5,07 & Mín - 1,3 \\
\hline Média & 42,20 & 33,73 & 12,07 & Máx - 3,9 \\
\hline Alta & 19,33 & 15,45 & 7,43 & Média $-2,5$ \\
\hline Muito Alta & 33,08 & 26,44 & 7,01 & Desv Padrão - 0,63 \\
\hline Restritiva & 8,42 & 6,73 & 5,27 & Moda $-3,41$ \\
\hline
\end{tabular}

O comportamento de médio a alto potencial do escoamento superficial é condicionado pela ocorrência de valores elevados de declividade em $38 \%$ da área e a textura argilosa dos materiais residual de migmatitos que constitui $70 \%$ desta (Tabela 8.72). A condição média susceptibilidade a erosão é condicionada pelas características de escoamento superficial e pela textura dos materiais inconsolidados, que exercem pouca influência no condicionamento de elevados valores de susceptibilidade. O 
comportamento de médio a muito alto potencial agrícola é condicionado, principalmente, pelas características de declividade inferiores a $20 \%$ constatadas em $72 \%$ da unidade e pelos elevados valores de espessura e capacidade de troca catiônica dos dois materiais residuais.

Tabela 8.72- Atributos do meio físico da unidade XXXVI.

\begin{tabular}{|c|c|c|c|}
\hline Declividade \% & Área $\left(\mathrm{Km}^{2}\right)$ & $\%$ área da unidade & $\%$ área da bacia \\
\hline$<2$ & 16,78 & 13,42 & 6,39 \\
\hline $2-10$ & 19,90 & 15,91 & 7,16 \\
\hline $10-20$ & 40,57 & 32,43 & 7,77 \\
\hline $20-30$ & 30,59 & 24,46 & 8,78 \\
\hline $30-45$ & 15,22 & 12,17 & 7,10 \\
\hline$>45$ & 2,05 & 1,64 & 3,92 \\
\hline Geologia & Área $\left(\mathrm{Km}^{2}\right)$ & $\%$ área da unidade & $\%$ área da bacia \\
\hline Migmatitos & 99,42 & 79,49 & 23,10 \\
\hline Blastomilonitos & 18,57 & 14,85 & 17,40 \\
\hline Granitos Porfiríticos & 7,09 & 5,67 & 2,11 \\
\hline Materiais Inco & Área $\left(\mathrm{Km}^{2}\right)$ & $\%$ área da unidade & $\%$ área da bacia \\
\hline Retrab 2 & 0,61 & 0,48 & 1,22 \\
\hline Mig 6 & 11,53 & 9,22 & 100,00 \\
\hline Mig 7 & 87,28 & 69,78 & 99,96 \\
\hline Grp 3 & 7,09 & 5,67 & 5,68 \\
\hline Btm 1 & 18,57 & 14,85 & 100,00 \\
\hline Classes Uso do Solo & Área $\left(\mathrm{Km}^{2}\right)$ & $\%$ área da unidade & $\%$ área da bacia \\
\hline Cafe & 1,58 & 1,27 & 1,48 \\
\hline Cidades & 1,19 & 0,95 & 3,77 \\
\hline Corpos D água & 0,65 & 0,42 & 9,34 \\
\hline Mata Nativa & 22,70 & 18,14 & 6,32 \\
\hline Mata Ciliar & 4,08 & 3,26 & 12,22 \\
\hline Outras Culturas & 7,17 & 5,73 & 9,69 \\
\hline Pastagem & 87,82 & 70,21 & 8,89 \\
\hline
\end{tabular}

Destacam-se como principais atividades de ocupação do terreno as classes de pastagem e mata nativa, presentes em $71 \%$ e 18\% da área, respectivamente (Figura 8.36). Atividades voltadas ao desenvolvimento agrícola correspondem a apenas $7 \%$ da unidade. A ocorrência pouco significativa destas práticas, apesar do alto potencial exibido pela unidade, caracteriza situação de aproveitamento inadequado das condições naturais do meio, que favorecem ao desenvolvimento de atividades voltadas a estes fins. 


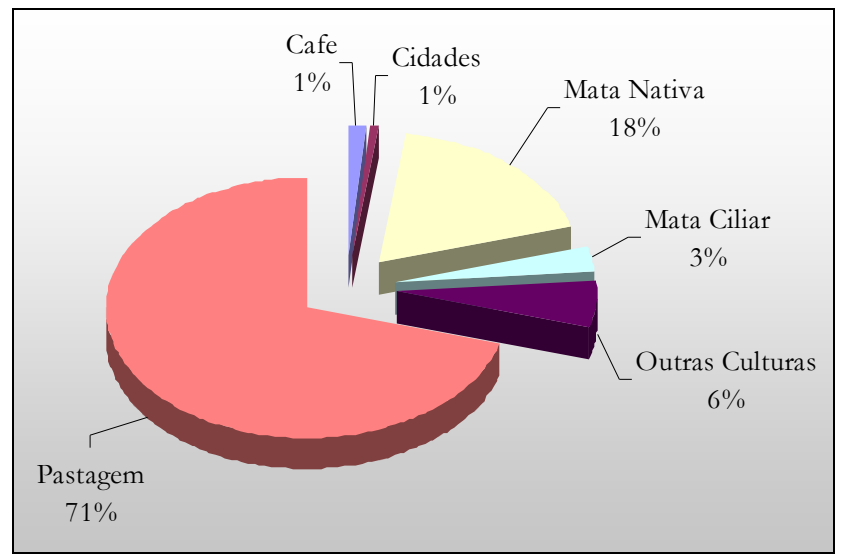

Figura 8.36 - Percentual de ocorrência das classes de uso e ocupação na Unidade Geoambiental XXXVI.

\section{Unidade XXXVII}

Corresponde a unidade de terreno E3. Caracteriza-se por apresentar 31\% de sua área com médio potencial ao escoamento, $50 \%$ com alto potencial e valores médios de pixels de 2,67. A susceptibilidade a erosão é retratada pela ocorrência de $89 \%$ da área na classe média, com valores médios dos pixels de 2,3. O potencial agrícola caracteriza-se por apresentar $41 \%$ da área enquadrada na classe baixa, e $22 \%$ na classe muito alta com valores médios dos pixels de 2,41 (Tabela 8.73).

Tabela 8.73 - Características de potencialidade e susceptibilidade do meio para unidade XXXVII.

\begin{tabular}{|c|c|c|c|c|}
\hline \multicolumn{5}{|c|}{ Potencial ao Escoamento } \\
\hline Classe & Área $\left(\mathrm{Km}^{2}\right)$ & \% área da unidade & $\%$ área da bacia & $\begin{array}{c}\text { Parâmetros estatísticos/Mapas } \\
\text { Numéricos }\end{array}$ \\
\hline Baixa & 0,00 & 0,00 & 0,00 & Mín - 2,07 \\
\hline Média & 3,66 & 31,75 & 0,56 & Máx $-3,80$ \\
\hline Alta & 5,77 & 50,04 & 0,87 & Média $-2,67$ \\
\hline \multirow{2}{*}{ Muito Alta } & \multirow[b]{2}{*}{2,10} & \multirow[b]{2}{*}{18,19} & \multirow[b]{2}{*}{1,12} & Desv Padrão - 0,35 \\
\hline & & & & Moda - 2,07 \\
\hline \multicolumn{5}{|c|}{ Susceptibilidade a Erosão } \\
\hline Classe & Área $\left(\mathrm{Km}^{2}\right)$ & $\%$ área da unidade & $\%$ área da bacia & $\begin{array}{c}\text { Parâmetros estatísticos/Mapas } \\
\text { Numéricos }\end{array}$ \\
\hline Baixa & 0,00 & 0,00 & 0,00 & Mín - 2,03 \\
\hline Média & 10,28 & 89,13 & 1,61 & Máx $-3,38$ \\
\hline Alta & 1,13 & 9,81 & 0,14 & Média $-2,3$ \\
\hline \multirow{2}{*}{ Muito Alta } & \multirow[b]{2}{*}{0,12} & \multirow[b]{2}{*}{1,06} & \multirow[b]{2}{*}{0,09} & Desv Padrão $-0,18$ \\
\hline & & & & Moda - 2,03 \\
\hline \multicolumn{5}{|c|}{ Potencial Agrícola } \\
\hline Classe & Área $\left(\mathrm{Km}^{2}\right)$ & \% área da unidade & $\%$ área da bacia & $\begin{array}{c}\text { Parâmetros estatísticos/Mapas } \\
\text { Numéricos }\end{array}$ \\
\hline Baixa & 4,81 & 41,71 & 1,11 & Mín $-1,84$ \\
\hline Média & 1,87 & 16,22 & 0,53 & Máx - 3,42 \\
\hline Alta & 1,74 & 15,07 & 0,67 & Média - 2,41 \\
\hline Muito Alta & 2,61 & 22,66 & 0,55 & Desv Padrão $-0,55$ \\
\hline Restritiva & 0,50 & 4,34 & 0,31 & Moda - 3,29 \\
\hline
\end{tabular}


Regiões com restrições legais a ocupação do meio correspondem a apenas 4\% da unidade e constituem, tanto faixas destinadas a preservação permanente junto aos cursos de drenagem, como regiões com valores de declividade superiores a $25^{\circ}$.

O comportamento de médio a alto potencial do escoamento superficial é condicionado pela ocorrência de valores elevados de declividade em $41 \%$ da área e a textura argilosa dos materiais residual de migmatitos que constitui 100\% desta (Tabela 8.74). A condição média susceptibilidade a erosão é condicionada pelas características de escoamento superficial e pela textura dos materiais inconsolidados, que exercem pouca influência no condicionamento de elevados valores de susceptibilidade. $O$ comportamento de médio a muito alto potencial agrícola exibido por $53 \%$ da área é condicionado, principalmente, pelas características de declividade inferiores a $20 \%$ constatadas em 59\% da unidade e pelos elevados valores de espessura e capacidade de troca catiônica dos dois materiais residuais.

Tabela 8.74- Atributos do meio físico da unidade XXXVII.

\begin{tabular}{c|r|r|r}
\hline Declividade $\%$ & \multicolumn{1}{|c|}{ Área $\left(\mathbf{K m}^{2}\right)$} & \% área da unidade & \% área da bacia \\
\hline$<2$ & 0,90 & 7,84 & 0,34 \\
\hline $2-10$ & 1,74 & 15,08 & 0,63 \\
\hline $10-20$ & 4,15 & 36,03 & 0,80 \\
\hline $20-30$ & 3,25 & 28,21 & 0,93 \\
\hline $30-45$ & 1,30 & 11,31 & 0,61 \\
\hline$>45$ & 0,21 & 1,80 & 0,40 \\
\hline Geologia & Área $\left(\mathbf{K m}^{2}\right)$ & \% área da unidade & \% área da bacia \\
\hline Migmatitos & 11,53 & 100,00 & 2,68 \\
\hline Materiais Inco & Área $\left(\mathbf{K m}^{2}\right)$ & \% área da unidade & \% área da bacia \\
\hline Mig 6 & 11,53 & 100,00 & 100,00 \\
\hline Classes Uso do Solo & Área $\left(\mathbf{K m}^{2}\right)$ & \% área da unidade & \% área da bacia \\
\hline Corpos D água & 0,01 & 0,06 & 0,17 \\
\hline Mata Nativa & 2,35 & 20,38 & 0,65 \\
\hline Mata Ciliar & 0,41 & 3,51 & \\
\hline Outras Culturas & 1,35 & 11,74 & \\
\hline Pastagem & 7,42 & 64,31 & \\
\hline
\end{tabular}

Destacam-se como principais atividades de ocupação do terreno as classes de pastagem e mata nativa, presentes em 64\% e 20\% da área, respectivamente (Figura 8.37). Atividades voltadas ao desenvolvimento agrícola compreendem $12 \%$ da unidade. A ocorrência pouco significativa destas práticas, apesar do alto potencial exibido em $53 \%$ unidade, caracteriza situação de aproveitamento inadequado das condições naturais do meio, que favorecem ao desenvolvimento de atividades voltadas a estes fins. 


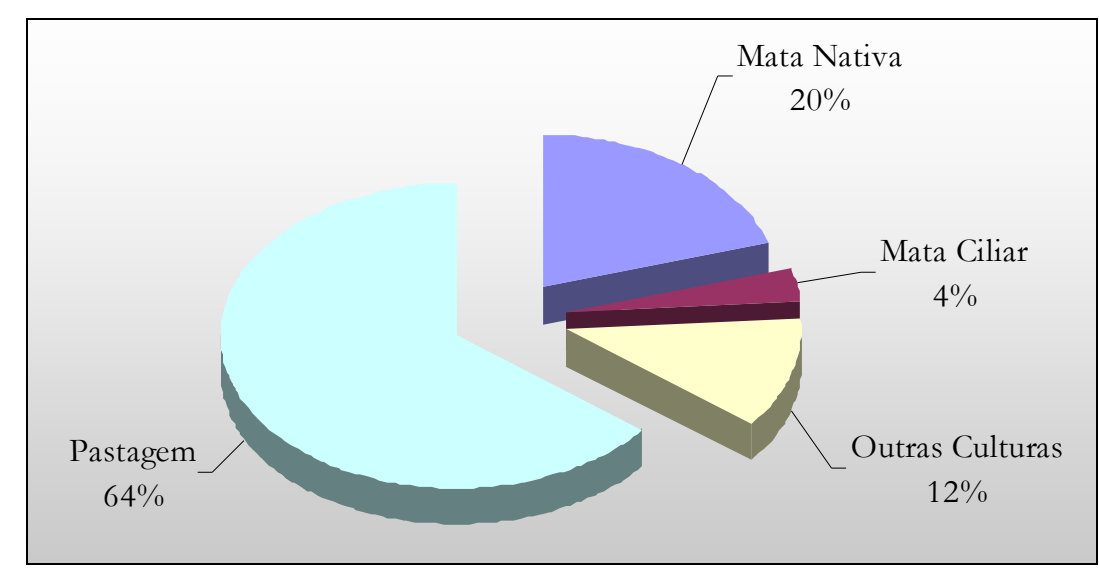

Figura 8.37 - Percentual de ocorrência das classes de uso e ocupação na Unidade Geoambiental XXXVII.

\section{Unidade XXXVIII}

Corresponde a unidade de terreno E4. Caracteriza-se por apresentar, aproximadamente, $77 \%$ de sua área com potencial ao escoamento alto a muito alto, e valores médios de pixels de 2,73. A susceptibilidade a erosão é retratada pela ocorrência de $67 \%$ da área na classe média, e $27 \%$ na classe alta com valores médios dos pixels de 2,45 . O potencial agrícola caracteriza-se por apresentar $41 \%$ da área enquadrada na classe média e 21\% na muito alta, e valores médios dos pixels de 2,51 (Tabela 8.75).

Regiões com restrições legais a ocupação do meio correspondem a apenas 7\% da unidade e constituem, principalmente, regiões com valores de declividade superiores a $25^{\circ}$, e secundariamente áreas destinadas a preservação permanente junto aos cursos de drenagem.

O comportamento de elevado potencial do escoamento superficial é condicionado pela ocorrência de altos valores de declividade em $50 \%$ da área e a textura argilosa dos materiais residual de migmatitos e granitos porfiríticos, que constitui $90 \%$ desta (Tabela 8.76). A condição susceptibilidade a erosão média a alta é condicionada pelas características de escoamento superficial e pela textura dos materiais inconsolidados, que exercem pouca influência no condicionamento de elevados valores de susceptibilidade. O comportamento de médio a muito alto potencial agrícola é condicionado, principalmente, pelas características de declividade inferiores a $20 \%$ constatadas em metade da unidade e pelos elevados valores de espessura, e capacidade de troca catiônica dos dois materiais residuais, em especial dos residuais de migmatitos. 
Tabela 8.75 - Características de potencialidade e susceptibilidade do meio para unidade XXXVIII.

\begin{tabular}{|c|c|c|c|c|}
\hline \multicolumn{5}{|c|}{ Potencial ao Escoamento } \\
\hline Classe & Área $\left(\mathrm{Km}^{2}\right)$ & \% área da unidade & \% área da bacia & $\begin{array}{c}\text { Parâmetros estatísticos/Mapas } \\
\text { Numéricos }\end{array}$ \\
\hline Baixa & 3,19 & 1,82 & 1,78 & Mín - 1,28 \\
\hline Média & 37,27 & 21,25 & 5,74 & Máx - 4,12 \\
\hline Alta & 97,38 & 55,53 & 14,74 & Média $-2,73$ \\
\hline \multirow{2}{*}{ Muito Alta } & \multirow{2}{*}{\multicolumn{2}{|c|}{21,39}} & \multirow[b]{2}{*}{20,00} & Desv Padrão - 0,34 \\
\hline & & & & Moda $-2,65$ \\
\hline \multicolumn{5}{|c|}{ Susceptibilidade a Erosão } \\
\hline Classe & Área $\left(\mathrm{Km}^{2}\right)$ & $\%$ área da unidade & \% área da bacia & $\begin{array}{l}\text { Parâmetros estatísticos/Mapas } \\
\text { Numéricos }\end{array}$ \\
\hline Baixa & 0,16 & 0,09 & 0,14 & Mín - 1,86 \\
\hline Média & 118,10 & 67,35 & 18,47 & Máx - 4,20 \\
\hline Alta & 47,90 & 27,31 & 6,13 & Média $-2,45$ \\
\hline \multirow{2}{*}{ Muito Alta } & \multirow[b]{2}{*}{9,20} & \multirow[b]{2}{*}{5,25} & \multirow[b]{2}{*}{6,54} & Desv Padrão - 0,28 \\
\hline & & & & Moda $-2,28$ \\
\hline \multicolumn{5}{|c|}{ Potencial Agrícola } \\
\hline Classe & Área $\left(\mathrm{Km}^{2}\right)$ & $\%$ área da unidade & $\%$ área da bacia & $\begin{array}{c}\text { Parâmetros estatísticos/Mapas } \\
\text { Numéricos }\end{array}$ \\
\hline Baixa & 23,63 & 13,48 & 5,44 & Mín - 1,74 \\
\hline Média & 72,26 & 41,21 & 20,67 & Máx - 3,87 \\
\hline Alta & 25,09 & 14,31 & 9,65 & Média $-2,51$ \\
\hline Muito Alta & 42,30 & 24,12 & 8,96 & Desv Padrão - 0,56 \\
\hline Restritiva & 12,06 & 6,88 & 7,55 & Moda $-3,04$ \\
\hline
\end{tabular}

Tabela 8.76- Atributos do meio físico da unidade XXXVIII.

\begin{tabular}{|c|c|c|c|}
\hline Declividade $\%$ & Área $\left(\mathrm{Km}^{2}\right)$ & $\%$ área da unidade & $\%$ área da bacia \\
\hline$<2$ & 14,40 & 8,21 & 5,48 \\
\hline $2-10$ & 24,57 & 14,01 & 8,84 \\
\hline $10-20$ & 57,50 & 32,79 & 11,02 \\
\hline $20-30$ & 47,28 & 26,96 & 13,58 \\
\hline $30-45$ & 26,80 & 15,28 & 12,49 \\
\hline$>45$ & 14,40 & 8,21 & 5,48 \\
\hline Geologia & Área $\left(\mathrm{Km}^{2}\right)$ & $\%$ área da unidade & $\%$ área da bacia \\
\hline Migmatitos & 119,09 & 67,91 & 27,67 \\
\hline Granitos Porfiríticos & 41,84 & 23,86 & 12,44 \\
\hline Granito-Gnaisses & 14,44 & 8,23 & 24,73 \\
\hline Materiais Inco & Área $\left(\mathrm{Km}^{2}\right)$ & $\%$ área da unidade & $\%$ área da bacia \\
\hline Retrab 2 & 3,22 & 1,84 & 6,47 \\
\hline Mig 7 & 0,02 & 0,01 & 0,02 \\
\hline Mig 8 & 115,85 & 66,07 & 100,00 \\
\hline Grp 2 & 41,83 & 23,85 & 100,00 \\
\hline GrGn 1 & 14,44 & 8,23 & 100,00 \\
\hline Classes Uso do Solo & Área $\left(\mathrm{Km}^{2}\right)$ & $\%$ área da unidade & $\%$ área da bacia \\
\hline Cafe & 3,74 & 2,14 & 3,49 \\
\hline Corpos D água & 0,13 & 0,07 & 3,00 \\
\hline Mata Nativa & 31,98 & 18,24 & 8,91 \\
\hline Mata Ciliar & 6,63 & 3,78 & 19,83 \\
\hline Outras Culturas & 11,00 & 6,27 & 14,88 \\
\hline Pastagem & 121,41 & 69,24 & 12,29 \\
\hline Reflorestamento & 0,13 & 0,07 & 2,46 \\
\hline
\end{tabular}


Destacam-se como principais atividades de ocupação do terreno as classes de pastagem e mata nativa, presentes em $70 \%$ e $18 \%$ da área, respectivamente (Figura 8.38). Atividades voltadas ao desenvolvimento agrícola compreendem $8 \%$ da unidade, e caracteriza o aproveitamento inadequado das condições naturais do meio, que favorecem ao desenvolvimento de atividades voltadas a estes fins.

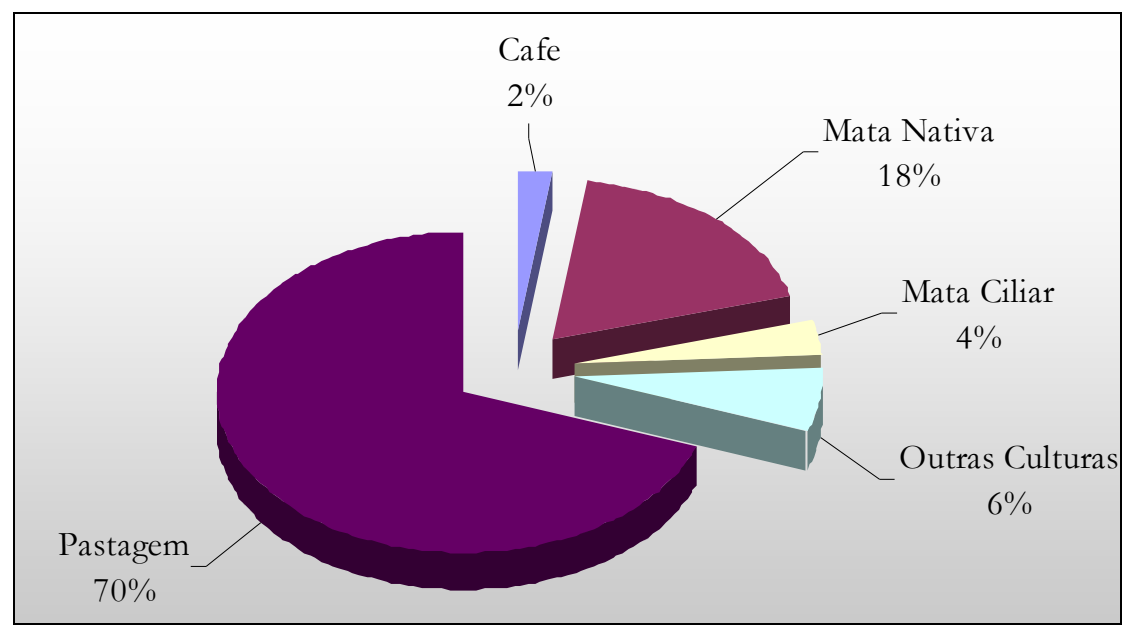

Figura 8.38 - Percentual de ocorrência das classes de uso e ocupação na Unidade Geoambiental XXXVIII.

\section{Unidade XXXIX}

Corresponde a unidade de terreno E5. Caracteriza-se por apresentar 67\% de sua área com médio potencial ao escoamento, 30\% com alto potencial e valores médios de pixels de 2,42. A susceptibilidade a erosão é retratada pela ocorrência de $78 \%$ da área na classe alta com valores médios dos pixels de 2,58. O potencial agrícola caracteriza-se por apresentar 39\% da área enquadrada na classe muito alta e $23 \%$ na baixa, e valores médios dos pixels de 2,7 (Tabela 8.77).

Regiões com restrições legais a ocupação do meio correspondem a apenas $6 \%$ da unidade e constituem, principalmente, destinadas a preservação permanente junto aos cursos de drenagem. 
Tabela 8.77 - Características de potencialidade e susceptibilidade do meio para unidade XXXIX.

\begin{tabular}{|c|c|c|c|c|}
\hline \multicolumn{5}{|c|}{ Potencial ao Escoamento } \\
\hline Classe & Área $\left(\mathrm{Km}^{2}\right)$ & $\%$ área da unidade & $\%$ área da bacia & $\begin{array}{c}\text { Parâmetros estatísticos/Mapas } \\
\text { Numéricos }\end{array}$ \\
\hline Baixa & 0,87 & 5,28 & 0,48 & Mín $-1,83$ \\
\hline Média & 11,03 & 67,07 & 16,98 & Máx $-4,05$ \\
\hline Alta & 4,96 & 30,16 & 0,75 & Média $-2,42$ \\
\hline \multirow{2}{*}{ Muito Alta } & \multirow[b]{2}{*}{0,31} & \multirow[b]{2}{*}{1,88} & \multirow[b]{2}{*}{0,16} & Desv Padrão - 0,25 \\
\hline & & & & Moda $-2,41$ \\
\hline \multicolumn{5}{|c|}{ Susceptibilidade a Erosão } \\
\hline Classe & Área $\left(\mathrm{Km}^{2}\right)$ & $\%$ área da unidade & $\%$ área da bacia & $\begin{array}{c}\text { Parâmetros estatísticos/Mapas } \\
\text { Numéricos }\end{array}$ \\
\hline Baixa & 0,00 & 0,00 & 0,00 & Mín $-2,18$ \\
\hline Média & 3,44 & 20,90 & 0,54 & Máx - 4,34 \\
\hline Alta & 12,95 & 78,74 & 1,66 & Média $-2,58$ \\
\hline \multirow{2}{*}{ Muito Alta } & \multirow[b]{2}{*}{0,06} & \multirow[b]{2}{*}{0,34} & \multirow[b]{2}{*}{0,04} & Desv Padrão - 0,11 \\
\hline & & & & Moda $-2,85$ \\
\hline \multicolumn{5}{|c|}{ Potencial Agrícola } \\
\hline Classe & Área $\left(\mathrm{Km}^{2}\right)$ & \% área da unidade & \% área da bacia & $\begin{array}{c}\text { Parâmetros estatísticos/Mapas } \\
\text { Numéricos }\end{array}$ \\
\hline Baixa & 3,89 & 23,65 & 0,90 & Mín $-1,82$ \\
\hline Média & 2,18 & 13,27 & 0,62 & Máx $-3,57$ \\
\hline Alta & 2,84 & 17,28 & 1,09 & Média $-2,70$ \\
\hline Muito Alta & 6,44 & 39,14 & 1,36 & Desv Padrão - 0,56 \\
\hline Restritiva & 1,10 & 6,68 & 0,69 & Moda $-3,04$ \\
\hline
\end{tabular}

O comportamento de médio potencial do escoamento superficial é condicionado pela predominância de ocorrência de valores de declividade inferiores a $20 \%$ da área e a textura intermediária dos materiais residual de migmatitos, que constitui 100\% desta (Tabela 8.78). A condição de alta susceptibilidade a erosão é condicionada pelas características de escoamento superficial e pela textura dos materiais inconsolidados. O comportamento de médio a muito alto potencial agrícola é condicionado, principalmente, pelas características de declividade, espessura, e capacidade de troca catiônica dos materiais residuais.

A atividade de pastagem caracteriza a principal ocupação do terreno presentes na unidade (Figura 8.39). Atividades voltadas ao desenvolvimento agrícola compreendem 9\% da unidade, e caracteriza o aproveitamento inadequado das condições naturais do meio, que favorecem ao desenvolvimento de atividades voltadas a estes fins. 
Tabela 8.78- Atributos do meio físico da unidade XXXIX.

\begin{tabular}{c|r|r|r}
\hline Declividade $\mathbf{\%}$ & Área $\left(\mathbf{K m}^{\mathbf{2}}\right)$ & \% área da unidade & \% área da bacia \\
\hline$<2$ & 3,61 & 21,93 & 1,37 \\
\hline $2-10$ & 3,44 & 20,89 & 1,24 \\
\hline $10-20$ & 5,76 & 35,04 & 1,10 \\
\hline $20-30$ & 2,83 & 17,20 & 0,81 \\
\hline $30-45$ & 0,76 & 4,61 & 0,35 \\
\hline$>45$ & 0,04 & 0,26 & 0,08 \\
\hline Geologia & Área $\left.\mathbf{( K m}^{\mathbf{2}}\right)$ & \% área da unidade & \% área da bacia \\
\hline Migmatitos & 16,44 & 100,00 & 3,82 \\
\hline Materiais Inco & Área $\left(\mathbf{K m}^{\mathbf{2}}\right)$ & $\mathbf{\%}$ área da unidade & \% área da bacia \\
\hline Mig 9 & 16,44 & 100,00 & 18,54 \\
\hline Classes Uso do Solo & Área $\left(\mathbf{K m}^{\mathbf{2}}\right)$ & \% área da unidade & \% área da bacia \\
\hline Cafe & 0,50 & 3,07 & 0,47 \\
\hline Mata Nativa & 1,45 & 8,83 & 0,40 \\
\hline Mata Ciliar & 0,94 & 5,71 & 2,81 \\
\hline Outras Culturas & 0,61 & 3,71 & 0,82 \\
\hline Pastagem & 12,60 & 76,63 & 1,28 \\
\hline Solo Exposto & 0,34 & 2,05 & 4,20 \\
\hline
\end{tabular}

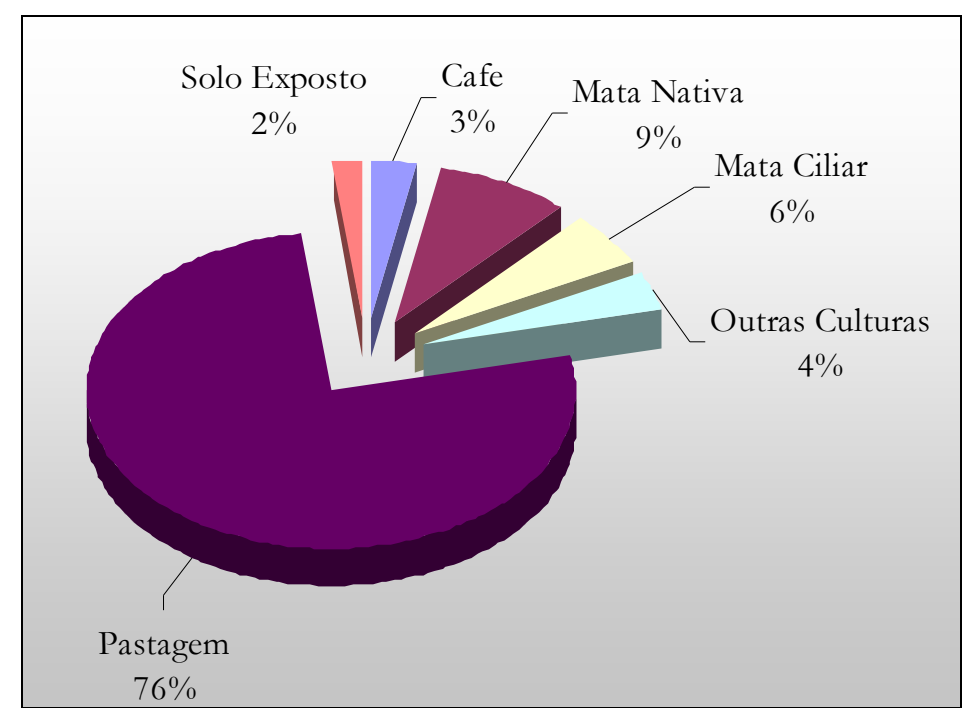

Figura 8.39 - Percentual de ocorrência das classes de uso e ocupação na Unidade Geoambiental XXXIX.

\section{$\underline{\text { Unidade XL }}$}

Corresponde a unidade de terreno E6. Caracteriza-se por apresentar 38\% de sua área com médio potencial ao escoamento, $48 \%$ com alto potencial e valores médios de pixels de 2,55. A susceptibilidade a erosão é retratada pela ocorrência de $81 \%$ da área na classe alta com valores médios dos pixels de 2,61. O potencial agrícola caracteriza-se por 
apresentar 52\% da área enquadrada na classe baixa. Os valores médios dos pixels são de 2,19 (Tabela 8.79).

Regiões com restrições legais a ocupação do meio correspondem a apenas 7\% da unidade e constituem, principalmente, destinadas a preservação permanente junto aos cursos de drenagem.

Tabela 8.79 - Características de potencialidade e susceptibilidade do meio para unidade XL.

\begin{tabular}{|c|c|c|c|c|}
\hline \multicolumn{5}{|c|}{ Potencial ao Escoamento } \\
\hline Classe & Área $\left(\mathrm{Km}^{2}\right)$ & \% área da unidade & \% área da bacia & $\begin{array}{c}\text { Parâmetros estatísticos/Mapas } \\
\text { Numéricos }\end{array}$ \\
\hline Baixa & 10,13 & 7,62 & 5,64 & Mín - 1,21 \\
\hline Média & 45,51 & 34,26 & 7,01 & Máx - 3,82 \\
\hline Alta & 64,54 & 48,58 & 9,77 & Média $-2,55$ \\
\hline \multirow{2}{*}{ Muito Alta } & \multirow[b]{2}{*}{12,71} & \multirow[b]{2}{*}{9,56} & \multirow[b]{2}{*}{6,78} & Desv Padrão - 0,36 \\
\hline & & & & Moda $-2,46$ \\
\hline \multicolumn{5}{|c|}{ Susceptibilidade a Erosão } \\
\hline Classe & Área $\left(\mathrm{Km}^{2}\right)$ & $\%$ área da unidade & \% área da bacia & $\begin{array}{c}\text { Parâmetros estatísticos/Mapas } \\
\text { Numéricos }\end{array}$ \\
\hline Baixa & 3,09 & 2,32 & 2,66 & Mín - 1,29 \\
\hline Média & 20,76 & 15,63 & 3,25 & Máx - 4,04 \\
\hline Alta & 107,92 & 81,23 & 13,81 & Média - 2,61 \\
\hline \multirow{2}{*}{ Muito Alta } & \multirow[b]{2}{*}{1,09} & \multirow[b]{2}{*}{0,82} & \multirow[b]{2}{*}{0,78} & Desv Padrão - 0,22 \\
\hline & & & & Moda $-2,60$ \\
\hline \multicolumn{5}{|c|}{ Potencial Agrícola } \\
\hline Classe & Área $\left(\mathrm{Km}^{2}\right)$ & $\%$ área da unidade & $\%$ área da bacia & $\begin{array}{c}\text { Parâmetros estatísticos/Mapas } \\
\text { Numéricos }\end{array}$ \\
\hline Baixa & 70,24 & 52,87 & 16,17 & Mín $-1,46$ \\
\hline Média & 18,80 & 14,15 & 5,38 & Máx - 3,39 \\
\hline Alta & 16,27 & 12,25 & 6,26 & Média - 2,19 \\
\hline Muito Alta & 17,10 & 12,87 & 3,62 & Desv Padrão - 0,54 \\
\hline Restritiva & 10,00 & 7,53 & 6,26 & Moda - 3,16 \\
\hline
\end{tabular}

O comportamento de médio a alto potencial do escoamento superficial é condicionado pela ocorrência de valores de declividade superiores a 20\% em 51\% da área, e a textura intermediária dos materiais residual de granitos porfiríticos, que constitui $88 \%$ desta (Tabela 8.80). A condição de alta susceptibilidade a erosão é condicionada pelas características de escoamento superficial e pela textura dos materiais inconsolidados. O comportamento de potencial agrícola médio a muito alto em apenas $39 \%$ da área é condicionado, principalmente, pelas características de declividade e espessura dos materiais inconsolidados.

Destacam-se como principais atividades de ocupação do terreno as classes de pastagem e mata nativa, presentes em 69\% e 19\% da área, respectivamente (Figura 8.40). Atividades voltadas ao desenvolvimento agrícola compreendem $10 \%$ da unidade, 
situação que demonstra o sub aproveitamento das condições naturais do meio, que favorecem ao desenvolvimento de atividades voltadas a estes fins em 39\% da área.

Tabela 8.80- Atributos do meio físico da unidade XL.

\begin{tabular}{|c|c|c|c|}
\hline Declividade $\%$ & Área $\left(\mathrm{Km}^{2}\right)$ & $\%$ área da unidade & $\%$ área da bacia \\
\hline$<2$ & 8,28 & 6,23 & 3,15 \\
\hline $2-10$ & 14,93 & 11,24 & 5,37 \\
\hline $10-20$ & 41,03 & 30,88 & 7,86 \\
\hline $20-30$ & 42,15 & 31,73 & 12,10 \\
\hline $30-45$ & 22,42 & 16,88 & 10,45 \\
\hline$>45$ & 4,03 & 3,03 & 7,72 \\
\hline Geologia & Área $\left(\mathrm{Km}^{2}\right)$ & $\%$ área da unidade & $\%$ área da bacia \\
\hline Granitos Porfiríticos & 120,02 & 90,34 & 35,70 \\
\hline Granito-Gnaisses & 12,84 & 9,67 & 21,99 \\
\hline Materiais Inco & Área $\left(\mathrm{Km}^{2}\right)$ & \% área da unidade & $\%$ área da bacia \\
\hline Retrab 2 & 6,39 & 4,81 & 12,83 \\
\hline Grp 3 & 117,71 & 88,60 & 94,32 \\
\hline GrGn 2 & 8,76 & 6,59 & 24,57 \\
\hline Classes Uso do Solo & Área $\left(\mathrm{Km}^{2}\right)$ & \% área da unidade & $\%$ área da bacia \\
\hline Cafe & 2,79 & 2,10 & 2,60 \\
\hline Cidades & 0,74 & 0,56 & 2,35 \\
\hline Corpos D água & 0,16 & 0,12 & 3,90 \\
\hline Mata Nativa & 25,63 & 19,29 & 7,14 \\
\hline Mata Ciliar & 3,10 & 2,33 & 9,26 \\
\hline Outras Culturas & 10,27 & 7,73 & 13,89 \\
\hline Pastagem & 89,96 & 67,72 & 9,11 \\
\hline Solo Exposto & 0,20 & 0,15 & 2,51 \\
\hline
\end{tabular}

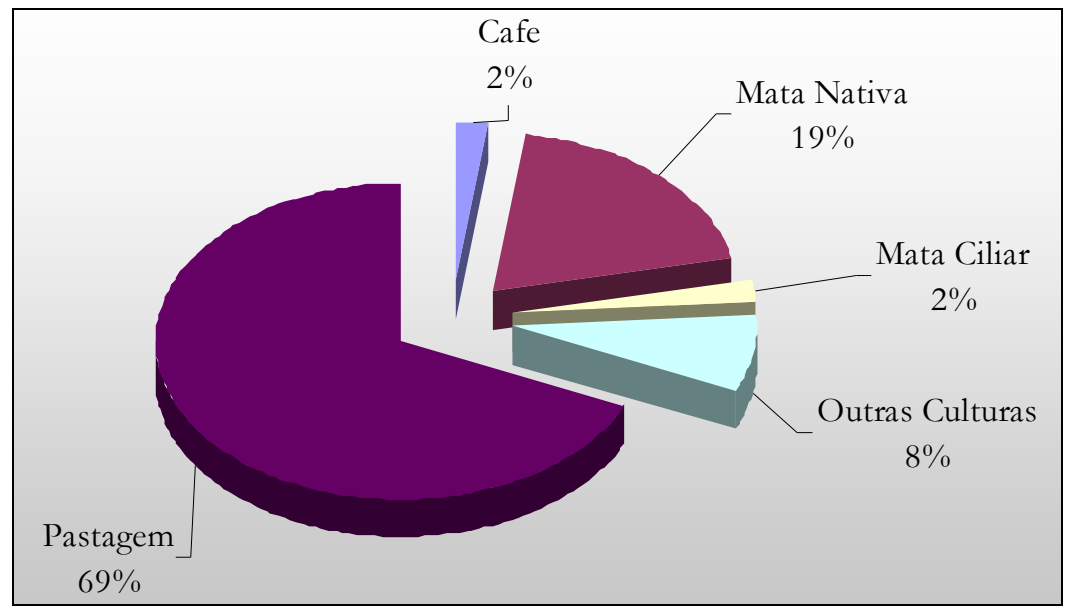

Figura 8.40 - Percentual de ocorrência das classes de uso e ocupação na Unidade Geoambiental XL. 


\section{Unidade XLI}

Corresponde a unidade de terreno E7. Caracteriza-se por apresentar 30\% de sua área com médio potencial ao escoamento, $46 \%$ com alto potencial e valores médios de pixels de 2,64. A susceptibilidade a erosão é retratada pela ocorrência de 54\% da área na classe média e 44\% na classe alta, com valores médios dos pixels de 2,46. O potencial agrícola caracteriza-se por apresentar 32\% da área enquadrada na classe baixa e $26 \%$ na classe alta. Os valores médios dos pixels são de 2,5 (Tabela 8.81).

Regiões com restrições legais a ocupação do meio correspondem a apenas 7\% da unidade e constituem, principalmente, destinadas a preservação permanente junto aos cursos de drenagem.

Tabela 8.81 - Características de potencialidade e susceptibilidade do meio para unidade XLI.

\begin{tabular}{|c|c|c|c|c|}
\hline \multicolumn{5}{|c|}{ Potencial ao Escoamento } \\
\hline Classe & Área $\left(\mathrm{Km}^{2}\right)$ & $\begin{array}{l}\% \text { área da } \\
\text { unidade }\end{array}$ & $\%$ área da bacia & $\begin{array}{c}\text { Parâmetros estatísticos/Mapas } \\
\text { Numéricos }\end{array}$ \\
\hline Baixa & 10,37 & 5,65 & 5,77 & Mín $-1,20$ \\
\hline Média & 55,01 & 29,93 & 8,47 & Máx - 3,85 \\
\hline Alta & 85,77 & 46,67 & 12,98 & Média $-2,64$ \\
\hline \multirow{2}{*}{ Muito Alta } & \multirow[b]{2}{*}{32,59} & \multirow[b]{2}{*}{17,74} & \multirow[b]{2}{*}{17,38} & Desv Padrão - 0,39 \\
\hline & & & & Moda $-2,41$ \\
\hline \multicolumn{5}{|c|}{ Susceptibilidade a Erosão } \\
\hline Classe & Área $\left(\mathrm{Km}^{2}\right)$ & $\begin{array}{l}\% \text { área da } \\
\text { unidade }\end{array}$ & $\%$ área da bacia & $\begin{array}{c}\text { Parâmetros estatísticos/Mapas } \\
\text { Numéricos }\end{array}$ \\
\hline Baixa & 2,40 & 1,30 & 2,07 & Mín $-0,67$ \\
\hline Média & 100,33 & 54,60 & 15,69 & Máx - 3,48 \\
\hline Alta & 80,84 & 43,99 & 10,34 & Média $-2,46$ \\
\hline \multirow{2}{*}{ Muito Alta } & \multirow[b]{2}{*}{0,20} & \multirow[b]{2}{*}{0,11} & \multirow[b]{2}{*}{0,14} & Desv Padrão - 0,2 \\
\hline & & & & Moda $-2,58$ \\
\hline \multicolumn{5}{|c|}{ Potencial Agrícola } \\
\hline Classe & Área $\left(\mathrm{Km}^{2}\right)$ & $\begin{array}{l}\% \text { área } \mathrm{da} \\
\text { unidade }\end{array}$ & \% área da bacia & $\begin{array}{c}\text { Parâmetros estatísticos/Mapas } \\
\text { Numéricos }\end{array}$ \\
\hline Baixa & 59,87 & 32,58 & 13,78 & Mín - 0,36 \\
\hline Média & 34,08 & 18,55 & 9,75 & Máx - 3,91 \\
\hline Alta & 28,54 & 15,53 & 10,97 & Média $-2,50$ \\
\hline Muito Alta & 47,59 & 25,90 & 10,09 & Desv Padrão - 0,58 \\
\hline Restritiva & 13,54 & 7,37 & 8,47 & Moda $-3,27$ \\
\hline
\end{tabular}

O comportamento de médio a alto potencial do escoamento superficial é condicionado pela ocorrência de valores de declividade superiores a $20 \%$ em $38 \%$ da área, e a textura intermediária dos materiais residuais de migmatitos e argilosa dos residuais de granitos porfiríticos, que constituem $92 \%$ da unidade (Tabela 8.82). A condição de susceptibilidade a erosão média a alta é condicionada pelas características de escoamento superficial e pela textura dos materiais inconsolidados. O 
comportamento, em quase $60 \%$ da área, de potencial agrícola médio a muito alto é condicionado pelos valores predominantes de declividade inferiores a $20 \%$ e espessura dos materiais inconsolidados.

Destacam-se como principais atividades de ocupação do terreno as classes de pastagem e mata nativa, presentes em $74 \%$ e 18\% da área, respectivamente (Figura 8.41). Atividades voltadas ao desenvolvimento agrícola compreendem apenas $3 \%$ da unidade, caracterizando aproveitamento inadequado das condições naturais do meio, que favorecem ao desenvolvimento de atividades voltadas a estes fins.

Tabela 8.82- Atributos do meio físico da unidade XLI.

\begin{tabular}{|c|c|c|c|}
\hline Declividade $\%$ & Área $\left(\mathrm{Km}^{2}\right)$ & $\%$ área da unidade & $\%$ área da bacia \\
\hline$<2$ & 22,63 & 12,31 & 8,61 \\
\hline $2-10$ & 30,25 & 16,46 & 10,88 \\
\hline $10-20$ & 61,08 & 33,24 & 11,70 \\
\hline $20-30$ & 44,27 & 24,09 & 12,71 \\
\hline $30-45$ & 21,92 & 11,93 & 10,22 \\
\hline$>45$ & 3,62 & 1,97 & 6,93 \\
\hline Geologia & Área $\left(\mathrm{Km}^{2}\right)$ & $\%$ área da unidade & $\%$ área da bacia \\
\hline Migmatitos & 74,47 & 40,52 & 17,30 \\
\hline Granitos Porfiríticos & 96,86 & 52,71 & 28,81 \\
\hline Granito-Gnaisses & 12,43 & 6,77 & 21,29 \\
\hline Materiais Inco & Área $\left(\mathrm{Km}^{2}\right)$ & $\%$ área da unidade & $\%$ área da bacia \\
\hline Retrab 2 & 2,38 & 1,29 & 4,77 \\
\hline Mig 7 & 0,02 & 0,01 & 0,02 \\
\hline Mig 9 & 72,23 & 39,31 & 81,46 \\
\hline Grp 4 & 96,70 & 52,62 & 100,00 \\
\hline GrGn 2 & 12,43 & 6,76 & 34,88 \\
\hline Classes Uso do Solo & Área $\left(\mathrm{Km}^{2}\right)$ & $\%$ área da unidade & $\%$ área da bacia \\
\hline Corpos D`água & 0,43 & 0,23 & 10,00 \\
\hline Mata Nativa & 32,67 & 17,78 & 9,10 \\
\hline Mata Ciliar & 9,94 & 5,41 & 29,74 \\
\hline Outras Culturas & 5,07 & 2,76 & 6,86 \\
\hline Pastagem & 135,44 & 73,70 & 13,71 \\
\hline Reflorestamento & 0,07 & 0,04 & 1,42 \\
\hline Solo Exposto & 0,14 & 0,08 & 1,78 \\
\hline
\end{tabular}




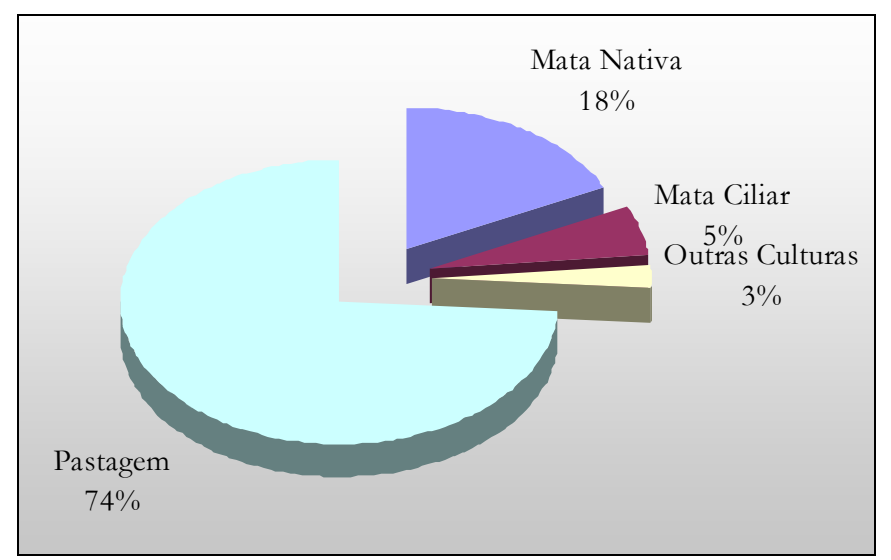

Figura 8.41 - Percentual de ocorrência das classes de uso e ocupação na Unidade Geoambiental XLI.

\section{$\underline{\text { Unidade XLII }}$}

Corresponde a unidade de terreno E8. Caracteriza-se por apresentar 50\% de sua área com médio potencial ao escoamento, $34 \%$ com alto potencial e valores médios de pixels de 2,36. A susceptibilidade a erosão é retratada pela ocorrência de $62 \%$ da área na classe média e $23 \%$ na classe alta, com valores médios dos pixels de 2,31. O potencial agrícola caracteriza-se por apresentar $72 \%$ da área enquadrada nas classes alta a muito alta. Os valores médios dos pixels são de 2,92 (Tabela 8.83).

Tabela 8.83 - Características de potencialidade e susceptibilidade do meio para unidade XLII.

\begin{tabular}{|c|c|c|c|c|}
\hline \multicolumn{5}{|c|}{ Potencial ao Escoamento } \\
\hline Classe & Área $\left.\mathrm{Km}^{2}\right)$ & $\%$ área da unidade & $\%$ área da bacia & Parâmetros estatísticos/Mapas Numéricos \\
\hline Baixa & 5,90 & 14,10 & 3,28 & Mín - 1,2 \\
\hline Média & 21,05 & 50,36 & 3,24 & Máx - 3,61 \\
\hline Alta & 14,41 & 34,47 & 2,18 & Média - 2,36 \\
\hline \multirow{2}{*}{ Muito Alta } & \multirow{2}{*}{\multicolumn{2}{|c|}{1,05}} & \multirow[b]{2}{*}{0,23} & Desv Padrão - 0,31 \\
\hline & & & & Moda $-1,83$ \\
\hline \multicolumn{5}{|c|}{ Susceptibilidade a Erosão } \\
\hline Classe & Área $\left(\mathrm{Km}^{2}\right)$ & $\%$ área da unidade & $\%$ área da bacia & Parâmetros estatísticos/Mapas Numéricos \\
\hline Baixa & 6,24 & 14,93 & 5,39 & Mín $-1,2$ \\
\hline Média & 25,96 & 62,10 & 4,06 & Máx - 3,29 \\
\hline Alta & 9,60 & 22,97 & 1,23 & Média - 2,31 \\
\hline \multirow{2}{*}{ Muito Alta } & \multirow[b]{2}{*}{0,02} & \multirow[b]{2}{*}{0,05} & \multirow[b]{2}{*}{0,01} & Desv Padrão - 0,29 \\
\hline & & & & Moda - 2,41 \\
\hline \multicolumn{5}{|c|}{ Potencial Agrícola } \\
\hline Classe & Área $\left(\mathrm{Km}^{2}\right)$ & $\%$ área da unidade & $\%$ área da bacia & Parâmetros estatísticos/Mapas Numéricos \\
\hline Baixa & 2,05 & 4,90 & 0,47 & Mín - 1,35 \\
\hline Média & 6,11 & 14,61 & 1,75 & Máx - 3,7 \\
\hline Alta & 13,76 & 32,93 & 5,29 & Média - 2,92 \\
\hline Muito Alta & 16,61 & 39,73 & 3,52 & Desv Padrão - 050 \\
\hline Restritiva & 2,89 & 6,90 & 1,80 & Moda $-3,49$ \\
\hline
\end{tabular}


Regiões com restrições legais a ocupação do meio correspondem a apenas 7\% da unidade e constituem, principalmente, destinadas a preservação permanente junto aos cursos de drenagem.

A condição de médio potencial do escoamento superficial é condicionada pela predominância de valores de declividade inferiores a $20 \%$ na área, e pelo comportamento variável da textura dos materiais inconsolidados presentes, intermediária dos granitos-gnaisses e argilosa dos granitos porfiríticos. Estes compreendem 89\% da unidade (Tabela 8.84). O aspecto de média susceptibilidade a erosão é condicionada pelas características de escoamento superficial e pela textura dos materiais inconsolidados. O comportamento de potencial agrícola alto a muito alto é condicionado, principalmente, pelos valores predominantes de declividade inferiores a $20 \%$ e espessuras dos materiais inconsolidados.

Destacam-se como principais atividades de ocupação do terreno as classes de pastagem e mata nativa, presentes em $77 \%$ e 12\% da área, respectivamente (Figura 8.42). Atividades voltadas ao desenvolvimento agrícola compreendem apenas $4 \%$ da unidade, caracterizando aproveitamento inadequado das condições naturais do meio, que favorecem ao desenvolvimento de atividades voltadas a estes fins.

Tabela 8.84- Atributos do meio físico da unidade XLII.

\begin{tabular}{|c|c|c|c|}
\hline Declividade $\%$ & Área $\left(\mathrm{Km}^{2}\right)$ & \% área da unidade & \% área da bacia \\
\hline$<2$ & 10,62 & 25,40 & 4,04 \\
\hline $2-10$ & 13,66 & 32,69 & 4,91 \\
\hline $10-20$ & 2,64 & 6,32 & 0,51 \\
\hline $20-30$ & 0,29 & 0,69 & 0,08 \\
\hline $30-45$ & 0,01 & 0,02 & 0,00 \\
\hline$>45$ & 0,00 & 0,00 & 0,00 \\
\hline Geologia & Área $\left(\mathrm{Km}^{2}\right)$ & \% área da unidade & $\%$ área da bacia \\
\hline Granitos Porfiríticos & 23,11 & 55,30 & 6,87 \\
\hline Granito-Gnaisses & 18,68 & 44,70 & 32,00 \\
\hline Materiais Inco & Área $\left(\mathrm{Km}^{2}\right)$ & $\%$ área da unidade & $\%$ área da bacia \\
\hline Retrab 1 & 4,24 & 10,14 & 4,47 \\
\hline Grp 5 & 23,11 & 55,30 & 100,00 \\
\hline GrGn 2 & 14,45 & 34,58 & 40,55 \\
\hline Classes Uso do Solo & Área $\left(\mathrm{Km}^{2}\right)$ & $\%$ área da unidade & $\%$ área da bacia \\
\hline Corpos D água & 0,05 & 0,12 & 1,19 \\
\hline Mata Nativa & 5,21 & 12,46 & 1,45 \\
\hline Mata Ciliar & 2,88 & 6,90 & 8,63 \\
\hline Outras Culturas & 1,81 & 4,33 & 2,45 \\
\hline Pastagem & 31,84 & 76,18 & 3,22 \\
\hline
\end{tabular}




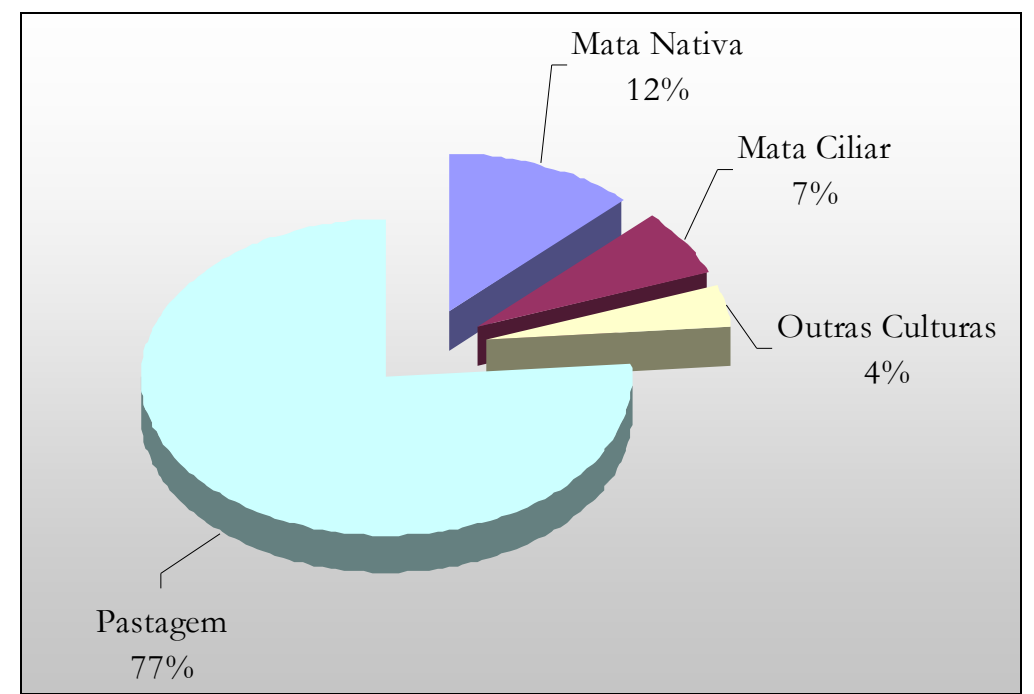

Figura 8.42 - Percentual de ocorrência das classes de uso e ocupação na Unidade Geoambiental XLII. 
CAPÍTULO 9

\section{9. - CONCLUSÕES}

\section{1 - QUANTO A UTILIZAÇÃO DA LÓGICA FUZZY NO PROCESSO DE AVALIAÇÃO AMBIENTAL}

A utilização da técnica de inferência fuz̧̧y para o modelamento de informações representativas de atributos e aspectos de potencialidades e restrições do meio físico mostrou-se eficiente. Permitiu a obtenção de resultados que representam de forma mais adequada o comportamento de distribuição espacial destes atributos e aspectos.

$\mathrm{Na}$ proposta aqui apresentada constatou-se como principal diferencial no resultado obtido, não só a viabilidade de representação do comportamento transicional entre unidade de diferentes compartimentos do meio, como a elaboração de modelos lógicos que melhor representam a distribuição espacial de aspectos e fenômenos do meio. Tais modelos trazem informações mais próximas das reais condições encontradas em campo, o que possibilita uma melhor compreensão das condições naturais apresentadas pelo meio físico e, por conseguinte, uma diminuição na perda de informações, levando a uma análise mais apurada das potencialidades e restrições de uma área.

No que se refere à representação espacial de unidades constituintes de um compartimento do meio, verificou-se que a técnica permite caracterizar e representar diferentes relações de transição que uma unidade possa apresentar com as adjacentes. Este aspecto possibilita não apenas informar sobre a distribuição espacial de atributo, mas no contexto do processo de obtenção de informações derivada e/ou interpretativas informa que as regiões de transição, em função da intensidade e peso de influência de 
cada atributo, podem caracterizar áreas que possam vir a merecer análise mais cuidadosa, pois podem caracterizar regiões com aspectos de vulnerabilidades e potencialidades diferentes do restante da unidade, como nos casos de unidades com contatos complexos, ou de unidades com pesos de influência diferenciados. Isto vem a confirmar que a técnica de inferência de lógica funsy possibilita melhor representação de informações do meio físico que os processos tradicionais fundamentados na lógica booleana, os quais permitem somente a representação de informações de forma rígida, sem a conotação de transição entre atributos.

A utilização da técnica para representação de aspectos de potencialidades e restrições naturais do meio, sob forma numérica contínua, informa melhor ao usuário o comportamento de variação desses, e possibilita uma análise mais adequada, informando não só os locais onde estes aspectos têm maior ou menor potencialidade ou restrição, mas dentro do contexto de faixas representativas de condições desde baixas a elevada, ilustrar um comportamento de gradação, ou seja, permite caracteriza não apenas uma região com alto potencial, mas o comportamento de variação da classe alta, o que para processos de avaliações e diagnósticos de maior detalhe vem a caracterizar informações de grande importância, e que tradicionalmente não são apresentadas.

A aplicação da técnica mostrou-se eficiente também para elaboração de modelos representativos do grau de influência dos diferentes atributos do meio no condicionamento de restrições e potencialidades.

Um aspecto importante constatado durante o processo de aplicação da inferência furąy foi o grande número de rotinas de processamento computacional elaboradas para obtenção da representação contínua das unidades constituintes dos compartimentos de substrato rochoso e materiais inconsolidados. Isto foi devido a técnica de análise adotada para caracterização das transições entre atributos, Individual Boundary Aproach, na qual cada unidade é assumida como um polígono que pode apresentar diferentes faixas de gradação ao longo de seus contatos, podendo ser abruptos em algumas partes e difusos em outras, assim como podem apresentar relações difusas variáveis. O número elevado de rotinas elaboradas vem a caracterizar uma das principais dificuldades de aplicação da técnica, resultando, para os caso de áreas de grande extensão, ou com grande número de atributos, a necessidade de considerável tempo computacional para obtenção das representações contínuas numéricas. 
Uma limitação encontrada na utilização da técnica refere-se a forma de apresentação dos resultados obtidos, os quais podem ser de difícil compreensão por diferentes usuários, o que acabou por resultar na necessidade de representação das informações em formato temático, por meio do processo de fatiamento das informações numéricas e enquadramento das mesmas em classes representativas dos aspectos de potencialidades e restrições do meio. No entanto, a informação numérica completa fica disponível e o usuário pode utilizá-la e inclusive fazer novas subdivisões, considerando outras classes.

\section{2 - QUANTO A FERRAMENTA COMPUTACIONAL UTILIZADA PARA APLICAÇÃO DA LÓGICA FUZZY NO PROCESSO DE AVALIAÇÃO AMBIENTAL}

O sistema de informações geográficas SPRING mostrou-se, de maneira geral adequado a obtenção dos objetivos propostos.Pequenas limitações foram constatadas na capacidade de processamento de grande número de informações. Estas limitações resultaram na necessidade de execução em etapas do processamento numérico das informações do meio fisico, para caracterização das condições de potencialidade e restrições da bacia. Isto mostra a necessidade de utilização de suporte físico, microcomputador, com grande capacidade de armazenamento e processamento dos dados, quando em situações que envolvam a manipulação de grande quantidade de informações e/ou regiões de grandes dimensões.

A linguagem de programação LEGAL vinculada ao sistema caracteriza um aspecto positivo do sistema, pois esta permitiu estabelecer uma interface com o SIG, de forma a permitir não somente as representações das informações sob formato contínuo, como a realização de diferentes operações sobre os dados analisados. A linguagem possibilitou a execução de análises e simulações de fenômenos do mundo real sobre atributos com a aplicação da inferência furæy de forma relativamente simples, e a obtenção de resultados adequados para os fins aqui propostos.

Uma limitação imposta pelo sistema é a inexistência de uma ferramenta adequada para avaliação dos resultados produzidos sob forma numérica. $\mathrm{O}$ sistema não permite a execução de análises e tratamentos estatísticos, de forma otimizada e sem envolvimento de elevado tempo de processamento, que melhor representem o 
comportamento de distribuição espacial dos aspectos de potencialidades e restrições do meio físico, o que eliminaria a necessidade de execução do processo de fatiamento das informações numéricas, para elaboração de representação de mais fácil compreensão dos dados por diferentes usuários. Entretanto, o sistema permite que sejam adicionadas sobre as informações temáticas os valores numéricos representativos do comportamento gradacional dos diferentes aspectos de restrições e favorabilidade. Isto permite passar ao usuário a noção do real comportamento destes aspectos.

\section{3 - QUANTO AO INDICADOR AMBIENTAL PROPOSTO PARA CARACTERIZAÇÃO DE ALTERAÇÕES AMBIENTAIS INTRODUZIDAS NO MEIO.}

A utilização do parâmetro de resistência a penetração com o equipamento sonda-TDR combinada mostrou-se adequado para aplicação do mesmo como geoindicador de modificações ocorridas no meio físico. Permitui aferir e comparar as modificações ambientais introduzidas no meio físico da bacia, em um mesmo intervalo de tempo, decorrentes das atividades de ocupação presentes.

Constatou-se que, de uma maneira geral, a umidade média do solo constitui um parâmetro de grande influência no comportamento da resistência a penetração. Aspecto este convencionalmente não considerado em muitos ensaios de caracterização geotécnica. Portanto, a eficiência de aplicação da resistência como indicador de alterações é devido, em grande parte, a utilização da sonda-TDR combinada, pois possibilita a obtenção de medidas indicativas da resistência, em conjunto com valores médios de umidade do solo, o que permite a caracterização das modificações no comportamento da resistência a penetração, causada por diferentes tipos de uso e ocupação do terreno, em termos de valores absolutos.

As análises realizadas em cinco tipos de solos existentes na bacia permitiram caracterizar, em três desses, que a prática de cultivo de café e desenvolvimento de pastagem constituem as atividades responsáveis pelos valores mais altos de resistência a penetração do solo, ou seja, pelas principais modificações no comportamento de compactação dos mesmos.

Outro aspecto positivo obtido com a utilização das medidas de resistência como indicador é que as mesmas podem ser tomadas para analisar mudanças futuras das 
características dos solos, haja vista que permitem a obtenção de valores absolutos do comportamento de resistência, eliminando assim a influência da variação de umidade, devido as mudanças de estações e condições climáticas.

Um aspecto que reflete a limitação em utilização da sonda-TDR como meio de medida da resistência a penetração é quanto a fragilidade do equipamento, o qual apresenta sérias restrições de uso em solos com alto percentual de cascalho ou que tenham grande quantidade de raízes. Portanto, faz-se necessário desenvolver uma sonda com revestimento mais resistente de forma a permitir o uso da mesma em regiões com estas condições. Isto garantiria a possibilidade de investigar o comportamento de resistência a penetração de diferentes solos, em área sem registro de alterações introduzidas por atividades antrópicas, as quais serviriam de background para melhor determinação das alterações geradas por diferentes tipos de ocupação.

\section{4 - QUANTO AO ZONEAMENTO GEOAMBIENTAL ELABORADO}

A elaboração do zoneamento geoambiental, por meio da aplicação da avaliação ambiental relativa aos atributos do meio, com a utilização da inferência de lógica fužyy e a avaliação de alterações introduzidas por atividade modificadoras, por meio do geoindicador resistência a penetração, permitiu caracterizar de forma satisfatória a área com relação às suas aptidões e restrições à atividades de ocupação vigentes. Permitiu também indicar porções do terreno com uma maior qualidade ambiental que devem ser preservadas, as quais constituem áreas com restrições legais a ocupação.

A utilização da técnica de analise hierárquica de informações, técnica AHP, no contexto do processo de avaliação ambiental, possibilitou a obtenção organizada de informações relativas aos aspectos de potencial ao escoamento superficial, de susceptibilidade a erosão e de potencial agrícola do meio físico.

O zoneamento elaborado resultou na obtenção da ordenação territorial da área em 42 unidades ambientais, as quais retratam potencialidades e vulnerabilidades do meio quanto ao uso e ocupação, e consistem de uma base de dados que permite orientar a ocupação do espaço e uso dos recursos da bacia.

No que se refere ao potencial de escoamento superficial, a bacia apresenta um predomínio de condições de elevado escoamento, fato constatado em 34 das 42 unidades, as quais exibem predomínio das classes média a alta. Em apenas três unidades 
são verificadas condições de escoamento baixo a médio, e em cinco as condições de alto a muito alto escoamento.

Com relação ao aspecto susceptibilidade a erosão, constatou-se predomínio das classes de média a alta susceptibilidade em 25 unidades, alta a muito alta em 17 unidades. Apenas uma unidade exibe condições de susceptibilidade a erosão báxa a média.

O potencial agrícola da bacia é caracterizado pela predominância das classes de baixo a médio potencial, condição verificada em 25 da 42 unidades. Em 16 unidades são verificadas as condições de potencial agrícola alto a muito alto. Apenas uma unidade exibe potencial ao desenvolvimento de atividades agrícola médio a alto. De uma maneira geral verificou-se, em 19 unidades, um aproveitamento adequado das condições naturais de potencial agrícola exibido pela bacia, seja pelo aproveitamento correto das condições de elevado potencial, , ou pela ocorrência pouca significativa de atividade agrícolas em áreas com baixo potencial elevado. Nove unidades caracterizam-se pelo sub aproveitamento das boas condições ao desenvolvimento de práticas agrícolas, e quartoze pelo aproveitamento inadequado das condições naturais de potencial agrícola do meio físico.

A caracterização de modificações no meio físico devido ao desenvolvimento de atividades antrópicas na bacia, a partir da utilização do geoindicador resistência à penetração, permitiu constatar que em 24 das unidades há predomínio de ocorrência em área das atividades de cultivo de café e pastagem. As unidades são II, X, XI, XII, XV, XVII, XVII, XXV, XXVI, XXVII, XXVII, XXIX, XXX, XXXI, XXXII, XXXIV e XXXXV a XLII. Nessas, as classes de café e pastagem ocupam de mais de 50\% do terreno de cada unidade. As atividades de cultivo de café e pastagem constituem as classes de ocupação responsáveis pelas maiores alterações nas condições naturais de compactação do solo, o elevado percentual de ocorrência em área destas deve ser tomado como um fator que pode vir a condicionar situações de escoamento superficial mais elevadas que as constatadas na avaliação das condições naturais do meio físico.

As regiões com restrições a ocupação por aspectos legais na área da bacia, Lei federal 4.771 - código florestal de 1965, correspondem principalmente a áreas destinadas a preservação permanente junto aos cursos de drenagem, e secundariamente a áreas com declividade superiores a $45^{\circ}$, onde é proibida derrubada de florestas para 
desenvolvimento de qualquer atividade de ocupação do meio, ou constitui área de preservação natural.

Vinte e duas unidades exibem menos de 10\% de suas áreas constituindo regiões com restrições legais, são elas unidades. Dezesseis, exibem entre $10 \%$ e $20 \%$ de suas áreas caracterizadas por restrições legais, e quatro apresentam valores acima de 20.

As informações de uso e ocupação da bacia revelam que áreas caracterizadas como destinadas a preservação permanente junto aos cursos de drenagem, localizadas nas porções da baixa e média bacia, não apresentam ocorrência da vegetação de mata ciliar e/ou nativa. Normalmente estas foram retiradas para ocupação do terreno por atividades agrícolas e de pastagem.

Nas regiões com declividades superiores $25^{\circ}$, onde é proibida a derrubada de florestas ou constituem área de preservação natural, as informações relativas ao uso e ocupação da bacia mostram que estas correspondem, em grande parte, a áreas com ocorrência de mata nativa, sem registro de outras classes de uso do terreno. 


\section{CAPÍTULO 10}

\section{REFERÊNCIAS BIBLIOGRÁFICAS}

Albrecht, K. J. (1992) - Mapeamento Geotécnico Preliminar da Região de Águas de Lindóia - Escala 1:50.000. Dissertação de Mestrado: EESC/USP, São Carlos, SP, 2v.

Aguiar, R.L. (1994) - Análise do mapeamento geotécnico nos processos de gestão ambiental. Seminário Gerais. Escola de Engenharia de São Carlos - EESC/USP. São Carlos. 102p.

Altman, D. (1994) - Fuzzy set theoretic approaches for handling imprecision in spatial analysis. International Journal of Geographical Information Systems. V. 8, n. 3, p. 271-289.

Amorim, H. R. (2003) - Estudo dos Atributos do Meio Físico como Base para o Zoneamento Geoambiental da Região de Influência do Reservatório da Usina Hidroelétrica de Cacinde (SP). Dissertação de Mestrado: EESC/USP, São Carlos, SP,

Assad, E.D. \& Sano, E.E. (1993) - Sistemas de Informacoōes Geográficas: Aplicações na Agricultura Brasileira. EMBRAPA.

Associação Brasileira de Normas Técnicas - ABNT - Análise granulométrica - NBR 7181/1989. URL: http://www.abnt.org.br. (consulta em outubro de 2003) 
Associação Brasileira de Normas Técnicas - ABNT - Análise granulométrica - NBR 7181/1984. URL: http://www.abnt.org.br. (consulta em outubro de 2003)

Associação Brasileira de Normas Técnicas - ABNT - Massa específica dos sólidos - NBR 6508/1984. URL: http://www.abnt.org.br. (consulta em outubro de 2003)

Bähr, H. R. \& Voglet, T. (1991) - Digitale Bilverabutung: Andewendug in Photogrametre. Kartographier. Und Karlsruhe, Wickman.98p.

Banai, R. (1993) - Fuzziness in geographical information system: contributions from analytic hierarchy process. International Journal of Geographical Information Systems. V.7, n. 4, p. 315-329.

Barrow, C. J. (1998) - River Basin Development Planing an Management: A Critical Review. World Development. 1 (26): 171-186.

Barison, M. R. (1995) - Mapeamento Geotécnico Regional da Quadrícula de Amparo - SP, Escla 1:50.000: com base na análise dos 'landforms e de perfis típicos de alteração. Dissertação de Mestrado: EESC/USP, São Carlos, SP, 2v.

Berger. A R. (1996) - Introduction to Geoindicator Checklist. In: BERGE, A R \& INAS, W. J. ed. Goeindicators: Assessing Rapid Environmental Changes in Earth Systems. Rotterdan. AA Balkema. P. 383-554.

Bertoni, J \& Lombardi Neto, F. (1990) - Conservação do Solo. São Paulo, Editora Ícone. 355 p.

Bradford J.M. (1986).Penatribility. In: KLUTE, A. (Ed) Methodos of Soil Analysis. Part I. Physical and Mineralogical Methodos, $2^{\text {nd }}$ Edition, Monograph Nunber 9. Americam Society of Agronomy . MAdson .

Bueno, B. S. \& Vilar, O. M. (1984) - Mecânica dos Solos. Apostila. São Carlos. Escola de Engenharia de São Carlos. Universidade de São Paulo. 
Bourlon, N.; Berthon, D. (1993). Desenvolvimento sustentável e gerenciamento das bacias hidrográficas na América Latina. Ciência e Cultura. p.16-22.

Burrough, P. A.; Heuvelink, G. B. M. The sensitivity of boolean and continuous (Fuzzy) logical modelling to uncertain data. In European Conference and Exhibition on Geographical Information Systems Munich, 3. (EGIS'92). Munich, Germany, 1992. Proceedings : Munich, Germany: EGIS'92. p. 1032-1041.

Burrough, P. A. (1996) - Fuzzy mathematical methods for soil survey and land evaluation. Journal of Soil Science. V. 40, p. 477-492.

Burrough, P. A. McDonell, R. A (1998) - Principles of Geographical Information Systems. Oxford, Oxford University Press. 333 p.

Burrough, P. A; Van Gaans, P. F. M; MacMillian, R.A (2000) - High-resolution landform classification using furzy K-means. http://www.eselvier.com/locate/fss

Câmara, G. \& Medeiros, J. S. (1998) - Geoprocessamento para Projetos Ambientais. INPE. $2^{\underline{a}}$ Ed. http://www.inpe.br.dpi/cursos/gisbrasil/index.html.

Campbell, D.J.V. (1993). Environmental management of landfill sites. Journal of the Institution od Water and Environmental Management, v.7, p. 170-174.

Cendrero, A. (1975) - Enviroment Geology of the Santander by Area. Northern Spain. Enviromenmtal Geology, Springer Verlag, New York, Vol.1, pp. 97-114.

Cendrero, A. (1983) - Tecnicas Y Instrumentos de Analise para la Avaliacion, Planificacion y Gestion de Medio Ambiente. Fascículos sobre Meio Ambiente. Series Opiniores, N.6, CIFCA. Madrid. 67p.

Cendrero, A. (1990) - Desarrollo y Tendencias de la Geologia Ambiental en Europa, AGID Report $n^{\circ} 3$. 
Centro Nacional de Ensino e Pesquisa Agronomica - CNEPA (1960) - Comissão de Solos. Levantamento de reconhecimento de solos do Estado de São Paulo. Rio de Janeiro, Serviço Nacional de Pesquisas Agronômicas. 634 p.

Chadwick, G. F. (1971) - A System View of Planning. Pergamon Press, New York.USA. 390p.

Collares, E.G. (1996). Degradação ambiental: bases conceituais, análise e avaliação. Seminário Gerais. Escola de Engenharia de São Carlos - EESC/USP. São Carlos. 104p.

Collares, E. G. (2000) - Avaliação de Alterações em Rede de Drenagem de Microbacias como Subsídio ao Zoneamento Geoambiental de Bacia Hidrográficas: Aplicação na Bacia Hidrográfica do Rio Capivari - SP. Tese Doutorado: EESC/USP, São Carlos, SP, 2v.

COGEOENVIRONMENT (Commission on Geological Sciences for Environmenta Planning) (1992) - Geoindicators: Tools for Assessing Rapid Environmental Changes. www.gcrio.org/geo

Corson, W.H. (1993). Manual global de ecologia: o que você precisa saber a respeito da crise no meio ambiente; tradução de A G. CAMARU. São Paulo, Augustus. 413p.

Davidson, J. Pedrycz, W., Goulter, I (1993) - A fuzzy decision model to design of rural natural gas networks. Furzy Set and Systems. 53 (3). P 241-252.

Dale, P. F. \& McLaughem, J.D. (1990) - Land Information Management, and Introdution with Spacial Reference Cadastral Problems in Third World Countries. Oxford. Oxford University Press. $259 \mathrm{p}$.

Diegues, A. C. (1989) - Desenvolvimento sustentado, gerenciamento ambiental e de recursos naturais. Cadernos FUND AP, São Paulo, n.9, n.16, junho. p.33-45.

Doyle, D. (1991). Sustentablie development : growth without losing ground. Journal of Soil and Water Conservation, v.46, n.1, p.8-12. 
Eastman, J. R. (1998) - IDRISI for Windows: User Guide version 2.0. Introduction. Worceste MA. Graduete School of Geography. Clark University

Enviromentla Visualization Image - ENVI - ENVI User's Guide. Version 3.6. 2002

Fang, J. H. Fuzzy logic \& geology. Geotimes Geotimes: News and Trends in the Geoscience, v. 42, n. 10, p. 23-26, 1997.

Fontes, S. B. (2004) - Estudo geoambiental da Bacia do Rio Pardo, a partir da compartimentação em Ottobacias - escala 1:100.000. Tese (Doutorado)- Escola de Engenharia de São Carlos, Universidade de São Paulo, São Carlos.

Fornasari Filho, N. \& Bitar, O.Y. (1995) - O meio físico em estudos de impacto ambiental - EIA. In: BITAR, O.Y. coord. (1995) - Curso de geologia aplicada ao meio ambiente. São Paulo. IBGE/IPT. P. 151-162

Fornasari Filho, N. coord (1992) - Alterações do meio físico decorrentes de obras de engenharia. São Paulo. IPT. 162p.

Francés, E.; Dias de Terán, J. R. \& Cendrero, A.(1990) - La aplicacion de la cartografia geoambiental al diagnostico de unidades territoriales: estabelecimiento de directrizes de ordenacion. In: ROMARIZ, C. Livro de bomenagem a Carlos Romariq. Lisboa. p. 377-402.

Galvão, C.O. (1999) - Introdução a Teoria dos Conjuntos Difusos. IN Galvão, C. O \& Valença, M. J. S. org (1999) - Sistemas inteligentes: Aplicações a Recursos Hídricos e Ciências Ambientais. Coleção ABRH. Ed. Univ. Federal do Rio Grande do Sul. p 167-191.

Guerra, A J. T. \& Cunha, S. B. (1996)- Geomorfologia e Meio Ambiente. Beltrand Brasil. p. 337-376. 
Grecchi, R. C. (1998) - Zoneamento geoambiental da região de Piracicaba-SP, com auxílio de geoprocessamento. Dissertação Mestrado. EESC/USP. São Carlos, 132p.

Gomide, F. \& Rocha, A (1992 - a) - A Neurofuzzy Controllers. 2nd International Conference on Furay Logic and Neural Networks - II ZUKA '92. Fukuoka, Japan.

Gomide, F. \& Rocha, A (1992 - b) - Neurofuzzy Componente Based on Threshold IFAC SICICA Simposium. Malaga. Espanha. P 425 - 430.

GTZ (1994) - Geographische Informationsytems. Eschon GTZ.99p.

Grossi Sad, J. H., et al. (1982) - Geologia e recursos minerais da Folha Socorro. São Paulo. Brasil, Belo Horizonte. Geosol, 2v. (Relatório Técnico Geoso).

Hall, G. B.; Wang, F. \& Subaryono, (1992) - Comparison of Boolean and Fuzzy Classification Methods in Lland Suitability Analysis by using Geographical Information Systems. Environmental and Planning. A. 24, 497-516.

Henderson, C. W. L. (1989) - Using a pentrometer to predict the effects of soil compactation on the growth and the yeld of wheat on uniform, sandy soils. Journal of Agricultural. Research. N. 40, p. 498-508.

INTERA TYDAC (1992) - Introduction to Data Structure Using SPANS OS/2 SPANS VERSION 5. OTAWA, intera tydac. 140p.

Instituto Brasileiro de Geografia e Estatística - IBGE (1972) Carta Topográfica da Folha Moji-Guaçu (SF-23-Y-A-III-3). Escala 1:50.000

Instituto Brasileiro de Geografia e EstatístTICA - IBGE (1972) Carta Topográfica da Folha Águas de Lindóia (SF-23-Y-A-III-4). Escala 1:50.000

Instituto Brasileiro de Geografia e EstatístICA - IBGE (1972) Carta Topográfica da Folha Ouro Fino (SF-23-Y-B-I-3). Escala 1:50.000 
Instituto Brasileiro de Geografia e Estatíst- IBGE (1972) Carta Topográfica da Folha Amparo (SF-23-Y-A-IV-1). Escala 1:50.000

Instituto Brasileiro de Geografia e Estatíst- IBGE (1972) Carta Topográfica da Folha Socorro (SF-23-Y-A-IV-2). Escala 1:50.000.

Instituto Brasileiro de Geografia e Estatíst- IBGE (1972) Carta Topográfica da Folha Munhoz (SF-23-Y-B-IV-1). Escala 1:50.000.

Instituto Brasileiro de Geografia e Estatíst- IBGE (1972) Carta Topográfica da Folha Cambuí (SF-23-Y-B-IV-2). Escala 1:50.000.

Instituto Brasileiro de Geografia (IBGE) - Censo 2000. http://www.ibge.gov.br. (acesso janeiro 2003).

Instituto Nacional de Pesquisas Espaciais - INPE - Manual SPRING. São José dos Campos. Departamento de Processamento de Imagens. http://www.dip.inpe.br/spring/usuario/indice.htm. (acesso em novembro de 2003)

International Institute for Aeroespatial Survey Earth Science - (ITC). (1996). Tools for assessing rapid environmental changes - The 1995 geoindicator checklist. Netherlands, pub. N46.

Jacinto, L. R. C (2003) - Geoprocessamento e sensoriamento remoto como ferramenta na gestão ambiental de unidade de conservação: $O$ caso da área de proteção ambiental (APA)do Capivari_Mono, São Paulo-SP. Dissertação (Mestrado). São Paulo. Instuto de Geociências. Universidade de São Paulo.

Lanna, A. E. (1993). Gestão dos recursos hídricos. IN: TUCCI, C. E. M. org. HidrologiaCiência e Aplicaşão. ABRH. Editora da Universidade do Rio Grande do Sul. p.727-768.

Leite, C. M. C. Gestão Ambiental: Uma breve reflexão. Trabalho apresentado no Curso Gestão Ambiental e de Recursos Hídricos na Perspectiva do Desenvolvimento Sustentável, Brasilia, 2000. 
Lolo, J. A (1995) - O uso da técnica de avaliação do terreno no processo de elaboração do Mapeamento Geotécnico: sistematização e aplicação na Quadrícula de Campinas. Tese (Doutorado). São Carlos. Escola de Engenharia de São Carlos. Universidade de São Paulo.

Lopes, P.M.S. (2000) - Estudo dos Atributos do Meio Físico com Base para o Zoneamento Geoambiental das bacias do Rio Passa Cinco e Rio da Cabeça: Escala 1:50.000. Dissertação Mestrado. EESC/USP. São Carlos. 136p. 2v.

Macedo, R. K. (1995) - A importância da avaliação ambiental. P. 11 - 26. In: Análise ambiental: uma visão multidisciplinar (Sâmia Maria Tauk - coord.)

MacMillian, R. A; Pettapice, W.W.; Nolan, S. C.; Goddard, T. W. (2000) - A generic proucedure for automatically segmenting landforms into landforms elements using DEM's, heuristic rules and fur:y logic. http://elsevier.com/locate/fss.

Macrozoneamento das Bacias dos Rios Mogi Guaçu, Pardo e Médio Grande: Questões Sócio Ambientais Regionais. Governo do Estado de São Paulo (1995).

Manieri, A J M \& Vaz, C M P (2003) - Calibração da Sonda Combinada para a medida da Resistência e Umidade de seis solos brasileiros. Relatório Interno EMBRAPA

Mio, G. (1992) - Mapeamento Geotécnico da Quadrícula de Mogi-Guaçú - SP. Dissertação (Mestrado). Escola de Engenharia de São Carlos, USP. 102 p.

Mion, L. C. \& Caavaleire, A. (1999) - Diagnóstico da Bacia Hidrográfica do Rio Mogi GuaçuRelatório Zero. CBH-Mogi. 252 p.

Montaño, M. (2002) - O recurso Hídrico e o Zoneamento Ambiental.: O caso do município de São Carlos Dissertação (Mestrado). Escola de Engenharia de São Carlos, Unversidade de São Paulo. 140 p. 
Moreira, F. R., Câmara, G. Almeida Filho, R. (2001) - Técnica de Suporte a Decisão para Modelagem Geográfica por Álgebra de Mapas. Relatório Técnico.Instituto Nacional de Pesquisa Espaciais. http://www.dip.inpe.br/gilberto/publicações (consulta em outubro 2003).

Nishyma, L. (1998) - Procedimentos de Mapeamento Geotécnico com Base para Análise e Avaliações Ambientais do Meio Físico, em Escala 1:100.000. Aplicados ao Município de Uberlândia. Tese (Doutorado). São Carlos. Escola de Engenharia de São Carlos. Universidade de São Paulo.

Oliveira, W., Gama, A, Igor, A Cedraz, B. (1999) - Lógica Fuzzy. Notas de Álgebra. http://www.led.ufba.br/algebra1a/trab6/aplicacoes.html.

Or, D., Bisher, B., Hubscher, R.A., Wratin, J. (1998) - WinTDR98 Software V4.0. User Guide. On-line Manual-format PDF, Plant Soil \& Biometeorology, Utha State University, 76 p.

Pejon. O. J. (1992) - Mapeamento Geotécnico da Folha Piracicaba (SP). Estudo de Aspectos Metodológicos de caracterização e de Apresentação de Atributos. Tese (Doutorado). São Carlos. Escola de Engenharia de São Carlos. Universidade de São Paulo.

Polette et al. (2000).Gerenciamento costeiro integrado e gerenciamento de recursos hídricos: Como compatibilizar tal desafio. In Munoz, Hector Raúl (org.). Interfaces da Gestão de Recursos Hídricos. Brasília: Secretaria de Recursos Hídricos.

Prochnow, M.C.R. (1990). Análise ambiental da sub-bacia do Rio Piracicaba: subsídio ao planejamento e manejo. Rio Claro, SP. Tese (Doutorado). Instituto de Geociências e Ciências Exatas/UNESP.

Ross, J.L. S; Del Petre, M.E. (1998) - Recursos hídricos e as bacias hidrográficas: âncoras do planejamento e gestão ambiental. In: Revista do Departamento de Geografia, n. 12, p. 89-121.

Saaty, T. L. (1980) - The analytic hierarchy process. New York, McGraw - Hill, 
Salati, E. (1996). Diagnóstico ambiental sintético de qualidade da água como subsídio para o planejamento regional integrado da bacia bidrográfica do Rio Corumbataí (SP). Tese (Doutorado). Escola de engenharia de São Carlos. EESC/USP.

Salomão, F.X.T. \& Iwasa, O.Y. (1995). Erosão e a ocupação rural e urbana. . In: BITAR, O.Y., coord. Curso de geologia aplicada ao ambiente. São Paulo, ABGE/IPT. P. 31-57.

Santos, R. F. (2004) - Planejamento Ambiental - Teoria e Prática. São Paulo. Oficina de Textos. 184p.

Saraiva, R. M. (1995) - Mapeamento Geotécnico da folha de Socorro com base na análise das formas de relevo (Landforms). Dissertação (Mestrado): EESC/USP, São Carlos, $\mathrm{SP}, 2 \mathrm{v}$.

Saraiva, G. J. P. (2000) - Lógica Fuzzy. Revista Militar de Ciência e Tecnologia. Rio de Janeiro. V XII, N 3

Seager, J; Jones, F; Rutt, G. (1992). Assessment and control of farm pollution. Journal of the Institution of Water and Environmental Management, v.6, p.48-54.

Silveira, A.L.L. da. (1993). Ciclo hidrológico e bacias hidrográficas. IN: TUCCI, C. E. M. org. Hidrologia - Ciência e Aplicação. ABRH. Editora da Universidade do Rio Grande do Sul. p.35-52.

Simões, S. J. C. (1997) - A dinâmica dos sistemas e a caracterização de geoindicadores. In: MARTOS, H. L. \& MAIA, N. B. (coords) - Indicadores Ambientais. Sorocaba, Departamento de Ciências Ambientais/PUC, p. 59-70.

Sobreira, F. G. (1995) - Estudo Geoambiental do Conselho de Sesimbra - Tese (Doutorado), Departamento de Geologia, Faculdade de Ciências da Universidade de Lisboa, 347p. 
Souza, I. S. T. de; MEDINA, A. I. M. (1997) - Manejo Integrado de Sub-bacias Hidrográficas. Revista Águas/CPRM. 1(1):59-66.

Sui, D. Z. (1992) - A Fuzzy GIS Modeling Approach for Urban Land Evolution. Computer Environment and Urban Systems. Vol. 16, nํ2, pp. 101-115.

Stolf, R., Fernandes, J. E Furlani Neto, V. L. (1983) - Recomendação para Uso do Penetrômetro de Impacto. Modelo IAA/Planasucar - Stolf. Revista Brasileira STBA Açúcar, Álcool e subprodutos, v. 1, n. 3.

Teixeira, A et. al. (1992) - Sistemas de informação geográfica: revisão e comentários. In: Boletim de Geografia Teorética, 21 (41): 135-147.

Topp G.C.; Davis, J.L. \& Annan, A.P. Electromagnetic determination of soil water content: measurement in coaxial transmission lines. Water Resour. Res. 16:574-582, 1980.

Tommasi, L.R. (1994). Estudo de impacto ambiental. São Paulo, CETESB: terra-graph artes e informática. 354p.

Troppmair, H. (1997) - Avaliação de Impactos Ambientais pela Alteração da Cobertura Vegetal. In:

Unitde Nations Comission on Sustainable Development - (UNCSD) - 1996. Global Environment Outlook 1. http://www.grid.no/geo1.

Vaz, C. M. P \&. Hopmans, J. W (2001) - Simutaneous Mesurament of Soil Strenght and Water Content with a Combined Penetrometer-Moisture Probe. Soil Sci. Soc. Am. Journal. 65 (1), pag. 4-12.

Vaz, C. M. P , Bassoi, L. H. Hopmans, J. W (2001) - Contribuition of Water content and Bulk Density to Field Soil Penetration Resistance as Measured by a Comned Cone Penetrometer_TDR Probe. Soil \& Tillage Research, v 60, pag. 35-42. 
Zadeh, L. A (1972) - Fuzzy-set theoretic interpretation of linguistic hedges. Journal of Cybernetics. V. 2, n. 3, p. 4-34.

Zadeh, L. A \& Jamshidi (1997) - Aplications of Fuzzy Logic: Towards High Machine Inteligence Quotient Systems. Series on Environmental and Intelligent Manufacturing. Prentice Hall.

Zimmermann, H. J.(1987) - Furay sets, decision making, and expert systems. Boston, Kluwer Academic Publishers. 335 p.

Zuquette, L. V. (1997) - Análise Crítica da Cartografia Geotécnica e Proposta metodológica para as Condições Brasileiras. Tese (Doutorado). São Carlos. Escola de Engenharia de São Carlos. Universidade de São Paulo.

Zuquette, L. V. (1993) Importância do mapeamento geotécnico no uso e ocupação do meio físico; fundamentos e guia para elaboração. São Carlos. Tese (Livre-Docência) - Escola de Engenharia de São Carlos, Universidade de São Paulo. 2v. 330p. 


\section{APENCIE A}

Rotinas de Programação em Linguagem LEGAL 
Programa LEGAL 1 - Programa de espacialização contínua da declividade entre 1 e 4.

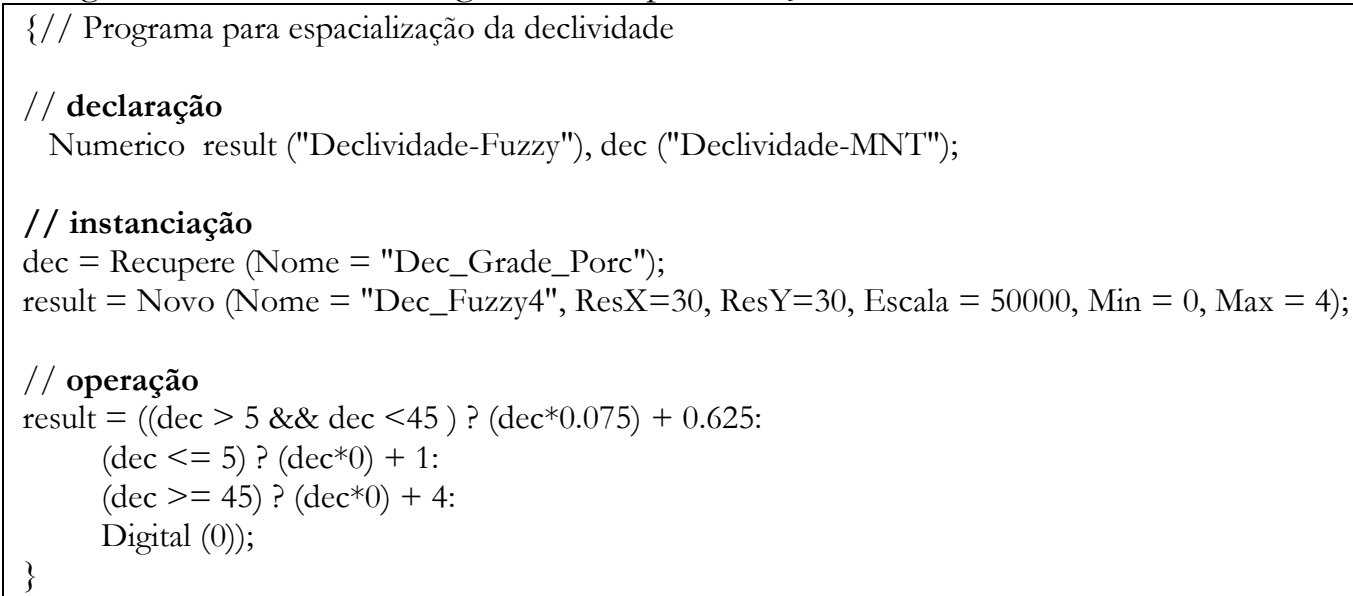

Programa LEGAL 2 - Programa de espacialização contínua da densidade de drenagem entre 1 e 4.

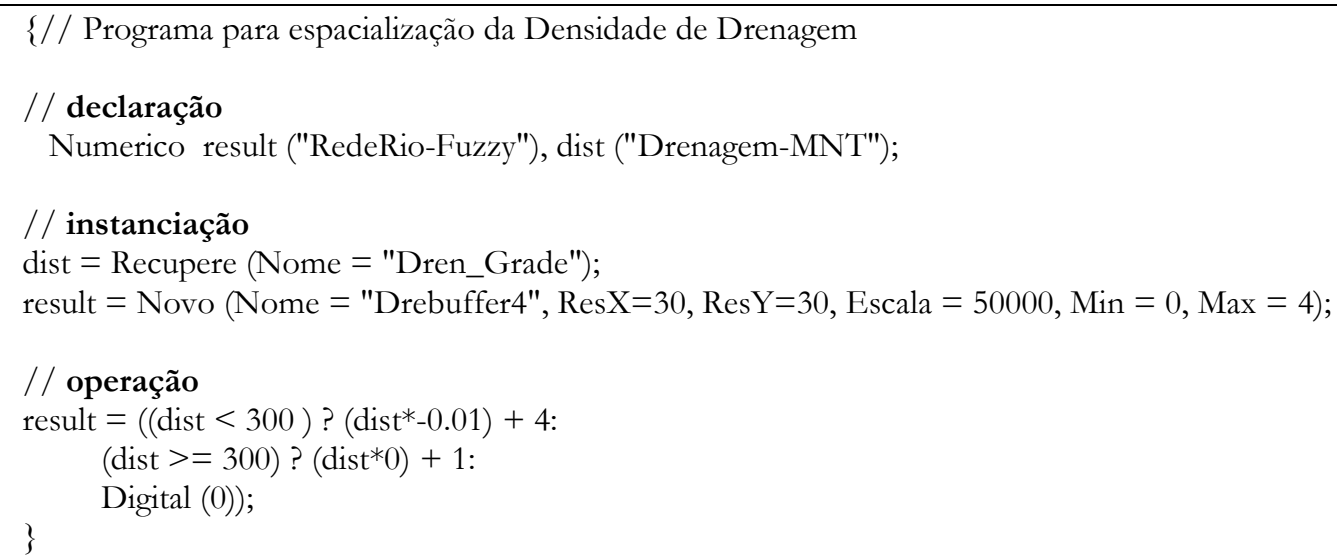

Programa LEGAL 3 - Programa de espacialização contínua de unidade de substrato rochoso Granito porfirítico entre 0 e 1.

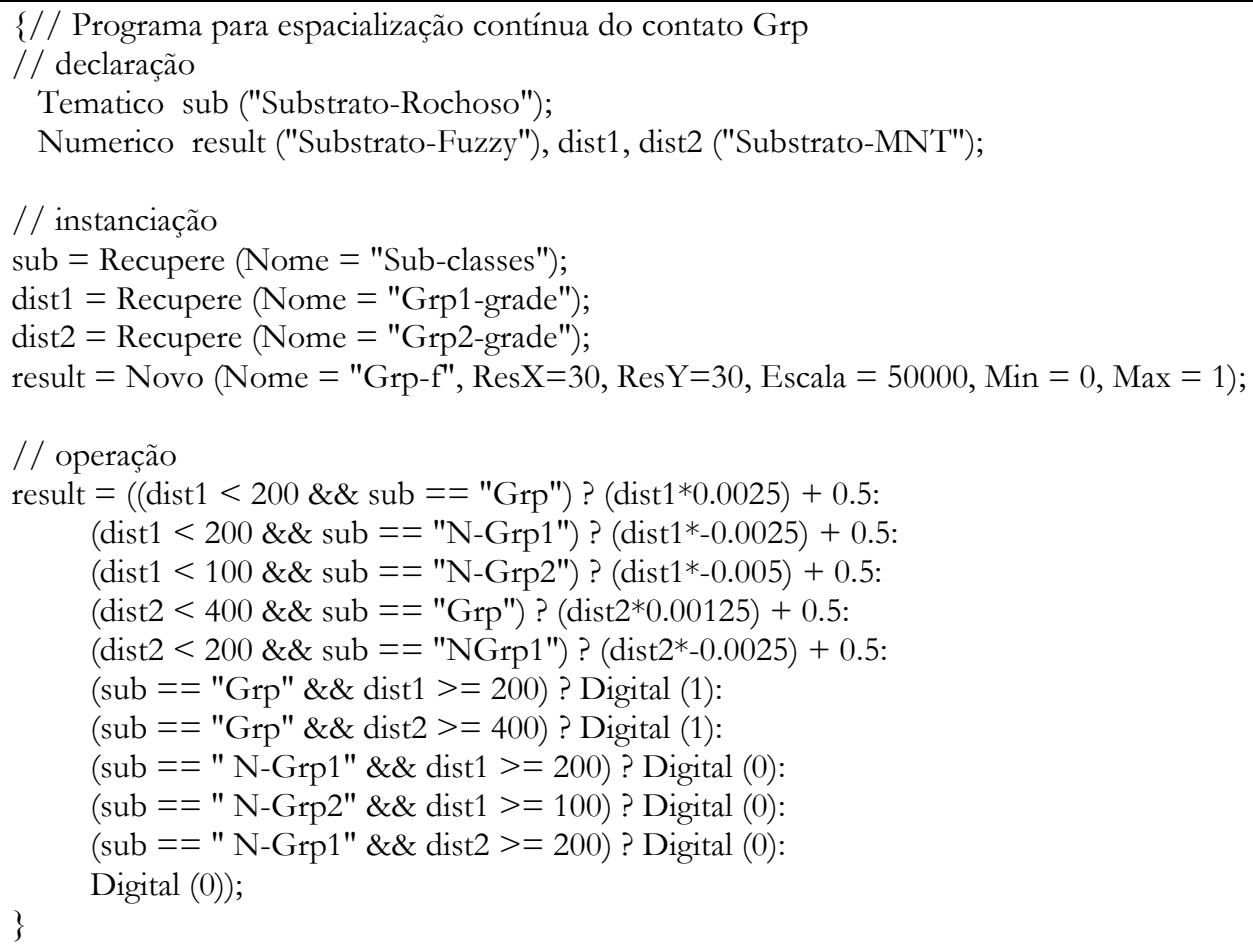


Programa LEGAL 4 - Programa de espacialização contínua de unidade de substrato rochoso Granito cataclasado entre 0 e 1.

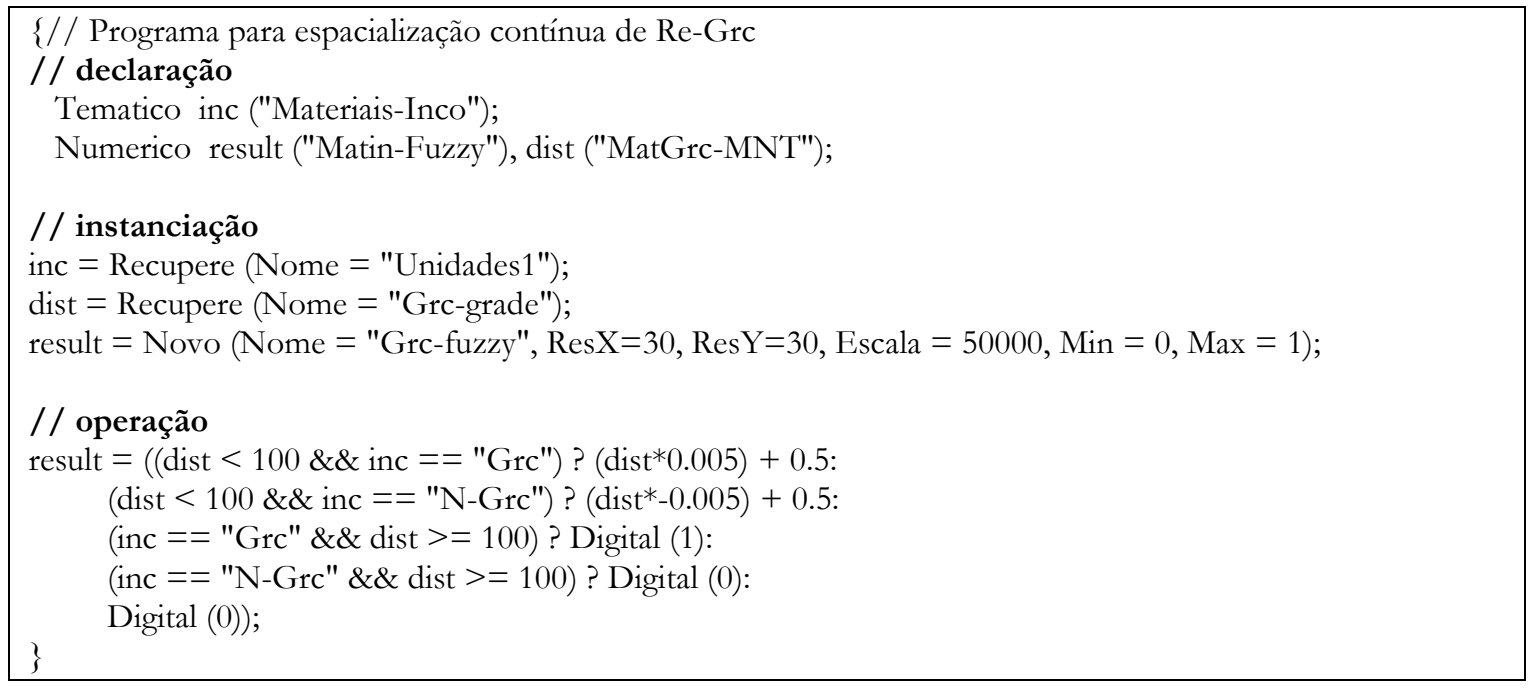

Programa LEGAL 5 - Programa de espacialização contínua de unidade de substrato rochoso Granito-gnaisse entre 0 e 1.

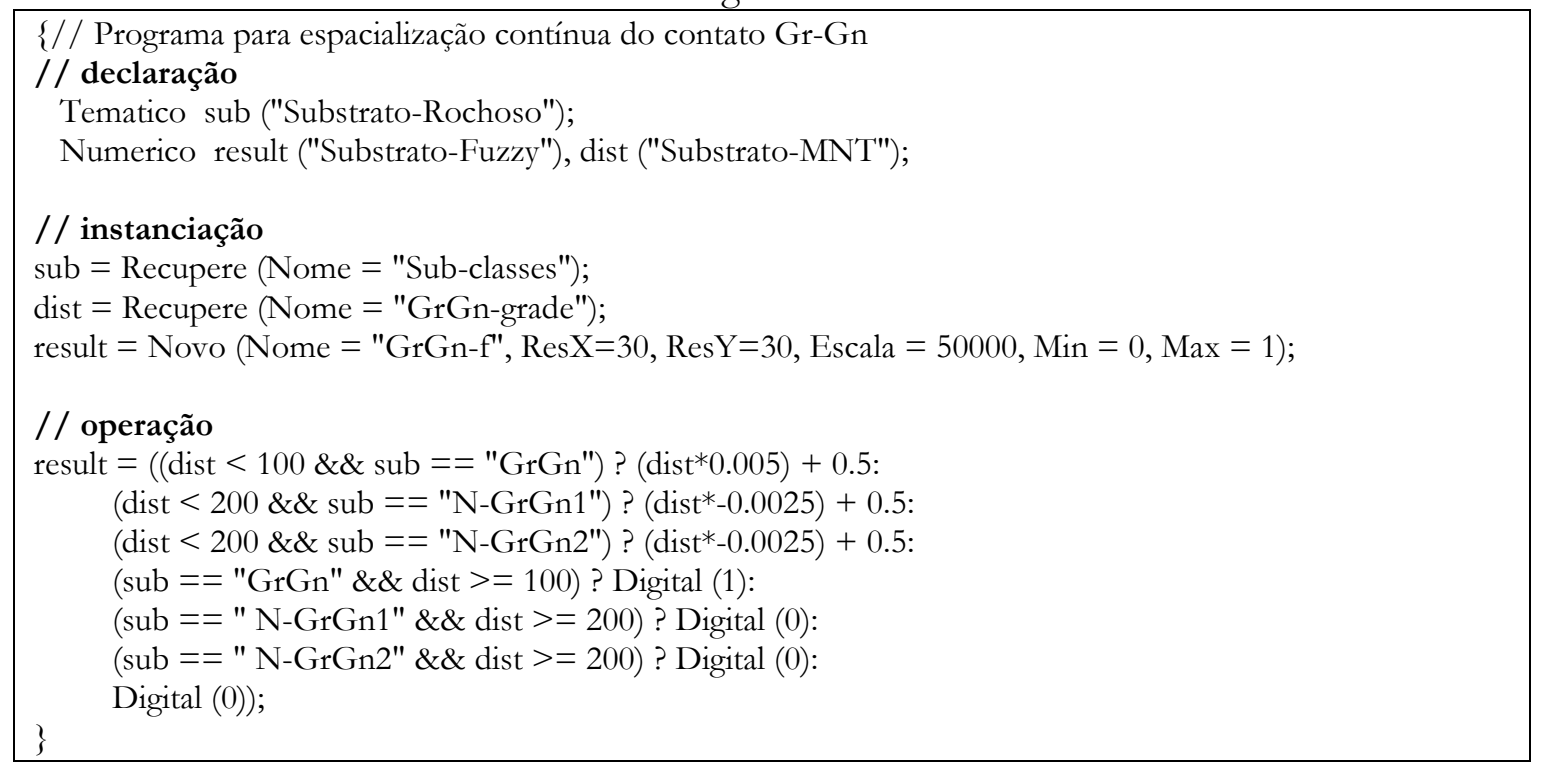


Programa LEGAL 7 - Programa de espacialização contínua de unidade de substrato rochoso Gnaisse intercalados com rochas básicas entre 0 e 1.

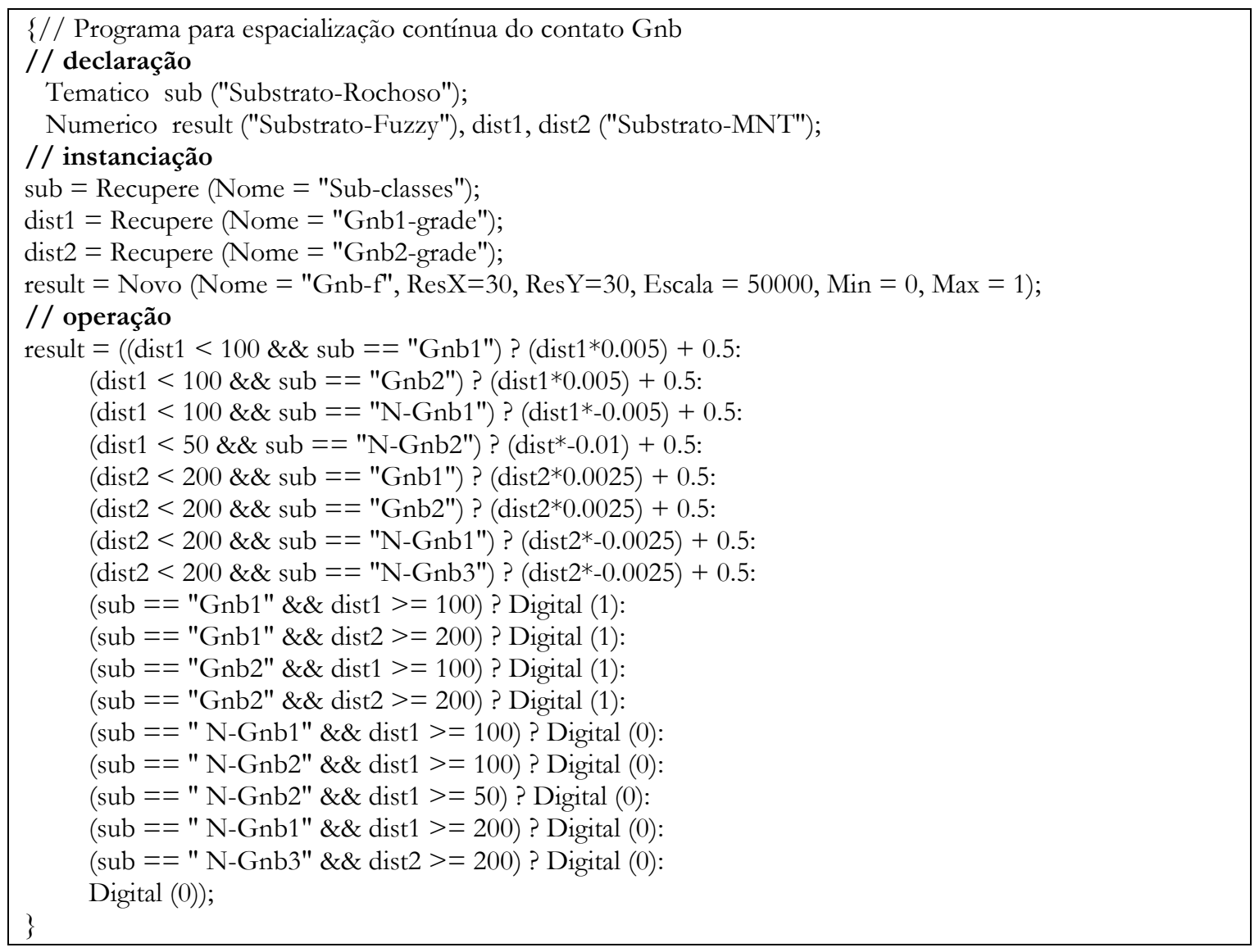

Programa LEGAL 8 - Programa de espacialização contínua de unidade de substrato rochoso Gnaisse intercalados com quartzitos entre 0 e 1.

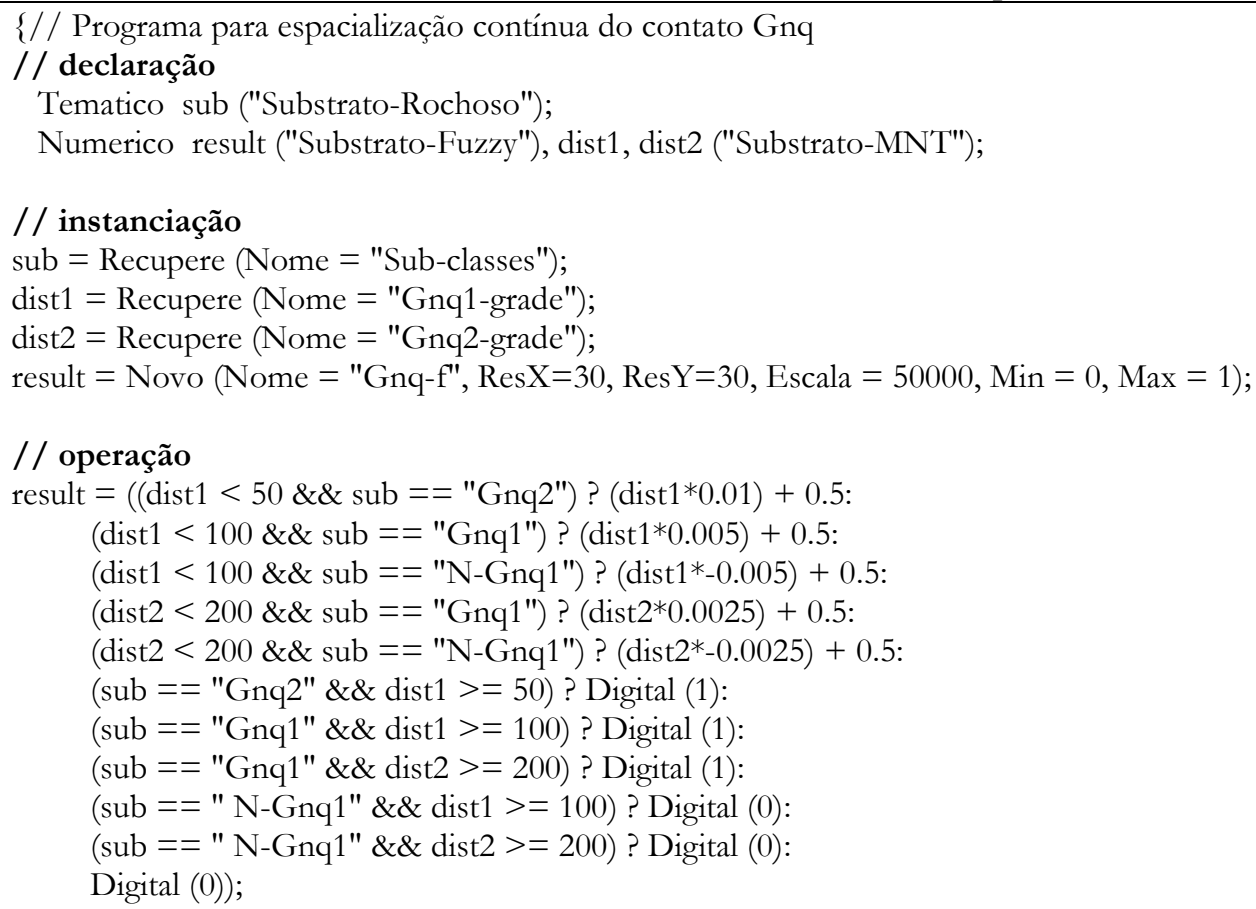


Programa LEGAL 9 - Programa de espacialização contínua de unidade de substrato rochoso entre Migmatitos 0 e 1.

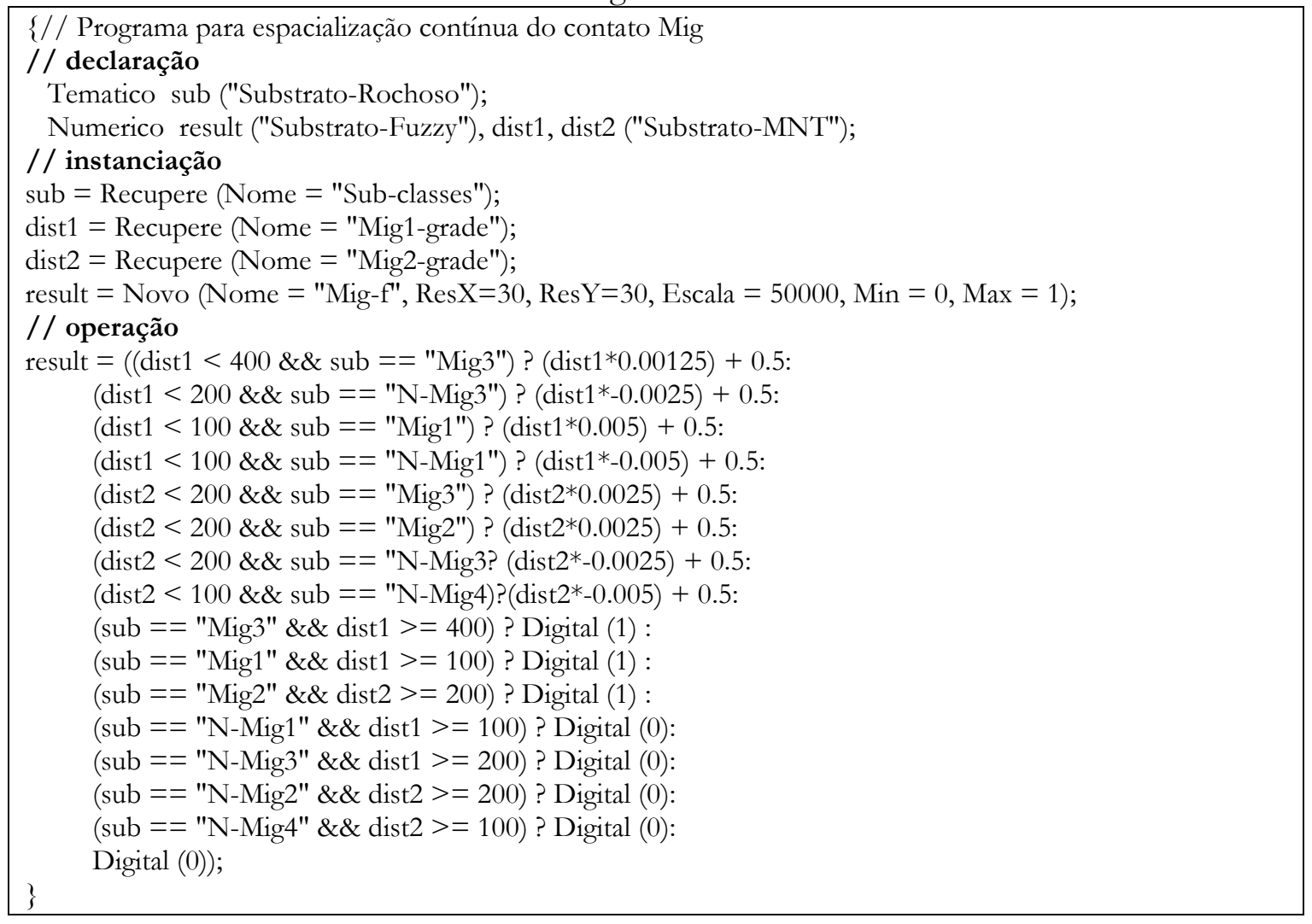

Programa LEGAL 10 - Programa de espacialização contínua de unidade de substrato rochoso Quartzitos entre 0 e 1.

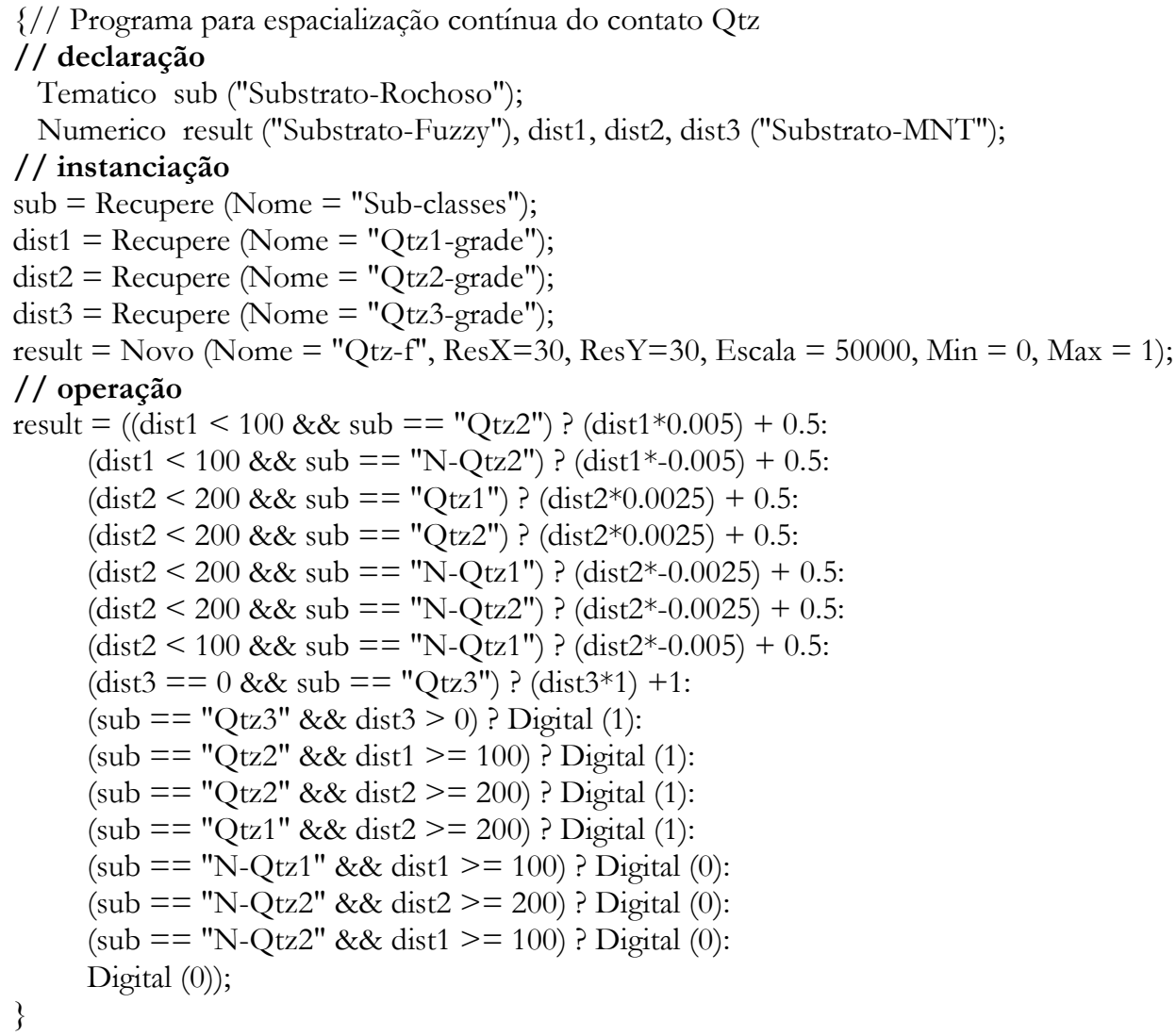


Programa LEGAL 11 - Programa de espacialização contínua de unidade de substrato rochoso Blastomilonitos entre 0 e 1.

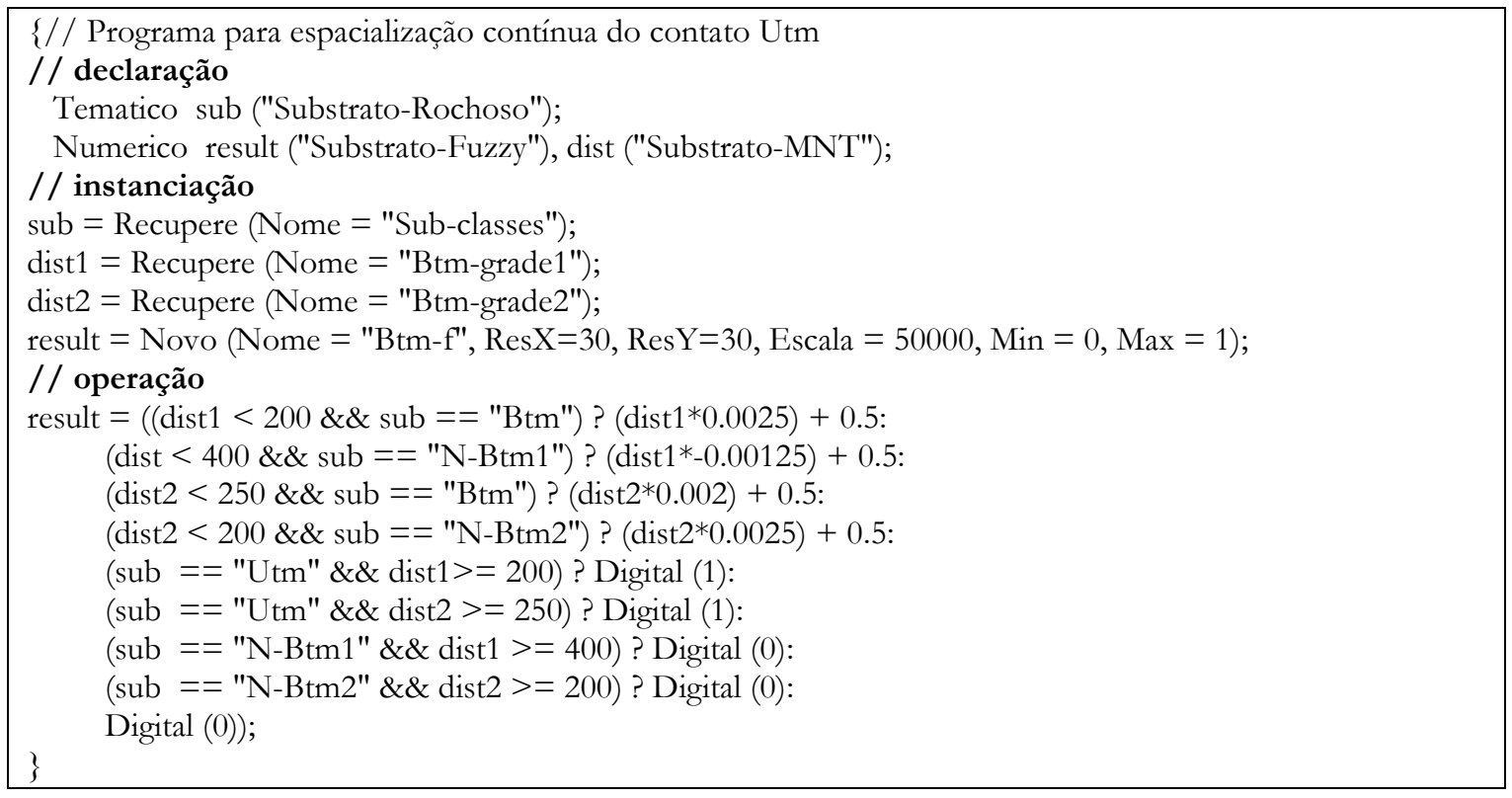

Programa LEGAL 12 - Programa de espacialização contínua de unidade de substrato rochoso Utramilonitos entre 0 e 1.

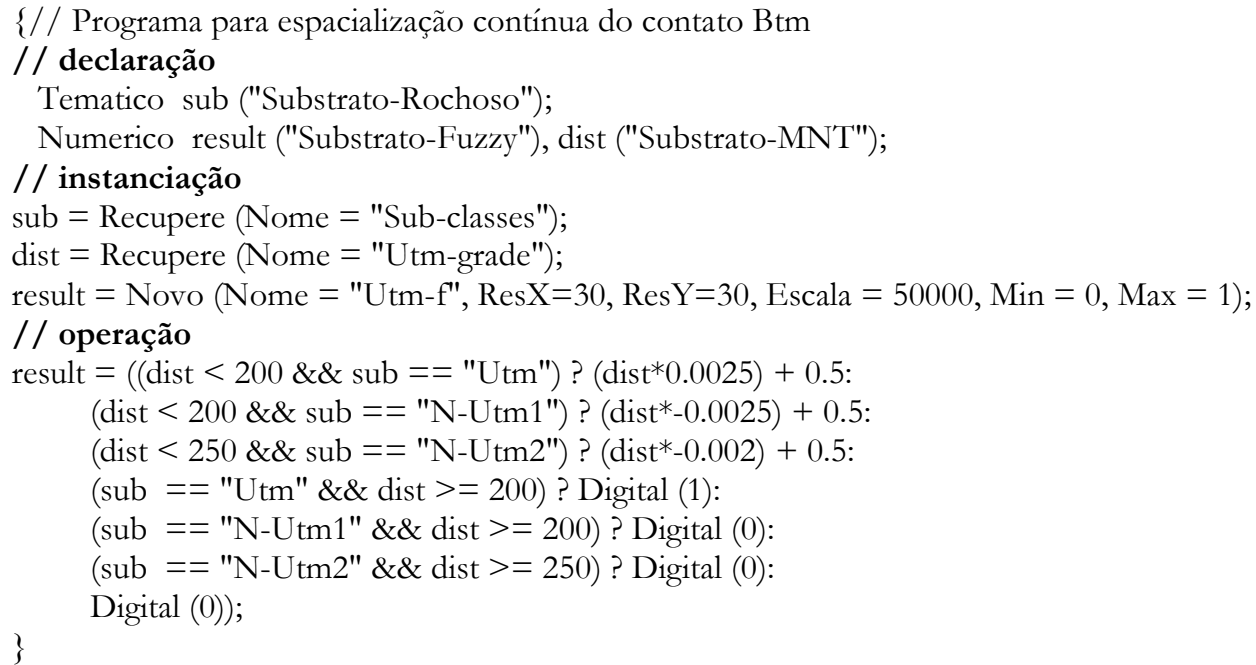

Programa LEGAL 13 - Programa de espacialização contínua de unidade material inconsolidado Aluvião entre 0 e 1.

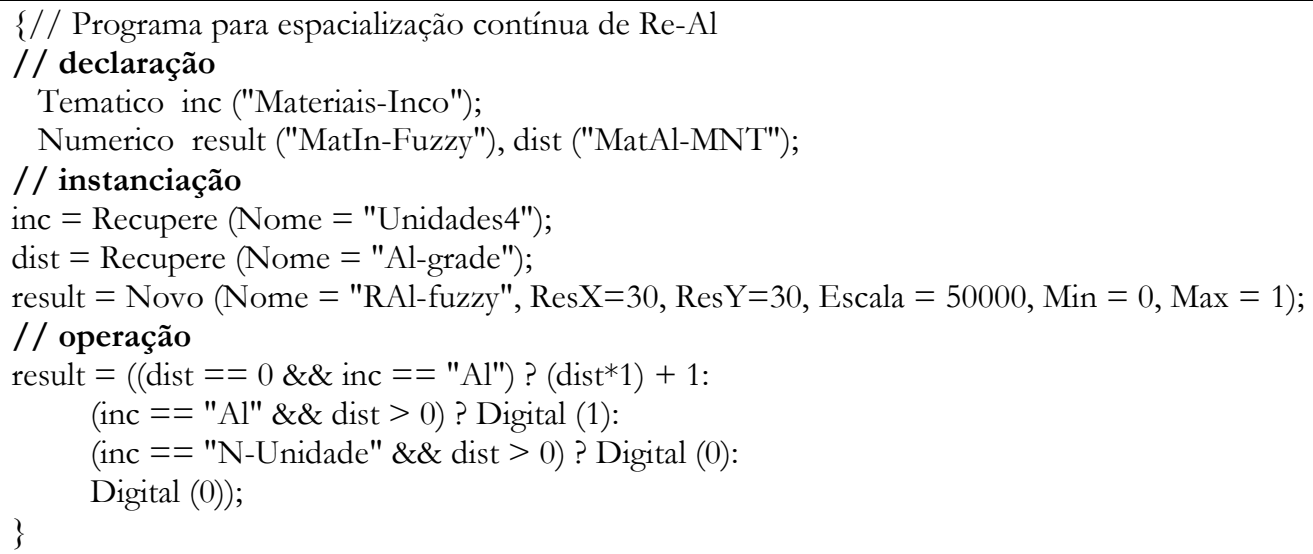


Programa LEGAL 14 - Programa de espacialização contínua de unidade material inconsolidado Retrabalhados 1 entre 0 e 1.

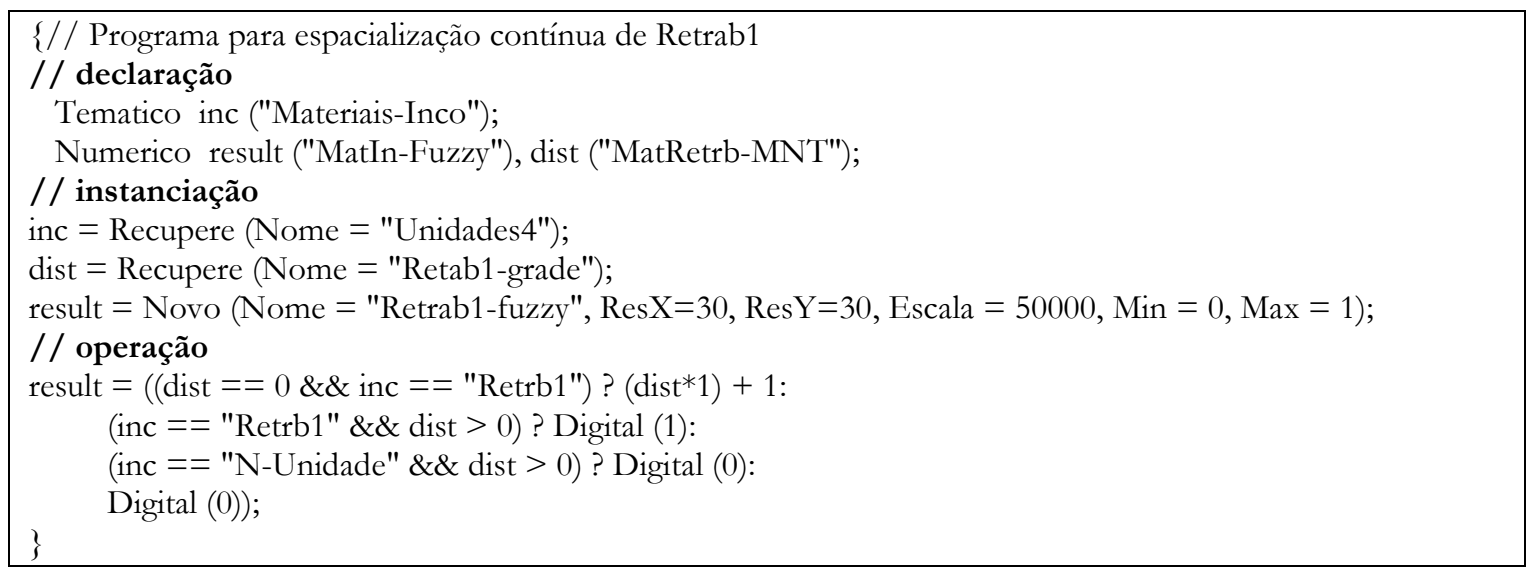

Programa LEGAL 15 - Programa de espacialização contínua de unidade material inconsolidado Retrabalhados 2entre 0 e 1.

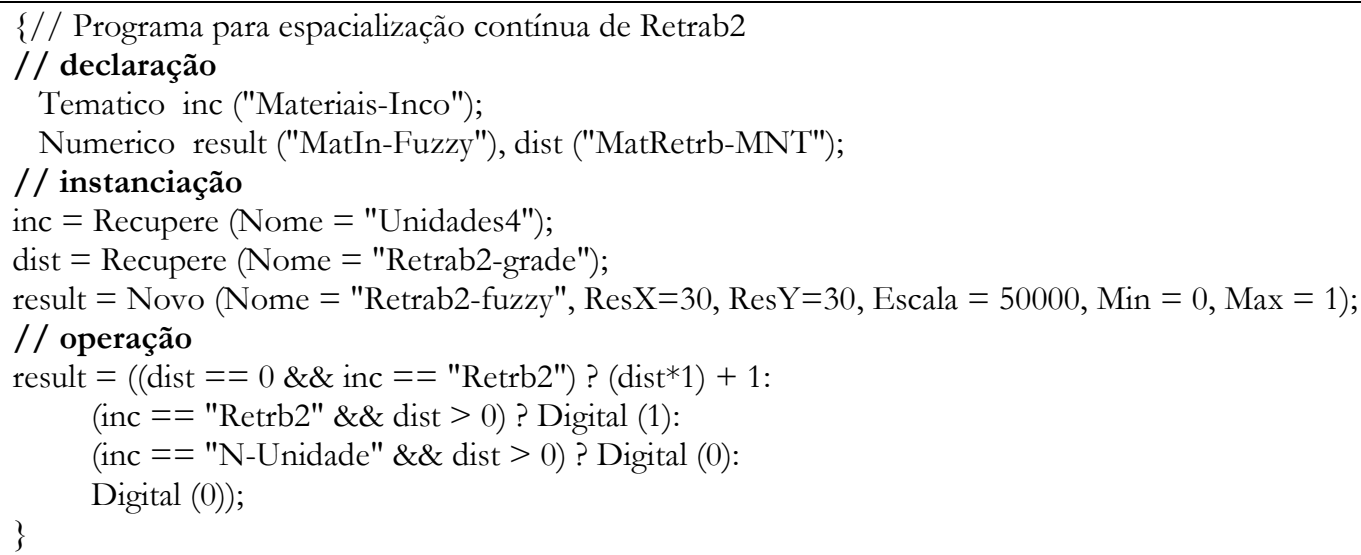

Programa LEGAL 16 - Programa de espacialização contínua de unidade material inconsolidado Blastomilonitos1entre 0 e 1.

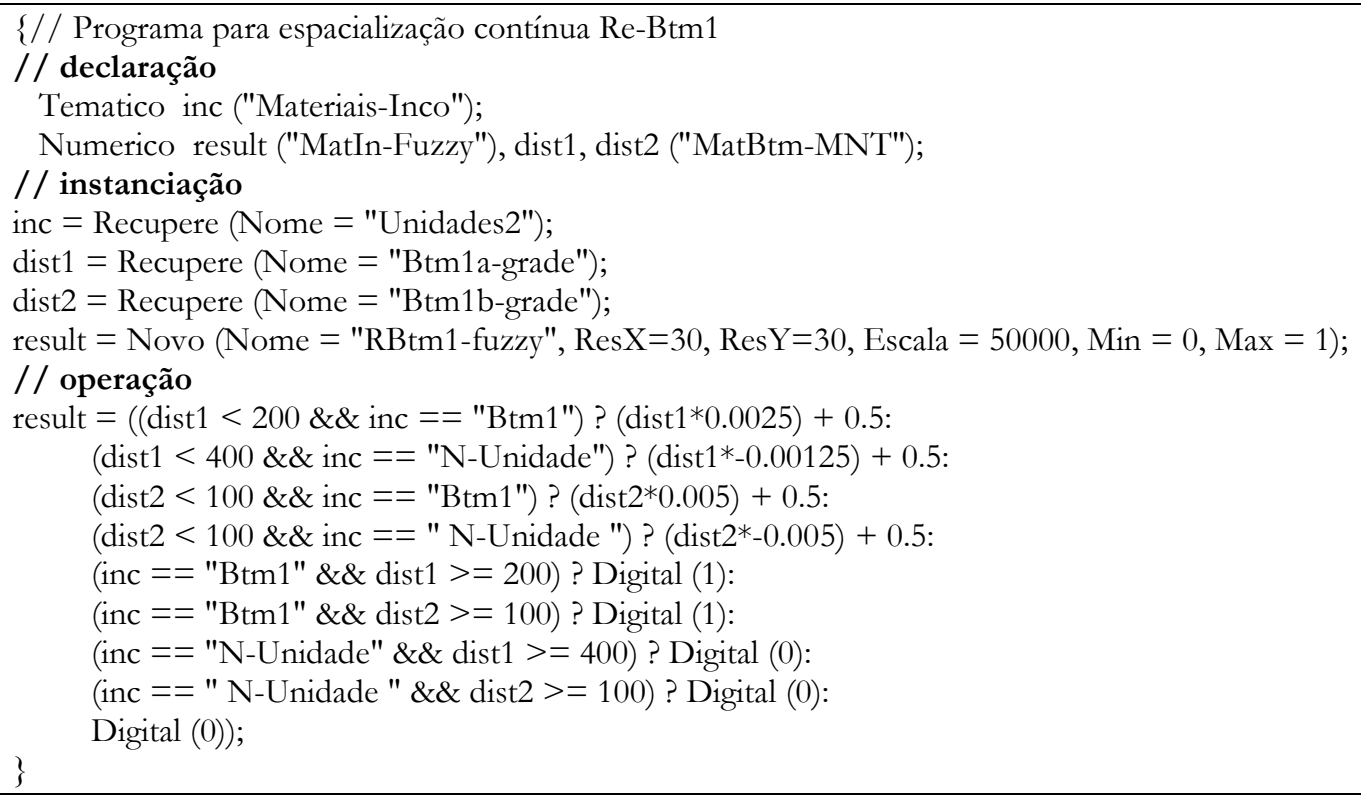


Programa LEGAL 17 - Programa de espacialização contínua de unidade material inconsolidado Blastomilonitos2entre 0 e 1.

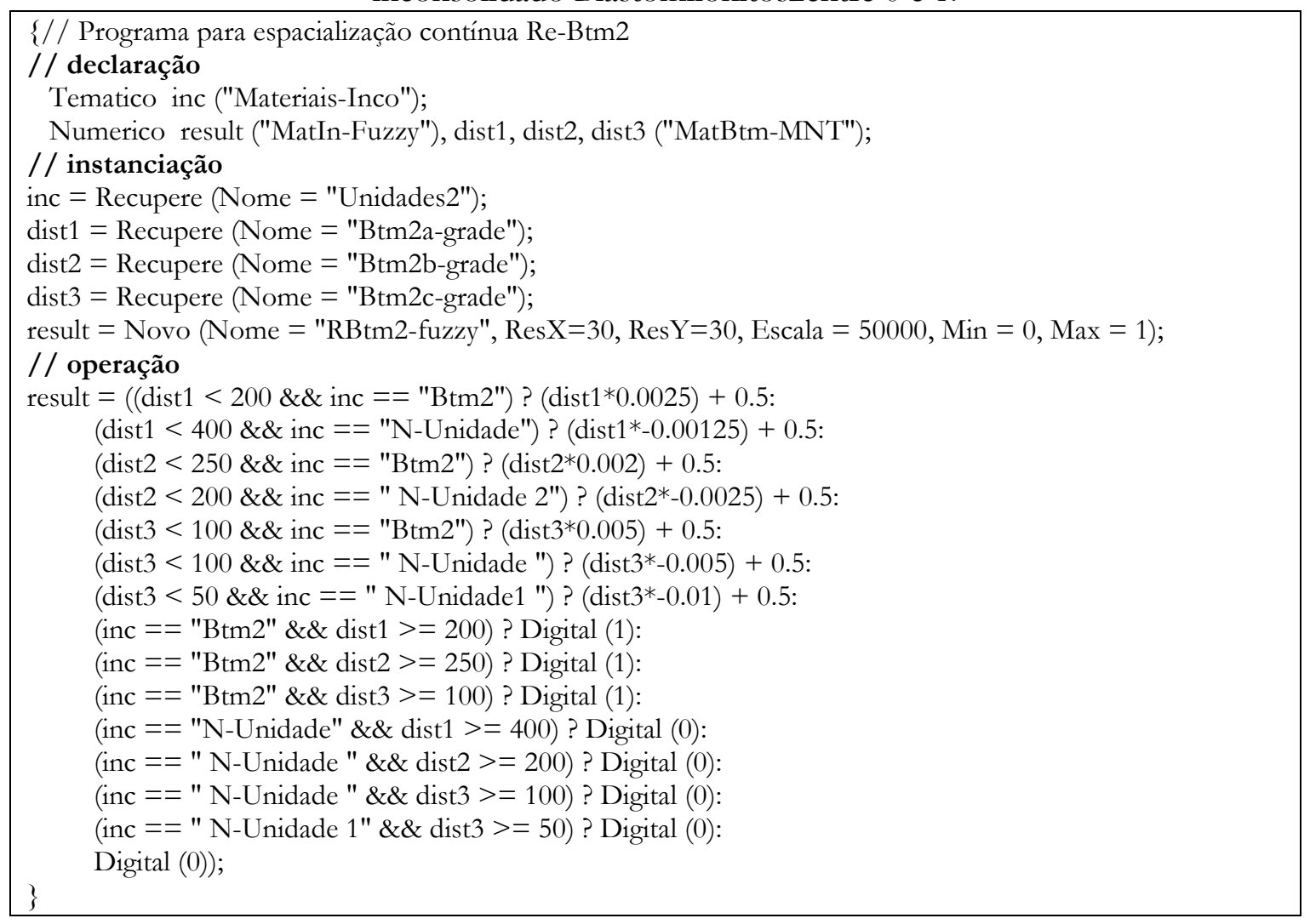

Programa LEGAL 18 - Programa de espacialização contínua de unidade material inconsolidado Blastomilonitos 3entre 0 e 1.

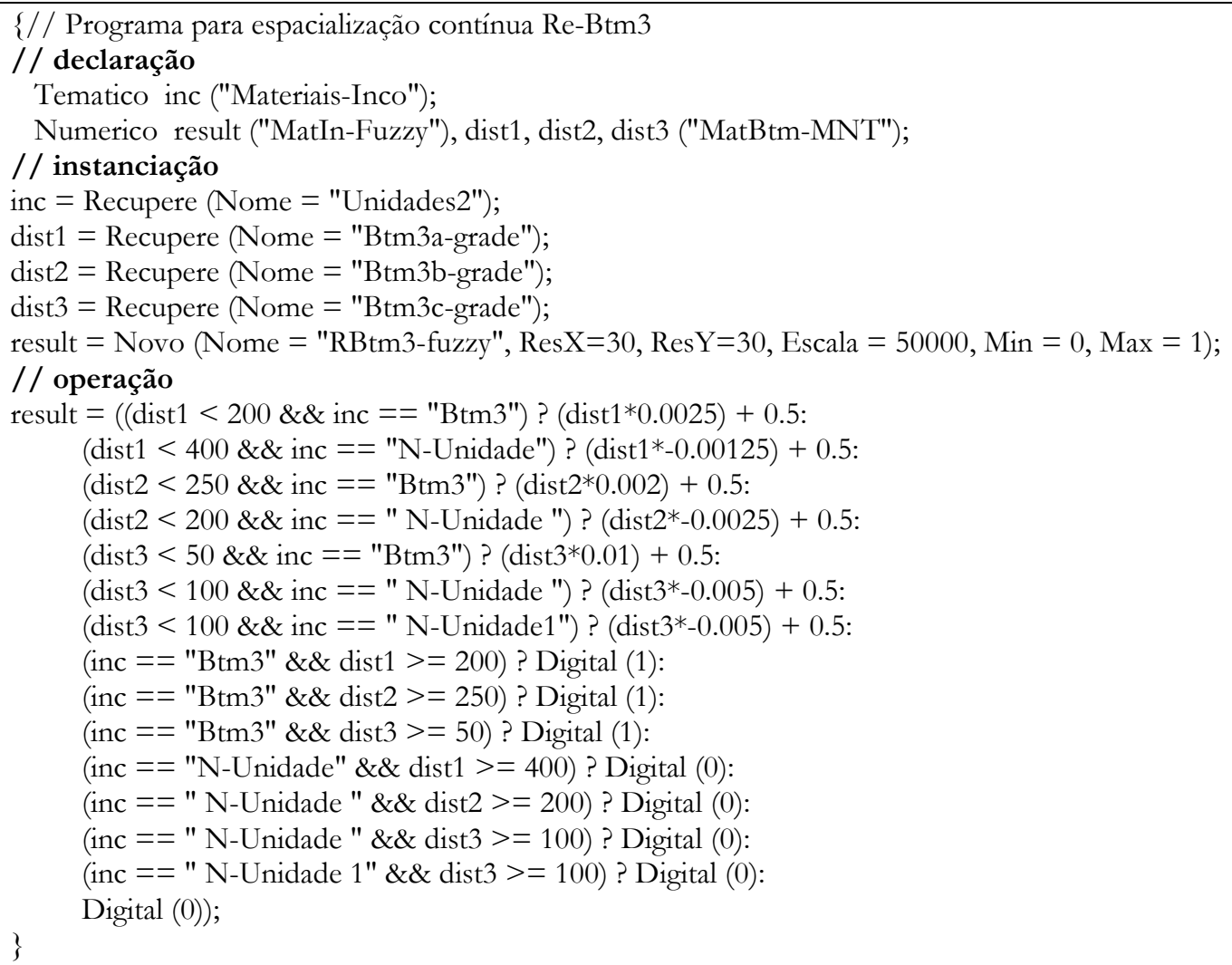


Programa LEGAL 20 - Programa de espacialização contínua de unidade material inconsolidado Blastomilonitos 4entre 0 e 1.

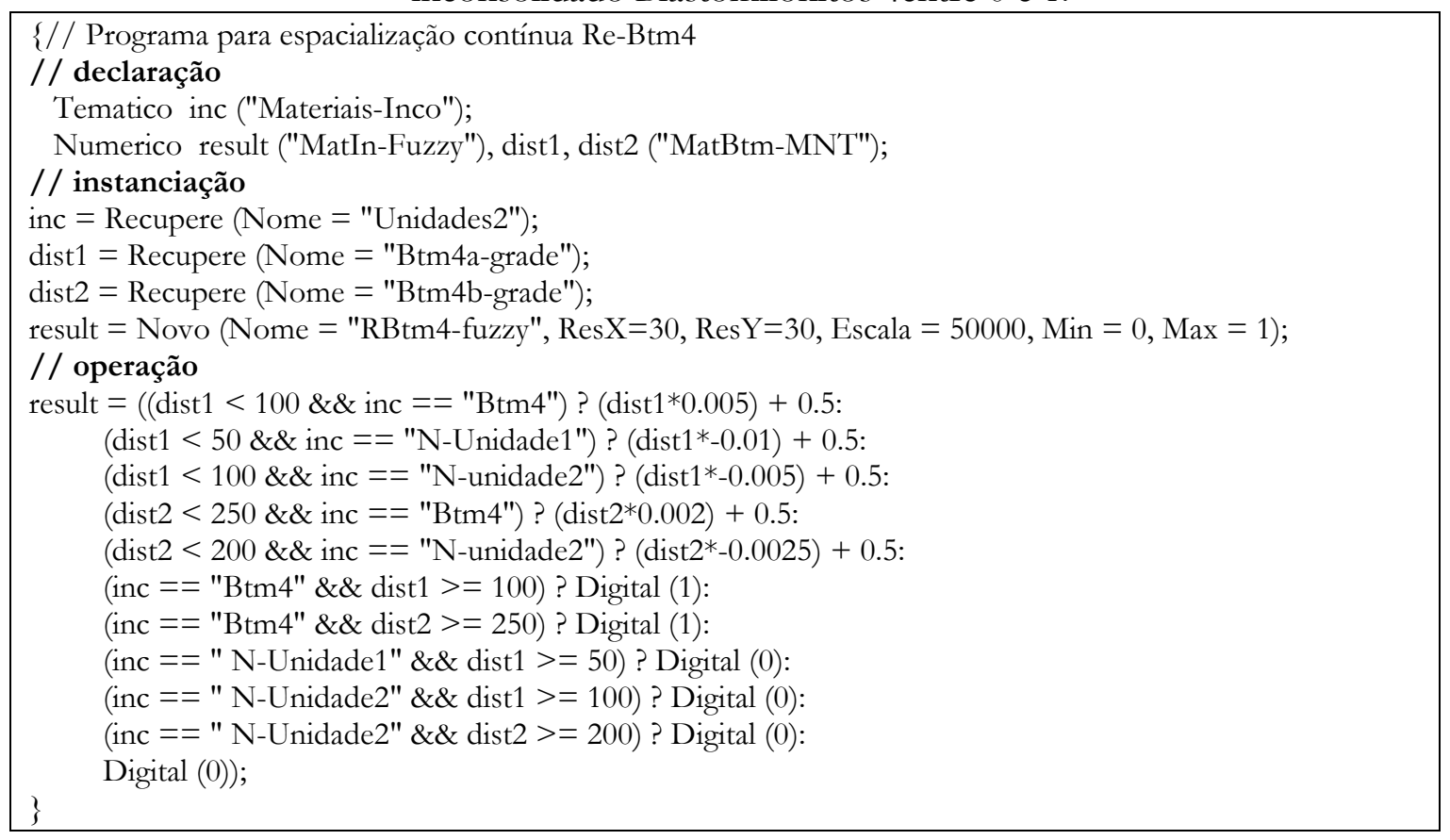

Programa LEGAL 21 - Programa de espacialização contínua de unidade material inconsolidado Blastomilonitos 5entre 0 e 1 .

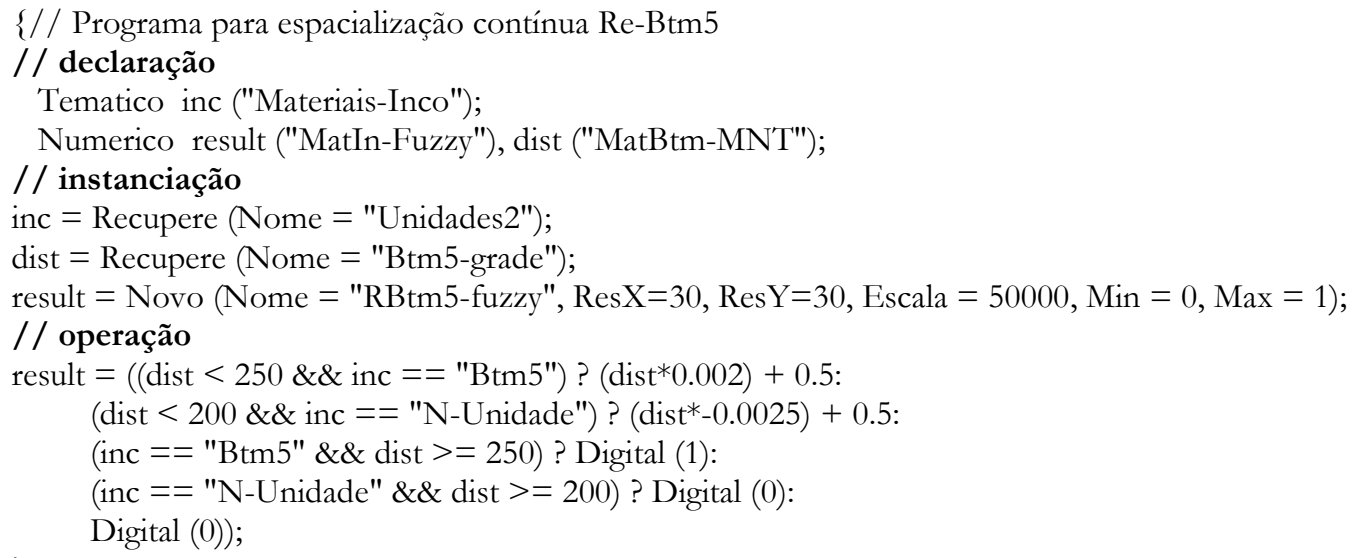


Programa LEGAL 22 - Programa de espacialização contínua de unidade material inconsolidado Gnaisse intercalados com rochas básicas 1 entre 0 e 1.

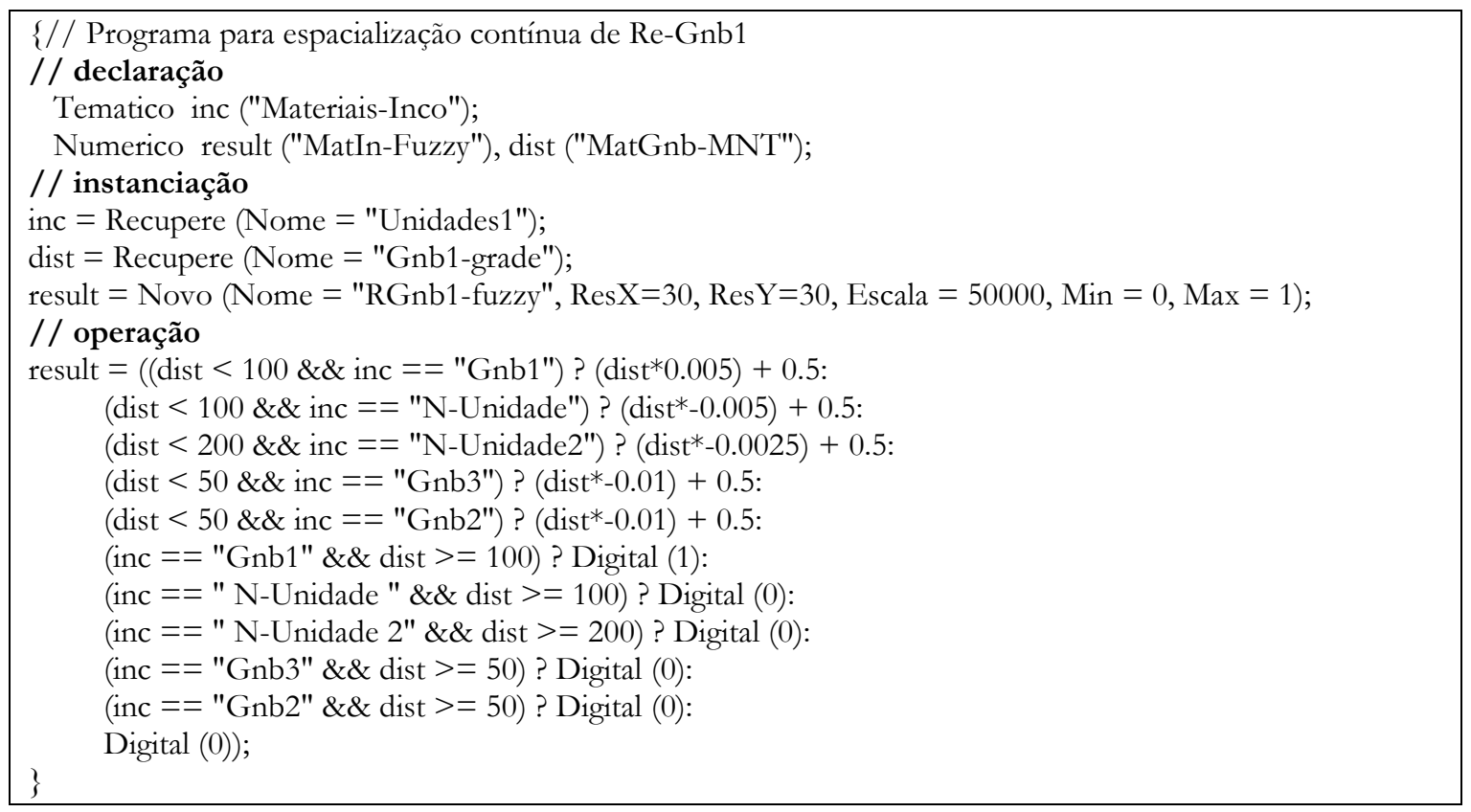

Programa LEGAL 23 - Programa de espacialização contínua de unidade material inconsolidado Gnaisse intercalados com rochas básicas 2entre 0 e 1.

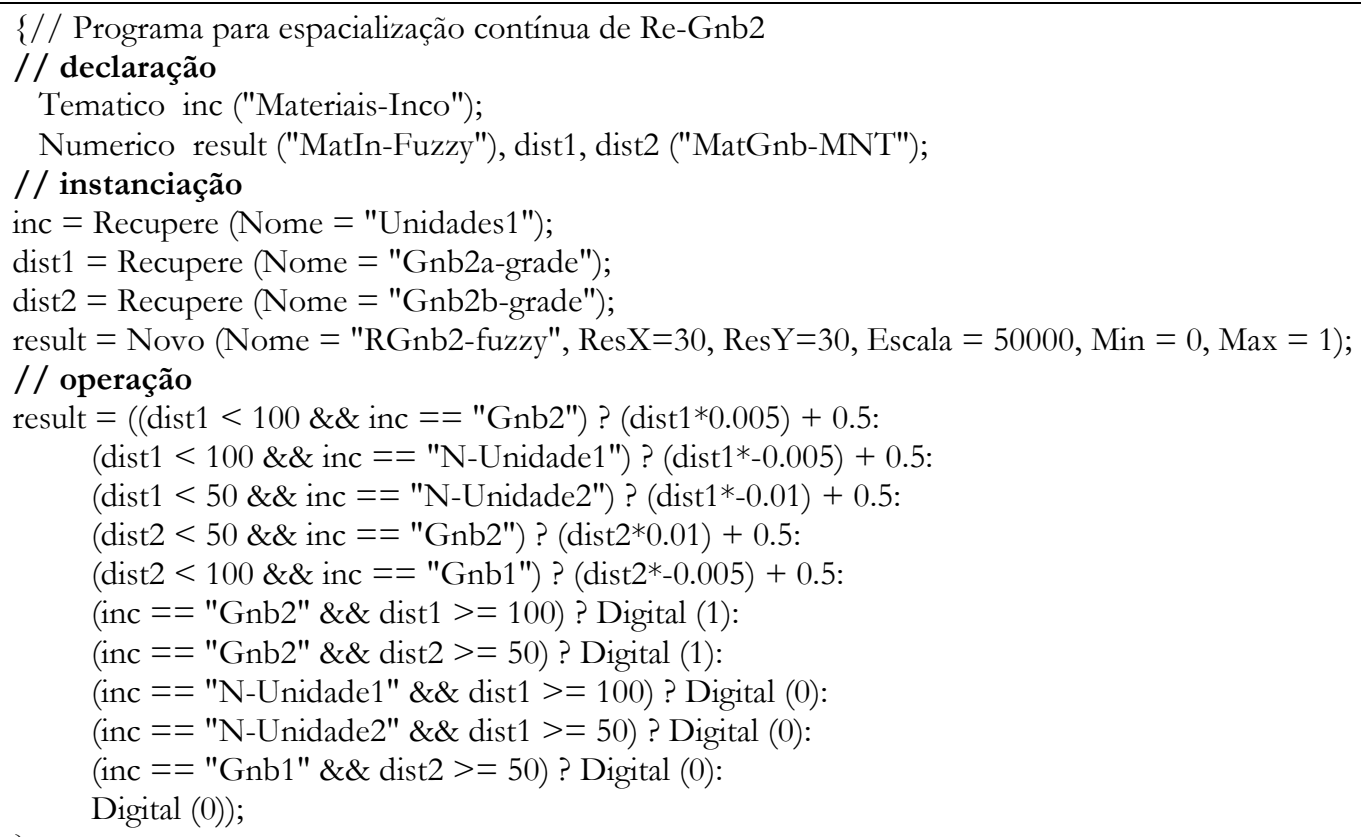


Programa LEGAL 24 - Programa de espacialização contínua de unidade material inconsolidado Gnaisse intercalados com rochas básicas 3entre 0 e 1.

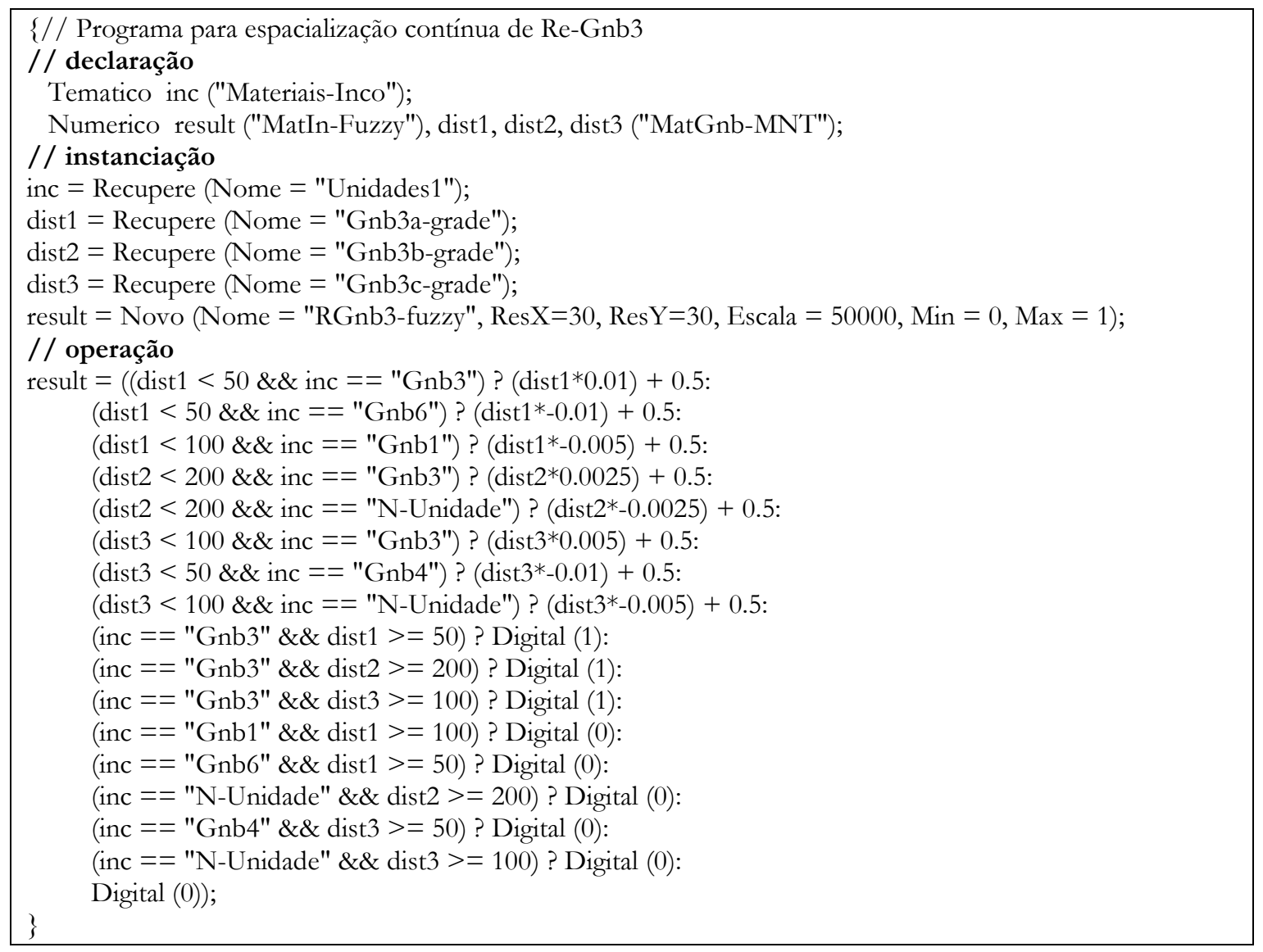

Programa LEGAL 25 - Programa de espacialização contínua de unidade material inconsolidado Gnaisse intercalados com rochas básicas 4entre 0 e 1.

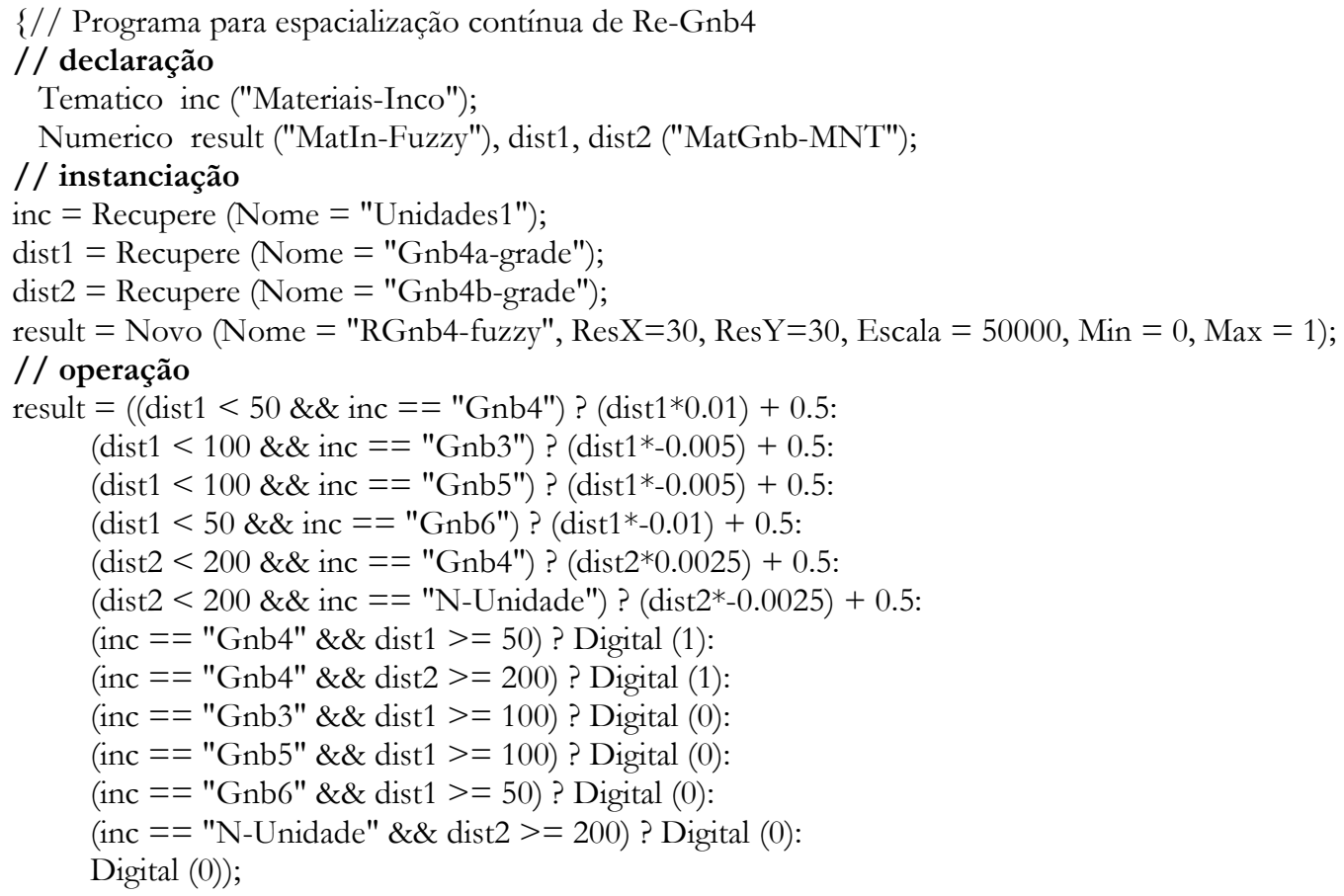


Programa LEGAL 26 - Programa de espacialização contínua de unidade material inconsolidado Gnaisse intercalados com rochas básicas 5entre 0 e 1.

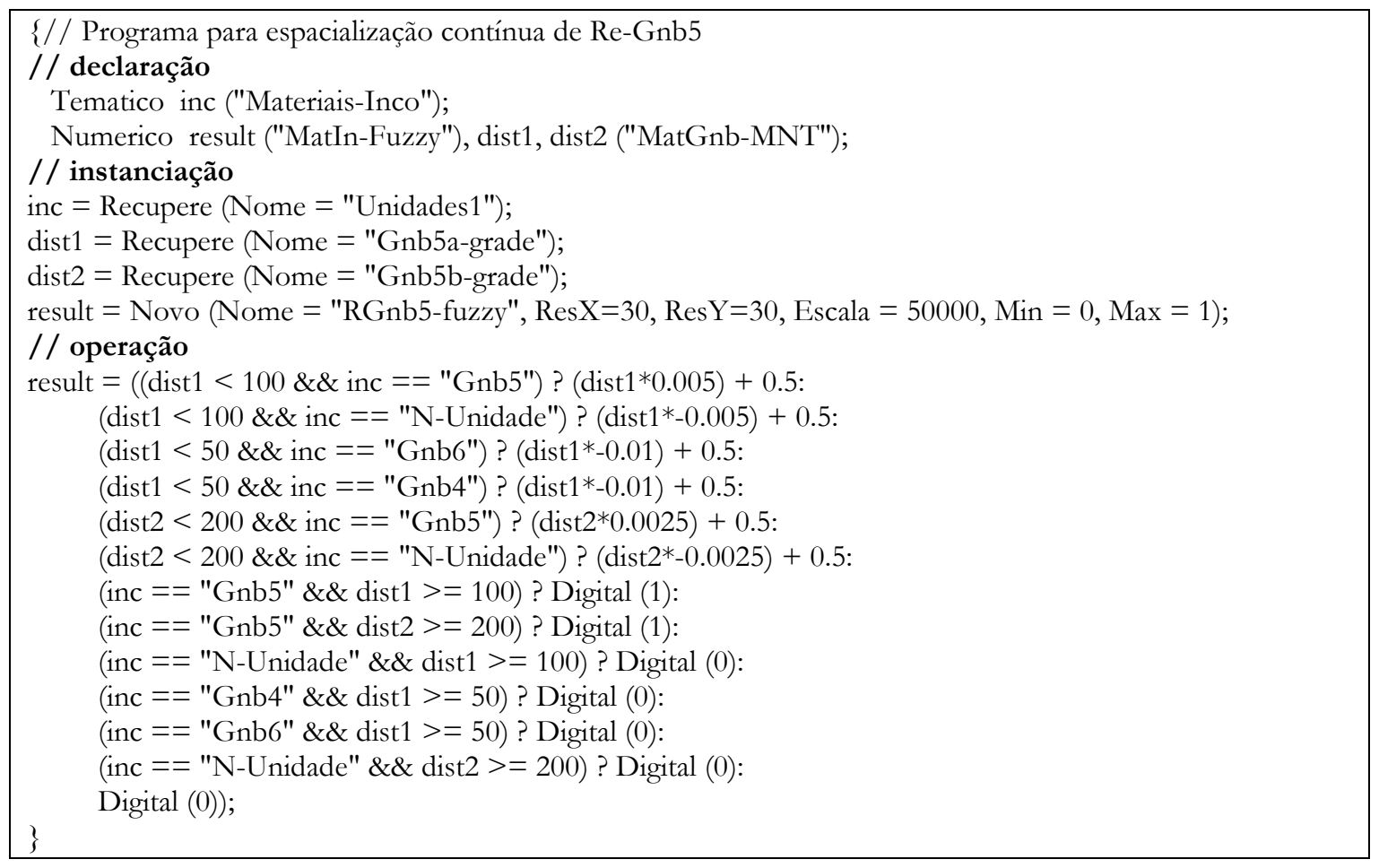

Programa LEGAL 27 - Programa de espacialização contínua de unidade material inconsolidado Gnaisse intercalados com rochas básicas 6 entre 0 e 1.

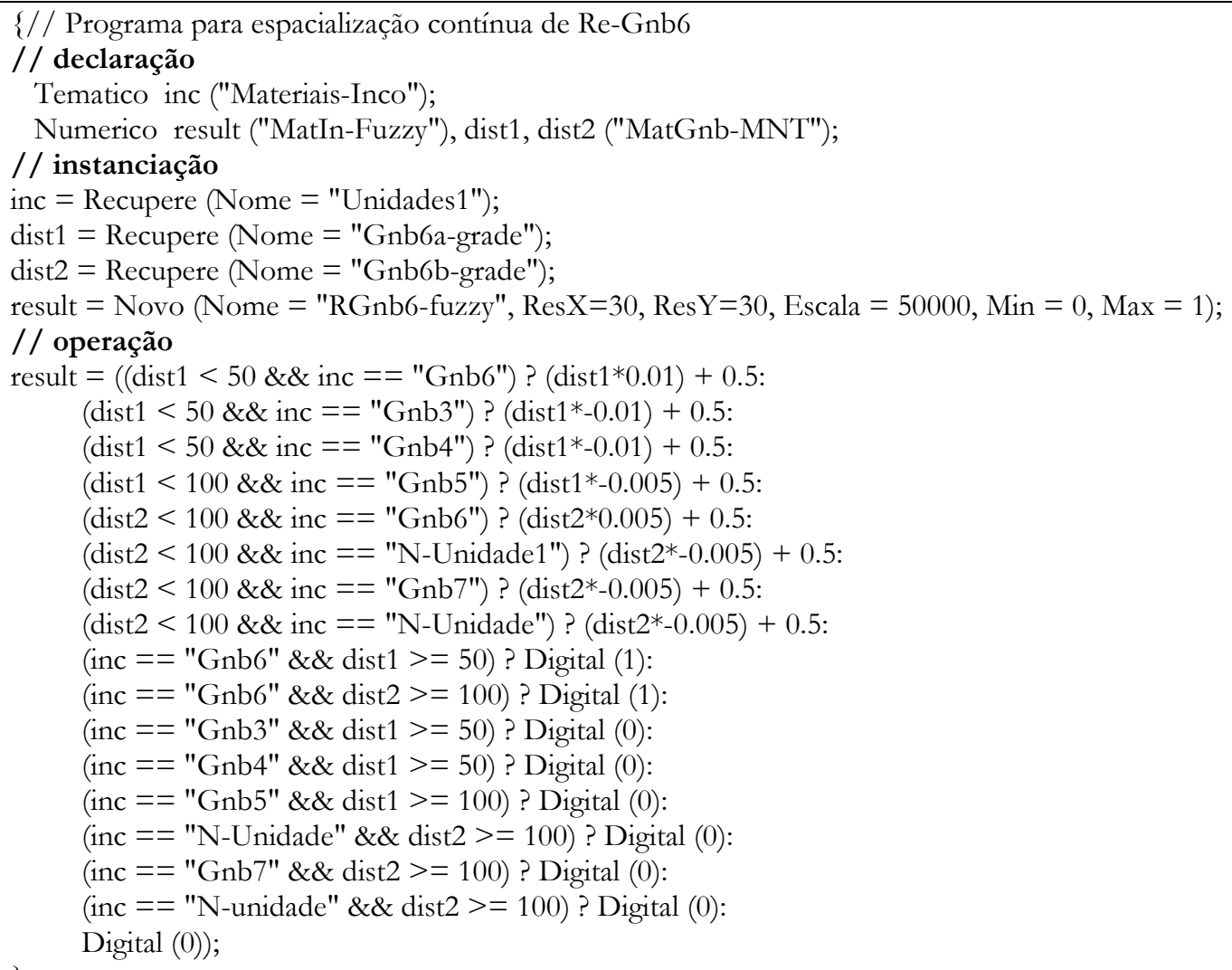


Programa LEGAL 28 - Programa de espacialização contínua de unidade material inconsolidado Gnaisse intercalados com rochas básicas 7 entre 0 e 1.

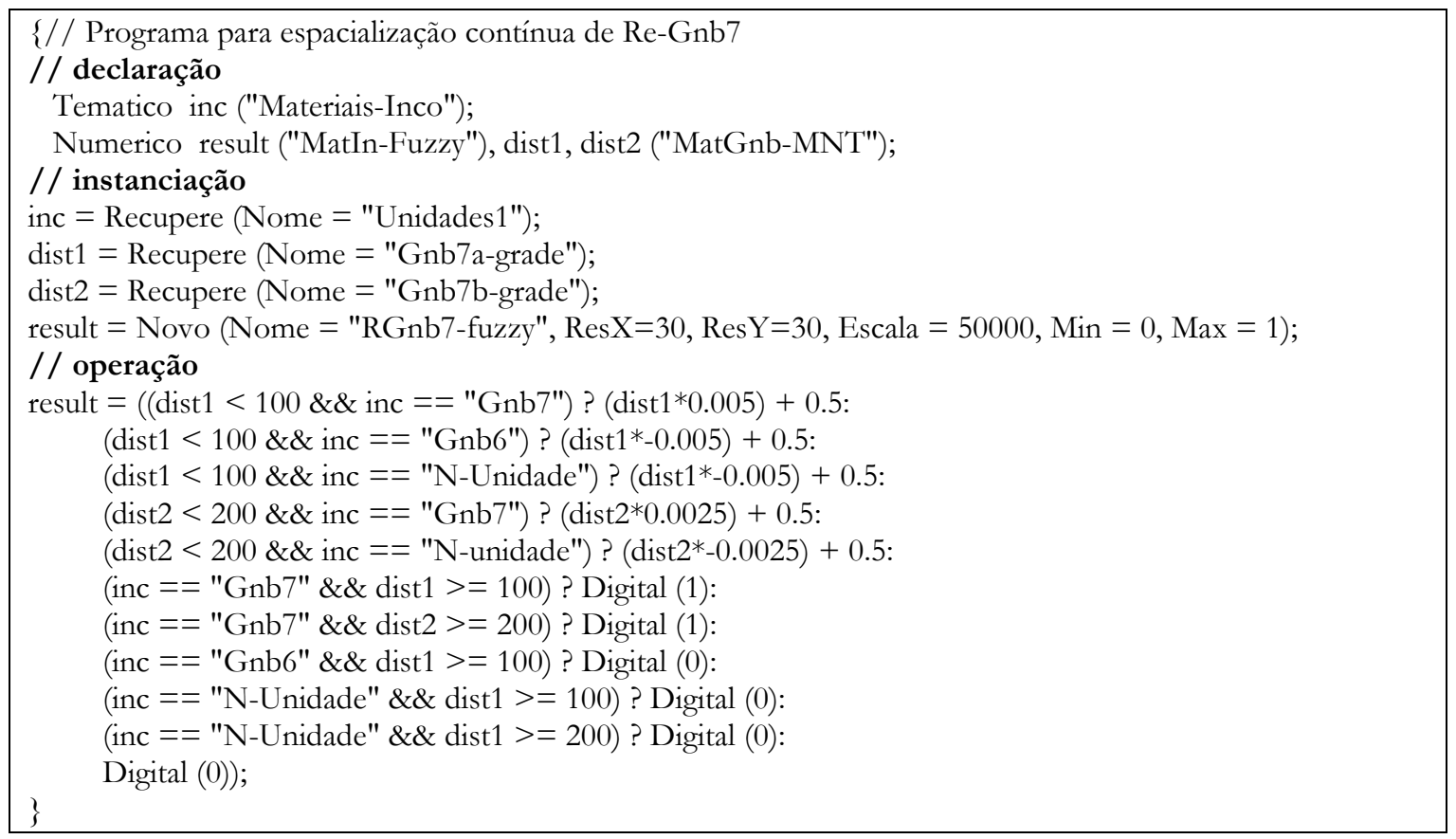

Programa LEGAL 29 - Programa de espacialização contínua de unidade material inconsolidado Gnaisse intercalados com rochas básicas 8 entre 0 e 1.

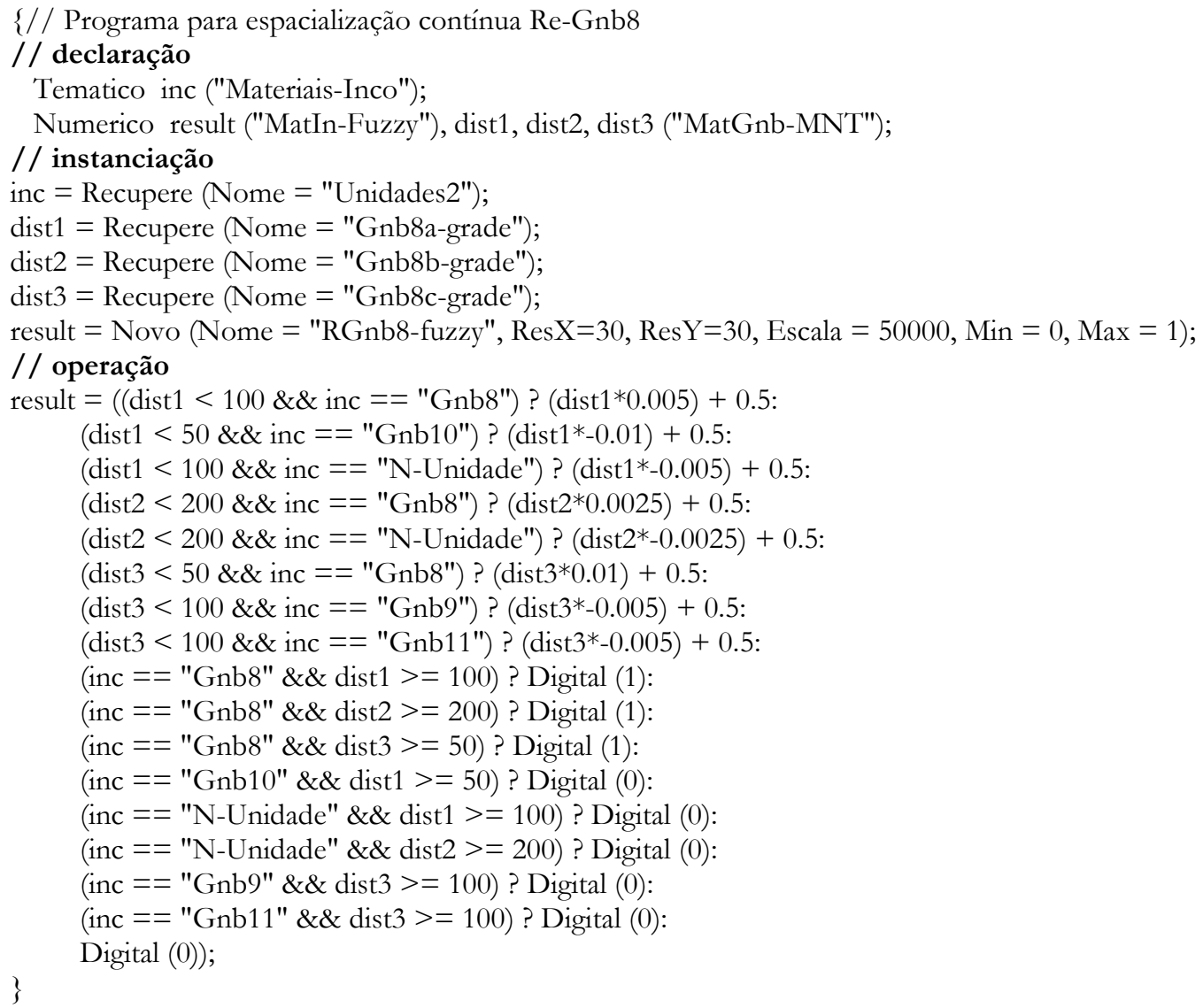


Programa LEGAL 30 - Programa de espacialização contínua de unidade material inconsolidado Gnaisse intercalados com rochas básicas 9 entre 0 e 1.

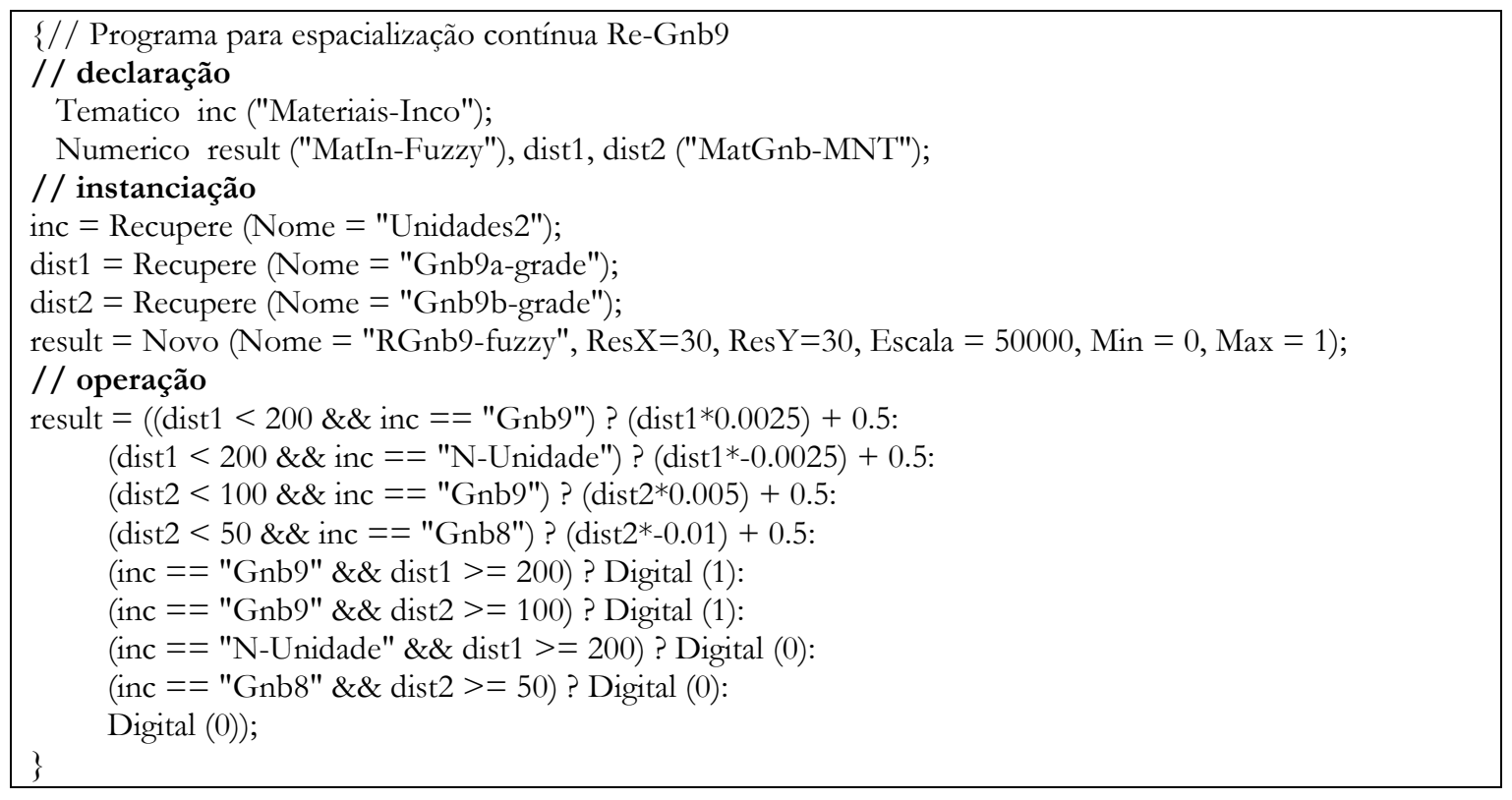

Programa LEGAL 31 - Programa de espacialização contínua de unidade material inconsolidado Gnaisse intercalados com rochas básicas 10 entre 0 e 1.

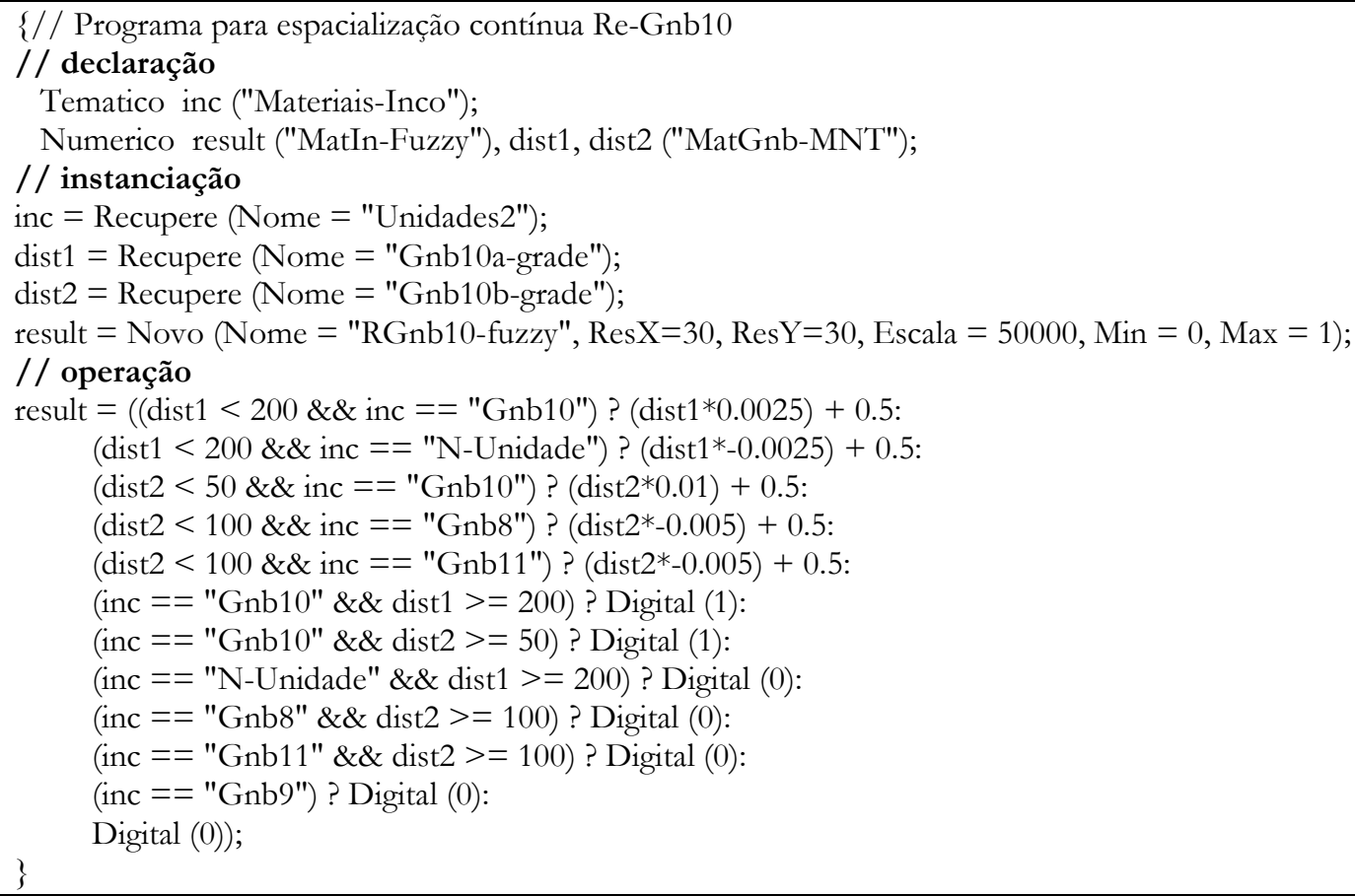


Programa LEGAL 32 - Programa de espacialização contínua de unidade material inconsolidado Gnaisse intercalados com rochas básicas 11 entre 0 e 1.

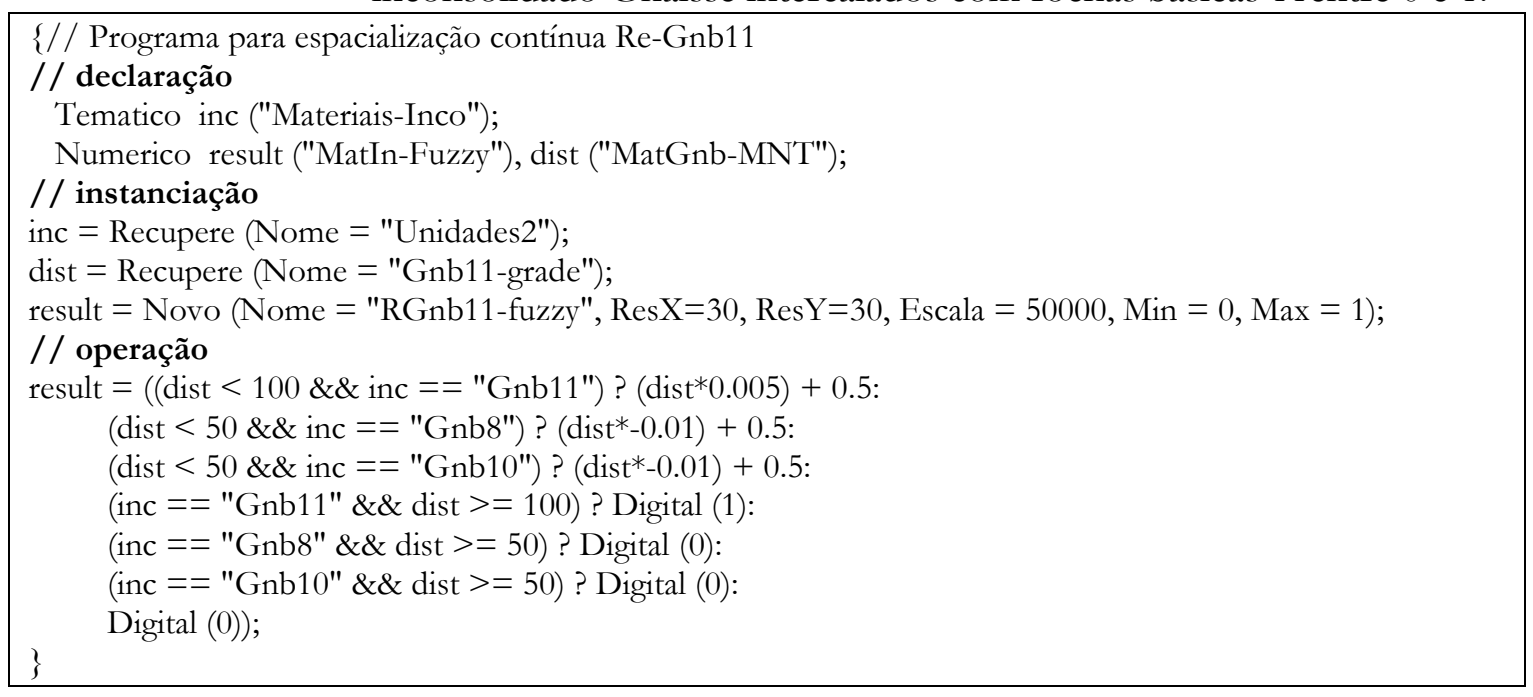

Programa LEGAL 33 - Programa de espacialização contínua de unidade material inconsolidado Gnaisse intercalados quartzitos 1 entre 0 e 1 .

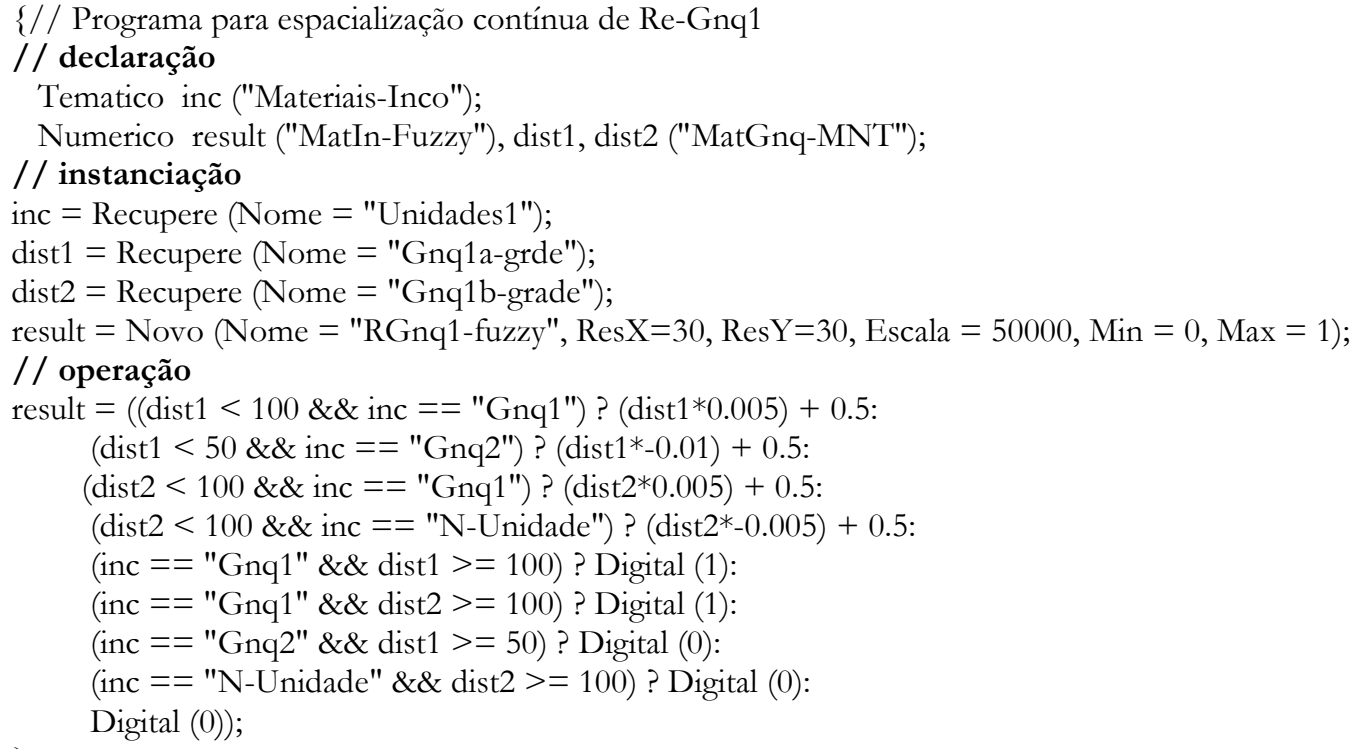


Programa LEGAL 34 - Programa de espacialização contínua de unidade material inconsolidado Gnaisse intercalados quartzitos 2 entre 0 e 1.

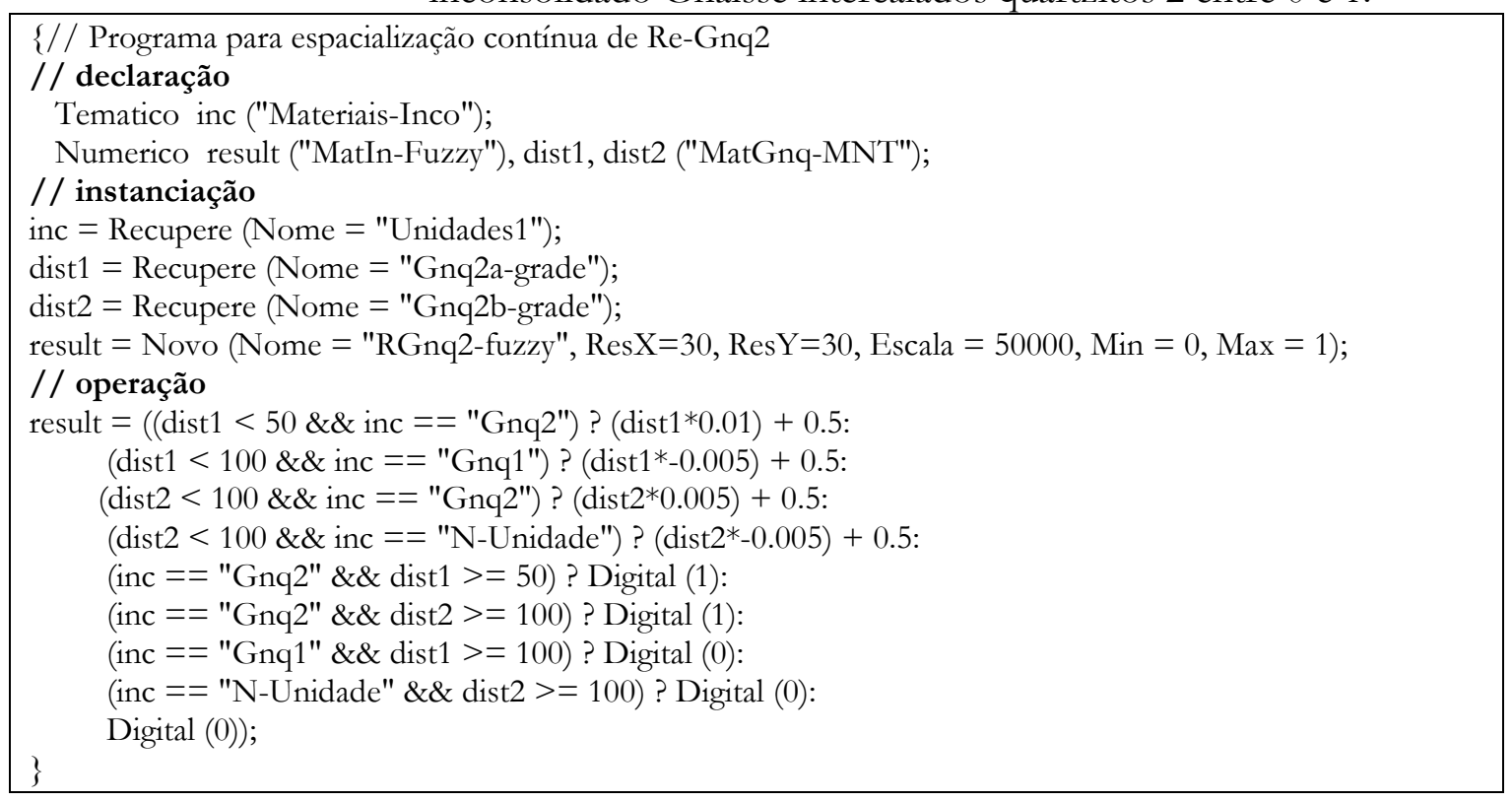

Programa LEGAL 35 - Programa de espacialização contínua de unidade material inconsolidado Gnaisse intercalados quartzitos 3 entre 0 e 1.

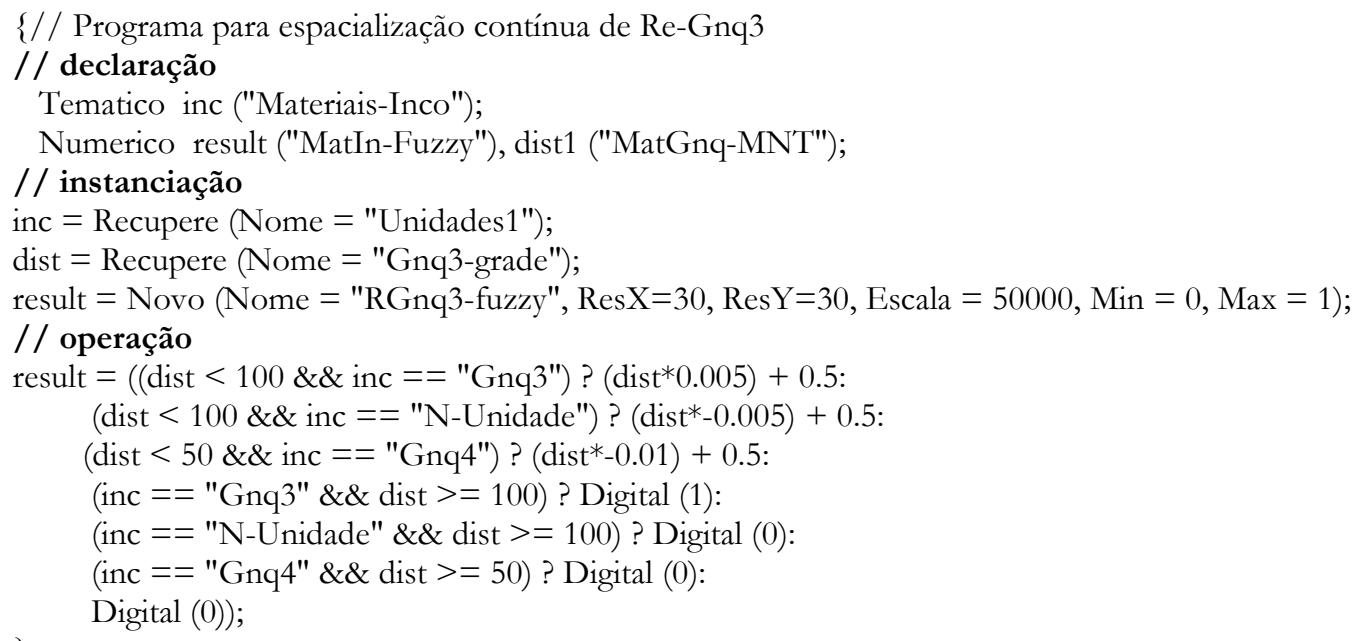


Programa LEGAL 36 - Programa de espacialização contínua de unidade material inconsolidado Gnaisse intercalados quartzitos 4 entre 0 e 1.

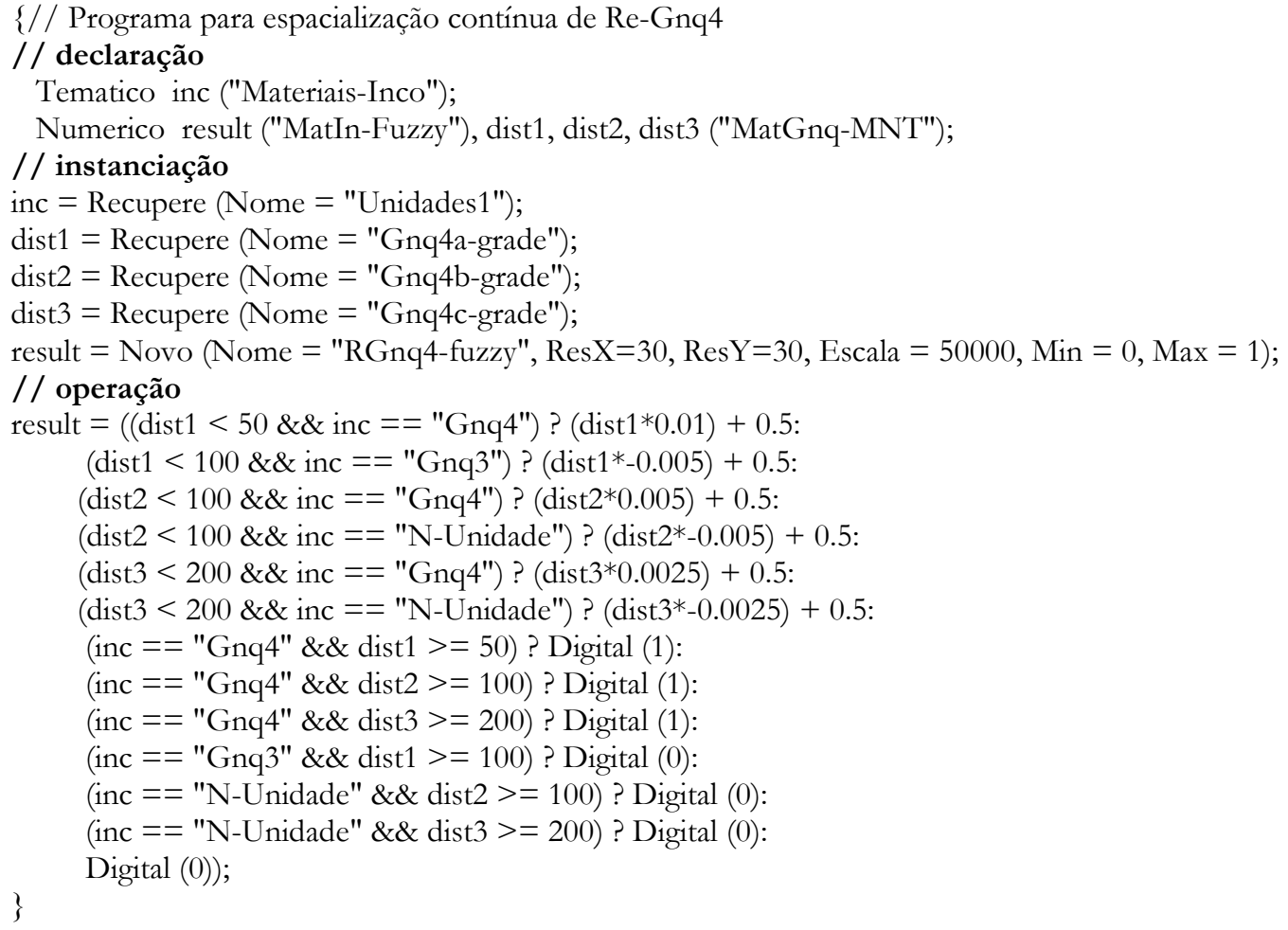

Programa LEGAL 37 - Programa de espacialização contínua de unidade material inconsolidado Gnaisse intercalados quartzitos 5 entre 0 e 1.

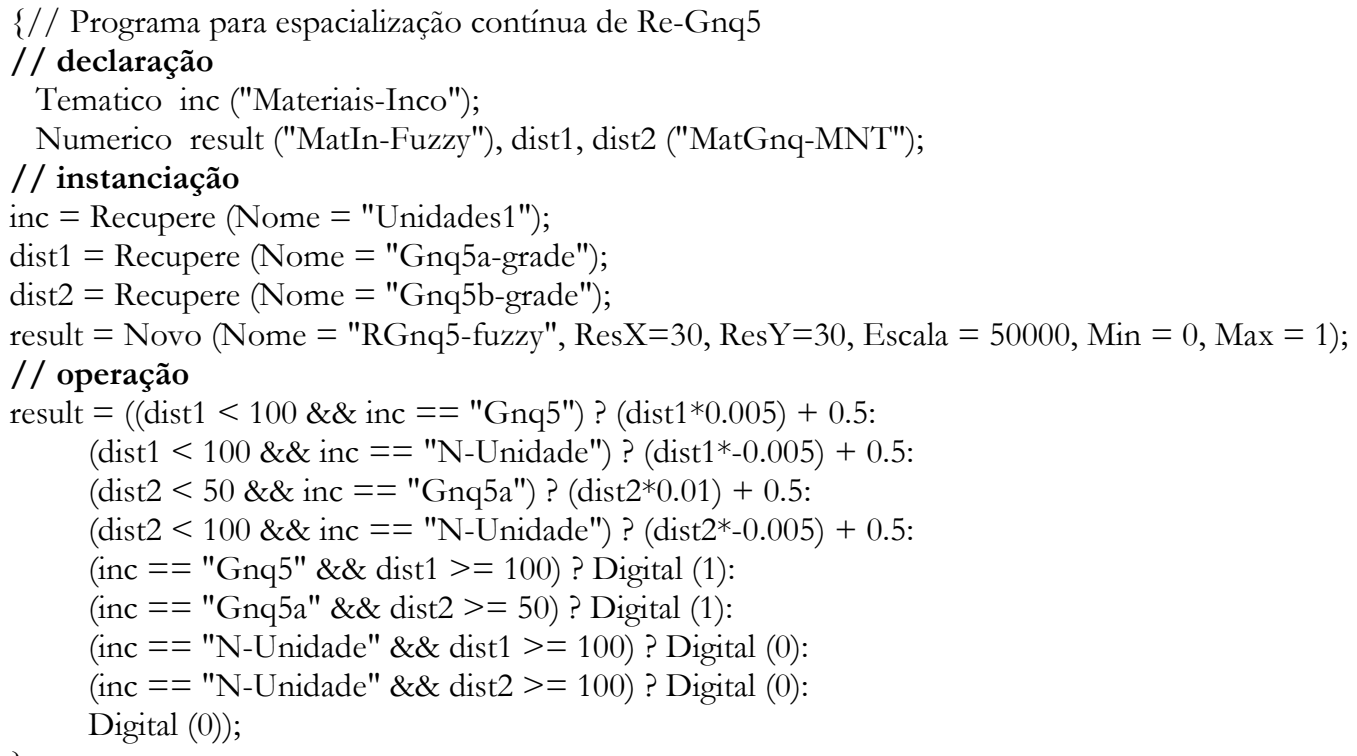


Programa LEGAL 38 - Programa de espacialização contínua de unidade material inconsolidado Granitos cataclasados entre 0 e 1.

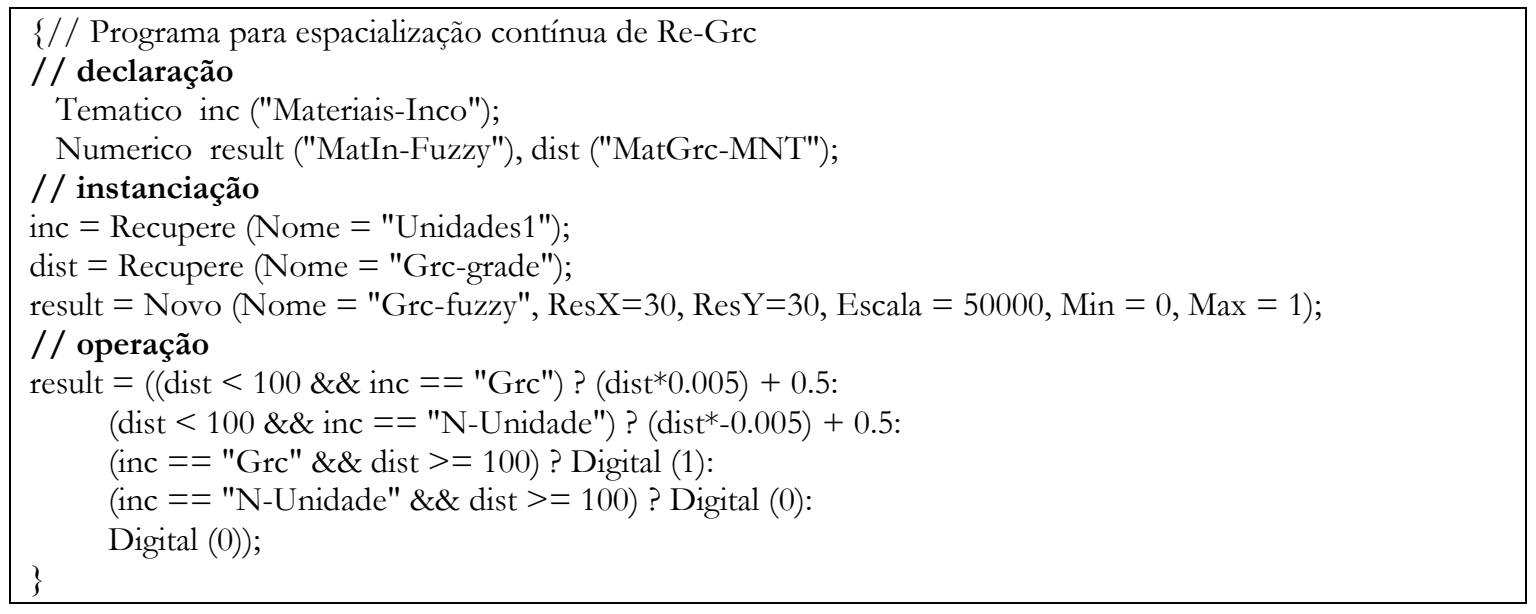

Programa LEGAL 39 - Programa de espacialização contínua de unidade material inconsolidado Granito-gnaisses 1 entre 0 e 1.

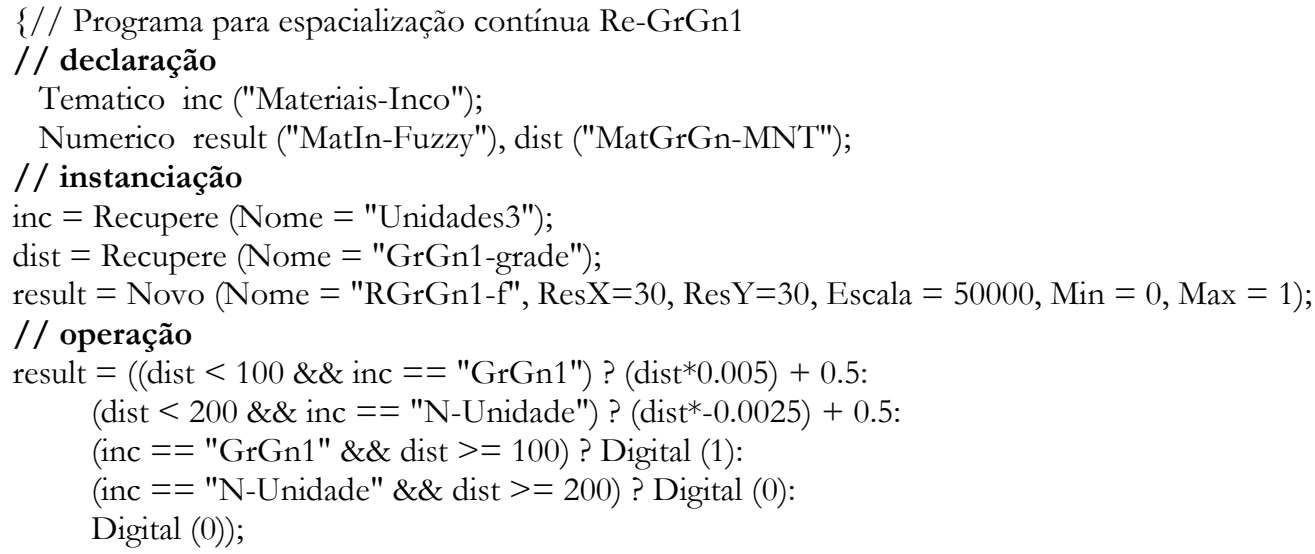

Programa LEGAL 40 - Programa de espacialização contínua de unidade material inconsolidado Granito-gnaisses 2 entre 0 e 1.

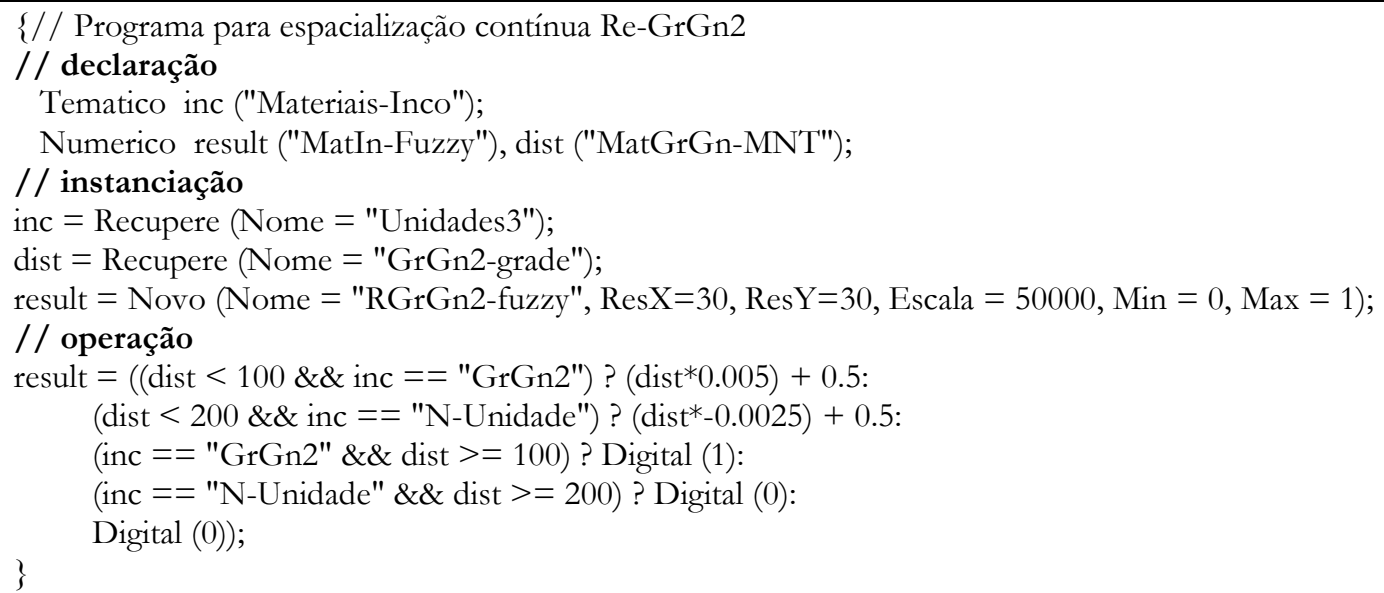


Programa LEGAL 41 - Programa de espacialização contínua de unidade material inconsolidado Granito porfiríticos 1 entre 0 e 1.

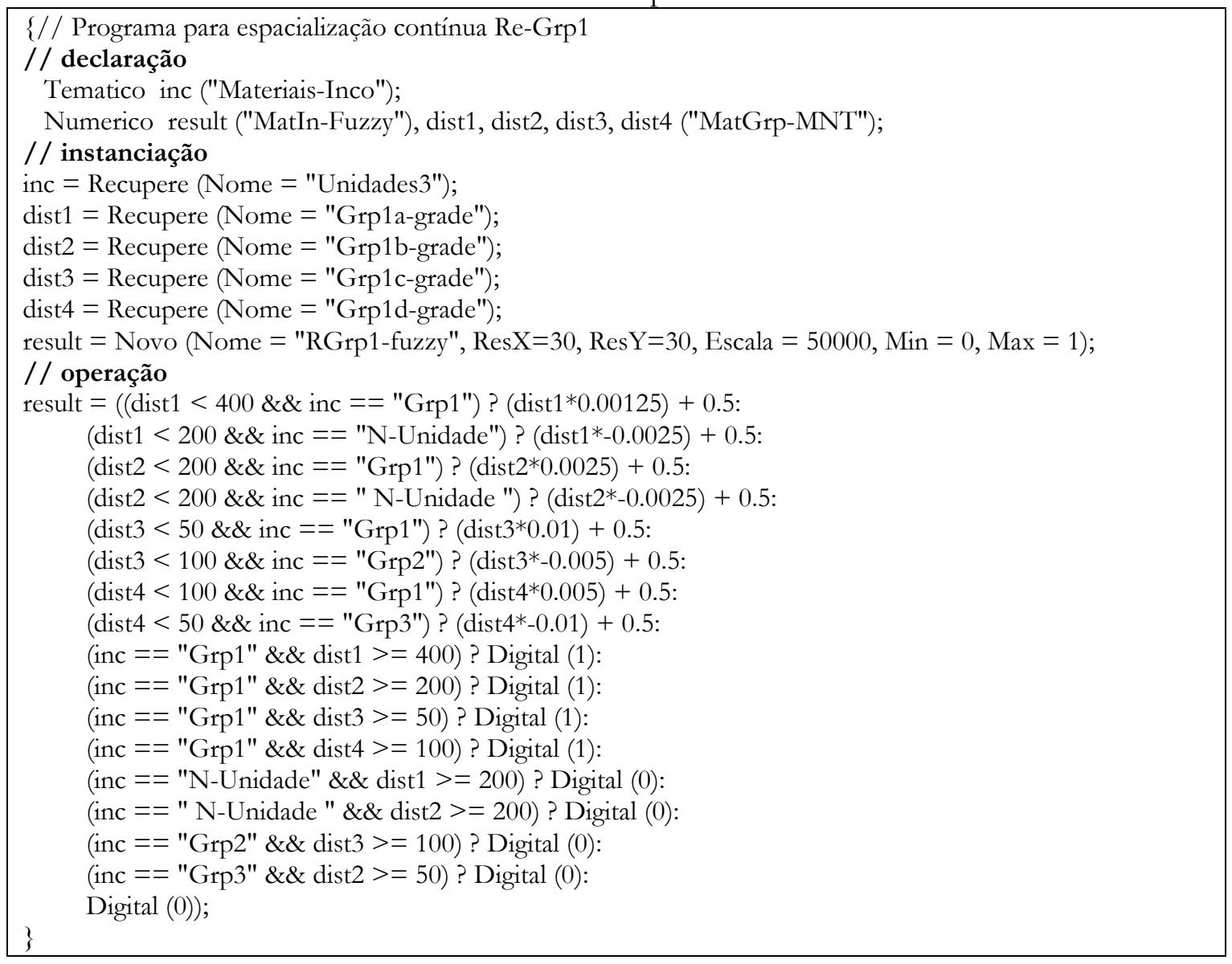

Programa LEGAL 42 - Programa de espacialização contínua de unidade material inconsolidado Granito porfiríticos 2 entre 0 e 1.

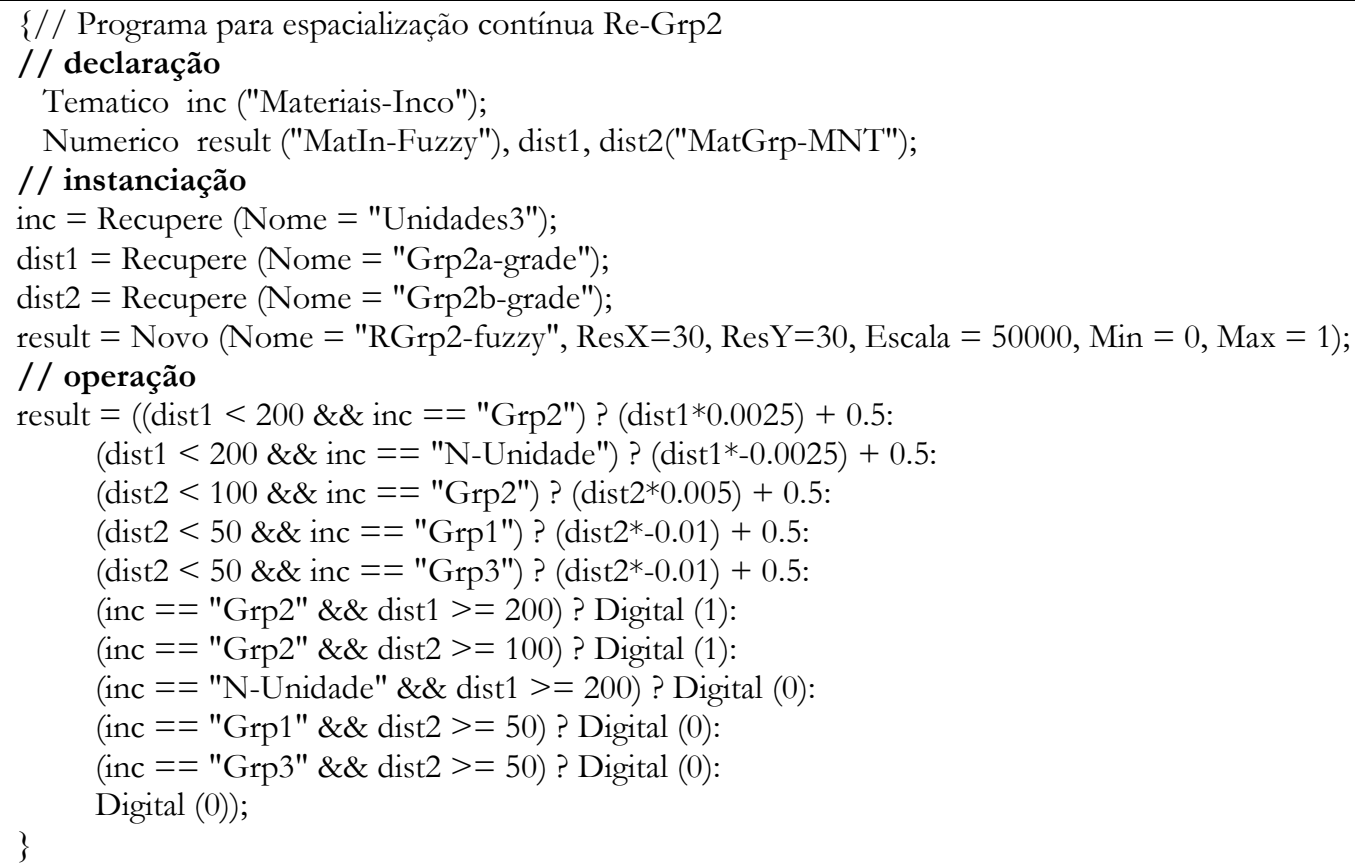


Programa LEGAL 43 - Programa de espacialização contínua de unidade material inconsolidado Granito porfiríticos 3entre 0 e 1.

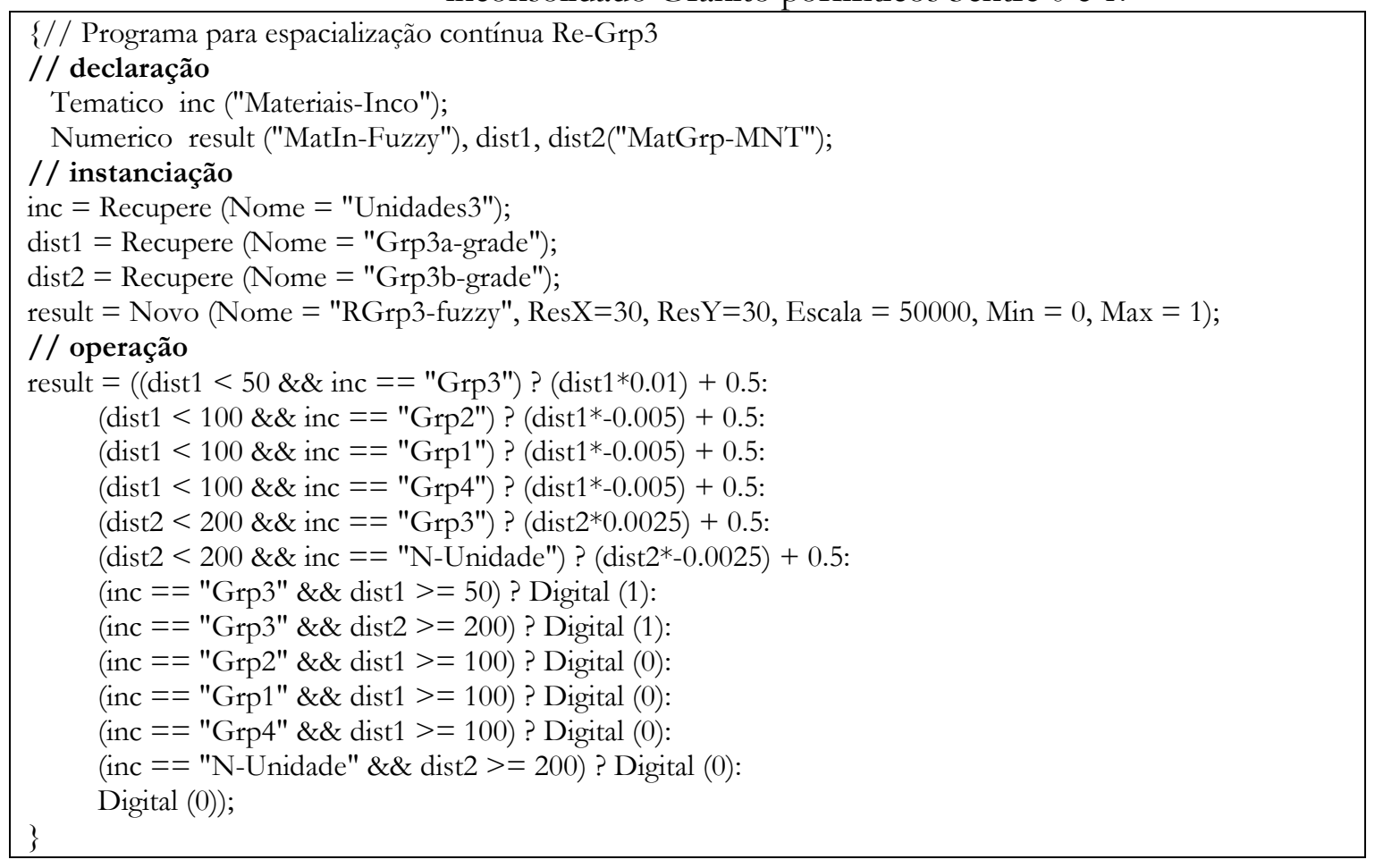

Programa LEGAL 44 - Programa de espacialização contínua de unidade material inconsolidado Granito porfiríticos 4 entre 0 e 1.

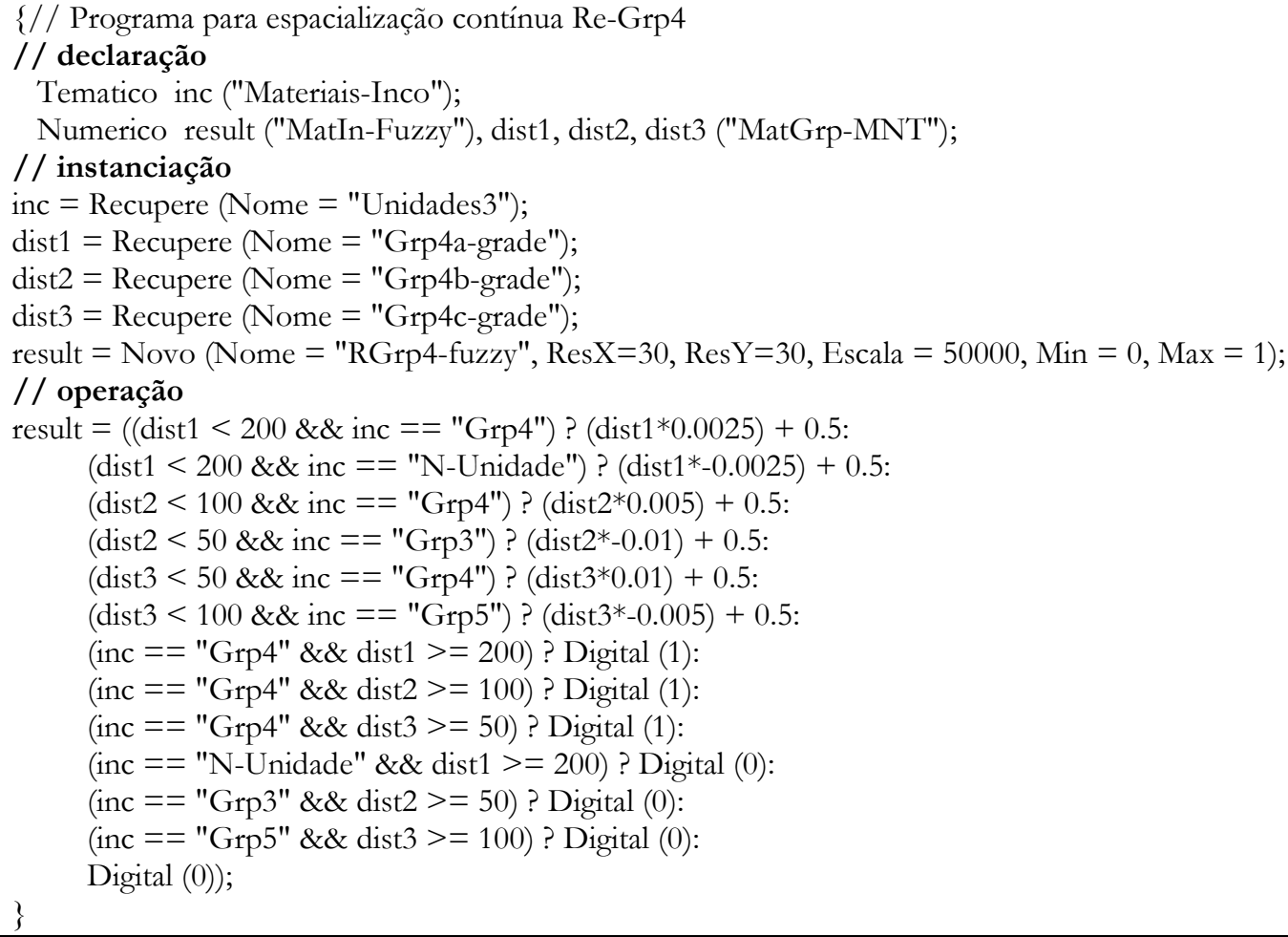


Programa LEGAL 45 - Programa de espacialização contínua de unidade material inconsolidado Granito porfiríticos 5 entre 0 e 1.

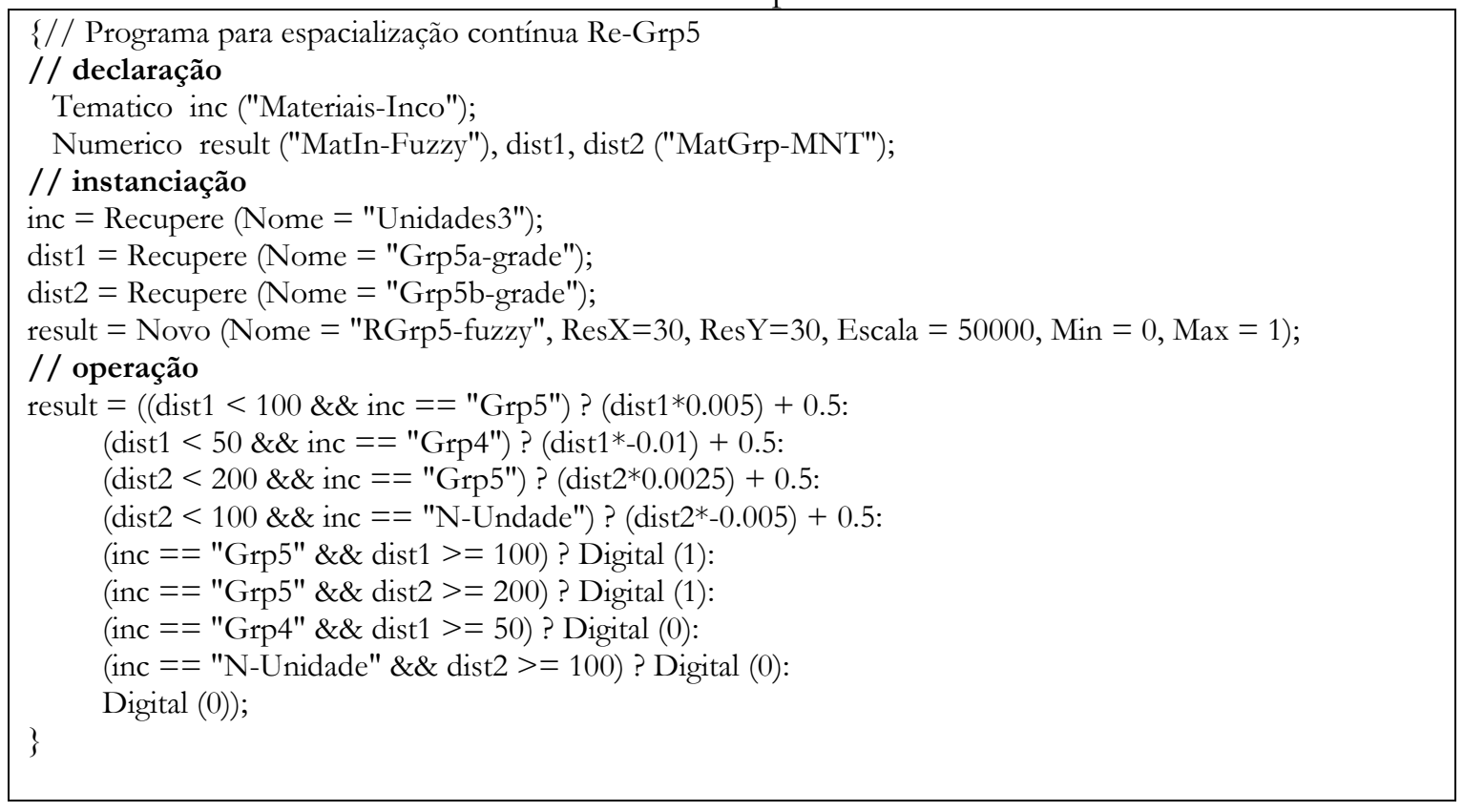

Programa LEGAL 46 - Programa de espacialização contínua de unidade material inconsolidado Migmatitos 1 entre 0 e 1.

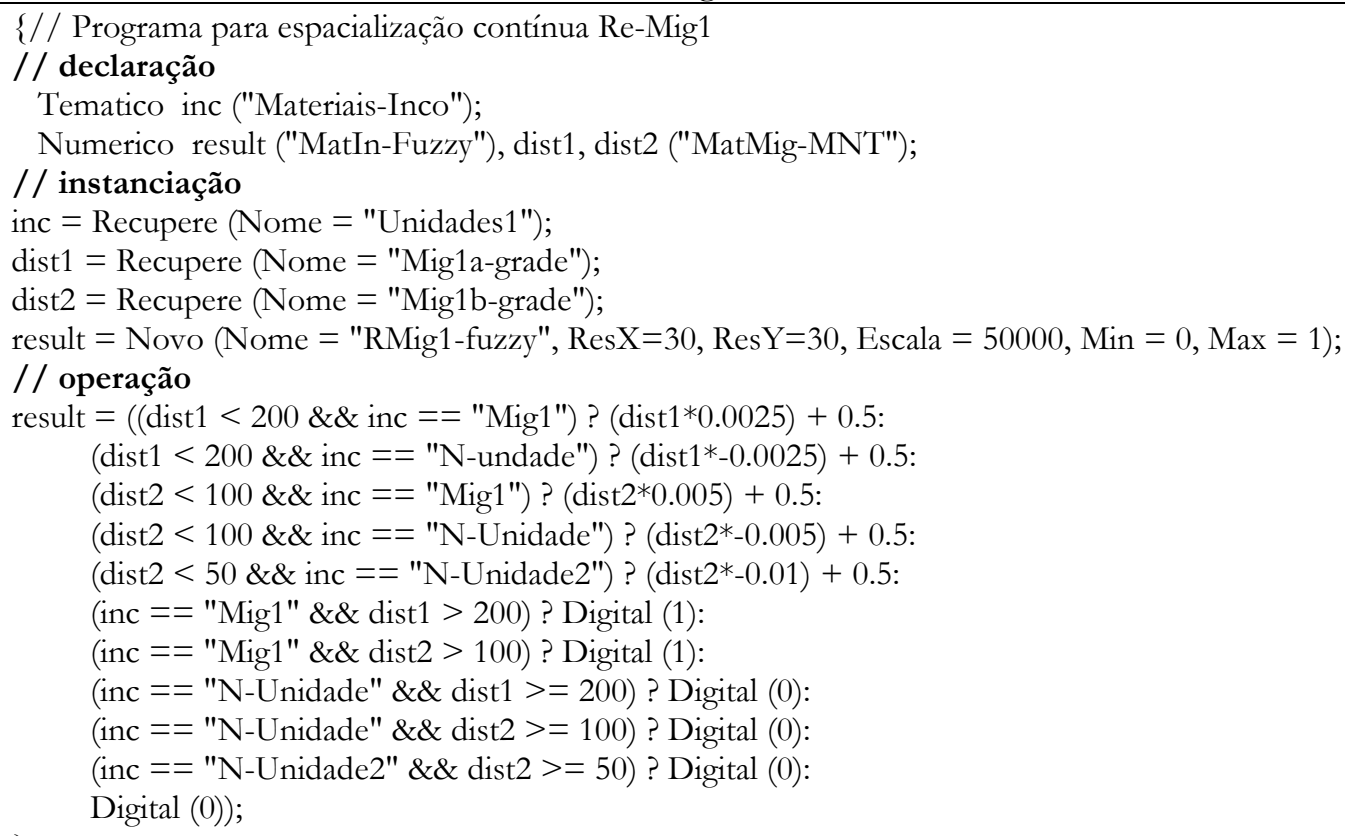


Programa LEGAL 47 - Programa de espacialização contínua de unidade material inconsolidado Migmatitos 2 entre 0 e 1.

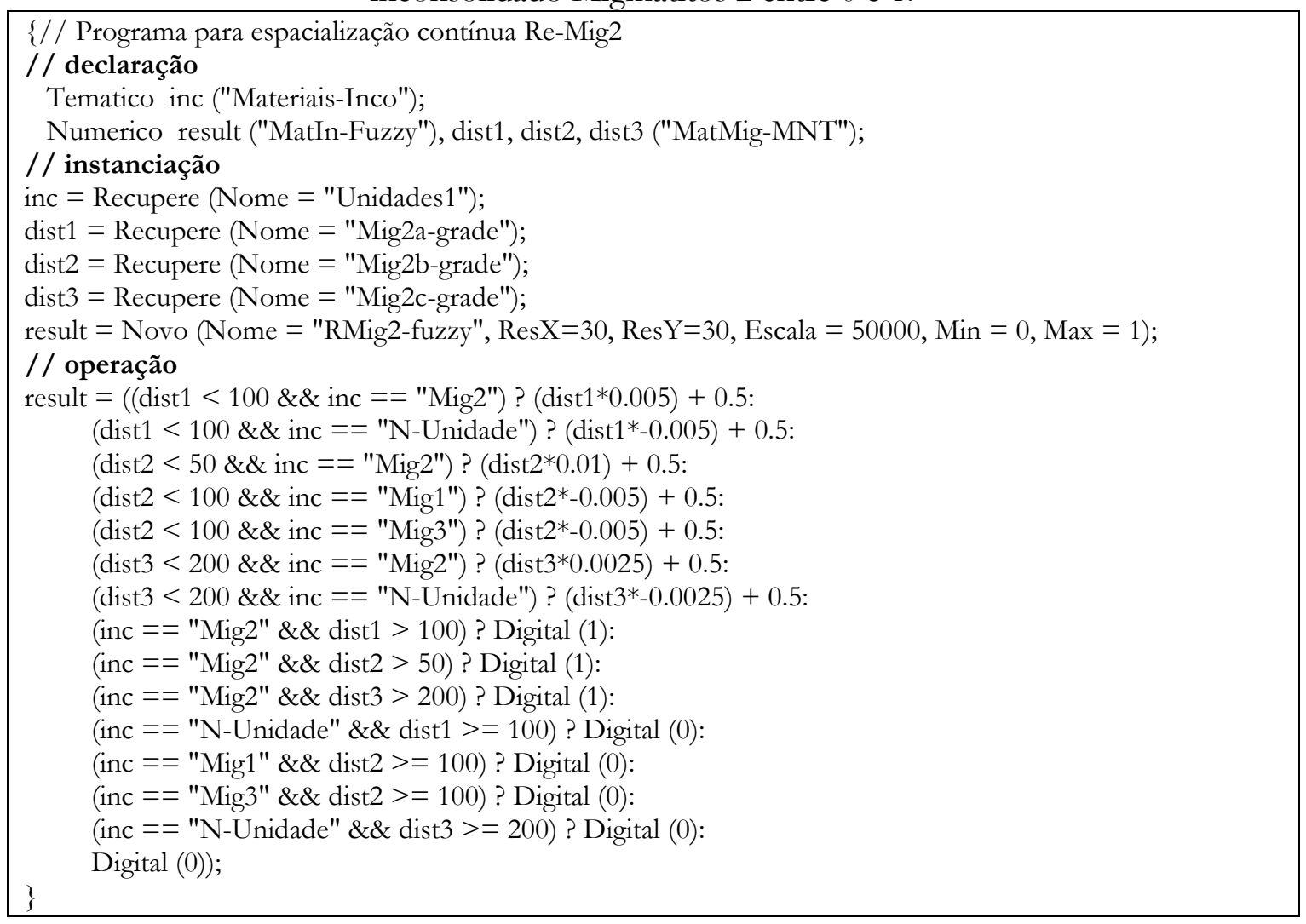

Programa LEGAL 47 - Programa de espacialização contínua de unidade material inconsolidado Migmatitos 3 entre 0 e 1.

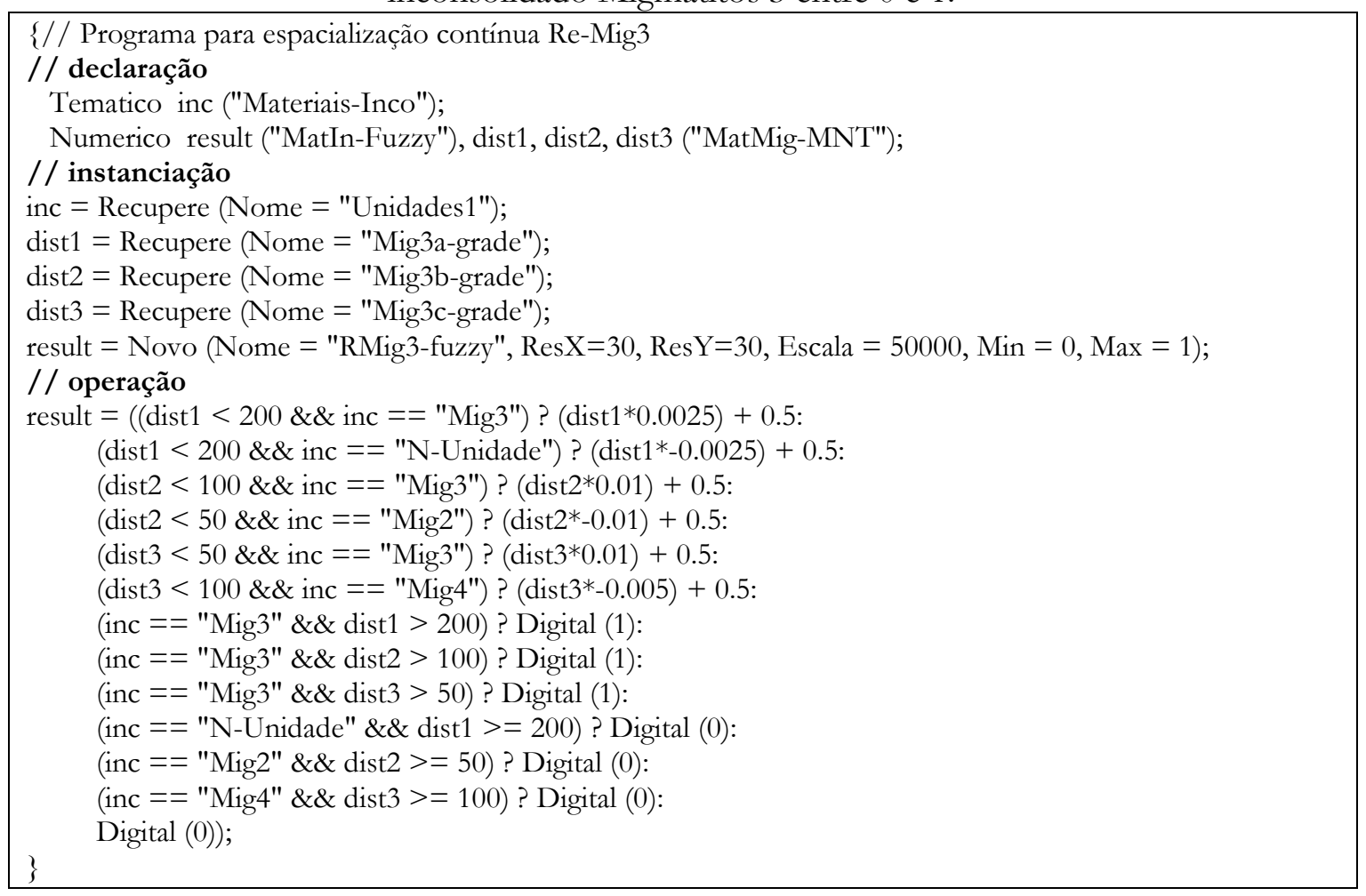


Programa LEGAL 48 - Programa de espacialização contínua de unidade material inconsolidado Migmatitos 4 entre 0 e 1.

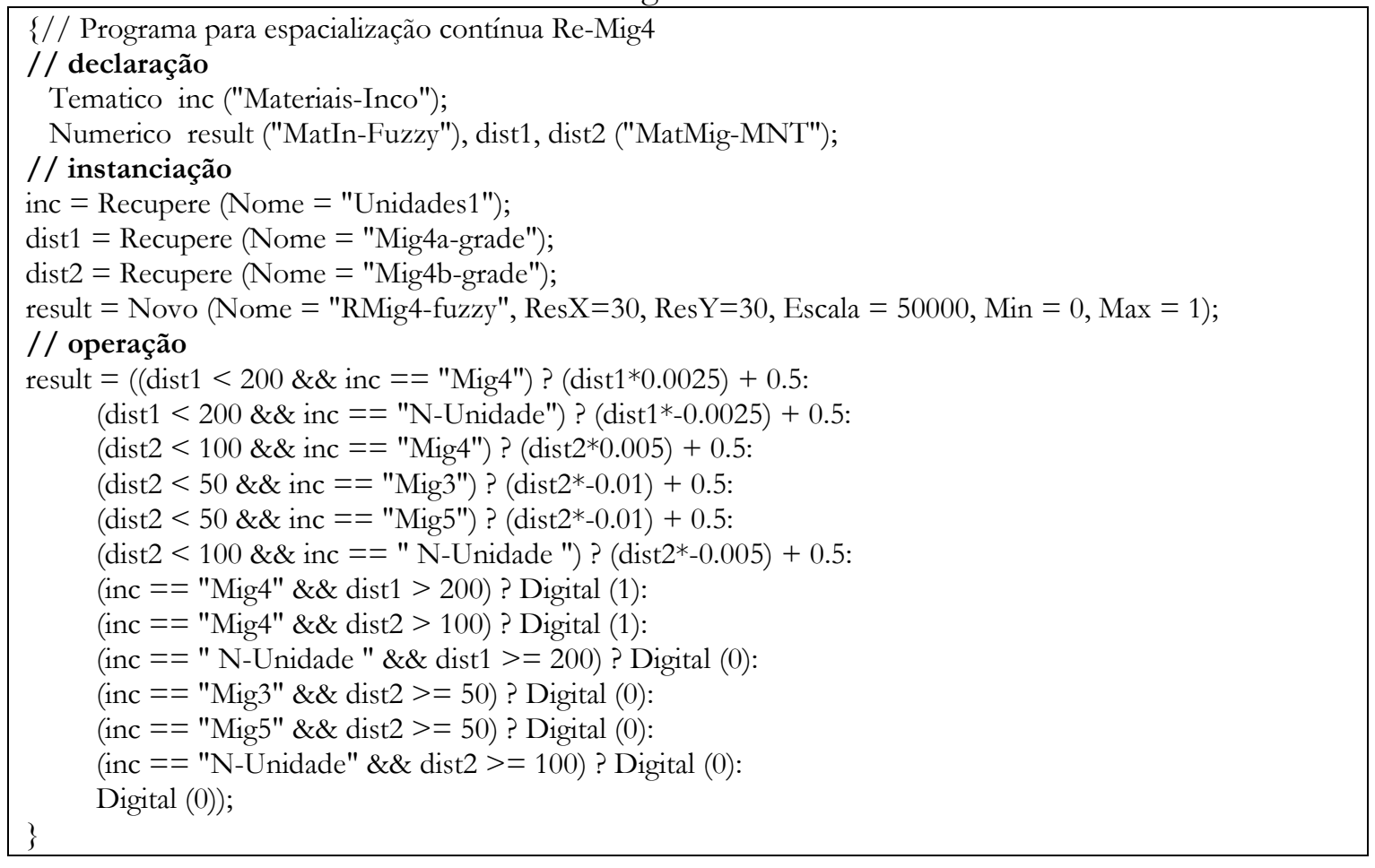

Programa LEGAL 50 - Programa de espacialização contínua de unidade material inconsolidado Migmatitos 5 entre 0 e 1.

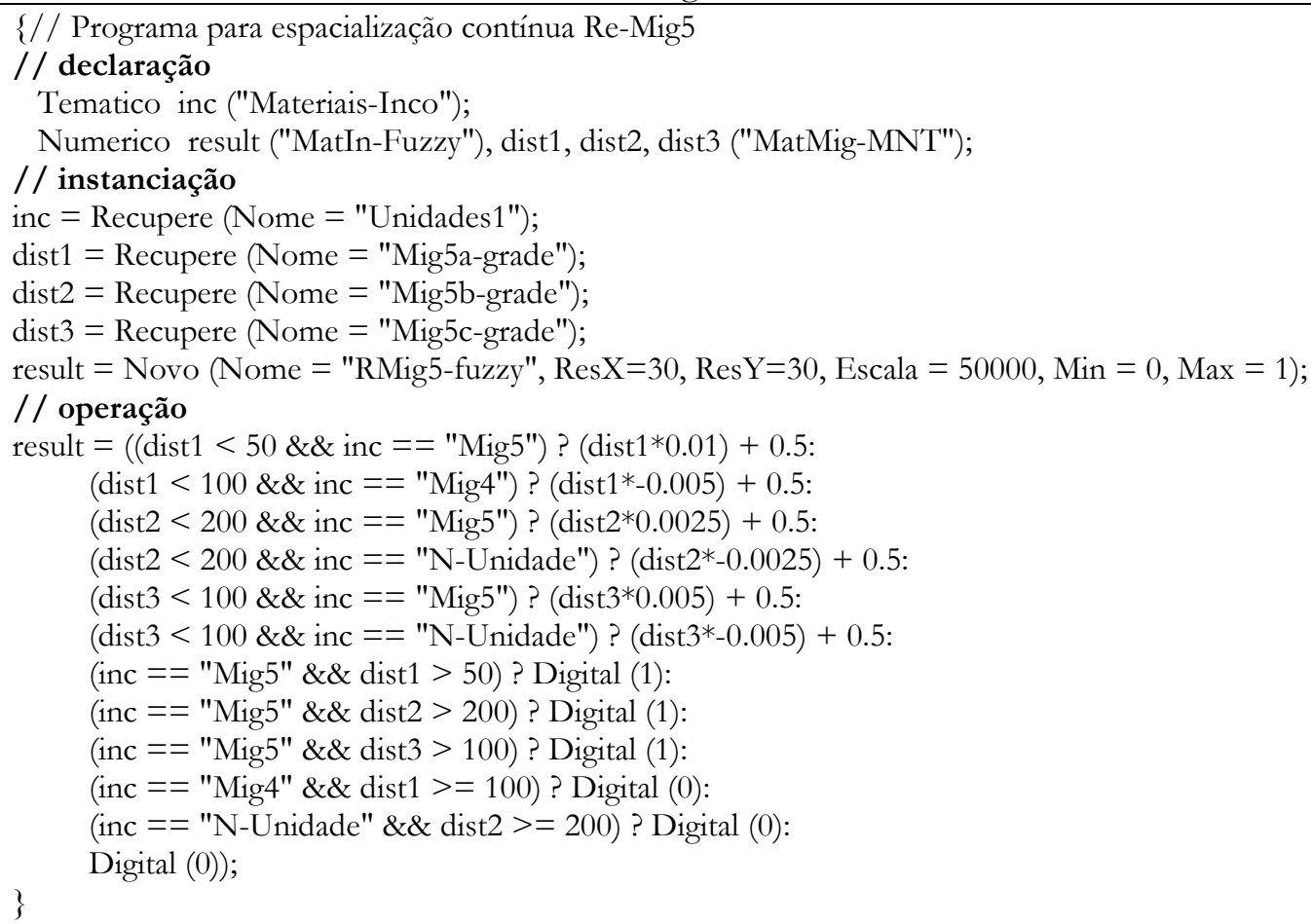


Programa LEGAL 51 - Programa de espacialização contínua de unidade material inconsolidado Migmatitos 6 entre 0 e 1.

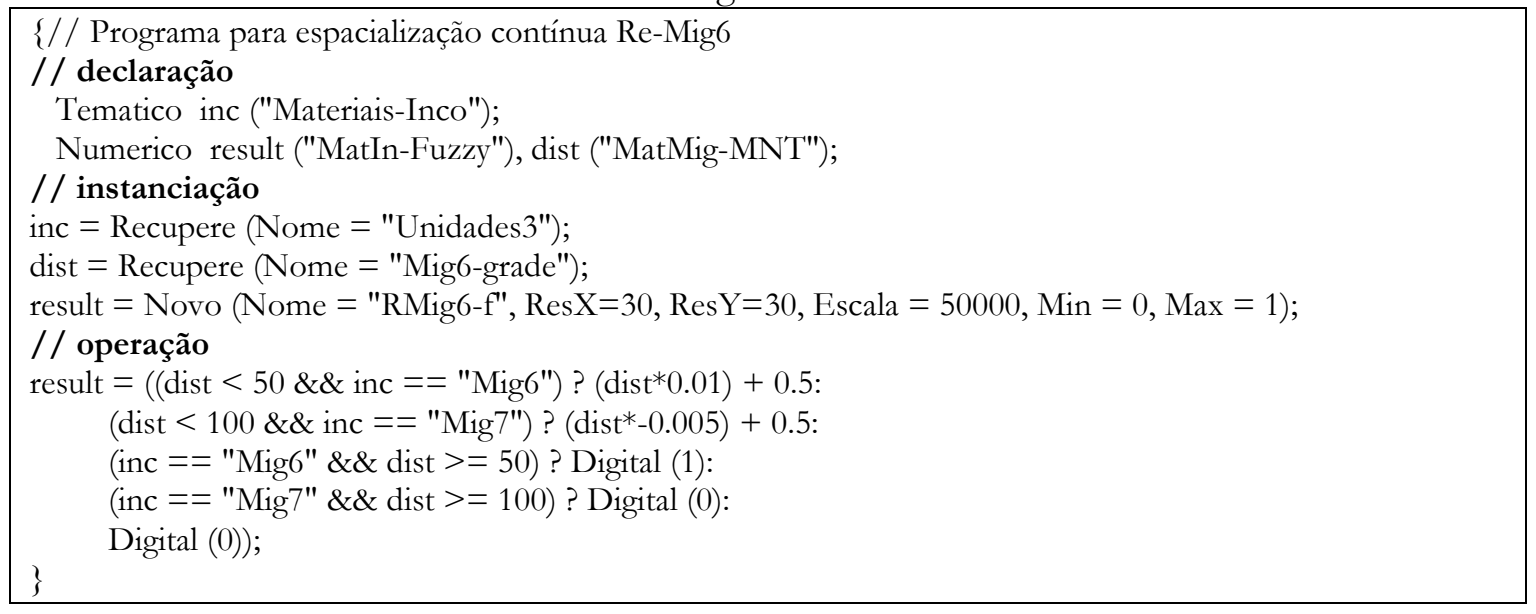

Programa LEGAL 52 - Programa de espacialização contínua de unidade material inconsolidado Migmatitos 7 entre 0 e 1.

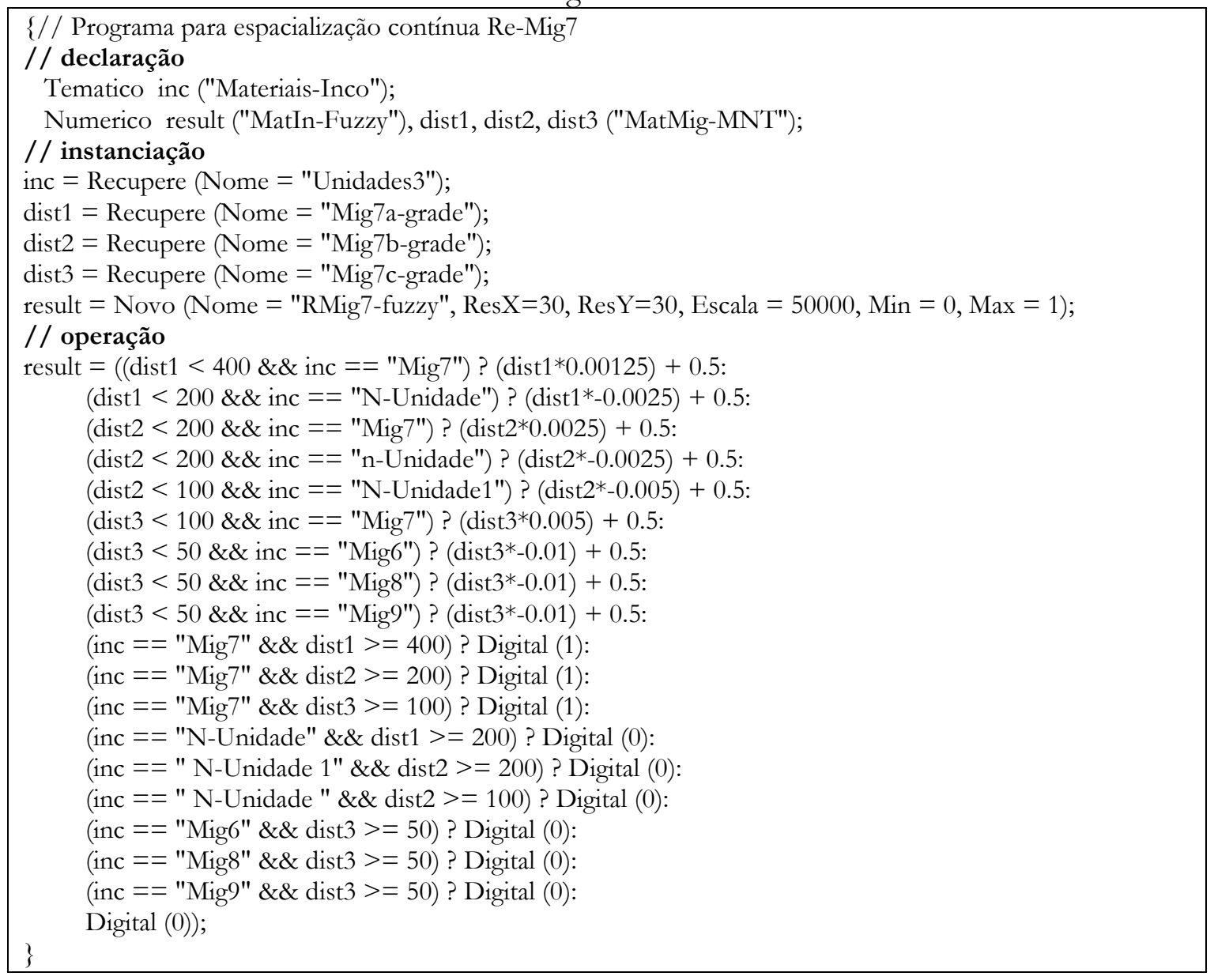


Programa LEGAL 53 - Programa de espacialização contínua de unidade material inconsolidado Migmatitos 8 entre 0 e 1.

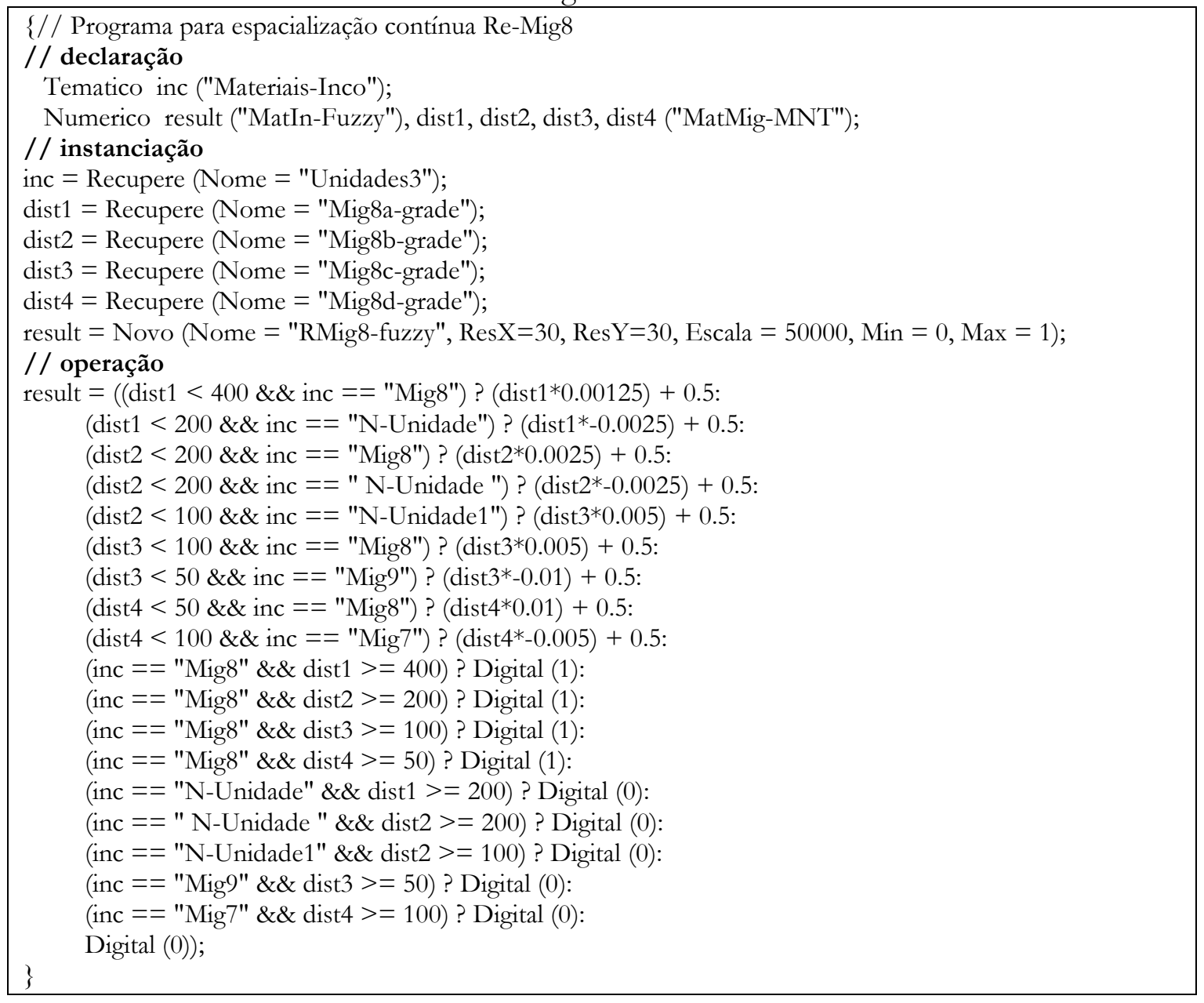

Programa LEGAL 54 - Programa de espacialização contínua de unidade material inconsolidado Migmatitos 9 entre 0 e 1.

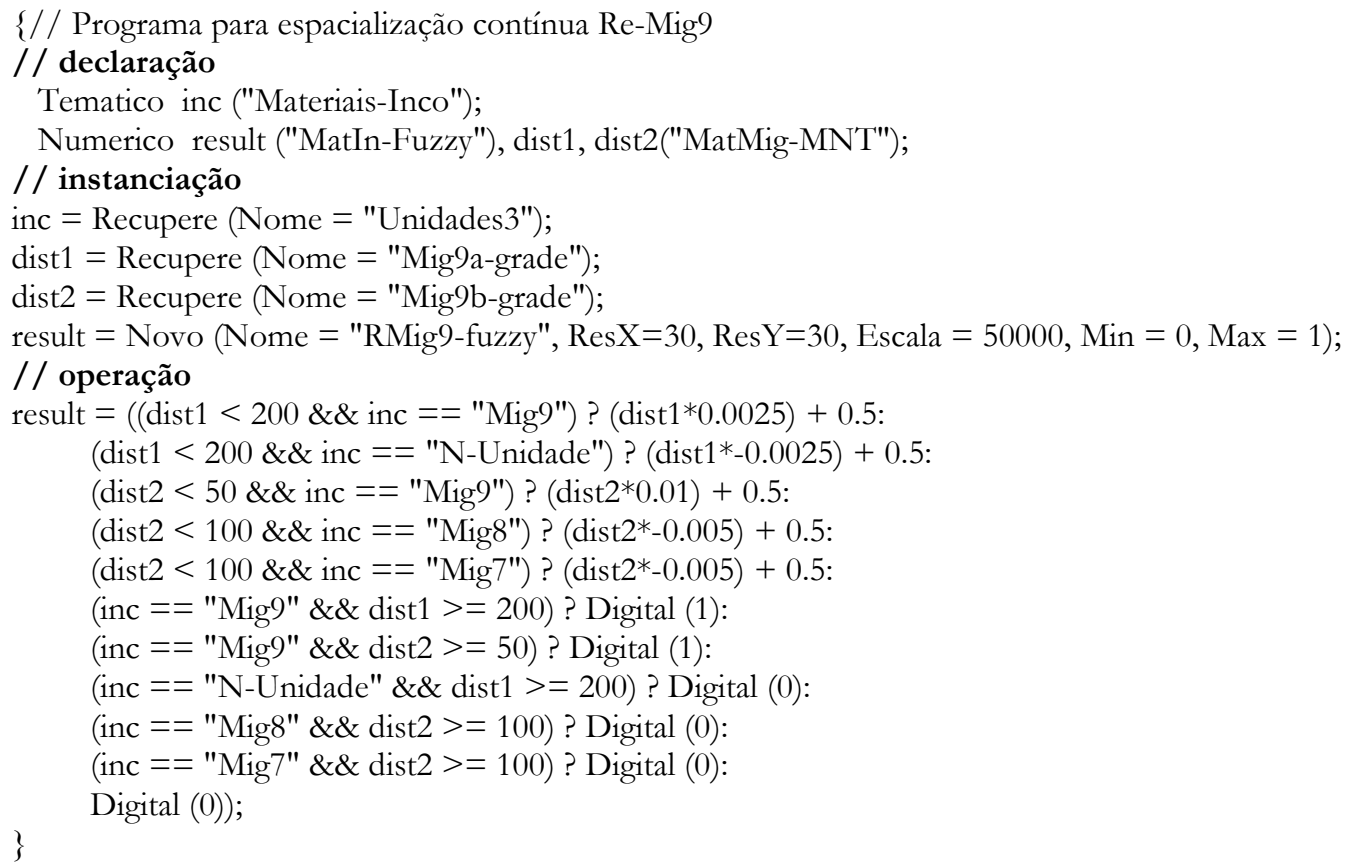


Programa LEGAL 55 - Programa de espacialização contínua de unidade material inconsolidado Quartzitos1 entre 0 e 1.

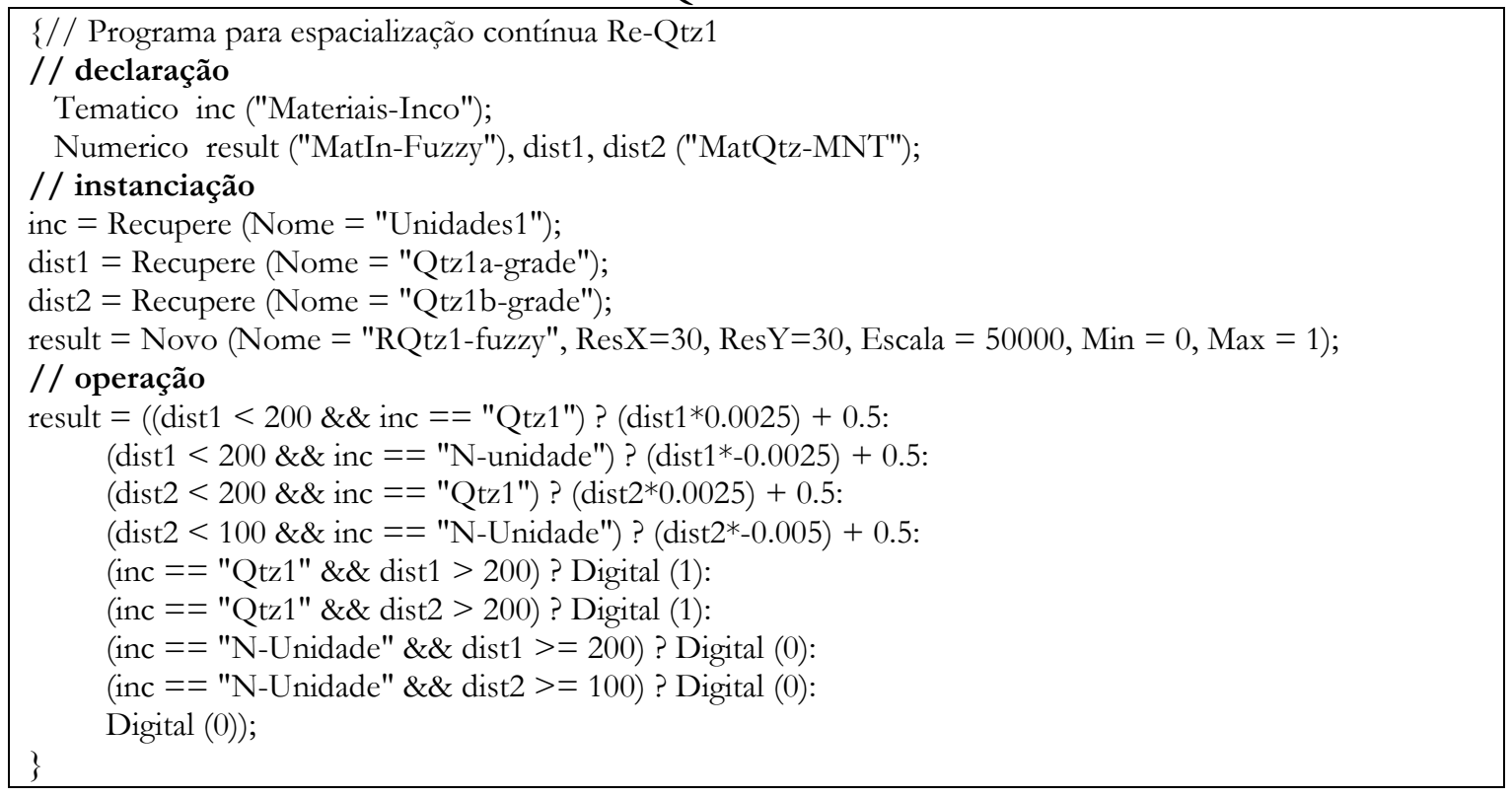

Programa LEGAL 56 - Programa de espacialização contínua de unidade material inconsolidado Quartzitos 2 entre 0 e 1.

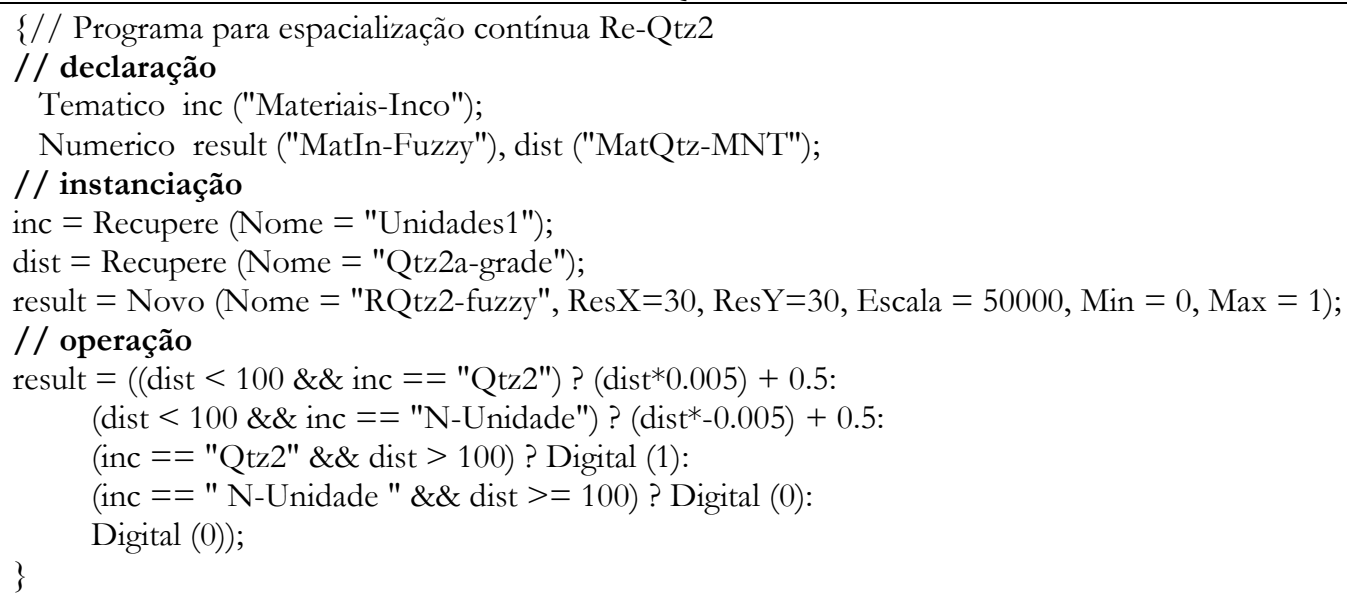

Tematico inc ("Materiais-Inco");

Numerico result ("MatIn-Fuzzy"), dist ("MatQtz-MNT");

// instanciação

inc $=$ Recupere $($ Nome $=$ "Unidades1");

dist $=$ Recupere (Nome $=$ "Qtz2a-grade");

result $=$ Novo $($ Nome $=$ "RQtz2-fuzzy", ResX=30, ResY=30, Escala $=50000$, Min $=0$, Max $=1)$;

// operação

result $=(($ dist $<100 \& \&$ inc $==$ "Qtz2") $?($ dist $* 0.005)+0.5$ :

$($ dist $<100 \& \&$ inc $==$ "N-Unidade") ? (dist*-0.005) + 0.5:

(inc $==$ "Qtz2" \&\& dist $>100)$ ? Digital (1):

(inc $=="$ N-Unidade " \&\& dist $>=100)$ ? Digital (0):

Digital (0));

Programa LEGAL 57 - Programa de espacialização contínua de unidade material inconsolidado Quartzitos 2a entre 0 e 1.

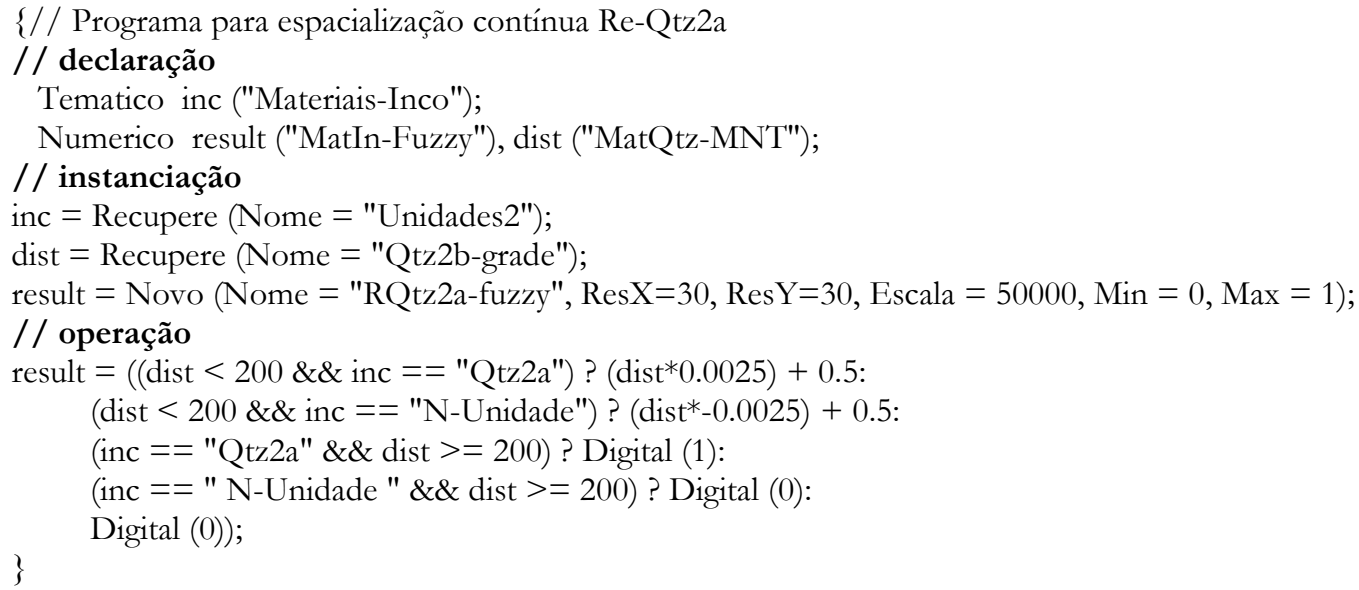


Programa LEGAL 58 - Programa de espacialização contínua de unidade material inconsolidado Quartzitos 3 entre 0 e 1.

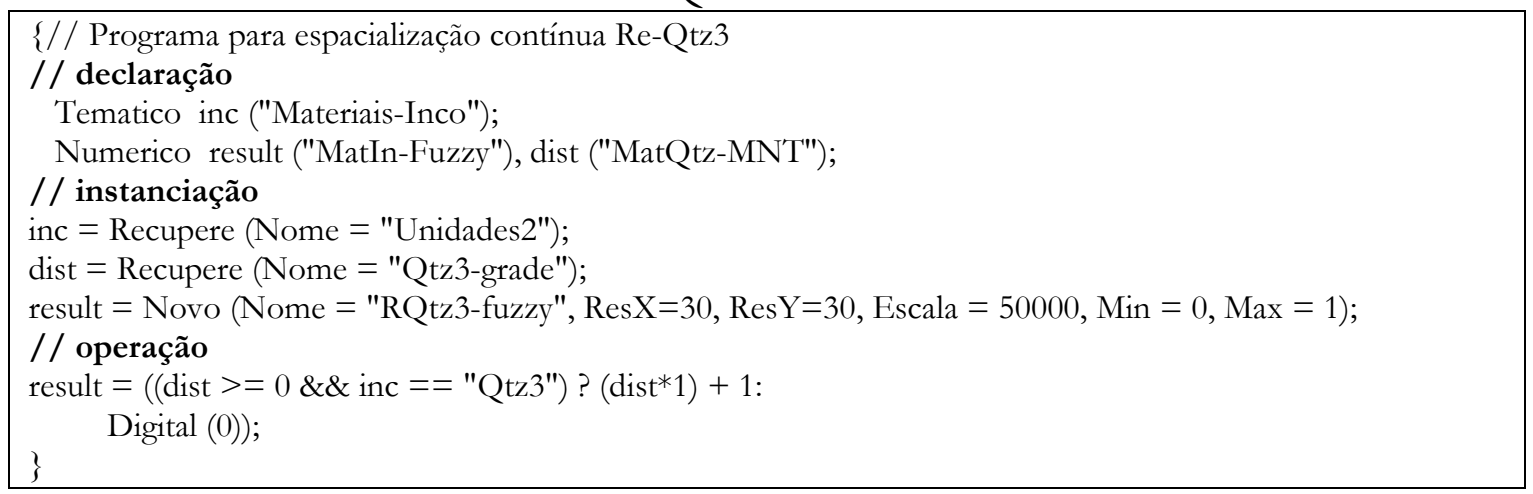

Programa LEGAL 59 - Programa de espacialização contínua de unidade material inconsolidado Ultramilonitos 1 entre 0 e 1.

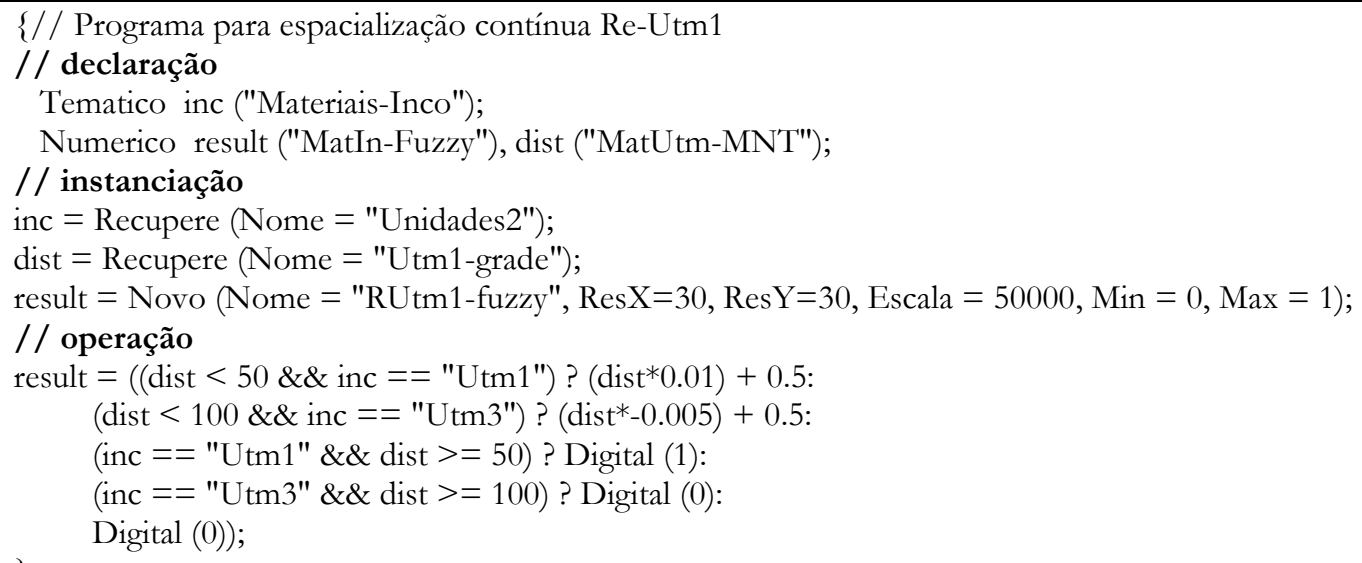

Programa LEGAL 60 - Programa de espacialização contínua de unidade material inconsolidado Ultramilonitos 2 entre 0 e 1.

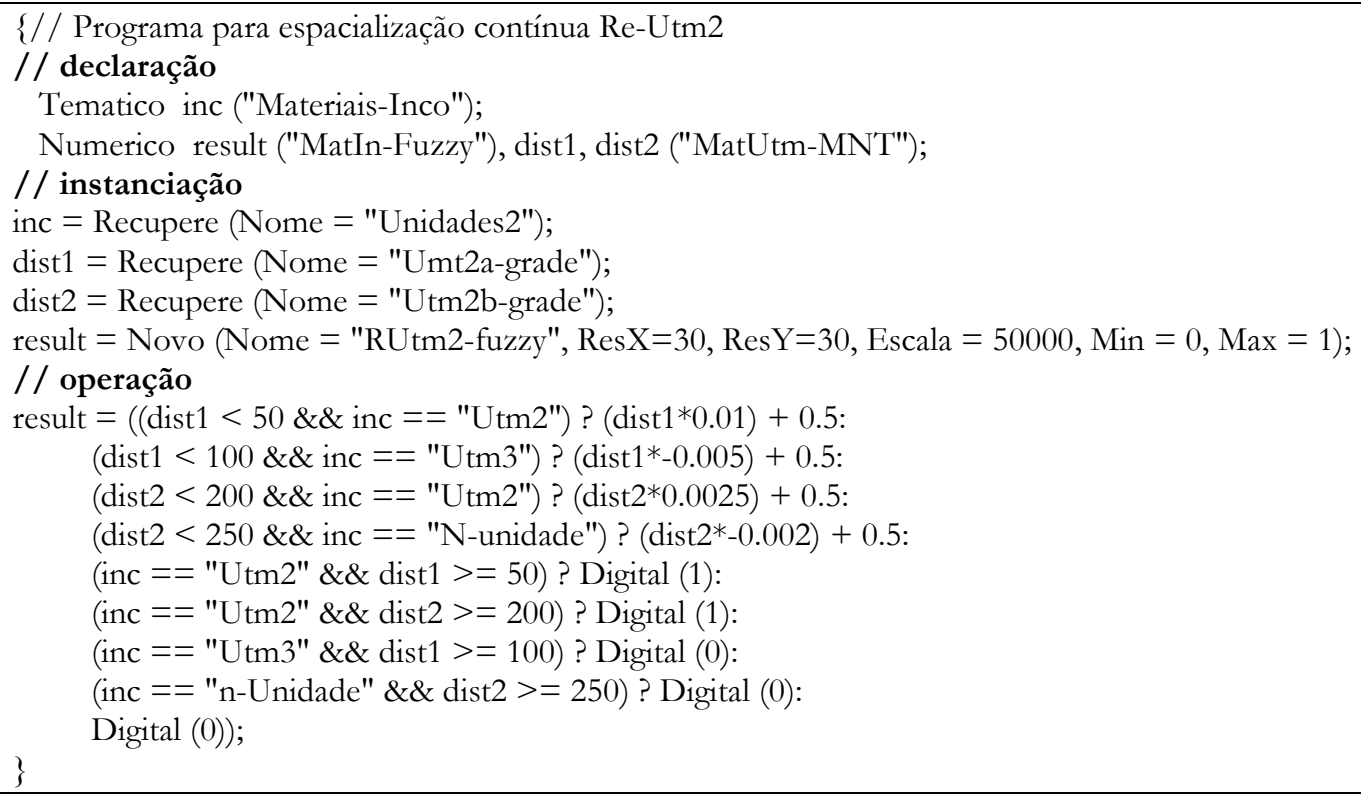


Programa LEGAL 61 - Programa de espacialização contínua de unidade material inconsolidado Ultramilonitos 3 entre 0 e 1.

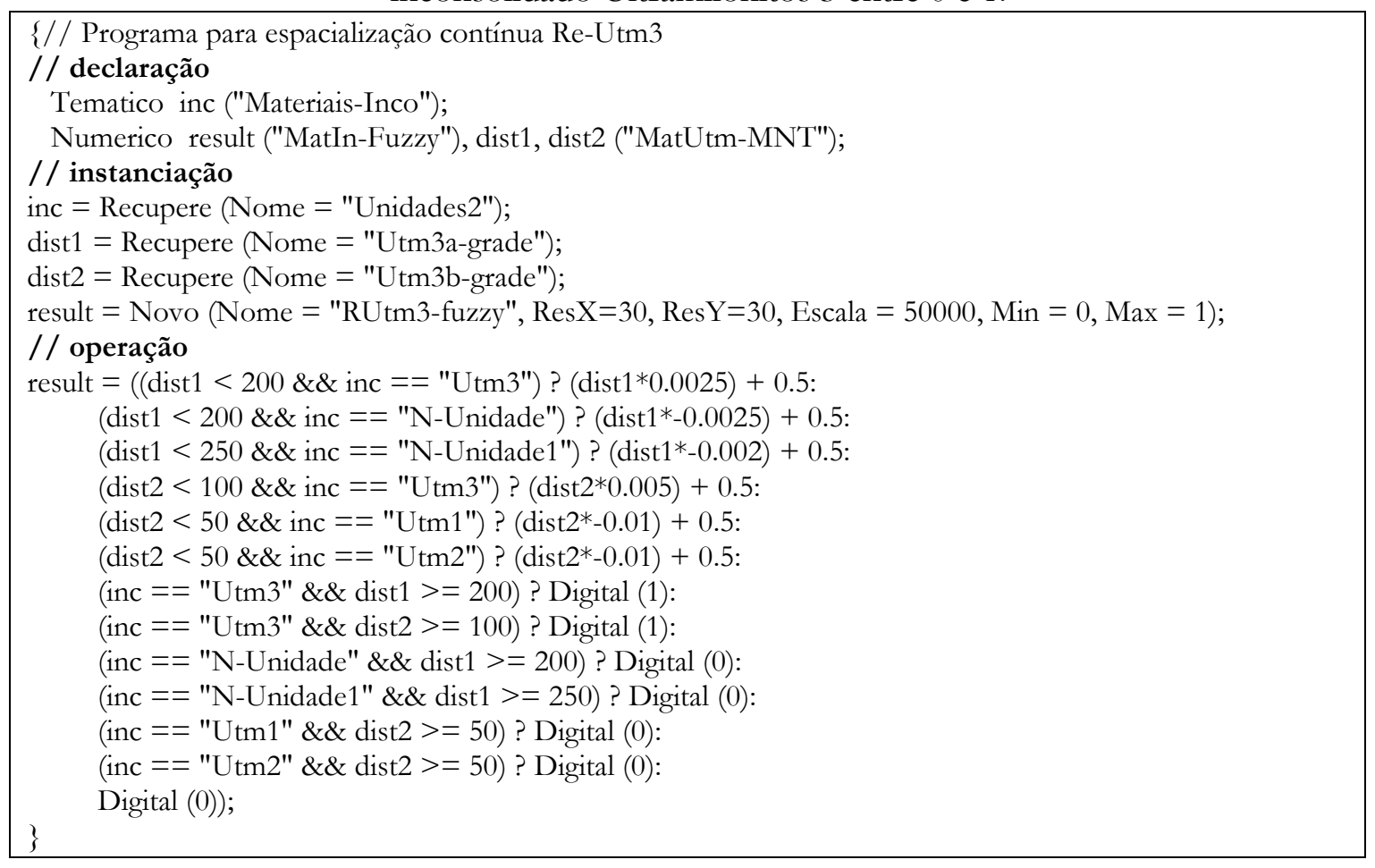

Programa LEGAL 62 - Programa de espacialização contínua de unidade material inconsolidado Ultramilonitos 4 entre 0 e 1.

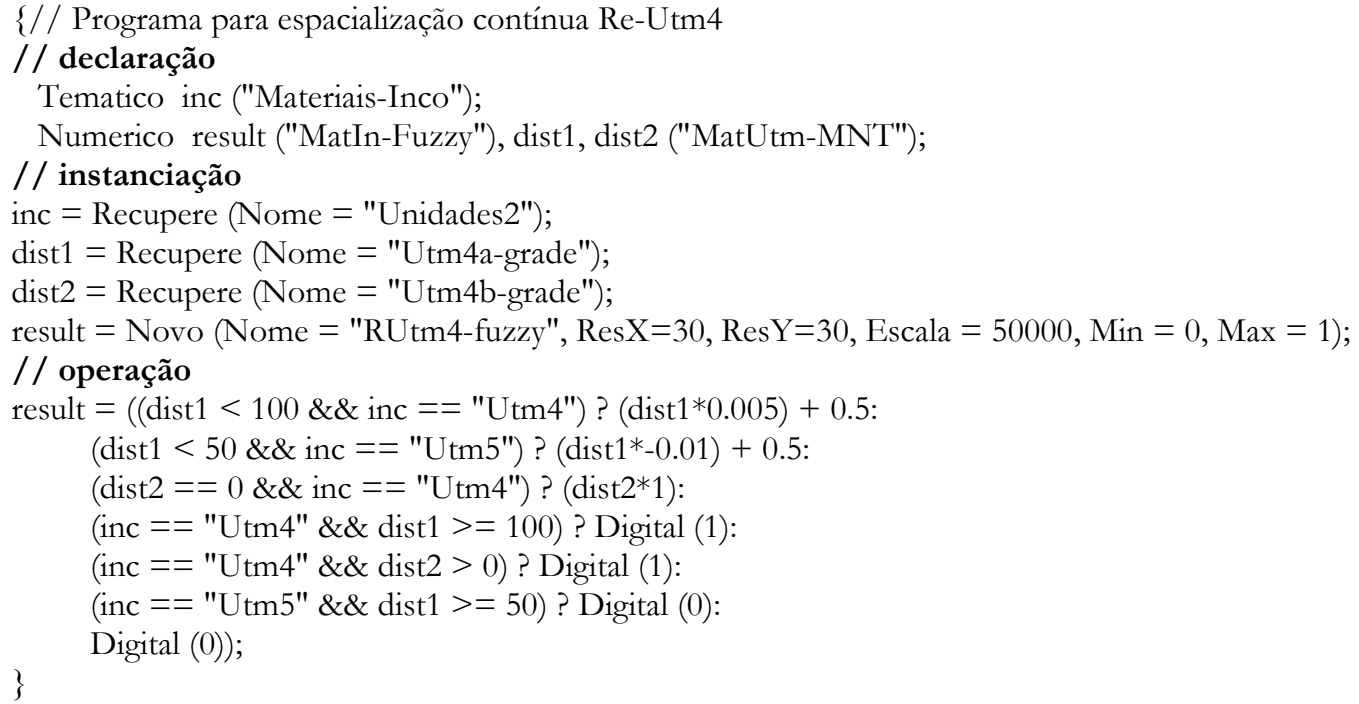


Programa LEGAL 63 - Programa de espacialização contínua de unidade material inconsolidado Ultramilonitos 5 entre 0 e 1.

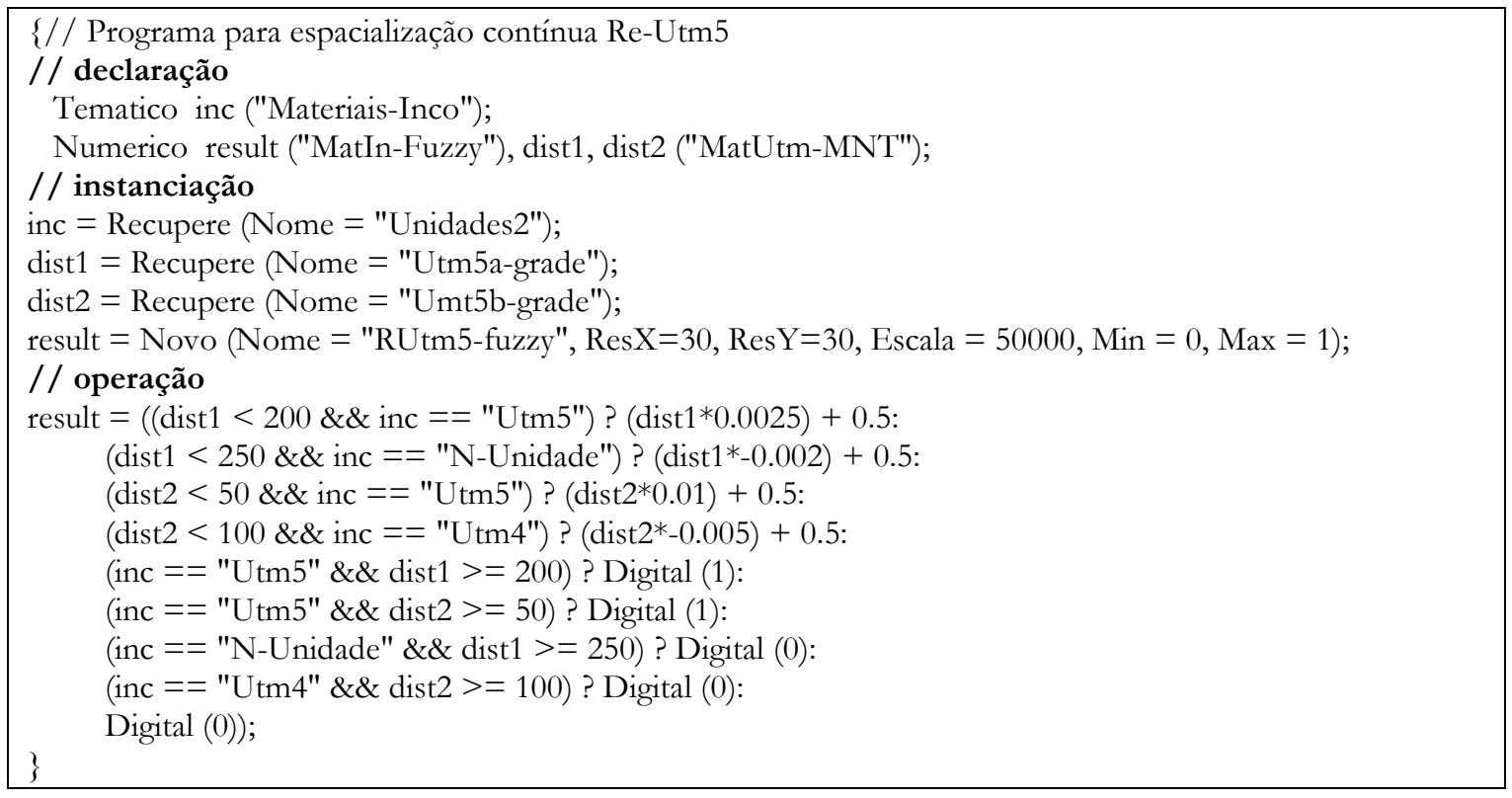

Programa LEGAL 64 - Programa de espacialização contínua de unidade material inconsolidado Ultramilonitos 6 entre 0 e 1.

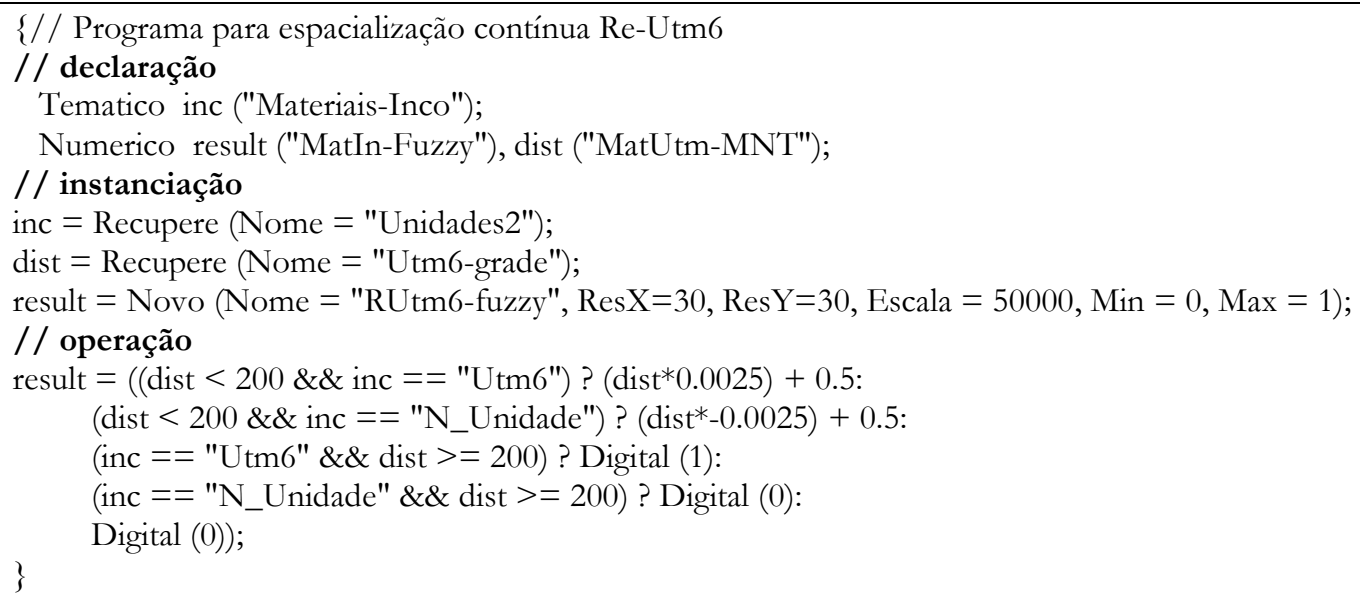

Programa LEGAL 65 - Programa de ponderação de unidades de materiais inconsolidados com baixo potencial ao escoamento, quanto ao aspecto gênese e textura.

$\{$ / / Programa em LEGAL para ponderação Materiais Inconsolidados - Escoamento Supeficial - Atributo Gênese/Textura - casse baixa

// declaração

Numerico var1, var2 ("MatIn-Fuzzy"), result ("MatIn-Escoamento");

// instanciação

var1 = Recupere (Nome="Retrab2-fuzzy");

var2 = Recupere (Nome="RAl-fuzzy");

result $=$ Novo $($ Nome $=$ "MatIn_Es_GT1a", ResX=30, ResY=30, Escala = 50000, Min = 0, Max = 4);

// operação

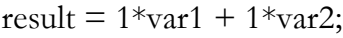

\} 
Programa LEGAL 66 - Programa de ponderação de unidades de materiais inconsolidados com médio potencial ao escoamento, quanto ao aspecto gênese e textura.

\{// Programa em LEGAL para ponderação Materiais Inconsolidados - Escoamento Supeficial - Atributo Gênese/Textura - classe média

// declaração

Numerico var3, var4, var5, var6, var7 ("MatIn-Fuzzy"), result ("MatIn-Escoamento");

// instanciação

$\operatorname{var3}=$ Recupere $($ Nome="RBtm1-fuzzy");

var4 = Recupere (Nome="RUtm4-fuzzy");

var5 = Recupere (Nome="RGnb8-fuzzy");

$\operatorname{var6}=$ Recupere (Nome="RGnb10-fuzzy");

$\operatorname{var} 7=$ Recupere $($ Nome $=" R Q t z 1-$ fuzzy");

result $=$ Novo (Nome $=$ "MatIn_Es_GT2a", ResX=30, ResY=30, Escala = 50000, Min = 0, Max = 4);

// operação

result $=2 * \operatorname{var} 3+2 * \operatorname{var} 4+2 * \operatorname{var} 5+2 * \operatorname{var} 6+2 * \operatorname{var} 7$

\}

Programa LEGAL 67 - Programa de ponderação de unidades de materiais inconsolidados com alto potencial ao escoamento, quanto ao aspecto gênese e textura.

\{// Programa em LEGAL para ponderação Materiais Inconsolidados - Escoamento Supeficial - Atributo Gênese/Textura - classe alta

// declaração

Numerico var8, var9, var10, var11, var12, var13, var14, var15, var16, var17, var18, var19, var20 ("MatInFuzzy"), result ("MatIn-Escoamento");

// instanciação

var8 $=$ Recupere (Nome="Retrab1-fuzzy");

$\operatorname{var} 9=$ Recupere (Nome="Grc-fuzzy");

$\operatorname{var10}=$ Recupere (Nome="RGrp3-fuzzy");

$\operatorname{var11}=$ Recupere (Nome="RGrGn2-fuzzy");

$\operatorname{var12}=$ Recupere (Nome="RGnq1-fuzzy");

$\operatorname{var13}=$ Recupere (Nome="RGnq2-fuzzy");

var14 = Recupere (Nome="RGnq3-fuzzy");

$\operatorname{var15}=$ Recupere (Nome="RGnq4-fuzzy");

$\operatorname{var16}=$ Recupere (Nome="RGnq5-fuzzy");

$\operatorname{var17}=$ Recupere (Nome="RMig1-fuzzy");

$\operatorname{var} 18=$ Recupere $($ Nome $=$ "RMig3-fuzzy");

$\operatorname{var} 19=$ Recupere $($ Nome="RMig4-fuzzy");

$\operatorname{var20}=$ Recupere (Nome="RMig9-fuzzy");

result $=$ Novo $($ Nome $=$ "MatIn_Es_GT3a", ResX=30, ResY=30, Escala $=50000, \operatorname{Min}=0$, Max $=4$ ); // operação

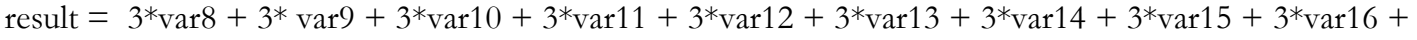
$3 * \operatorname{var} 17+3 *^{*} \operatorname{var} 18+3 *^{*} \operatorname{var} 19+3 * \operatorname{var} 20$

\} 
Programa LEGAL 68 - Programa de ponderação de unidades de materiais inconsolidados com alto potencial ao escoamento, quanto ao aspecto gênese e textura.

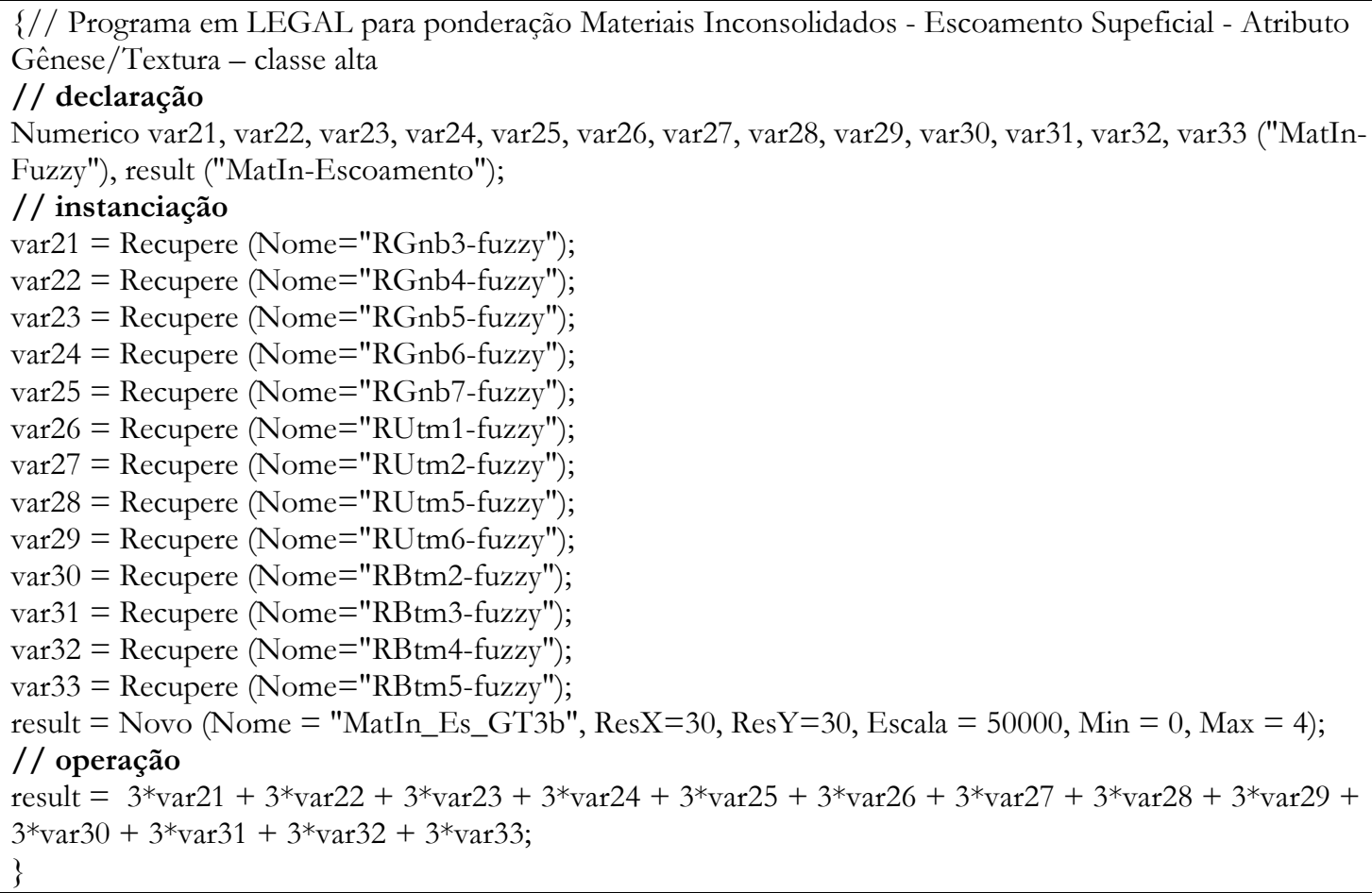

Programa LEGAL 68 - Programa de ponderação de unidades de materiais inconsolidados com muito alto potencial ao escoamento, quanto ao aspecto gênese e textura.

\{ / Programa em LEGAL para ponderação Materiais Inconsolidados - Escoamento Supeficial - Atributo Gênese/Textura - Classe muito alta

\section{// declaração}

Numerico var34, var35, var36, var37, var38, var39, var40, var41, var42, var43, var44, var45, var46, var47, var48, var49, var50, var51 ("MatIn-Fuzzy"), result ("MatIn-Escoamento");

// instanciação

var34 = Recupere (Nome="RUtm3-fuzzy");

$\operatorname{var35}=$ Recupere (Nome="RGnb1-fuzzy");

$\operatorname{var} 36=$ Recupere (Nome="RGnb2-fuzzy");

$\operatorname{var37}=$ Recupere (Nome="RGnb9-fuzzy");

$\operatorname{var} 38=$ Recupere (Nome="RGnb11-fuzzy");

var39 = Recupere (Nome="RMig2-fuzzy");

var40 = Recupere (Nome="RMig5-fuzzy");

var41 $=$ Recupere (Nome="RMig6-fuzzy");

$\operatorname{var42}=$ Recupere (Nome="RMig7-fuzzy");

var43 = Recupere (Nome="RMig8-fuzzy");

$\operatorname{var44}=$ Recupere (Nome="RGrp1-fuzzy");

$\operatorname{var45}=$ Recupere (Nome="RGrp2-fuzzy");

$\operatorname{var46}=$ Recupere (Nome="RGrp4-fuzzy");

var47 = Recupere (Nome="RGrp5-fuzzy");

var48 $=$ Recupere (Nome="RGrGn1-fuzzy");

$\operatorname{var} 49=$ Recupere (Nome="RQtz2-fuzzy");

$\operatorname{var} 50=$ Recupere (Nome="RQtz2a-fuzzy");

$\operatorname{var} 51=$ Recupere (Nome="RQtz3-fuzzy");

result $=$ Novo $($ Nome $=$ "MatIn_Es_GT4", ResX=30, ResY=30, Escala = 50000, Min = 0, Max = 4);

// operação

result $=4 *^{*} \operatorname{var} 34+4 * \operatorname{var} 35+4 * \operatorname{var} 36+4 * \operatorname{var} 37+4 * \operatorname{var} 38+4 * \operatorname{var} 39+4 * \operatorname{var} 40+4 * \operatorname{var} 41+4 * \operatorname{var} 42+$ $4 *^{*} \operatorname{var} 43+4{ }^{*} \operatorname{var} 44+4 *^{*} \operatorname{var} 45+4 *^{*} \operatorname{var} 46+4 *^{*} \operatorname{var} 47+4 *^{*} \operatorname{var} 48+4 *^{*} \operatorname{var} 49+4 *^{*} \operatorname{var} 50+4 * \operatorname{var} 51 ;$

\} 
Programa LEGAL 69 - Programa somatória de unidades de materiais inconsolidados para obtenção de superfície contínua, quanto ao aspecto gênese e textura.

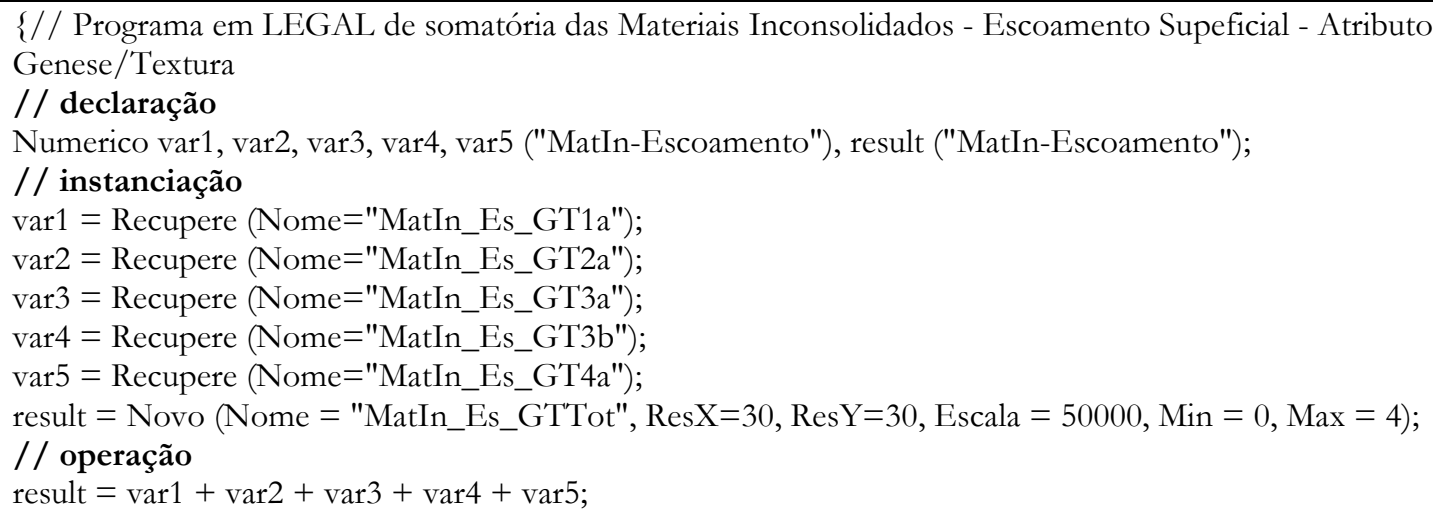

Programa LEGAL 70 - Programa de ponderação de unidades de materiais inconsolidados com baixo potencial ao escoamento, quanto ao aspecto espessura.

$\{/ /$ Programa em LEGAL para ponderação Materiais Inconsolidados - Escoamento Supeficial - Atributo Espessura - Classe baixa

\section{// declaração}

Numerico var1, var2, var3, var4, var5, var6, var7, var8, var9, var10, var11, var12 ("MatIn-Fuzzy"), result

\section{// instanciação}

("MatIn-Escoamento");

var1 = Recupere (Nome="RGnb5-fuzzy");

$\operatorname{var} 2=$ Recupere (Nome $=$ "RGnb8-fuzzy");

var3 = Recupere (Nome="RGnb9-fuzzy");

var4 = Recupere (Nome="RGnb10-fuzzy");

$\operatorname{var} 5=$ Recupere (Nome="RGnb11-fuzzy");

$\operatorname{var6}=$ Recupere (Nome="RMig1-fuzzy");

$\operatorname{var} 7=$ Recupere (Nome="RMig2-fuzzy");

$\operatorname{var} 8=$ Recupere $($ Nome="RMig3-fuzzy");

$\operatorname{var} 9=$ Recupere (Nome="RMig4-fuzzy");

$\operatorname{var10}=$ Recupere (Nome $=$ "RUtm3-fuzzy");

var11 = Recupere (Nome="RUtm4-fuzzy");

var12 = Recupere (Nome="RUtm5-fuzzy");

result $=$ Novo $($ Nome $=$ "MatIn_Es_Esp1", ResX=30, ResY=30, Escala = 50000, Min = 0, Max = 4);

// operação

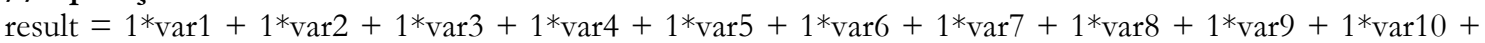
$1 *_{\operatorname{var} 11}+1 *^{*} \operatorname{var} 12$

\}

Programa LEGAL 71 - Programa de ponderação de unidades de materiais inconsolidados com médio potencial ao escoamento, quanto ao aspecto espessura.

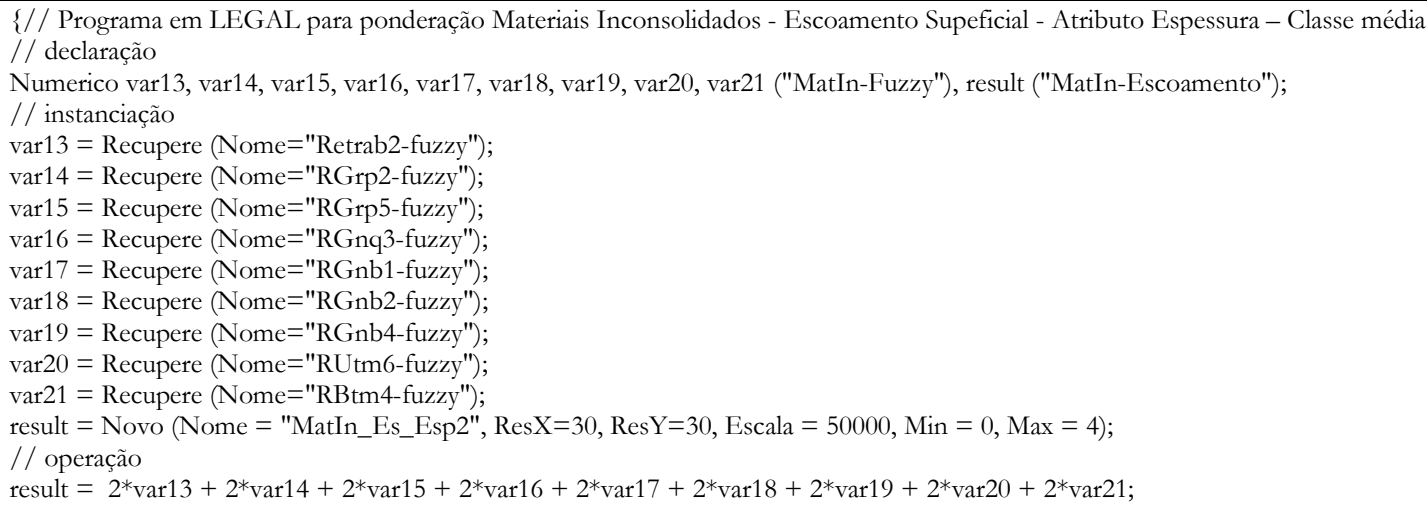


Programa LEGAL 72 - Programa de ponderação de unidades de materiais inconsolidados com alto potencial ao escoamento, quanto ao aspecto espessura.

$\{$ // Programa em LEGAL para ponderação Materiais Inconsolidados - Escoamento Supeficial - Atributo Espessura

\section{/ / declaração - Classe Alta}

Numerico var22, var23, var24, var25, var26, var27, var28, var29, var30, var31, var32, var33, var34, var35, var36, var37, var38, var39, var40, var41, var42, var43, var44, var45, var46, var47, var48, var49 ("MatIn-

Fuzzy"), result ("MatIn-Escoamento");

// instanciação

var22 = Recupere (Nome="Retrab1-fuzzy");

$\operatorname{var} 23=$ Recupere $($ Nome $=$ "Grc-fuzzy");

$\operatorname{var} 24=$ Recupere (Nome="RGrp1-fuzzy");

$\operatorname{var} 25=$ Recupere (Nome="RGrp3-fuzzy");

var26 = Recupere (Nome="RGrp4-fuzzy");

$\operatorname{var} 27=$ Recupere (Nome="RGrGn1-fuzzy");

$\operatorname{var} 28=$ Recupere (Nome="RGrGn2-fuzzy");

var29 $=$ Recupere (Nome $=$ "RQtz1-fuzzy");

$\operatorname{var} 30=$ Recupere $($ Nome $=" R Q t z 2-$ fuzzy");

$\operatorname{var} 31=$ Recupere (Nome="RQtz2a-fuzzy");

$\operatorname{var} 32=$ Recupere $($ Nome="RQtz3-fuzzy");

$\operatorname{var33}=$ Recupere (Nome="RGnq1-fuzzy");

var34 = Recupere (Nome="RGnq2-fuzzy");

$\operatorname{var} 35=$ Recupere (Nome="RGnq4-fuzzy");

$\operatorname{var} 36=$ Recupere (Nome="RGnb3-fuzzy");

$\operatorname{var37}=$ Recupere (Nome="RGnb6-fuzzy");

$\operatorname{var} 38=$ Recupere (Nome="RGnb7-fuzzy");

$\operatorname{var} 39=$ Recupere $($ Nome="RMig5-fuzzy");

$\operatorname{var} 40=$ Recupere $($ Nome $=$ "RMig6-fuzzy");

var41 = Recupere (Nome="RMig7-fuzzy");

var42 = Recupere (Nome="RMig8-fuzzy");

var43 = Recupere (Nome="RMig9-fuzzy");

var44 = Recupere (Nome="RUtm1-fuzzy");

var45 = Recupere (Nome="RUtm2-fuzzy");

$\operatorname{var46}=$ Recupere (Nome="RBtm1-fuzzy");

$\operatorname{var47}=$ Recupere (Nome="RBtm2-fuzzy");

$\operatorname{var48}=$ Recupere (Nome $=$ "RBtm3-fuzzy");

var49 = Recupere (Nome="RBtm5-fuzzy");

result $=$ Novo $($ Nome $=$ "MatIn_Es_Esp3", ResX=30, ResY=30, Escala = 50000, Min = 0, Max = 4);

// operação

result $=3^{*} \operatorname{var} 22+3^{*} \operatorname{var} 23+3^{*} \operatorname{var} 24+3^{*} \operatorname{var} 25+3^{*} \operatorname{var} 26+3^{*} \operatorname{var} 27+3^{*} \operatorname{var} 28+3^{*} \operatorname{var} 29+3^{*} \operatorname{var} 30+$ $3{ }^{*} \operatorname{var} 31+3{ }^{*} \operatorname{var} 32+3{ }^{*} \operatorname{var} 33+3{ }^{*} \operatorname{var} 34+3{ }^{*} \operatorname{var} 35+3{ }^{*} \operatorname{var} 36+3 *^{*} \operatorname{var} 37+3{ }^{*} \operatorname{var} 38+3{ }^{*} \operatorname{var} 39+$ $3 *^{*}$ var40 + 3*var41 + 3*var42 + 3*var43 + 3*var44 + 3*var45 + 3*var46 + 3*var47 + 3*var48+ $3 * \operatorname{var} 49$; 
Programa LEGAL 73 - Programa de ponderação de unidades de materiais inconsolidados com muito alto potencial ao escoamento, quanto ao aspecto espessura.

\{// Programa em LEGAL para ponderação Materiais Inconsolidados - Escoamento Supeficial - Atributo Espessura - Classe muito alta

// declaração

Numerico var50, var51 ("MatIn-Fuzzy"), result ("MatIn-Escoamento");

// instanciação

$\operatorname{var50}=$ Recupere (Nome="RGnq5-fuzzy");

$\operatorname{var} 51=$ Recupere $($ Nome $=$ "RAl-fuzzy");

result $=$ Novo $($ Nome $=$ "MatIn_Es_Esp4", ResX=30, ResY=30, Escala = 50000, Min = 0, Max = 4);

// operação

result $=4 * \operatorname{var} 50+4 * \operatorname{var} 51$

\}

Programa LEGAL 74 - Programa de somatória de unidades de materiais inconsolidados para obtenção de superfície contínua, quanto ao aspecto espessura.

$\{$ // Programa em LEGAL para ponderação Materiais Inconsolidados - Escoamento Supeficial - Atributo Espessura

// declaração

Numerico var1, var2, var3, var4 ("MatIn-Escoamento"), result ("MatIn-Escoamento");

// instanciação

var1 = Recupere (Nome="MatIn_Es_Esp1");

var2 = Recupere (Nome="MatIn_Es_Esp2");

var3 = Recupere (Nome="MatIn_Es_Esp3");

var4 = Recupere (Nome="MatIn_Es_Esp4");

result $=$ Novo $($ Nome $=$ "MatIn_Es_Esp", ResX=30, ResY=30, Escala = 50000, Min = 0, Max = 4);

// operação

result $=$ var1 + var2 + var3 + var 4

\}

Programa LEGAL 75 - Programa ponderação de unidades de substrato rochoso para obtenção de superfície contínua realtiva ao aspecto potencial ao escoamento.

\{// Programa em LEGAL para poderação substrato rochoso - Escoamento Supeficial

// declaração

Numerico var1, var2, var3, var4, var5, var6, var7, var8, var9 ("Substrato-Fuzzy"), result ("Substrato-

Escoamento");

// instanciação

$\operatorname{var1}=$ Recupere (Nome="Grc-f");

$\operatorname{var} 2=$ Recupere $\left(\right.$ Nome $\left.=" B t m-f^{\prime}\right) ;$

var3 = Recupere (Nome $\left.=" \mathrm{Utm}-\mathrm{f}^{\prime}\right)$;

var4 = Recupere (Nome="Gnb-f");

var5 $=$ Recupere $($ Nome $="$ Gnq-f");

$\operatorname{var} 6=$ Recupere $($ Nome $="$ Mig-f");

$\operatorname{var} 7=$ Recupere (Nome $\left.=" G r G n-f^{\prime \prime}\right)$;

var8 = Recupere (Nome $="$ Grp-f");

$\operatorname{var} 9=$ Recupere $($ Nome $="$ Qtz-f");

result $=$ Novo $($ Nome $=$ "Sub_Escoamento", ResX=30, ResY=30, Escala $=50000$, Min $=0$, Max $=4)$;

// operação

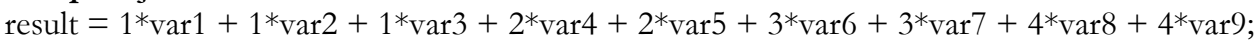

\} 
Programa LEGAL 76 - Programa atribuição de peso ao atributo declividade, quanto ao aspecto potencial ao escoamento.

$\{$ // Programa para atribuição de peso - Atributo Declividade - Potencial ao Escoamento

// declaração

Numerico dec ("Declividade-Fuzzy"), result ("Escoamento_Super");

// instanciação

dec $=$ Recupere $($ Nome $=$ "Dec_Fuzzy4");

result $=$ Novo $($ Nome $=$ "Dec_EcSup4", ResX=30, ResY=30, Escala = 50000, Min =0, Max = 4);

// operação

result $=0.36307 * \mathrm{dec}$

\}

Programa LEGAL 77 - Programa atribuição de peso ao atributo densidade de drenagem, quanto ao aspecto potencial ao escoamento.

$\{/ /$ Programa para atribução de peso - Atributo Densidade de drenagem - Potencial ao Escoamento // declaração

Numerico dre ("RedeRio-Fuzzy"), result ("Escoamento_Super");

// instanciação

dre $=$ Recupere $($ Nome $=$ "Drebuffer4");

result $=$ Novo $($ Nome $=$ "DreEsc_Sup4", ResX=30, ResY=30, Escala = 50000, Min = 0, Max = 4);

// operação

result $=0.2174 *$ dre;

\}

Programa LEGAL 78 - Programa atribuição de peso ao atributo gênese/textura de materiais inconsolidados, quanto ao aspecto potencial ao escoamento.

$\{$ // Programa para atribuição de peso - Atributo MatIn_G/T - Potencial aoEscoamento

// declaração

Numerico mat ("MatIn-Escoamento"), result ("Escoamento_Super");

// instanciação

mat $=$ Recupere $($ Nome $=$ "MatIn_Es_GTTot");

result $=$ Novo (Nome $=$ "GTEsc_Sup", ResX=30, ResY=30, Escala = 50000, $\operatorname{Min}=0$, Max $=4)$;

// operação

result $=0.24221 *$ mat;

\}

Programa LEGAL 79 - Programa atribuição de peso ao atributo espessura de materiais inconsolidados, quanto ao aspecto potencial ao escoamento.

$\{/ /$ Programa para atribuição de peso - MatIn_Espesura - Potencial ao Escoamento

// declaração

Numerico mat ("MatIn-Escoamento"), result ("Escoamento_Super");

// instanciação

mat $=$ Recupere $($ Nome $=$ "MatIn_Es_Esp");

result $=$ Novo $($ Nome $=$ "MEspEsc_Sup", ResX=30, ResY=30, Escala = 50000, Min = 0, Max =4);

// operação

result $=0.12875^{*}$ mat;

\} 
Programa LEGAL 80 - Programa atribuição de peso ao atributo substrato rochoso, quanto ao aspecto potencial ao escoamento.

$\{/ /$ Programa para atribuição de peso - Atributo Substrato - Potencial ao Escoamento

// declaração

Numerico sub ("Substrato-Escoamento"), result ("Escoamento_Super");

// instanciação

sub $=$ Recupere $($ Nome $=$ "Sub_Escoamento");

result $=$ Novo $($ Nome $=$ "SubEsc_Sup", ResX=30, ResY=30, Escala = 50000, $\operatorname{Min}=0$, Max $=4)$;

// operação

result $=0.04557^{*}$ sub;

\}

Programa LEGAL 81 - Programa obtenção de superfície contínua representativa do potencial ao escoamento da área.

$\{$ // Programa para obtenção Mapa Escoamento Superficial Fuzzy

// declaração

Numerico result, dre, dec, mat1, mat2, sub ("Escoamento_Super");

// instanciação

dre $=$ Recupere $($ Nome $=$ "DreEsc_Sup4");

dec $=$ Recupere (Nome = "Dec_EcSup4");

mat1 $=$ Recupere $($ Nome $=$ "GTEsc_Sup");

mat2 $=$ Recupere (Nome $=$ "MEspEsc_Sup");

sub $=$ Recupere $($ Nome $=$ "SubEsc_Sup");

result $=$ Novo (Nome $=$ "Esc4_Sup_Fuzzy", ResX=30, ResY=30, Escala = 50000, Min = 0, Max = 4);

// operação

result $=$ dre + dec + mat $1+$ mat $2+$ sub;

\}

Programa LEGAL 82 - Programa de ponderação de unidades de materiais inconsolidados com baixa suscptibilidade a erosão, quanto ao aspecto gênese/textura.

$\{$ // Programa em LEGAL para ponderação Materiais Inconsolidados - Erosao - Atributo Gênese/Textura

// declaração

Numerico var1 ("MatIn-Fuzzy"), result ("MatIn-Erosao");

// instanciação

var1 = Recupere (Nome="Retrab1-fuzzy");

result $=$ Novo (Nome $=$ "MatIn_Ero_GT1a", ResX=30, ResY=30, Escala = 50000, Min = 0, Max = 4);

// operação

result $=1 *$ var 1

\} 
Programa LEGAL 83 - Programa de ponderação de unidades de materiais inconsolidados com média suscptibilidade a erosão, quanto ao aspecto gênese/textura.

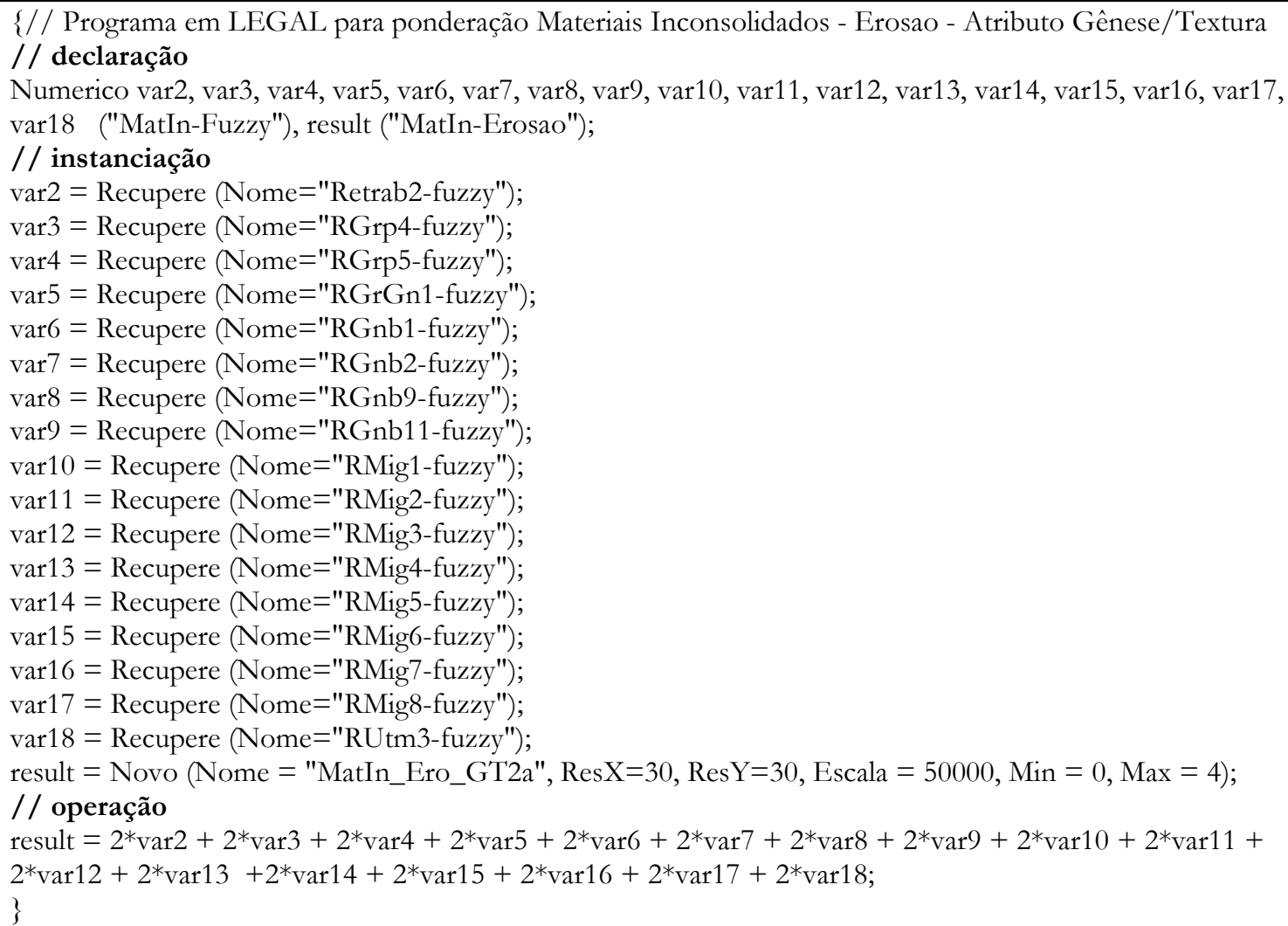

Programa LEGAL 84 - Programa de ponderação de unidades de materiais inconsolidados com alta suscptibilidade a erosão, quanto ao aspecto gênese/textura.

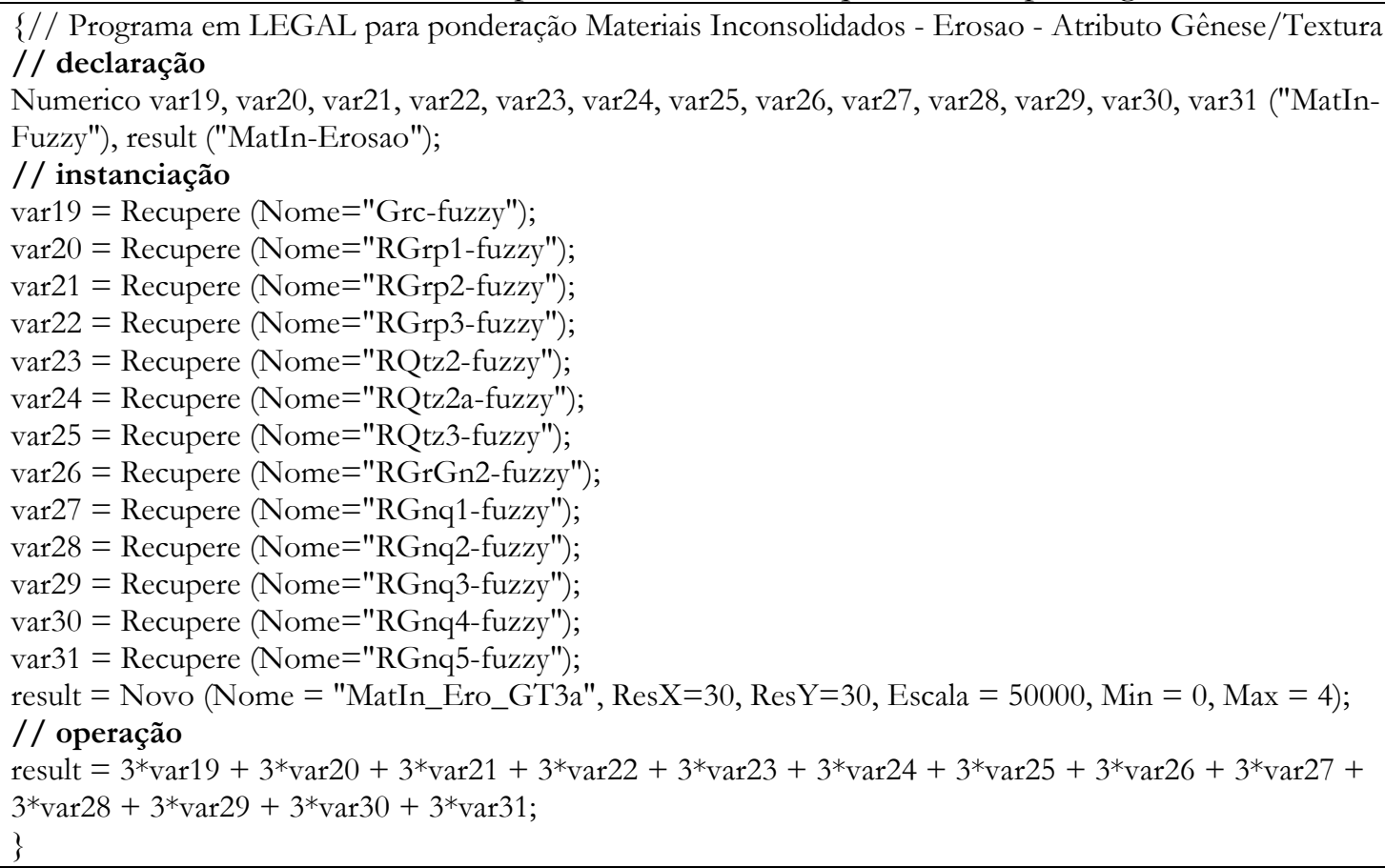


Programa LEGAL 85 - Programa de ponderação de unidades de materiais inconsolidados com alta suscptibilidade a erosão, quanto ao aspecto gênese/textura.

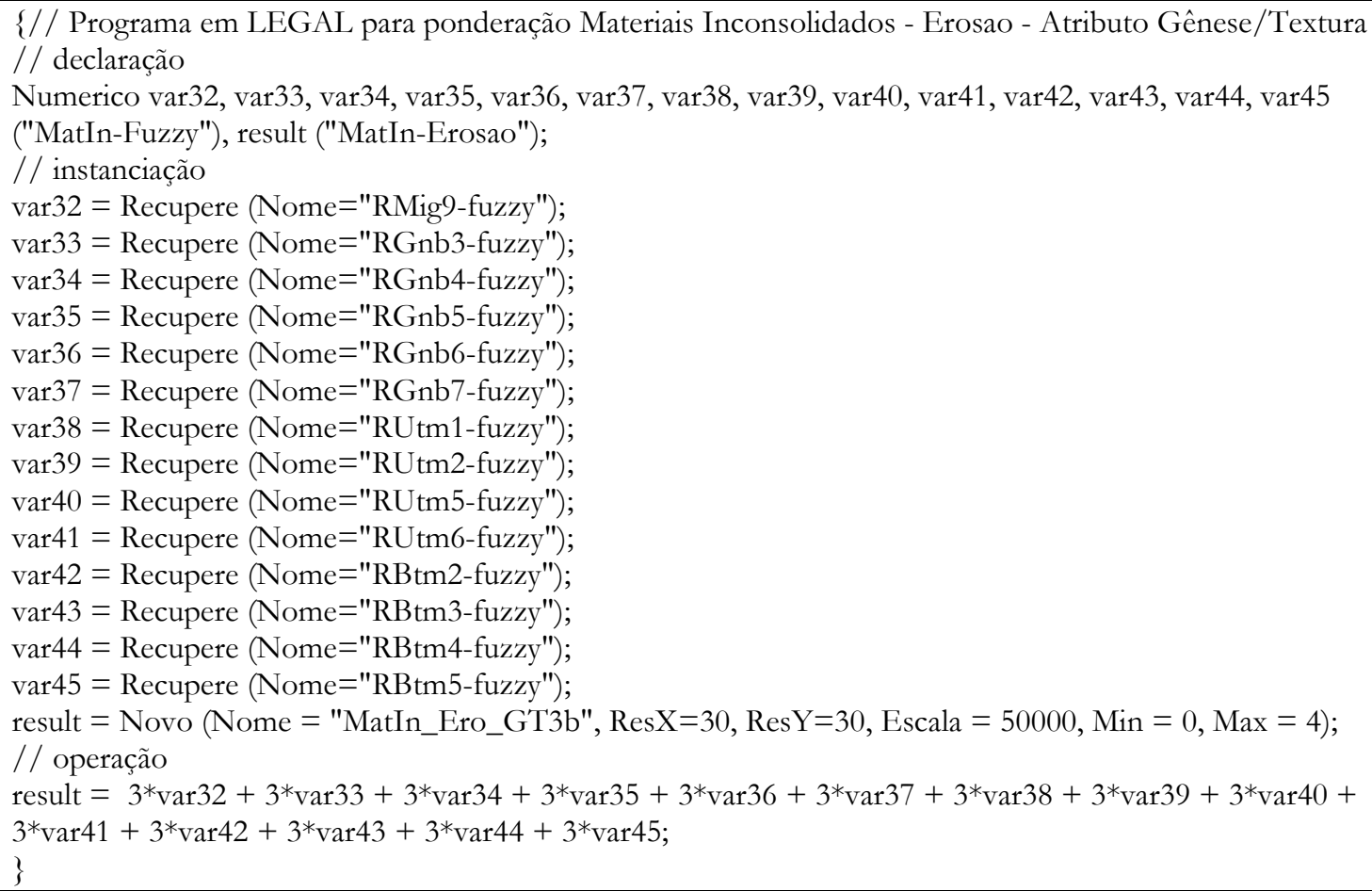

Programa LEGAL 86 - Programa de ponderação de unidades de materiais inconsolidados com muito alta suscptibilidade a erosão, quanto ao aspecto gênese/textura.

\{// Programa em LEGAL para ponderação Materiais Inconsolidados - Erosao - Atributo Gênese/Textura // declaração

Numerico var46, var47, var48, var49, var50, var51 ("MatIn-Fuzzy"), result ("MatIn-Erosao");

// instanciação

var46 = Recupere (Nome="RBtm1-fuzzy");

$\operatorname{var47}=$ Recupere (Nome="RUtm4-fuzzy");

$\operatorname{var} 48=$ Recupere $($ Nome $=" R Q$ tz1-fuzzy");

$\operatorname{var49}=$ Recupere (Nome="RAl-fuzzy");

$\operatorname{var50}=$ Recupere (Nome="RGnb8-fuzzy");

var51 = Recupere (Nome="RGnb10-fuzzy");

result $=$ Novo (Nome $=$ "MatIn_Ero_GT4a", ResX=30, ResY=30, Escala $=50000$, Min = 0, Max = 4);

// operação

result $=4 * \operatorname{var} 46+4 * \operatorname{var} 47+4 * \operatorname{var} 48+4 * \operatorname{var} 49+4 * \operatorname{var} 50+4 * \operatorname{var} 51$

\}

Programa LEGAL 86 - Programa de somatória de unidades de materiais inconsolidados para obtenção de superfície contínua, quanto ao aspecto gênese/textura.

$\{/ /$ Programa em LEGAL para ponderação Materiais Inconsolidados - Erosao - Atributo Genese/Textura // declaração

Numerico var1, var2, var3, var4, var5 ("MatIn-Erosao"), result ("MatIn-Erosao");

// instanciação

var1 = Recupere (Nome="MatIn_Ero_GT1a");

var2 = Recupere (Nome="MatIn_Ero_GT2a");

var3 = Recupere (Nome="MatIn_Ero_GT3a");

var4 = Recupere (Nome="MatIn_Ero_GT3b");

$\operatorname{var5}=$ Recupere (Nome="MatIn_Ero_GT4a");

result $=$ Novo $($ Nome $=$ "MatIn_Ero_GT", ResX=30, ResY=30, Escala = 50000, Min = 0, Max $=4$ );

// operação

result $=\operatorname{var} 1+\operatorname{var} 2+\operatorname{var} 3+\operatorname{var} 4+\operatorname{var} 5$

\} 
Programa LEGAL 87 - Programa de ponderação de unidades de materiais inconsolidados com baixa suscptibilidade a erosão, quanto ao aspecto espessura.

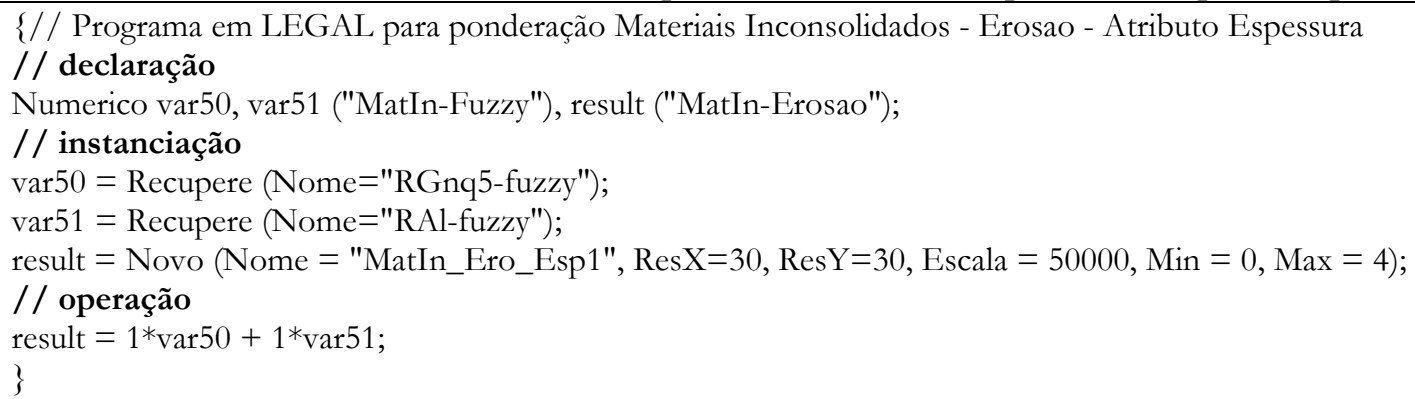

Programa LEGAL 88 - Programa de ponderação de unidades de materiais inconsolidados com média suscptibilidade a erosão, quanto ao aspecto espessura.

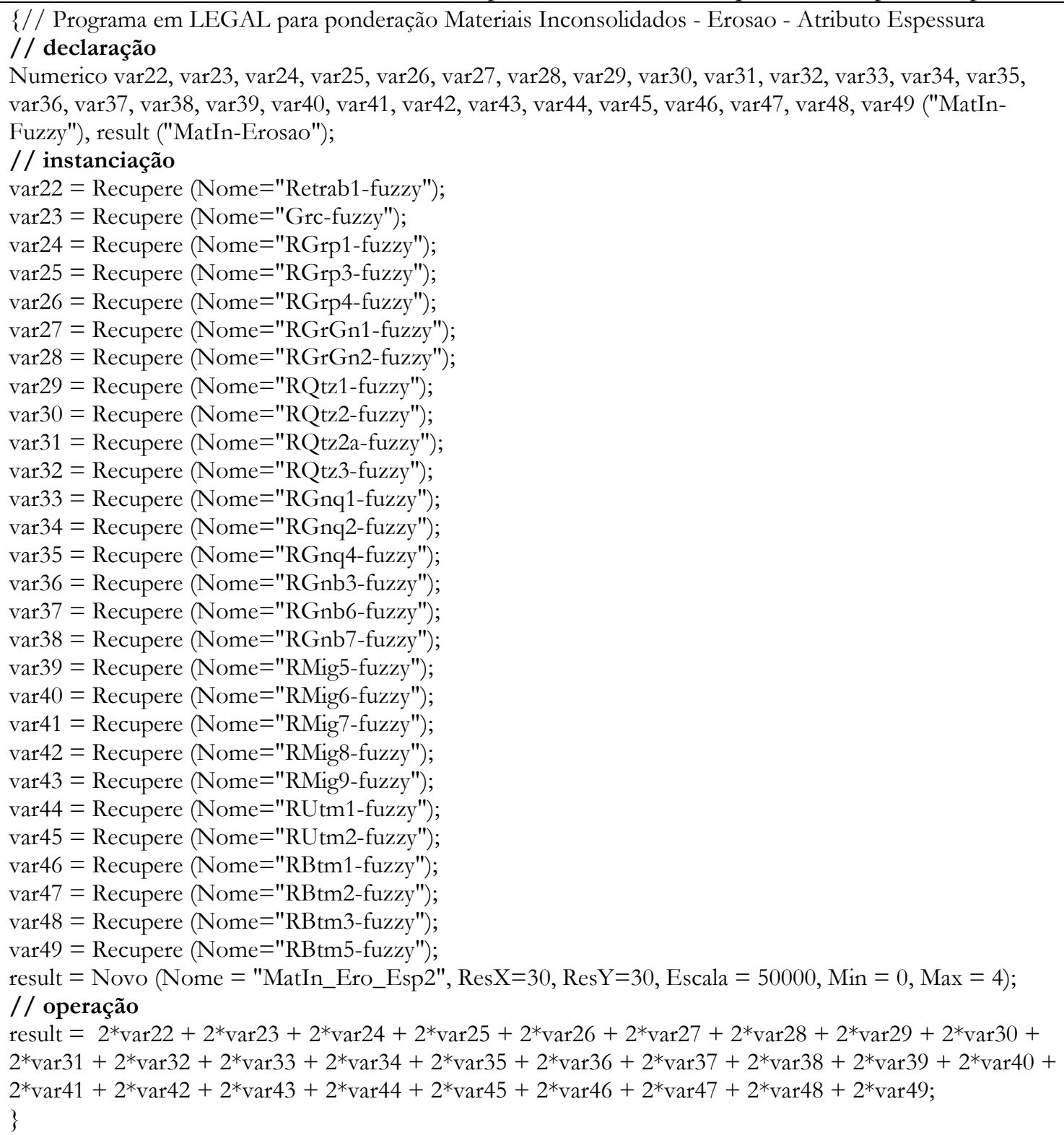


Programa LEGAL 89 - Programa de ponderação de unidades de materiais inconsolidados com alta suscptibilidade a erosão, quanto ao aspecto espessura.

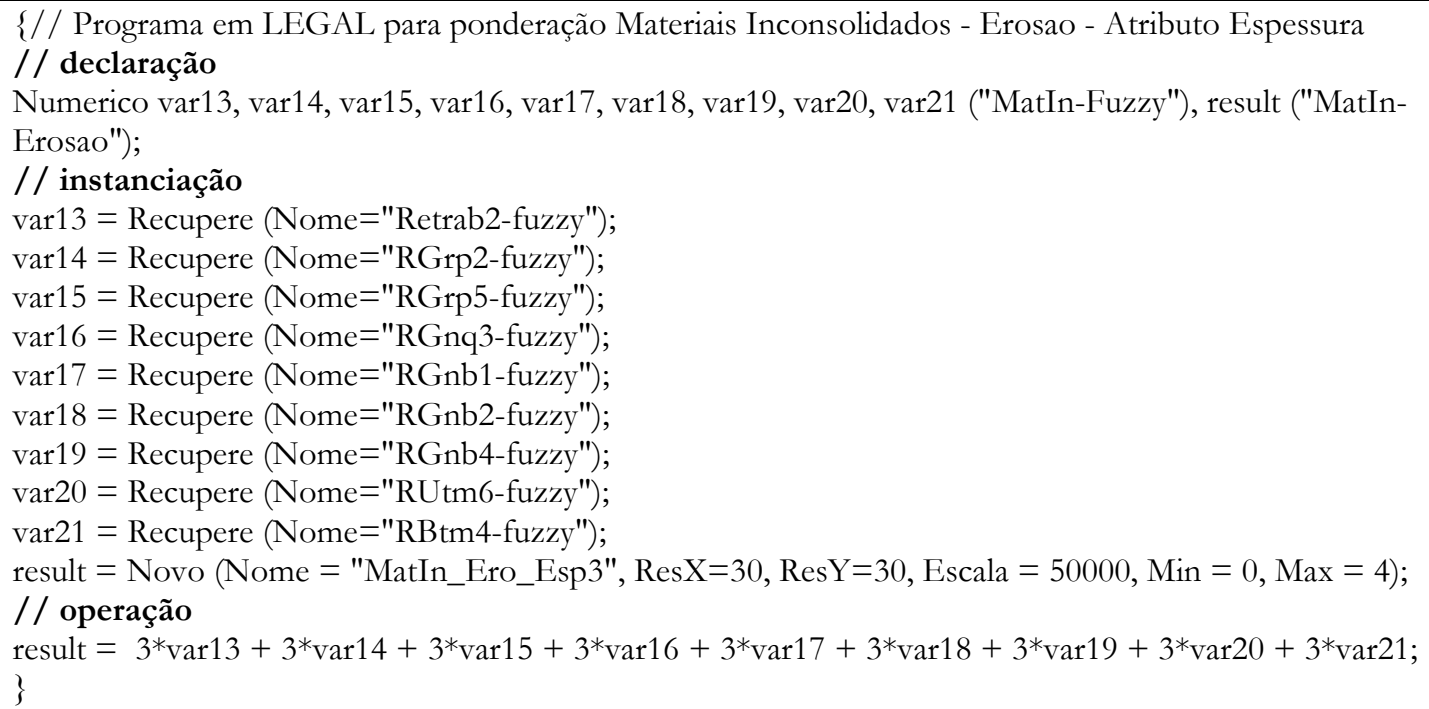

Programa LEGAL 90 - Programa de ponderação de unidades de materiais inconsolidados com muito alta suscptibilidade a erosão, quanto ao aspecto espessura.

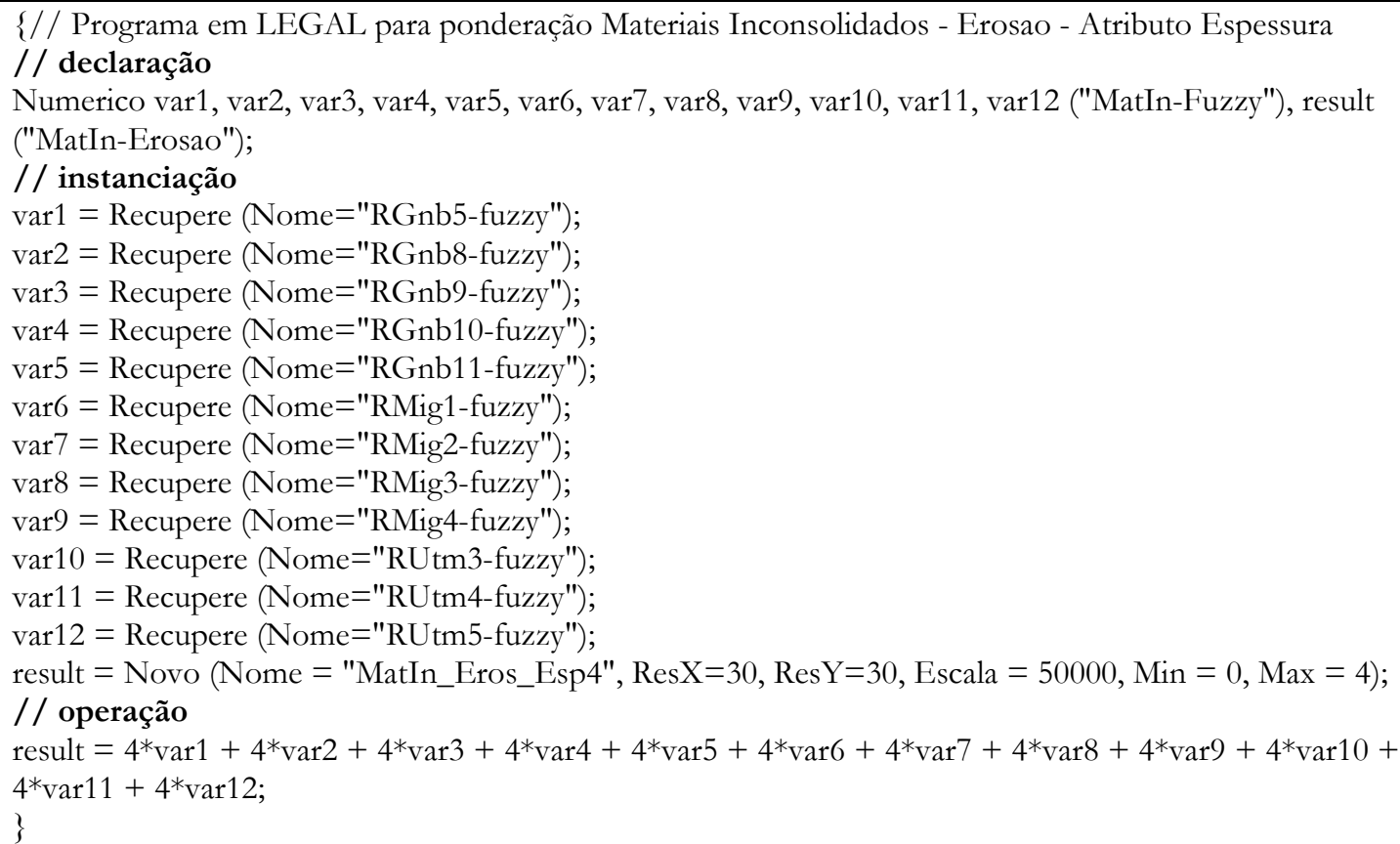

Programa LEGAL 91 - Programa de somatória de unidades de materiais inconsolidados para obtenção de superfície contínua, quanto ao aspecto espessura.

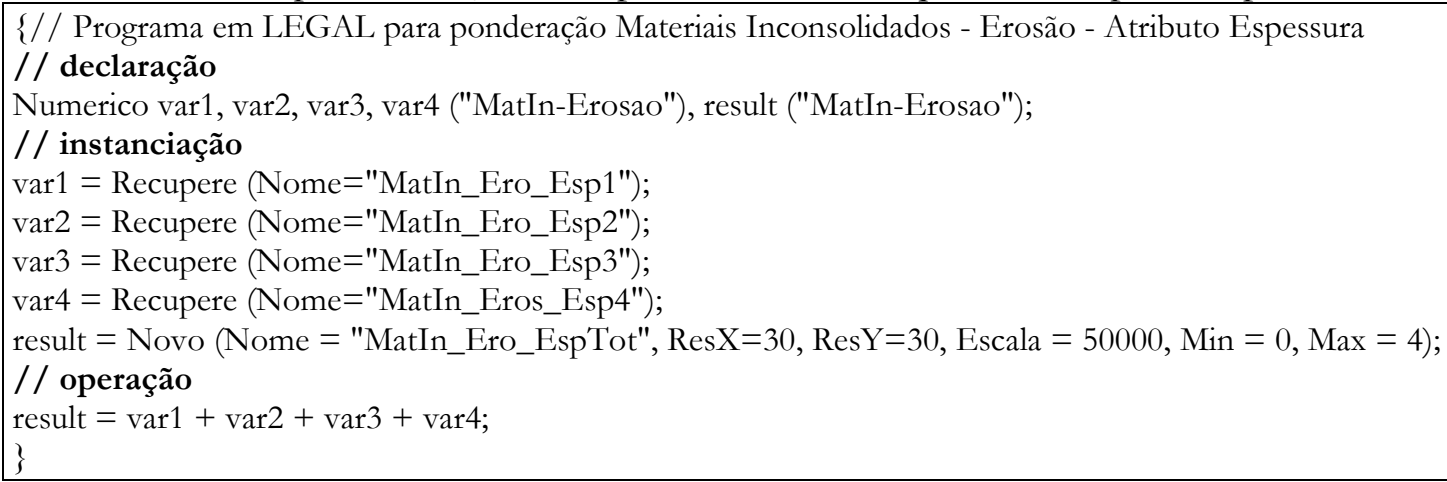


Programa LEGAL 92 - Programa atribuição de peso ao atributo potencail ao escoamento, quanto ao aspecto susceptibilidade a erosão.

\{// Programa para ponderação peso - Atributo Potentical Escoamento - Mapa Susceptibilidade Erosao -

// declaração

Numerico esc ("Escoamento_Super"), result ("Suscp_Erosao");

// instanciação

esc $=$ Recupere (Nome $=$ "Esc4_Sup_Fuzzy");

result $=$ Novo $($ Nome $=$ "PotEsc4_Erosao", ResX=30, ResY=30, Escala = 50000, Min = 0, Max =4);

// operação

result $=0.42702 * \mathrm{esc}$

\}

Programa LEGAL 93 - Programa atribuição de peso ao atributo gênese e texturas das unidades de materiais inconsolidados, quanto ao aspecto susceptibilidade a erosão.

\{// Programa para ponderação peso- Atributo Genese/Textura Mat Inço -Mapa Susceptibilidade Erosao // declaração

Numerico mat ("MatIn-Erosao"), result ("Suscp_Erosao");

// instanciação

mat $=$ Recupere (Nome = "MatIn_Ero_GT'Tot");

result $=$ Novo (Nome $=$ "MI_GT3_Erosao", ResX=30, ResY=30, Escala = 50000, Min = 0, Max =4);

// operação

result $=0.40351 *$ mat;

\}

Programa LEGAL 94 - Programa atribuição de peso ao atributo espessura das unidades de materiais inconsolidados, quanto ao aspecto susceptibilidade a erosão.

\{// Programa para obtenção Mapa Susceptibilidade Erosao - Mat In Espessura

// declaração

Numerico mat ("MatIn-Erosao"), result ("Suscp_Erosao");

// instanciação

mat $=$ Recupere (Nome $=$ "MatIn_Ero_EspTot");

result $=$ Novo $($ Nome $=$ "MI_Esp_Erosao", ResX=30, ResY=30, Escala = 50000, Min = 0, Max = 4);

// operação

result $=0.16946^{*}$ mat;

\}

Programa LEGAL 95 - Programa obtenção de superfície contínua representativa da susceptibilidade a erosão da área.

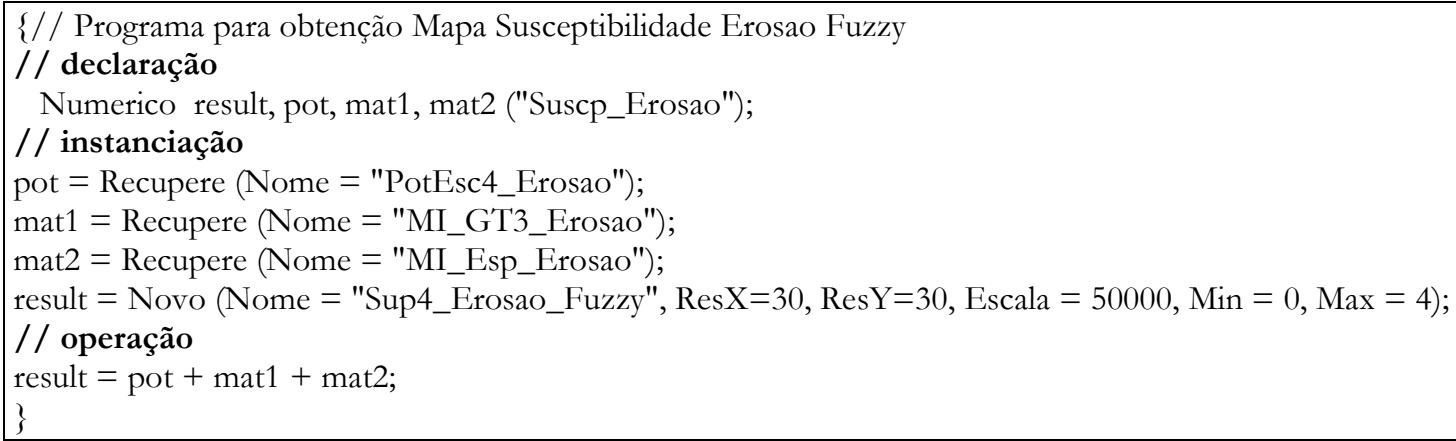


Programa LEGAL 96 - Programa de espacialização contínua da declividade deacordo com faixas restritivas ao desenvolvimento de atividades agrícolas.

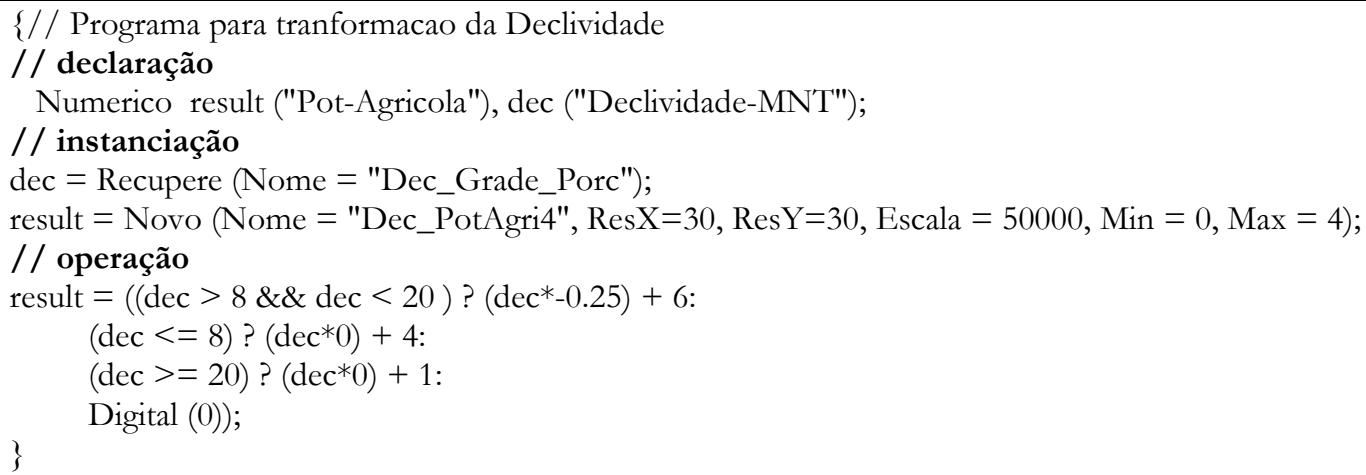

Programa LEGAL 97 - Programa inversão superfície contínua representativa da susceptibilidade a erosão, para caracterização de potencial agrícola.

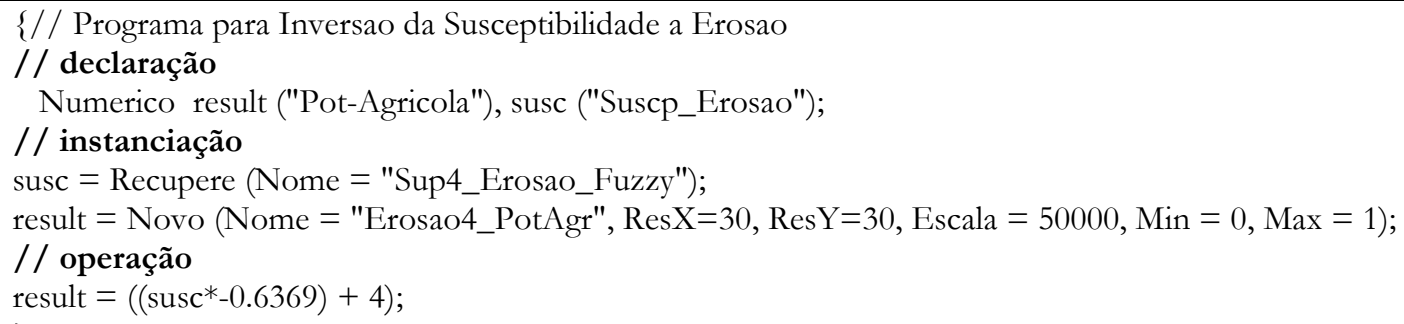

Programa LEGAL 98 - Programa de ponderação de unidades de materiais inconsolidados com baixo potencial agrícola, quanto ao aspecto espessura.

\{// Programa em LEGAL para ponderação Materiais Inconsolidados - Potencial Agricola - Atributo Espessura

// declaração

Numerico var1, var2 ("MatIn-Fuzzy"), result ("MatIn-PotAgr");

// instanciação

var1 = Recupere (Nome="RGnq5-fuzzy");

$\operatorname{var} 2=$ Recupere (Nome="RAl-fuzzy");

result $=$ Novo $($ Nome $=$ "MatIn_Esp1", ResX=30, ResY=30, Escala = 50000, Min = 0, Max =4);

// operação

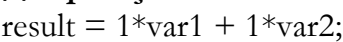

\}

Programa LEGAL 99 - Programa de ponderação de unidades de materiais inconsolidados com médio potencial agrícola, quanto ao aspecto espessura.

\{// Programa em LEGAL para ponderação Materiais Inconsolidados - Potencial Agricola - Atributo Espessura

// declaração

Numerico var3, var4, var5, var6, var7 ("MatIn-Fuzzy"), result ("MatIn-PotAgr");

// instanciação

var3 = Recupere (Nome="RQtz1-fuzzy");

var4 = Recupere (Nome="RQtz2-fuzzy");

$\operatorname{var5}=$ Recupere $($ Nome $="$ RQtz2a-fuzzy");

$\operatorname{var6}=$ Recupere (Nome="RQtz3-fuzzy");

$\operatorname{var} 7=$ Recupere (Nome="RBtm1-fuzzy");

result $=$ Novo $($ Nome $=$ "MatIn_Esp2", ResX=30, ResY=30, Escala = 50000, Min = 0, Max = 4);

// operação

result $=2 * \operatorname{var} 3+2 * \operatorname{var} 4+2 * \operatorname{var} 5+2 * \operatorname{var} 6+2 * \operatorname{var} 7$

\} 
Programa LEGAL 100 - Programa de ponderação de unidades de materiais inconsolidados com alto potencial agrícola, quanto ao aspecto espessura.

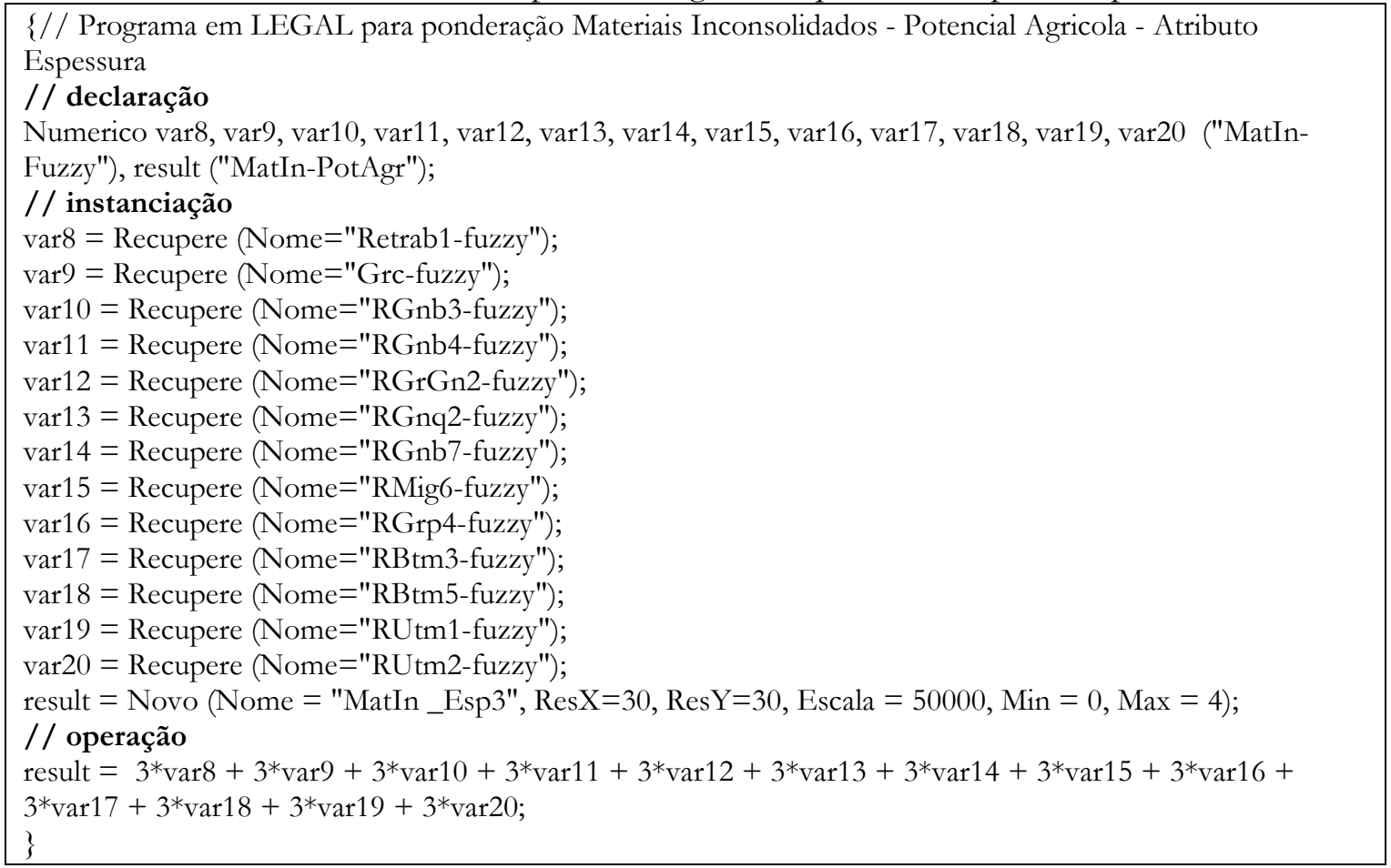

Programa LEGAL 101 - Programa de ponderação de unidades de materiais inconsolidados com muito alto potencial agrícola, quanto ao aspecto espessura.

$\{$ // Programa em LEGAL para ponderação Materiais Inconsolidados - Potencial Agricola - Atributo Espessura

\section{// declaração}

Numerico var36, var37, var38, var39, var40, var41, var42, var43, var44, var45, var46, var47, var48, var49, var50, var51 ("MatIn-Fuzzy"), result ("MatIn-PotAgr");

// instanciação

$\operatorname{var36}=$ Recupere (Nome="RGnb10-fuzzy");

$\operatorname{var} 37=$ Recupere $($ Nome $=$ "RGnb11-fuzzy");

$\operatorname{var38}=$ Recupere (Nome="RMig1-fuzzy");

$\operatorname{var39}=$ Recupere (Nome="RMig2-fuzzy");

$\operatorname{var40}=$ Recupere (Nome $=$ "RMig3-fuzzy");

var41 = Recupere (Nome="RMig4-fuzzy");

$\operatorname{var42}=$ Recupere (Nome="RMig5-fuzzy");

$\operatorname{var} 43=$ Recupere (Nome="RMig7-fuzzy");

var44 = Recupere (Nome="RMig8-fuzzy");

$\operatorname{var45}=$ Recupere (Nome="RMig9-fuzzy");

var46 = Recupere (Nome="RUtm3-fuzzy");

$\operatorname{var47}=$ Recupere (Nome="RUtm4-fuzzy");

$\operatorname{var} 48=$ Recupere $($ Nome $=$ "RUtm5-fuzzy");

var49 $=$ Recupere $($ Nome $=$ "RUtm6-fuzzy");

$\operatorname{var} 50=$ Recupere (Nome $=" R B t m 2$-fuzzy");

$\operatorname{var51}=$ Recupere (Nome="RBtm4-fuzzy");

result $=$ Novo (Nome $=$ "MatIn_Esp4a", ResX=30, ResY=30, Escala = 50000, Min = 0, Max = 4);

// operação

result $=4 * \operatorname{var} 36+4 * \operatorname{var} 37+4 * \operatorname{var} 38+4 * \operatorname{var} 39+4 * \operatorname{var} 40+4 * \operatorname{var} 41+4 * \operatorname{var} 42+4 * \operatorname{var} 43+4 * \operatorname{var} 44+$ $4 *^{*} \operatorname{var} 45+4 *^{*} \operatorname{var} 46+4 *^{*} \operatorname{var} 47+4 *^{*} \operatorname{var} 48+4 *^{*} \operatorname{var} 49+4 *^{*} \operatorname{var} 50+4 *^{*} \operatorname{var} 51$

\} 
Programa LEGAL 102 - Programa de somatória de unidades de materiais inconsolidados para obtenção de superfície contínua representativa de potencail agrícola, quanto ao aspecto espessura.

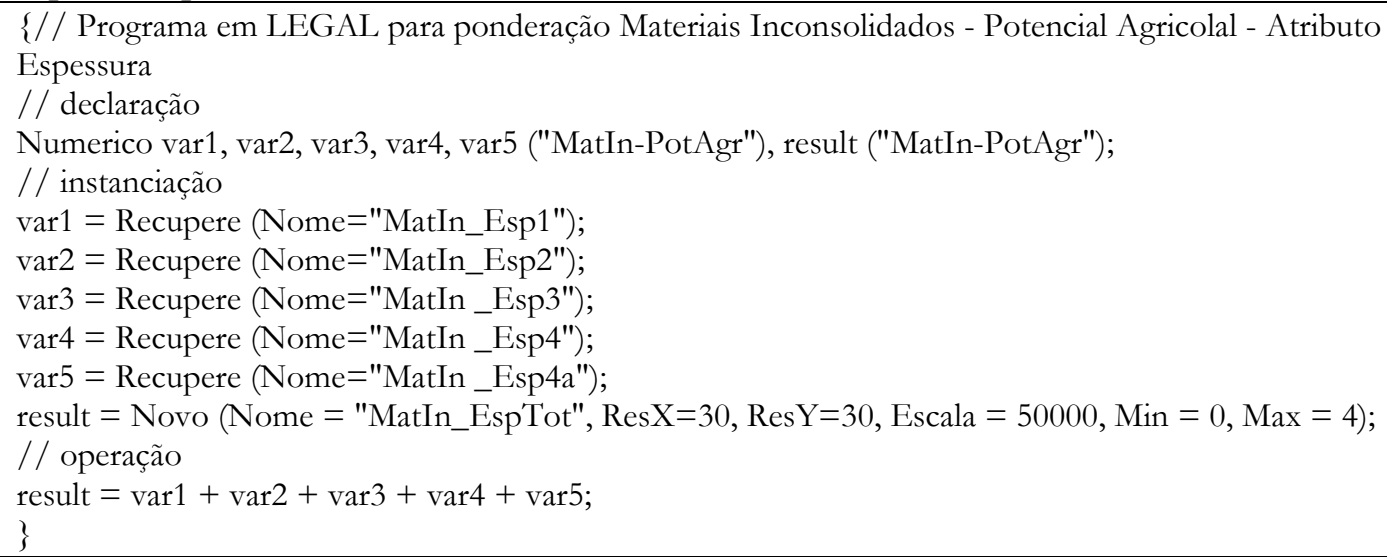

Programa LEGAL 103 - Programa de ponderação de unidades de materiais inconsolidados com baixo potencial agrícola, quanto ao aspecto textura.

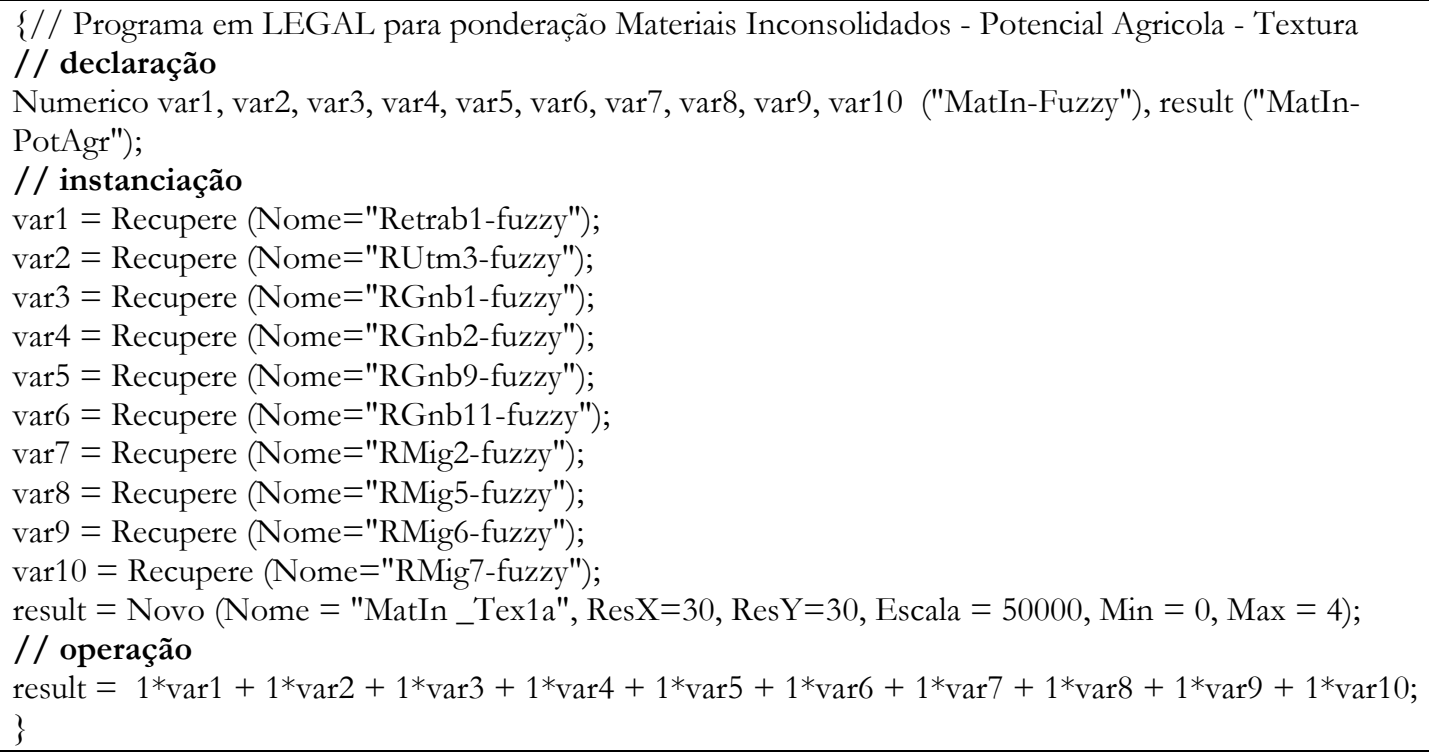

Programa LEGAL 104 - Programa de ponderação de unidades de materiais inconsolidados com baixo potencial agrícola, quanto ao aspecto textura.

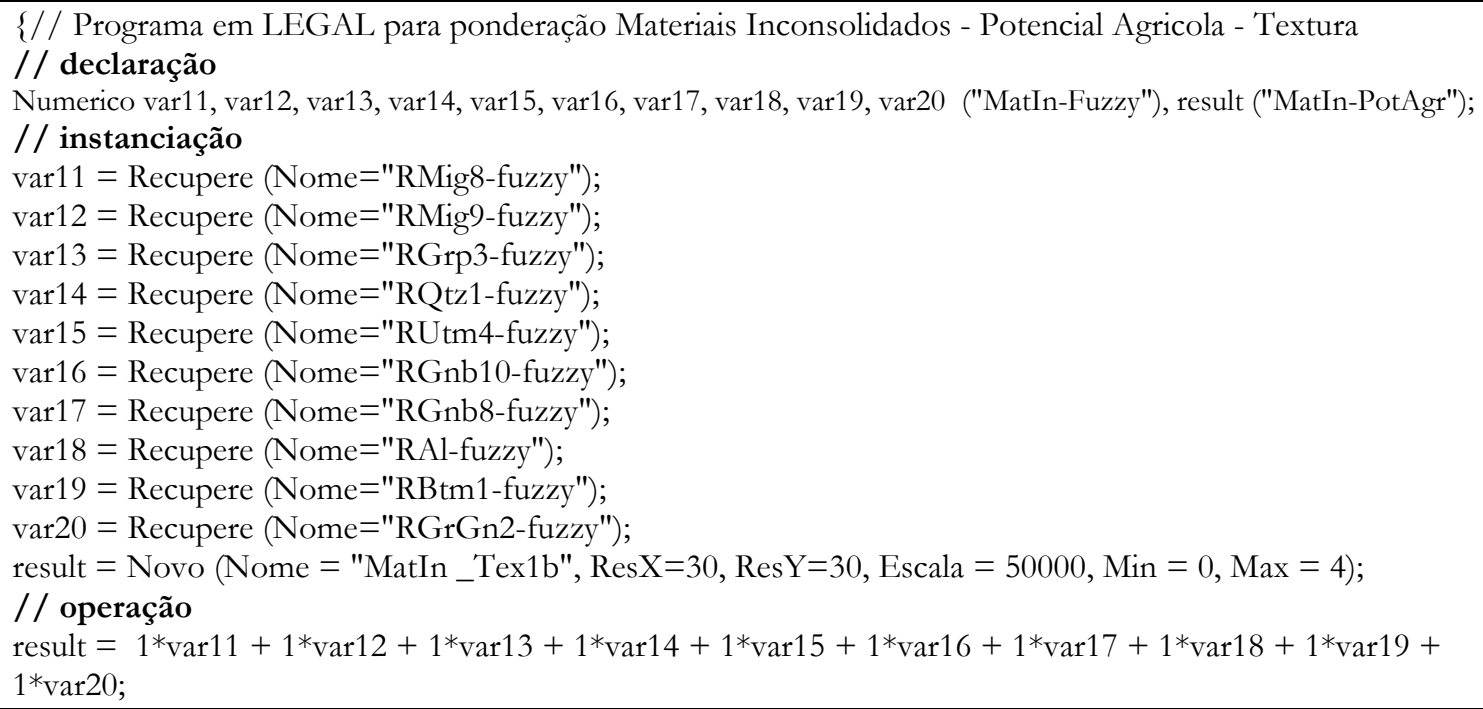


Programa LEGAL 104 - Programa de ponderação de unidades de materiais inconsolidados com médio potencial agrícola, quanto ao aspecto textura.

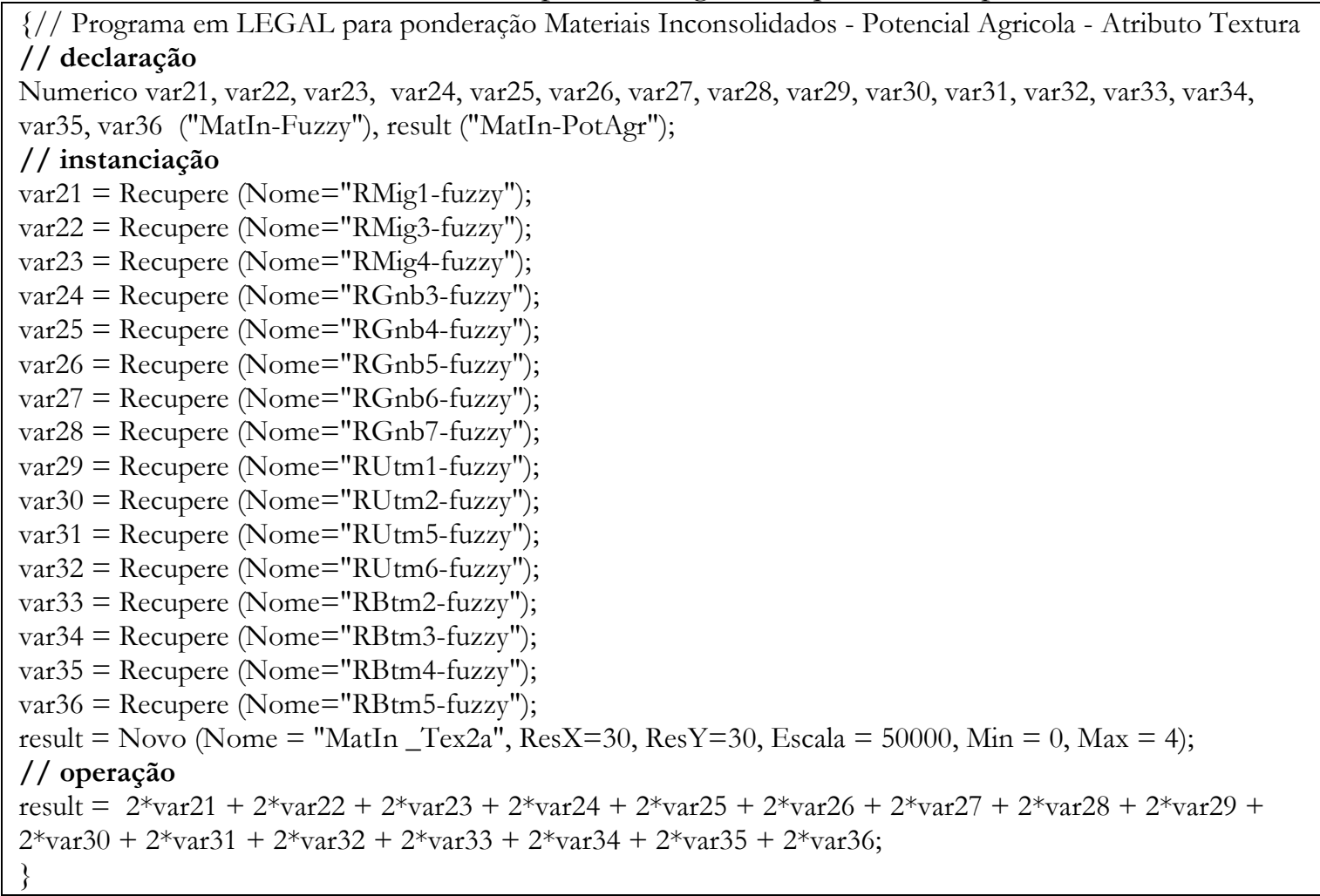

Programa LEGAL 105 - Programa de ponderação de unidades de materiais inconsolidados com alto potencial agrícola, quanto ao aspecto textura.

\{// Programa em LEGAL para ponderação Materiais Inconsolidados - Potencial Agricola - Atributo Textura // declaração

Numerico var37, var38, var39, var40, var41, var42, var43, var44, var45, var46, var47, var48, var49 ("MatInFuzzy"), result ("MatIn-PotAgr");

// instanciação

$\operatorname{var37}=$ Recupere (Nome="RGrp1-fuzzy");

$\operatorname{var38}=$ Recupere (Nome="RGrp2-fuzzy");

$\operatorname{var39}=$ Recupere (Nome="RGrp4-fuzzy");

$\operatorname{var} 40=$ Recupere $($ Nome="RGrp5-fuzzy");

var41 = Recupere (Nome="RGrGn1-fuzzy");

var42 = Recupere (Nome="RGnq1-fuzzy");

$\operatorname{var} 43=$ Recupere (Nome="RGnq2-fuzzy");

$\operatorname{var} 44=$ Recupere (Nome="RGnq3-fuzzy");

var45 = Recupere (Nome="RGnq4-fuzzy");

var46 = Recupere (Nome="RGnq5-fuzzy");

$\operatorname{var} 47=$ Recupere $($ Nome $=$ "RQtz2-fuzzy");

$\operatorname{var48}=$ Recupere (Nome="RQtz2a-fuzzy");

$\operatorname{var} 49=$ Recupere $($ Nome $="$ RQtz3-fuzzy");

result $=$ Novo $($ Nome $=$ "MatIn_Text3a", ResX=30, ResY=30, Escala = 50000, Min = 0, Max = 4);

// operação

result $=3 *^{*} \operatorname{var} 37+3 * \operatorname{var} 38+3 * \operatorname{var} 39+3 * \operatorname{var} 40+3 * \operatorname{var} 41+3 * \operatorname{var} 42+3 * \operatorname{var} 43+3 * \operatorname{var} 44+3 * \operatorname{var} 45+$

$3 *^{*} \operatorname{var} 46+3 *^{*} \operatorname{var} 47+3 *^{*} \operatorname{var} 48+3 * \operatorname{var} 49$

\} 
Programa LEGAL 106- Programa de ponderação de unidades de materiais inconsolidados com muito alto potencial agrícola, quanto ao aspecto textura.

$\{$ // Programa em LEGAL para ponderação Materiais Inconsolidados - Potencial Agricola - Atributo Textura // declaração

Numerico var50, var51 ("MatIn-Fuzzy"), result ("MatIn-PotAgr");

// instanciação

$\operatorname{var50}=$ Recupere (Nome="Grc-fuzzy");

var51 = Recupere (Nome="Retrab2-fuzzy");

result $=$ Novo $($ Nome $=$ "MatIn_Text4a", ResX=30, ResY=30, Escala = 50000, Min = 0, Max = 4);

// operação

result $=4 *^{*}$ arr $50+4 *^{*}$ ar 51

\}

Programa LEGAL 107 - Programa de somatória de unidades de materiais inconsolidados para obtenção de superfície contínua representativa de potencail agrícola, quanto ao aspecto textura.

$\{$ // Programa em LEGAL para ponderação Materiais Inconsolidados - Potencial Agricolal - Atributo Textura

// declaração

Numerico var1, var2, var3, var4, var5 ("MatIn-PotAgr"), result ("MatIn-PotAgr");

// instanciação

var1 = Recupere (Nome="MatIn_Tex1a");

$\operatorname{var} 2=$ Recupere $($ Nome $=$ "MatIn_Tex1b");

$\operatorname{var} 3=$ Recupere $($ Nome $=$ "MatIn_Tex2a");

var4 = Recupere (Nome="MatIn_Text3a");

$\operatorname{var} 5=$ Recupere $($ Nome $=$ "MatIn_Text4a");

result $=$ Novo $($ Nome $=$ "MatIn_GTTot", ResX=30, ResY=30, Escala = 50000, Min = 0, Max = 4);

// operação

result $=$ var1 + var2 + var3 + var4 + var5;

\}

Programa LEGAL 108- Programa de ponderação de unidades de materiais inconsolidados com baixo potencial agrícola, quanto ao aspecto capacidade de troca catiônica.

$\{/ /$ Programa em LEGAL para ponderação Materiais Inconsolidados - Potencial Agricola - Atributo CTC // declaração

Numerico var1, var2, var3, var4, var49 ("MatIn-Fuzzy"), result ("MatIn-PotAgr");

// instanciação

$\operatorname{var1}=$ Recupere (Nome="Retrab2-fuzzy");

$\operatorname{var} 2=$ Recupere (Nome="Grc-fuzzy");

$\operatorname{var3}=$ Recupere (Nome="RGrGn2-fuzzy");

$\operatorname{var} 4=$ Recupere $($ Nome $=" R Q t z 1-$ fuzzy");

var49= Recupere (Nome="RAl-fuzzy");

result $=$ Novo $($ Nome $=$ "MatIn_CTC1", ResX=30, ResY=30, Escala = 50000, Min = 0, Max = 4);

// operação

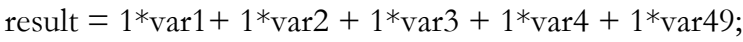

\} 
Programa LEGAL 109- Programa de ponderação de unidades de materiais inconsolidados com médio potencial agrícola, quanto ao aspecto capacidade de troca catiônica.

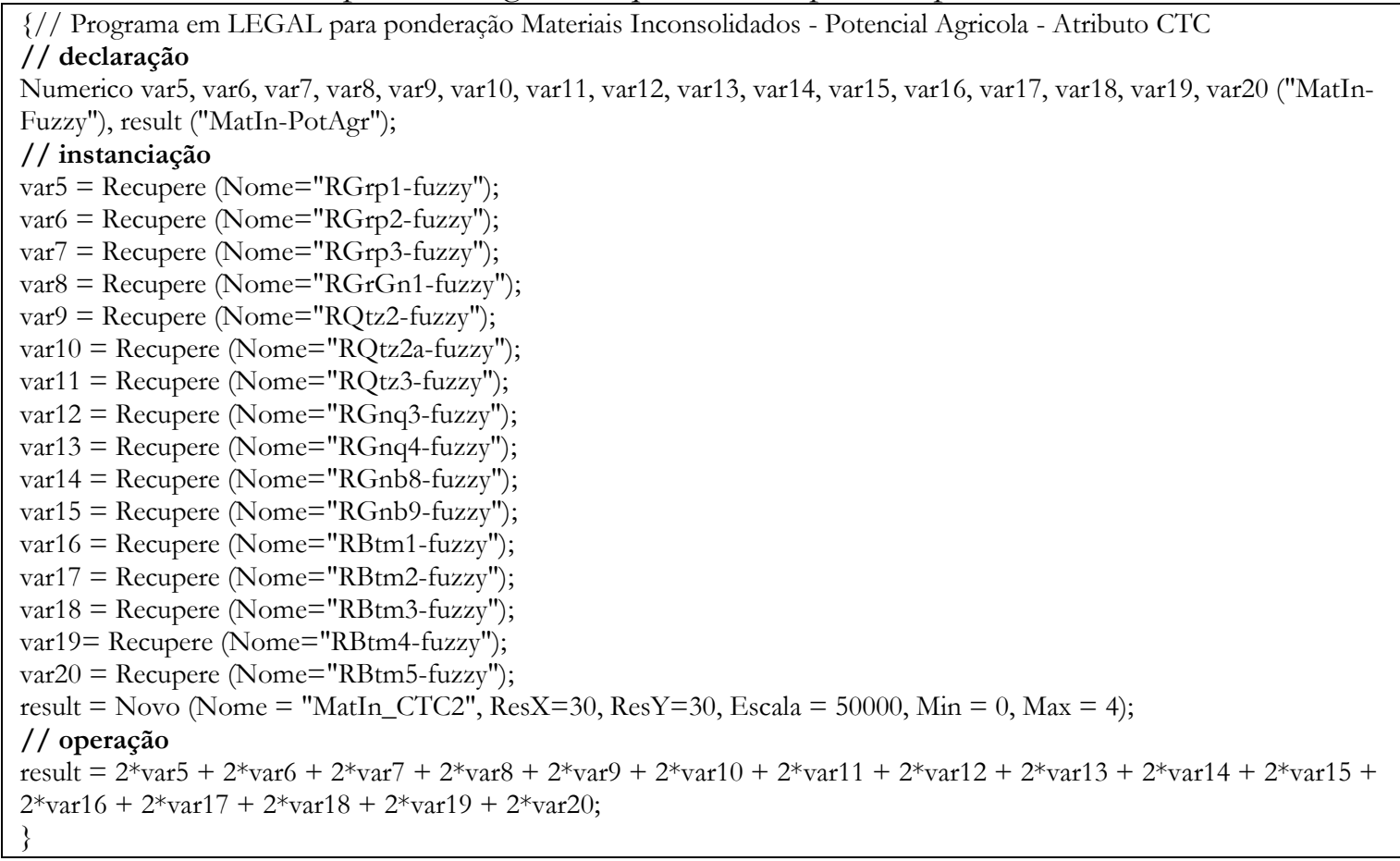

Programa LEGAL 110 - Programa de ponderação de unidades de materiais inconsolidados com alto potencial agrícola, quanto ao aspecto capacidade de troca catiônica.

\section{\{// Programa em LEGAL para ponderação Materiais Inconsolidados - Potencial Agricola - Atributo CTC}

// declaração

Numerico var21, var22, var23, var24, var25, var26, var27, var28, var29, $\operatorname{var30,var31,~var32,~var33,~var34,~} \operatorname{var} 35, \operatorname{var} 36$, var37, var38, var39, var40, var41, var42, var43 ("MatIn-Fuzzy"), result ("MatIn-PotAgr");

// instanciação

$\operatorname{var} 21=$ Recupere $($ Nome $="$ Retrab1-fuzzy");

$\operatorname{var} 22=$ Recupere $($ Nome $=$ "RGrp4-fuzzy");

$\operatorname{var23}=$ Recupere $($ Nome="RGrp5-fuzzy");

$\operatorname{var} 24=$ Recupere $($ Nome $=$ "RGnq1-fuzzy");

$\operatorname{var} 25=$ Recupere (Nome="RGnq2-fuzzy");

$\operatorname{var} 26=$ Recupere (Nome="RGnq5-fuzzy");

$\operatorname{var} 27=$ Recupere (Nome="RGnb1-fuzzy");

$\operatorname{var} 28=$ Recupere (Nome="RGnb2-fuzzy");

$\operatorname{var} 29=$ Recupere (Nome="RGnb3-fuzzy");

$\operatorname{var} 30=$ Recupere (Nome="RGnb4-fuzzy");

$\operatorname{var} 31=$ Recupere $($ Nome $=" R G n b 5-$ fuzzy");

$\operatorname{var} 32$ = Recupere (Nome="RGnb6-fuzzy");

var33 = Recupere (Nome="RGnb7-fuzzy");

var34 = Recupere (Nome="RGnb10-fuzzy");

$\operatorname{var} 35=$ Recupere (Nome="RGnb11-fuzzy");

$\operatorname{var36}=$ Recupere $($ Nome $=$ "RMig1-fuzzy");

$\operatorname{var} 37=$ Recupere $($ Nome $=$ "RMig3-fuzzy");

$\operatorname{var} 38=$ Recupere (Nome="RMig4-fuzzy");

$\operatorname{var} 39=$ Recupere $($ Nome $=$ "RMig9-fuzzy");

$\operatorname{var} 40=$ Recupere (Nome="RUtm1-fuzzy");

$\operatorname{var} 41=$ Recupere (Nome="RUtm2-fuzzy");

$\operatorname{var} 42=$ Recupere (Nome="RUtm3-fuzzy");

$\operatorname{var} 43=$ Recupere (Nome $=" R U t m 5-$ fuzzy");

result $=$ Novo $($ Nome $=$ "MatIn_CTC3", ResX=30, ResY=30, Escala $=50000$, Min = 0, Max $=4)$;

// operação

result $=3{ }^{*} \operatorname{var} 21+3{ }^{*} \operatorname{var} 22+3{ }^{*} \operatorname{var} 23+3 *^{*} \operatorname{var} 24+3{ }^{*} \operatorname{var} 25+3{ }^{*} \operatorname{var} 26+3 *^{*} \operatorname{var} 27+3 *^{*} \operatorname{var} 28+3 *^{*} \operatorname{var} 29+3 *^{*} \operatorname{var} 30+$ $3 *^{*} \operatorname{var} 31+3 *^{*} \operatorname{var} 32+3 *^{*} \operatorname{var} 33+3 *^{*} \operatorname{var} 34+3 *^{*} \operatorname{var} 35+3{ }^{*} \operatorname{var} 36+3{ }^{*} \operatorname{var} 37+3 *^{*} \operatorname{var} 38+3{ }^{*} \operatorname{var} 39+3{ }^{*} \operatorname{var} 40+3 *^{*} \operatorname{var} 41+$ $3 *^{*} \operatorname{var} 42+3 *^{*} \operatorname{var} 43$ 
Programa LEGAL 111- Programa de ponderação de unidades de materiais inconsolidados com muito alto potencial agrícola, quanto ao aspecto capacidade de troca catiônica.

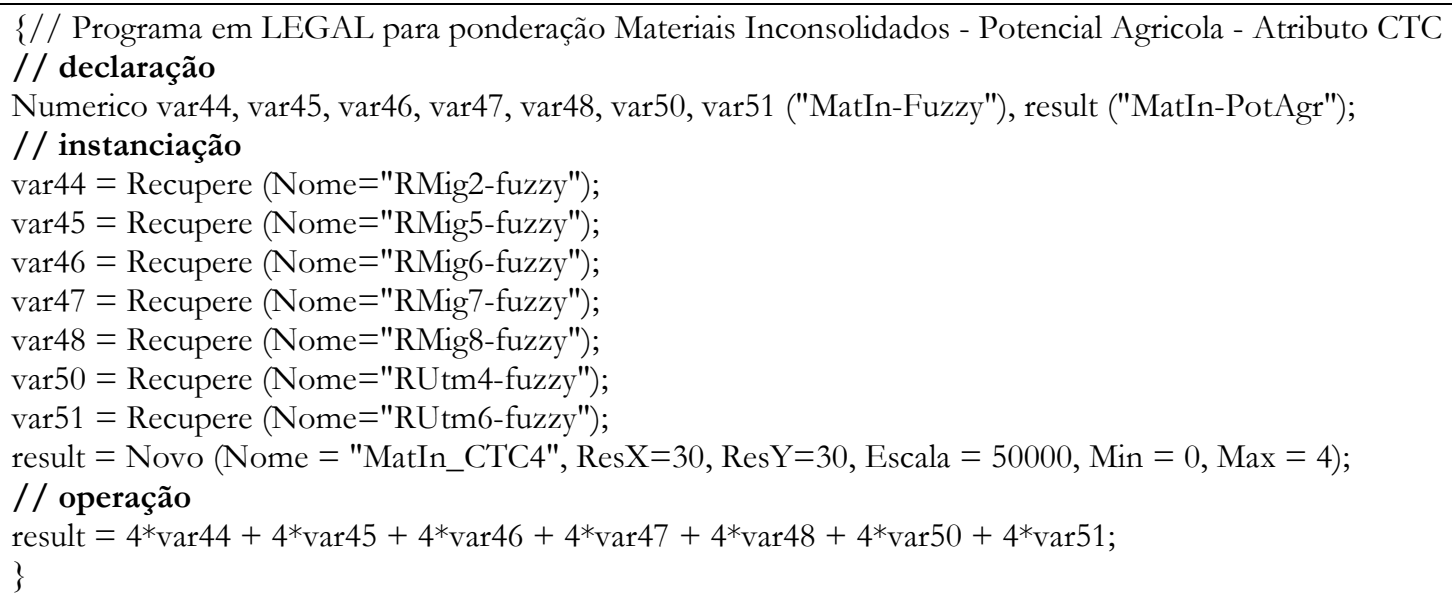

Programa LEGAL 112- Programa de somatória de unidades de materiais inconsolidados para obtenção de superfície contínua representativa de potencail agrícola, quanto ao aspecto capacidade de troca catiônica.

$\{$ // Programa em LEGAL para ponderação Materiais Inconsolidados - Potencial Agricolal - Atributo CTC // declaração

Numerico var1, var2, var3, var4 ("MatIn-PotAgr"), result ("MatIn-PotAgr");

// instanciação

$\operatorname{var1}=$ Recupere (Nome="MatIn_CTC1");

var2 = Recupere (Nome="MatIn_CTC2");

$\operatorname{var3}=$ Recupere (Nome="MatIn_CTC3");

$\operatorname{var4}=$ Recupere (Nome="MatIn_CTC4");

result $=$ Novo (Nome $=$ "MatIn_CTCTot", ResX=30, ResY=30, Escala = 50000, Min = 0, Max = 4);

// operação

result $=$ var1 $+\operatorname{var} 2+\operatorname{var} 3+\operatorname{var} 4$

\}

Programa LEGAL 113 - Programa atribuição de peso ao atributo susceptibilidade a erosão, quanto ao aspecto potencial agrícola.

\{ // Programa para podenra cão de peso - Susceptibilidade Erosão -Mapa Potencial Agricola

// declaração

Numerico susc ("Pot-Agricola"), result ("Potencial_Agricola");

// instanciação

susc $=$ Recupere $($ Nome $=$ "Erosao4_PotAgr");

result $=$ Novo $($ Nome $=$ "Erosao4_PA", ResX=30, ResY=30, Escala = 50000, $\operatorname{Min}=0$, Max $=4)$;

// operação

result $=0.254$ susc;

\}

Programa LEGAL 114 - Programa atribuição de peso ao atributo espessuras dos materiais inconsolidados, quanto ao aspecto potencial agrícola.

$\{$ // Programa para ponderação de peso - Mat In Espessura - Mapa Potencial Agricola

// declaração

Numerico mat ("MatIn-PotAgr"), result ("Potencial_Agricola");

// instanciação

mat $=$ Recupere $($ Nome $=$ "MatIn_Esp'Tot");

result $=$ Novo $($ Nome $=$ "Esp_PA", ResX=30, ResY=30, Escala $=50000$, Min =0, Max = 4);

// operação

result $=0.15^{*}$ mat;

\} 
Programa LEGAL 115 - Programa atribuição de peso ao atributo textura dos materiais inconsolidados, quanto ao aspecto potencial agrícola.

$\{$ // Programa para ponderação de peso - Mat In Textura - Mapa Potencial Agricola -

// declaração

Numerico mat ("MatIn-PotAgr"), result ("Potencial_Agricola");

// instanciação

mat $=$ Recupere $($ Nome $=$ "MatIn_GTTot");

result $=$ Novo $($ Nome $=$ "GT3_PA", ResX=30, ResY=30, Escala = 50000, Min = 0, Max = 4);

// operação

result $=0.10^{*}$ mat;

\}

Programa LEGAL 116 - Programa atribuição de peso ao atributo capacidade de troca catiônica dos materiais inconsolidados, quanto ao aspecto potencial agrícola.

\{// Programa para ponderação de peso - Mat In CTC - Mapa Potencial Agricola

// declaração

Numerico mat ("MatIn-PotAgr"), result ("Potencial_Agricola");

// instanciação

mat $=$ Recupere $($ Nome $=$ "MatIn_CTCTot");

result $=$ Novo $($ Nome $=$ "CTC_PA", ResX=30, ResY=30, Escala $=50000$, Min $=0$, Max $=4$ );

// operação

result $=0.10 *$ mat;

\}

Programa LEGAL 117 - Programa atribuição de peso ao atributo declividade, quanto ao aspecto potencial agrícola.

\{// Programa para ponderação de peso - Declividade - Mapa Potencial Agricola

// declaração

Numerico dec ("Pot-Agricola"), result ("Potencial_Agricola");

// instanciação

dec $=$ Recupere (Nome $=$ "Dec_PotAgri4");

result $=$ Novo $($ Nome $=$ "Dec4_PA", ResX=30, ResY=30, Escala = 50000, Min = 0, Max = 4);

// operação

result $=0.35 * \mathrm{dec}$

\}

Programa LEGAL 118 - Programa obtenção de superfície contínua representativa do potencial agrícola da área.

\{// Programa em LEGAL para obtencao Mapa Potencial Agricolal Fuzzy

// declaração

Numerico result, var1, var2, var3, var4, var5 ("Potencial_Agricola");

// instanciação

var1 = Recupere (Nome="Dec4_PA");

$\operatorname{var} 2=$ Recupere (Nome="Esp_PA");

$\operatorname{var} 3=$ Recupere (Nome="GT3_PA");

$\operatorname{var} 4=$ Recupere $($ Nome $=$ "CTC_PA");

var5 = Recupere (Nome="Erosao4_PA");

result $=$ Novo $($ Nome $=$ "Potencial_Agricola4", $\operatorname{ResX}=30, \operatorname{ResY}=30$, Escala $=50000$, Min = 0, Max $=4$ );

// operação

result $=\operatorname{var} 1+\operatorname{var} 2+\operatorname{var} 3+\operatorname{var} 4+\operatorname{var} 5$

\} 
Programa LEGAL 119 - Programa obtenção de mascara representativa de áreas restritivas por faixas de declividade.

\{// Programa para obtencao de máscara a partir de supaefície de declividade em graus

// declaração

Numerico result ("Pot-Agricola"), dec ("Declividade-MNT");

// instanciação

dec $=$ Recupere $($ Nome $=$ "Dec_Grade_Gaus");

result $=$ Novo $($ Nome $=$ "Dec_PotAgri4_Leis", ResX=30, ResY=30, Escala = 50000, Min = 0, Max = 4);

// operação

result $=\left((\operatorname{dec}<=25) ?\left(\operatorname{dec}^{*}-0\right)+1\right.$ :

$(\operatorname{dec}>25) ?\left(\operatorname{dec}^{*} 0\right)$ :

Digital (0));

\}

Programa LEGAL 120 - Programa obtenção de mascara representativa de áreas restritivas para faixas de distância de cursos de drenagem.

$\{/ /$ Programa para espacialização da Densidade de Drenagem

// declaração

Numerico result ("Pot-Agricola "), dist ("Drenagem-MNT");

/ / instanciação

dist $=$ Recupere (Nome $=$ "Dren_Grade");

result $=$ Novo $($ Nome $=$ "Drebuffer_Lei", ResX=30, ResY=30, Escala = 50000, Min = 0, Max = 4);

// operação

result $=\left((\right.$ dist $<=30)$ ? $\left(\right.$ dist $\left.^{*}-0\right)$ :

$($ dist $>30) ?(\operatorname{dist} * 0)+1$ :

Digital (0));

\}

Programa LEGAL 121 - Programa obtenção da superfície final representativa do potencial agrícola da área.

$\{$ // Programa em LEGAL para obtencao Mapa Potencial Agricolal Fuzzy

// declaração

Numerico result, var1, var2, var3, ("Potencial_Agricola");

// instanciação

var1 = Recupere (Nome=" Potencial_Agricola4");

var2 $=$ Recupere (Nome $=$ " Drebuffer_Lei ");

var3 = Recupere (Nome=" Dec_Grade_Gaus ");

result $=$ Novo $($ Nome $=$ " Potencial_Agricola4_Final", ResX=30, ResY=30, Escala $=50000$, Min $=0$, Max

$=4$ );

/ / operação

result $=\operatorname{var} 1 * \operatorname{var} 2 * \operatorname{var} 3$;

\} 


\section{ANEXO I}

Mapa de Documentação 


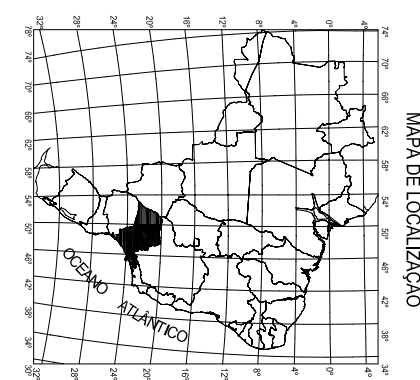
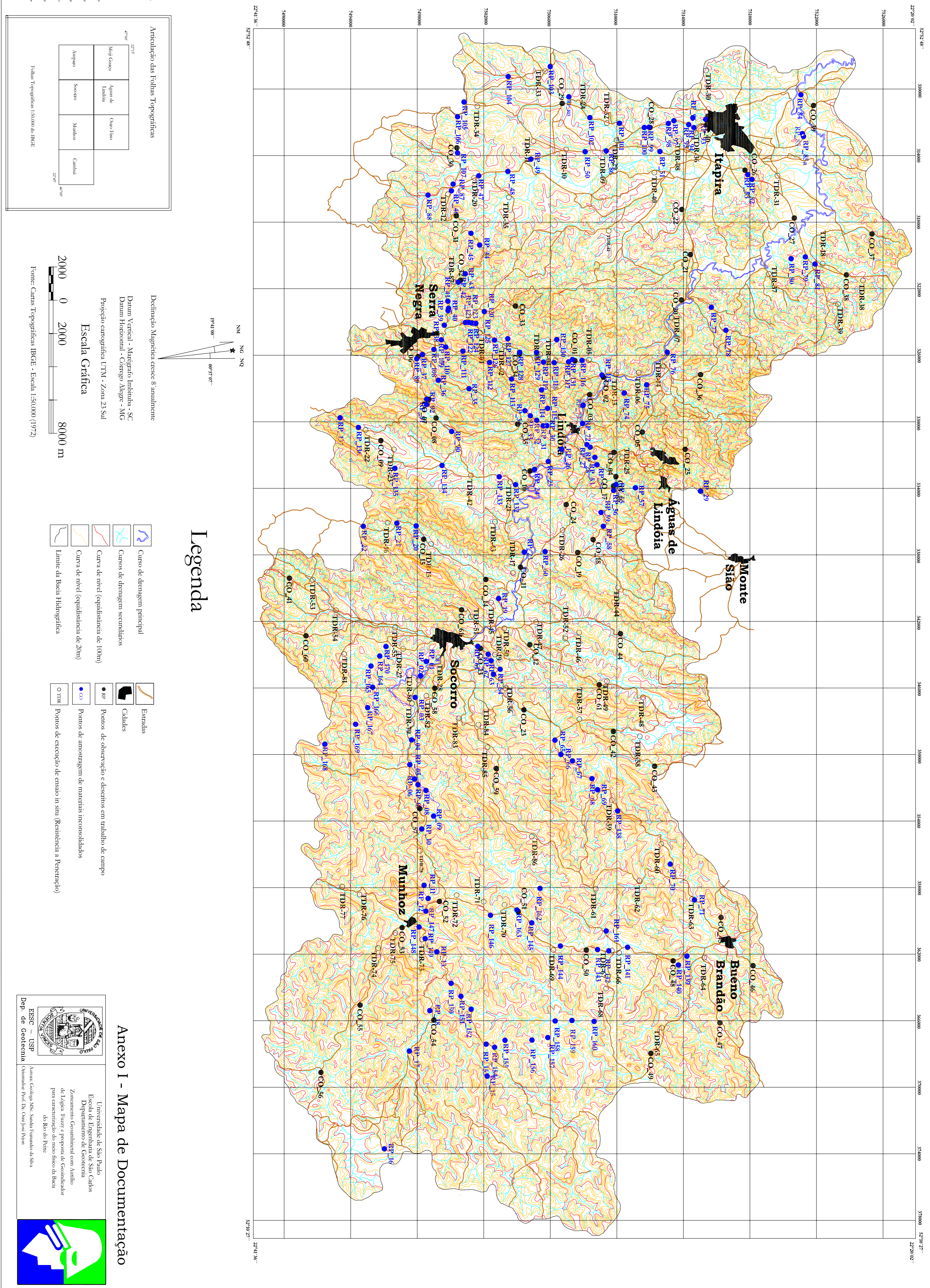


\section{ANEXO II}

Mapa de Substrato Rochoso 

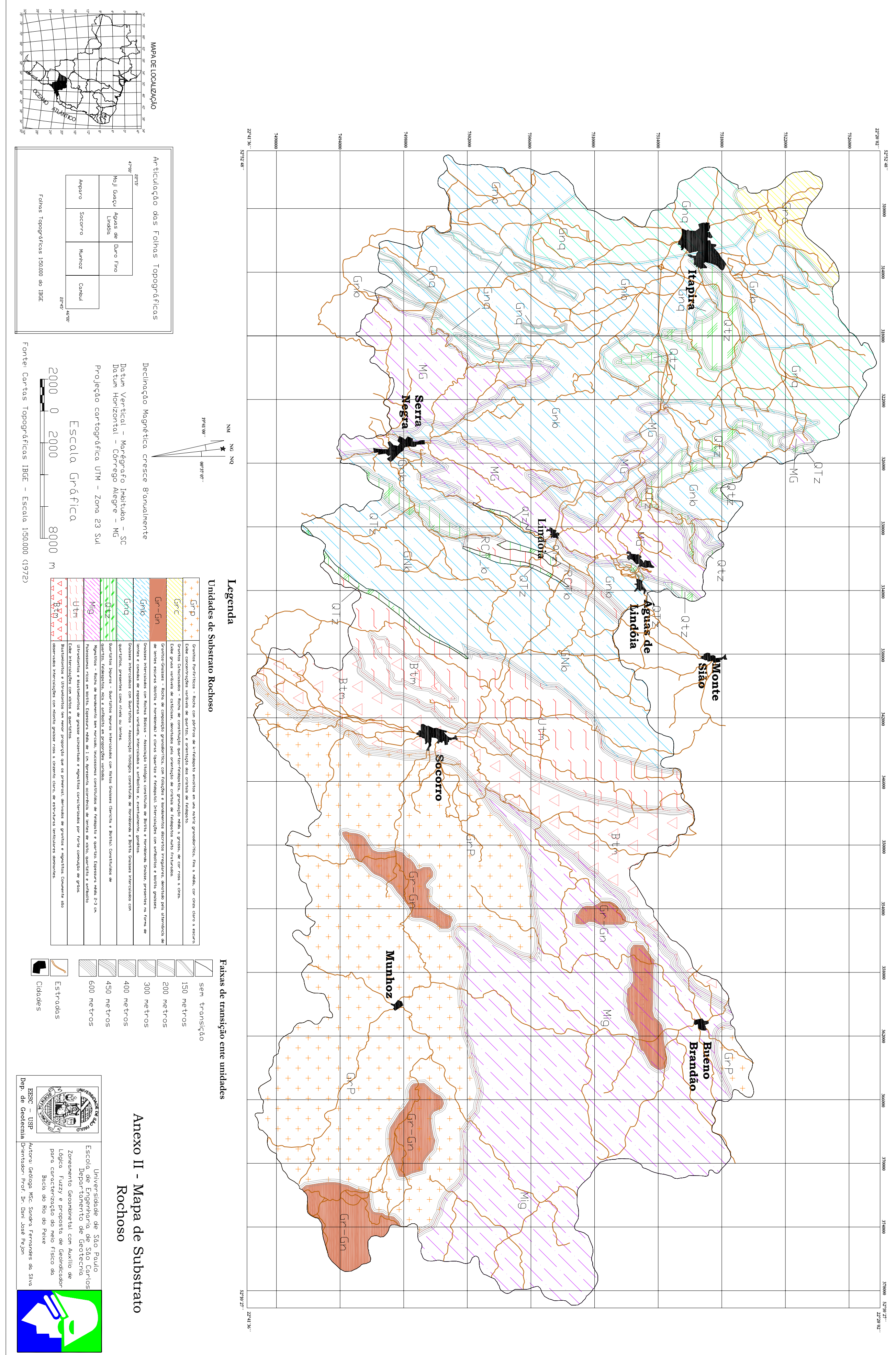
ANEXO III

Mapa de Landforms 

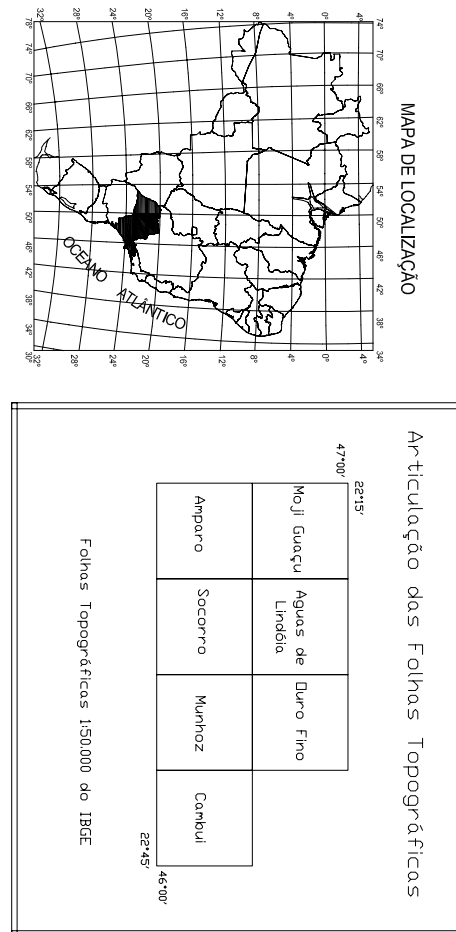

(1)

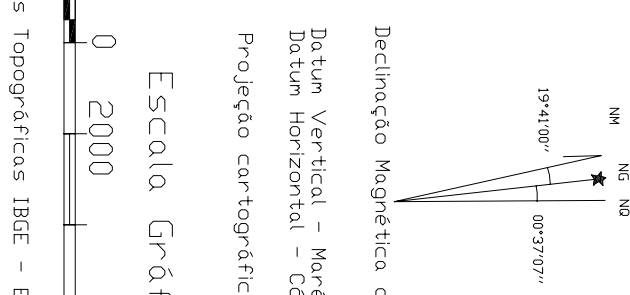

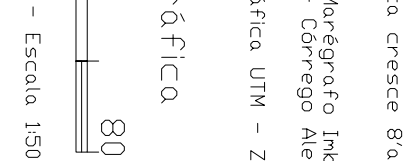

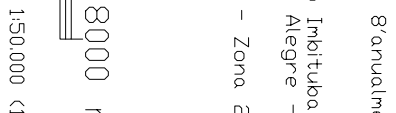

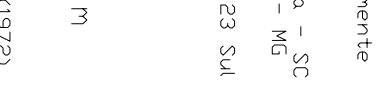

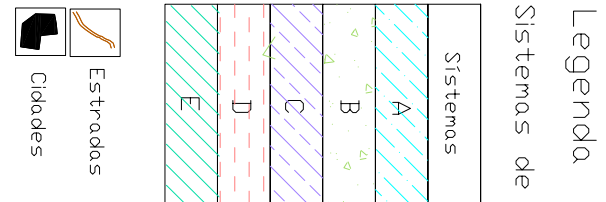

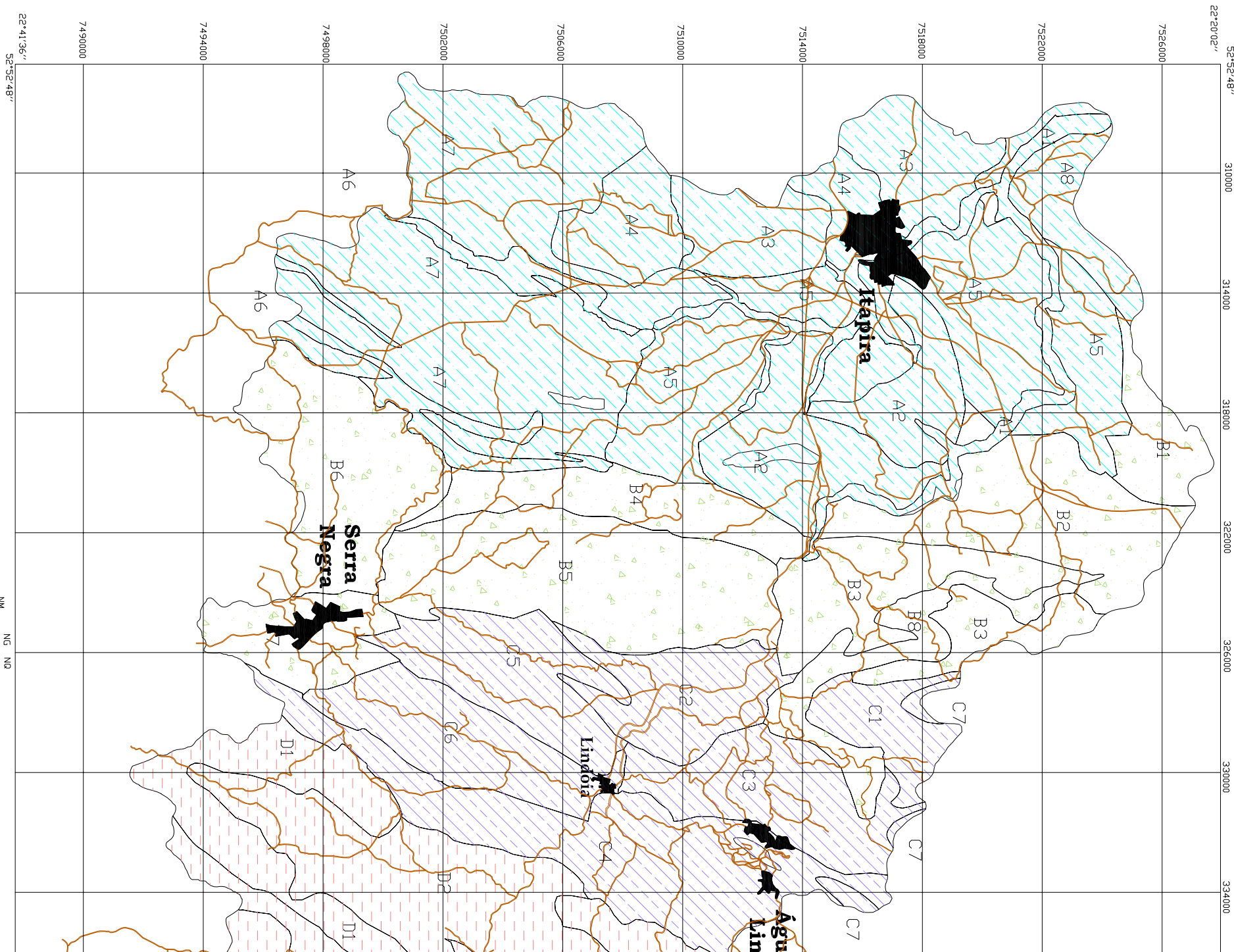

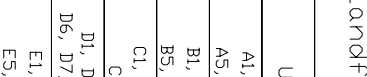

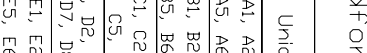

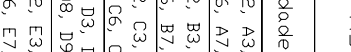

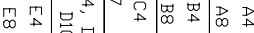

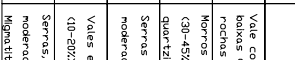

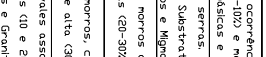

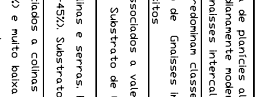

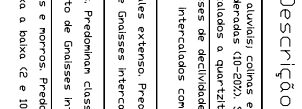

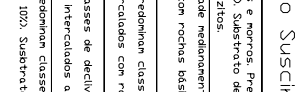

In:

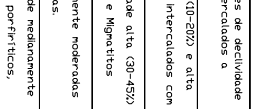
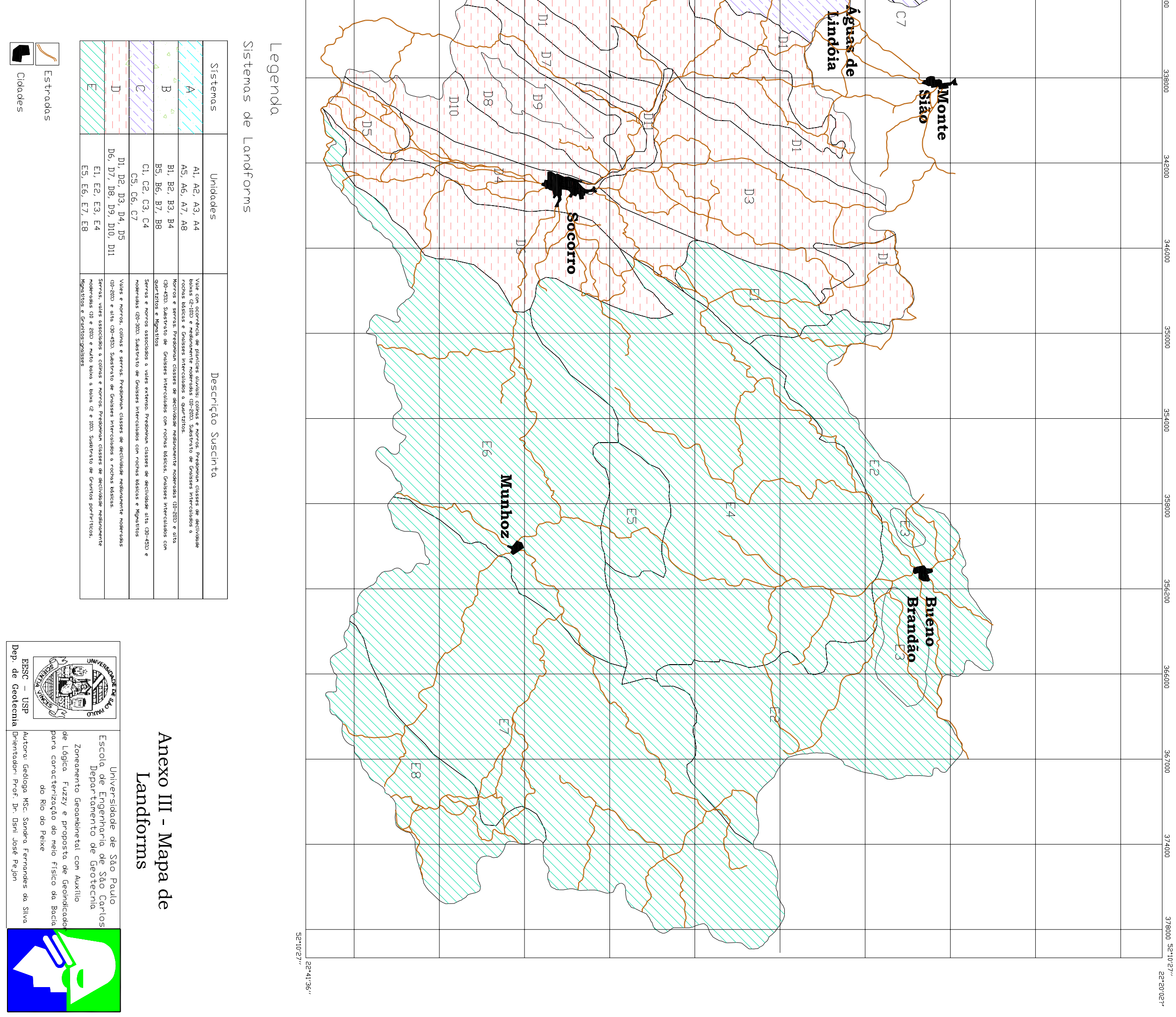


\section{ANEXO IV \\ Mapa de Materiais Incosolidados}




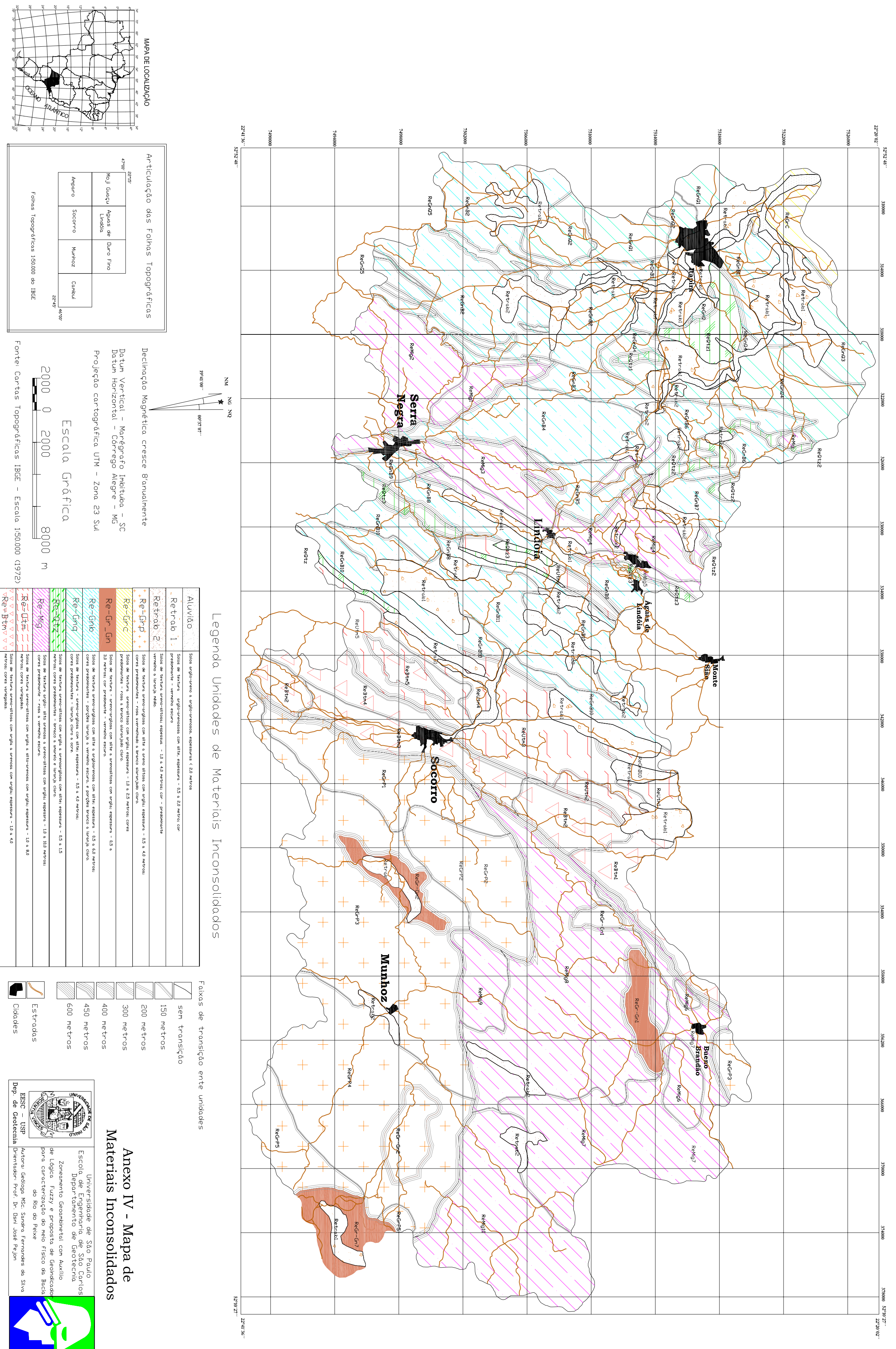




\section{ANEXO V \\ Mapa de Uso e Ocupação}




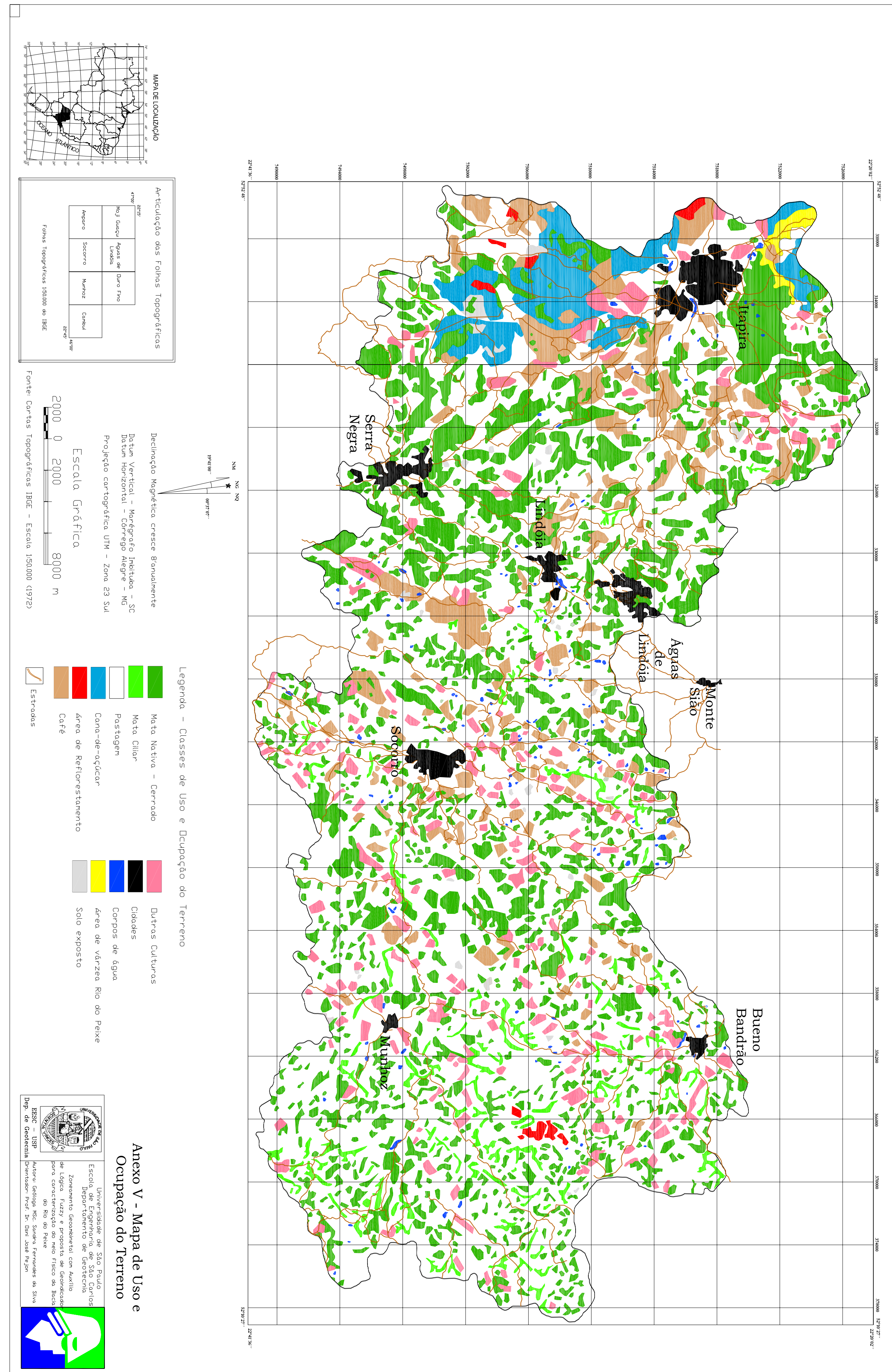




\section{ANEXO VI}

Carta de Declividade 


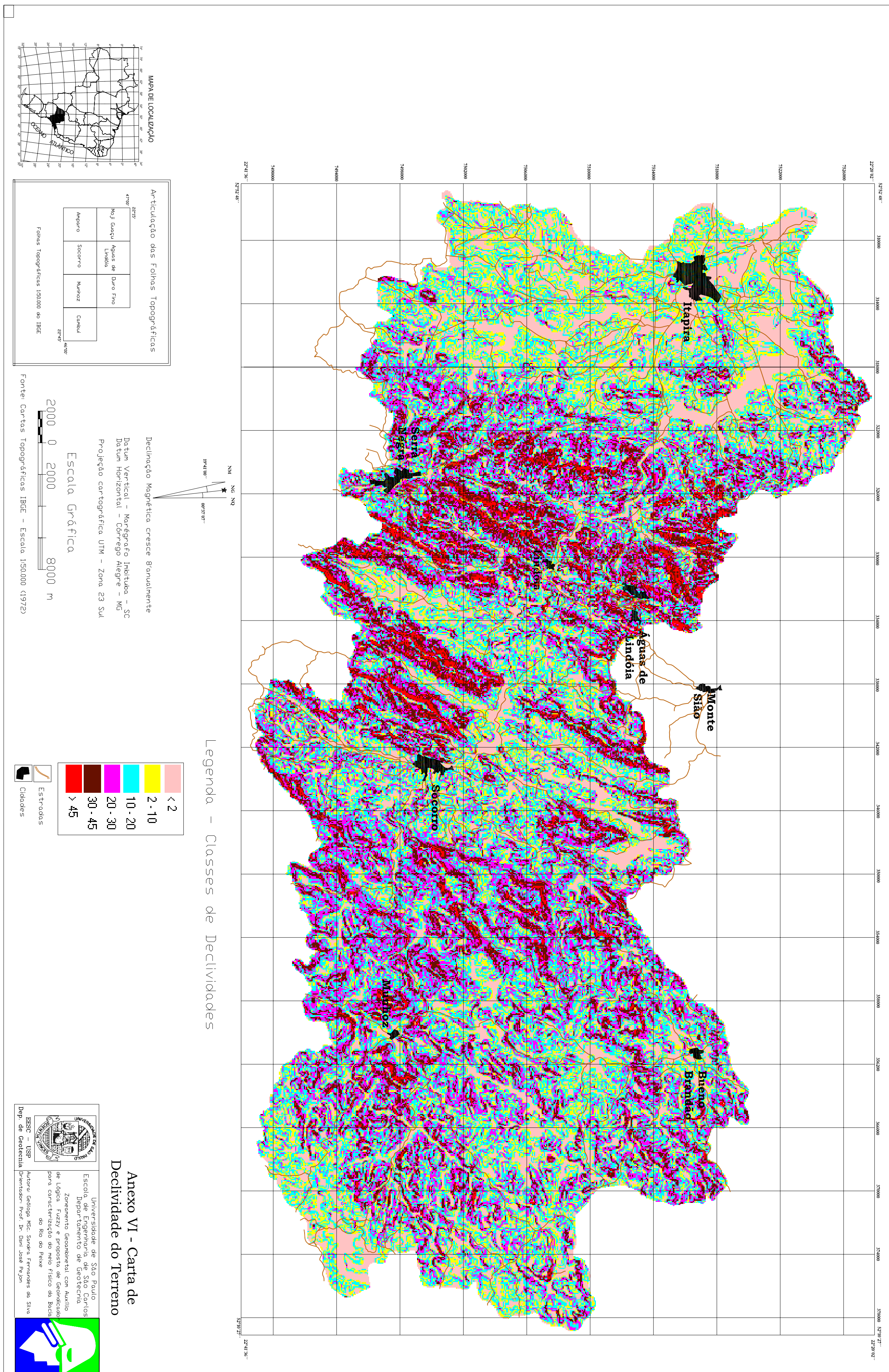




\section{ANEXO VII}

Carta de Potencial ao Escoamento Superficial 


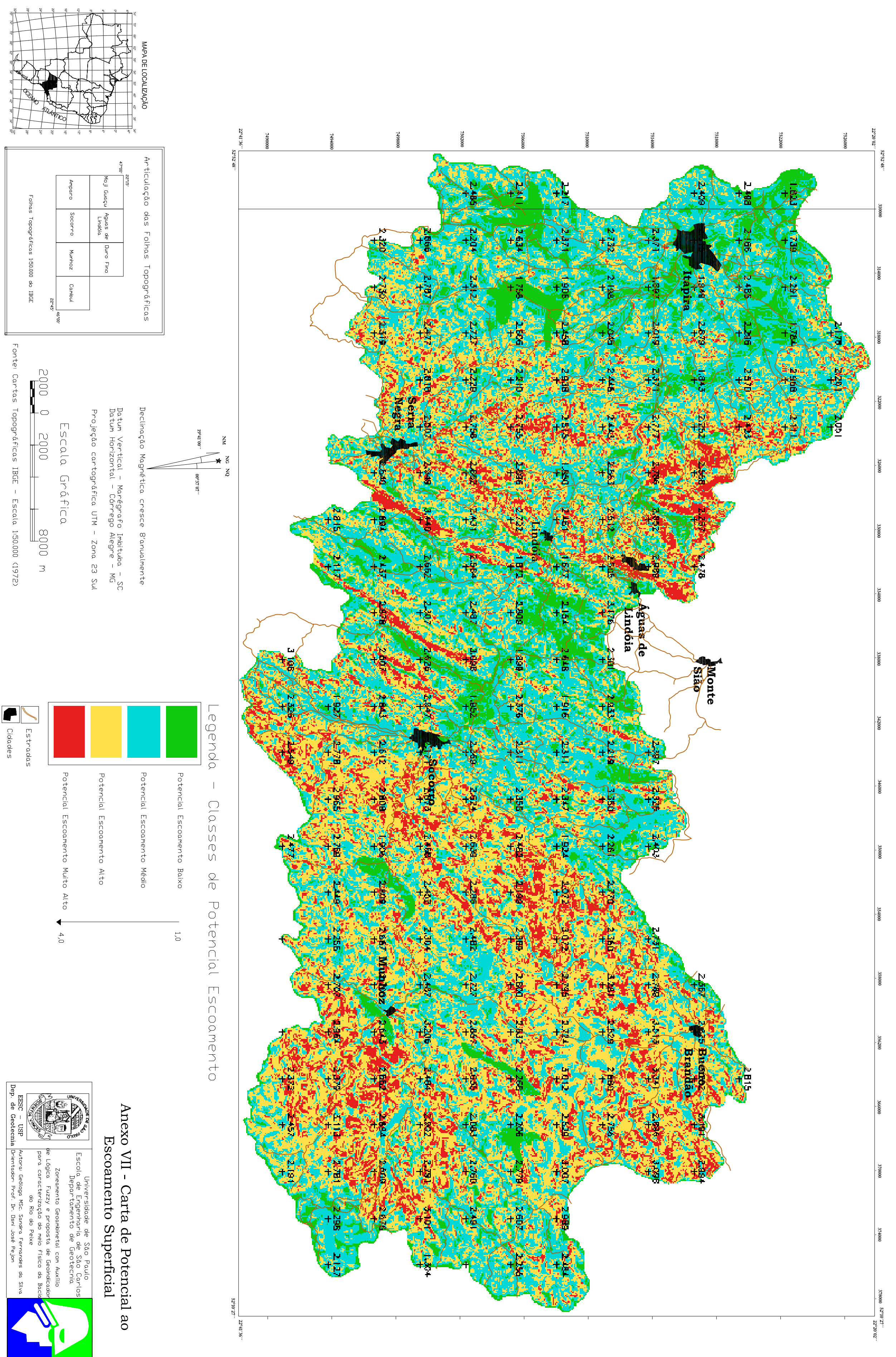




\section{ANEXO VIII}

Carta de Susceptibilidade a Erosão 


\section{: \\ $\frac{15}{43}$}
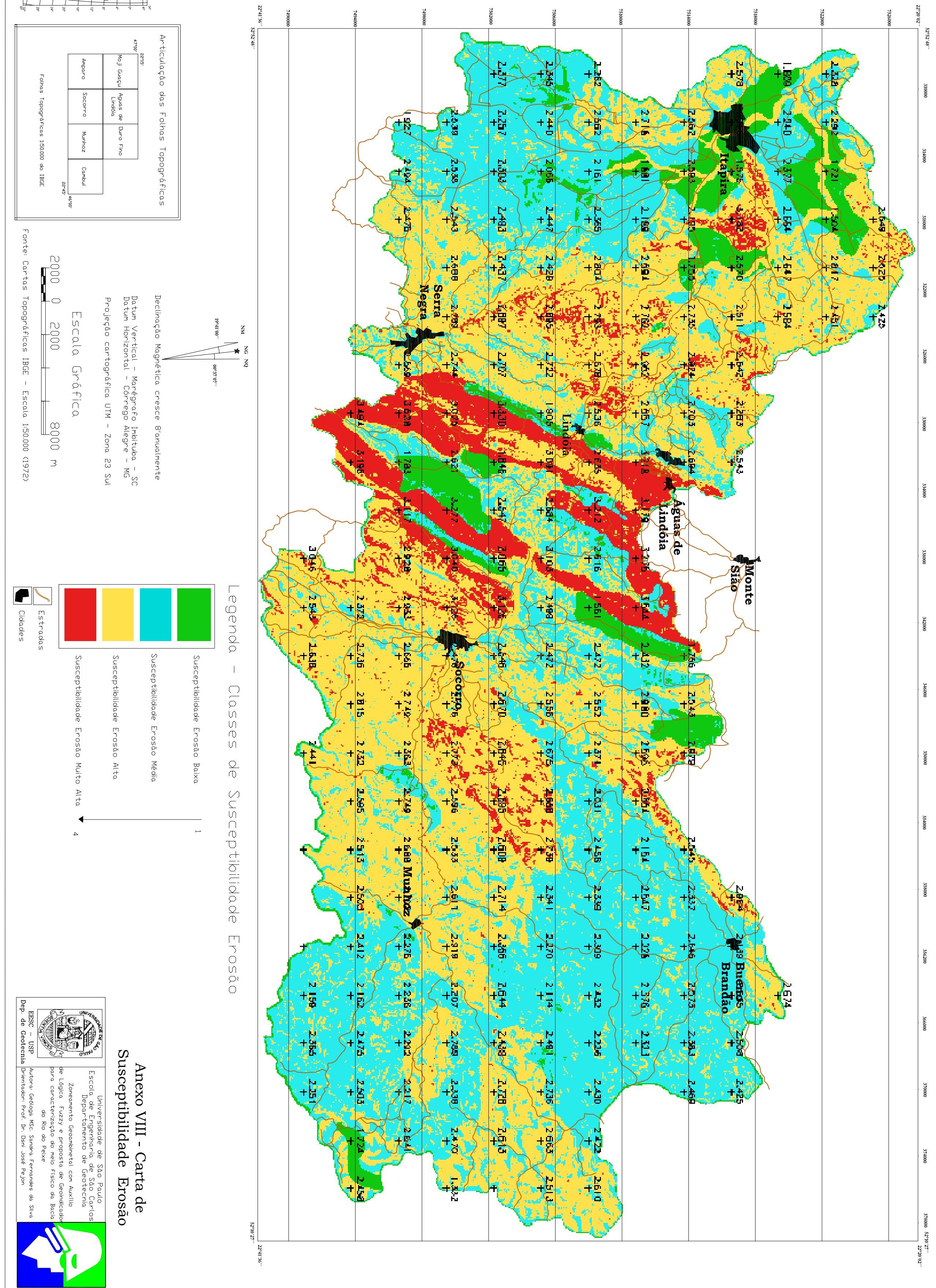
ANEXO IX

Carta de Potencial Agrícola 


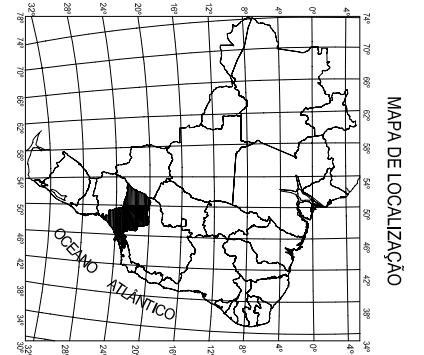
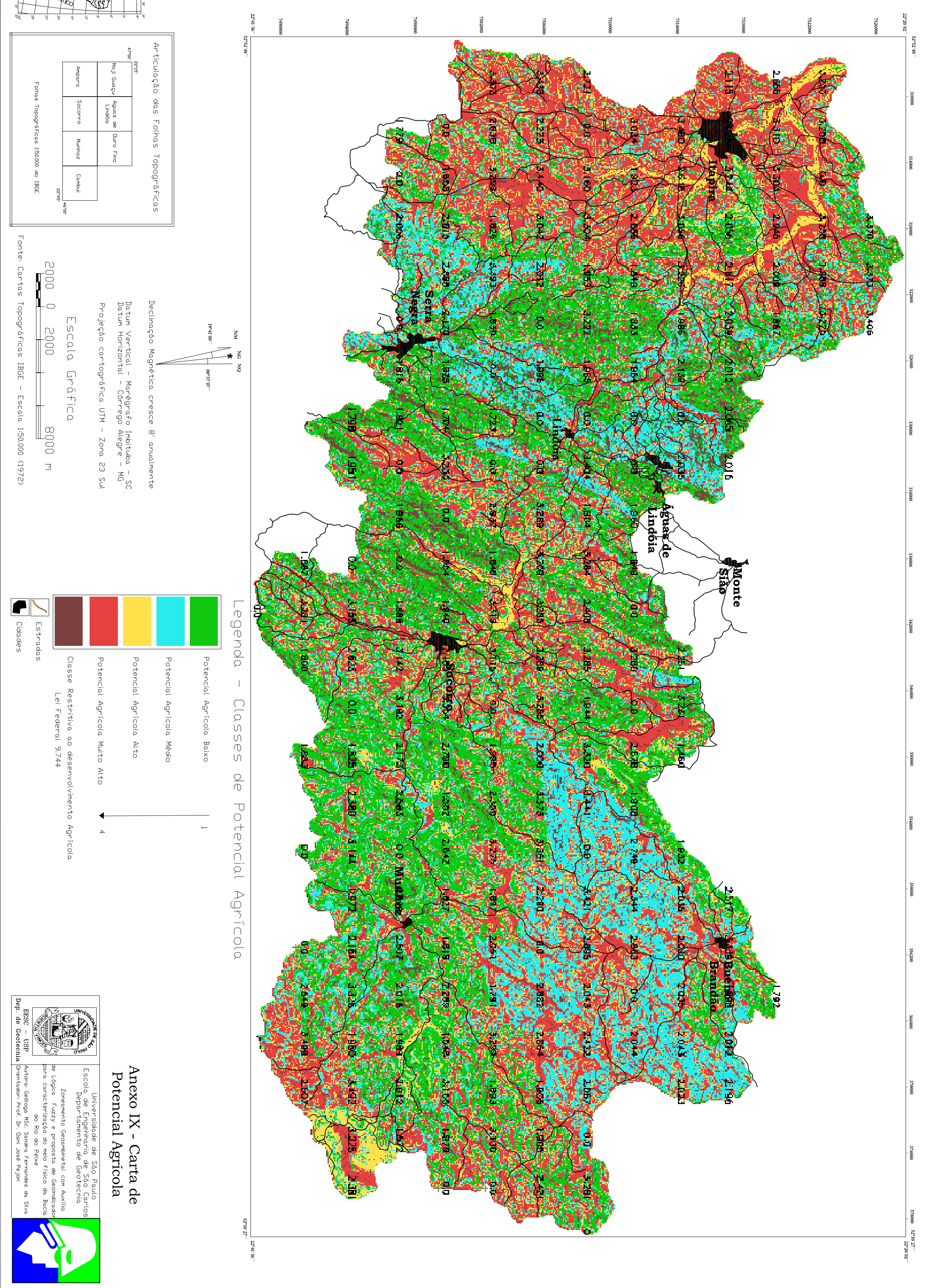


\section{ANEXO X}

Carta de Zoneamento Geoambiental 


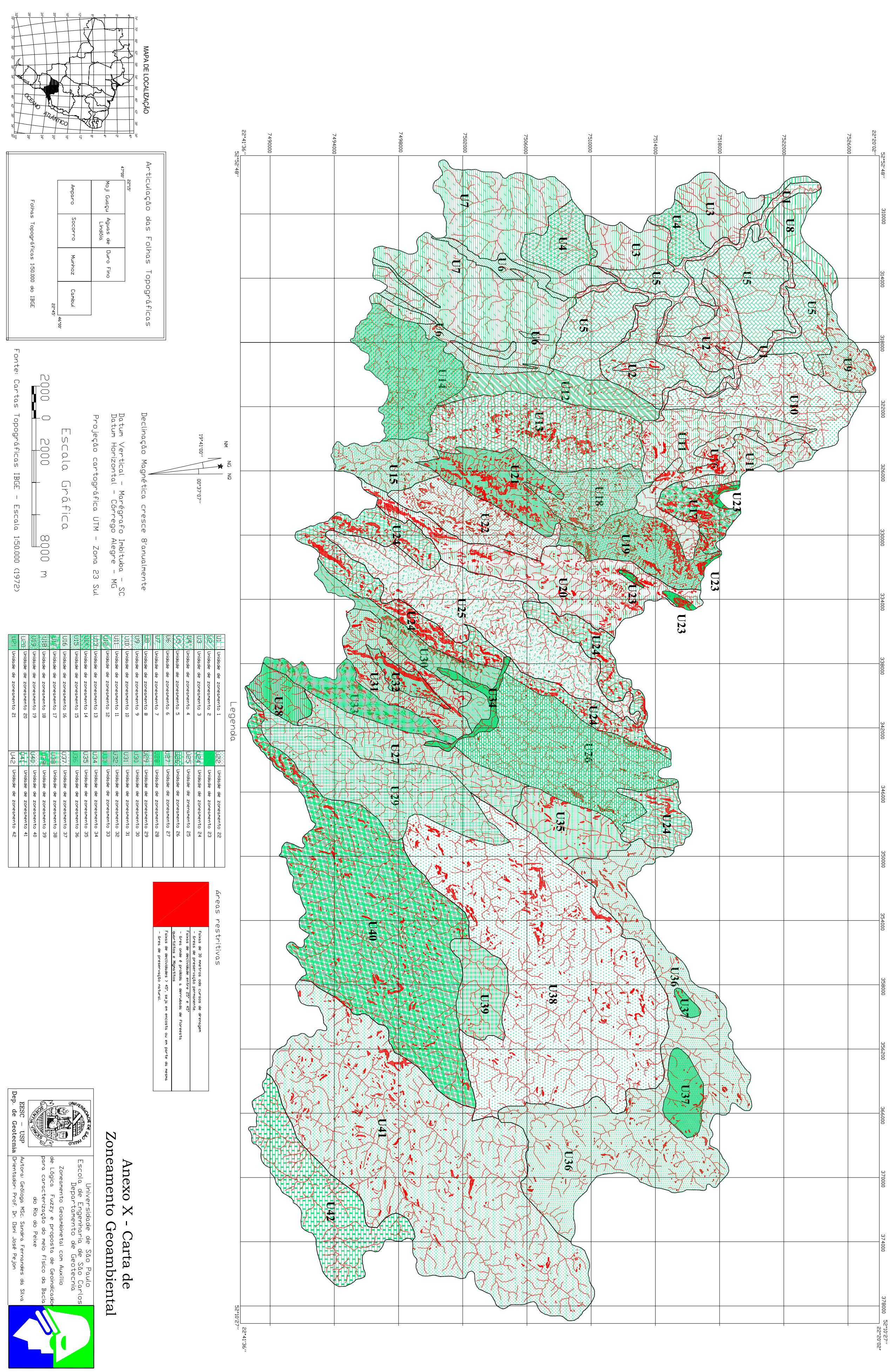

